Szegedi Tudományegyetem, Bölcsészettudományi Kar

Neveléstudományi Doktori Iskola

Fejes József Balázs

\title{
A CÉLORIENTÁCIÓK ÉS AZ OSZTÁLYTERMI KÖRNYEZET ÖSSZEFÜGGÉSE MATEMATIKA TANTÁRGYHOZ KÖTŐDŐEN 5-8. ÉVFOLYAMON
}

PhD értekezés

\author{
Témavezető: \\ Dr. Józsa Krisztián \\ egyetemi docens
}

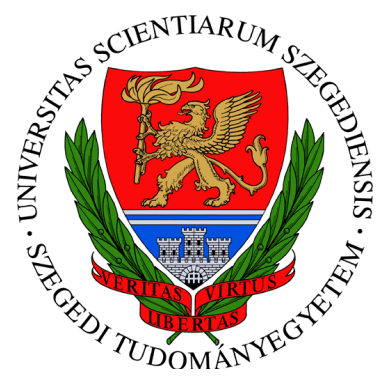

Oktatáselmélet doktori program

Szeged

2012 


\section{TARTALOMJEGYZÉK}

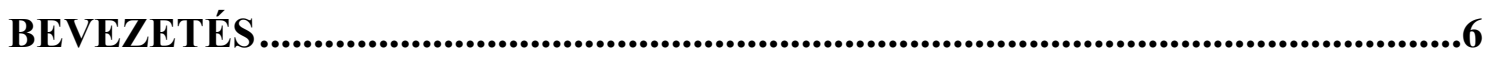

1. A TANULÁSI MOTIVÁCIÓ KUTATÁSÁNAK ELMÉLETI ALAPJAI............9

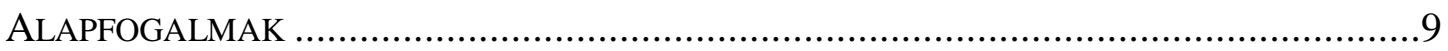

Tanulási motiváció mint kutatási terület ...........................................................9

Motívum, motiváció, motiválás, motívumfejlesztés ............................................11

A TANULÁSI MOTIVÁCIÓ KUTATÁSÁNAK FEJLŐDÉSI IRÁNYAI..................................... 12

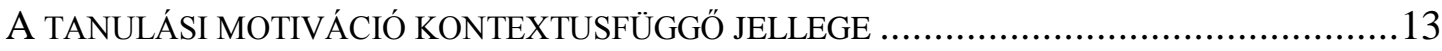

A kontextus megjelenése az oktatástudományban............................................. 13

A kontextuális nézőpont a tanulási motiváció kutatásában.................................. 14

A kontextuális nézőpont hatása az osztálytermi gyakorlatra ..............................17

A TANULÁSI MOTIVÁCIÓ KUTATÁSÁNAK JELENTÖSÉGE ............................................19

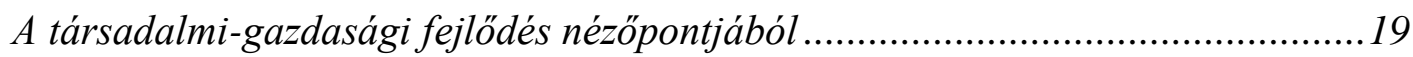

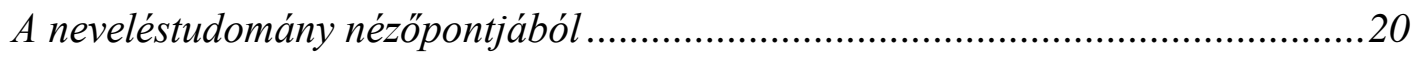

Egy komplexebb megközelítés felé ........................................................20

Lehetőség az oktatás hatékonyságának emelésére .......................................20

Az innovatív tanulási környezetek kihívásai............................................ 21

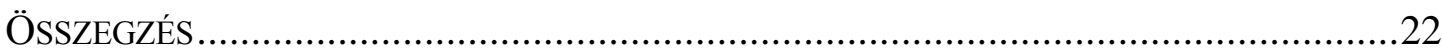

2. A TÁRSAS KÖRNYEZET ÉS A TANULÁSI MOTIVÁCIÓ KAPCSOLATA.23

AZ ELSŐDLEGES SZOCIALIZÁCIÓS SZÍNTÉR, A CSALÁD SZEREPE ..............................23

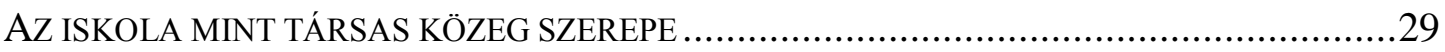

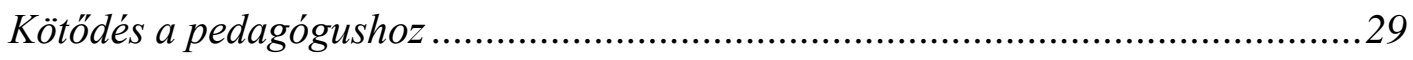

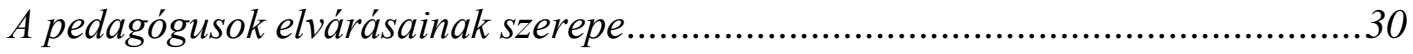

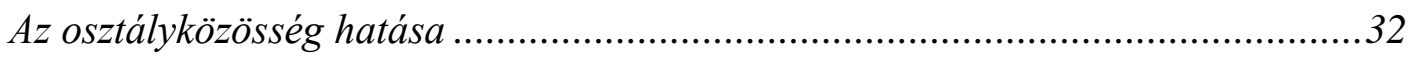

A TÁGABB KÖZÖSSÉG SZEREPE: KULTURÁLIS KÜLÖNBSÉGEK................................... 35

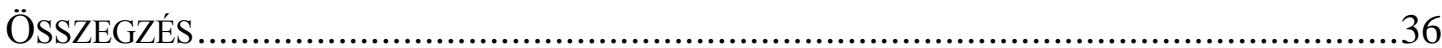

3. TANULÓINK ÉS ISKOLÁINK NÉHÁNY MOTIVÁCIÓS JELLEMZŐJE ....37

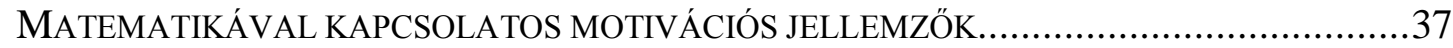

A TANULÁSI MOTIVÁCIÓ ÉLETKORI VÁLTOZÁSA..................................................42

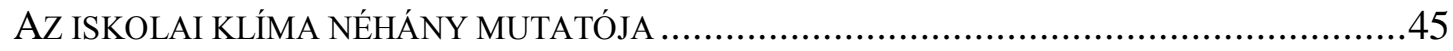

A TANULÁSI MOTIVÁCIÓ ÉS AZ ISKOLAI EREDMÉNYESSÉG KAPCSOLATA ....................48

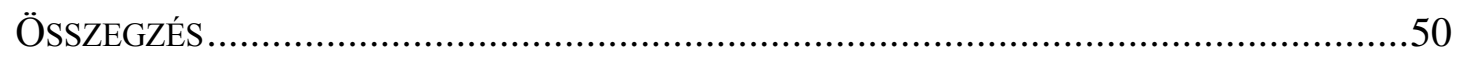

4. A CÉLORIENTÁCIÓS ELMÉLET ....................................................................52

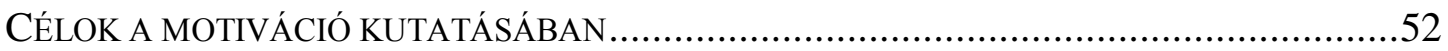

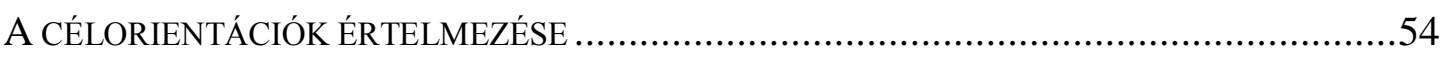

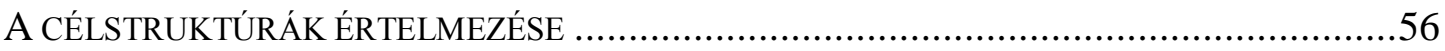

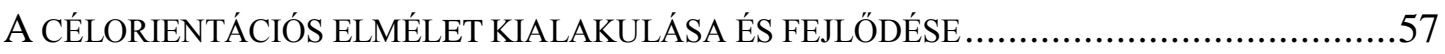

A célorientációs elmélet megjelenése a tanulási motiváció kutatásában................57 
A teljesitménykeresö-teljesitménykerülö dimenzió beépülése

Többszörös célok elmélete

A CÉLORIENTÁCIÓK ÉS A TANULÁS EREDMÉNYESSÉGÉT BEFOLYÁSOLÓ EGYÉB VÁLTOZÓK KAPCSOLATA.

A TANULÁSI KÖRNYEZET ÉS A TANULÁST BEFOLYÁSOLÓ VÁLTOZÓK ÖSSZEFÜGGÉSE ..63

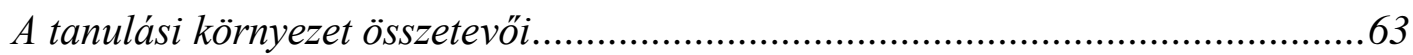

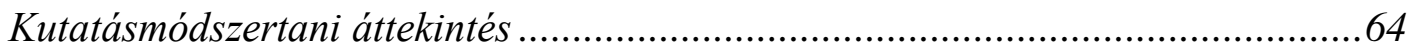

A célstruktúrák és a tanulás eredményességét befolyásoló változók kapcsolata.....65

A tanulási környezet lényeges összetevői a célorientációs elmélet alapján ............69

A célorientációs elméleten alapuló intervenciós programok ..............................72

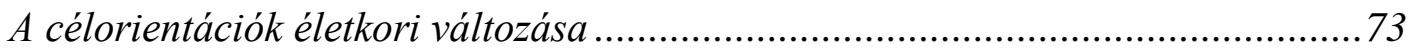

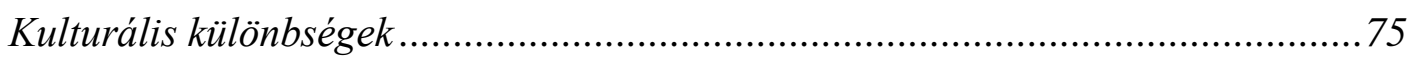

A GYAKORLATI ALKALMAZÁS LEHETÖSÉGEI ÉS KORLÁTAI ....................................76

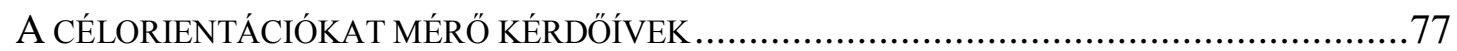

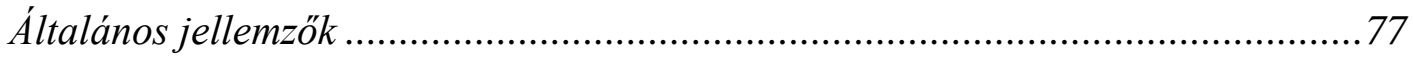

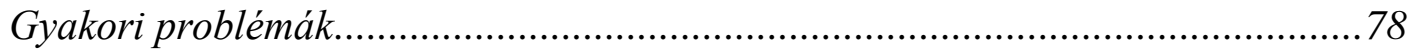

A 2 2x-es felosztás újszerüsége.............................................................. 78

A célok és az egyéb, célokkal összefüggő változók elkülönítése .....................78

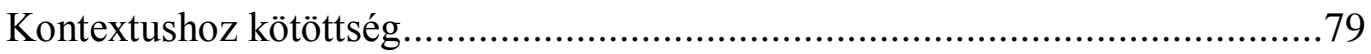

A kérdőívtételek megfogalmazásának problémái ............................................8 80

A TANULÁSI KÖRNYEZET MEGISMERÉSÉT CÉLZÓ KÉRDÖÍVEK ....................................81

Holisztikus megközelitésü kérdöívek ........................................................... 81

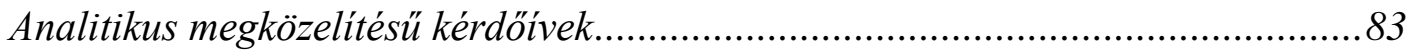

A KÉRDÖÍVES ADATGYÜJTÉS KORLÁTAI ÉS A TOVÁBBLÉPÉS IRÁNYAI.........................84

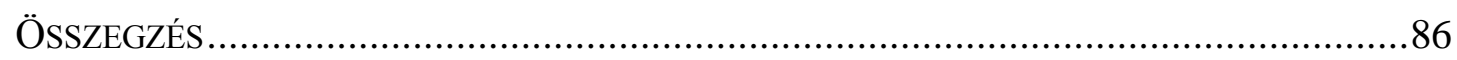

5. AZ EMPIRIKUS VIZSGÁLATOK KONCEPCIÓJA ....................................87

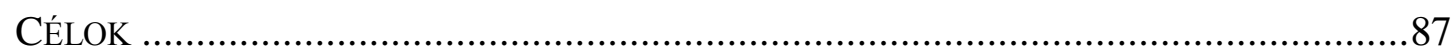

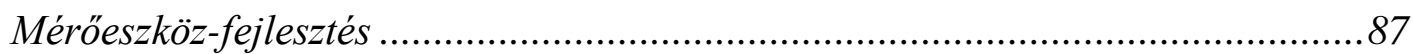

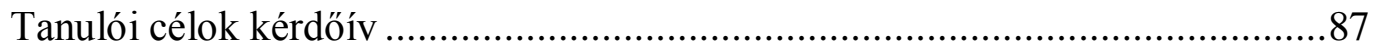

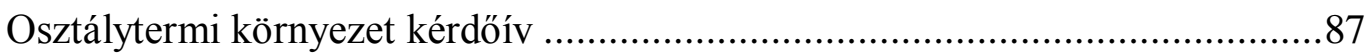

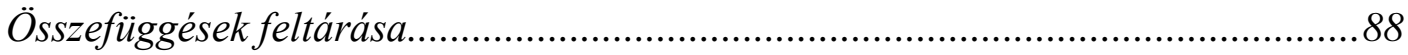

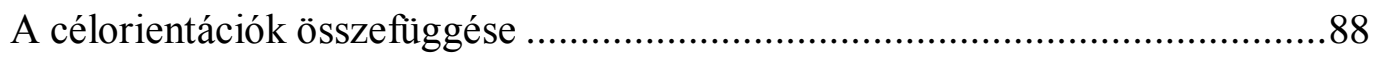

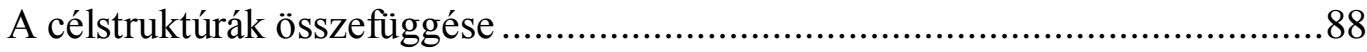

A célorientációk és az osztályzatok összefüggése..........................................8 88

A célorientációk és a célstruktúrák összefüggése ........................................ 88

A célorientációk összefüggése a tanári tevékenységekkel, társas környezettel...89

A célstruktúrák összefüggése a tanári tevékenységekkel, társas környezettel.....89

KÉRDÉSEK .90

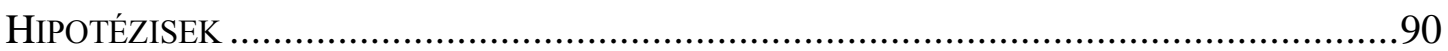

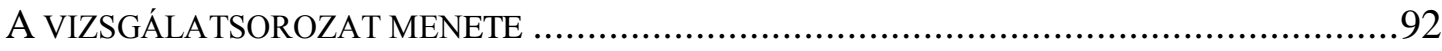

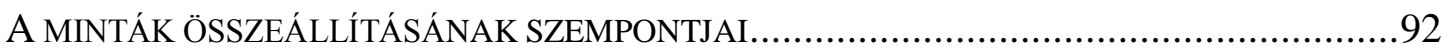

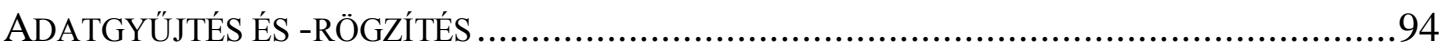

ADATELEMZÉS: A MODERN TESZTELMÉLET LEHETÖSÉGEI ........................................95 


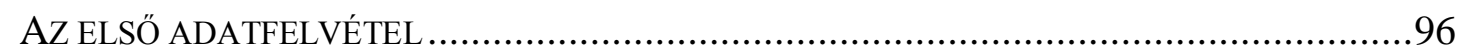

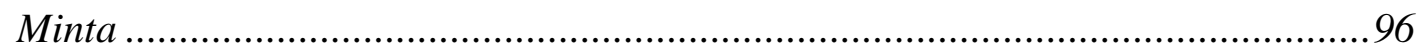

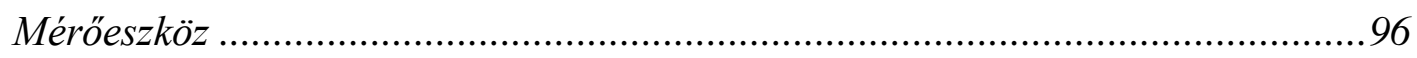

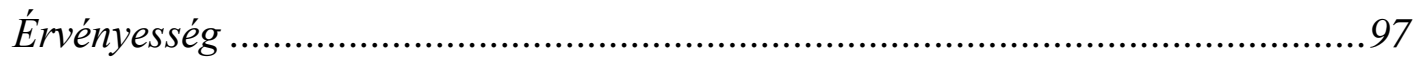

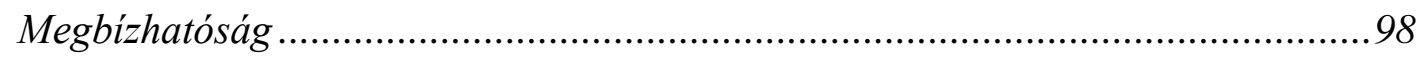

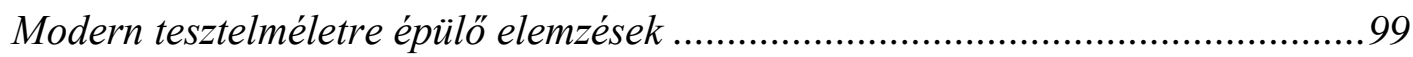

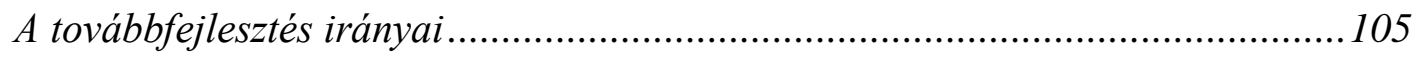

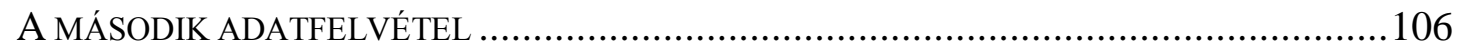

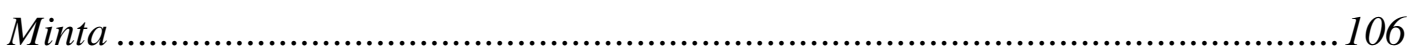

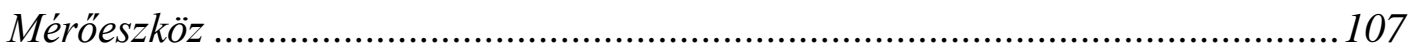

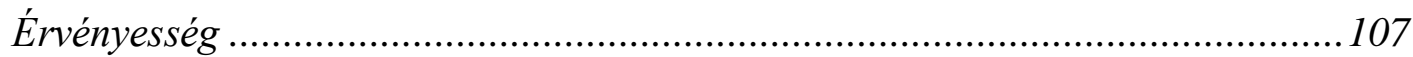

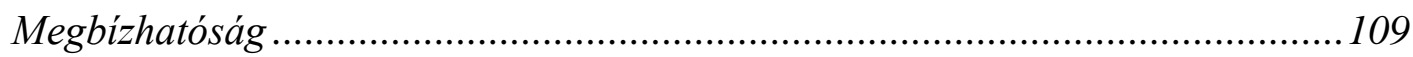

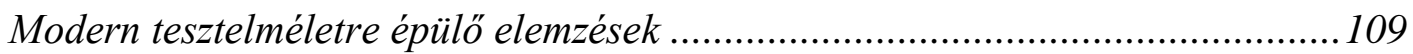

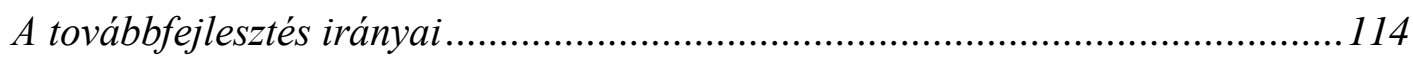

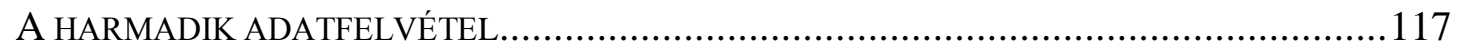

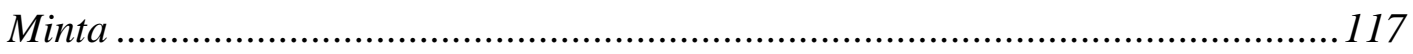

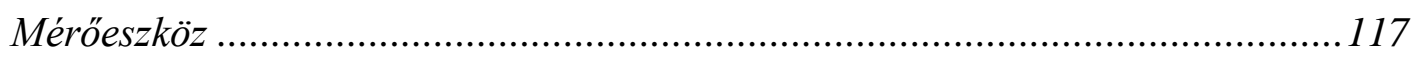

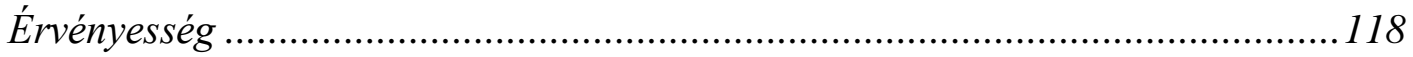

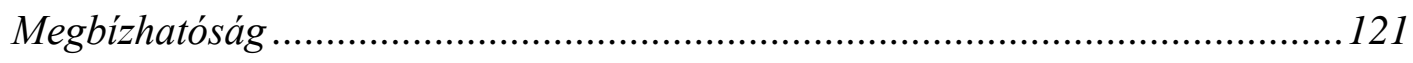

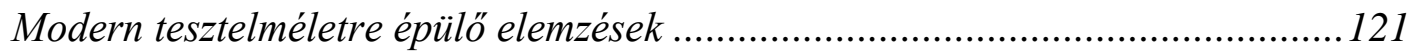

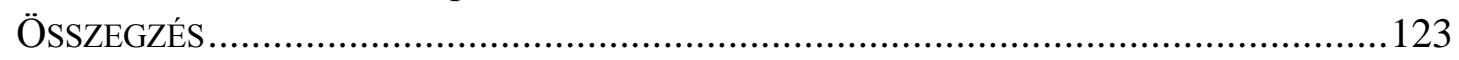

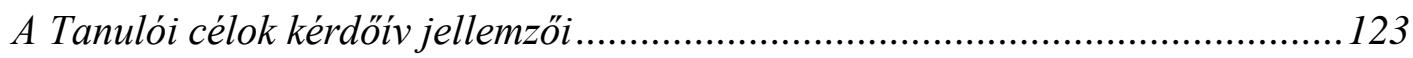

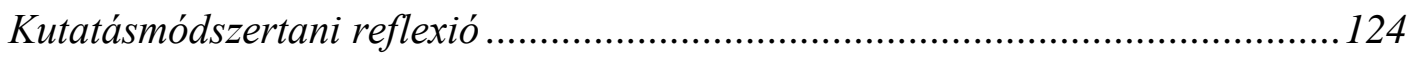

7. AZ OSZTÁLYTERMI KÖRNYEZET KÉRDÖÍV FEJLESZTÉSE.................128

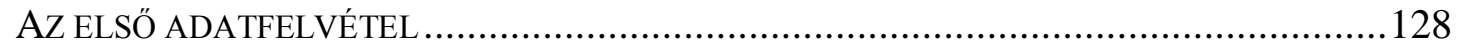

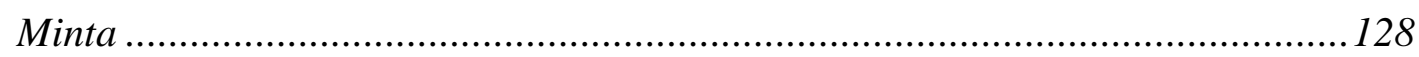

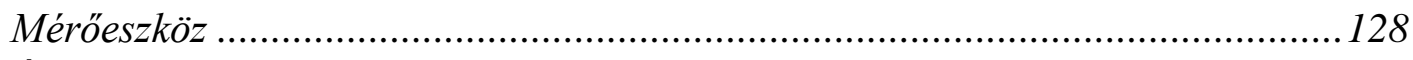

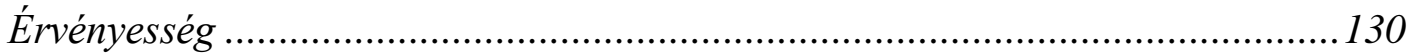

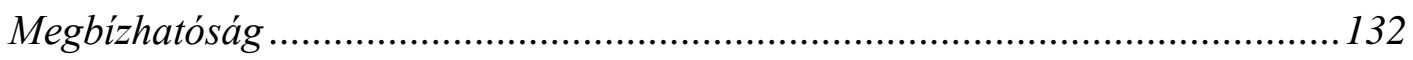

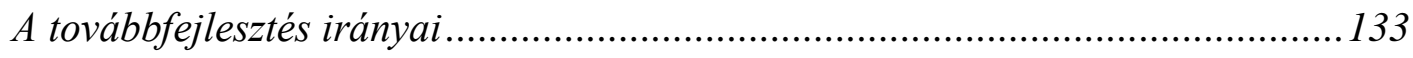

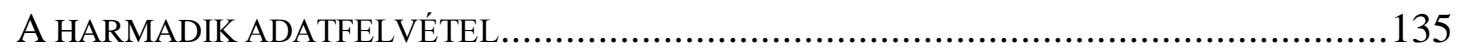

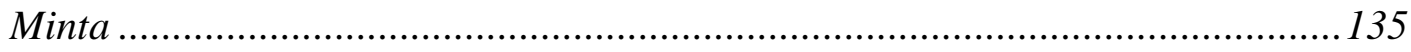

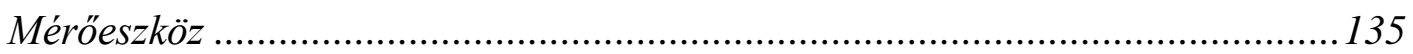

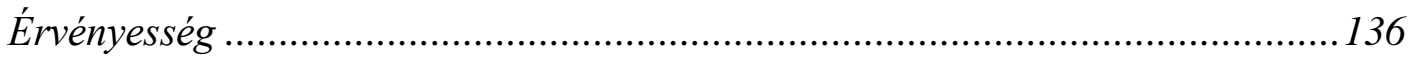

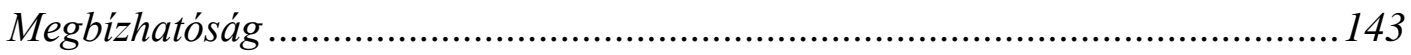

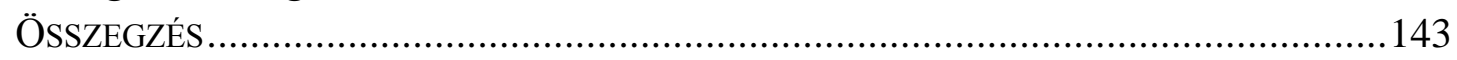

8. A VIZSGÁLT KONSTRUKTUMOK JELLEMZÖI .........................................144

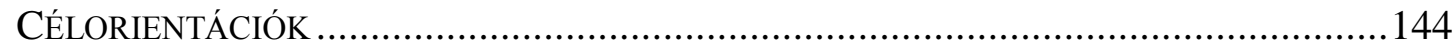

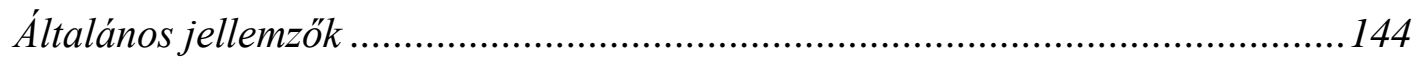

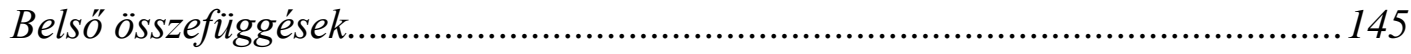

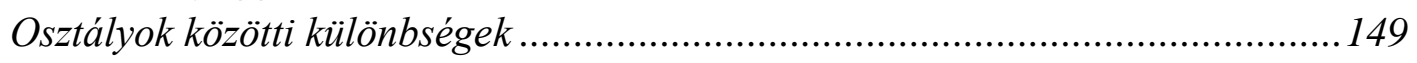




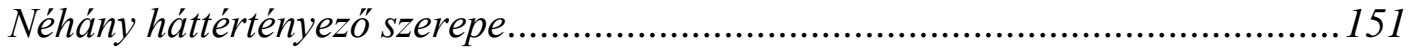

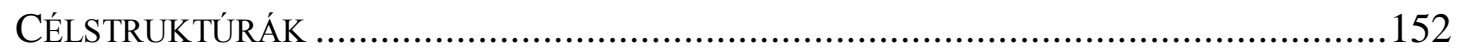

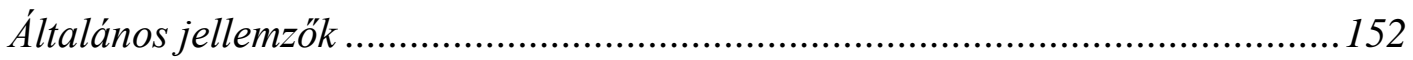

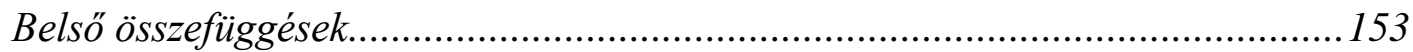

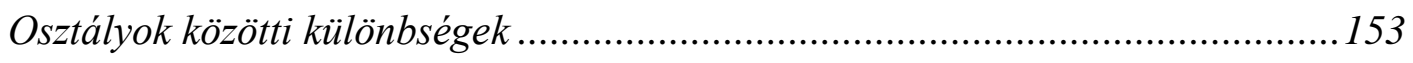

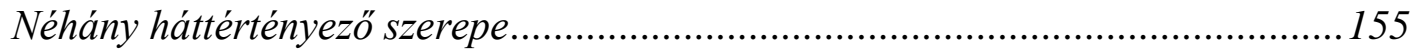

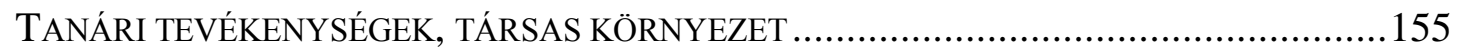

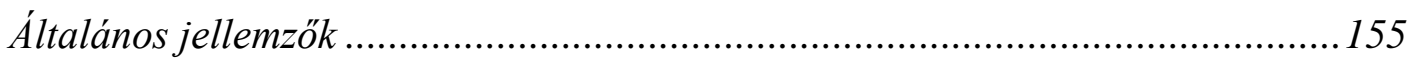

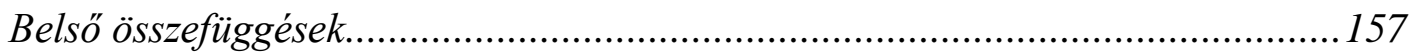

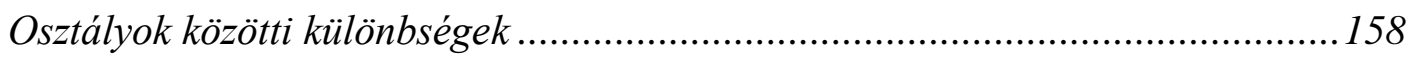

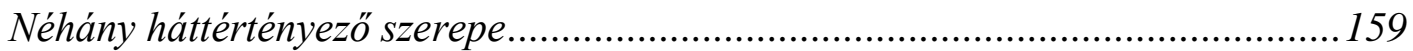

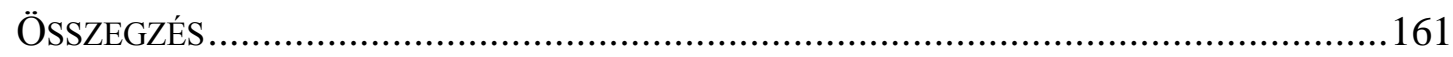

9. A VIZSGÁLT KONSTRUKTUMOK ÖSSZEFÜGGÉSE..................................162

A CÉLORIENTÁCIÓK ÉS AZ OSZTÁLYZATOK KÖZÖTTI ÖSSZEFÜGGÉSEK ….................... 162

A CÉLORIENTÁCIÓK ÉS A CÉLSTRUKTÚRÁK KÖZÖTTI ÖSSZEFÜGGÉSEK ......................170

A CÉLORIENTÁCIÓK ÖSSZEFÜGGÉSE A TANÁRI TEVÉKENYSÉGEKKEL ÉS A TÁRSAS

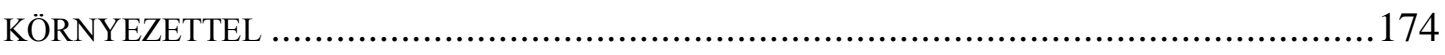

A CÉLSTRUKTÚRÁK ÖSSZEFÜGGÉSE A TANÁRI TEVÉKENYSÉGEKKEL ÉS A TÁRSAS

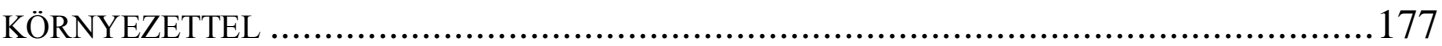

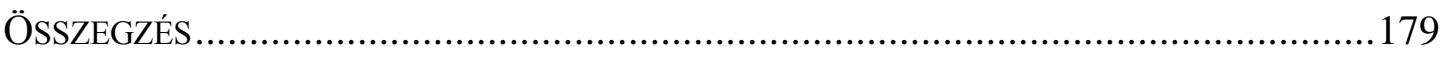

10. ÖSSZEGZÉS, KÖVETKEZTETÉSEK .............................................................181

AZ EREDMÉNYEK ÖSSZEFOGLALÁSA, ÉRTELMEZÉSE........................................... 181

A kifejlesztett méröeszköz-család müködése .................................................. 181

A célorientációk jellemzői tanulóink körében................................................... 182

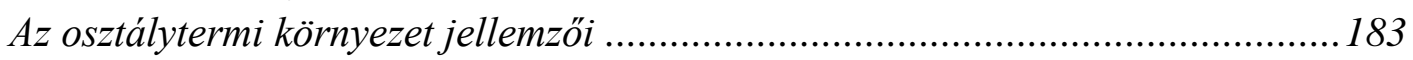

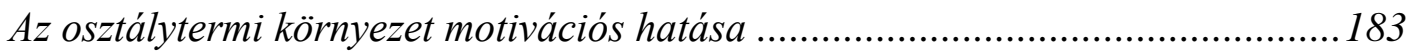

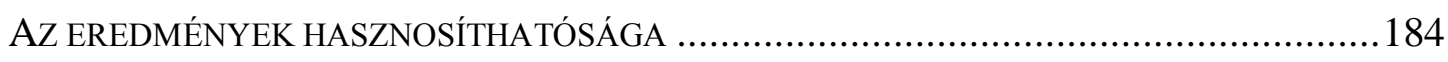

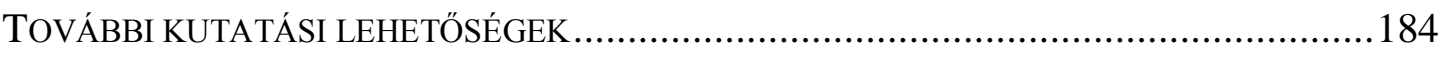

KÖSZÖNETNYILVÁNÍTÁS ...........................................................................187

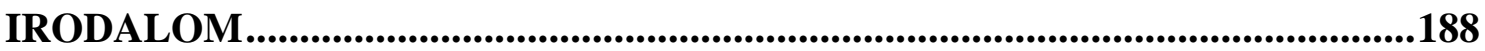

ÁBRÁK JEGYZÉKE ..................................................................................217

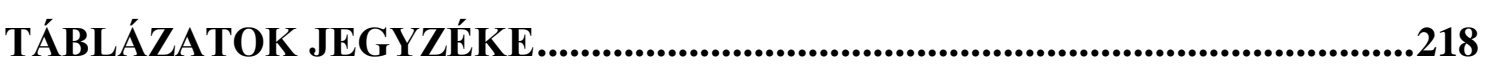

MELLÉKLETEK JEGYZÉKE......................................................................222

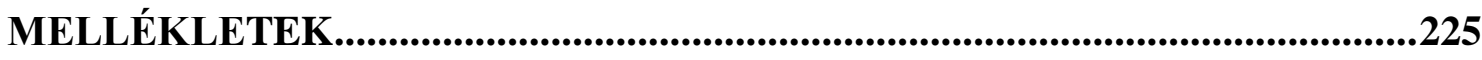




\section{BEVEZETÉS}

Az utóbbi fél évszázadban a tanulási motiváció magyarázatára, elörejelzésére számos konstruktum született, azonban az empirikusan megalapozott intervenció lehetősége csak a közelmúltban merült fel, mely jelentős részben a motivációkutatásban bekövetkező szemléletváltásnak köszönhető. Míg a klasszikus elméletek a motívumokat az egyén személyes jellemzőiként kezelték, addig az újabb megközelítések a kontextustól elválaszthatatlannak tekintik azokat, így egyre inkább a tanulók motivációs jellemzői és a környezet közötti interakció tanulmányozása kerül elötérbe. E szemléletváltás nyomán elindult intervenciós kísérletek egyértelmüen jelzik, hogy a tanulási motiváció empirikusan megalapozott fejlesztése elérhető közelségbe került. Ugyanakkor hazai viszonylatban e területen még a beavatkozási pontok feltárása sem történt meg, rendkívül kevés empirikus ismerettel rendelkezünk a tanulási motiváció osztálytermi folyamatait tekintve, miközben számos területen problémát jeleznek diákjaink tanulási motivációját illetően a nemzetközi (pl. Artelt, Baumert, Julius-McElvany és Peschar, 2003; OECD, 2004) és a hazai vizsgálatok (pl. Csapó, 2000; Józsa, 2007).

Az elmúlt két évtizedben a célorientációs elméletként (goal orientation theory) vagy célelméletként (goal theory) említett megközelítés a tanulók motivációs jellemzői, a tanulási környezet, valamint a kognitív, az affektív és a viselkedési folyamatok között fennálló összefüggések tanulmányozásának egyik domináns elméleti keretévé vált (Kaplan és Maehr, 2007). Ma talán a legdinamikusabban fejlödö területét jelentik a célorientációs elmélet alapján folyó vizsgálatok a tanulási motiváció kutatásának. E konstruktum alkalmas lehet a tanulási motiváció pedagógiai célú befolyásolásának a korábbiaknál szilárdabb, empirikusan alátámasztott megalapozására, hiszen az elemzések hangsúlyos törekvése a tanuló és környezete közötti interakció feltárására.

Bár a tanulási motiváció kutatása egyre nagyobb teret kap a hazai neveléstudományi szakirodalomban (1. Józsa és Fejes, 2012), és a célorientációk oktatási folyamatban betöltött szerepét illetően is találhatunk utalásokat (Bacsa, 2008; Fülöp, 2001, 2008; Józsa, 2002, 2007; Molnár É., 2002; Réthyné, 2003; Szenczi, 2010b), a célorientációs megközelítés nem kellően hangsúlyos. Vagyis a nemzetközi szakirodalomban a tanulási motiváció fejlesztésével kapcsolatban e területen felhalmozódott tudás alkalmazása aligha valósulhatott meg eddig országunkban. Jelen munka e hiányosság enyhítésére vállalkozik, megteremtve a célelmélettel kapcsolatos eredmények alkalmazásának feltételeit az elméleti alapok áttekintésével, mérőeszközök létrehozásával, valamint néhány fontosabb összefüggés feltárásával.

A dolgozat a célorientációs elmélet kínálta kereteket felhasználva a tanulók motivációs jellemzőinek megismerése és az azokat befolyásoló környezeti faktorok közül néhány központi jelentőségű azonosítására vállalkozik felső tagozatos általános iskolások körében. Arra a kérdésre keressük a választ, hogy tanári magatartás és az osztálytermi társas környezet mely összetevőinek van központi szerepe a tanulási motiváció formálódásában. E cél eléréséhez nélkülözhetetlen egy olyan mérőeszközrendszer kidolgozására, amely alkalmas a célorientációs elmélet alapján az egyéni különbségek és a tanulási környezet sajátosságainak feltérképezésére. Így az említett kérdés megválaszolása mellett munkánk lényegi részét képezi két kérdőív kifejlesztése.

Az empírián alapuló, az osztálytermi gyakorlat során hasznosítható motivációs megoldások hiányoznak a hazai neveléstudományi szakirodalomból. A feltárt összefüggések jelentősen elörelendíthetik a lehetséges beavatkozási pontok számbavételét, majd olyan motívumfejlesztést támogató stratégiák kidolgozását, amelyek közvetlen hatást gyakorolhatnak a pedagógusok mindennapi munkájára, ezáltal 
diákjaink tanulási motivációjára, ezen keresztül pedig a tanítási-tanulási folyamat eredményességére. A megfelelő vizsgálati módszerek kidolgozása emellett jelentős előrelépést jelenhet a fejlesztő programok hatásának a korábbiaknál részletesebb kiértékeléséhez, illetve ezen keresztül olyan további - mind a tanulási motivációt, mind az ismeret, mind a képesség jellegü tudást célzó - fejlesztő programok tervezéséhez, amelyek a tanulási motiváció alakulására az empirikus eredmények felhasználásával az eddigieknél lényegesen jelentősebb figyelmet fordíthatnak. Összességében e kutatás nagymértékben elősegítheti azt a folyamatot, amelynek eredményeként a tanulási motiváció fejlesztése empirikusan megalapozott, tervszerüen végzett pedagógiai gyakorlattá válhat hazánkban.

Empirikus munkánk kontextusaként a matematika tárgyat választottuk, amely több okból is elönyös. Föként azért, mert a matematika a kevésbé kedvelt tantárgyak egyike (pl. Csapó, 2000; Csíkos, 2012a), miközben - kevés kivételtől eltekintve - a tankötelezettség kezdetétől a végéig a kötelezően tanulandó müveltségterületek közé tartozik, és éppen a vizsgált életkorban tapasztalható a legdrasztikusabb csökkenés a matematikához való viszonyban. Ezzel munkánk a felvázolt célok mellett közoktatásunk egy központi jelentőségü problémájának megoldásához is közelebb vihet. Emellett megemlítendő, hogy a nemzetközi szakirodalom által feltárt eredmények is elsősorban a matematikához füződnek, így a témakörben megtett első hazai lépésekhez mi is e tantárgyat választottuk. További praktikus okként megemlíthető, hogy a tantárgyak jelentős részének elnevezése az iskolák között nagymértékü változatosságot mutathat, ugyanakkor a matematika esetében ez talán kevésbé jellemzö, ami a kérdőívtételek megfogalmazása során jelentett előnyt.

A dolgozat keretében három empirikus vizsgálat eredményeit összegezzük, melyből az első kettő a tanulók motivációs jellemzőinek, valamint a tanulási környezet motivációs hatásának megismerésére alkalmas mérőeszközök kifejlesztésére irányult. A harmadik adatgyüjtés során a mérőeszköz továbbfejlesztésének szándéka ugyancsak megjelent, azonban az elsődleges cél az egyéni jellemzők és környezeti tényezők összefüggésének feltárása volt. Az első mérésünkben közel 600 tanuló vett részt 4-7. évfolyamon, a második adatgyüjtésünk során a mérőeszköz továbbfejlesztett változatát 4. és 5. évfolyamon körülbelül 300 tanuló töltötte ki, míg a harmadik adatfelvétel majdnem 900 tanuló részvételével történt 5-8. évfolyamon.

A disszertáció első fejezete a tanulási motiváció témakörébe nyújt bevezetést néhány alapfogalom és a fontosabb kutatási irányok áttekintésével, valamint a tanulási motivációnak a munkánk szempontjából központi jelentőségü kontextusfüggő sajátosságának ismertetésével. Az ezt követő fejezet a tanulási motiváció és a társas környezet viszonyát tárgyalja a legfontosabbnak vélt jelenségek megragadásán keresztül a családdal, az iskolával és a kulturális közeggel összefüggésben. A harmadik fejezet azokat a hazai és nemzetközi kutatási eredményeket foglalja össze, amelyek diákjaink tanulási motivációjáról és iskoláink motivációt befolyásoló jellemzőiről kínálnak empirikus vizsgálatunkhoz támpontként használható ismereteket. A negyedik fejezet a célorientációs elméletet, a tanulási motiváció kutatásának vizsgálatunk hátteréül választott megközelítését részletezi az alapfogalmaktól kezdve a teória fejlődésének legfontosabb állomásain át a tanulási teljesítménnyel összefüggő, valamint a tanulási környezet hatásával kapcsolatos kutatási eredményeken keresztül az elmélethez kötődő kutatásmódszertani kérdésekig. A sorban következő fejezet vizsgálatsorozatunk koncepcióját, így a célokat, kérdéseket, hipotéziseket, valamint a végrehajtás fontosabb részleteit ismerteti. A hatodik, hetedik, nyolcadik és kilencedik fejezet az empirikus vizsgálatok eredményeit tartalmazza. A hatodik és a hetedik a mérőeszköz-fejlesztés folyamatát mutatja be, a nyolcadik a felmért konstruktumok általános jellemzőiről 
tájékoztat, míg a kilencedikben elemezzük a vizsgált konstruktumok összefüggéseit. A munkát az összegzést, következtetéseket tartalmazó, valamint a további kutatási lehetőségeket kijelölő fejezet zárja.

A fejezetek közül néhány alapja korábban megjelent önálló vagy társzerzővel írt munka. Tanulmánykötet részeként jelent meg a társas környezet és a tanulási motiváció összefüggéséről szóló második fejezet (Józsa és Fejes, 2010), valamint a tanulóink és iskoláink motivációs jellemzőiről szóló harmadik fejezet egyes részei (Józsa és Fejes, 2012). A célorientációs elméletet tárgyaló fejezet néhány szakasza ugyancsak közlésre került egy könyvfejezet (Fejes, 2010b) és egy, a Magyar Pedagógia címü folyóiratban megjelent tanulmány (Fejes, 2011) keretében. A tanulói célok megismerését szolgáló kérdőív fejlesztésének részleteiről konferencia-elöadásokon (Fejes és Vigh, 2011, 2012) számoltunk be. 


\section{A TANULÁSI MOTIVÁCIÓ KUTATÁSÁNAK ELMÉLETI ALAPJAI}

E fejezetben a tanulási motiváció témakörével kapcsolatos fogalmak közül értelmezzük azokat, amelyekre munkánk során támaszkodni kívánunk. Ezen túl egy körképet vázolunk fel a tanulási motiváció vizsgálatának fontosabb irányairól. Tesszük ezt egyrészről azért, mert ennek áttekintése hozzájárulhat a tanulási motiváció komplex fogalmának értelmezéséhez, másrészről azért, hogy elhelyezhessük saját vizsgálatunkat e kutatási irányok között. Részletesen ismertetjük továbbá azt a kutatási megközelítést, amelyre munkánk leginkább épít. Emellett vizsgálatunk jelentőségét igyekszünk igazolni azzal, hogy rámutatunk a tanulási motiváció kutatásának jelentőségére.

\section{Alapfogalmak}

\section{Tanulási motiváció mint kutatási terület}

A tanulási motiváció kutatása arra a kérdésre keresi a választ, hogy miért tanulunk. Bár első ránézésre a miért tanulunk kérdés egyszerünek tünhet, az okok teljes feltérképezése egyetlen személy esetében is lehetetlen vállalkozásnak tűnik. Tanulási motivációnkban szerepet játszik többek között saját képességeink megítélése, az egyes tantárgyakhoz füződő viszonyunk, a tanuláshoz kapcsolódó rövidebb és hosszabb távú céljaink, emellett átélt sikereink és kudarcaink, valamint azok okainak megítélése, de fontos szerepe van alakulásában mind a családi, mind az iskolai társas környezetnek, valamint annak a kulturális közegnek, amelyben szocializálódtunk. A felsorolást hosszan folytathatnánk, de talán e néhány példából is kitetszik, hogy a tanulási motiváció kifejezése egy szerteágazó, nehezen megragadható jelenségkörre, illetve kutatási területre utal. Az előzőek alapján talán nem meglepő, hogy nem áll rendelkezésünkre egyetlen olyan elmélet, amely a tanuláshoz kötődő motivációs jelenségekre átfogó magyarázatot kínálna, így természetesen a tanulási motiváció széles körben elfogadott meghatározásával sem rendelkezünk (Elliot és Zahn, 2008; Józsa, 2007). Terminológiai eklekticizmus, párhuzamosan futó elméletek sokasága jellemzi a motiváció tanulmányozását (Murphy és Alexander, 2000; Réthyné, 2003; Schunk, 2000), a témakörhöz kapcsolódó fogalmak többsége tekintetében legfeljebb adott kutatási paradigmán belül találhatunk valamiféle konszenzust (Józsa, 2007). A jelentősebb elméletekről magyarul Biehler és Snowman (1986/1994), Good és Brophy (2008), Józsa (2007), Réthyné (2003), Szabó (2004), valamint Szenczi (2010b) munkája nyújt áttekintését.

A tanulási motiváció olyan elméleti konstruktumnak tekinthető, amelynek számos összetevője van, azonban az összetevők teljes listáját valószínűleg lehetetlen feltérképezni. Legfeljebb az éppen aktuális, népszerünek tetsző elméleti megközelítéseket sorolhatnánk fel, mint ahogy ezt általában a fogalmat körüljáró kurrens lexikonok szócikkeiben teszik (pl. Bempechat és Mirny, 2005; Elliot és Zahn, 2008; McInerney, 2012; Oka, 2005; Usher és Morris, 2012). A fogalom egy önkényesen kiválasztott meghatározása helyett Maehr és Meyer (1997) operacionalizációs kísérletét ismertetjük, amely talán a legkifejezőbben járja körül a tanulási motiváció jelentését. A szerzők azoknak az általános jellemzőknek, fontosabb változóknak az összegyüjtésére vállalkoztak, amelyeket az elméleti megközelítésektől függetlenül a tanulási motiváció vizsgálatában gyakran alkalmaznak, és e változók mindegyikéhez szemléletes példát rendeltek (1. táblázat). 
1. táblázat. A személyes befektetés dimenziói (Maehr és Meyer, 1997, 374-375. o.)

\begin{tabular}{|c|c|c|}
\hline Dimenzió & Változó & Példa \\
\hline \multirow[t]{3}{*}{ Irány } & Választás/preferencia & $\begin{array}{l}\text { A harmadikos Andi hazamegy az iskolából, és a házi feladat elkészítése, a zongoragyakorlatok vagy a barátokkal való játék helyett } \\
\text { inkább a TV nézést választja. }\end{array}$ \\
\hline & Kitartás & $\begin{array}{l}\text { A tízéves Dávid este hét órakor elöször } 5 \text { percet szán egy magyar tantárgyhoz kapcsoló feladatra, majd tovább dolgozik a } \\
\text { modellautóján. Tíz órakor úgy kell „,beparancsolni” az ágyába. }\end{array}$ \\
\hline & Folyamatosság & $\begin{array}{l}\text { A negyedikes Márk a kéthetente tartott könyvtári foglalkozáson kiválaszt egy könyvet, amit elhoz az osztályterembe is, és elkezdi } \\
\text { olvasni. Amikor a tanító rászól, félreteszi a könyvet, és a matekkal foglalkozik. Hazaviszi a könyvet, és, ahogy az édesanyja } \\
\text { fogalmaz, „le se tudja tenni”. }\end{array}$ \\
\hline \multirow[t]{2}{*}{ Erősség } & $\begin{array}{l}\text { Itemek/problémák } \\
\text { megoldási } \\
\text { kísérleteinek, } \\
\text { megoldásainak száma }\end{array}$ & $\begin{array}{l}\text { Tibinek megmutatják a filctoll használatát a délelötti óvodai foglalkozáson. Ezután } 20 \text { perc alatt tíz különbözö képet sikerül } \\
\text { kiszíneznie. }\end{array}$ \\
\hline & $\begin{array}{l}\text { Aktivitás } \\
\text { megfigyelhető szintje }\end{array}$ & $\begin{array}{l}\text { Editet a szobájába küldik, hogy készítse el a házi feladatát. Edit lefekszik az ágyára a könyveivel, és } 20 \text { percen keresztül többnyire a } \\
\text { plafont nézi, majd elalszik. }\end{array}$ \\
\hline \multirow[t]{5}{*}{ Minőség } & Stratégiai tanulás & $\begin{array}{l}\text { A 10. osztály azt a feladatot kapta, hogy írjon fogalmazást egy híres tudósról. Egy nappal a feladat kiadása után Péter már néhány } \\
\text { lehetséges könyvcímet kért a tanártól, a könyvtári foglalkozás során pedig további könyveket keresett. Később számos könyvbe } \\
\text { belenézett, elkezdett olvasni, majd nekilátott a fogalmazás megírásának, egy héttel a leadási határidő előtt. }\end{array}$ \\
\hline & & $\begin{array}{l}\text { Egy nappal a leadási határidő előtt Norbert felhívja a könyvtárat, és segítséget kér. Számos forrást kap, amelyeket mind elolvas } \\
\text { elejétől a végéig. A leadás előtti nap, este hét órakor még nem rendelkezik elég információval ahhoz, hogy meg tudja írni a } \\
\text { fogalmazást. Kétségbeesetten hívja fel föiskolás bátyját, hogy megkérdezze, van-e valami régi fogalmazása, amelyet „mintaként” } \\
\text { használhatna. }\end{array}$ \\
\hline & $\begin{array}{l}\text { Értelemgazdag } \\
\text { tanulás }\end{array}$ & $\begin{array}{l}\text { A technikatanár minden ötödikes osztályban azt kéri a tanulóktól, hogy készítsenek el önállóan egy projektet. Vali hetedikes } \\
\text { nővérétől érdeklődik, hogy ő mivel készült két évvel korábban. Nővére elbeszélése alapján Vali hasonló típusú információkat gyüjt, } \\
\text { posztert készít belölük, hasonlóan ahhoz, ahogy a nővére is tette. }\end{array}$ \\
\hline & & $\begin{array}{l}\text { Miután a technika tanár az elektromosságról tart órát, Bea kíváncsi lesz, hogy a víz segítségével hogyan lehet elektromos áramot } \\
\text { elöállítani. Belekezd egy vízimalom építésébe, és az apukája segítségével készít egy generátort. A mérete miatt a kész modellt ugyan } \\
\text { nem tudja elvinni az iskolában, de végül is Beának sikerül egy olyan vízimalmot építenie, ami elektromos áramot termel. }\end{array}$ \\
\hline & Vállalkozó szellem & $\begin{array}{l}\text { László másodéves a mérnöki karon, amikor rájön, hogy eddig többnyire matekot és fizikát tanult, és a humán tudományokkal eddig } \\
\text { kevéssé foglalkozott. Ezért az egyik félévben úgy dönt, finn nyelvet és irodalmat fog tanulni, mit sem törődve az átlagával. }\end{array}$ \\
\hline
\end{tabular}

Megj.: a személyes befektetés kifejezést a tanulási motiváció szinonímájaként használják a szerzők; a példákat a fordítás során lokalizáltuk. 


\section{Motivum, motiváció, motiválás, motívumfejlesztés}

A motivációkutatás irányainak áttekintése elött kitérünk néhány további kifejezés - a motívum, a motiváció, a motiválás és a motívumfejlesztés - értelmezésére, amelyekre munkánk a későbbiekben támaszkodni kíván. E fogalmak ismertetése során a hazai szakirodalomban elterjedt értelmezésekre támaszkodunk. A motiválás és a motívumfejlesztés kifejezések esetében nem is tehetnénk másként, mivel nem találunk hasonló értelemben széles körben használt kifejezéseket a nemzetközi szakirodalomban.

Motívumok alatt a viselkedés viszonyítási pontjaiként funkcionáló azon személyiség-összetevőket értjük, amelyek alapján tudatos vagy tudattalan döntést hozunk egy viselkedés megkezdéséről, folytatásáról. Az emberi motívumok egy része már az élet legkorábbi szakaszában, az idegrendszer kevéssé fejlett állapotában is müködik, ilyenek például az alapvető biológiai motívumok, mint az éhség, szomjúság, vagy az értelmi fejlődésben kulcsfontosságú elsajátítási motívumok. Az egyén élete során szerzett tapasztalatai nyomán a motívumok változnak, fejlödnek, vagyis a motívumokat is tanuljuk. Ez részben az öröklött alapú motívumok változását (fejlödést, elsorvadását), részben pedig a motívumkészlet további gyarapodását, szerveződését, hierarchizálódását jelenti (Nagy, 2000). Életünk során szerzett speciális tapasztalatok eredményeként a motívumok bizonyos köre a direkt iskolai tanuláshoz kapcsolódik, ezeket nevezzük tanulási motívumoknak (Józsa, 2007). Tanulási motívumok - mint a tanulással kapcsolatos döntések alapjai - például a célorientációk, a tanulási énkép vagy a tantárgyi attitüdök.

A motiváció kifejezést a viselkedés hátterében álló pszichológiai folyamat jelölésére is használják (pl. Atkinson, Atkinson, Smith és Bem, 1993/1994; Gage és Berliner, 1991; Nagy, 2001), ugyanakkor e folyamat meghatározására ritkán tesznek kísérletet. Nagy József (2001) egy olyan folyamatként írja le a motivációt, amely négy fázisra bontható. Az első fázist érdekértékelésre és érdekeltségi döntésre késztetésnek nevezi, amely a motiváció kiinduló feltételének tekinthető, és a külső/belső környezet állapotának vagy állapotváltozásának érzékeléséhez köthető. A második fázisban megtörténik az érdekértékelés és érdekeltségi döntés, mely során eldöl, hogyan érinti az egyént az észlelt állapot, állapotváltozás. A harmadik fázisban az érdekeltségi jelzés történik meg az érzelmek, majd a negyedikben az aktivitásra késztetés az arousal által. A leírt folyamatban a motívumok a második fázishoz kapcsolódóan az érdekértékelés és érdekeltségi döntés viszonyítási pontjaiként értelmezhetők.

A pedagógusok számára a tanulási motiváció kapcsán elsősorban olyan kérdések merülnek fel, mint, hogyan lehet rávenni a tanulókat egy feladat elvégzésre, hogyan lehet adott tanórán lekötni figyelmüket, illetve érdeklődésüket felkelteni egy-egy téma iránt. A tanulási motiváció e megközelítésére Józsa (2002) a motiválás elnevezést javasolja. A motiválás kifejezése így a pedagógusok körében elterjedt gyakorlatorientált megközelítését jelenti. Megjegyezzük, hogy e tekintetben kevés hazai empirikus kutatás áll rendelkezésünkre, ugyanakkor ezek (Réthyné, 1999, 2001b, 2003; Szenczi, 2011), illetve a különböző tantárgyak tanításának módszertanával foglalkozó munkák hátterében kirajzolódó kép (pl. Farsang, 1993; Pintér, 2009; Revákné, 2002; Veidner, 2003) véleményünk szerint indokolja e szóhasználatot. A motívum meghatározását figyelembe véve a motiválás azokat a tevékenységeket jelöli, amelyek elsősorban a tanulók meglévő tanulási motívumainak mozgósítását célozzák.

A neveléstudomány nézőpontjából a tanulási motívumok elsősorban a személyiségfejlődés céljaiként jelennek meg, így a hangsúly a motívumok müködtetéséről a motívumok elsajátításának segítésére helyeződik át. Ezt a megközelítést fejezi ki a hazai szakirodalomban a Nagy József (2000) által meghonosított motívumfejlesztés kifejezés. Az előzőek alapján a motívumfejlesztés a 
meglévő motívumkészlet további gyarapodásának, szerveződésének, hierarchizálódásának segítését értjük.

Természetesen a motiválás és motívumfejlesztés között nem húzható éles határ, hiszen a rövidebb távra koncentráló motiválás általában hozzájárul a megfelelő tanulási motívumok elsajátításához. Például adott tantárgy esetében a játékos tanórák vagy a sorozatos sikerélmények minden bizonnyal a tantárgy és a tanulás iránti attitüdöt is kedvezően befolyásolják. Ugyanakkor elképzelhető, hogy a rövid távon kedvező motiválás hatása hosszú távon kedvezőtlen következményekkel jár, és megfordítva, ami a motívumfejlesztés szempontjából előnyös, rövid távon a motiváció csökkenéséhez vezethet. Az előbbi klasszikus példája a jó osztályzatokért járó pénzjutalom lehet (1. Németh, 1998), míg utóbbié egy sikertelen dolgozat utáni fejlesztő célzatú kritika (1. Körössy, 1997). A motiválás és a motívumfejlesztés megkülönböztetésének hátterében nyilvánvalóan a tanulási motiváció köznapi és tudományos értelmezésének kettőssége is tetten érhető.

\section{A tanulási motiváció kutatásának fejlődési irányai}

Habár a tanulási motiváció fogalma nehezen definiálható, elméleti kereteit illetően számos ponton konszenzus alakult ki, amelyeket a motivációkutatás fejlődési irányai szemléletesen kirajzolnak. A tanulási motiváció jelentésének megragadásához így további segítséget kínálhat a napjainkban látható fejlődési tendenciák felvázolása.

A tanulási motiváció kutatásában az utóbbi két évtizedben végbement változásokra több szempontból is használható az integráció kifejezés. Egyrészről különböző tudományterületek, másrészről korábban különálló motivációs elméletek kapcsolódnak össze egyre több ponton. A személyiség kognitív és nem kognitív tényezői minden kétséget kizáróan átszövik egymást, azonban a „hűvösnek” nevezett kognitív és „forróként” is emlegetett nem kognitív kutatási irányok csak a közelmúltban találkoztak. A tanulási motívumok és a kognitív tényezők egymást befolyásoló hatásának, finomszerkezetének feltárása az oktatástudomány egyik alapvető fejlődési irányaként jelölhető meg (Pintrich, 2003). Számos kutatás támasztja alá, hogy a tanulással összefüggésben az érzelmek jelentös hatást gyakorolnak mind a kognitív, mind a motivációs folyamatokra (pl. Dai és Sternberg, 2004; Schutz és Pekrun, 2007), így az integráció e területek között is egyre szorosabb. Bár az emberi motiváció biológiai hátterének feltárása nem új keletủ kutatási irány, a tanulási motívumok tekintetében eddig kevéssé vizsgált terület volt. A hozzávetőleg egy évtizede megerösödő neurológiai megközelítésű kutatások jelentőségét szemléletesen mutatja, hogy bizonyos szempontból már cáfolattal szolgálnak széles körben elfogadott motivációs modellek létezését tekintve (1. Fülöp, 2010b; Marr, 2005).

A tanulási motiváció vizsgálatának kezdetén a teljesítménymotivált viselkedést elsősorban a sikerorientált-kudarckerülő dichotómia mentén írták le. A tanulási motiváció több elméletében is jellemző volt az ellentétpárok felállítása. Többek között az önjutalmazó (intrinzik) motívumok szembeállítása a külső környezetből érkező (extrinzik) ösztönzőkkel, motívumokkal, majd ehhez hasonlóan az elsajátítási és a viszonyító célok megkülönböztetése és szembeállítása következett. E szembeállításokat sok esetben jellemezte az, hogy az egyik oldalt pozitívnak, fejlesztendőnek tekintették, míg a másik aspektust károsnak, adott esetben rombolónak. Fülöp Márta (2008, 2010b) találóan a „Szépség és a Szörnyeteg” analógiával illeti a jelenséget. Az utóbbi évek nemzetközi kutatásait ugyanakkor alapvetően új szemléletmód jellemzi, a korábbi dichotóm megközelítéseket kezdik felváltani a motívumok ötvöződésére, a különböző 
motívumok egymásra ható müködésének, fejlődésének integrált vizsgálatára irányuló kutatások. Egyre nyilvánvalóbbá válik, hogy a fejlett tanulási motivációt nem egy-egy motívum domináns volta adja, hanem egy többkomponensü, optimálisan fejlett motívumrendszer, mely lehetővé teszi a környezeti feltételekhez, a tanulási környezethez való adaptív alkalmazkodást (Józsa, 2007).

A kognitív és affektív oldal áthidalásaként értelmezhető a „készség és akarat” fúziójaként is emlegetett (McCombs és Marzano, 1990; Pintrich és DeGroot, 1990) önszabályozó tanulás konstruktumának megjelenése is, amely a tanulási motivációt és a tanulási stratégiákat foglalja koherens keretbe. Bár az elméleti keretek tisztázása még korántsem fejeződött be, a motiváció központi jelentősége az önszabályozó tanulásban nem kérdéses, a legtöbb megközelítés alapvető szerepet tulajdonít a tanulási hajtóerőnek, többek között a célorientációknak (D. Molnár, 2012). Az önszabályozó tanulás további nézőponttal bővítette a tanulási motiváció értelmezését, mivel a motiváció önszabályozást befolyásoló hatásának elemzésén túl megjelent az önszabályozó motiváció fogalma, vizsgálata, amely arra hívja fel a figyelmet, hogy a motiváció dinamikus öndetermináló folyamat, nem pusztán a külső és belső tényezőkre adott válaszok együttese (Réthyné, 2001a).

A kogníció és motiváció viszonyának újrafogalmazásával a motívumok tanulásának folyamata is egyre inkább előtérbe kerül. Ebből az irányzatból kiemelkedik az elsajátítási motívumok felfedezése. Az elsajátítási motívumok veleszületett alapokkal bírnak, már csecsemőkorban is a fejlődés meghatározó elemei, feltételezik, hogy ezek differenciálódásával jön létre számos további motívum (Morgan és Yang, 1995). Vagyis az elsajátítási motívumok nemcsak csecsemőkorban jelentik a tanulás bázisát, hanem óvodás, iskoláskorú gyermekeknél, sőt, felnőtteknél is. Példaként elég a számlálást, olvasást élvezettel elsajátító gyermekekre, a szakmájukat mesterfokon müvelőkre gondolnunk. E készségek esetében azonban a müködés nem veleszületetten meghatározott, vagyis a pedagógia eszközeivel segíthető (Józsa, 2007).

További jellemző a társas tényezők szerepének felértékelődése. Míg a klasszikus elméletek a motívumok müködését az egyén személyes jellemzőjeként kezelték, napjaink megközelítései arra mutatnak rá, hogy a motívumok müködése nem ragadható ki abból a környezetböl, amelyben a tanulás zajlik (Józsa, 2007; Réthyné, 2001a; Rueda és Moll, 1999). A motiváció szociokulturális megközelítése szerint a társas interakcióknak, illetve a kulturálisan megalapozott tudásnak kiemelkedő jelentősége van a tanulási motívumok fejlődésében. Az eltérő szociális, kulturális közeg eredményeként jellegzetes különbségek alakulhatnak ki a tanulók motívumrendszerei között (Hickey, 2003; Rueda és Moll, 1999).

A kogníció és motiváció integrációjának, a kontextusfüggőség felismerésének, valamint a motivációs elméletek összekapcsolódásának egyidejü megjelenéseként értelmezhető a tanulási motiváció területspecifikus vizsgálata, amely adott tantrágy vagy képesség esetében több motivációs konstruktum megismerésére vállalkozik. A hazai szakirodalomban e megközelítésre Szenczi (2010a, 2010b) munkái kínálnak példát az olvasáshoz kötődően, míg a nemzetközi szakirodalomban többek között a PISA mérések követik ezt az irányvonalat (OECD, 2004, 2007, 2010b).

\section{A tanulási motiváció kontextusfüggő jellege}

\section{A kontextus megjelenése az oktatástudományban}

A kontextus ma már a társadalomtudományok számos területének gyakran használt kifejezése, de beágyazottsága talán a nyelvészeti szakirodalomban a legmélyebb. A 
kontextus a kommunikáció szempontjából azt fejezi ki, hogy a megnyilatkozások körülményei alapvetően meghatározhatják annak értelmezési lehetőségeit (Tátrai, 2004). A tanulás fogalmának újraértelmezésében ugyancsak központi szerepet kapnak a tanulás körülményei, a nyelvészetben használatos kontextus jelentésének analógiájára azt mondhatjuk, hogy a tanulás - elsősorban társas - körülményei alapvetően meghatározhatják annak végtermékét, a tudást (1. D. Molnár, 2010; De Corte, 2001; Nahalka, 2002).

A tanulás kapcsán a társas környezet szerepére már a múlt század első felében felhívták Vigotszkij (magyarul: 1967, 1971) munkái a figyelmet, ennek ellenére az oktatáskutatásban e terület felé nem irányult különösebb érdeklődés a kilencvenes évek második feléig. Körülbelül ekkora tehetők azok a változások, amit kontextuális fordulatként is emlegetnek a szakirodalomban. E kifejezés azt jelzi, hogy a környezeti tényezőknek a korábbiaknál lényegesen nagyobb szerepet tulajdonítanak. Számos kutatás központi elemévé vált annak vizsgálata, hogy a kontextusnak, különösen a társas környezetnek milyen szerepe van a tanulásban. A kontextus iránti érdeklődés a kognitív fejlődés tanulmányozásának azt a trendjét tükrözi, mely a tanulás szociális jellegét hangsúlyozza, ugyanakkor hozzájárult a szemléletváltáshoz az interdiszciplináris megközelítésmódok erősödése is (Anderman és Anderman, 2000).

A kontextuális fordulat hatására a kontextus mellett a hasonló értelemben használt tanulási környezet fogalma is egyre nagyobb teret kapott az oktatáskutatásban, ezt jelzi például a Learning Environments Research folyóirat 1998-as indulása. A gyakran hasonló értelemben használt iskolaethosz, iskolai klíma, osztálytermi klíma, osztálytermi kultúra és tanulási környezet kifejezések olyan gyüjtőfogalmak, amelyek holisztikusan, a tanuló környezetének pszichológiai, társas, érzelmi, szervezési, vezetési és tárgyi jellemzőit egyaránt meg kívánják jeleníteni, hangsúlyozva, hogy ezek dinamikus kapcsolatban állnak (pl. Adelman és Taylor, 2005; Babad, 2009; Kozéki, 1991 Tímár, 1994). A pszichológiában használatos ökológiai megközelítés ugyancsak hasonló nézőpontot fejez ki (pl. Szitó, 1991). E megközelítések az oktatással kapcsolatban nem új keletűek, elég Lewin, Lippitt és White (1939) sokat idézett - az autokratikus, a demokratikus és a laissez-faire vezetési stílus tanulókra gyakorolt hatását vizsgáló - kísérletét megemlítenünk, melyet egyértelműen e kutatási paradigmába illesztenek (pl. Babad, 2009).

A tanulás újraértelmezését érintő változások hatására a kontextus és a tanulási környezet kifejezések az oktatáskutatás központi fogalmaivá váltak. Egyre gyakrabban használják ezeket, nem ritkán felcserélhető fogalmakként, ennek ellenére széles körben elfogadott definíciót nem találunk egyik esetében sem, jelentésük általában implicit módon jelenik meg a különböző munkákban. A továbbiakban a kontextus és a tanulási környezet kifejezéseket szinonímaként használjuk.

\section{A kontextuális nézōpont a tanulási motiváció kutatásában}

A környezeti faktorok, a kontextus szerepének felértékelödése a motiváció kutatásában is megindult az ezredforduló környékén (pl. Urdan, 1999; Volet és Järvelä, 2001), és több lényeges változást indított útjára. Ezek közül talán a legfontosabb, hogy a motiváció vizsgálatának elméleti iránya egyre inkább az osztálytermi folyamatok tanulmányozása felé látszik elmozdulni. Pintrich (2003) Stokes (1997) tipológiáját használja, hogy az alapkutatást és az alkalmazott kutatást szembeállító paradigmát meghaladva, differenciáltabb képet nyújtson a motivációkutatás fejlődéséről. A tipológia két szempont, az elméleti és a gyakorlati irányultság egyidejü figyelembe vétele alapján négy kategóriába sorolja a kutatásokat. Stokes a kategóriák közül három elnevezéséhez egy-egy híres, munkásságával az adott kategóriát példázó tudóst is 
hozzárendelt (2. táblázat). E megközelítést és fogalomhasználatot figyelembe véve azt mondhatjuk, hogy a motiváció tanulmányozását hagyományosan az alapkutatás típusa uralta, miközben az oktatás gyakorlati világában az alapkutatásokhoz alig kapcsolódó alkalmazott kutatások jelentek meg. Kiváló példa lehet erre Keller (1987) számítógéppel támogatott tanulási környezetek hatásvizsgálata céljából kifejlesztett modelljének széleskörü alkalmazása és számos továbbfejlesztése. A kontextuális fordulat e két irány, az alapkutatás és az alkalmazott kutatás kapcsolatának erösödését eredményezi, hiszen a kontextuális nézőpont rámutat az általánosíthatóság korlátozottságára, az elméletek empirikus alátámasztásának szükségességére eltérő tanulási környezetekben, ezzel a használatorientált alapkutatást ösztönzi. Ennek eredményeképpen az empirikus forrásokból származó ismereteink rendkívüli sebességgel bővülnek a motivációkutatás területén, megalapozva ezzel a tanulási motiváció fejlesztésére irányuló beavatkozások lehetőségét is.

2. táblázat. A motivációtudomány különbözö típusú kutatásai (Pintrich, 2003, 669. o.)

\begin{tabular}{|c|c|c|c|c|}
\hline & $\begin{array}{c}\text { Alapkutatás } \\
\text { (Bohr negyed) }\end{array}$ & $\begin{array}{c}\text { Használatorientált } \\
\text { alapkutatás } \\
\text { (Pasteur negyed) }\end{array}$ & Címke nélküli & $\begin{array}{l}\text { Alkalmazott } \\
\text { kutatás } \\
\text { (Edison } \\
\text { negyed) }\end{array}$ \\
\hline $\begin{array}{l}\text { Kutatási } \\
\text { cél: } \\
\text { tudományos } \\
\text { megértés }\end{array}$ & Magas & Magas & Alacsony & Alacsony \\
\hline $\begin{array}{l}\text { Kutatási } \\
\text { cél: } \\
\text { gyakorlati } \\
\text { hasznosság } \\
\end{array}$ & Alacsony & Magas & Alacsony & Magas \\
\hline $\begin{array}{l}\text { Kutatási } \\
\text { példák }\end{array}$ & $\begin{array}{l}\text { A motiváció } \\
\text { pszichológiai } \\
\text { mechanizmu- } \\
\text { sai; biológiai } \\
\text { motívumok és } \\
\text { tudattalan } \\
\text { folyamatok } \\
\text { szerepe }\end{array}$ & $\begin{array}{l}\text { Elméleti meg- } \\
\text { alapozottságú } \\
\text { dizájn kísérletek } \\
\text { és beavatkozások; } \\
\text { longitudinális } \\
\text { vizsgálatok a } \\
\text { kontextus } \\
\text { motivációs } \\
\text { konstruktumok } \\
\text { fejlődésében } \\
\text { betöltött } \\
\text { szerepének } \\
\text { feltárására }\end{array}$ & $\begin{array}{l}\text { A módszertan } \\
\text { fejlesztése } \\
\text { céljából } \\
\text { végrehajtott } \\
\text { kutatások }\end{array}$ & $\begin{array}{l}\text { Motivációt } \\
\text { erősítő } \\
\text { beavatkozás- } \\
\text { ok, technikák } \\
\text { és tantervek } \\
\text { tesztelése és } \\
\text { fejlesztése }\end{array}$ \\
\hline
\end{tabular}

Annak ellenére, hogy a kontextus jelentőségével a motivációkutatás területén egyetértés mutatkozik, a tanulási környezetek motivációs szempontú vizsgálata számos kihívással küzd. Anderman és Anderman (2000) ezek közül két problémát tekint alapvető jelentőségünek: (1) a környezet komplexitásának megragadását, illetve azon komponensek azonosítása, amelyek központi szerepet játszanak a tanulási motivációban; valamint (2) a kontextus egyéni interpretációjának problémáját.

A kontextus motivációs hatásának analizálásakor az egyes szerzők eltérő összetevőkre fókuszálnak. Ryan (2000) kutatásának alapja például a kortárscsoport, míg Turner és Meyer (2000) az osztályteremre koncentrál, habár mindkét tanulmány 
tulajdonképpen a kortársak szerepét hangsúlyozza. A tanár általában a szociális környezet kiemelt aktoraként jelenik meg, aki a tanulási környezet egészét jelentősen befolyásolhatja (Wentzel, 1998). Egyes kutatók az iskola egészének motivációs hatására helyezik a hangsúlyt (Maehr és Midgley, 1991), de megjelenik kontextusként a szocioökonómiai státusz (pl. Murdock, 2000) és a kultúra is (Rueda és Moll, 1999). A felsorolt megközelítések ötvöződnek is, például Strigler, Gallimore és Hiebert (2000) az osztálytermi környezetet kultúrközi nézöpontból vizsgálja, de a kontextus összetevőinek rendszerezésére is születtek modellek (pl. Gurtner, Monnard és Genoud, 2001; Jacobs és Osgood, 2002; Turner és Patrick, 2008; Volet, 2001). E néhány példa is kiválóan szemlélteti a konszenzus hiányát a kontextus lényeges aspektusait illetően.

A következő lényeges probléma, hogy a kontextus interpretációja az egyének számára különböző lehet. Ez mindenekelőtt annak a kérdését veti fel, hogy kinek a szemszögéből, a tanuló, a tanár vagy az „objektív” kutató nézőpontjából gyüjtsünk információt. Az eddigi kutatások egyértelműen a tanulói nézőpontra épülnek, az empirikus kutatások szerint a motivációs jellemzők a tanulók saját kontextusra vonatkozó interpretációjával állnak a legszorosabb kapcsolatban, ugyanakkor a pedagógusokéval és a megfigyelésre épülö adatgyüjtésekkel is kimutatható összefüggés (Anderman és Anderman, 2000; Järvelä és Volet, 2004).

A kontextus egyéni értelmezésének következménye, hogy a környezeti feltételek és a tanulás eredményessége közötti kapcsolat közvetett, azaz a tanulók észlelése, egyéni interpretációi által közvetített. Így a tanulók affektív különbségei miatt az azonos környezet is eltérő hatásokat válthat ki (Järvelä és Niemivirta, 1999). Ez további kérdéseket vet fel az egyéni észlelést, interpretációt befolyásoló tényezőkkel kapcsolatban. Dermitzaki és Efklides (2001) például az életkor és a nem szerepét vizsgálja, Turner (2001) pedig a korábbi tapasztalatok hatását elemzi. Ugyanakkor az osztálytermi környezet észlelésének osztályok közötti és osztályokon belüli összevetésének vizsgálataiból egyértelműen kiderül, hogy az azonos osztályban tanulók észlelésében felfedezhetők bizonyos hasonlóságok (pl. Urdan, 2004c, Wolters, 2004). Ez azt jelenti, hogy bár léteznek egyéni különbségek a tanulási környezet észlelésében, léteznek ugyanakkor olyan elemek is, amelyek megítélésében bizonyos egyetértés mutatkozik osztályok szerint. A tanulási motiváció befolyásolása tekintetében talán a legfontosabb kérdések, hogy a tanulási környezet mely összetevőit látják hasonlóan, és melyeket eltérően a tanulók, illetve milyen szerepe van a pedagógusnak e különbségek kialakulásában.

A kontextus nézőpontja egy módszertani megújulást is elindított a motivációkutatás területén, ami a kérdőíves adatgyüjtés dominanciáját egyértelmüen megtörte. Ennek egyik oka, hogy ha a tanulók egyéni interpretációi lényegesen különbözhetnek, akkor tulajdonképpen nem is tudhatjuk, hogy valójában mi történik a tanteremben. A probléma megoldásának egyik lehetősége a több forrásból származó adatgyüjtés, amely esetében a különböző forrásból származó információk összeillesztése további módszertani kihívásként jelentkezik (Anderman és Anderman, 2000). Emellett a tanulási szituációk lényegesen eltérő interpretációinak sokféleségét kérdöívek segítségével korlátozottan lehetséges csak megragadni (Dowson és McInerney, 2003; Patrick és Ryan, 2008). E változások a tanulási motiváció kvantitatív és kvalitatív tanulmányozásának összefüzése irányába mutatnak, így a kérdőívek mellett, általában azokkal kombinálva, egyre gyakrabban alkalmazzák az osztálytermi megfigyeléseket (pl. Lemos és Gonçalves, 2004; Lewalter és Krapp, 2004) és az interjú módszerét (pl. Järvelä és Salovaara, 2004; Urdan, 2004c).

A tanulók szubjektív észlelésének figyelembe vétele továbbá annak kérdését is felveti, hogy az egyéni interpretációkat milyen tényezők befolyásolják, melyek köthetők 
az adott szituációhoz, illetve melyek azok, amelyeket a személyiség stabilabb összetevőjeként értelmezhetünk, azaz különböző szituációkban bizonyos mértékü konzisztenciát mutatnak. E kérdések átvezetnek a tanulási motiváció vonás és állapot jellegével kapcsolatos problematikához. Nyilvánvaló, hogy a környezet és a motiváció között a tanulási folyamat során dinamikus interakció zajlik, a hagyományos megközelítés azonban a motiváció vonás jellegét hangsúlyozza, vagyis a körülményektől (pl. tantárgy, osztályközösség) viszonylag független konstruktumnak tekinti. E megközelítés, illetve az ehhez kapcsolható mérőeszközök kevéssé alkalmasak a tanulási folyamat során lejátszódó kölcsönhatások vizsgálatára. Például amikor a tanulási környezetre vonatkozó információkat kérnek a tanulóktól kérdőívek segítségével, akkor nem világos, hogy a válaszadáskor az osztálytermi történések, tevékenységek mely elemére, epizódjára gondolnak a válaszadók (Maehr és Meyer, 1997). A környezet és a motiváció közötti folyamatos interakció feltárásához elengedhetetlen, hogy a motiváció az eddigieknél jóval több ponton nyomon követhető legyen (Turner és Patrick, 2008).

A kvalitatív metodológia terjedése mellett új statisztikai eljárások is megjelentek a kontextus motivációs szempontú hatásának megismerését vizsgáló munkákban. Ezek közül a hierarchikus lineáris modellek alkalmazása érdemel külön említést, amelyek segítségével lehetővé válik, hogy a tanulási környezet egyéni interpretációit több szinten vizsgálják, vagyis külön kezeljék például a tanulók, az osztályok és az iskolák szintjére vonatkozó változókat. Így többek között annak a kérdésnek a megválaszolásában lehet kulcsfontosságú szerepe, hogy a tanulási környezet észlelésének mely elemeit illetően léteznek hasonlóságok a tanulói közösségek különböző egységein belül. A hagyományosan alkalmazott statisztikai megoldások egyszerüen az adott osztályba járó tanulók véleményét átlagolják, ezek a tanulói interpretációk azonban nem függetlenek az adott osztályon belül, így nehezen fogalmazhatók meg általánosítható következtetések, illetve javaslatok a motívumfejlesztés tekintetében. Kellően nagy minta esetében azonban a tanulóközösségek jellemzői kontrolálhatók, így világossá válhatnak például az azonos osztályban, az azonos iskolában vagy az azonos pedagógusnál tanulók véleményei közötti hasonlóságok, és a tanulási környezet egyéni értelmezései kezelhetőbbé válnak (Miller és Murdock, 2007). Magyarul Tóth és Székely (2011) munkája kínál áttekintést a hierarchikus lineáris modellek pedagógiai alkalmazásának lehetőségeiről.

Számos kutató véli úgy, hogy a felsorolt kihívások leküzdését, azaz a tanulási motiváció kontextuális jellemzőinek tanulmányozását leginkább a dizájn kísérletek segíthetik elő (pl. Järvelä és Volet, 2004; Pintrich, 2003; Urdan, 2010b). E kutatási megközelítés a 90-es évek elején jelent meg, felismerve a laboratóriumi körülmények között végzett oktatási kísérletek korlátait. A dizájn kísérleteket valós oktatási szituációkban, számos függő változó mellett, egy rugalmas folyamat keretében, a tanulási környezet holisztikus megközelítésével végezik azzal a céllal, hogy egyszerre érjenek el erőlelépést az alapkutatás és az oktatás hatékonyságának növelése területén. $\mathrm{E}$ kísérletek általában a pedagógusok és a kutatók szoros együttmüködésén alapulnak (1. Collins, Joseph és Bielaczyc, 2004; Schoenfeld, 2006). Magyarul De Corte (2001), Csíkos (2012b) és Marton (2004a, 2004b) munkáiban találhatunk leírást e kutatási megközelítésröl.

\section{A kontextuális nézópont hatása az osztálytermi gyakorlatra}

Bár rohamosan növekszik a tanulási motiváció kutatásának fejlödése következtében az iskolai gyakorlat szempontjából is hasznosítható eredmények köre, ezek tényleges átültetése az osztálytermi gyakorlatba számos nehézségbe ütközik. Sokat tudunk arról, 
hogyan jelezhető előre a tanulók motivációs jellemzőiből a tanulók tanulással kapcsolatos viselkedése, ugyanakkor keveset tudunk arról, hogyan segítsük a kedvezőtlen motivációs jellemzők kedvezőkké alakulását. E ponton fontos megemlíteni, hogy a tanulókkal kapcsolatos nehézségek jelentős része az iskolai hétköznapokban motivációs problémaként jelenik meg (Réthyné, 2001b), hiszen a kognitív terület lemaradását általában motivációs gondok kísérik, amelyek gyakran a legfőbb akadályként tünnek fel a behozhatónak tünő lemaradások csökkentésében. Például a roma tanulók gyenge iskolai teljesítménye kapcsán a hazai szakirodalomban a tanulási motiváció alacsony szintje talán a leggyakrabban említett probléma (1. Harsányi és Radó, 1997; Hegedüs, 1993; Liskó, 2001; Nagy, 2002; Radó, 1997). Ugyanakkor az átlagos teljesítményt nyújtó tanulók kapcsán is elökerül, a „többet is kihozhatna magából egy kis igyekezettel" mondat. Sőt, a legjobban teljesítők esetében is felmerül az aggodalom, hogy a jó teljesítmény nem jár együtt a tanulás élvezetével vagy éppen az adott tantárgy kedveltségével, megérezve azt, hogy ez a jövőben (pl. a pályaválasztásban) lényeges lehet.

A pedagógusok elégedetlenségét a gyakorlatban is alkalmazható stratégiák terén a motiválással foglalkozó hazai írások szemléletesen fejezik ki, hiszen ezekben többnyire motivációs ötletekről, tapasztalatokról számolnak be, miközben alig támaszkodnak a tanulási motivációval kapcsolatos kutatások megállapításaira (pl. Farsang, 1993; Pintér, 2009; Revákné, 2002; Veidner, 2003). A következőkben e problémakört kívánjuk körbejárni, vagyis arra a kérdésre keresünk választ, hogy milyen akadályokba ütközik a motivációkutatás eredményeinek, következtetéseinek átültetése az osztálytermi gyakorlatba. Lehetséges válaszként a tanulási motiváció komplexitásából, kontextusfüggő jellegéből eredő problémákat foglaljuk össze, elsősorban Järvelä és Niemivirta (1999) írására támaszkodva.

A tanulási motiváció kutatásának összetettségét, így az osztályteremi gyakorlatban a motiválás érdekében hasznosítható stratégiák leírásának akadályait Järvelä és Niemivirta (1999) kifejezően foglalja össze, megvilágítva annak a folyamatnak a komplexitását, amely során adott szituációban a tanuló a tanulást vagy egyéb tevékenységet választ. E szerint minden egyes tanulást és teljesítményt igénylő iskolai helyzet a tanulók számára egy megküzdési helyzet is egyben, a tanulók tevékenységét pedig a kognitív követelmények és az érzelmi terhelés együttesen határozza meg. A tanulói tevékenységet az adott helyzet tanuló általi értelmezése és szociokulturális faktorok (pl. tanári tevékenységek) kölcsönhatása hívja életre, illetve határozza meg. Az egyes helyzetek jelentése a tanulók korábbi tanulási tapasztalataira épül. Az adott helyzet értelmezésének megfelelően a tanulók különböző stratégiákat alkalmaznak, amelyek segítenek számukra, hogy megfeleljenek a helyzet támasztotta követelményeknek. Ha a tanuló azt tapasztalja, hogy az adott tanulási helyzet a tanulási szándékot erősítő értelmes kihívást képvisel számára, akkor a feladatra koncentrál, illetve arra, hogyan kell azt megoldani. Ezzel szemben, ha a tanuló úgy érzi, hogy forrásai nem megfelelőek a feladat elvégzéséhez, tevékenysége a tanulás helyett inkább az érzelmi terhelés csillapítására irányul. Vagyis a szabályozási stratégiák irányulhatnak a feladat elvégzésére (pl. koncentráció, figyelem irányítása, önértékelés) vagy a feladat szempontjából irreleváns tényezőkre (pl. a teljesítmény becsmérlésére, osztálytársakkal való játékokra, egyéb pótcselekvésekre). A tanulási tapasztalatok kumulálódása érzékennyé teszi a tanulókat bizonyos helyzet értelmezésére, és azokhoz kapcsolódó stratégiákat alakítanak ki. A vigotszkiji megközelítésre közvetlenül támaszkodó kutatók (pl. Hickey, 2003; Walker, Pressick-Kilborn, Sainsbury és MacCallum, 2010) emellett azt hangsúlyozzák, hogy a tanuláshoz és gondolkodáshoz hasonlóan a tanulási motiváció is elsődlegesen egy társas folyamat eredménye, így a tanulási helyzetek 
egyéni értelmezéseit elsősorban a közösségenként eltérően alakuló célok, értékek, normák és érdeklődés határozza meg, és csak másodlagos az egyéni különbségek szerepe.

Tehát a motiváció és a kontextus kapcsolatára vonatkozó tudás az osztálytermi gyakorlat szempontjából egyaránt szolgál jó és rossz hírrel. Egyrészről rámutat arra, hogy a tanulási motiváció alakulása a környezet hatása alatt áll, azaz befolyásolható, másrészröl arra is felhívja a figyelmet, hogy a tanulók motiválására nem dolgozhatók ki kontextusfüggetlen, valamint a tanulók egyéni különbségei miatt minden tanuló számára egyszerre hatékony megoldások.

\section{A tanulási motiváció kutatásának jelentősége}

\section{A társadalmi-gazdasági fejlődés nézőpontjából}

A tanulási motiváció jelentőségét egyértelműen hangsúlyossá teszik azok a társadalmigazdasági változások, amelyeket a tudásalapú társadalom, az információs társadalom, a tudásalapú gazdaság vagy az élethosszig tartó tanulás kifejezések írnak le (1. OECD, 2004a; Tamás, 2003). A közelmúlt társadalmi, gazdasági és technikai változásai következtében a tudás olyan gazdasági erőforrássá vált, amely alapvetően meghatározza mind az egyén életminőségét, mind az adott ország társadalmi-gazdasági fejlődést. Az egyén életminősége szempontjából az iskolázottság jelentőségéről az iskolai végzettség és a munkapiaci pozíció összefüggését vizsgáló hazai elemzések egyértelmü bizonyítékokat szolgáltatnak (pl. Galasi és Varga, 2005; Kertesi és Varga, 2005), míg a nemzetközi tudásmérések országonkénti eredményinek és a gazdasági fejlettség mutatószámainak összevetésére épülő munkák az iskolázottság társadalmi-gazdasági előnyeiről tájékoztatnak (pl. Coulombe, Tremblay és Marchand, 2004; Hanushek és Kimo, 2000; OECD, 2010a). Egy társadalom iskolázottsági jellemzői természetesen számos olyan területen is fontos szerepet kapnak, amelyek a gazdasági fejlettséggel nincsenek közvetlen kapcsolatban, így például a társadalmi szolidaritással vagy a környezettudatossággal összefüggésben (részletesen 1. Csapó, 2011).

A gyors társadalmi, gazdasági és technikai változások a releváns tudás folyamatos változásával és az élethosszig tartó tanulás általánossá válásával járnak együtt. Ezzel egy időben a tudásátadás helyszínei is megváltoznak, hiszen egyre nagyobb szerepet kap a formális iskoláztatás után megszerezhető tudás, de javul azoknak az információforrásoknak a mennyisége és elérhetősége is, amelyek lehetőséget teremtenek az iskolán kívüli tudás megszerzésére. Mindezen folyamatok hatására jelentősen átalakulnak az iskola szerepére, az iskolában elsajátítandó tudásra vonatkozó nézetek is. Egyre világosabb, hogy a jövőben szükséges ismeretek és képességek jelentős részét nem lehet megtanítani, így elsődleges feladattá válik a tudás megszerzéséhez kapcsolódó képességek alakítása, valamint a tanulással kapcsolatos értékek, vagyis a tanulási motiváció fejlesztése (Csapó, 2002a).

A tanulási motiváció az iskolával összefüggésben ma már nemcsak egy olyan eszközként jelenik meg, amely elösegítheti a hatékony tanulást, hanem a nevelés egyik központi céljává válik. Kétségtelen, hogy a müveltség értékként való elfogadtatása, a müvelődés iránti igény befolyásolása mindig is a pedagógusok feladatai közé tartozott, napjainkban azonban már nemcsak egy kívánatos „melléktermékként” kezelendő, hanem kulcsfontosságú célként, hiszen a formális oktatást követően is jelentős hatást gyakorolhat mind az egyén életére, mind adott ország társadalmi-gazdasági fejlődésre. Az összefüggéseket figyelembe véve a tanulási motiváció kutatásának eredményei a tanulási motívumok fejlesztésén, az élethosszig tartó tanulásra felkészítésen keresztül, 
vagyis közvetve jelentős mértékben hozzájárulhatnak a társadalmi-gazdasági fejlődéshez.

\section{A neveléstudomány nézöpontjából}

\section{Egy komplexebb megközelítés felé}

Az affektív dimenzió kutatása az iskolával összefüggésben a kilencvenes évek elejétől felgyorsult, az utóbbi két évtizedben pedig egyre inkább a figyelem középpontjába került (Bickhard, 2003; Wentzel és Wigfield, 2009). Az érzelmekre utaló affektív szféra kifejezés szerteágazó kutatási területet jelöl, az érzelmi tényezők mellett magába foglalja például a tanulási motivációt, és a társas viselkedés bizonyos elemeivel is átfedést mutat. Az oktatással összefüggésben az affektív szférán belül a legkiterjedtebb vizsgálatok a tanulási motiváció területén folynak. A „hüvös” és „forró” magyarázatok integrálásának igénye az oktatásban leginkább úgy merül fel, hogy a kognitív terület belső összefüggéseinek elemzése nem ad teljes körü magyarázatot a tanulói teljesítményeket illetően, illetve egyre nehezebb új kapcsolatokat feltárni a kognitív tényezők között. Emellett az is előrelépéseket generál, hogy a kognitív oldal kutatásában kialakult módszerek már rendelkezésre állnak (Csapó, 2000).

A kogníció és motiváció viszonyának feltárásával, a korábbiaknál komplexebb megközelítéssel, az előzőleg különálló kutatási területek eredményeinek egyesítésével teljesebb képet kaphatunk többek között azokról a folyamatokról, amelyek a tudás elsajátítását kísérik. A kapcsolódási pontokat illetően hazai eredményekről is beszámolhatunk. A Nagy József-i (2000) - a személyiséget motívumrendszerre és képességrendszerre osztó - modell alapján végzett kutatások egyértelmüen bizonyították, hogy a motívumok és képességek kölcsönösen segítik egymás fejlődését, müködését, vagyis a tanulási motívumok tudatos alakítása a hiányzó vagy fejletlen készségek, képességek elsajátításához, fejlesztéséhez is hozzájárulhat (Józsa, 2007).

\section{Lehetőség az oktatás hatékonyságának emelésére}

A tanulási motiváció és a tanulmányi eredmények kapcsolata széles körben ismert, hiszen könnyen megtapasztalható: amit kedvvel tesznek a tanulók, abba általában több energiát fektetnek, ebből következően többnyire eredményesebbek is, és megfordítva, a sikerek a legtöbb esetben kedvező tanulói hozzáállást eredményeznek. A hétköznapi tapasztalatokon túl a tanulási motiváció összefüggését a tanulmányi teljesítménnyel, így az osztályzatokkal, valamint a kognitív képességek fejlödésével több hazai munka megerősítette (pl. Józsa, 2002, 2007), vagyis a tanulmányi eredményesség emelésének egyik eszköze lehet a tanulási motiváció befolyásolása (részletesen 1. „A tanulási motiváció és az iskolai eredményesség kapcsolata" című pontban).

A tanulási motiváció erősítését célzó iskolai, osztálytermi szintű intervenciós programok ma már nem ritkák, általában kognitív képességek fejlesztésével összekötve, szük tanulói kör bevonásával szervezik ezeket, az olvasáshoz kötődően különösen gyakran (pl. Fejes, 2010a; Guthrie, Wigfield és Vonsecker, 2000; Miller és Meece, 1997). Elsősorban a tanulmányi kudarcok kockázatának leginkább kitett, legkevésbé motivált tanulókra fókuszáló beavatkozások azok, amelyek szélesebb tanulói kört céloznak, és kifejezetten gyakorlati céllal születnek (pl. OECD, 2000). Bár e munkák a motivációkutatás eddigi eredményeit felhasználják, tudományos megalapozottságuk általában elmarad a kognitív területen megszokott intervenciókétól.

A rendszer szint valószínűleg ugyancsak lehetőséget kínál a tanulási motiváció alakítására, például a családi háttér szerinti szelektivitás mértékének befolyásolásán 
keresztül. Bár nemzetközi felmérések eredményei alapján a tanulási motiváció és az iskolarendszer szelektivitása közötti kapcsolatot eddig nem vizsgálták részletesen, számos elemzés mutat rá arra, hogy a hátrányos helyzetü, tanulási problémákkal küzdő, kevésbé motivált tanulók nagy aránya egy közösségben, kedvezőtlenül érinti a tanulási motivációt (1. később részletesen). Minden valószínűség szerint az extrém mértékben szelektáló hazai oktatási rendszer e jellemzőjéhez köthetők azok a nemzetközi viszonylatban is szélsőségesen nagy iskolák közötti különbségek, amelyek a tanulási motivációval szoros kapcsolatban álló változók esetében, így az odatartozás és a tanári támogatottság érzésében, valamint a fegyelmezési problémák előfordulásának gyakoriságában tapasztalhatók (OECD, 2004b).

Az oktatás hatékonyságának növelése tekintetében további lehetőségként kínálkozik az osztálytermi beavatkozások eddigieknél részletesebb motivációs szempontú vizsgálata. A lehetőségek egyike a motiváció számítógép-alapú tesztelésének fejlődéséhez köthető (1. Józsa, Szenczi és Hricsovinyi, 2011), amely segítséget nyújthat a beavatkozás közbeni folyamatos, a korábbiaknál részletesebb információgyüjtésben. Így a fejlesztő kísérletek motivációs sajátosságainak holisztikus megítélését felválthatják a beavatkozások különböző összetevőinek hatására irányuló elemzések.

\section{Az innovatív tanulási környezetek kihívásai}

A tanulás fogalma az utóbbi évtizedekben jelentősen gazdagodott, átértelmeződött. Az új megközelítések nyomán az osztálytermeket is elérő változások talán legfontosabb jellemzője a tanulás életszerüvé tételére, a tanulói aktivitás, cselekvés növelésére, a tanultak különböző körülmények közötti alkalmazására és a tanulók közötti interakciók növelésére való törekvés (pl. Kock, Sleegers és Voeten, 2004). Jól látható, hogy e célok egyedül a tanári tevékenységek átalakításán keresztül már nem érhetők el, így a hangsúly olyan tanulási környezetek kialakítására helyezödött át, amelyekben e feltételek együttesen jelen vannak. E megközelítést képviselik többek között az autentikus tanulási környezet (pl. Gulikers, Bastiaens és Martens, 2005), vagy a problémaalapú tanulási környezet (pl. Arts, Gijselaers és Segers, 2002) kifejezések köré szerveződő törekvések. A tanulás újabb értelmezését követő, összefoglalóan innovatív tanulási környezetnek (pl. Kirschner, 2005) vagy hatékony tanulási környezetnek (powerful learning environment, pl. De Corte, Verschaffel, Entwistle és Van Merriënboer, 2003) keresztelt kezdeményezések általában kihasználják az információskommunikációs technológia előnyeit is, elsősorban az életszerüség megteremtése és az interakciók elősegítése terén.

Az életszerüség emelése miatt evidenciának tűnhet, hogy az oktatáskutatás elvei szerint kialakított tanulási környezetekre pozitívan reagálnak a tanulók, azaz erős motiváló hatást tulajdonítható ezeknek, az eredmények nem egyértelműek. Számos új probléma vetődik fel, vagyis sok esetben túlértékeljük az innovatív környezetek motivációs következményeit. Az új típusú tanulás környezetek kedvezőtlen motivációs következményeit több empirikus kutatás is alátámasztja (pl. Gulikers, Bastiaens és Martens, 2005; Hickey, Moore és Pellegrino, 2001; Lodewyk és Winne, 2005). A motivációs problémákat leginkább arra vezetik vissza, hogy az innovatív környezetek a tanulói önállóság növelésére épülnek, amely implicit módon magában foglalja azt a feltételezést, hogy a tanulók megfelelő erősségű motivációval és önszabályozó stratégiákkal rendelkeznek (Blumenfeld, Kempler és Krajcik, 2006; Boekaerts és Martens, 2006; Järvelä és Volet, 2004).

A tanulás újraértelmezése és a technikai változások teremtette lehetőségek tehát jelentős hatást gyakorolnak az oktatásra, ugyanakkor új problémákat is felvetnek, 
amelyek kiküszöbölése nélkül az innovációk nem érhetik el a kívánt hatást. Az innovatív környezetek előnyeinek kiaknázása szempontjából a motivációs folyamatok alaposabb megismerése megkerülhetetlennek látszik.

\section{Összegzés}

A tanulási motivációt egyrészről egy átfogó kutatási területként értelmeztük, amely számos olyan teóriát magában foglal, amelyek bepillantást, illetve magyarázatot kínálnak a tanulást kísérő pszichológiai és szociális folyamatokkal kapcsolatosan. Nem rendelkezünk azonban egyetlen elmélettel, amely kielégítő magyarázatot kínálna a tanulással összefüggő motivációs jelenségek egészéről, ugyanakkor a jelenségek egyegy szeletéröl információt kínáló különféle megközelítések egyre inkább összeérnek, a harmonizálódó kutatási irányok pedig egyre komplexebb képet nyújtanak.

Bemutattuk, hogy a tanulási motivációra a viselkedés hátterében meghúzódó folyamatként is tekinthetünk, amelynek lefolyását többek között az egyén motívumkészlete határozza meg. E motívumkészlet számtalan öröklött és tanult összetevőből áll, amelyek teljes körü feltérképezése minden bizonnyal lehetetlen, azonban a fontosabb motívumok azonosíthatók.

Rámutattunk a tanulási motívumok müködésének egy lényeges sajátosságára, a kontextushoz kötődő jellegükre. E jellemző a motivációt kísérő társas és pszichológiai folyamatok egyidejű figyelembevételére hívja fel a figyelmet, és az iskolai motívumfejlesztés megalapozásához szükséges tudás megszerzésében központi jelentőségű akadályként jelenik meg. A tanulási motiváció e kontextusfüggő jellegének figyelembe vétele fontos elörelépést jelenthet azon az úton, amely a tanulási motívumok intuitív, rövid távú célokat szem előtt tartó befolyásolásától, vagyis a motiválástól a tudományos bizonyítékokon alapuló, hosszú távra tervező motívumfejlesztés felé vezet.

Megállapítottuk, hogy a tanulási motiváció jelentősége a folyamatos tanulást kívánó modern társadalmakban felértékelődik, hiszen az élethosszig tartó tanulás megvalósulásán keresztül a társadalom egészének müködésre, állapotára kihat. Emellett rövid távon kiaknázatlan lehetőségeket rejt a motivációkutatás az oktatás hatékonyságának növelése terén, többek között az eddigi eredmények gyakorlati alkalmazásán, továbbá az innovatív tanulási környezetek fejlesztésén keresztül. 


\section{A TÁRSAS KÖRNYEZET ÉS A TANULÁSI MOTIVÁCIÓ KAPCSOLATA}

A nemzetközi és a hazai szakirodalom eredményeit egyaránt felhasználva ebben a fejezetben áttekintjük, hogy miként függ össze a társas környezet és a tanulási motiváció. A tanulási motivációt magyarázó elméletek sokféleségéből, a szakirodalom kiterjedtségéből következően e munka óhatatlanul szelektív. Nem kezelünk kiemelten egyetlen motivációs elméletet sem, a legfontosabbnak vélt összefüggéseket kíséreljük meg megragadni. Áttekintésünket a családi közeg motivációt befolyásoló tényezőiből kiindulva, az iskolai társas jelenségek szerepének elemzésén át a kulturális hatások felé tágítva tesszük meg.

\section{Az elsődleges szocializációs színtér, a család szerepe}

A kutatók között egyetértés mutatkozik abban, hogy a tanulási motívumrendszer fontos alappillérei, az elsajátítási motívumok veleszületett alapokon állnak. Mindemellett kiemelik a szocializáció szerepét a fejlödésében, az egyéni különbségeket nagymértékben ennek tulajdonítják (Harter, 1981; Morgan, MacTurk és Hrncir 1995; Seifer és Vaughn, 1995; Stipek, 1993). A csecsemő- és koragyermekkori empirikus vizsgálatok az elsajátítási motiváció alacsony időbeli stabilitását mutatják. Ez alapján feltételezik, hogy a környezeti hatásoknak jelentős szerepe lehet a motiváció alakulásában. Az empirikus adatok alapján emellett azt is valószínüsítik, hogy legalább is az élet első éveiben - az elsajátítási motiváció az értelmi fejlődésénél képlékenyebb, formálhatóbb (MacTurk, Morgan és Jennings, 1995). Bizonyítékul szolgál erre például Butterfield és Miller (1984) fejlesztő programja, melynek keretében sikerült szignifikánsan növelni a kisgyermekek elsajátítási motivációját. Ez az eredmény arra utal, hogy a gyermekek elsajátítási motivációja a társas környezet, a szülök, tanárok beavatkozásának köszönhetően alakítható, fejleszthető.

A szocializációnak a kutatók kiemelt szerepet tulajdonítanak az elsajátítási motiváció fejlődésében. A kötődés, főképp az élet első éveiben, a szocializációs folyamat alapvető eleme (Zsolnai, 2001a, 2001b). Az elsődleges gondozó (aki legtöbb esetben az anya) és a gyermek közötti kapcsolatnak, az elsődleges kötődésnek meghatározó szerepe van a gyermek személyiségfejlődésében. Másfél- és hároméves gyermekekkel végzett vizsgálatok szerint az anya-gyermek kapcsolat érzelmi telítettsége kihat az elsajátítási motivációra. Kölcsönösen pozitív érzelmi viszony esetén a gyermekek nagyobb valószínüséggel kitartóak egy feladat elsajátításában, intenzívebben fejezik ki az eközben átélt örömöt. Ha az anya és a gyermek között viszonylag gyakoribb a negatív interakció, akkor a gyermek kevésbé kitartó, ennek következtében képességei kevésbé fejlettek. Megállapítják, hogy az erősen korlátozó szülői magatartás gátolja az elsajátítási motiváció fejlődését, a független elsajátításra való törekvést (Busch-Rossnagel, Knauf-Jensen és DesRosiers, 1995).

Pomerantz, Grolnick és Price (2005) gazdag szakirodalmi áttekintése jól áttekinthető rendszert kínál a szülők tanulási motivációt formáló szerepét illetően, így e téma ismertetésében e munkában felállított kategóriákat használjuk keretül, melyhez további kutatási eredményeket illesztünk. A szerzők az empirikus kutatások alapján három csoportba sorolják a szülők hatását gyermekük iskolai teljesitménnyel kapcsolatos nézeteit illetően, melyet a szülő (1) nevelési gyakorlatán, (2) gyermekével kapcsolatos gondolkodásán és (3) a szülő-gyermek kapcsolaton keresztül befolyásolhat. A háttérben meghúzódó mechanizmusokra Pomerantz, Grolnick és Price (2005) a 
gyermek bizonyos pszichológiai szükségleteinek kielégítésével kísérelnek meg magyarázatot találni. A gyermekek későbbi tanulási motivációját befolyásoló szükségleteket elsősorban az öndeterminációs elméletéből (self-determination theory) vezetik le (1. Ryan és Deci, 2002), így a környezet feletti kontroll gyakorlására irányuló kompetencia, az önálló döntés érzetét jelentő autonómia, a másokhoz tartozást érzését jelölő kapcsolat, és egy további szükséglet, az ésszerü, értékes tevékenységekhez kapcsolódó célszerüség igényének kielégítését tartják elsődlegesnek a szülő részéröl.

A szülői nevelési gyakorlat meghatározó eleme például az, ahogyan bekapcsolódik a szülő az óvodával, iskolával kapcsolatos tevékenységekbe. Ilyen tevékenység lehet például a mesélés, a közös olvasás, az olvasmányélmények megbeszélése, vagy akár a közös rajzolás, számolás, továbbá a gyermek ilyen irányú próbálkozásaira, produkcióira adott reakciók. Minden bizonnyal meghatározó tényező e tekintetben, hogy a család felnőtt tagjainak milyenek voltak saját iskolai tapasztalataik, milyen érzelmek kísérték az iskolai tanulásukat, milyen az iskolai végzettségük, mennyire tekintik értéknek a tanulást (Szabóné, 2003).

Az ügyesen megválasztott közös tevékenységek fejlesztik a gyermek készségeit, képességeit. A kapcsolódó élmény a „meg tudom csinálni” érzését nyújtja, elsajátítási örömöt okoz, kielégíti a gyermek hozzáértés-szükségletét. A közös játékok erősítik a szülö-gyermek kapcsolatot, a kötödést. Emellett a tanulás értékét, célszerüséget tapasztalhatja meg a gyermek, hiszen a szülö kommunikációja szerint értékes tevékenységekben vesz részt (Pomerantz, Grolnick és Price, 2005). A szülö olyan környezet létrehozásán keresztül segítheti a tanulási motiváció fejlődését, melyben autonómia és segítségnyújtás áll egyidejüleg a gyermek rendelkezésére. Vigotszkij (1967) elmélete szerint a képességfejlesztés szempontjából azok a feladatok a leghatékonyabbak, melyeket a gyermek már megért, ugyanakkor önállóan nem lenne képes megoldani ezeket. Vigotszkij elmélete legközelebbi fejlödési zóna (Zone of Proximal Development) néven vált ismertté. A gyermek legközelebbi fejlődési zónáját az önállóan megoldott feladat (aktuális fejlettségi szint) és a segítséggel megoldott feladat (lehetséges fejlettségi szint) közötti távolsággal definiálja. Vigotszkij szerint az intellektuális fejlődésben a legközelebbi fejlődési zóna meghatározóbb, mint az aktuális kognitív fejlettségi szint. Ez alapján a fejlesztés akkor tekinthető optimálisnak, ha az a legközelebbi fejlődési zónában zajlik. A kutatási eredmények alapján valószínűsíthető, hogy a gyermek többségénél az ilyen feladatok esetében erősödnek a tanulási motívumok (Józsa, 2001).

Az optimális kihívást jelentő feladatok az önszabályozásra, az autonómia és a másokhoz tartozás szükségletére is hatást gyakorolnak. Kedvező következményekkel jár az önállóság támogatása, mely föként a kompetencia és autonómia szükségletét érinti, és azt jelenti, hogy a szülő biztosítja gyermeke számára a környezet önálló felfedezését, valamint tevékenységek kezdeményezésére, a gyermeket érintő problémák aktív megoldására ösztönöz. Előnyökkel járhat továbbá a tanulási folyamatra fókuszáló nevelési gyakorlat, mely olyan szülői reakciókat jelöl, amikor az elért eredmény helyett az erőfeszítést és a tanulási folyamatot helyezi középpontba a szülő, ezzel csökkentve annak a lehetőségét, hogy a képességekre mint stabil személyiségjellemzőkre tekintsen a gyermek, valamint, hogy a kudarcot a kompetencia hiányának tulajdonítsa (Pomerantz, Grolnick és Price, 2005).

Az elmélethez hozzákapcsolható Geen (1995) modellje, melynek alapjait még a hetvenes évek végén Harter (1981) rakta le. Harter elsőként alkotott átfogó modellt a társas közeg elsajátítási motivációra gyakorolt hatásának leírására. Megállapítása szerint az elsajátítási motívumok erősödéséhez fontos, hogy (1) a társas közeg támogassa a gyermek önállóságra, önálló elsajátításra irányuló próbálkozásait és (2) kevés 
megerősítést adjon a másoktól való függésre irányuló törekvéseire. Lényeges, hogy a gyermek viselkedésében a megerösitést a kitartó próbálkozás kapja, ne kizárólag a sikeres megvalósítás. Ha az elsajátítási motívumokat kívánjuk erősítni, akkor a sikertelen kimenetelü próbálkozásokban mutatott kitartásra is megerősítést kell adni.

Geen (1995) modellje szerint az elsajátítási próbálkozásra adott társas megerősítés belsővé válik (internalizálódik), azaz beépül az egyén önjutalmazó rendszerébe, ezáltal az elsajátítási motívumok megerősödhetnek (1. ábra). Az elsajátítási motívumok a későbbi viselkedés viszonyítási alapjául szolgálnak, ez pedig az elsajátítás-irányú célok növekedésében jelenik meg. A kihívást jelentő tevékenységek már önmagukban elörevetíthetik az öröm érzését. Az aktivitás során elért siker pedig a hozzáértés (kompetencia) érzését kelti, erősíti azt az elsajátítási motívumot, ami magát a folyamatot létrehozta. Ezzel tehát az elsajátítási motívum fejlődésében egy öngerjesztő ciklust látunk. Ha az önálló elsajátítási próbálkozás helyett inkább a szociális közegtől való függésben kap megerősítést a gyermek, akkor a mások által elvárt céloknak való megfelelés motívuma erősödhet meg. Ez pedig az inkompetencia érzésének kialakulásához, a külső-kontrollos attitüdök megerősödéséhez vezethet. A kihívást jelentő szituációk ekkor nem az öröm elörevetítésének a forrásai, hanem félelmet és szorongást keltő helyzetek, amelyek az elsajátítási motívumok háttérbe szorulásához, az elsajátítási motiváció csökkenéséhez vezethetnek.

E modell jelentős pedagógiai következménye, hogy az elsajátítási motívumok a szociális interakció során változnak. Ez azt jelenti, hogy a szülők, a tanárok visszajelzéseinek tudatos alakításával az elsajátítási motívumok befolyásolhatók, fejleszthetők. Fontosnak tartjuk kiemelni, hogy a fentebb ismertetett hatások nem csak a szülők esetében érvényesülnek. A motivációt befolyásoló hatások nagyon hasonlóan müködnek a pedagógusok esetében is. 


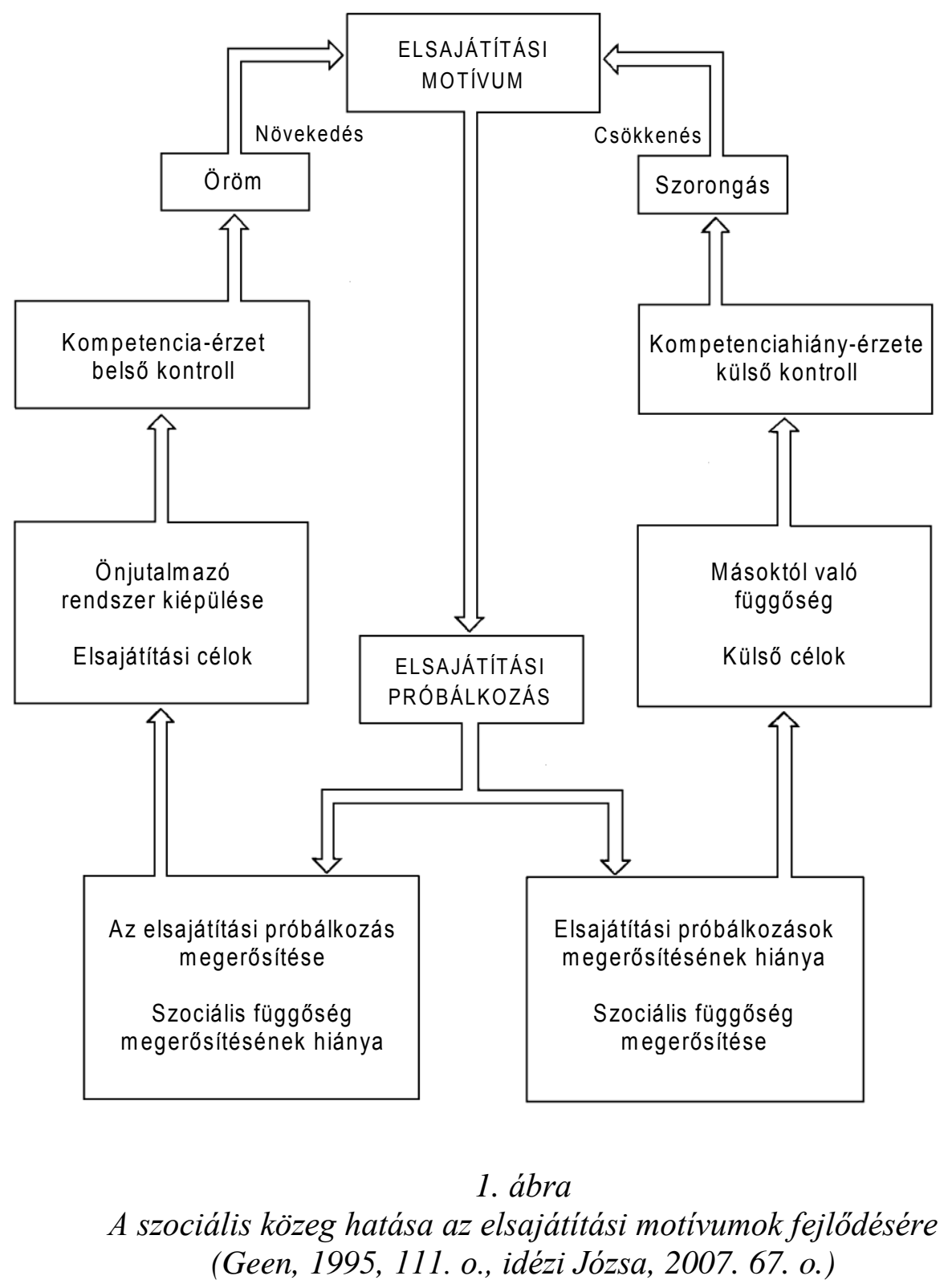

A tanulási motivációval kapcsolatos problémák családi okait vizsgálva Vauras, Salonen, Lehtinen és Lepola (2001) a kedvezötlen szülöi nevelési gyakorlat két csoportját különbözteti meg, a következetlen és a túlszabályozó típust. A következetlen szülöi viselkedés jelenthet túlzott engedékenységet ( $\mathrm{pl}$. a gyermek pillanatnyi igényeinek extrém mértékü kiszolgálása), ,aszinkron” visszacsatolást (pl. amikor a szülői válasz nem kapcsolódik a gyermek által végzett tevékenységéhez), véletlenszerủen váltakozó pozitív és negatív szülöi választ (pl. a szülő pillanatnyi hangulatától függő büntetés, jutalmazás), valamint a válasz elmaradását, hanyagolást. A szülői következetlenség gátolhatja, hogy a gyermek felismerje a viselkedése és annak következménye közötti kapcsolatot, ezáltal kedvezőtlenül érinti az énhatékonyságot, ami kihat a tanulási motiváció alakulására. A túlszabályozó szülői viselkedés magában foglalhatja a túlvédést, a külső ösztönzés túlzott alkalmazását, a túlságosan gyakori segítségnyújtást és jutalmazást, az önálló tevékenységek gyakori akadályozását. Ide tartozik a negatív érzelmekkel való befolyásolás, és a durva fegyelmezés is. A szülői túlszabályozás csökkentheti a tevékenységben lelt saját örömöt, az önjutalmazó motivációt, egyidejüleg erősitheti a szociális függőséget. Ez esetben a tevékenység szabályozásának felelőssége 
nem a gyermeké, ezért a feladattal kapcsolatos énhatékonyságra kedvezőtlen hatást gyakorolhat a túlszabályozás.

A szülö gyermekével kapcsolatos gondolkodása egyrészt a gyermek kompetenciájának észlelésén és az elvárásokon, másrészt a szülői értékek közvetítésével fejti ki hatását. Bár az empirikus bizonyítékok egyértelmüek abban a tekintetben, hogy a felsoroltak befolyásolják a tanulási motiváció fejlődését, a közvetítő mechanizmusokat illetően e területen kevésbé biztosak a magyarázatok. A gyermekek kompetenciájának pozitív szülői megítélése minden bizonnyal a kompetencia érzésének szükségletén keresztül vezet előnyös következményekhez. A magasabb elvárások hatásának egyik lehetséges magyarázata, hogy ez nagyobb fokú szülői részvétellel jár együtt a gyermek iskoláztatásával kapcsolatban, másrészt indirekt módon, a szülői visszajelzéseken keresztül hatást gyakorolhat a gyermek önmagával kapcsolatos meggyőződéseire. A szülői értékek valószínüleg a célszerüség érzetén keresztül hatnak, itt azonban meg kell említenünk, hogy a kutatások csak az édesapák esetében találtak összefüggést az iskolai munka fontosságának megítélése és gyermekük néhány motivációs változója között (Pomerantz, Grolnick és Price, 2005).

A szülö-gyermek kapcsolat többféle módon is befolyásolhatja a későbbi tanulási motivációt. Az optimális kötödés és közelség a pozitív belső reprezentáció és a környezet magabiztos, autonóm felfedezésén keresztül fejti ki hatását, részben annak köszönhetően, hogy eközben a gyermek nem aggódik a szülővel való kapcsolata miatt. Vagyis a kapcsolat szükségletének teljesülése a kompetencia és autonómia érzéséhez vezethet el. További elem a családi kötelezettség érzése, melynek erösségével párhuzamosan nő a szülői célokkal való azonosulás, illetve a célszerüség érzése. A szülő-gyermek kapcsolat egy további dimenziója a tanuló önreprezentációjához köthető, mely ugyancsak érintheti e szükségletet. Amennyiben a tanuló önmeghatározásának fontos részét képezi a szülővel kialakult kapcsolata, a szülő oktatással kapcsolatos céljainak megvalósításába több energiát fektet, illetve nagyobb valószínüséggel internalizálja azokat, amely maga után vonja az autonómia érzésének erősödését is (Pomerantz, Grolnick és Price, 2005).

Urdan, Solek és Shoenfelder (2007) e témában ritkán alkalmazott módszerrel, tanulókkal készült interjúk segítségével számos olyan pontra rámutat, melyek a kvantitatív elemzések fókuszán kívül esnek, illetve amelyekre eddig kevés figyelmet fordított a szakirodalom. Kutatásukban 47 középiskolás vett részt, akiknek válaszaiból az elemzések alapján öt jól elkülöníthető csoport rajzolódott ki a család motivációt befolyásoló szerepének észlelésével kapcsolatosan. Középiskolás tanulókkal készült interjúk alapján öt csoport rajzolódott ki. (1) A diákok egy része azért tanul, hogy örömet szerezzen családjának. (2) Vannak gyermekek, akik törleszteni szeretnének a tanulás érdekében a családtagok által hozott áldozatvállalásért. (3) A tanulók egy csoportja az erős támogatáson keresztül érzékeli családjának motivációs szerepét. (4) Mások szeretnék elkerülni a család negatív reakcióit, például a durva, kritizáló szülői viselkedést, ez ösztönzi őket tanulásra. (5) Végül volt a tanulóknak egy olyan csoportja, mely egyáltalán nem érzékelte a család szerepét a tanulási motiváció szempontjából.

A fentebb vázolt kutatásban a családi modellek fontossága többféleképpen is megjelenik a gyermekeknél. A tanulók egy részére például erős hatást gyakorolnak azok a nehézségek, melyekkel a szüleik küzdenek a megfelelő iskolai végzettség hiányában. Felbukkantak a diákok interjúiban olyan családtagok is, akik negatív példát képviselnek. Sok tanuló említett a szülő mellett további rokonokat, akik fontos hatást gyakoroltak a tanulási motivációjukra. Annak vágyát is többen említették, hogy ők maguk szeretnének majd pozitív modellként megjelenni a fiatalabb családtagoknak. 
A tanulók családi-kulturális helyzetéről közelítő képet ad a szülők iskolai végzettsége, ezért a pedagógiai vizsgálatok során gyakran alkalmazzák e változót a családi háttér jellemzésére. Számos kutatás mutatta ki, hogy az eltérő szociokulturális környezetből származó gyermekek képességeinek fejlettségében (pl. Csapó, 2003; Molnár É. és B. Németh, 2006), tantárgyi osztályzataiban (Józsa és Nikolov, 2005) jelentős különbségek vannak. A hátrányos társadalmi-gazdasági helyzetű családok gyermekeinek kognitív és szociális készségeit már óvodás korban jelentős fejlődésbeli megkésettség jellemzi (Józsa, 2004; Józsa és Zentai, 2007). A tanulási motiváció és a szocioökonómiai háttér kapcsolatáról azonban ma még nemzetközileg is viszonylag kevés empirikus kutatási adat áll rendelkezésre. A következőkben néhány ilyen kutatás eredményeit tekintjük át.

Stipek és Ryan (1997) óvodás és elsős gyermekeknél vizsgálta az elsajátítási motivációt. Megállapításuk szerint nem fedezhető fel motivációs deficit az alacsony szocioökonómiai státusszal rendelkező családok gyermekeinél. Howse, Lange, Farran és Boyles (2003) a motiváció és az önszabályozás kapcsolatának megismerése céljából lényegében megismételték Stipek és Ryan kutatását, és hasonló következtetésekre jutottak. Egy másik, hasonló vizsgálat megállapítása szerint a magasabb jövedelmü családok gyermekeinél kismértékben erősebb az értelmi elsajátítási motiváció, ezek a gyermekek kitartóbbnak bizonyultak az elsajátítási szituációkban. Az elsajátítási motiváció további komponensei esetén azonban nem kaptak szignifikáns összefüggést a család anyagi helyzetével, továbbá nem kaptak összefüggést más, családot jellemző változóval sem (Morgan, Maslin-Cole, Harmon, Busch-Rossnagel, Jennings, HauserCram, és Brockman, 1996).

Gottfried, Flaming és Gottfried (1998) 9, 10 és 13 éves korban vizsgálta a szocioökonómiai státusznak, valamint az otthoni intellektuális ingereknek az iskolai tanuláshoz kapcsolódó önjutalmazó motívumokra gyakorolt hatását. Eredményeik szerint ez utóbbi befolyása meghatározó, a szocioökonómiai státusz azonban csak áttételes kapcsolatban áll a motivációval: magas értéke intellektuálisan ösztönző otthoni környezet valószínüségét jelzi. A szocioökonómiai háttér hasonló szerepéről számol be Stevenson és Baker (1992) is: a második iskolában nagyobb valószínüséggel szereznek pozitív tanulási tapasztalatokat a magas szocioökonómiai háttérrel rendelkező tanulók, ami motívumaik erősödését eredményezheti.

Néhány hazai munka ugyancsak kitért a tanulási motiváció és a családi háttér kapcsolatára, de az összefüggések nem bizonyultak jelentősnek. Józsa (2000) 7. és 9. osztályos tanulók körében vizsgálta a tanulási motivációt, a kutatásban nem adódott említhető kapcsolat a szülők iskolázottsága és a tanulási motiváció között. Egy további vizsgálatban hetedikes tanulók körében a szülök iskolázottsága és a tanulók motiváltsága között adataink ugyancsak 0,2-0,3 erősségü korrelációkat jeleztek. Eredményeink szerint az anya esetében a felsőfokú végzettség egyértelmüen kedvező hatást gyakorol a tanulási motivációra, az apa esetében pedig már az érettségi is hasonló előny forrása. A tartósan munkanélküli szülők gyermekeinek szignifikánsan gyengébb a matematika és az olvasás énképe. Az értelmi és a szociális elsajátítási motívumok fejlettségében ugyanakkor nem mutatható ki különbséget a munkanélküli és a munkával rendelkező szülők gyermekei között (Fejes és Józsa, 2005).

A gyermek családi háttérének további jellemzője lehet a hátrányos helyzet. A hátrányos helyzet a hazai neveléstudományi szakirodalomban elöforduló meghatározásokat tekintve azokat a gazdasági, társadalmi és kulturális körülményeket jelöli, amelyek a gyermek fejlődése szempontjából a többséghez képest kedvezőtlen helyzetet eredményeznek (Fejes, 2006). Hátrányos helyzetünek tekintendő a gyermek, ha a helyzete a szokásosnál, átlagosnál nehezebb körülményeket idéz elö, mely kihathat 
a személyiségfejlődésére, tanulására, életminőségére. Egy jó anyagi körülmények között élő gyermek is lehet hátrányos helyzetü, ha például nyelvi hátrányban van, diszfunkciós családi közegben él, elöítéleteknek van kitéve, kirekesztődik stb. (Réthyné, 2004; Réthyné és Vámos, 2006). Egy tanuló több szempontból is hátrányos helyzetü lehet. Gyakran megkülönböztetik az anyagi, az érzelmi és a nyelvi hátrányt. Ezek a hátrányok sok esetben halmozódnak is a gyermekeknél (1. Fejes és Józsa, 2005; Józsa és Zentai, 2007). A hátrányos helyzetü tanulók iskolai teljesítményét számottevő lemaradás jellemzi (Andor, 2001; Kertesi és Kézdi, 2005). Elemi alapkészségeik fejlettsége már iskolába lépéskor jelentősen megkésik a kedvező körülmények között nevelkedő társaikéhoz képest (Józsa, 2004; Józsa és Zentai, 2007).

A gyermekek hátrányos helyzete a tanulási motívumaik fejlettségében is megmutatkozik. Az anyagi, az értelmi és a nyelvi hátránnyal jellemezhető gyermekek értelmi és társas elsajátítási motívumai egyaránt számottevő mértékben elmaradnak kedvező körülmények között élő társaikéhoz képest. A hátrányos helyzetü gyermekek fejletlenebb elsajátítási motívumai minden bizonnyal hátráltatják az értelmi és a szociális készségeik fejlődését is. Emellett a hátrányos helyzetü gyermekek lényegesen rosszabb énképpel rendelkeznek matematikából és olvasásból. Az érzelmi hátrány szempontjából nagyobb különbségeket találunk az elönyös és előnytelen helyzetü gyermekek között, mint az anyagi és a nyelvi hátrány szerint képzett tanulócsoportok között (Fejes és Józsa, 2005).

$\mathrm{Az}$ empirikus kutatások tehát nem kínálnak egyértelmü bizonyítékot arra vonatkozóan, hogy a kedvezőtlen szocioökonómiai háttér markáns szerepet játszik a tanulási motiváció alakulásában, ezen keresztül pedig a hátrányos helyzetü tanulók iskolai sikertelenségeiben. Ez a vizsgálatok alacsony számának, a tanulási motiváció kutatását jellemző egységes elméleti kiindulópont hiányának, illetve ennek következtében a motiváció kutatásonként eltérő operacionalizálásának, valamint annak a következménye, hogy az azonos családi háttér szerinti tanulóközösségek létrejöttéböl adódó kedvezőtlen hatások mértéke nehezen kiszürhető (részletesen 1. ,Az osztályközösség hatása" címü pontban). Ezenkívül problémaként említhető, hogy a kérdést vizsgáló kutatások a kedvezőtlen szocioökonómiai státuszt is eltérő módon definiálják, mely az eredmények szintetizálásának további akadálya (Fejes, 2012).

\section{Az iskola mint társas közeg szerepe}

\section{Kötödés a pedagógushoz}

A gyermekek szociális környezetének meghatározó szereplői a szülök mellett a pedagógusok. A pedagógushoz füződő viszony, a pedagógiai kötődés fontos tanulási motívumként funkcionál (Nagy, 2000). Az iskolázás kezdeti szakaszában egy kisgyermek tanulásszeretete szinte szétválaszthatatlan attól, hogy szereti-e tanítóját. A pedagógiai kötődés mint tanulási motívum alapját a stabil koragyermekkori gondozógyermek kötődés adja (Barkóczi és Putnoky, 1980). Annál a gyermeknél, aki nem élte át a koragyermekkori kötődés nyújtotta biztonságot, a pedagógushoz való kötődés is nehezebben alakítható, így kisebb az esélye, hogy a ragaszkodás tanulási motívumként müködik.

Józsa és Fazekasné (2008) kutatásának eredménye szerint az alsó tagozatos gyermekek esetében a pedagógushoz való kötődés a legerősebb tanulási motívumok egyike. Hatodik osztálytól - vélhetően a kamaszkor kezdetéhez köthetően - kezd csökkeni ennek a motívumnak az átlagos erőssége. E vizsgálatban tanulásban akadályozott gyermekek is részt vettek. A pedagógus szerepe a tanulásban akadályozott 
gyermekeknél minden életkorban egyértelműen erőteljesebb, mint a többségi tanulóknál. Esetükben serdülökorban is megmarad a pedagógushoz való viszony meghatározó jellege. Ez az eredmény összhangban van a speciális iskolákban tanító nevelök tapasztalataival, mely szerint a tanulásban akadályozott gyermekek kezdeti ragaszkodása később sem csökken számottevően. Felső tagozatban sincs leválás, kevésbé tapasztalják a többségi iskolákban jellegzetesen megnyilvánuló kamaszkori önérvényesítő törekvéseket. Ugyanakkor felmerül annak a kérdése, hogy e különbségek mennyiben kapcsolódnak a tanulásban akadályozottsághoz, és mennyiben köthetők a speciális tantervü iskolák eltérő tanulási környezetéhez.

\section{A pedagógusok elvárásainak szerepe}

A tanári elvárások szerepét feltáró kutatások egyik meghatározó kiindulópontját azok a pszichológiai munkák jelentik, melyek az önbeteljesitő jóslat jelenségét vizsgálják. E jelenség lényege: ha elvárásokkal rendelkezünk egy másik személy viselkedésével, vagy egy szituációval kapcsolatban, akkor hajlamos az adott egyén olyan viselkedést produkálni, hogy az elvárások beigazolódjanak (Cserné, 1986; Eccleston, 2007; Sallay, 1997).

A Pygmalion-effektusnak is nevezett jelenség első vizsgálata iskolai környezetben Rosenthal és Jacobson (1968, idézi Rosenthal, 2002) nevéhez füződik. A jelenséget feltáró vizsgálat keretében egy iskolában elsőtől hatodikig a tanulók megközelítőleg 20 százalékát véletlenszerüen választottak be a kísérleti csoportba. A tanév elején a tanulók kitöltöttek egy intelligencia-tesztet, majd a tanárok megkapták a kísérleti csoportba sorolt gyermekek neveit, azzal a kiegészítő információval, hogy a kitöltött teszt a rejtett intellektuális képességek felmérésére alkalmas, és az eredmények alapján e tanulók várhatóan meglepően gyors intellektuális fejlődést fognak mutatni a tanév hátralévő részében. A kontroll és a kísérleti csoport között ezen kívül más különbség nem volt. A különbséget a pedagógusok vélekedésében, a tanulókkal szembeni beállítódásaiban hozták létre. Az eredmények egyértelmüen igazolták: azok a diákok, akiktől gyorsabb intellektuális fejlődést vártak a pedagógusok, gyorsabb ütemü fejlődést is mutattak.

A jelenség hátterében álló mechanizmust leginkább Brophy és Good (1970) modellje alapján szemléltetik, mely hat szakaszra bontja azt a folyamatot, melyen keresztül a tanári elvárások befolyásolják a tanulói teljesítményt. (1) A tanárban elvárások alakulnak ki a tanulók viselkedésére és teljesítményére vonatkozóan. (2) A elvárásoknak megfelelően különbözően viselkedik a tanár az egyes tanulókkal. (3) A tanári bánásmód alapján érzékelik a tanulók a tanári elvárások egy részét. (4) Ha a tanári bánásmód konzisztens, és a tanulók nem aktívak abban a tekintetben, hogy ezen változtassanak, akkor ez valószínüleg hatást gyakorol tanulási motivációjukra, magatartásukra és a tanárral folytatott interakciókra. (5) A tanulók viselkedése kiegészíti, illetve megerősíti a tanári elvárásokat. (6) A tanári elvárások hatást gyakorolnak a tanulói teljesítményekre. A modell szerint a tanári elvárások önbeteljesítő hatása abban az esetben mutatkozik meg, ha a modell minden eleme megjelenik.

Brophy és Good (1974) szerint a legtöbb tanár viszonylag pontos becslésekkel rendelkezik tanulók képességeit illetően, illetve általában módosítja előfeltevéseit, amennyiben annak ellentmondó információval szembesül, vagyis az önbeteljesítő jóslatnak nem mindig van számottevő hatása. Abban az esetben várható jelentősebb Pygmalion-effektus, amikor pontatlanok, illetve rugalmatlanok a tanári becslések. Raudenbush (1984) munkája szerint a pontatlanság föleg az első néhány évfolyam esetében jellemző, mely nyilvánvalóan kapcsolatban áll a pedagógusok számára a tanulókról rendelkezésre álló információk mennyiségével. További kutatások arra 
mutattak rá, hogy a pedagógusi elvárások formálódását jelentősen befolyásolhatják a tanulók jellemzői, így például az etnikai hovatartozás, szocioökonómiai státusz, nem, külső megjelenés, korábbi teljesítmény vagy a magatartás (Good és Brophy, 2008).

Harris és Rosenthal (1986) metaanalízise szerint a tanárok elvárásai négy főbb csoportba sorolhatók. A „négytényezős modell” szerint az osztálytermi klíma az egyik ilyen faktor, mely a pedagógus által létrehozott szocioemocionális légkörre utal. Ezt mind verbálisan, mind non-verbálisan közvetíti a pedagógus diákjai felé. A bemeneti tényező a pedagógus diákjai számára felkínált tananyag mennyiségét takarja. A kimeneti összetevő az oktatás folyamán a tanulók számára biztosított kommunikációs lehetőségekre utal. A negyedik faktor a visszajelzés elnevezést kapta, és olyan tanári reakciókra utal, mely egyrészröl magában foglalja a válaszok helyességére vonatkozó visszacsatolást, másrészről annak mértékét, hogy a tanári visszajelzés mennyire szorosan kapcsolódik a tanulók által elmondott tartalomhoz. Good és Brophy (2008) szakirodalmi összefoglalója számos konkrét tanári viselkedést említ, melyek a negatív önbeteljesítő jóslatot előidézhetik. Az alacsonyan teljesítőnek vélt tanulóknak például a pedagógusok kevesebb időt adnak egy kérdés megválaszolására, gyakrabban kritizálnak hibázás esetén, ritkábban fejezik ki elismerésük siker esetén, ritkábban nyújtanak visszacsatolást és ezek kevésbé informatívak, egyszerübb kérdéseket, feladatokat kínálnak számukra, ritkábban fogadják el ötleteiket, meglátásaikat.

A tanulók számos területen már első osztályban érzékelik az eltérő tanári bánásmódot. E témával kapcsolatban az egyik legtöbbet idézett kutatás Weinstein és McKown (1998) nevéhez füződik, melyben tanulókkal készült interjúk alapján nyolc olyan dimenziót különítettek el, ahol a gyermekek különbséget tapasztalnak a tanári viselkedésben. Eltéréseket észleltek a diákok (1) a tanulócsoportok kialakításában, (2) a kiadott feladatok, a tananyag tekintetében, (3) a motivációs stratégiák (pl. elismerés) alkalmazásában, (4) a tanulók számára nyújtott lehetőségekben, segítésben, (5) az értékelésben, (6) a tanár-diák és a (7) tanár-szülö kapcsolat minőségében, valamint a (8) tanárok egyes osztályokkal kialakított kapcsolatának minőségében.

A tanári elvárások teljesítményt befolyásoló szerepe vitathatatlan, ugyanakkor erősségével, jelentőségével kapcsolatban eltérőek a vélemények. Babad (1993) szakirodalmi áttekintése szerint a tanári elvárások általában a tanulói teljesítmények különbségeinek 5-10 százalékát magyarázzák a kognitív területeken. Ezt a hatást jelentősnek tekinthetjük, elemzése megkerülhetetlen az osztálytermi folyamatok teljesítményt befolyásoló hatásainak tanulmányozásakor. A képet tovább színesíti, hogy különbségek fedezhetök fel a pozitív és a negatív önbeteljesítő jóslat hatása között, valamint a hatás mértékének tekintetében az egyes tanulói csoportok között. Madon, Jussim és Eccles (1997) eredményei szerint a pozitív tanári elvárások hatása eröteljesebb, és a gyenge teljesítményt nyújtó tanulók általában többet profitálnak ebből. Ugyanakkor, ha az önbeteljesítő jóslat negatív, a gyengén teljesítőket kedvezőtlenebbül érinti, azaz teljesítményt befolyásoló szerepe körükben erőteljesebben jelentkezik.

A speciális nevelési szükségletü, akadályozott gyermekek fejlödést gyakran fogja vissza a Pygmalion-effektus. A környezetük sok esetben lemondó, a feléjük közvetített csekély elvárások önbeteljesítő jóslatként hatnak (Józsa és Fazekasné, 2008).

Egyetértés mutatkozik abban, hogy a tanári elvárások a tanulási motiváción keresztül befolyásolják a teljesítményt, vagyis a pedagógusok elvárásai nemcsak a tanulók kognitív fejlődésében, de tanulási motivációjuk formálódásában is meghatározó szerepet játszhatnak (Babad, 2009; Good és Brophy, 2008), az utóbbi területekre vonatkozóan azonban alig áll rendelkezésünkre információ. Kivételként említhetö Rubie-Davis (2006) munkája, mely a matematikai és olvasási énképet vizsgálta. A 
kutatás alacsony és magas elvárásokat közvetítő pedagógusok osztályába járó tanulók énképnek változását mérte fel a tanév elején és végén. Az eredmények szerint a magas elvárásokkal rendelkező tanárok tanulóinak énképe pozitív, míg az alacsony elvárásokkal rendelkezőké negatív irányba változott.

\section{Az osztályközösség hatása}

A tanulási motiváció alakulásában fontos szerepe van a kortársaknak, osztálytársaknak. A tanulás motívumokhoz a viszonyítási alapot ez esetben a többiek teljesítménye, a többiek szociális elismerése adja. Cél lehet mások teljesítményének az elérése, túlszárnyalása. A mások túlteljesítéséhez kapcsolódó érzelmi reakció, az átélt öröm attól függ, mennyivel teljesít többet, jobban a diák a többieknél (Hidi és Harackiewicz, 2000). A tanulás szociális motívumainak a müködésében fontos szerepe van a versengésnek. A gyermekek már hároméves koruk körül képessé válnak az egyszerü versengésre: például ki lesz kész előbb az öltözéssel, kivel játszik az óvó néni. Ekkor még nem a versengés az elsődleges cél, megfigyelhető azonban, hogy szünetet tartanak, lassabban folytatják, vagy esetleg abbahagyják a tevékenységet, ha a másik fél, a „győztes” befejezte (Jennings, 1996). Az óvodáskorban megjelenő versengés iskoláskorra a gyermekek életének szerves részévé válik. „A versengés egyik legnyilvánvalóbb és legfontosabb funkciójának tartják a motiváló erejét" (Fülöp, 2001. 8. o.). A versengés mellett a gyermekek közötti együttmüködés, egymás munkájának elismerése is jelentős motiváló erővel bír (Józsa és Székely, 2004). Az együttmüködés és a versengés nem egymással szemben álló, nem egymást kizáró folyamatok. Egyidejüleg, a tanulási motiváció szempontjából egymást erősítve lehetnek jelen az osztályközösségben (Fülöp, 2008).

A tanulók egy része esetében a társas közegnek kiemelkedő jelentősége van a tanulási motiváció alakulásában. A szociális függőséggel jellemezhető tanulók elsősorban azért tanulnak, hogy mások elismerését megszerezzék. Teljesítményüket a társas közegen keresztül értelmezik, tanulási tevékenységüket az innen származó visszajelzéseknek megfelelően szervezik (Szenczi, 2010b).

A tanulási motívumok egy részének a gyökerét a tanulók saját képességeikkel kapcsolatos vélekedései, meggyőződései jelentik. Ezek alakulásában központi szerepet játszik a társas környezet, az osztályközösség. Az osztályközösség jelenségvilágát, a referenciacsoportok alakulását a szociálpszichológia részletekbe menően elemzi, a témáról Mészáros (2002) tankönyv jellegü tanulmánykötete ad részletes áttekintést. Az alábbi rövid összegzésben elsősorban arra koncentrálunk, hogy a tanulóközösségek összetétele, az osztálytársak teljesítménye miként befolyásolja a tanulási motivációt.

A tanulói közösségek, csoportok kialakításának különböző megoldásai egymástól jelentősen eltérő motivációs közeget eredményezhetnek, melynek formálódásában a pedagógusoknak és a kortársaknak egyaránt meghatározó szerepe van. A tanulói csoportok különbözö szervezési megoldásai mögött a pedagógusok részéről gyakran a képességek szerinti különbségek csökkentésének a célja jelenik meg. E racionális érv gyakorlati megvalósítása azonban számos nehézségbe ütközik, melyek részben a társas környezet tanulási motivációt befolyásoló szerepére vezethetők vissza.

A képességek szerint szelektáló iskolák teljesítményre gyakorolt hatásának vizsgálata főként oktatási rendszerek összehasonlításához kötődik. Ireson és Hallam (2001) a szakirodalom áttekintése alapján azt a következtetést fogalmazza meg, hogy a különböző képességü tanulókat külön oktató rendszerek esetében összességében nem mutatható ki előnyös hatás. $\mathrm{Ha}$ az egyes tanulói csoportokra gyakorolt következményeket vizsgáljuk, akkor úgy tünik, inkább a jobban teljesítők csoportjába tartozó diákok profitálnak a szelektív rendszerekben, míg a kevésbé szelektívek 
esetében a gyengén teljesítők, habár az eredmények nem konzisztensek. A nemzetközi összehasonlító vizsgálatok ugyanakkor egyértelmüvé teszik, hogy az azonos képességü tanulókból álló iskolák, osztályok kialakítása nem feltétlenül jár együtt a várt teljesítménynövekedéssel. A szelektív iskolarendszerek - ezek közé tartozik Magyarország is - tanulóinak teljesítménye elmarad a kevésbé szelektív országokétól (Csapó, Molnár Gy. és Kinyó, 2009; Csíkos, 2006). Ennek hátterében részben motivációs okok feltételezhetők.

Fontosnak tartjuk megjegyezni, hogy a képességek szerinti tanulói közösségek kialakítása a kitüzött célokkal ellentétben gyakran szocioökonómiai státusz szerinti elkülönítést jelent (a hazai folyamtokról 1. Berényi, Berkovits és Erös, 2008; Fejes, 2006; Kertesi és Kézdi, 2005; Szücs és Fejes, 2011). A szelektív oktatási rendszerek pedig kevésbé hatékonyak az alacsony szocioökonómiai státuszból adódó hátrányok enyhítésében (Haahr, Nielsen, Hansen, és Jakobsen, 2005).

Good és Brophy (2008) szakirodalmi munkája a tanulói csoportképzés teljesítményre gyakorolt hatását összegzi. A tananyag és az oktatás módja gyakran eltér a szelektív módon létrehozott osztályokban. A lassan haladó osztályokban a tanárok gyakran leegyszerüsített tananyagot oktatnak, a memorizálásra nagyobb hangsúlyt fektetnek, és a számonkérés is gyakrabban irányul a bemagolt tananyagra. Kevésbé jelenik meg a teljességre való törekvés a tartalom tekintetében, a témákat ritkábban kapcsolják össze a diákok érdeklődésével, és a pedagógusok általában kevésbé fogékonyak a tanulók véleményére. Ezek az osztályok általában a gyengén teljesítők gyüjtőhelyévé válnak, ahol inkább csökkentett minőségü oktatás, mint igényeik hatékonyabb kielégítése jellemző. Ezek a tényezők nagy valószínüséggel visszahatnak a diákok tanulási motivációjára.

A képességek szerinti szelekció, csoportképzés motivációs hatását vizsgáló empirikus kutatások többsége a tanulási énképre összpontosít. A tanulási énkép mint tanulási motívum jelentős mértékben befolyásolja a teljesítményt. A diákok tanulási énképének formálódásában központi jelentőségü a társas összehasonlítás, melynek során a tanulók saját képességeiket és teljesítményüket vetik össze társaikéval. Az összehasonlításhoz kapcsolódó egyik ismert jelenséget Nagy Hal Kis Tó hatásnak (BigFish-Little-Pond Effect) nevezik (Szenczi, 2008).

Ha a tanuló olyan közösségben van, ahol jobban teljesít, mint a társai, akkor pozitív Nagy Hal Kis Tó hatás léphet fel. Ebben az esetben a tanuló énképe pozitívabb hasonló képességü társaiénál, ami annak köszönhető, hogy kevésbé jó képességü tanulókhoz hasonlítja saját képességeit, teljesítményét. Negatív a Nagy Hal Kis Tó hatás akkor, ha a tanuló olyan közösségben van, ahol a gyengébben teljesítők közé tartozik. Ekkor a tanulási énképe alacsonyabb lehet a képességei alapján vártnál, mivel jobb képességü tanulókhoz viszonyítva ítéli meg a teljesítményét. Vagyis a diákok tanulási énképét az adott iskola, osztály többi tanulójának képessége, teljesítménye is jelentősen befolyásolja (Marsh és Craven, 2002). Ez pedig visszahat a teljesítményre: a tanulási énkép jelentős mértékben befolyásolja a későbbi teljesítményt (Józsa, 2007).

A tehetséges tanulók számára indított programok esetében számos empirikus kutatás igazolta, hogy a tehetséggondozás céljából homogén közösségekbe átkerült tanulók jelentős részének énképe számottevően csökkent a továbbra is heterogén képességü tanulóközösségekben oktatott társaikéhoz képest (pl. Marsh, Chessor, Craven, és Roche, 1995; Zeidner és Schleyer, 1999). Ha egy diák olyan iskolában tanul, ahol a többi tanuló teljesítménye jobb az övénél, akkor az énképe általában az átlagosnál gyengébb. Ha pedig olyan iskolában jár, ahol a teljesítménye meghaladja az átlagot, akkor a tanulási énképe erősebb. A hatás különösen jelentős a versenyt 
hangsúlyozó, normatív értékelést preferáló oktatási környezetben (Ireson, Hallam és Plewis, 2001; Marsh és Rowe, 1996).

A diákok tanulási énképe az iskolai osztályzataikkal sokkal erősebben összefügg, mint a képességfejlettségükkel. A tanulási énképet nagyobb mértékben alakítják az osztályzatok, mint a képességek tényleges fejlettségi szintje. Ez az eredmény a pedagógusok értékelésének szerepére hívja fel a figyelmet (Szenczi és Józsa, 2009). A tanulási motívumok alakulásában fontos szerepe van a tanulók munkájára adott értékelésnek, az osztályozásnak. Az osztályozással szemben a tanulók többségénél a segítő, formáló visszacsatolás segíti leginkább a tanulási motiváció erösödését (Hidi, 2000; Réthyné, 1989).

Ireson és Hallam (2001) felmérésének eredményei a gyengén teljesítők esetében részben ellent mondanak a Nagy Hal Kis Tó hatásnak. Azokban az iskolákban, ahol képességek szerinti tanulói csoportok kialakítása gyakoribb, az alacsonyan teljesítők közösségéhez tartozás kedvezőtlen önértékeléshez, iskolaellenes attitűd kialakulásához, az iskolától való elidegenedéshez vezethet. Ebben szerepet játszik e tanulók stigmatizálása a kortársak részéről, illetve az eltérő elvárások és visszajelzések a pedagógusok részéröl. E közösségekben a kedvezőtlen motivációs jellemzők Good és Brophy (2008) szerint arra vezethetők vissza, hogy a tanulásban vezető szerepet játszó, vagyis modellt jelentö tanulók hiányoznak ezekböl az osztályokból, illetve ezekben a közösségekben a tanulás területén erőfeszítést mutató társakat kigúnyolással a többségi normához való igazodásra kényszerítik. Az osztálytermi munkába való bekapcsolódás, az aktív részvétel (classroom engagement) mértéke jelentősen függ az adott tanulói közösség normáitól, például a tanulási tevékenységekbe fektetett munka társak általi verbális elítélésétől (Bishop, Bishop, Bishop, Gelbwasser, Green, Peterson, Rubinsztaj és Zuckerman, 2004).

A Nagy Hal Kis Tó hatás speciális jelenségének lehetünk tanúi az integráltan oktatott tanulásban akadályozott tanulóknál (1. Fejes és Szenczi, 2010). Ezeknek az integrált gyermekeknek a készség- és képességfejlettsége jelentős fejlődésbeli megkésettségben van az osztálytársaikhoz képest. Józsa Krisztián eredményei szerint az integráció pozitívan hat a tanulásban akadályozott gyermekek olvasására (Józsa, 2008) és matematikai képességeire (Józsa, 2009b). A tanulási motiváció és az énkép esetében azonban éppen ellentétes hatást lehet felfedezni. Az integrált harmadikos tanulók matematikai attitüdje, olvasási motivációja, tanulási motivációja egyaránt elmarad a többségi társaikétól (Józsa, 2008, 2009b). Feltételezhetően ennek egyik oka az integrált tanulók referenciaközege, amelyhez képest az ő teljesítményük jelentős mértékben alacsonyabb.

A tanulási motivációt a magatartási problémák gyakoribb előfordulása is befolyásolhatja az alacsonyan teljesítő közösségekben. A szakirodalomban egyetértés mutatkozik abban, hogy a magatartási zavarok gyakoribbak a tanulási problémákkal küzdő (Felleginé, 2004), illetve alacsony szocioökonómiai státusszal rendelkező tanulók körében (Ranschburg, 2001). Figlio (2007) empirikus bizonyítékokkal szolgál arra vonatkozóan, hogy a magatartási problémák elöfordulásának gyakorisága az osztályban negatívan befolyásolja a tanulási teljesítményt, és növeli a valószínüségét az osztálytársak problémás viselkedésének. E tényezők a direkt hatásokon túl a pedagógusok elvárásait is jelentősen befolyásolhatják (Good és Brophy, 2008). 


\section{A tágabb közösség szerepe: kulturális különbségek}

A szocializáció folyamata kultúrába ágyazott, így az emberi fejlődésnek jellegzetes, az adott kultúrához kötődő vonásai alakulnak ki. Az állítás evidenciának tünhet, a pszichológia és a nevelés tudománya azonban a közelmúltig kevés figyelmet fordított a kultúrának a fejlödésben betöltött szerepére. Ezt igyekszik enyhíteni a kulturális, valamint a kulturális összehasonlító pedagógia és pszichológia (1. Gordon Győri, 2004; Nguyen Luu, 2003). Az új megközelítések mindenekelött a szociális környezet korábbi szük értelmezésére, valamint az eredmények korlátozott érvényességi körére hívják fel a figyelmet. Rámutatnak arra, hogy az egyén pszichológiai jellemzői, valamint a pszichológiai jellemzők és a háttérváltozók közötti kapcsolatok a különböző kultúrákban, etnikai csoportokban, szubkultúrákban jelentős eltéréseket mutathatnak (Nguyen Luu, 2003; Vajda és Kósa, 2005). A kulturálisan megalapozott tudás szerepet játszhat a tanulási motiváció alakulásában (pl. Gordon Győri, 2004, 2009; Réthyné, 2001a, 2003). A tanulók társas és kulturális környezete, illetve a környezet észlelése, értelmezése lényegesen eltérő lehet, így jellegzetes különbségek alakulhatnak ki a tanulók motívumrendszerei között.

A különböző kultúrákhoz tartozó egyének motívumrendszerének eltéréseit számos kutatás bizonyította (pl. Mau és Lynn, 1999; Niles, 1995). Különösen jól dokumentáltak a nyugati (elsősorban észak-amerikai) és a kelet-ázsiai kultúrák közötti eltérések. A kelet-ázsiai és nyugati társadalmakban szocializálódott tanulók motivációs különbségeiről magyar nyelven Gordon Győri János (2006) ad részletes áttekintését. Jellegzetes eltérés például, hogy a kelet-ázsiai diákok a teljesítményükben nagyobb szerepet tulajdonítanak a saját erőfeszítéseiknek, míg nyugati társaik inkább a képességeik, adottságaik szerepét hangsúlyozzák. A legismertebb különbségek egyike talán az, hogy a kudarc, a kudarctól való félelem ösztönzőbben hat a teljesítményre a kelet-ázsiai kultúrákban (Eaton és Dembo, 1997; Heine, Kitayama, Lehman, Takata, Lueng és Matsumoto, 2001; Zusho, Pintrich és Cortina, 2005). A kelet-ázsiai tanulók esetében kevésbé választható el egymástól a külső ösztönzők szerepe és az önjutalmazó motívumok hatása.

Ezek az eredmények arra hívják fel a figyelmet, hogy a kelet-ázsiai kultúra tanulóinak motívumrendszere csak korlátozott mértékben értelmezhető a több évtizede elfogadott nyugati tanulási motiváció modellek keretei között (Gordon Győri, 2009). Ezek a felismerések megkérdőjelezik az eddigi motivációs modellek általános érvényességét. A további kutatások irányát minden bizonnyal annak a vizsgálata fogja meghatározni, hogy az eddigi ismereteink mennyiben alkalmazhatók különféle kultúrákra. A tanulási motiváció működésének megértésében alapvető fontosságú lesz a kultúrafüggő modellek felállítása (Pintrich, 2003).

A tanulási motiváció kulturális meghatározottsága a hazai kutatásokban elsősorban a többségi és roma diákok motivációs eltérései kapcsán merülhet fel (Fejes, 2005). A roma diákok iskolai sikertelenségeinek magyarázatában a tanulási motiváció gyakran említett tényező (Harsányi és Radó, 1997; Hegedüs, 1993; Radó, 1997). A pedagógusokkal készült interjúk szerint a roma gyermekek kevésbé motiváltak a tanulására, a hagyományos módszerekkel kevésbé lehet az érdeklődésüket felkelteni az iskolai tanulás iránt (Liskó, 2001; Nagy, 2002).

A tanulási motiváltság egyik indikátora a továbbtanulási szándék. Szembetűnő a különbség ebből a szempontból a roma és a nem roma tanulók között. Kiss és Gordos (2003) adatai szerint a nem roma tanulók 68 százaléka tervez gimnáziumi vagy szakközépiskolai tanulmányokat, addig ez mindössze 39 százalék a roma tanulók körében. Forray és Hegedüs (1998) eredményei szerint a roma gyermekek 
továbbtanulási szándéka összefügg a család polgári életbe való beilleszkedésével és kapcsolatban áll az apák munkahelyi integrációjával.

Saját korábbi kutatásunkban roma és nem roma hetedikes diákok tanulási motivációját hasonlítottuk össze. Vizsgálatunkban nem kaptunk számottevő különbséget sem az elsajátítási motivációjában, sem az összevont tanulási motiváció indexben. Az olvasási énképnél és a számolási énképnél szignifikáns különbség fedezhető fel a többségi tanulók javára (Fejes és Józsa, 2007). A roma és nem roma iskolások tanulási motívumainak átlagai között felfedezhetők eltérések mértéke jóval alatta marad a hátrányos és kedvező feltételek között nevelkedő tanulók között feltárt különbségeknek (Fejes és Józsa, 2005). Ezt a megállapítást erősítette meg a regressziós modellünk is, mely szerint a roma származás nem befolyásolja a tanulási motiváció erősségét; a hátrányos helyzet azonban mintegy 12 százaléknyi magyarázó erővel bír a tanulási motiváció egyéni különbségeiben. E vizsgálatból arra következtethetünk, hogy a roma tanulók kedvezőtlenebb motivációs háttere elsősorban hátrányos helyzetükre vezethető vissza, vagyis a hazai viszonyok között a kulturális különbségeknek önmagában nincs tanulási motivációt befolyásoló hatása. Nyitott kérdés ugyanakkor, hogy a specifikus tanulási motívumok esetében feltárható-e eltérés a roma és a nem roma tanulók között.

\section{Összegzés}

A szakirodalom alapján rámutattunk arra, hogy bár a tanulási motiváció hátterében veleszületett alapok valószínüsíthetők, a társas környezet szerepe jelentős a tanulási motívumok formálódásában. Az elsődleges szocializációs színtér hatótényezőit vizsgálva a szülők nevelési gyakorlatának, a gyermekkel kapcsolatos nézeteinek és a szülő-gyermek kapcsolat jellegének a szerepét emeltük ki, valamint kitértünk a család társadalmi-gazdasági helyzetének jelentőségére. E terület áttekintését követően megfogalmazható, egyrészt hogy a hazai vizsgálatok alig érintik az otthoni környezet motivációs hatását, másrészt, hogy a nemzetközi szakirodalom számos olyan pontra rámutat, mely a kedvezőtlen családi háttérből adódó hátrányok kompenzálását célzó kezdeményezésekben figyelemre érdemes lehet.

A pedagógusok esetében az eddigi kutatások főként a tanár-diák kapcsolat minőségével, illetve a tudatos és a nem tudatos tanári visszajelzések hatásával foglalkoztak. A társak egyrészt a tanulók saját képességeik, teljesítményük megítélésének viszonyítási pontjaiként, másrészt az elismerés megszerzésének lehetőségét kínáló közösségként jelennek meg. Az iskolai környezet motivációs lehetőségeit illetően különösen fontos kutatási irányként jelölhető meg a különböző összetételü tanulói közösségek hatásának, illetve az eltérő oktatási megoldásoknak, osztálytermi gyakorlatoknak a korábbiaknál részletesebb feltárása.

Szakirodalmi szintézisünk arra is rávilágított, hogy a tanulási motivációban kulturális különbségek is tükröződhetnek. Korábbi kutatásaink alapján azonban úgy látjuk, hogy hazai kontextusban az eddigi vizsgálatok nem jelezték ennek számottevő szerepét. 


\section{TANULÓINK ÉS ISKOLÁINK NÉHÁNY MOTIVÁCIÓS JELLEMZŐJE}

Ebben a fejezetében azokat a kutatásokat tekintjük át, amelyek a magyar tanulók motivációs sajátosságairól, valamint iskoláink motivációt befolyásoló jellemzőiről közölnek információkat, így támpontként szolgálhatnak a tervezett vizsgálat lebonyolítása, valamint az eredmények értelmezése során. Elsőként összefoglaljuk azokat a felméréseket, amelyek a matematikával kapcsolatos motivációról a magyar tanulókra vonatkozóan eredményeket kínálnak. Ezt követően a tanulási motiváció életkori változásáról tájékoztató, továbbá a tanulási motivációt befolyásoló iskolai tényezőkkel kapcsolatos hazai vizsgálatokat ismertetjük. Végezetül a tanulási motiváció és a tanulmányi eredményesség összefüggéseiről eredményeket közlő hazai munkákat kivonatoljuk.

\section{Matematikával kapcsolatos motivációs jellemzők}

Tanulóink matematikára vonatkozó motivációs jellemzőinek ismertetésekor az ezredfordulót követő munkákra fókuszálunk, érintve a fontosabb hazai és nemzetközi adatgyüjtéseket. Az áttekintés során arra törekszünk, hogy lehetőség szerint más tárgyakkal, müveltségi területekkel vessük össze a matematikát érintő eredményeket, illetve, hogy más országok tanulóinak jellemzőit felhasználjuk viszonyítási pontként.

A tantárgyi attitüdök alakulásáról a hetvenes évek elejétől, a nemzetközi összehasonlító vizsgálatokban való részvétel kezdetétől rendelkezünk ismeretekkel (pl. Ballér, 1973). A kilencvenes évek közepétől már a jelentősebb hazai tudásszintmérések és képességvizsgálatok is alkalmaznak erre vonatkozó kérdéseket (pl. Báthory, 1989; Bánfi, 1999; Csapó, 2000; Kocsis, 2000; Józsa és Pap-Szigeti, 2006; Papp és Józsa, 2000; Orosz, 2001). Ezek a vizsgálatok egymást megerősítve igazolták, hogy az iskolázásban való előrehaladással a tanulók fokozatosan elfordulnak a tantárgyaktól, vagyis a tantárgyi attitüdök folyamatosan romlanak. A tantárgyi attitüdök romlása más országokban is kimutatott jelenség (1. pl. az IEA és TIMSS vizsgálatok eredményeit), ugyanakkor nálunk - föleg a természettudományos tantárgyak esetében - a romlás sokkal erőteljesebb (Csapó, 2000).

Csapó (2000) megyék és településtípusok szerint reprezentatív mintáján végzett felmérését 5., 7., 9. és 11 . évfolyamon végezte, évfolyamonként megközelítőleg kétezer tanulóval. Eredményei szerint a legkevésbé kedvelt tantárgyak egyike a matematika, a tantárgyak kedveltségi rangsorában a kémiával, a fizikával és a nyelvtannal együtt sereghajtónak számít (2. ábra). 


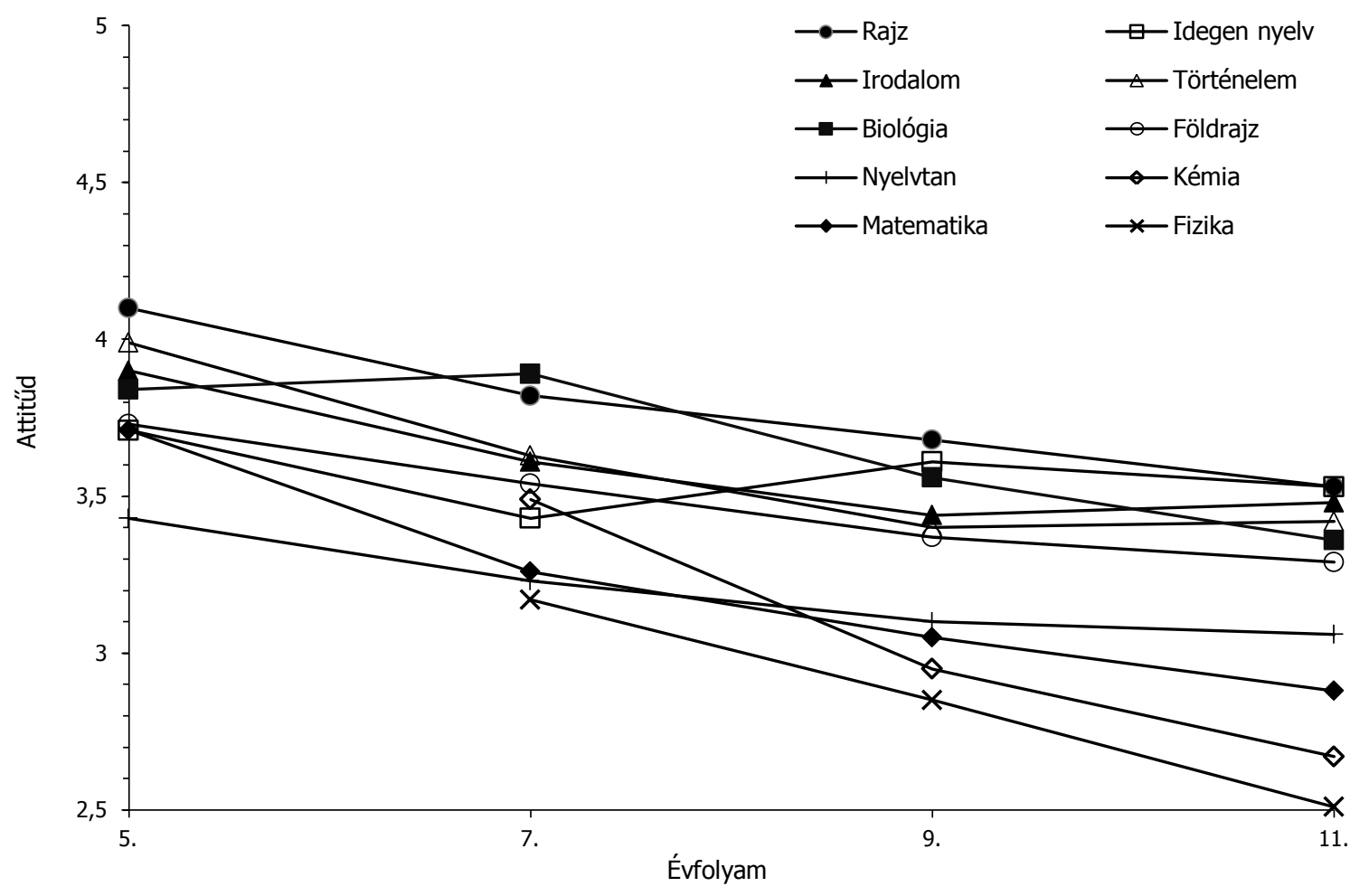

2. ábra

A tantárgyakkal kapcsolatos attitüdök az iskolai évek függvényében (Csapó, 2000, 351.o.)

Az utóbbi évek tantárgyi attitüdjeire vonatkozó kutatásai közül külön említést érdemel Józsa és Pap-Szigeti (2006) vizsgálata, mivel longitudinális adatokkal szolgál e témakörben. A két évet átfogó vizsgálat mintája két kohorszból tevődött össze: 102 nyolcadik és 173 tizedikes tanulóból. Az utómérés idején a fiatalabbik kohorsz 10. évfolyamra, az idősebbik 12. évfolyamra járt. E vizsgálat adatai szintén megerősítették a tantárgyi attitüdök csökkenő tendenciáját. A két mérési időpont között a korrelációk közepes erősségűek, 0,3-0,6 közöttiek (3. táblázat). Ez azt mutatja, hogy számottevő mértékben megváltozott a tantárgyak kedveltsége alapján képezhető tanulói rangsor. Az egyes tantárgyak esetében bekövetkezö változásokban is eltérések láthatók. Például a nyelvtan $(0,41-0,42)$, kémia $(0,36-0,42)$, biológia $(0,31-0,36)$ korrelációs együtthatói szignifikánsan kisebbek, mint az irodalom $(0,50-0,58)$ és a matematika $(0,52-0,60)$ korrelációi (Józsa és Pap-Szigeti, 2006). Ez azt jelenti, hogy egyes tantárgyakhoz füződő attitűdökben jelentősebb átrendeződés történik a tanulók között, míg más tárgyak esetében ez kevésbé látványos. Utóbbiak közé tartozik a matematika, ami arra utal, hogy a tárggyal kapcsolatban kialakított attitüd más tantárgyakhoz képest stabilabb, nehezebben változik. 
3. táblázat. A tantárgyak kedveltségének változása: az elö- és utómérés korrelációi (Józsa és Pap-Szigeti, 2006, 147. o.)

\begin{tabular}{lcccccccc}
\hline Kohorsz & $\begin{array}{c}\text { Nyelv- } \\
\text { tan }\end{array}$ & $\begin{array}{c}\text { Iroda- } \\
\text { lom }\end{array}$ & $\begin{array}{c}\text { Törté- } \\
\text { nelem }\end{array}$ & $\begin{array}{c}\text { Idegen } \\
\text { nyelv }\end{array}$ & $\begin{array}{c}\text { Mate- } \\
\text { matika }\end{array}$ & Fizika & Kémia & $\begin{array}{c}\text { Bioló- } \\
\text { gia }\end{array}$ \\
\hline $\begin{array}{l}8-10 . \\
\text { évf. }\end{array}$ & 0,41 & 0,50 & 0,34 & 0,42 & 0,60 & 0,30 & 0,36 & 0,36 \\
$\begin{array}{l}10-12 . \\
\text { évf. }\end{array}$ & 0,42 & 0,58 & 0,45 & 0,41 & 0,52 & 0,54 & 0,42 & 0,31 \\
\hline
\end{tabular}

Megj.: a táblázatban szereplő valamennyi korrelációs együttható p $<0,01$ szinten szignifikáns.

A 8-10. között tapasztalt változásban minden bizonnyal szerepe lehet az iskolaváltásnak, illetve a tanárok változásának. A további okok egyike lehet az is, hogy a középiskola vége felé már kevéssé változik a tanulóknak a vélekedése egy-egy tárggyal kapcsolatban. A vizsgálat emellett arra is rámutatott, hogy a csökkenés nem minden tanuló esetében jelentkezik, mintegy ötödüknél az attitűdök javulását tapasztalhatjuk.

Az előzőekben bemutatott kvalitatív kutatási metodikától eltérően Csíkos (2012a) a tantárgyi attitüdöket nyílt végü kérdések segítségével vizsgálata. A kedvenc és a legkevésbé szeretett tárgyat kellett megnevezniük az említett felmérésben a 7. évfolyamos tanulóknak ( $\mathrm{n}=570)$. A legkevésbé kedvelt tantárgy kérdése kapcsán három tárgy ért el 10 százalék feletti relatív gyakorisági értéket: a földrajz, a matematika és a fizika.

Artelt, Baumert, Julius-Mc-Elvany és Peschar (2003) munkája az önszabályozó tanulás koncepciója alapján kiválasztott motivációs konstruktumokról tartalmaz elemzéseket a 2000-es PISA-mérés adatai alapján. Témánk szempontjából a matematikai énkép, illetve a matematikai és olvasási énkép viszonya érdemel említést. Eredményeik szerint az olvasáshoz kapcsolódó énkép átlagai minden országban pozitívnak, a matematikai énképnél erősebbnek mutatkoztak, a matematikai énkép az országok több mint felénél a negatív kategóriába került (3. ábra). A matematikához kötődő negatív énkép egyetlen országban, Koreában kedvezőtlenebb a magyar diákokénál, emellett a magyar tanulók esetében kiugróan nagy az olvasási és a matematikai énkép közötti távolság. 


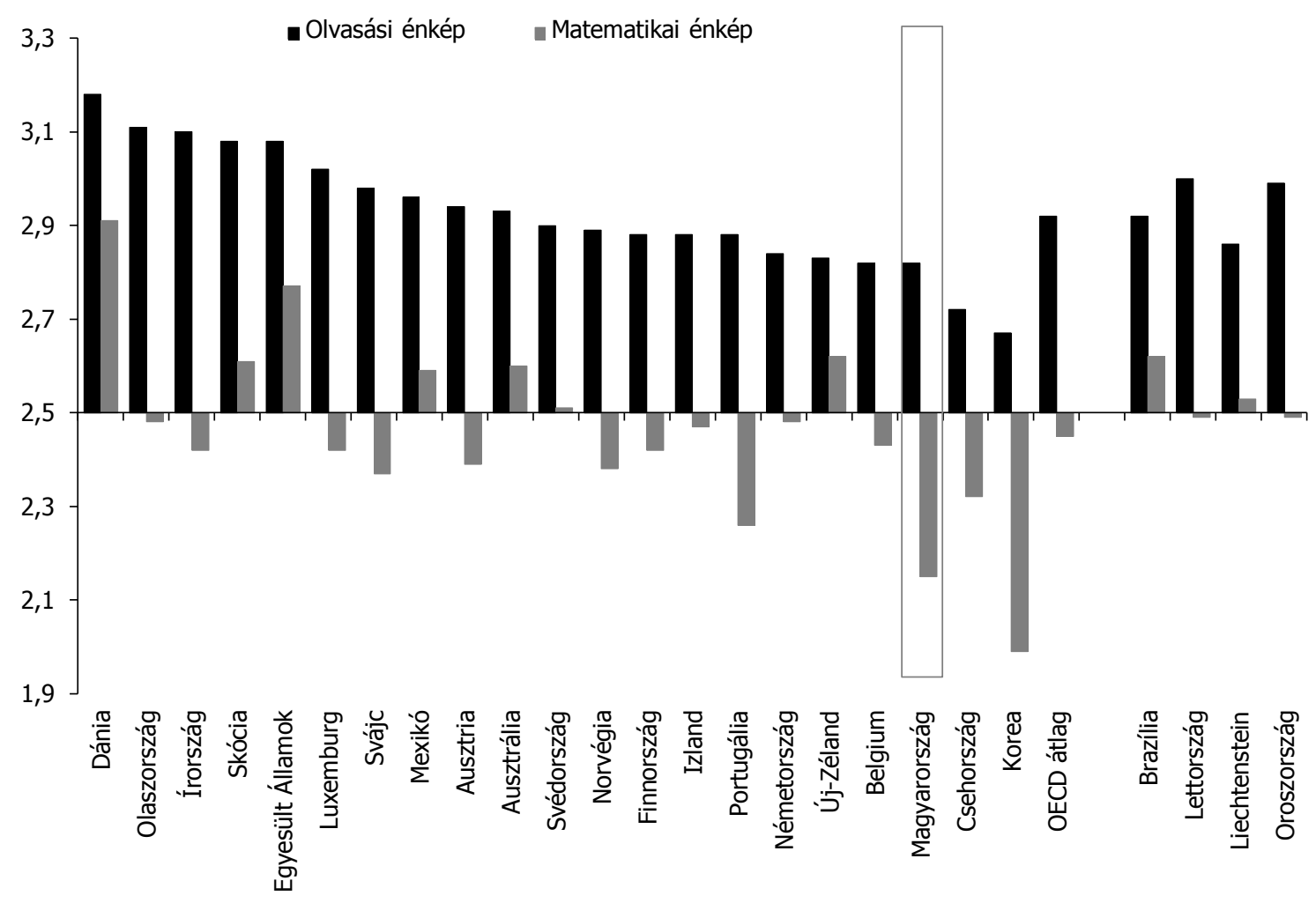

Megj.: négyfokú Likert-skálát használtak, a 2,5-ös értéket semleges viszonyulásnak tekintették; az ábra jobb oldalán a nem OECD országok eredményei láthatók.

\section{3. ábra}

Olvasási és matematikai énkép

(Forrás: OECD PISA 2001 database, Table C.3.2.; Józsa és Fejes, 2012, 395. o.)

B. Németh és Habók (2006) a 2000-es PISA-vizsgálat önszabályozó tanulásra kidolgozott mérőeszközével 2005-ben további korcsoportokra kiterjesztve újra elvégezte a vizsgálatot hazai mintán. A 3385 hetedikes és 2037 tizenegyedikes tanulóból álló minta a régiónkénti lefedettség, a tanulók neme és a szülők iskolai végzettsége szempontjából reprezentatív volt. Eredményeik szerint a motiváció minden összetevője csökkenést mutat 13 és 17 éves kor között, a legnagyobb csökkenés a matematikai érdeklődés terén tapasztalható, míg az olvasás iránti érdeklődés változatlan. Jelentős a visszaesés a matematikai énkép esetében is, míg az olvasási énképet tekintve ez rendkívül kis mértékü.

A 2003-as PISA-mérésben a kiemelt müveltségterülethez kapcsolódóan a matematikát érintő motivációs jellemzők megismerése került előtérbe, amelyet a (1) matematika iránti érdeklödéssel és matematikatanulás élvezetével, a matematikához kapcsolódó (2) instrumentális motivációval és (3) szorongással, valamint a (4) matematikai énképpel és (5) én-hatékonysággal vizsgálták. A matematika iránti érdeklődést és a matematikatanulás élvezetének - 0 átlagra és 1-es szórásra transzformált - mutatója szerint nemzetközi összehasonlításában Magyarország az egyik legkedvezőtlenebb helyzetü ország $(-0,21)$, az OECD országok közül csak Japánban, Ausztriában, Luxemburgban és Finnországban kedvezőtlenebb a fiataloknak ez a jellemzője. A nemzetközi átlaghoz viszonyítva a legmarkánsabb lemaradást a legfelső negyedbe tartozó tanulók mutatják, e tekintetben csak Csehország marad mögöttünk. A matematika jövőbeni hasznosságára utaló instrumentális motiváció országok közötti összevetése szerint elmaradunk az OECD átlagtól $(-0,11)$, ennek 
mértéke azonban nem számottevő, és ismét a legfelső negyedbe tartozó tanulók kapcsán számolhatunk be jelentősebb elmaradásról. A szorongást tekintve az OECD országok átlagával jellemezhetőek a tanulóink $(-0,01)$, mind a tanulók összességét, mind az egyes negyedeket figyelembe véve. A nemzetközi átlagnál a magyar tanulók matematikai énképe rosszabb $(-0,15)$, ugyanakkor ezen adatok alapján nem tartozunk a legkedvezőtlenebb helyzetü országok közé, számos ország eredményei hasonlóak, illetve gyengébbek, így például a japán $(-0,53)$ és a koreai $(-0,35)$ fiatalok énképe (OECD, 2004b). A 2000-es (Artelt és mtsai, 2003) és a 2003-as (OECD, 2004b) mérésben a matematikai énkép egyaránt szerepelt, ugyanakkor nem ugyanarról a konstruktumról, mérőeszközről van szó, így a két mérés adatai nem összevethetők. Az országok sorrendje is jelentősen eltér, így tendenciák felrajzolásához sem nyújtanak fogódzót az eredmények.

A matematikai én-hatékonyság mérése során különböző számolási feladatokkal kapcsolatban kellett magabiztosságukat kifejezniük a tanulóknak. A magyar fiatalok énhatékonysága kifejezetten pozitívnak mondható, az OECD országokat tekintve egyedül a szlovák fiatalok vannak elönyösebb helyzetben (OECD, 2004b).

További lényeges információt nyújthat tanulóink matematikához füződő tanulási motivációjáról, ha összevetjük, hogy egymáshoz képest mennyire érzik fontosnak a tanulók a jó teljesítményt az olvasás, a matematika és a természettudományok területén (4. ábra). Bár a magyar tanulók a jó teljesítménynek a természettudományos tárgyakhoz viszonyítva mind a matematika, mind az olvasás területén jóval nagyobb jelentőséget tulajdonítanak, ugyanakkor a matematikában nyújtott jó teljesítmény fontossága nemzetközi viszonylatban tanulóink körében a legalacsonyabb $(O E C D, 2004 b)$.

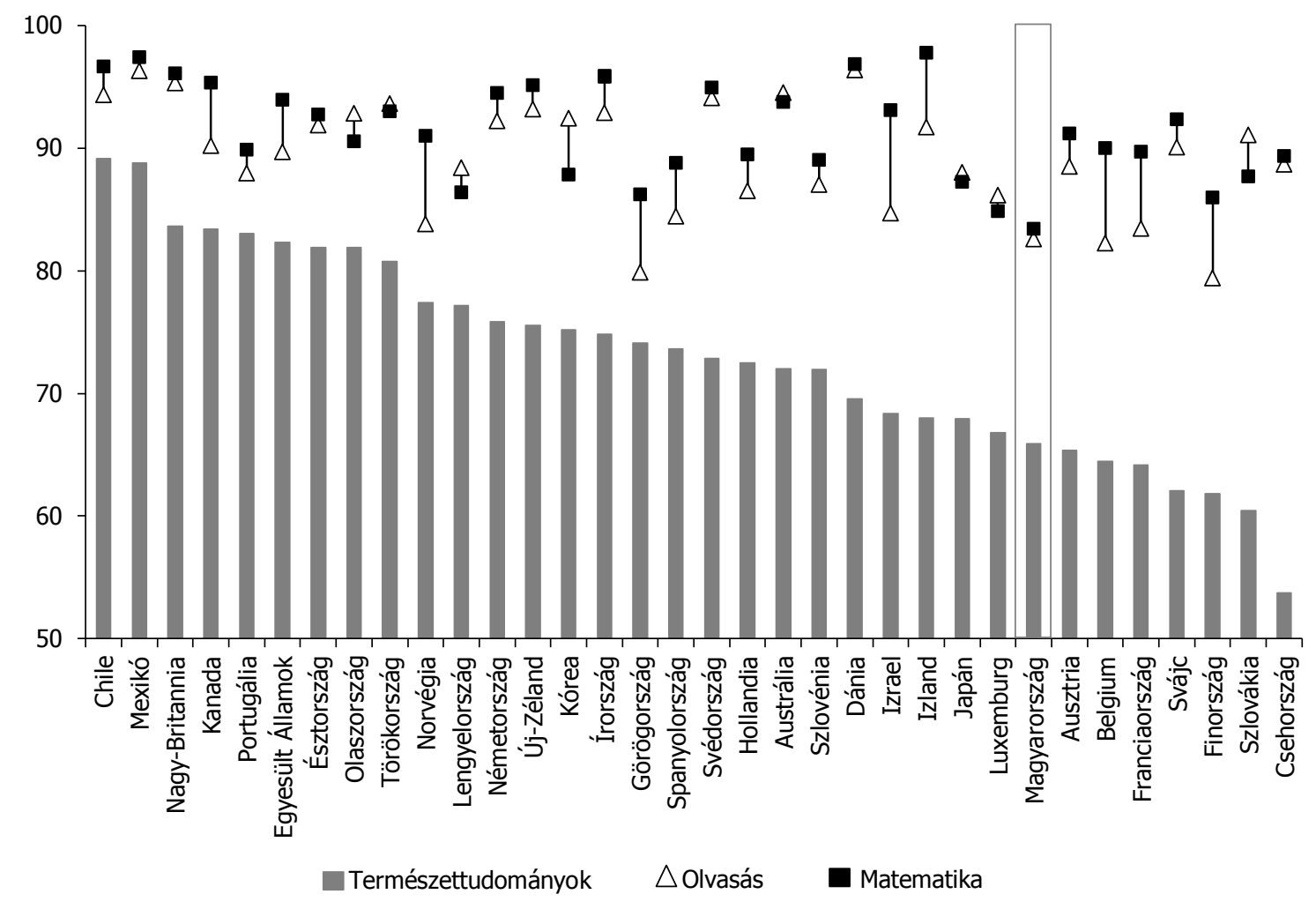

4. ábra

A jó teljesitmény fontossága természettudományok, olvasás és matematika területén (\%) (Forrás: OECD PISA 2006 database, Table 3.7.; Józsa és Fejes, 2012, 397. o.) 


\section{A tanulási motiváció életkori változása}

Az előzőekben láthattuk, hogy a matematikával kapcsolatos motivációs jellemzők az életkorral párhuzamosan egyre kedvezötlenebbül alakulnak. Több hazai vizsgálat is foglalkozott a tanulási motiváció további összetevőinek az iskolai évek alatt bekövetkező változásával, az alábbiakban ezek közül ismertetjük a fontosabb kutatásokat. Ezek egyrészröl a tantárgyakhoz való viszony változása mögött meghúzódó okok számos részletét megvilágíthatják, másrészről a különböző életkorú tanulók motivációs sajátosságai tekintetében lényeges viszonyítási pontokat kínálhatnak a későbbiekben eredményeink értelmezéséhez.

Az általános tanulói attitüdökre irányuló első jelentős kutatást Veczkó József (1986) végezte az 1967/1968-as tanévben, a tanulók iskolához füződő viszonyának megismerése érdekében. Az általános és középiskolás korú tanulók 12 ezer fös mintájának összeállításakor a település, illetve az iskola osztott jellege (osztott, részben osztott és osztatlan általános iskola) szerinti reprezentativitás szempontjait helyezte előtérbe. Általános iskola első és második osztályában egyéni és csoportos beszélgetésekkel végeztek adatgyüjtést, melyek során képeket használtak projekciós céllal (pl. érkezés az iskolába, dolgozatírás, feleltetés). Harmadik osztálytól kérdőívet alkalmaztak, mely zárt és nyílt kérdéseket egyaránt tartalmazott. Az adatfelvételt a tanév három időpontjában, szeptember elején, december közepén és június elején végezték. Az eredmények szerint az iskola iránti pozitív attitűddel jellemezhető tanulók arányának csökkenése az életkor elörehaladtával, különösen az 5. és 6. évfolyamon látható jelentős visszaesés. A vizsgálat megállapítása szerint kisiskoláskorban a tanulók iskolához füződő kedvező viszonya főképp a pedagógussal kialakult kapcsolathoz köthetö, míg a negatív attitüd hátterében a tanulmányi sikertelenség, szorongás, illetve a tanítók elutasító viselkedése áll. A felső tagozatosok pozitív viszonyulásukat az érdekességgel, változatossággal, sikerélményekkel magyarázzák, és megjelenik a kortárs kapcsolatok fontossága is, megelőzve a tanár-diák kapcsolatot. A negatív oldalon a korábban említettek kiegészülnek a „militarizált, beszabályozott” iskolai légkörrel, a jövőbeni hasznosság hiányával, illetve megjelenik a kedvezőtlen szociális kapcsolatok és a gyenge tanulmányi eredmények közötti összefüggés is az indokok között. A középiskolában a tudás, a tanulás jövőt alakító szerepe hangsúlyos, a tanár pedig szaktekintélyként, mintaadóként tünik fel, mely a diákok válaszai szerint fontos szerepet játszik iskolához való viszonyukban. A negatív attitüd mögött új elemként az iskola teljesítmény-centrikus, monoton atmoszférája tünik fel.

Az attitüdromlás egy tanéven belül is kimutatható, a tanév kezdetekor mindig kedvezőbb a kép, mint a tanév közepén, illetve végén. A decemberi vizsgálat a szeptemberi adatokhoz képest az elsösök kivételével minden évfolyamon visszaesést jelez. A legnagyobb mértékü átrendeződés az alsó tagozatosok körében figyelhető meg. A két vizsgálat összehasonlításakor a legszembetünőbb az elsősök kedvező attitüdjének 7 százalékos emelkedése. A másodikosok pozitív viszonya 10, a harmadikosoké 16, a negyedikeseké pedig 17 százalékkal csökkent. A júniusi adatfelvétel a pozitív beállítódás további fokozatos romlásról tanúskodik, maga után vonva az ambivalens hozzáállással jellemezhető tanulók részarányának emelkedését.

1968-1972 között egy 359 fôs mintán longitudinális adatgyüjtést is végeztek az általános iskola első és ötödik, illetve a középiskola első évfolyamának követésével, mindhárom korcsoportban öt-öt osztály bevonásával. A követéses vizsgálat a keresztmetszeti eredmények kontrollálása céljából indult, és megerősítette azokat, vagyis az attitüdök változásának trendje megegyezett a korábbiakban mérttel (Veczkó, 1986). 
Józsa (2002) kutatásában 594 fós mintán keresztmetszeti adatfelvétellel elemezte a tanulási motiváció változását hetedik és tizenegyedik osztály között. A tanulási motiváció vizsgálatához Kozéki (1985) kérdőívének rövidített változatát használta. A tanulási motiváció átlagos fejlettsége hetedik osztályban 74 százalékpont, tizenegyedikben a gimnazistáknál 67 százalékpont, a szakközépiskolásoknál 63 százalékpont. Az egyes osztályok motiváltsága között jelentős különbségeket kaptak. A hetedikeseknél a leginkább (82\%p) és a legkevésbé (54\%p) motivált osztály motivációátlaga közötti eltérés 28 százalékpont. Az eredmények szerint a tanulási motiváció alakulásában döntő szerepe van az osztályközösségnek.

Molnár Éva (2003) 3-11. között páratlan évfolyamokon vizsgálta a tanulási motiváció néhány összetevőjének (elsajátítási motívum, szorongás, feladat értéke, önhatékonyság, szorgalom-attribúció, teljesítmény-motívum) az életkori változását. Keresztmetszeti vizsgálatában minden évfolyamon több mint 500 tanuló vett részt. Eredményei szerint a szorgalom-attribúció kivételével az összes többi motívum erőssége jelentősen csökken az iskolai évek elörehaladtával. A tanulási motiváció összevont változójának az átlaga a harmadikos 64 százalékpont szintről tizenegyedikre 51 százalékpontra csökken.

A tanulási énkép esetében is számottevő csökkenés mutatható ki az iskolai évek alatt. Az SDQ (Self-Description Questionnaires) kérdőív magyar adaptációjával végzett 3., 5. és 7. évfolyamos tanulókra $(n=586)$ kiterjedő vizsgálat tanulságai szerint nagymértékben romlik 3. és 7 . évfolyam között a diákok iskolai tanuláshoz kötődö énképe. Nem mutatható ki ugyanakkor lényegi változása az iskolához nem kötődő általános énképben (Szenczi és Józsa, 2008).

$\mathrm{Az}$ Egészségügyi Világszervezet (World Health Organisation, WHO) égisze alatt zajló HBSC-felmérésekben (Health Behaviour in School-aged Children) rendszeresen rákérdeznek a tanulók iskola iránti attitüdjére. Az 5., 7., 9. és 11. évfolyamra kiterjedő kutatások korcsoportonként több mint 1500 tanuló bevonásával készülnek, fenntartó, megye, településtípus és a középiskolák esetében képzési típus szerinti reprezentativitással. Az utolsó felmérés adatait Zsiros és Örkényi (2011) közli. $\mathrm{Az}$ eredmények évfolyamok szerinti bontásban a 4. táblázatban láthatók, amelyek ugyancsak arról tájékoztatnak, hogy az iskola iránti attitüd egyre kedvezőtlenebbé válik az életkör növekedésével párhuzamosan. Azonban az is kiolvasható az adatokból megerősítve a korábbi adatgyüjtések eredményeit (pl. Szabó, 2003) -, hogy a középiskolába kerülés pozitív irányú változást eredményez, majd itt is elindul a csökkenés.

4. táblázat. A tanulók iskola iránti attitüdje évfolyam szerint (\%) (Zsiros és Örkényi, 2011, 105. o.)

\begin{tabular}{lcccc}
\hline \multicolumn{1}{c}{ Évfolyam } & Nagyon & Egy kicsit & Nem nagyon & $\begin{array}{c}\text { Egyáltalán } \\
\text { nem }\end{array}$ \\
\hline 5. & 32,0 & 42,8 & 17,0 & 8,2 \\
7. & 22,7 & 44,2 & 20,5 & 12,6 \\
9. & 36,5 & 41,8 & 13,6 & 8,1 \\
11. & 23,1 & 46,5 & 20,6 & 9,9 \\
\hline Összesen & 28,6 & 43,9 & 17,9 & 9,6 \\
\hline
\end{tabular}

Az utóbbi évtizedben a legnagyobb mintával dolgozó hazai vizsgálat az elsajátítási motiváció életkori változásának a feltárására irányult (Józsa, 2007). Az elsajátítási motiváció vizsgálata a DMQ kérdőívek magyar változatainak (H-DMQ) alkalmazásával valósult meg. A keresztmetszeti adatfelvételre 2., 4., 6., 8. és 10. évfolyamon került sor. 
7410 tanuló önjellemező kérdőívét elemezték. Közülük 3504 tanulóról tanári, 3843 tanulóról pedig szülői jellemzés is rendelkezésre állt. A minta a tanulók szüleinek iskolai végzettsége, az ország területi lefedettsége, valamint a tanuló neme szempontjából reprezentatív. A 10. évfolyamos minta reprezentatív módon képezte le a gimnáziumba, szakközépiskolába, szakiskolába járó tanulók arányát. A vizsgálat szerint a szülők vélekednek legpozitívabban a gyermekeik motiváltságáról, többnyire az ő értékeléseikben a legmagasabbak az átlagok. A tanári értékelések átlagai tipikusan a legalacsonyabbak. A tanulói önjellemzések átlagai az előző kettő között helyezkednek el. A három értékelő motivációról alkotott képe meglehetősen különbözö, a korrelációk legfeljebb közepes erősségüek. A három értékelő átlagaként kiszámított mutató alapján elmondható, hogy 2-4. osztály között nincs szignifikáns változás, 4-6. osztály között 5 százalékpontnyi a csökkenés. 6-8. osztály között stagnálás van, 8-10. osztály között pedig ismét szignifikáns, 4 százalékpontnyi a csökkenés (5. ábra).

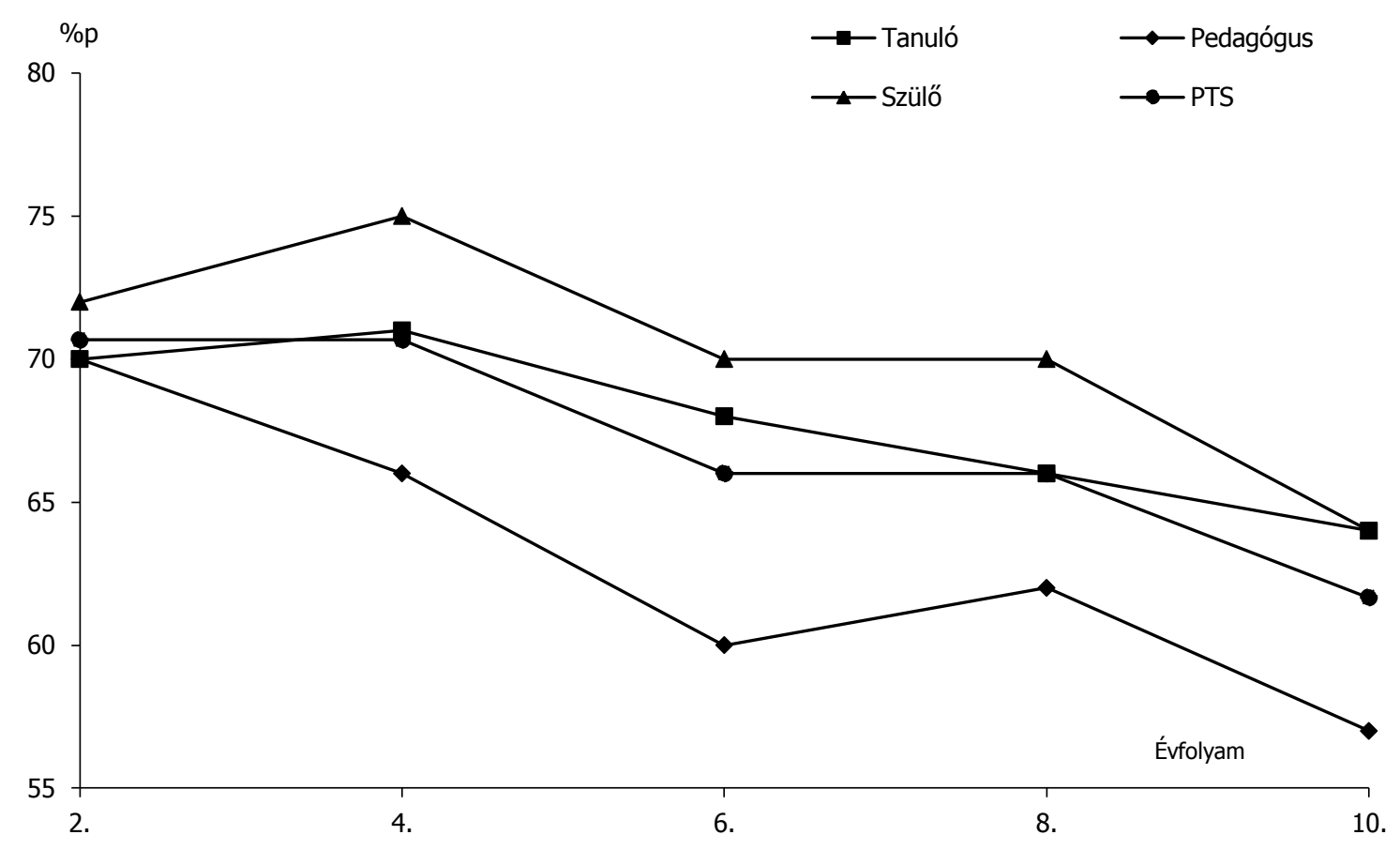

Megj.: PTS= pedagógus, tanuló, szülő megítélésének az átlaga.

\section{5. ábra}

Az elsajátítási motiváció életkori változása (Józsa, 2007 alapján)

A fentebb összegzett keresztmetszeti kutatások azt mutatták, hogy az elsajátítási motiváció az iskolai évekkel csökken. De vajon minden tanulót egyformán jellemez-e ez a csökkenés? Esetleg vannak olyan diákok, akiknek az életkor előrehaladtával nő az elsajátítási motivációja? E kérdések megválaszolására kereste longitudinális vizsgálatában Józsa Krisztián (2009a) a választ. A kutatásban az első adatfelvételre negyedik osztály őszén került sor, a második mérés nyolcadik öszén volt. 24 osztály vett részt a vizsgálatban, 372 tanulóról állnak rendelkezésre mindkét mérés adatai. A gyermekek a szülök iskolai végzettsége szerint reprezentatív mintát alkotnak.

Az eredmények szerint az értelmi elsajátítási motívum fejlettsége 4. osztályról (67\%p) 8. osztályra (52\%p) átlagosan 15 százalékpontot csökken. A tendencia tehát 
longitudinális mérés esetében is csökkenő, a csökkenés mértéke azonban ez esetben duplája a keresztmetszeti vizsgálatban kapott adatoknak. A longitudinális mérés két adatfelvételi pontja között a korreláció 0,37 -es erősségü $(\mathrm{p}<0,001)$. Ez arra utal, hogy a gyermekek egyéni motivációcsökkenése nem azonos mértékü. A tanulók 70 százalékát jellemzi a motiváció szignifikáns csökkenése. Emellett a gyermekek 15 százaléknál a motívum szignifikáns erősödése tapasztalható. A tanulók 15 százalékánál pedig nincs lényegi változás az értelmi elsajátítási motivációban a vizsgált időszak alatt. A legnagyobb mértékü csökkenést a negyedik osztályban legmotiváltabb gyermekek esetében figyelhetö meg. Emellett pedagógia szempontból fontos eredménynek véli a szerző, hogy a legalsó kvartilisbe tartozó - eredetileg legkevésbé motivált - gyermekek egyharmadánál a motiváció szignifikáns növekedése figyelhető meg (Józsa, 2009a).

A vizsgálat adatai szerint a legjobb tanulók esetében ugyanolyan nagyságú csökkenést figyelhetünk meg, mint a leggyengébbek teljesítők esetében. Jelentős különbségeket tapasztaltak ugyanakkor a résztvevő 24 osztály között a motiváció csökkenésében. Az osztályok tekintetében a legkisebb átlagos csökkenés 5 százalékpont, míg a legnagyobb 29 százalékpont (Józsa, 2010). Ez a nagymértékü különbség a pedagógusoknak és az osztálytermi folyamatoknak a jelentős szerepére hívja fel a figyelmet, vagyis az osztálytermi kutatások szükségességére mutat rá.

A tanulási motiváció életkori változásáról eredményeket közlő hazai munkák alapján megállapítható, hogy minden konstruktum esetében valamilyen mértékü csökkenés tapasztalható. Anderman és Maehr (1994) áttekintése szerint e folyamat általánosan jellemző, föként harmadik és hatodik osztály között indul, és a középiskola végéig folyamatos. Józsa (2002) számos lehetséges okot megemlít, amelyek a folyamat hátterében állhatnak. A csökkenéshez valószínüleg hozzájárul a feladatok komplexitásának emelkedése, amellyel párhuzamosan az elsajátítás egyre nehezebbé válik, és egyre távolabbiak lesznek az elérendő célok. A tanulók közötti különbségek növekedésével egyre nehezebb az optimális elsajátítást biztosítani az iskolában, és egyre nagyobb szerep jut a külső ösztönzőknek. Ennek egyenes következménye, hogy egyre kevésbé müködnek az iskolai feladatok kapcsán az önjutalmazó motívumok. Az évfolyamok emelkedésével a tanulók iránti elvárás is változik, általában egyre hangsúlyosabb lesz a minősítő értékelés. A tanulók életkorával változnak a társas kapcsolatok jellegzetességei is, ami ugyancsak része lehet a folyamatnak. A pedagógusok, szülők befolyása, legalábbis mint megkérdőjelezhetetlen felnőtté, egyre csökken, miközben nő a kortárskapcsolatok szerepe, melyeknek fontos színtere az iskola. Emellett a serdülőkort kísérő lelki folyamatok is jelentős hatást gyakorolhatnak a tanulási motiváció változására.

Az elsajátítási motivációban tapasztalható csökkenési periódusok párhuzamba állíthatók a magyar iskolarendszer szerkezeti váltásaival is (5. ábra). A 4. osztály végén a gyerekek alsó tagozatból felső tagozatba lépnek, ezzel jelentősen megváltoznak a tanítási körülményeik. Az alsó tagozatra jellemző egytanítós rendszert felváltja a szaktárgyi oktatás, tantárgyanként többnyire más-más pedagógussal. A 8. osztály végén a tanulók iskolát váltanak. Az adatok alapján úgy tünik, hogy ezek a váltások a legtöbb tanuló esetében nem hatnak kedvezően a motiváció alakulására.

\section{Az iskolai klíma néhány mutatója}

A tanulási környezet motivációs hatását vizsgáló első hazai kutatások Kozéki Béla nevéhez füződnek, aki „Az iskolethosz és a személyiségstruktúra kölcsönhatása” címü munkájában adja közre koncepcióját és fontosabb eredményeit (Kozéki, 1991). E munka 
úttörő jellegét egyrészt az adja, hogy a tanulási környezet minden fontos jellemzőjét igyekszik megragadni, így az iskola és a szülők szerepét több aspektusból vizsgálja, másrészt a kifejlesztett mérőeszközök a tanulási motiváció hazai kutatásának empirikus megalapozását jelentik. Az eredmények ugyanakkor nehezen értelmezhetők. A feltárt összefüggések viszonyítási pontját brit iskolák jelentik, az adatokból pedig elsősorban a két iskolarendszer különbségeire lehet így következtetni.

A legnagyobb mintára támaszkodó hazai kutatás, amelyben az iskolai klíma néhány összetevőjéről rendszeresen információt gyüjtenek, a korábban említett HBSCfelmérés. A reprezentatív minta általánosítható következtetésekre ad lehetőséget, ugyanakkor a tanulási motivációval és a tanulmányi teljesítményekkel nincsenek összekötve az adatok. A HBSC-kutatások eredményei tehát közvetve kínálnak információt a motivációt befolyásoló tanulási környezetről. A következőkben az ezredforduló utáni mérésekből azokra az eredményekre fókuszálunk, amelyeket évfolyamok szerinti bontásban is közölnek.

A 2002-es adatgyüjtésben az iskolai légkörre vonatkozó általánosabb kérdések szerepeltek, melyek eredményeit az 5. táblázat foglalja össze, a Likert-skálák egyetértést jelölő kategóriáinak összevonásával. Ezek az eredmények összecsengenek a tanulási motiváció életkori változásának témakörében korábban bemutatottal: ez esetben is azt láthatjuk, hogy a magasabb évfolyamokon az iskolai munkát élvezetesnek találó diákok aránya alacsonyabb. Emellett egyre kevesebben érzik, hogy az iskolai rendszabályok kialakításában részt vehetnek, és mind többen érzik nyomasztónak az iskolai feladatokat. Az adatok szerint az 5. és 7. évfolyam közötti időszak különösen problematikus, ebben az időszakban tapasztalható a legjelentősebb visszaesés a tanulási környezetet globálisan jellemző kérdéseknél (Szabó, 2003).

5. táblázat. Az iskola percepciója (\%) (Szabó, 2003, 121. o.)

\begin{tabular}{|c|c|c|c|c|}
\hline Kérdések, állitások & 5. évf. & 7. évf. & 9. évf. & 11. évf. \\
\hline $\begin{array}{l}\text { Mennyire nyomasztanak téged az iskolai } \\
\text { feladatok? }\end{array}$ & 17 & 25 & 31 & 37 \\
\hline $\begin{array}{l}\text { Iskolánkban a tanulók részt vesznek a } \\
\text { rendszabályok kialakításában. }\end{array}$ & 60 & 45 & 44 & 31 \\
\hline Élvezem az iskolai munkát/tevékenységeket. & 43 & 28 & 23 & 18 \\
\hline
\end{tabular}

A tanárokkal és osztálytársakkal kapcsolatban is információt gyüjtenek a HBSCmérések keretében. A 6. táblázat a pedagógusokkal kapcsolatos vélekedéseket mutatja a négy évfolyam esetében a 2006-os adatfelvétel alapján (Várnai és Örkény, 2007). Az adatok alapján jól látható a tanárok magatartásának megítélésében a negatív tendencia, a legnagyobb mérvü csökkenés ebböl a szempontból is az 5. és 7. évfolyam között tapasztalható, emellett a csökkenés folyamatos. A külön segítséget érintő állítás kivételével nemek szerinti különbségekről is beszámolnak, amelyek minden esetben a lányok kedvezőtlenebb véleményéről tájékoztatnak. 
6. táblázat. A tanári magatartás percepciója (\%) (Várnai és Örkény, 2007, 164. o.)

\begin{tabular}{lcccc}
\hline \multicolumn{1}{c}{ Állítások } & 5. évf. & 7. évf. & 9. évf. & 11. évf. \\
\hline $\begin{array}{l}\text { Tanáraink igazságosan bánnak velünk. } \\
\begin{array}{l}\text { Tanáraim arra ösztönöznek, hogy elmondjam } \\
\text { véleményemet az osztályban. }\end{array}\end{array}$ & 61 & 40 & 35 & 23 \\
$\begin{array}{l}\text { Ha külön segítségre van szükségem, tölük } \\
\text { megkapom. }\end{array}$ & 69 & 58 & 51 & 45 \\
$\begin{array}{l}\text { Tanáraimat érdekli, hogy milyen az } \\
\text { egyéniségem. }\end{array}$ & 52 & 41 & 35 & 26 \\
\hline
\end{tabular}

Megj.: a táblázat az ötfokú skálán az egyetértek és teljesen egyetértek válaszkategóriát jelelök összevont arányát mutatja.

Az osztályközösséggel kapcsolatos vélemények is egyre kedvezőtlenebbé válnak az idő előrehaladtával párhuzamosan, bár e tekintetben nem találunk olyan életkort, ahol feltűnően erőteljes lenne a csökkenés (7. táblázat). Egyedül az osztály kohéziójára utaló állításnál láthatunk markánsabb különbségeket, ez azonban az általános iskola és a középiskola közötti átmenethez köthető. Szignifikáns nemek szerinti különbségek egyrészről az osztály kohézióját érintő állításnál adódnak, ami föként 7. évfolyamon számottevő, másrészről az elfogadásra vonatkozó állításnál, ahol 11. évfolyamon jelentős az eltérés. Mindkét esetben negatívabban érzékelik a tanulási környezet e jellemzőit a lányok.

7. táblázat. A tanári magatartás percepciója (\%) (Várnai és Örkény, 2007, 164. o.)

\begin{tabular}{lcccc}
\hline \multicolumn{1}{c}{ Állítások } & 5. évf. & 7. évf. & 9. évf. & 11. évf. \\
\hline $\begin{array}{l}\text { Osztályom tanulói szívesen vannak együtt. } \\
\begin{array}{l}\text { Osztálytársaim többsége kedves és } \\
\text { segítőkész. }\end{array}\end{array} \quad 63$ & 52 & 50 & 37 \\
$\begin{array}{l}\text { Osztálytársaim elfogadnak olyannak, } \\
\text { amilyen vagyok. }\end{array}$ & 75 & 72 & 71 & 66 \\
\hline
\end{tabular}

Megj.: a táblázat az ötfokú Likert-skálán az egyetértek és teljesen egyetértek válaszkategóriát jelelők összevont arányát mutatja.

Iskolai bevonódás összefoglaló kifejezéssel jelölve gyüjtöttek affektív jellemzőkről adatokat a 2000-es PISA-mérésben (Willms, 2003). Az iskolai bevonódás egyrészröl az odatartozás érzését jelöli, ami arra utal, hogy mennyire érzi magát a tanuló iskolájában magányosnak, kívülállónak, másrészről az iskolai részvételt, ami a hiányzást és késést mutatja. A bevonódás két változójának országonkénti összevetése arról tájékoztat, hogy a hazai tanulók átlaga mindkét változó esetében valamivel meghaladja a nemzetközi átlagot. Néhány ország, közöttük Magyarország esetében az alacsony társadalmi státuszú fiataloknak az átlagos családi háttérrel rendelkezőkhöz viszonyítva 50 százaléknál is nagyobb az esélyük, hogy az odatartozás érzését tekintve a kiábrándultak közé tartozzanak. A PISA-mérések egyik fontos üzenete, hogy a tanulók teljesítményét erőteljesen befolyásolja iskolájuk családi háttér szerinti összetétele, az összehasonlító elemzéseket e szempont szerint is elvégezték. Ez azt mutatja, hogy minél nagyobb az adott iskolában a kedvezőtlen családi háttérrel rendelkező tanulók aránya, annál nagyobb az esélye, hogy az odatartozás érzését és az iskolai részvétel mértékét tekintve a kedvezőtlen jellemzőkkel rendelkező csoportba tartoznak a tanulók.

Az osztálytermi gyakorlat bizonyos összetevőinek hatását is megvizsgálták az iskolától való elfordulás szempontjából. E tekintetben három tényező, a fegyelmezési problémák, a tanár-diák kapcsolat és a teljesítményre irányuló tanári nyomás emelkedett 
ki. Az országonkénti összehasonlításból az derül ki, hogy a 10 pontos skála 5 pontos átlagtól kismértékben tér el hazánk a tanár-diák viszonyt $(5,3)$ és a fegyelmezési problémákat $(5,9)$ tekintve. Ugyanakkor a teljesítményre irányuló nyomás $(6,4)$ már jelentősebb mértékben meghaladja a nemzetközi átlagot.

Az iskolai klíma motivációs jellemzőiről a matematika órákkal összefüggésben a 2003-as PISA-mérés összefoglaló jelentése (OECD, 2004b) 0 átlagos értékre és 1-es szórásra transzformálva közöl országonként összehasonlítható adatokat, valamint kitér országonként az iskolák közötti eltérésekre a legrosszabb és a legjobb iskola (a szélsőségek elhagyása miatt az 5. és 95. percentilisnél található iskola) közötti különbség bemutatására. Tanulóink véleménye a nemzetközi átlagnál negatívabb abban a tekintetben, hogy az iskola mennyiben járul hozzá a felnőtt életre való felkészüléshez $(-0,22)$, ami föképp abból adódik, hogy a diákok legkedvezőbb negyedének véleménye $(0,87)$ mintegy félszórásnyival elmarad az OECD átlagtól $(1,33)$. Az odatartozás érzését tekintve a magyar tizenöt évesek a nemzetközi átlagtól nem térnek el. A tanári támogatás érzése valamivel elmarad a nemzetközi átlagtól. Az észlelt fegyelmezési problémákat tekintve pedig az OECD átlagnál valamivel kedvezőbb a helyzet. Az átlagok ugyanakkor elfedik a hazai iskolák közötti különbségeket, melyek nemzetközi viszonylatban is jelentősek. Az 5. és 95. percentilisnél található iskola közötti távolság az ismertetett változók mindegyikénél jelentős, például a fegyelmezési problémák előfordulását tekintve az összes felmért ország közül egyikben sem olyan kedvezőtlen a helyzet az 5. percentilisnél elhelyezkedö iskolákban, mint hazánkban.

\section{A tanulási motiváció és az iskolai eredményesség kapcsolata}

Az iskolában a tanulók motivációja és tanulási eredménye szorosan összefonódik, kölcsönösen alakítják egymást. Az elért eredmények, a sikerek vagy éppen a kudarcok visszacsatolást adnak, és ezzel tovább formálják a motívumrendszert. Új motívumok épülhetnek a meglévő rendszerbe, meglévő motívumok megerősödhetnek, egyes motívumok háttérbe szorulhatnak.

Józsa (2002) elemzése a tanulási motiváció kapcsolatát vizsgálta az osztályzatokkal és a tudásszintmérő tesztekkel hetedikes és tizenegyedikes tanulók körében. A tanulási motiváció és az osztályzatok kapcsolatának erőssége közelítőleg minden tantárgy esetén hasonló (8. táblázat). Nincs olyan osztályzat, a szakközépiskolások matematika jegyét kivéve, amellyel feltűnően erösebb, vagy gyengébb összefüggést mutatna a tanulók motiváltsága. Jellegzetes az eltérés azonban a két évfolyam korrelációi között, a gimnazista és a szakközépiskolás évfolyam között azonban nincs jelentős eltérés. Az iskolai eredményességet globálisan jellemző tanulmányi átlag és a tanulási motiváció korrelációja a hetedikesek esetében 0,42.

$\mathrm{Az}$ osztályzatok mellett egy más jellegű visszacsatolást ad a tanulóknak a szorgalmukra, magatartásukra adott értékelés. Ezeknek az összefüggése a tanulási motivációval hasonló erősségü, mint a tantárgyi osztályzatoké. A szorgalom jegy mindhárom részmintában hasonló kapcsolatban van a tanulási motivációval, mint a tanulmányi átlag. Feltételezhető ez alapján, hogy a szorgalom jegy jelentős befolyást gyakorol a tanulók motivációjára. Természetesen a szorgalom jegyben fóképp a tanulók hozzáállását, törekvését értékelik, ami szoros kapcsolatban áll a motiváltságukkal. Úgy tünik tehát, hogy a szorgalomjegy megítélésekor a tanárok elég jól látják a tanulók motivációjában rejlö különbségeket. 
8. táblázat. A tanulási motiváció és az osztályzatok, teszteredmények összefüggése (Józsa, 2002, 258. o.)

\begin{tabular}{lccc}
\hline \multirow{2}{*}{\multicolumn{1}{c}{ Változók }} & \multicolumn{3}{c}{ Tanulási motiváció } \\
\cline { 2 - 4 } & 7. évfolyam & \multicolumn{2}{c}{$\mathbf{1 1 . ~ e ́ v f o l y a m ~}$} \\
\cline { 2 - 4 } & & Gimnázium & Szakközépiskola \\
\hline Tanulmányi átlag & 0,42 & 0,36 & 0,28 \\
Matematika jegy & 0,34 & 0,31 & 0,36 \\
Fizika jegy & 0,37 & 0,28 & 0,26 \\
Kémia jegy & 0,32 & 0,36 & 0,18 \\
Biológia jegy & 0,35 & 0,33 & 0,30 \\
Angol jegy & 0,36 & 0,30 & 0,25 \\
Irodalom jegy & 0,40 & 0,29 & 0,29 \\
Nyelvtan jegy & 0,33 & 0,19 & 0,13 \\
Történelem jegy & 0,37 & 0,24 & 0,27 \\
Szorgalom jegy & 0,43 & 0,42 & 0,30 \\
Magatartás jegy & 0,36 & 0,25 & 0,21 \\
Angol teszt & 0,27 & $0,07^{\#}$ & $0,08^{\#}$ \\
Irodalom teszt & 0,27 & $0,04^{\#}$ & $0,18^{\#}$ \\
Történelem teszt & 0,36 & $-0,11^{\#}$ & $0,01^{\#}$ \\
Tesztek átlaga & 0,51 & $0,03^{\#}$ & $0,10^{\#}$ \\
\hline
\end{tabular}

Megj.: \# nem szignifikáns, a jelöletlen korrelációs együtthatók p $<0,01$ szinten szignifikánsak; min. $\mathrm{n}=88$.

A tanulási motivációt ugyanakkor nemcsak a jegyek formájában adott visszajelzés alakíthatja. A korábbi kutatások arra is rámutattak, hogy a tanárok visszajelzései, elvárásai befolyásolják a tanulók teljesítményét. A tanári elvárások sokszor önmagukat beteljesítő jóslatként müködnek: a ki nem mondott elvárások is jelentősen befolyásolják a tanulókba, hogy milyen teljesítményekre lehetnek képesek, alakítva ezáltal énképüket, motívumaikat (Csapó, 2002b; Józsa és Fejes, 2010; Szenczi, 2008). Réthy Endréné (1989) a különböző tanári visszajelzések, az értékelés teljesítményre, motivációra gyakorolt hatásának elemzésekor megállapítja, hogy az egyéni fejlődésre alapozó, korábbi teljesítményhez viszonyító visszacsatolás a kudarcmotivált, alacsony önértékelésü, szorongó tanulók esetén hat pozitívan. Ezzel szemben a jó eredményeket elérő, sikermotivált tanulóknál a teljesítmény osztályhoz való viszonyítása, a társas összehasonlítás a hatékony. Az ő esetükben föképp a szociális összehasonlításból táplálkozik a motiváció. A 8. táblázatban közölt vizsgálat adatai azt mutatják, hogy a tantárgyi osztályzatok szorosabban kapcsolatban állnak a tanulási motivációval, mint a tesztekkel mérhető tudás (Józsa, 2002). A tanulási énkép és az iskolai eredményesség összefüggését elemző kutatás hasonló eredményre vezetett. A tanulási énkép egyes komponensei szignifikánsan erősebben korrelálnak az osztályzatokkal, mint a képességekkel, a korrelációs együtthatók 0,4 és 0,5 között vannak. A matematika énkép szignifikánsan összefügg a matematikai képességek fejlettségével, az olvasási énkép pedig a szövegértéssel, az összefüggések 0,3 körüliek (Szenczi és Józsa, 2009; 2010).

$\mathrm{Az}$ elsajátítási motivációnak is jelentős szerepe lehet az iskolai készségek elsajátításában, a tanulás sikerességében (Barrett és Morgan, 1995; Józsa, 2001). Az elméleti alapon feltételezett összefüggést iskolai kontextusban elöször magyar vizsgálati eredmények igazolták empirikusan (Józsa, 2007). A 928, 2-6. osztályos tanuló adatainak elemzése során a motívum fejlettségét a tanárok és a szülök is megítélték, emellett a tanulók önjellemzést adtak magukról a H-DMQ kérdőívek felhasználásával. $\mathrm{Az}$ értelmi elsajátítási motívum kifejezetten magas, 0,8 körüli korrelációban áll a tanulmányi átlaggal. A három értékelő motívum-megítélését külön-külön megvizsgálva 
szintén erős összefüggést láthatunk. A pedagógusok értékelésénél 0,88 és 0,81 , a szülőkénél kissé alacsonyabb 0,70 és 0,61 , a tanulókénál pedig még alacsonyabb, de még mindig jelentős 0,39 erősségü összefüggés van a tanulmányi átlag és az értelmi elsajátítási motívum között.

A regresszióanalízis eredménye szerint a tanulmányi átlag egyéni különbségségeinek alakulását az intelligencia, a kognitív készségek fejlettsége (olvasás, számolás, mértékegységváltás, összefüggés-megértés) és a motívumfejlettség egyaránt befolyásolja (9. táblázat). Az ismert hatás háromnegyedét fedi le együtt ez a három független változó. $\mathrm{Az}$ értelmi elsajátítási motiváció erősebben meghatározza a tanulmányi átlagot, mint az IQ és a készségek. Úgy tünik, hogy az iskolai eredményességhez az elsajátítási motivációnak erőteljesebb a hozzájárulása, mint az értelmi fejlettségnek (Józsa, 2005). Mindez a tanulási motiváció kulcsszerepére irányítja rá a figyelmet.

9. táblázat. Az alapkészségek, az intelligencia és az értelmi elsajátítási motívum regresszióanalízise a tanulmányi átlaggal mint függő változóval (rß\%) (Józsa, 2007 alapján)

\begin{tabular}{lcc}
\hline \multicolumn{1}{c}{ Független változók } & 3. évfolyam & 6. évfolyam \\
\hline Alapkészségek* & 7 & 25 \\
Intelligencia & 8 & 9 \\
Értelmi elsajátítási motívum** $^{2}$ & 59 & 40 \\
\hline $\mathrm{R}^{2}$ & 74 & 74
\end{tabular}

Megj.: * négy készség (olvasás, számolás, mértékegységváltás, összefüggés-megértés) összevont mutatója; ** a három értékelő együtt.

\section{Összegzés}

Az egyes tantárgyak tanulói megítélésében, valamint a tantárgyak kedveltségének változásában jelentős különbségek azonosíthatók. A természettudományos tantárgyak a legkedvezötlenebb helyzetü tárgyak közé tartoznak, különösen a kémia, fizika és matematika megítélése aggasztó. A fizika esetében az okok részletesebb megismerése már több kutatást is életre hívott (pl. Józsa, 1999; Papp és Józsa, 2000; Radnóti, 2004, 2005), és a kiutak keresése is megkezdődött (pl. Papp és Nagy, 2004, 2007; Papp és Pappné, 2000). Bár a matematikával kapcsolatos affektív jellemzők néhány sajátos vonásáról találhatunk elemzéseket a hazai szakirodalomban (Csíkos és Dobi, 2001; Dobi, 2001), a probléma részletesebb feltárását, megoldását célzó empirikus kutatások nem indultak el. A matematika tekintetében különösen fontos lenne, hogy a háttérben álló okokat részletesen megismerjük, hiszen e tárgy tanulása a tanulók iskolai pályafutását a kezdetektől a közoktatás végéig kíséri. Emellett a matematikai tudás alkalmazására más, elsősorban természettudományokkal foglalkozó tantárgyak tanulása során is szükség van, vagyis az eredmények feltételezhetően más tárgyak kedveltségének, eredményességének javulásához is hozzájárulhatnak.

A tanulók motivációs jellemzői az életkorral párhuzamosan egyre kedvezőtlenebbé válnak, ami természetes folyamatnak tekinthető. Ebből a szempontból a felső tagozat különösen problematikus szakasza az iskolai oktatásnak Magyarországon. A motivációt jellemző konstruktumok kedvezőtlenebbé válása, valamint a tanulási környezet megítélésével kapcsolatos kérdések, változók tekintetében egyértelmủen ebben a periódusban a legjelentősebb a visszaesés. 
A kutatások arra is rámutattak, hogy jelentős különbségek adódnak a tanulási motivációban, illetve a tanulási környezet megítélésében iskolák, osztályok szerint. Bár a PISA-mérésekből a középiskolai tanulási környezetre következhetünk, e tekintetben a nemzetközi összehasonlításban is hatalmasak az intézmények közötti eltérések.

A hazai motivációkutatások eddig kevéssé foglalkoztak az osztályteremben tapasztalható folyamatokkal, így alig találunk olyan munkát, ami a tanulási környezet motivációs vonatkozásait vizsgálja, illetve amelyekből erre következtethetünk. Így kevés olyan ismerettel rendelkezünk, amelyek a hazai jellemzők figyelembe vételével a motívumfejlesztéshez segítséget kínálnának. A tanulási motiváció és az iskolai eredményesség összefüggéséről is eredményeket kínáló hazai kutatások egyértelmüen jelzik a tanulási motiváció központi szerepét az osztályzatokat illetően, másként fogalmazva a motívumfejlesztés lehetőségeit a teljesítmény javításában. 


\section{A CÉLORIENTÁCIÓS ELMÉLET}

Jelen fejezet célja a célorientációs elmélet fogalmi kereteinek felvázolása, kutatási irányainak, valamint fontosabb eredményeinek bemutatása. Összefoglalásunkban elhelyezzük a célorientációs elméletet a célokkal foglalkozó egyéb pszichológiai teóriák sorában, majd kitérünk az elmélettel kapcsolatos fontosabb fogalmakra, így a tanulók motivációs jellemzőire utaló célorientációkra, illetve a tanulási környezet motivációs hatását leíró célstruktúrákra. Ezt követően röviden ismertetjük az elmélet fejlődésének fontosabb mérföldköveit és pedagógiai jelentőségét. A továbbiakban a célorientációs megközelítésen alapuló kutatások közül azokat kivonatoljuk, amelyek a tanulási környezet és a tanulók teljesítményét befolyásoló változók kapcsolatáról közölnek eredményeket. A kutatásmódszertani kérdések egy részét a megértés elősegítését szem elött tartva a tanulási motiváció és a tanulási környezet összefüggését tárgyaló rész elején érintjük. Mivel empirikus vizsgálatainkban tanulói kérdőívek kidolgozására, valamint a kifejlesztett mérőeszközökön alapuló adatgyüjtésre vállalkozunk, a fejezet végén a célorientációs elmélettel összefüggésben alkalmazott kérdőívekre vonatkozó ismereteket összegezzük.

\section{Célok a motiváció kutatásában}

A gondolat, miszerint az emberi viselkedés célok elérésére irányul, hosszú ideje jelen van a pszichológiai elméletekben (1. Austin és Vancouver, 1996; valamint Elliot és Fryer, 2008 áttekintését), de csak az 1980-as években kerül az érdeklődés homlokterébe a motivációról való gondolkodás kognitív alapokon álló irányzataként, ami hamarosan egy új személyiségpszichológiai megközelítést is életre hívott (1. Carver és Scheier, 1998; Demetrovics és Nagy, 2001).

A célokkal kapcsolatos elméletek meghatározó vonulata szerint a szelf, vagyis az „én” (1. Körössy, 2004; Marton, 1998; Nagy, 1994) részben az egyén céljai köré szerveződik, így a célok a szelf megértésének kulcselemeiként tünnek fel. E kiindulópont képezi alapját több nagyhatású személyiségelméletnek. Például Markus és Nurius (1986) lehetséges szelf vagy Higgins (1987) ideális énképek fogalmának központi összetevői a célok, illetve Carver és Scheier (1998) önszabályozó folyamatokra épülö személyiségelmélete célok alapján kísérli meg bemutatni, hogy milyen mechanizmusokon keresztül vezet a kogníció cselekvéshez. A célalapú megközelítést napjainkban egyre több területen alkalmazzák pszichológiai folyamatok magyarázatára, de a célok magatartásszabályozással való közvetlen kapcsolata miatt az elméletek gyakorlati alkalmazására is találunk példákat (1. Martos, 2009a, 2009b).

Miközben a célok széles körben használt fogalmakká váltak - elsősorban a személyiségpszichológia, a kognitív tudomány és a motivációkutatás területén -, értelmezésük tekintetében nem alakult ki konszenzus. Austin és Vancouver (1996) gyakran hivatkozott szakirodalmi munkája mikroteóriák sokaságáról tanúskodik, melyek a biológiai folyamatoktól (pl. testhőmérséklet szabályozása) az elérendő kimenetek komplex kognitív megrajzolásáig (pl. karriercél) terjednek. Szakirodalmi áttekintésük alapján megfogalmazott definíciójuk szerint a célok elérni kívánt állapotok belső reprezentációi, ahol a célok egyaránt utalhatnak eredményekre, eseményekre és folyamatokra. Funkciójuk, hogy viszonyítási pontokat kínálnak, melyek a jelenlegi vagy előre látható állapotok összevetése által fejtik ki hatásukat.

Elliot és Fryer (2008) a célokkal kapcsolatos pszichológiai elméletek fejlődésének áttekintése alapján a következő jellemzőket emeli ki, melyek a célok 
meghatározásainak többségében explicit vagy implicit módon szerepelnek: (1) meghatározott dologra irányul, (2) a viselkedést irányítja, (3) a jövőre fókuszál, (4) belsőleg létrehozott és (5) valaminek az elérésére vagy elkerülésére ösztönzi az organizmust. Rövid meghatározásuk szerint így a cél egy jövőbeni dolog kognitív reprezentációja, ami valaminek az elérésére vagy elkerülésére ösztönöz.

A legtöbb kutató feltételezi, hogy a célok relevanciája az egyén számára nem azonos, vagyis a célok hierarchiába rendezhetök (1. Molnár, 2009), így megkülönböztetnek alacsonyabb és magasabb rendủ célokat, a hierarchia csúcsát pedig az elérni kívánt szelf jelenti (pl. Carver és Scheier, 2000). Ugyanakkor e hierarchia nem állandó, az adott kontextus szerint változhat (Boekaerts és Niemivirta, 2000), ami pedagógiai szempontból kulcsfontosságú, hiszen e gondolatmenetet követve a megfelelö tanulási környezet kialakításával befolyásolható a célok rendszere.

Teljesítménykontextusban, vagyis a tanulási motiváció jelenlegi kutatásaiban felmerülő célokkal kapcsolatosan Pintrich (2000a) szerint három nézőpont tapintható ki: a (1) feladat-specifikus nézőpont, a (2) tartalmi szempontú megközelítés és a (3) célorientációs elmélet. E megközelítések a célok tanulmányozásának eltérő szintjeit képviselik.

A feladat-specifikus megközelítés az egyén céljait egy konkrét feladat, probléma kapcsán vizsgálja (pl. milyen osztályzat elérését célozza meg a tanuló egy konkrét dolgozat megírásakor). E célok egy specifikus kritériumot jelentenek, amihez viszonyítva az egyén értékeli saját teljesítményét, azonban az a látómezőn kívül esik, hogy miért ezeket a célokat választják. A célok vizsgálatának e megközelítésmódját képviseli például Locke és Latham (1994/1999) célkitüzés-elmélete.

A következő nézőpont jóval általánosabb értelemben tanulmányozza a célokat, és a megcélzott eredmények mellett az okokat is számba veszi. A tartalmi szempontú nézőpont a viselkedést előidéző lehetséges célok feltárására törekszik. Ide sorolható például Ford (1992) 24 kategóriából álló céltaxonómiája, valamint a Wentzel (1993) által vizsgált szociális célok köre. Ezen célok további jellemzője, hogy nem mindig tartalmazzák az elérni kívánt kritériumokat.

A célorientációs nézőpont a feladat-specifikus és a tartalmi szempontú megközelítés közé helyezhető. E célok a korábban említett nézőpontokkal ellentétben kizárólag teljesítményszituációban müködnek (pl. oktatás, sport vagy a munka világa), és egyaránt utalnak az egyén szándékaira és a viszonyítási kritériumokra. Ugyanakkor nem képezi részét e teóriának a konkrét tartalom vagy az elérni kívánt konkrét eredmény. Anderman és Maehr (1994) megfogalmazása szerint a célorientációs elmélet nem arra fókuszál, hogy mit kíván elérni az egyén egy feladat elvégzése során, hanem arra, hogy miért és hogyan vesz részt a feladat teljesítésében.

A célorientációs-elmélet által tárgyalt célokat egy további megközelítés szerint egyéni céloknak tekintik, melyek elkülöníthetők szociális céloktól, ugyanakkor szoros kapcsolatban állnak azokkal. E kapcsolatok feltárására irányuló kutatások általában a célorientációs és tartalmi szempontú nézőpont házasításán alapulnak (pl. Wentzel, 2000).

A célok között megkülönböztethetök a közeli és a távoli jövőre vonatkozó célok, bár a határvonal nem egyértelmü. A célorientációs-elmélet által tárgyalt célok a rövid távú, közeljövőre vonatkozó célok közé sorolhatók, míg a hosszú távú célok közé tartozhatnak például az életfeladatok (Cantor, Norem, Niedenthal, Langston és Brower, 1987) vagy a személyes törekvések (Emmons, 1986). A hosszú és rövid távú célok szoros kapcsolatban állnak egymással, például egy jó osztályzat megszerzése nemcsak rövid távú cél lehet, általában része egy hosszú távú célnak, mint például egy adott végzettség megszerzésének, foglalkozás elsajátításának egy lépése. A hosszú távú célok 
és a tanulási motiváció egyes konstruktumai közötti viszonyt számos vizsgálat igazolta (1. Husman és Lens, 1999; Simons, Vansteenkiste, Lens és Lacante, 2004), azonban még kevéssé feltárt területnek számít a hosszú távú célok és a célorientációk közötti kapcsolat, bár e területen is megindultak az empirikus kutatások (pl. Lee, McInerney, Liem és Ortiga, 2010). A hosszú távú célokról magyarul Jámbori (2003a, 2003b, 2007) és Sallay (2003) munkái kínálnak áttekintést.

A célok számos további motivációs elméletnek képezik lényegi részét, például az elsajátítási motiváció (Józsa, 2007) vagy a flow elméletének (Csíkszentmihályi, 2001), azonban e kutatási irányok célorientációkkal való kapcsolódási pontjai még kevéssé tisztázottak. A tanulási motiváció és a tanulási stratégiák vizsgálatát koherens keretbe foglaló önszabályozó tanulás elmélete e tekintetben külön említést érdemel, mivel a célorientációs megközelítés fogalmi rendszerét, illetve vizsgálati eszközeit felhasználva talán a legszorosabban kötődik a jelen munka által áttekintett kutatási területhez (D. Molnár, 2012).

\section{A célorientációk értelmezése}

Az angol nyelvű szakirodalom azonos értelemben használja a célorientáció (goal orientation), a cél (goal) és a személyes cél (personal goal) kifejezéseket, jelen munka így ugyancsak szinonímaként használja ezek magyar megfelelőjét. A célorientációs elmélet keretei között többnyire két általános célt különböztetnek meg, melyek elérésére az egyén adott feladat esetén egy teljesítményszituációban törekszik. E két cél megnevezésére számos címke használatos. Például a tanulás - teljesítmény (learning performance), feladat - képesség (task - ability), feladat - én (task - ego), feladatvezérelt - énvezérelt (task-involved - ego-involved), elsajátítás - teljesítmény (mastery - performance) elnevezésekkel találkozhatunk. A különböző elnevezések alapjában véve azonos tartalommal bírnak (Linnebrink és Pintrich, 2002a). Egyre inkább konszenzus figyelhető meg, és a két cél megnevezésére a nemzetközi szakirodalomban a mastery goal és performance goal kifejezés elterjedését láthatjuk. A hazai szakirodalomban az elmélet újszerüsége miatt ugyanazon angol kifejezés többféle fordítása is megtalálható (vö. Bacsa, 2008; Fülöp, 2001, 2008; Józsa, 2002; Molnár É., 2002). A továbbiakban Józsa Krisztián (2002) alapján - a jelentést véleményünk szerint legpontosabban tükröző - elsajátítási cél és viszonyító cél megjelöléseket követjük.

Elsajátítási cél alatt új készségek, képességek elsajátítására, a tananyag megértésére, a kompetencia fejlesztésére irányuló törekvés értendő, míg a viszonyító cél a mások túlteljesítésére, az egyéni képességek kifejezésére irányuló törekvést jelenti. A tanulási folyamat értékelésekor az elsajátítási célt követők viszonyítási pontjai belső normákhoz igazodnak (pl. Megtanultam? Fejlődtem?), míg a viszonyító célt követőké a szociális környezethez (pl. Jobban teljesítettem, mint az osztálytársaim? Mások okosnak tartanak?) (Urdan és Schoenfelder, 2006).

Az elsajátítási célt követők esetében kedvező motivációs és kognitív folyamatokat, illetve magasabb teljesítményt feltételeznek, míg a viszonyító célt követők kapcsán kevésbé kedvező vagy kedvezőtlen folyamatokat, illetve teljesítményt, bár az utóbbi években e polarizáló felfogás megdölni látszik. E feltevések azon a logikán alapulnak, hogy ha a tanuló a korábbi teljesítményéhez viszonyítva kíván elörehaladást elérni, vagyis elsajátítási célt követ, akkor e cél sikertelenség esetén az önhatékonyság érzését fenntartja, megakadályozza a negatív érzelmek és a társas összehasonlításból eredő szorongás kialakulását, kisebb a valószínüsége a figyelmet elvonó gondolatok megjelenésének, ezáltal elősegíti a kognitív bevonódást és a 
teljesítmény növekedését. Ezzel szemben, amikor a tanuló például arra koncentrál, hogy a legjobb legyen vagy másoknál jobb osztályzatot szerezzen, azaz viszonyító célt követ, akkor a másokkal való összehasonlítás nagyobb valószínüséggel eredményez negatív érzelmeket, figyelmet elvonó irreleváns gondolatokat, melyek a bevonódás és a teljesítmény ellen hatnak (Linnenbrink és Pintrich, 2002a).

A tanulási motivációt befolyásoló célokat strukturált tudásnak, kognitív reprezentációknak tekintik, melyek a teljesítményszituációkkal kapcsolatos szándékokból és viszonyítási pontokból épülnek fel (Kaplan és Maehr, 2007; Pintrich, 2000a). A kutatók egy része (pl. Ames, 1992) ennél tágabban, számos teljesítménnyel kapcsolatos változó koherens rendszereként értelmezi a célokat, így az előbbiek mellett olyan komponenseket is a konstruktum részeiként kezel, mint a siker és kompetencia jelentése, vagy az erőfeszítések és hibák szerepe (10. táblázat). Annak kérdése, hogy a meglévő komponensek következményeként jelenik meg egy cél vagy a követendő cél alakítja az elemeket, nem tisztázott. Továbbá az sem világos, hogy a kognitív pszichológia számos modellje közül melyik a legalkalmasabb e strukturált tudás megragadására, habár a megközelítések többsége implicit módon sémákon alapul (Pintrich, 2000a). A teljesítménymotivációval foglalkozó klasszikus elméletek fogalomhasználatát figyelembe véve a célok nem tekinthetők motívumoknak, e teóriák a motívumokat implicit, kevéssé tudatos, az affektív oldalhoz erősen kötődő összetevőknek tekintik (Trash és Elliot, 2001).

10. táblázat. Az elsajátítási és a viszonyitó cél meghatározásai (Maehr és Meyer, 1997, 388. o.)

\begin{tabular}{|c|c|c|}
\hline & Elsajátítási cél & Viszonyító cél \\
\hline Siker & $\begin{array}{l}\text { Fejlődés, előrehaladás, } \\
\text { elsajátítás, innováció, } \\
\text { kreativitás }\end{array}$ & $\begin{array}{l}\text { Jobb jegyek, magasabb } \\
\text { teljesítmény másokhoz } \\
\text { viszonyítva }\end{array}$ \\
\hline Érték & $\begin{array}{l}\text { Erőfeszítés, nehéz feladatok } \\
\text { megoldásának kísérlete }\end{array}$ & Kudarc elkerülése \\
\hline Elégedettség & Fejlődés, elsajátítás & $\begin{array}{l}\text { A legjobbnak lenni, a siker } \\
\text { és erőfeszítés összevetése }\end{array}$ \\
\hline $\begin{array}{l}\text { Munka/teljesítmény } \\
\text { kontextusa }\end{array}$ & $\begin{array}{l}\text { Egyéni lehetőségek } \\
\text { kiaknázása, tanulás }\end{array}$ & $\begin{array}{l}\text { Teljesítményre épülő } \\
\text { hierarchia megalapozása }\end{array}$ \\
\hline Erőfeszítés forrása & $\begin{array}{l}\text { Belső, a tevékenység } \\
\text { személyes jelentősége }\end{array}$ & $\begin{array}{l}\text { Az egyéni értékek } \\
\text { demonstrálása }\end{array}$ \\
\hline Értékelési kritérium & Abszolút, előrehaladás & $\begin{array}{l}\text { Normák, szociális } \\
\text { összehasonlítás }\end{array}$ \\
\hline Hibák & $\begin{array}{l}\text { Az elörehaladás része, } \\
\text { információt hordoz }\end{array}$ & $\begin{array}{l}\text { Kudarc, az érték vagy } \\
\text { képesség hiányának } \\
\text { bizonyítéka }\end{array}$ \\
\hline Kompetencia & Erőfeszítés által fejleszthető & Örökölt, állandó \\
\hline
\end{tabular}

Bár abban egyetértés mutatkozik, hogy a kontextus hatással van a célok adoptációjára, ugyanakkor annak tekintetében sem alakult ki konszenzus, hogy a célorientációk mennyire tekinthetök stabil személyiségjellemzőknek. Ennek alapján a célorientációs elméletek két nagyobb csoportját különbözteti meg Kaplan és Maehr (2007): azokat, melyek a célokat adott teljesítményszituációra vonatkozó sémáknak tekinti (schemas of 
achievement situations), illetve amelyek a teljesítménnyel kapcsolatos szelf-hez köthető sémákon alapulnak (achievement self-schemas). Elöbbiek a kontextustól függö, azaz akár szituációnként is változó jelenségként, míg utóbbiak viszonylag stabil személyiségjellemzőként tekintenek a célorientációkra. A szerzőpáros emellett további négy nézőpontot említ alternatív megközelítések címen, melyek a séma-szkript paradigmán kívül definiálják a célokat. Ezek a szükségletek, értékek, éntudat, illetve a szituatív szociálisan konstruált jelentés elméleti kereteit használják fel.

A célorientációs elmélet korai szakaszában az ismertetett kettős cél mellett néhány további céltípus is feltünt a teljesítményszituációban tapasztalt viselkedés magyarázataként, azonban ezek többsége a továbbiakban nem kapott jelentősebb figyelmet. A nagyobb érdeklődést kiváltó tanulói célokkal foglalkozó elméletek közül a tanulástól való eltávolodás (academic alienation) vagy munkakerülés (work-avoidance, work-avoidant goal) teóriája vívott ki számottevő érdeklődést, melynek segítségével a célorientációk kontrasztjaként azon tanulókat kívánják azonosítani, akik nem mutatnak érdeklődést az iskolai teljesítményszituációk iránt, vagyis a lehető legkevesebb energiát kívánják az adott iskolai feladatra fordítani (Kaplan és Maehr, 2007). Míg a kutatók egy része nem fordít figyelmet e jellemzőre, mások amellett érvelnek, hogy ennek vizsgálata elengedhetetlen a tanulók teljesítménnyel kapcsolatos viselkedésének feltérképezéséhez, a tanulók közötti lényeges különbségek számbavételéhez (pl. Dowson és McInerney, 2001; Meece és Miller, 2001; Tapola és Niemivirta, 2008).

\section{A célstruktúrák értelmezése}

A célstruktúrák (goal structure) azokra a környezetböl érkezö üzenetekre utalnak, amelyek befolyásolják a tanulók célorientációit (Ames, 1992), vagyis a kontextus motivációra gyakorolt hatását jelenítik meg. A személyes célorientációkhoz hasonlóan a célstruktúráknak is két típusa jelent meg a szakirodalomban. Az elsajátítási célstruktúra az elsajátítást, megértést, korábbi teljesítmény túlszárnyalását ösztönzi az osztályteremben, míg a viszonyitó célstruktúra a képességek összevetésére és a versenyre ösztönöz (pl. Ames, 1992; Linnenbrink, 2004; Urdan, 2004a). Habár ezek az átfogó meghatározások széles körben elfogadottak, ennél részletesebb, operacionalizálható definícióval nem találkozunk a szakirodalomban.

Egyetértés mutatkozik abban, hogy a különböző tanulási környezetek különböző célorientációkat hangsúlyoznak, és a kontextus által megjelenített célok hatással vannak az egyén céljaira. A célokat befolyásoló üzeneteknek számos forrása lehet egy iskolai teljesítményszituációban, többek között az, ahogyan egy feladat kapcsán a sikert definiálják, hogy mennyi időt kapnak a tanulók a feladat megoldására, ahogyan elismerik, jutalmazzák egy feladat megoldását, vagy ahogyan értékelik a tanulói teljesítményeket. Például ha a tanár értékelési stratégiájában központi helyet foglal el a tanulók teljesítményének, jegyeinek összevetése, és a tanuló önmagához mért fejlödése kevéssé hangsúlyos, az osztálytermi célstruktúra vélhetően a viszonyító cél követésére ösztönöz (Brophy, 2004).

A környezetből érkező üzenetek azonban nem köthetők kizárólag a pedagógusokhoz. Az előző fejezetben számos példán keresztül mutattunk rá arra, hogy az osztálytársak is szerepet játszanak adott tanuló motivációjában. Lényegesek lehetnek például azok a tanulói célorientációk is, amelyekkel a gyerekek az iskolába érkeznek, hiszen a rendelkezésre álló adatok alapján nem tudunk következtetni ok-okozatra. Ugyanakkor könnyen belátható, ha a pedagógus azt tapasztalja, hogy tanulói elsősorban versengéssel, társas összehasonlítással foghatók tanulásra, akkor nagy valószínüséggel 
ki is fogja ezt használni. Vagyis a tanulói célok és a célstruktúrák között minden bizonnyal kölcsönösen egymásra ható kapcsolat áll fenn (Urdan, 2004a).

\section{A célorientációs elmélet kialakulása és fejlődése}

\section{A célorientációs elmélet megjelenése a tanulási motiváció kutatásában}

A tanulási motiváció iránti megnövekedett érdeklődés az 1950-es évekre tehető, azonban sokáig állatkísérletekböl, laboratóriumi vizsgálatokból levont következtetések jelentették a tanulási motivációval kapcsolatos tudás alapját (Józsa, 2007; Réthyné, 2001a). Az 1970-es évek második felében indult meg a tanulási motiváció elemzése az iskolai hétköznapokban, a célorientációs elmélet alapjainak lerakása is erre az időszakra tehető. A fogalmi keretek kidolgozása Elliot (2005) szakirodalmi áttekintése szerint föként az Illinois-i Egyetem egy kutatóközösségéhez köthető (Carol Ames, Carol Dweck, Martin Maehr, John Nicholls). E kutatók közül Dweck és Nicholls elméleti alapvetéseit röviden áttekintjük, mivel az elmélet megjelenésében központi jelentőséggel bírnak.

Mindkét szerző célokkal kapcsolatos munkája szorosan kötődik a képességekről, intelligenciáról való gondolkodás fejlődésének vizsgálatához. Megjegyezzük, hogy az említett szerzők eredményeinek ismertetése során használt képesség, illetve intelligencia kifejezés nem valamely pszichológiai, pedagógiai elmélethez köthető egzakt módon definiálható fogalomként értelmezendő, hanem köznapi jelentésében használatos. Ennek oka, hogy e kutatási irány a vizsgált személyek önészlelésére épül, vagyis a kérdezettek értelmezése érvényesül e fogalmak esetében. Ebböl következően e kutatások beszámolóiban a képességet és intelligenciát gyakran szinonimaként használják (pl. Dweck, 2002).

Dweck (1986; Dweck és Leggett, 1988) célkoncepciójának alapját általános iskolások körében végzett felmérések eredményei jelentik, melyek szerint adott teljesítményszituációban az azonos képességü tanulók különbözőképpen reagálnak a kudarchelyzetre. A tanulók egy része erőfeszítései hiányának tulajdonítja a kudarcot, ami a feladattal kapcsolatos pozitív hozzáállás, várakozás fennmaradásával, változatlan vagy növekvő teljesítménnyel, és újabb kihívások keresésével párosul. Azonban a tanulók másik csoportja képességei hiányával magyarázza a sikertelenségeket, ami a feladattal kapcsolatos negatív hozzáállást, várakozást vetít előre, csökkenő kitartással és teljesítménnyel, valamint a további kihívások kerülésével jár. A kudarchelyzetekre adott eltérő válaszokat $D$ weck a tanulók eltérő teljesítménycéljaira vezette vissza, melyek az intelligenciával kapcsolatos nézeteikkel állnak összefüggésben. A célok két fajtáját különböztette meg: a teljesitmény célt (performance goal), ami mögött egy nem fejleszthető, változatlan intelligencia képzete áll, és a tanulási célt (learning goal), ami az intelligencia fejleszthető elképzeléséből következik. Előbbi a kompetencia, hozzáértés demonstrálásával, az inkompetencia kerülésével jár együtt, utóbbi a saját kompetencia fejlesztésére fókuszáló viselkedéssel jellemezhető. Az elmélet további alapvetése, hogy a képességekkel kapcsolatos önbizalom és a célok kölcsönösen hatnak egymásra. Az eredmény cél pozitív válasz-mintázathoz vezet, ha a képességekhez kapcsolódó önbizalom magas szintü, és negatív válaszokhoz, ha alacsony. A tanulási cél a képességekhez kötődő önbizalomtól függetlenül pozitív hozzáállást, gondolkodási folyamatot és viselkedést eredményez.

Nicholls célelméletét a képességek fogalmának fejlődésével kapcsolatos vizsgálatai alapozták meg. Megfigyelései szerint (Nicholls, 1978) hatéves korig a képesség fogalma differenciálatlan, így nem különül el például az erőfeszítés vagy a 
nehézség, a kompetencia érzése egyszerüen egy adott feladat megoldásának eredményéhez kapcsolódik. Hétéves kor körül kezdik megérteni a gyerekek, hogy a képességek összemérhetők a teljesítmények összehasonlításával. Így elindul a fogalom differenciálódása, és általában tizenkét éves kor környékén alakul ki a képesség differenciált fogalma, melyben már elkülönül a képesség az erőfeszítéstől. Tizenkét éves kor előtt a fejlett képesség a gyerekek gondolkodásában szorosan összekapcsolódik a tanulás során befektetett energiával. Ebböl a nézőpontból a siker az erőfeszítésen múlik, ami a képességek fejlődését eredményezi, azaz e nézet a képességeket fejleszthetőnek tételezi. Azonban tizenkét éves kor után a képességek gyakran mint állandó jellemzők jelennek meg a serdülők gondolkodásában, így a fejlett képesség úgy mutatkozhat meg, ha az adott személy másokat túlteljesít azonos energia-befektetéssel, vagy ha másokhoz hasonlóan teljesít kevesebb erőfeszítéssel. E megközelítés a képességeket stabil személyiségjellemzőknek tekinti. Ugyanakkor a serdülők és a felnőttek körében a képesség differenciálatlan és differenciált értelmezésével egyaránt találkozhatunk.

A képesség fogalmának fejlődésére és a tanulási motivációra vonatkozó ismeretek felhasználásával Nicholls (1984) teljesítményt magyarázó elméletében feladatvezérelt (task involvement) és énvezérelt (ego involvement) célt különböztetett meg. A feladatvezérelt cél esetében a képesség és az erőfeszítés nem különül el, így a normatív értékelés sem jelenik meg. E céltípus a képességek fejlesztésére motivált állapotot jelöl, ami a teljesítmény szempontjából pozitív válaszokat eredményez. Ezzel szemben az énvezérelt cél a képességek normatív értékelésével jellemezhető motivációs állapot. Az énvezérelt cél az észlelt képességektől függően vetít előre válaszokat (pl. feladatok választását). Ha az énvezérelt cél az észlelt képesség magas szintjével társul, akkor pozitív következményekkel jár (pl. megfelelő nehézségü feladat választása), ellenben ha az észlelt képesség alacsony szintjével jár együtt, negatív következményekhez vezet (pl. túlzottan nehéz vagy könnyü feladat választása).

Dweck és Nicholls munkája alapján tehát egy önfejlesztésre irányuló motívum (elsajátítási cél) és egy teljesítmény demonstrálására irányuló motívum (viszonyító cél) különböztethető meg. Ezek megjelenése egyrészről a képességekkel kapcsolatos nézetektől, másrészről és az aktuális feladattól, szituációtól függ.

Dweck és Nicholls eredményeit, illetve a célokkal kapcsolatos egyéb ismereteket Ames és Archer (1988; Ames, 1992) integrálta, megalapozva ezzel a tanulási motiváció célokkal kapcsolatos további kutatásainak koherenciáját. Így jelentősen hozzájárultak ahhoz, hogy az 1990-es évek közepétől a célorientációs elmélet a tanulási motiváció vizsgálatának egyik központi konstruktumává vált. Emellett kiemelendő Dweck és Leggett (1988) munkája, amely a célorientációk és egyéb személyiségjellemzők kapcsolatával foglalkozik, elindítva így az elméleti megközelítés terjedését az oktatáshoz szorosan nem kötődő területeken is.

\section{A teljesítménykeresö-teljesítménykerülö dimenzió beépülése}

A motiváció teljesítménykereső-teljesítménykerülő (sikerorientált-kudarckerülö) dimenziója a motiváció kutatásának kezdeti szakaszához kötődik. Az első kísérlet e témában Hoppe (1930, idézi Elliot, 1997) nevéhez füződik, aki a teljesítményre irányuló viselkedést két egymástól független törekvésre vezette vissza: a siker elérésének és a kudarc elkerülésének vágyára. Az elmélet a motiváció iránti megnövekedett érdeklődés idején, az 1950-es években, elsősorban McClelland és Atkinson munkájának köszönhetően váltak dominánssá a teljesítménymotivált viselkedés magyarázatában (1. Atkinson, 1966/1988; Maehr és Sjogren, 1971/1997). Bár Dweck célelméletének magyarázatakor felhívja a figyelmet arra, hogy a célok a korábbi elméletek 
kiegészítéseként, mintsem helyettesítéseként értelmezhetők, a kapcsolatok feltárása sokáig váratott magára, a célelmélet megjelenése háttérbe szorította a korábbi megközelítéseket. A 1990-es évek elején Elliot vetette fel a célokra és a teljesítménykereső-teljesítménykerülő viselkedésre vonatkozó elméletek összekapcsolásának lehetőségét, melynek helytállóságát az empirikus eredmények később egyértelmüen igazoltak (Rawsthorne és Elliot, 1999). Ennek megfelelően a dichotóm célelméletet először egy hármas megközelítés váltotta fel, mely a viszonyító céllal kapcsolatos inkonzisztens eredmények magyarázatára fókuszált. E nézőpont az elsajátítási cél mellett egy viszonyító teljesítménykereső és egy viszonyító teljesítménykerülő célt különböztetett meg, de hamarosan megfogalmazódott a teljesítménykereső-teljesítménykerülő megkülönböztetés az elsajátítási céllal kapcsolatban is (Elliot, 1999; Pintrich, 2000a), melynek helytállóságát több empirikus kutatás is alátámasztja (Baranik, Bynum, Stanley és Lance, 2010; Moller és Elliot, 2006). A viszonyító és elsajátítási cél tehát tovább osztható teljesítménykereső és teljesítménykerülő célra, így a felosztás egy $2 \times 2$-es mátrixszal szemléltethető (11. táblázat).

Thrash és Elliot (2001) interpretációja szerint a teljesítménymotiváció kutatása a viselkedés irányának és energetizálásának magyarázatát jelenti. Míg az elsajátítási és viszonyító cél főképp a viselkedés irányának magyarázatát adja, a teljesítménykeresőteljesítménykerülő dimenzió - annak ellenére, hogy irányító funkciót is ellát elsősorban a befektetett energia mennyiségét befolyásolja. E funkció azáltal valósul meg, hogy az egyén egy lehetséges pozitív kimenet elérésére vagy egy negatív eshetőség elkerülésére fókuszál (Elliot és Friedman, 2007).

11. táblázat. A célok teljesítménykeresö és teljesitménykerülö formái (Linnenbrink és Pintrich, 2001, 254. o.)

\begin{tabular}{lcc}
\hline & \multicolumn{1}{c}{ Teljesítménykeresö } & Teljesítménykerülö \\
\hline $\begin{array}{l}\text { Elsajátítási } \\
\text { cél }\end{array}$ & A teljes elsajátításra, megértésre & A hiányos elsajátítás, megértés \\
& fókuszál & elkerülésére fókuszál \\
& Viszonyítási pontként az egyén & Viszonyítási pontként a \\
& saját fejlödése, a tananyag & feladathoz, önmagához mért \\
& megértésének mélysége szolgál & gyenge teljesítmény elkerülése \\
& & szolgál \\
\hline Viszonyító & Mások túlteljesítésére fókuszál & Másoknál alacsonyabb \\
cél & & teljesítmény elkerülésére \\
& & fókuszál \\
& & Normatív viszonyítási pont \\
& Normatív viszonyítási pont & jellemzi, a legrosszabb \\
& jellemzi, a legjobb osztályzat, & osztályzat, teljesítmény \\
& teljesítmény elérése az & elkerülése az osztályban \\
\hline & osztályban &
\end{tabular}

A teljesítménykereső-teljesítménykerülő dimenziók megjelenése a célstruktúrák mérésére is hatott, a célorientációkkal ellentétben a célstruktúrák esetében a $2 \times 2$-es felosztást követő kérdőív azonban nem készült. A célstruktúrák mérésében leginkább elterjedt eszközön a személyes célok hármas felosztású modelljét alkalmazzák az osztálytermi kontextus leírására, így az elsajátítási célstruktúra mellett a viszonyító célstruktúra viszonyitó teljesitménykeresö és viszonyitó teljesítménykerülő dimenziói jelentek meg. A viszonyító teljesítménykereső célstruktúra mások túlteljesítésére, a saját 
tudás demonstrálására ösztönöz, míg a viszonyító teljesítménykerülő célstruktúra a gyengébb teljesítmény, a hozzá nem értés elfedésére (Midgley és mtsai, 2000).

A célstruktúrák e hármas felosztása nem terjedt el széles körben. Többen felvetik, hogy ezek észlelése a tanulók egyéni jellemzőinek következménye is lehet (pl. Linnenbrink, 2004; Urdan, 2004a). Például ha a tanulók úgy gondolják, hogy nem lehetnek sikeresek, akkor inkább viszonyító teljesítménykerülő célt követnek, és a viszonyító teljesítménykerülő célstruktúra észlelése is ennek tudható be. A teljesítménykereső-teljesítménykerülő dimenziók létezése a célstruktúrák esetében további kutatásokat igényel.

\section{Többszörös célok elmélete}

Megközelítőleg az ezredfordulóig egymást kizáró, egymással szemben álló motivációs komponensként értelmezték az elsajátítási és a viszonyító célt. Az elsajátítási célra a tanulást elősegítő, tágabb összefüggésbe helyezve számos kognitív, szociális és affektív folyamatra pozitív hatást gyakorló tényezőként tekintettek, míg a viszonyító célt a tanulást kedvezőtlenül befolyásoló, kizárólag negatív következményekkel kísért összetevőként értelmezték (pl. Ames, 1992). E dichotóm, polarizáló felfogás nemcsak e motivációs konstruktum esetében volt jellemző, a motiváció pedagógiai szempontú kutatását általánosan végigkísérö jelenségröl van szó (Fülöp, 2008; Józsa 2007). A célorientációk esetében a többszörös célok elméletének (multiple goal perspective) megjelenésével azonban e nézet egyértelmüen megváltozott. Az új nézőpont felbukkanása egyrészről a célok teljesítménykereső-teljesítménykerülő dimenzióra osztásának, illetve az ennek következtében megjelenő újabb empirikus eredményeknek köszönhető, másrészről a versengés kutatásában bekövetkező paradigmaváltással hozható összefüggésbe.

A teljesítménykereső-teljesítménykerülő felosztás az elsajátítási cél esetében viszonylag újnak számít, így kevés empirikus bizonyíték áll rendelkezésre ezen a területen, ugyanakkor számos kutatás napvilágot látott, mely a viszonyító célon belül a teljesítménykereső és a teljesítménykerülő összetevőket vizsgálja (erről részletesebben a következő pontban). A viszonyító teljesítménykereső cél kedvező hatásait feltáró kutatások alapján mára egyre többen úgy vélik, hogy mindkét célorientáció fontos összetevője lehet az optimálisan fejlett tanulási motivációnak, ugyanakkor ezzel ellentétes vélemények is megfogalmazódtak a szakirodalomban. A vita elsősorban az inkonzisztens eredmények értelmezéséből fakadt. Midgley, Kaplan és Middleton (2001) véleménye szerint az eredmények arra utalnak, hogy csak meghatározott helyzetekben, vagyis kivételes esetekben jelentkeznek a viszonyító teljesítménykereső cél kedvező hatásai, összességében pedig a kedvezőtlen hatások túlsúlyáról beszélhetünk. Ezzel szemben Harackiewicz, Barron, Pintrich, Elliot és Thrash (2002) az inkonzisztenciát e cél eltérő operacionalizálására és mérési megoldásaira vezeti vissza. A célok kombinációját vizsgáló tanulmányokra hivatkoznak, melyek több esetben a viszonyító teljesítménykereső cél kedvező hatásáról számoltak be, például ha a magas elsajátítási cél magas viszonyító teljesítménykereső céllal párosult (pl. Barron és Harackiewicz, 2001; Pintich, 2000b).

A versengés-együttmüködés kutatásának és a célorientációs elmélettel kapcsolatos vizsgálatoknak az összefüggéseiről Fülöp Márta (2008) munkája ad részletes áttekintést. E kutatási irányok egyik kapcsolódási pontja, hogy a viszonyító célt követő tanulók körében hangsúlyosabb saját teljesítményük megítélése során a társas összehasonlítás, így e motivációs jellemző szorosan összekapcsolódott a versengés fogalmával, illetve az ahhoz kapcsolódó negatív konnotációval. A versengés és együttmüködés pszichológiájával foglalkozó szakirodalom a versengést évtizedekig 
egyöntetűen destruktív, míg a versengéssel szembeállított együttmüködést konstruktív jelenségként értelmezte. Az 1990-es évek elejétől azonban megkezdődött e szemléletmód átalakulása, és a kutatások egyre inkább figyelembe veszik a versengés pozitív és a kooperáció negatív következményeit, illetve a versengés és a kooperáció kombinációjának hatását (pl. Kasik, 2011). A versengés és együttmüködés kutatásában bekövetkező paradigmaváltás így közvetett módon hozzájárult a viszonyító céllal kapcsolatos eredmények újraértelmezéséhez, a többszörös célok elméletének elterjedéséhez, melyet leginkább talán azok az ideológiai irányultságú érvek szemléltetnek, amelyek a viszonyító cél iskolai versengésre kifejtett hatásának értékelésével kapcsolatban merültek fel (pl. Kaplan és Middleton, 2002).

Mára széles körben elfogadottá vált az az álláspont, mely szerint kedvezö és kedvezötlen következményekkel egyaránt együtt járhat, ha valaki az oktatási folyamat során jobban akar teljesíteni társainál, a társas összehasonlítást pedig az iskolai élet természetes velejárójának, mintsem az iskolából számúzendő jelenségnek tekintik (Fülöp, 2010a). A célorientációs elmélet fejlődése szempontjából a viszonyító cél előnyös hatásának felfedezése mellett az is lényeges felismerés, hogy a tanulók többféle célt is követhetnek egy-egy osztálytermi teljesítményszituációban. Azonban viszonylag keveset tudunk arról, hogy a célok különféle kombinációi milyen hatást gyakorolnak a motivációra, illetve az iskolai tanulással összefüggő egyéb lényeges változókra, az újabb kutatások így egyre inkább a célok interakciójára fókuszálnak (pl. Linnenbrink, 2005; Tuominen-Soini, Salmela-Aro és Niemivirta, 2011; Wolters, 2004).

\section{A célorientációk és a tanulás eredményességét befolyásoló egyéb változók kapcsolata}

A célorientációk kulcsszerepét elsősorban az egyéb személyiségjellemzőkkel kimutatott kapcsolataik támasztják alá. E kapcsolatokat a leggyakrabban kérdőívek segítségével vizsgálják. Az oktatással összefüggésében a teljesítményre gyakorolt hatások feltárásakor fóként az osztályzatokat alkalmazzák a teljesítményt kifejező mutatóként. Emellett szük körben, elsősorban a felsőoktatásban egy-egy kurzus teljesítéséhez kötődően láthatunk példát tudásszintmérő tesztek használatára is, azonban a teszteken elért eredményekböl - többek között azok kontextushoz kötöttsége, heterogenitása miatt - nehezen vonhatók le általánosítható következtetések.

Az elsajátítási cél pozitív következményeit illetően széleskörü egyetértés mutatkozik, az eredmények szerint e cél követése egyaránt pozitív hatást gyakorol a tanulók gondolkodási folyamataira, motivációjára, érzelmeire, viselkedésére. A célorientációk és a tanulási stratégiák kapcsolata talán az egyik leggyakrabban vizsgált terület, az eredmények pedig egyértelmüek, az erős elsajátítási céllal rendelkező tanulókra kevésbé jellemző a felszínes tanulási stratégiák alkalmazása és gyakrabban használnak metakognitív, önszabályozó stratégiákat (Elliot és McGregor, 2001; Pintrich, 2000b; Wolters, 1999). Az elsajátítási cél előnyös hatása kimutatható a befektetett energia és a kitartás területén (Grant és Dweck, 2003; Miller, Greene, Montalvo, Ravindran és Nichols, 1996; Wolters, 2004), pozitívan befolyásolja a tanulási készségek és az önhatékonyság megítélését (Roser, Midgley és Urdan, 1996; Wolters, 2004), az önjutalmazó motívumot (Rawsthorne és Elliot, 1999) az érzelmi jólétet (Kaplan és Maehr, 1999; Tuominen-Soini, Salmela-Aro és Niemivirta, 2008), a fogalmi fejlödést (Linnenbrink és Pintrich, 2002b) vagy a kortársakkal való kapcsolatokat (Levy-Tossman, Kaplan és Assor, 2007). 
A 2x2-es felosztás újszerüsége miatt az elsajátítási teljesítménykerülő célról rendelkezünk a legkevesebb információval, az elsajátítási teljesítménykereső célt a korábbi elsajátítási céllal azonosítják. Az eddigi vizsgálatok eredményei szerint az elsajátítási teljesítménykerülő cél kedvezőtlen hatást gyakorol az önjutalmazó motivációra (Cury, Elliot, Da Fonseca, és Moller, 2006), összefüggést mutat negatív érzelmekkel, a teszt-szorongással (Elliot és McGregor, 2001) és a segítségkéréstől való félelemmel (Karabenick, 2003). Baranik, Stanley, Bynum és Lance (2010) metaanalízise elsősorban felnőttek körében felvett kérdőíves kutatások eredményeit összegzi. Eredményeik szerint az elsajátítási teljesítménykerülö cél bár pozitív és negatív következményekkel egyaránt összekapcsolódik, a negatív hatások vannak túlsúlyban.

A viszonyító cél kedvezőtlen hatásai közé sorolja a szakirodalom a felszínes tanulási stratégiák követését (Elliot és Harackiewicz, 1996; Graham és Golan, 1991), a kifogáskereső viselkedést (Urdan, Midgley és Anderman, 1998), illetve a csalást, puskázást (Anderman, Griesinger és Westerfield, 1998). Ugyanakkor a teljesítménykereső-teljesítménykerülő dimenzió megjelenésével a teljesítménykereső viszonyító cél kedvező következményeiről is beszámolnak, például az önjutalmazó motívum (Elliot és Harackiewicz, 1996), az önhatékonyság (Roser, Midgley és Urdan, 1996; Wolters, Yu és Pintrich, 1996) vagy az önszabályozás területén (Wolters, Yu és Pintrich, 1996), míg a teljesítménykerülö viszonyító célt illetően a vizsgálatok konzisztensen negatív következményekről tájékoztatnak (Urdan, 2004a).

Pintrich (2000b) a teljesítménykerülő viszonyító cél szerepének feltárása érdekében magas elsajátítási/magas viszonyító, illetve magas elsajátítási/alacsony viszonyító céllal jellemezhető csoportokat hasonlított össze. Az önhatékonyság, a kognitív stratégiák használata, illetve a metakogníció tekintetében nem különbözött a két csoport, továbbá nem mutatkozott számottevő eltérés a szorongás, érzelmek, tehetetlenség és kockázatvállalás tekintetében sem, míg erősebb érdeklődésről számoltak be a magas elsajátítási/magas viszonyító céllal rendelkező csoport tagjai. Ugyanakkor más kutatások (pl. Wolters, 2004) nem erősítették meg a magas elsajátítási/magas teljesítménykereső viszonyító célok kombinációjának kedvező hatását.

A tanulmányi eredményekkel kapcsolatos következtetések nem egyértelmüek, a kutatások általában nem találnak kapcsolatot az elsajátítási cél és az osztályzatok között az általános iskolás tanulók körében, míg a középiskolában és a felsőoktatásban tanulók között néhány esetben kimutatható összefüggés (Wolters, 2004). A teljesítménykereső viszonyító céllal rendelkezők esetében a felsőoktatásban pozitív kapcsolat mutatható ki a jegyek tekintetében (Elliot és Church, 1997; Elliot és McGregor, 2001), míg a fiatalabb tanulóknál egymásnak ellentmondó eredmények olvashatók a szakirodalomban (Skaalvik, 1997; Wolters, 2004). A viszonyító teljesítménykerülő célt követő tanulóknál egyértelmü a helyzet, ezeknek a tanulóknak az osztályzatai gyengébbek társaikénál (Elliot és Church, 1997; Elliot és McGregor, 2001).

Az elsajátítási cél és az osztályzatok közötti hiányzó kapcsolat lehetséges magyarázataként az értékelési gyakorlatot, elsősorban a feleletválasztó tesztek alkalmazását említik, illetve az értékeléshez választott viszonyítási pontok problémáját. Továbbá felvetik, valószínűleg szerepet játszik a kapcsolat hiányában, hogy az elsajátítási céllal jellemezhető tanulók számára az iskolai érdemjegyek kevésbé fontosak (Harackiewicz, Barron, Tauer, Carter és Elliot, 2000). Senko és Miles (2008) kutatása egy további lehetőséget tárgyal. Felmérésük felsőoktatásban tanulók körében arra a következtetésre jutott, hogy az elsajátítási célt követő hallgatók a tananyag iránti erős érdeklődésük következtében akaratlanul gyengíthetik teljesítményüket, mivel a tananyag számukra érdekes részeire fókuszálnak. 
A munkakerülő cél követése esetében egyértelmü a helyzet, a tanulási motiváció és teljesítmény különféle indikátorait tekintve általában negatív korrelációs kapcsolatról számolnak be a kutatások, így például a megértést elősegítő tanulási stratégiák, a tantárggyal kapcsolatos pozitív attitűd, illetve az osztályzatok esetében, míg pozitív az összefüggés a csalással vagy a túlzottan gyakori segítségkéréssel az osztálytársaktól, illetve pedagógusoktól (Brophy, 2004).

\section{A tanulási környezet és a tanulást befolyásoló változók összefüggése}

Ebben a pontban azokat a fontosabb kutatásokat tekintjük át, amelyek a célorientációs elméletre építve a tanulási környezet és a tanulást befolyásoló egyéb változók összefüggését érintik. Mielőtt az összefüggésekkel foglalkozó fontosabb vizsgálatok eredményeit ismertetjük, egyrészről tisztázzuk azoknak a fogalmaknak a viszonyát, amelyeket a célorientációs elmélet kapcsán a tanulási környezet különböző szintjeit illetően használnak, másrészről röviden kitérünk néhány módszertani kérdésre, amelyek áttekintése szükségesnek látszik az eredmények értelmezéséhez.

\section{A tanulási környezet összetevői}

A célorientációs elmélet keretei között először is meg különböztetnünk a tanulási környezet két legátfogóbb halmazát, az iskolai és az otthoni környezetet (6. ábra). Bár az eddigi kutatások föként a célok és az iskolai környezet kapcsolatának feltérképezésére fókuszáltak, az utóbbi években az iskolán kívüli környezet célokra gyakorolt hatásának megismerése irányuló vizsgálatok is elindultak (pl. Bong, 2008; Gonida, Kiosseoglou és Voulala, 2007; Kumar, 2006). Az iskolai és otthoni környezet viszonya leginkább úgy merül fel, hogy adott osztályközösség tanulóinak „otthonról hozott céljai" is szerepet játszhatnak abban, hogy milyen motivációs sajátosságai alakulnak ki az osztályközösségnek. Például az erős viszonyító céllal rendelkező tanulók motiválására valószínűleg gyakrabban alkalmazza a tanulók elvárásainak megfelelően a pedagógus a nyilvános összehasonlítást.

Az iskolai környezet motivációs hatását leíró konstruktumok közül elsősorban a - „A célstruktúrák értelmezése” címü pontban korábban már definiált - célstruktúrákat alkalmazzák. A célstruktúrák alaptípusának a tanári célstruktúrák tekinthetők, amelyek adott pedagógus által formálódó környezet motivációs hatását jelentik. Ugyanakkor megkülönböztetik a tanári célstruktúráktól az osztálytermi és az iskolai célstruktúrákat is. Az osztálytermi célstruktúra fogalmának bevezetése azon felismerés nyomán vált szükségessé, hogy adott osztályterem motivációs közege nem kizárólag a pedagóguson múlik, ahogyan azt az iskolai és otthoni környezet elkülönítésére vonatkozó példa szemléletesen kifejezi. Vagyis az osztálytermi célstruktúra a tanári célstruktúrát magában foglalja, de emellett további, elsősorban az adott osztályközösséghez kapcsolódó tényezők alakítják. Az iskolai célstruktúra használat azt teszi indokolttá, hogy minden bizonnyal iskolai szinten is létezik egy jellemző motivációs közeg, amelyet például adott iskola pedagógusainak bizonyos kérdésekben kialakított konszenzusa jelenthet. Ez azonban nem feltétlenül egyezik a tanári és osztálytermi célstruktúrákkal. Például azt feltételezik, hogy adott osztályközösség tanulói által követett célokat befolyásolja az is, hogy pedagógusaik mennyiben alakítanak ki hasonló vagy különböző célstruktúrákat (1. Maehr és Midgley, 1991). Ugyanakkor az iskola egésze által közvetített célstruktúrák nyilvánvalóan bizonyos mértékig befolyásolják az adott iskola tanárainak vagy az adott iskola osztályközösségeinek célstruktúráját. 
Munkánkban az osztálytermi környezet motivációs hatására fókuszálunk, így az osztálytermi célstruktúra konstruktumát alkalmazzuk. A továbbiakban amennyiben a célstruktúra típusát nem közöljük, az osztálytermi célstruktúrára gondolunk.

A célstruktúrák holisztikus megközelítésü konstruktumai mellett a környezet konkrétabb elemeit is vizsgálják, így például a tanár-diák kapcsolatot, illetve - ,A tanulási környezet lényeges összetevői a célorientációs elmélet alapján" címü pontban később bemutatásra kerülő - TARGET dimenziókat. Látni fogjuk, hogy az osztálytermi környezet ezen összetevői a tanári és osztálytermi célstruktúrák elemeiként is értelmezhetők.

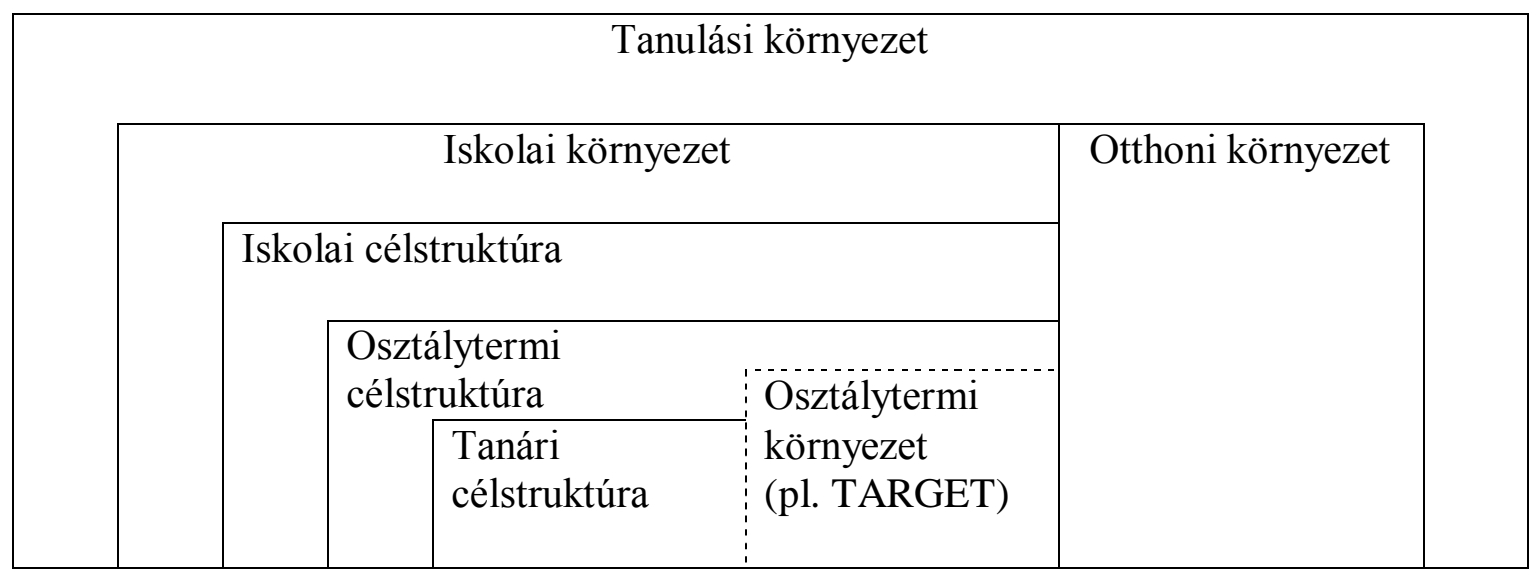

\section{6. ábra}

A tanulási környezet különbözö összetevöire utaló fogalmak áttekintése a célorientációs elmélet alapján

\section{Kutatásmódszertani áttekintés}

Az egyéni célok és célstruktúrák közötti kapcsolatot többek között laboratóriumi kísérletek támasztják alá. A laboratóriumi kísérletek szerint, ha a környezetből érkező üzenetek egyértelmüek, akkor az azonos feladaton, de különböző környezeti feltételek (célstruktúrák) között dolgozó kísérleti alanyok célorientációi különböznek. E kísérletekben különböző üzeneteket közvetítenek a kísérleti személyeknek, általában az adott feladat céljával és a teljesítmény értékelésével kapcsolatban (pl. hozzák ki magukból a legtöbbet, érezzék jól magukat, másokat teljesítsenek túl), - hasonlóan a tanár által az osztályteremben közvetített üzenetekhez (pl. Elliot és Dweck, 1988; Elliott és Harackiewicz, 1996). Bár a laboratóriumi kísérletek fontosak abban a tekintetben, hogy bizonyítékot szolgáltatnak a tanulói célok befolyásolhatóságával kapcsolatban, a célelmélet osztálytermi alkalmazását illetően természetesen korlátozottan használhatók, így e vizsgálati eljáráson alapuló eredményekre nem térünk ki.

A tanulók által követett célok és a tanulási környezet kapcsolatát vizsgáló leggyakoribb megoldásának az egyidejüleg mindkettőről, a célokról és környezetről információt gyüjtő kérdőíves vizsgálatok számítanak. A kapcsolatot kérdőívekkel vizsgáló kutatások egy további iránya a tanárok percepcióján keresztül vizsgálja az osztálytermi célstruktúrákat, illetve a tanári vélekedések, a tanárok által alkalmazott stratégiák és a tanulói célok, tanulók által észlelt célstruktúrák közötti összefüggéseket kutatja (pl. Patrick, Anderman, Ryan, Edelin és Midgley, 2001; Ryan, Gheen és Midgley, 1998; Wolters és Daugherty, 2007). E megközelítés gyakorlati szempontból arra a kérdésre adhat választ, hogy a tanárképzés és -továbbképzés segítségével hogyan 
befolyásolhatók a célstruktúrák, illetve ezen keresztül a célorientációk. A tanárok saját tevékenységükről való beszámolójuk és a tanulók néhány eredményváltozója között is felfedezhetők kapcsolatok, ugyanakkor ezek általában gyengébbek, mint a tanulók által észlelt célstruktúrák és a tanulók eredményváltozói közötti kapcsolatok (Meece, Anderman és Anderman, 2006). A gyenge kapcsolatokat fóként a pedagógusok elvárásokat szem előtt tartó válaszaira vezetik vissza (Linnenbrink, 2004).

$\mathrm{Az}$ egyéni észleletek szubjektivitását leginkább kizáró kutatási módszert a célstruktúrák feltárásában az osztálytermi megfigyelések jelentik (Urdan, 2004a). Az elemzések során elsősorban a megfigyelések eredményei és a kérdőívek által gyüjtött adatok között keresnek kapcsolatot (pl. Milyen különbségek figyelhetők meg a tanulói kérdőívek alapján dominánsan elsajátítási vagy viszonyító célstruktúrát közvetítő osztálytermi folyamatok között?), de találunk példát a megfigyelés és a tanulói interjú kombinációjára is (pl. Dowson és McInerney, 2003).

$\mathrm{Az}$ alkalmazott módszertől függetlenül külön említést érdemelnek azok a megoldások, amelyek a tanulási környezet változását is magukban foglalják. A tanulási környezet beavatkozás nélküli változását használják ki azok a kutatások, amelyek az alapfok és az alsó középfok közötti átmenethez (pl. Anderman és Midgley, 1997), illetve a tanulók új osztályba kerüléséhez kötődnek (pl. Urdan és Midgley, 2003). E felmérések elönye, hogy valós tanulási környezetekhez kapcsolódnak, ugyanakkor nehéz azonosítani a tanulói célok változását előidéző tényezőket. Külön említést érdemelnek azok a megoldások, melyek közvetett úton vizsgálják a tanulási környezet változásának hatását. Stipek, Givvin, Salmon és MacGyvers (1998) például tanárok számára szervezett továbbképzések különböző formáinak hatását vizsgálta, többek között az osztálytermi célstruktúrák alakulása szempontjából. Végül találunk példákat a célstruktúrák manipulálására osztálytermi keretek között (pl. Linnenbrink, 2005) és iskolák szintjén is (pl. Maehr és Midgley, 1996, idézi Urdan, 2004a), amelyek természetesen a legértékesebb információkkal szolgálhatnak, mind az elmélet, mind az alkalmazás tekintetében.

\section{A célstruktúrák és a tanulás eredményességét befolyásoló változók kapcsolata}

A célstruktúrák összefüggését a tanulási teljesítményt befolyásoló változókkal elsősorban kérdőívek segítségével vizsgálják. E kutatási megközelítés alapján gyüjtött információk esetében a legnagyobb problémát egyértelmüen az okozza, hogy a célstruktúrák és a tanulás eredményességét meghatározó változók közötti viszonyt jelentősen befolyásolhatják az egyéni interpretációk. A tanulók tanulási környezetről adott leírásának formálódásában számos egyéni sajátosság jelentőségét tárták fel, illetve számos továbbiakkal feltételeznek összefüggést. Az egyéni interpretációkat befolyásoló változókat, azok fontosabb kapcsolatait a célstruktúrákkal, valamint a célstruktúrák és a motiváció, illetve teljesítmény közötti összeköttetéseket Urdan (2010a) hipotetikus modellje alapján szemléltetjük (7. ábra).

Megjegyezzük, hogy a tanulók egyéni interpretációi közötti különbségei nemcsak az észlelés szubjektivitásához köthetők, hiszen ennek akár „objektív” alapja is lehet. Ez többek között eredhet abból, hogy a pedagógusok eltérően kezelik a különböző jellemzőkkel bíró tanulókat (pl. Tapola és Niemivirta, 2008). A tanulói interpretációk különbségének ez az értelmezése nem szerepel a bemutatott ábrán. 


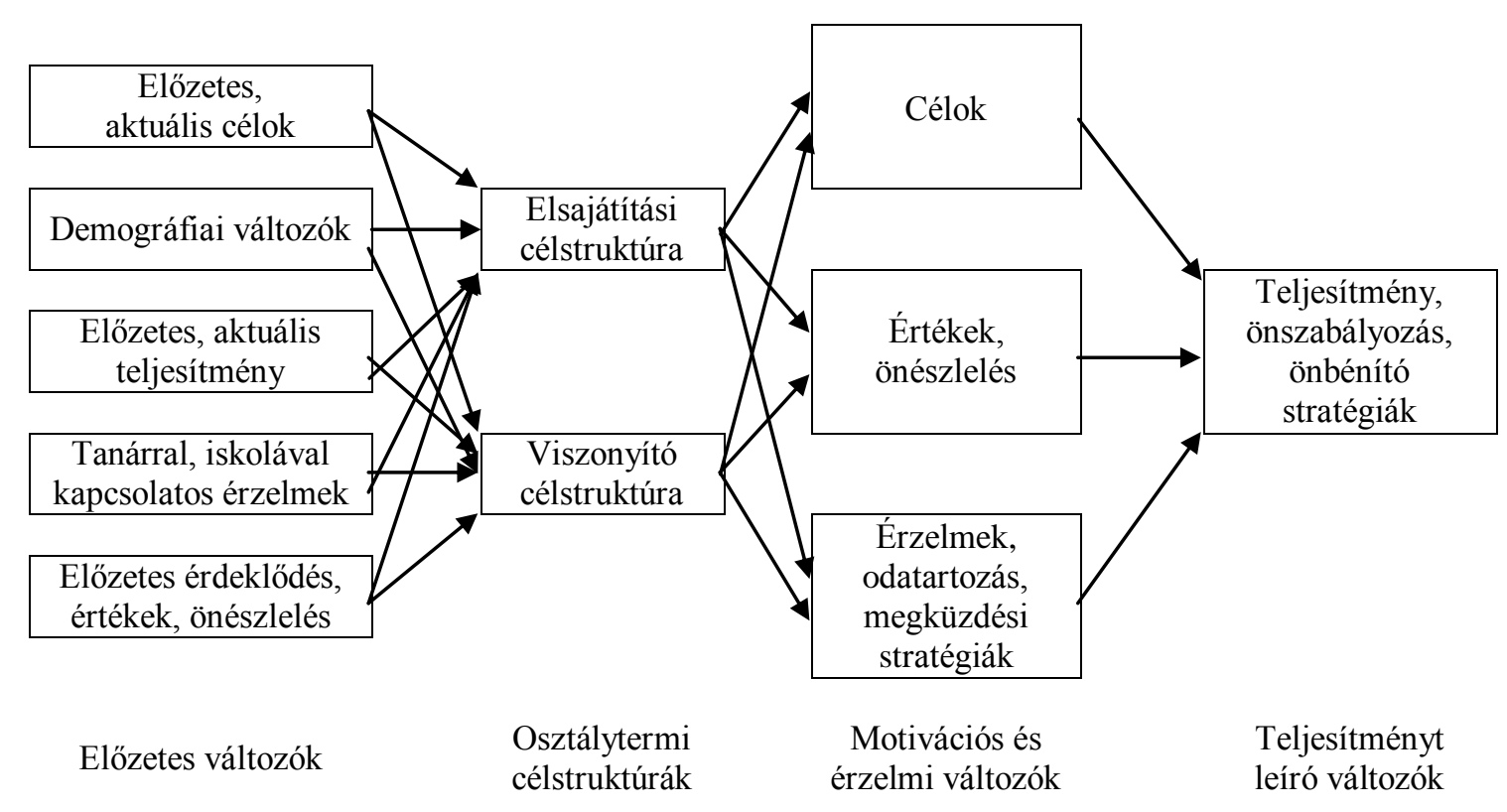

7. ábra

Az osztálytermi célstruktúrákat befolyásoló elözetes változók és hatások lehetséges modellje (Urdan, 2010a, 99. o.)

A tanulók írásbeli kikérdezésén alapuló munkák szerint az elsajátítási célstruktúra észlelése általában kedvezően befolyásolja a tanulás eredményességéhez köthető változókat. Pozitív kapcsolatot találtak például a személyes elsajátítási célorientációval, az iskolával kapcsolatos pozitív érzelmekkel, az önszabályozó és metakognitív stratégiák használatával, a szubjektív jóléttel, az adaptív segítségkéréssel és az osztályzatokkal. Negatív kapcsolat adódott vagy nem találtak kapcsolatot általában a tanulást kedvezötlenül befolyásoló tényezők tekintetében, így többek között a csalással, a kedvezőtlen segítségkéréssel vagy a tanulással és iskolával kapcsolatos negatív érzelmekkel (pl. Ames és Archer, 1988; Anderman, 1999; Anderman és Midgley, 2004; Kaplan és Maehr, 1999; Karabenick, 2004; Urdan és Midgley, 2003). A teljesség kedvéért megemlítjük, hogy néhány esetben a kutatók nem találtak összefüggést az elsajátítási osztálytermi célstruktúra és egyéb motivációról és teljesítményröl informáló változó között, így például az elsajátítási osztálytermi célstruktúra és a kitartás, a kihívást jelentő feladatok választása vagy az osztályzatok között (Wolters, 2004), valamint az elsajátítási osztálytermi célstruktúra észlelésében bekövetkező változás és a matematika és az angol tantárgyaknak tulajdonított érték változása között (Anderman és Midgley, 1997).

A felmérések többsége a viszonyító osztálytermi célstruktúra előnytelen következményeiről tájékoztat. Például a viszonyító osztálytermi célstruktúra pozitívan korrelál a tanulás halogatásával, az önbénító (self-handicapping) stratégiák használatával, az alacsonyszintü kitartással és a (pl. Urdan, Midgley és Anderman, 1998; Wolters, 2004). Ugyanakkor a viszonyító osztálytermi célstruktúra ugyancsak összefügg például azzal, hogy a tanulók a sikert az erőfeszítéseknek, a kudarcot a halogató stratégiának tulajdonítják (Ames és Archer, 1988), vagyis pozitív következményekkel is járhat e célstruktúra.

A felmérések változó erősségü korrelációt mutatnak a célorientációk és a célstruktúrák között mind a viszonyító, mind az elsajátítási cél esetében. A legerősebb kapcsolatról Anderman és Midgley (1997) számol be. Hatodik évfolyamosokkal végzett 
felmérésükben ( $n=341)$ az angol tantárgyhoz kötődő elsajátítási cél és az észlelt tanári elsajátítási célstruktúra között $0,57-e s(\mathrm{p}<0,01)$ korrelációt kaptak.

A többszörös célelmélet alapján - a személyes célokhoz hasonlóan - a célstruktúrák esetében is felvetődik a kérdés, hogy egyszerre többféle célstruktúrát támogató üzenet is érkezhet a tanulási környezetből. Így találhatunk példát a különböző célstruktúrák kombinációját vizsgáló kutatásra is (pl. Turner, Meyer, Midgley és Patrick, 2003), ugyanakkor e vizsgálatok alacsony számából nem vonhatók le általánosítható következtetések.

A pedagógusok írásbeli kikérdezésén alapuló felmérések összességében a tanulói kérdőívekéhez hasonló mintázatát rajzolták ki az összefüggéseknek (Urdan, 2010a). Tehát az elsajátítási célstruktúra kialakításának elősegítése támogatandó cél, míg a viszonyító célstruktúra esetében nem egyértelmű a helyzet, mivel kedvező és kedvezőtlen következmények egyaránt kapcsolhatók az osztálytermi környezet e típusához, hasonlóan a viszonyító célhoz. Megemlítendő még, hogy több kutatás a tanulói célorientációktól függetlenül kapcsolatot fedezett fel az iskolai, osztálytermi célstruktúrák és a teljesítmények között, azaz a célstruktúrák a célorientációk közvetítő szerepe nélkül is hatást gyakorolnak a teljesítményre (pl. Kaplan és Midgley, 1999; Ryan, Gheen és Midgley, 1998; Ryan és Patrick, 2001; Urdan, Midgley és Anderman, 1998).

A célstruktúrák hatásmechanizmusára, illetve az inkonzisztens eredmények értelmezésére többféle magyarázat is született. Ezek egyike egyszerüen azt a feltételezést fogalmazza meg, hogy az osztálytermi célstruktúrák által közvetített üzenetek nem elég erősek, nem elég világosak a legtöbb osztályteremben. A tanulók észlelése szubjektív, nagy különbséget mutathat, amelyet inkább a személyes célorientációk, mint az inkonzisztens üzenetekkel jellemezhető környezet befolyásol (Brophy, 2005). A másik lehetséges magyarázat, hogy a különböző kutatások az osztálytermi célstruktúrát különböző módon definiálják, így az e területen folyó vizsgálatok következtetetései nem összevethetők (Urdan, 2010a). Egy harmadik magyarázat a lehetséges fejlődésbeli különbségek szerepére utal. Linnenbrink (2004) arra hívja fel a figyelmet, hogy az otthoni és az iskoláztatás korai szakaszában észlelt célstruktúrák kritikus szerepet tölthetnek be a személyes célorientációk formálásában, így elképzelhető, hogy a tanulók személyes céljai már stabilak azokban az életkorokban, amelyekről eddig sikerült információt gyüjtenünk.

Egy további magyarázat, melyet ugyancsak Linnenbrink (2004) vetett fel, részletesebb kifejtést igényel. Linnenbrink (2004) a szakirodalom áttekintése alapján három lehetőséget fogalmaz meg, ahogyan az osztálytermi célstruktúrák befolyásolhatják a tanulás szempontjából fontos változókat: (1) a személyes célok közvetítő szerepet töltenek be, amelyeken keresztül a célstruktúrák kifejtik hatásukat; (2) a célstruktúrák közvetlenül, a célorientációktól függetlenül fejtik ki hatásukat; (3) a személyes célok befolyásoló tényezők, és a különböző célorientációk és célstruktúrák interakciója együttesen fejti ki hatását. Murayama és Elliot (2009) az indirekt, a direkt és az interakciós hatásmodell elnevezést használja e megközelítésekre, amelyeket a könnyebb áttekintés érdekében sematikusan is ábrázolnak munkájukban (8. ábra). A korábbi kutatások áttekintése alapján mindhárom lehetőséget alátámasztják empirikus bizonyítékok (1. Linnenbrink, 2004; Linnenbrink és Pintrich, 2001; Murayama és Elliot, 2009). 
Direkt hatásmodell

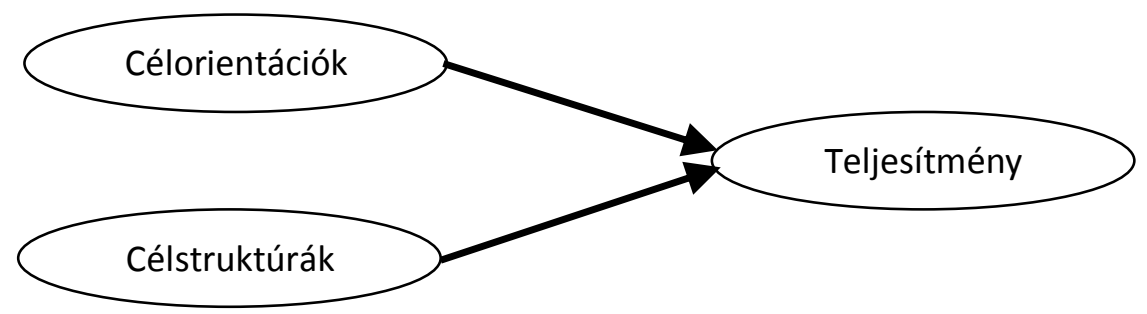

Indirekt hatásmodell

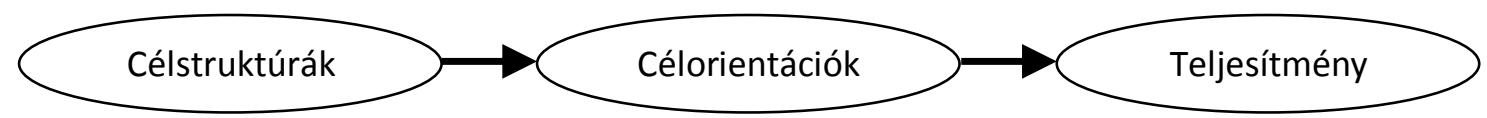

Interakciós hatásmodell

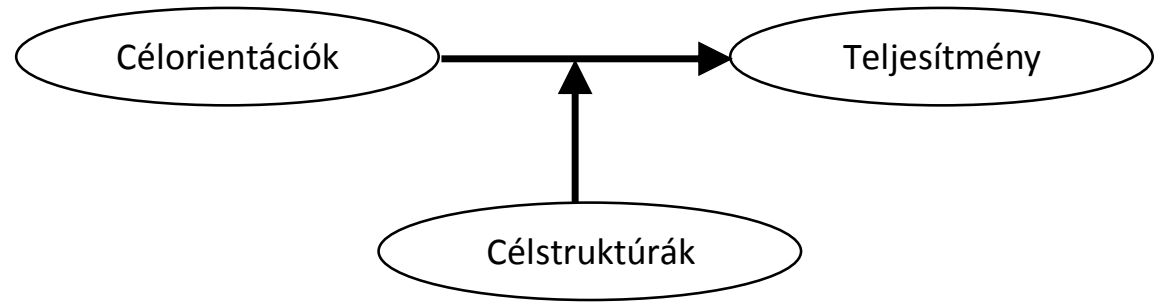

8. ábra

Elemzési keret a célorientációk és a célstruktúrák együttes, teljesitménnyel kapcsolatos változókra kifejtett hatásának vizsgálatához (Murayama és Elliot, 2009, 433. o.)

Az inkonzisztens eredmények magyarázatában, illetve a célorientációs elmélet továbbépítésében föként a célorientációk és célstruktúrák interakcióját feltételező lehetőség jelenthet elörelépést. E megközelítés számol a személyes célok viszonylagos stabilitásával (1. Tuominen-Soini, Salmela-Aro és Niemivirta, 2011; Wolters, Yu és Pintrich, 1996), és arra a feltételezésre épít, hogy ebből következően a tanulók olyan környezetbe kerülhetnek, ahol a személyes céljaikat az osztályteremi célstruktúra nem támogatja. Vagyis a célorientációk és célstruktúrák különböző kombinációi eltérő módon befolyásolhatják a tanulás szempontjából lényeges változókat (Linnenbrink, 2004). Linnenbrink és Pintrich (2001) két eltérö hipotézist fogalmaz meg ezen interakciók leírására.

A puffer hipotézis (buffering hypothesis) szerint akár az elsajátítási cél, akár az elsajátítási célstruktúra adaptív jellegüknél fogva pufferként tompítják a viszonyító cél vagy célstruktúra káros hatását. Például egy elsajátítási célt követő tanuló viszonyító célstruktúrával jellemezhető környezetben csökkenti a környezet kedvezőtlen hatásait a tanulás eredményességét kifejező változók esetében. Vagyis e nézőpontból nem elsősorban a személyes célok és célstruktúrák illeszkedése vagy eltérése az, ami igazán 
lényeges, hanem az elsajátítási cél vagy célstruktúra megjelenése. Azaz a legkevésbé előnyös következményekkel az jár, ha a viszonyító célorientáció viszonyító célstruktúrával párosul.

Egy alternatív hipotézis az illeszkedési hipotézis (matching hypothesis) nevet viseli, mely arra utal, hogy a tanulók számára az a legelőnyösebb, ha a személyes cél és az osztálytermi célstruktúra megegyezik, ellenkező esetben frusztráció jelentkezik, a bevonódás csökken, ami negatív következményekkel kísért folyamat. Vagyis nem feltétlenül az elsajátítási cél vagy célstruktúra jelent elönyt, hanem a környezet által hangsúlyozott és a személy által követett cél illeszkedése.

Barron és Harackiewicz (2001) szelektív célok hipotézise (selective goal hypothesis) az illeszkedései hipotézis kiegészítéseként értelmezhető, mivel hasonló logikán alapul, ugyanakkor a többszörös osztálytermi célstruktúrával, vagyis azzal is számol, hogy egy osztályteremi környezet egyszerre hangsúlyozhatja az elsajátítási és viszonyító célt. E hipotézis alapján a többszörös osztálytermi célstruktúra tekinthető a legkedvezőbbnek, hiszen így minden tanuló személyes céljával illeszkedést mutathat.

Murayama és Elliot (2009) munkája az egyetlen olyan empirikus vizsgálat, amely arra vállalkozott, hogy a tanulás eredményességét befolyásoló néhány változó tekintetében egyetlen mintán megvizsgálja és összevesse a direkt, indirekt és interakciós hatásmodellek müködését. Felmérésük keretében 1578 7-11. évfolyamos tanulóval töltettek ki kérdöívet, melyek segítségével a személyes célok és észlelt célstruktúrák mellett az önjutalmazó motivációt és a tanulási énképet mérték fel. Eredményeik mindhárom modell müködése tekintetében szolgáltattak bizonyítékot. A célstruktúrák mind direkt, mind indirekt módon kapcsolatba hozhatók az önjutalmazó motivációval és a tanulmányi énképpel, míg a célorientációk és a célstruktúrák összefüggése az interakciós hatásmodell alapján magyarázható, és mind a puffer, mind az illeszkedési hipotézis müködésére találtak bizonyítékot.

\section{A tanulási környezet lényeges összetevői a célorientációs elmélet alapján}

A tanulási környezet legfontosabb jellemzőit Ames (1992) gyüjtötte össze, és ezeket azóta is e célorientáció fejlesztését elősegítő tanulási környezet alapjaként használják. A szakirodalom áttekintése alapján, - föként Epstein (1988, idézi Ames, 1992) elméleti keretét felhasználva - Ames hat dimenziót különböztet meg, melyek a tanulási motivációt befolyásoló környezet lényeges jellemzőinek leírására szolgálnak. Ezek a következők: feladat, irányítás, elismerés, csoportalkotás, értékelés és idő (12. táblázat). $\mathrm{Az}$ angol szavak (Task, Authority, Recognition, Grouping, Evaluation, Time) kezdőbetűinek összeolvasásából e dimenziókra a TARGET betüszó terjedt el a szakirodalomban. Bár a TARGET alapjai empirikus kutatásokhoz kötődnek, illetve további vizsgálatok igazolták e dimenziók jelentőségét, ezek jelentős része nem kapcsolódik a célorientációs elmélethez, azaz e felmérésekben a tanulói célorientációk helyett a tanulási motiváció jellemzésére használható egyéb változókat alkalmaztak. A TARGET dimenziók egyaránt vezérfonalként szolgálnak a tanulási környezet feltárásban, illetve - látni fogjuk - a célorientációs elmélet alapján szervezett beavatkozások megtervezéséhez. 
12. táblázat. A célorientációkat befolyásoló körülmények szempontjai (TARGET) (Kaplan és Maehr, 2007, 159. o., részlet)

\begin{tabular}{ll}
\hline $\begin{array}{c}\text { A környezet } \\
\text { dimenziói }\end{array}$ & Leírás \\
\hline Feladat & $\begin{array}{c}\text { Mit kérnek a tanulótól? Mi a végeredmény? Milyen lehetőségei } \\
\text { vannak tanulónak a feladat befolyásolásra? Mennyire tünik } \\
\text { hasznosnak, jelentéssel bírónak a feladat az egyén számára? }\end{array}$ \\
Irányítás & $\begin{array}{c}\text { Az egyénnek mennyire van beleszólása abba, hogy hogyan és mikor } \\
\text { végezze el a feladatait? Meg lehet-e változtatni a szabályokat? Ki } \\
\text { vesz részt a döntéshozatalban, és hogyan? }\end{array}$ \\
Elismerés & $\begin{array}{c}\text { Milyen eredménnyel és viselkedéssel foglalkozunk, és milyen } \\
\text { eredményt és viselkedést ismernek el? }\end{array}$ \\
Csoportmunka & $\begin{array}{c}\text { Melyek a csoportba rendezés kritériumai? Milyenek a csoporton } \\
\text { belüli interakció normái, szabályai? }\end{array}$ \\
Értékelés & $\begin{array}{c}\text { Mit közvetít a feladat értékelése a feladat céljairól? Hogyan zajlik az } \\
\text { értékelés? }\end{array}$ \\
Idő & Milyen az idővel való gazdálkodás? Mennyire rugalmas a \\
& menetrend? Mi az üzenete az időkorlátoknak?
\end{tabular}

Megj.: a teljes táblázat megtalálható az 1. mellékletben.

A következőkben a célorientációs elmélet kereteit felhasználó azon empirikus kutatások rövid összefoglalása olvasható, amelyek kapcsolatot tártak fel a tanulási környezet bizonyos elemei és a célorientációk követése, valamint a tanulási környezet bizonyos elemei és a célstruktúrák észlelése között. A célorientációk esetében az összefüggések megismerésére általában kvantitatív megközelítést alkalmaznak, elsősorban kérdőívek használatával kísérelik meg feltárni ezeket, míg a célstruktúrák esetében a tanulói kérdőívek alapján kategorizált osztályokban kvalitatív módszerekkel, főként osztálytermi megfigyelések segítségével igyekeznek az eltéréseket megragadni. A kivonatolt kutatások jelentős részét az Egyesült Államokban végezték, ahol az iskolába lépés 5 és 7 éves kor között változik az adott állam szabályaitól függően, de a 6 éves kor a leggyakoribb (U. S. Department of State, é. n.). Munkánkban a kutatási beszámolókban közölt évfolyamokat jelenítjük meg, mivel valószínüsítjük, hogy az iskolában eltöltött éveknek az életkornál fontosabb a szerepe a célok formálódásában (1. „A célorientációk életkori változása” címü pontot).

Stipek, Givvin, Salmon és MacGyvers (1998) egy matematikatanárok számara szervezett továbbképzés motivációs hatását vizsgálta, így a tanulók célorientációinak alakulásáról is információt gyüjtöttek 4., 5. és 6. évfolyamos tanulók körében. Felmérésükben a pedagógusok néhány óráját videóra rögzítették, majd a tevékenységeket kódolták, és összefüggéseket kerestek többek között a tanári tevékenységek és a tanulók célorientációi között. Eredményeik szerint az elsajátítási célok követése gyakoribb volt azokban az osztályokban, ahol a pedagógus több energiát fektetett a megértés segítésére és az erőfeszítések szerepének hangsúlyozására.

Church, Elliot és Gable (2001) azt vizsgálta felsőoktatásban tanuló hallgatók körében kérdőívek segítségével, hogy az osztálytermi célstruktúra egyes elemei és a személyes célorientációk között milyen kapcsolat létezik. Az előadás érdekessége előre jelezte az elsajátítási cél követését, míg az értékelésre fókuszáló tanári gyakorlat a 
viszonyító teljesítménykereső cél választását jelezte előre, a szigorú értékelés pedig a viszonyító teljesítménykerülő cél megjelenését.

A legnagyobb mintára támaszkodó kérdőíves vizsgálatot, mely a pedagógusok tevékenysége és a tanulók személyes céljai között kapcsolatot keres, Meece, Herman és McCombs (2003) végezte. 4615 5-12. évfolyamos tanuló körében vizsgálták a tanulók néhány motivációs jellemzőjét, többek között elsajátítási és viszonyító teljesítménykereső célorientációit, emellett a tanulóközpontú tanári gyakorlatra vonatkozó kérdőívet töltettek ki, melyen a pozitív tanár-diák viszonyra törekvés, a tanulói vélemények tiszteletben tartása, a tudásszervezés támogatása, valamint az egyéni különbségekhez igazodás skálák szerepeltek. A tanulóközpontú tanári gyakorlat minden alskálája pozitív kapcsolatban állt mindkét vizsgált céltípussal.

Ryan és Patrick (2001) az önszabályozó tanulás, a szociális kapcsolatok, az énhatékonyság és a társas környezet közötti összefüggés megismerését célozták meg kérdőíves vizsgálatukban. A társas környezet leírására több konstruktumot alkalmaztak, a tanári támogatás érzését, a tanulók közötti interakció támogatását és a kölcsönös tisztelet támogatását, emellett a viszonyító célstruktúrát leíró kérdőívtételeket is használtak. A viszonyító célstruktúra támogatása negatívan korrelált a tanári támogatás érzésével, a kölcsönös tisztelet támogatásával, valamint a tanulók közötti interakció támogatásával. Továbbá az önszabályozó tanulás, a szociális kapcsolatok és az énhatékonyság tekintetében is hasonló, vagyis negatív kapcsolat mutatkozott.

Urdan, Kneisel és Mason (1999) videóval támogatott felidézést alkalmazott 5. és 6. osztályos tanulók körében. Eredményeik szerint a tanulók leginkább akkor érzékelték a tanári gyakorlatot konzisztensen elsajátítási célstruktúrát elősegítőnek, ha a pedagógus figyelembe vette a tanulók megnyilvánulásait, illetve szem elött tartotta a tananyag személyessé tételét.

Turner, Midgley, Meyer, Gheen, Anderman és Kang (2002) hatodikos tanulók körében a célstruktúrákra vonatkozó kérdőívet töltettek ki, valamint osztálytermi megfigyeléseket végeztek a pedagógusok oktatási folyamatra vonatkozó verbális kommunikációjára fókuszálva. Azt vizsgálták, hogy a pedagógusok mit mondanak az oktatási folyamat során, és ez hogyan befolyásolja a tanulókat matematika tárgy esetében, kiemelten foglalkoztak a teljesítménykerülő tanulói motivációval, illetve viselkedéssel. A munka fontos következtetése, hogy az elsajátítási célstruktúrával jellemezhető osztályterem kognitív és motivációs támogatást egyaránt magában foglal. Az elsajátítási célstruktúrát közvetítő tanárok jellemzője volt, hogy saját gondolkodási folyamataikat láthatóvá teszik, lehetőséget kínálnak az új tudás bemutatására, szóbeli közlésekkel gyakran támogatják a tanulók motivációját, melybe beletartozik, hogy felhívják a tanulók figyelmét a hibázás és kérdések természetességére a tanulási folyamat során, megdorgálják a tanulókat, amennyiben megértési problémák esetén nem megfelelő érzéseket (pl. szégyen) fedeznek fel körükben, ösztönzik a kitartást, valamint humort alkalmaznak.

Patrick, Anderman, Ryan, Edelin és Midgley (2001), illetve Patrick, Turner, Meyer és Midgley (2003) két megegyező módszerrel végzett kutatásában osztálytermi megfigyeléseket végeztek a tanulói kérdőívek alapján kategorizált osztályokban ötödikes és hatodikos tanulók körében. Az eredmények szerint elsősorban a feladattal kapcsolatos tanári üzenetek, az irányítás és az elismerés hozható kapcsolatba az elsajátítási célstruktúrával. Ugyanakkor a TARGET dimenziók közül az idő kezelésében nem találtak eltéréseket a különböző osztályok között. Emellett arra hívják fel a figyelmet, hogy a célstruktúrák összefüggenek az osztályok affektív és szociális jellemzőivel is. Az erős elsajátítási célstruktúrájú osztályokban kedvezőbb tanár-diák kapcsolatot, magasabb tanári elvárásokat és a tanulók közötti együttmüködés erősebb 
ösztönzését figyeltek meg. A gyenge elsajátítási célstruktúrával jellemezhető osztályok lényeges jellemzője a tanári elvárások alacsony szintje volt.

Anderman, Patrick, Hruda és Linnenbrink (2002) ugyancsak ötödikes tanulók körében végeztek osztálytermi megfigyeléseket azzal a céllal, hogy a tanulói kérdőívek alapján kategorizált osztályok jellegzetes tanári gyakorlatát feltárják, elsősorban a célstruktúrát érintő kommunikációt vizsgálva. A megfigyelésekből feltáruló kép szerint a társas összehasonlítás önmagában nem biztos, hogy viszonyító célstruktúrát jelez, inkább az összehasonlítás pozitív vagy negatív kontextusa számít. Anderman és munkatársai (2002) a korábban ismertetetteket megerösítve azt tapasztalták, hogy a tanár-diák viszonynak és az osztályban uralkodó társas légkörnek ugyancsak fontos szerepe van abban, kialakul-e elsajátítási célstruktúra. Emellett a tanulók intellektusa, tanulási képességei iránti tisztelet megjelenését találták meghatározónak. Gyengébb elsajátítási célstruktúráról számoltak be azokban az osztálytermekben, amelyekben a pedagógus nagy hangsúlyt fektetett a szabályok, bevett eljárásmódok követésére.

Patrick és Ryan (2008) a korábbiaktól eltérő módszertannal vizsgálta 6-8. évfolyamon az elsajátítási célstruktúra összetevőit. Az elsajátítási célstruktúrára vonatkozó kérdöív kitöltése után nyílt végü kérdéseken keresztül kértek példákat a tanulóktól arra vonatkozóan, hogy az egyes kérdőívtételek értékelésekor mire gondoltak. A TARGET dimenziók közül a tanárok feladatokkal kapcsolatos gyakorlata, az értékelés és az elismerés egyértelmüen kiemelkedett, ugyanakkor megjelent az idő dimenzió is, ami a korábbi osztálytermi megfigyelésekre támaszkodó kutatások során nem tủnt lényegesnek. A válaszok alapján a tanár-diák interakció mind általánosságban, mind a tananyaggal összefüggésben kulcsfontosságú, utóbbi esetében a megértés elősegítése, a magyarázattal kapcsolatos erőfeszítések szerepe tünt meghatározónak.

Összegzésként megállapítható, hogy az eredmények bizonyítják, hogy a tanári tevékenységek egy része összefügg a tanulók által választott célorientációkkal, illetve a tanulók által észlelt osztálytermi célstruktúrákkal, ugyanakkor ok-okozati összefüggés nem fogalmazható meg. A TARGET dimenziók jelentőségét több kutatás is megerősítette, azonban további lényeges szegmensekre hívják fel a figyelmet az áttekintett munkák. Fontos tanulság, hogy az osztályterem szociális jellemzőinek is fontos szerep tulajdonítható a tekintetben, hogy a tanulók milyennek látják az osztályterem motivációs jellemzőit.

\section{A célorientációs elméleten alapuló intervenciós programok}

A következőkben áttekintjük a tanulási környezet motivációs jellemzőinek befolyásolását célzó azon beavatkozásokat, amelyek a célorientációs elméletre épülnek. Bár az eddigi kutatási eredményekből világosan következik, hogy a célstruktúrák manipulálásával - legalábbis bizonyos mértékben - befolyásolható a tanulási motiváció, kétségkívül a legmeggyőzőbb bizonyítékokat az intervenciós kísérletek szolgáltathatják. E beavatkozások többsége a TARGET dimenzióit követi, illetve viszonyítási pontként alkalmazza azokat.

Ames (1990, idézi Urdan, 2004a) a TARGET dimenzióit alapul véve a tanulási környezet manipulálását, elsajátítási célstruktúra kialakítását tüzte ki célul. Kontrollcsoportos vizsgálatában nem ért el változást a kísérleti csoportban a tanulók önjutalmazó motivációja, tanulási stratégiája, az olvasás, a matematika és az iskola iránti attitüdje, illetve az észlelt kompetencia tekintetében a kísérleti csoportban, ugyanakkor a kontrollcsoport tanulói esetében szignifikáns csökkenést mutatott ki az észlelt kompetencia és az iskola iránti attitüd kivételével a vizsgált változókban.

Maehr és Midgley (1996, idézi Urdan, 2004a) az alapfok és az alsó középfok közötti átmenethez kötődően a tanulók új osztályokba kerülését használta ki, mely során 
az új osztályok egy részében elsajátítási célt hangsúlyozó környezet megteremtésére törekedtek. A kísérleti osztályokba került tanulók között a viszonyító célok követésének enyhe csökkenéséről számoltak be, míg a kontroll osztályokban növekedésről. Ugyanakkor a kísérleti csoportban a viszonyító cél érzékelése az osztályteremben nem változott, míg a kontrollcsoportban erősödött.

Fuchs, Fuchs, Karns, Hamlett, Katzaroff és Dutka (1997) fejlesztő kísérlete a TARGET több komponensét felhasználva általános iskolások matematikaoktatását célozta, elsősorban a tantervi tartalmak elsajátítására fókuszálva. A kísérleti csoport tanulói a kontrollcsoporthoz képest több kihívást jelentő feladatot választottak, illetve ezek témái változatosabbak voltak. Emellett a kísérleti csoport alulteljesítő diákjai esetében a befektetett erőfeszítés növekedését tapasztalták, azonban az önjutalmazó motiváció esetében nem találtak különbséget a kísérleti és a kontrollcsoport között.

Miller és Meece (1997) 3. osztályos tanulók motívumfejlesztésére vállalkozott az olvasás és az írás területén a hagyományos munkafüzetek rövid választ igénylő feladatainak esszé jellegüekre cserélése, a saját fejlődés nyomon követésére alkalmas lehetőségek növelése, valamint az osztálytársakkal való együttmüködés ösztönzése által. Eredményeik szerint azokban az osztályokban, ahol a megfigyelések szerint a kutatók elvárásainak megfelelően átalakították a tanári gyakorlat említett jellemzőit, a tanulók kevésbé követtek viszonyító célokat.

Egy további intervenciós kísérlet Linnenbrink (2005) nevéhez füződik. Az előzőekben ismertetettekhez képest e beavatkozás lényeges vonása, hogy a kísérlet során a célstruktúrák mellett a célorientációk felmérése is megtörtént. Az öt hétig tartó kísérlet keretében elsajátítási, viszonyító, illetve e kettő kombinációjával jellemezhető célstruktúra kialakítására törekedtek 5. és 6 . évfolyamon matematikaórákon. A tanulási környezet átalakítása az értékelés, elismerés, a csoportalkotás és a csoportok közötti versenyhelyzetek manipulálásán alapult. A tanulói kérdőívek szerint a célstruktúrák létrehozása sikeres volt, ugyanakkor az egyéni célok nem változtak a kísérlet során. A vizsgált eredményváltozókon azonban kimutatható volt az új környezet befolyása, a legkedvezőbb hatása az elsajátítási és viszonyító célt kombináló célstruktúrának volt.

\section{A célorientációk életkori változása}

A beavatkozások szervezésével kapcsolatban központi kérdésként merül fel, hogy a célorientációk mennyire stabil személyiségjellemzők, azaz milyen mértékben befolyásolhatók, milyen elvárások támaszthatók a tanulói célorientációk formálását célzó intervenciós törekvésekkel szemben. A kutatók egy része a kontextus szerepét hangsúlyozza, vagyis úgy tekint a célorientációkra, melyek a különböző szituációkban jelentős eltérést mutathatnak adott személy esetében is, ebből következően relatíve könnyen befolyásolhatók (pl. Ames, 1992). Mások az egyéni jellemzőket helyezik előtérbe, vagyis az előbbi megközelítéssel szemben a környezeti feltételektől viszonylag független, stabil személyiségjellemzőként kezelik a célorientációkat ( $\mathrm{pl}$. Dweck és Leggett, 1988). A kérdés megválaszolásában a longitudinális vizsgálatoké lehet a föszerep. A célelméleten alapuló kutatások nem fordítanak kiemelt figyelmet a személyes célok időbeni alakulására természetes körülmények között, azaz változatlan tanulási környezet esetén. Ennek oka egyrészről az elméleti alapvetések következménye, hiszen a személyes célokat - bár különböző mértékben - a környezettel kölcsönhatásban álló személyiségjellemzőnek tekintik. A másik ok, hogy az elméleti alapvetésböl következően a keresztmetszeti vizsgálatok nem alkalmasak a célorientációk változásának feltárására. Longitudinális kutatásokat azonban alig indítanak a környezet manipulálása, vagy a tanulási környezet valamilyen természetes átalakulásának kihasználása nélkül. 
$\mathrm{Az}$ alapfok és az alsó középfok közötti, 4. évfolyam utáni iskolaváltáshoz kötődően több kutatás is megvizsgálta a tanulók célorientációit. Az eredmények a tanulók többségénél az elsajátítási cél csökkenéséről és a viszonyító cél erősödéséről számolnak be, amit a teljesítményt, ezen keresztül pedig a viszonyító célstruktúrát egyre inkább hangsúlyozó tanulási környezethez kötnek (pl. Anderman és Anderman, 1999; Anderman és Midgley, 1997). Meece, Herman és McCombs (2003) 5-12. évfolyamos tanulók körében végzett keresztmetszeti felmérése ugyancsak megerösítette, hogy a fiatalabb tanulók elsajátítási célorientációja erősebb. Meece és Miller (2001) az olvasáshoz és íráshoz kapcsolódóan vizsgálta a célorientációk változását longitudinális vizsgálatában 3. és 5. évfolyam között, a célokat a tanév elején és végén egyaránt felmérve. Eredményeik szerint az évfolyamok elörehaladtával és a tanéven belül is mind az elsajátítási, mind a viszonyító célok gyengülése tapasztalható.

Vizsgálatukban Freeman és Anderman (2005) azonban az elöbbieknek ellentmondó eredményeket kapott, amely 6. és 7. évfolyam között vállalkozott az elsajátítási célok változásának összevetésére nagyvárosi és vidéki iskolák tanulói körében. A várakozásokkal ellentétben mindkét almintában az elsajátítási célok erősödéséről számoltak be. Mivel a korábbi eredmények egy része az iskolaváltáshoz köthető, az inkonzisztens eredmények magyarázatként a szerzők felvetik egyrészről, hogy a korábbi mérésekben a csökkenés csak ideiglenes visszaesés, másrészről, hogy az utóbbi évek oktatási reformjainak lehetséges pozitív hatásának megnyilvánulása is állhat a háttérben.

A problémát egy másik, személyközpontúnak (person-centered method vagy pattern analysis) nevezett megközelítésben is érdemes megvizsgálni. E nézőpont a hasonló motivációs profillal jellemezhető tanulókat kívánja azonosítani, vagyis az egyes célorientációk vizsgálata (variable-centered method) helyett azok mintázatára helyezi a hangsúlyt, a többszörös célok elméletére hivatkozva (1. Niemivirta, 2002a). Konzisztensen hasonló motivációs mintázattal rendelkező tanulói csoportokat azonosított több felmérés is, továbbá az is megállapítást nyert, hogy e csoportok eltérő módon észlelik a tanulási környezetet (pl. Meece és Holt, 1993; Niemivirta, 2002b; Tapola és Niemivirta, 2008; Tuominen-Soini, Salmela-Aro és Niemivirta, 2008).

Tuominen-Soini, Salmela-Aro és Niemivirta (2011) e motivációs mintázatokat szem elött tartva a korábbiaktól eltérő módon keres választ arra, hogy mennyiben érzékenyek a célorientációk a kontextusra. A különbözö motivációs mintázatokkal jellemezhető csoportokba sorolt tanulók körében elemzik az időbeli stabilitását. Két longitudinális felmérés eredményeiről számolnak be, amelyek egyikében a tanulói célorientációk mérést négy, míg a következőben tizenkét hónap elteltével ismételték meg 15 és 17 éves középiskolások körében. A tanulók közel 60 százalékának motivációs jellemzői állandónak bizonyultak mindkét felmérésben. Kismértékü változást tapasztaltak a tanulók közel harmadánál, ami azt jelenti, hogy továbbra is a korábban azonosított motivációs jellemzőkkel bíró csoportban maradtak. A diákok mindössze öt százaléka esetében jeleztek számottevő változást az adatok. Ezek az eredmények így e motivációs jellemzők viszonylagos stabilitását támasztják alá.

Schwinger és Wild (2012) ugyancsak longitudinális vizsgálatban követte 3. és 7. évfolyam között a motivációs profil változását a matematikához kötődően. A tanulók motivációs mintázatát minden évben felmérték. Három csoportot különböztettek meg: magas többszörös céllal, átlagos többszörös céllal és elsajátítási céllal rendelkező tanulókat. Eredményeik szerint mindössze a tanulók egyharmada tartozott ugyanazon mintázattal jellemezhető csoportba mind az öt tanévben. A változások két jellemző tendenciáját fedezték fel, ezek egyike az volt, hogy minden évben egyre többen kerültek át a magas többszörös céllal jellemezhetők közül az átlagos többszörös céllal 
rendelkezők közé, emellett egyre csökkent az elsajátítási célra orientálódó tanulók aránya.

Összességében tehát viszonylag keveset tudunk arról, hogy hogyan változnak a tanulók személyes céljai az életkor elörehaladtával. Bár a vizsgálatok eredményeinek többsége változásról, főként az elsajátítási célok követésének csökkenéséről tanúskodik az életkor elörehaladtával, ennek ellenmondó eredmények is napvilágot láttak. Azonban fontos lehet az a körülmény is, hogy eltérő életkorokat vizsgálnak az említett kutatásokban. Korábban rámutattunk a hazai tanulók kapcsán arra, hogy a változások a motivációs konstruktumok tekintetében különböző életkorokat tekintve különböző mértéküek lehetnek. Emellett az eltérő koncepcióra épülő, valamint a kontextus eltérö szintjét (általános vagy tantárgyhoz kötődő célok) képviselő mérőeszközök is akadályozzák az eredmények szintetizálását.

\section{Kulturális különbségek}

Mint korábban rámutattunk, a tanulási motiváció erősen kontextusfüggő jelenség, így alakulásában a tágabb környezetnek, a kultúrának is szerepe lehet. E megállapítás a célorientációkra is igaz, bár a kulturális különbségek keresése, a kultúrák összehasonlítása nem tartozik a célorientációs elmélet kurrens kutatási irányai közé.

Különböző mértékben és hangsúllyal, de a célelmélettel foglalkozók egyetértenek abban, hogy a célorientációk alakulása összefüggésbe hozható mind a környezeti tényezőkkel, mind az adott egyén további személyiségjellemzőivel. Elméletileg bármelyik irányból közelítjük meg a kérdést, mindkét úton elérhetünk a kultúrák közötti különbségek kialakulásáig. A környezeti tényezők esetében elég csak az eltérő nevelési, oktatási felfogásokra és hagyományokra gondolnunk. A személyiség egyéb tényezőivel összefüggésben példaként az euro-amerikai független és kelet-ázsiai kölcsönös függöségen alapuló kultúrákhoz társítható pszichológiai folyamatok említhetök (Markus és Kitayama, 1991), amelyek többek között a társas összehasonlításra, így vélhetően a viszonyító cél müködésére is hatással vannak.

Az euro-amerikai és kelet-ázsiai kultúrák összehasonlítása a célelmélet esetében is a gyakran összevetettek közé tartoznak, feltárva e területen is eltéréseket (pl. Elliot, Chirkov, Kim és Sheldon, 2001; Ho és Hau, 2008; Lee, Tinsley és Bobko, 2003), ugyanakkor kevésbé távoli kultúrák között is felfedeztek már különbségeket. Például Bernardo és Ismail (2011) Fülöp-szigeteki és malajziai hallgatók közötti eltérésekről számol be. A kulturális különbségek létezése kapcsán azonban ellenérveket is találhatunk a szakirodalomban, McInreney és Leim (2009) áttekintésében több tucatnyi munkát sorol fel, amelyekben az általuk is használt, többek között a tanulási célokra is kitérő mérőeszközzel gyüjtöttek információkat. Ezek nem mutattak lényeges különbséget az angolszász, európai, ázsiai, aboriginal, közel-keleti, afrikai és navahó indián minták között.

Empirikus vizsgálatunk szempontjából a kulturális különbségek közül az egyes célorientációk közötti összefüggések emelhetők ki, amelyek viszonyítási pontot jelenthetnek számunkra is. A célok közötti kapcsolatok az angolszász kultúrkörben meglehetősen hasonló mintázatot mutatnak (1. Ross, Shannon, Sailsbury-Glennon és Guarino, 2002). Niemivirta, Rijavec és Yamauchi (2001) ugyanakkor horvát, finn és japán tanulókat azonos mérőeszközzel vizsgáló kutatásában a célok kapcsolatát tekintve eltéréseket fedezett fel a korrelációkban mindhárom minta között. Lau és Lee (2008) egy angol nyelvü mérőeszköz adaptációja során ugyancsak kulturális különbségekre utaló eredményeket kapott kínai hallgatók körében, amelyet Shih (2005) saját fejlesztésű mérőeszközével tajvani általános iskolások körében végzett adatai alátámasztani látszanak, mint a kelet-ázsiai kultúrák jellemző mintázatát. 
Az eddigi rendkívül alacsony számú és nagyon különböző kérdésfeltevéssel elindított munkákból általánosítható megállapítások nehezen vonhatók le. Ebböl következően arra vonatkozóan sem fogalmazhatók meg feltételezések, hogy a magyarországitól sok tekintetben eltérő körülmények között feltárt összefüggések mennyiben helytállóak tanulóink esetében.

\section{A gyakorlati alkalmazás lehetőségei és korlátai}

A célorientációs elmélet szerint a célstruktúrák hatást gyakorolnak a tanulói célorientációra, ebből következően a megfelelő tanulási környezet kialakításával a tanulói célorientációkon keresztül befolyásolható a tanulási folyamat.

Brophy (2004) összefoglalása szerint az osztálytermi alkalmazást tekintve a célorientációs elméleten alapuló kutatások legfontosabb üzenete, hogy az elsajátítási cél ösztönzését kellene elősegítenie a pedagógusnak, illetve tágabb értelemben az iskolának. Vagyis a cél, hogy a tanulók úgy érezzék, a környezet a befektetett erőfeszítések mennyiségének növelésére, a tananyag megértésre, tudásuk önmagukhoz mért gyarapítására ösztönöz. Bár az elsajátítási céllal kombinálva a teljesítménykereső viszonyító cél követése is lehet kedvező, a kutatók gyakran ellenzik az ezt hangsúlyozó tanulási környezet létrehozását. Ellenérvként jelenik meg többek között, hogy csak addig jár kedvező következményekkel követése, míg a tanuló sikeres, sikertelenség esetén pedig feltehetően a negatív hatásokat kiváltó teljesítménykerülő viszonyító cél erősödik meg; továbbá, hogy csak bizonyos környezeti feltételek megléte mellett bizonyult elönyösnek e cél. A kutatások alapján különösen kerülendő egyrészről a túlzottan szigorú osztályozási gyakorlat, ami indokolatlanul megnehezíti a siker elérését, ezzel az osztályzatokra irányuló szorongást eredményezhet; másrészről azon értékelési gyakorlatot, amely során a szociális összehasonlítás jóval hangsúlyosabb, mint az egyéni fejlödés nyomon követése.

A célorientációs elmélet következtetéseinek gyakorlati felhasználásához, vagyis az elsajátítási célstruktúra kialakításának elősegítéséhez az egyes TARGET dimenziókhoz kapcsolódó javaslatok gyüjteményét készítik el. Az általában táblázatos formájú összefoglalóban az elsajátítási célstruktúra hangsúlyozásának irányelvei mellett ellenpólusként gyakran tüntetik fel az elsajátítási célstruktúra szempontjából kedvezőtlen osztálytermi gyakorlatot, így például Kaplan és Maehr (2007) a viszonyító célstruktúrát kialakító tanári gyakorlatot szerepelteti egymás mellett (1. melléklet), míg Brophy (2004) a „hagyományos gyakorlattal” állítja szembe a „TARGET javaslatokat” (2. melléklet).

Fontosnak tartjuk annak kiemelését, hogy a TARGET betüszó nem egy rögzített oktatási programot jelöl, hanem olyan keretként értelmezhető, amely felhasználásával a motivációval kapcsolatok megfontolások különböző oktatási szituációkra adaptálhatók (Brophy, 2004). Vagyis inkább a gyakorlati tevékenységek fejlesztéséhez, értékeléséhez használható vezérfonal lehet, mintsem a tanterv vagy tanári tevékenységek átalakítását meghatározó előírás-gyüjtemény. Emellett megjegyezzük, hogy a tanulási motivációra vonatkozó korábbi elméletek gyakorlati tanácsait figyelembe véve lényegesen új javaslatokat nem fogalmaz meg. Urdan és Turner (2005) a szociálkognitív vonulatba illeszkedő fontosabb motivációs elméletek (célorientációs elmélet, érdeklődés és önjutalmazó motiváció, énhatékonyság, elvárás-érték elmélet, öndeterminációs elmélet, attribúciós elmélet) gyakorlati tanácsait összegzi. Az áttekintésben egyetlen olyan motivációs stratégiát sem jelölnek meg, amely más elmélet keretei között ne tünne fel. 
Ugyanakkor a körképből az is látszik, hogy a célelmélet a korábbi stratégiák jelentős részét megerősítve egy koherens elméleti keretként tünik fel.

Annak ellenére, hogy számos empirikus vizsgálat, és több kedvező eredménnyel záruló beavatkozás bizonyítja a célorientációs elmélet előnyeit a tanulási motiváció és a tanulás eredményességével szoros kapcsolatban álló további változók esetében, az elmélet széles körü terjedésének számos akadályát fogalmazza meg Urdan (2004a). Ezek egy része kifejezetten a célorientációs elmélet gyakorlati következtetéseihez köthetö, míg más részük tulajdonképpen a legtöbb oktatási innováció bevezetésére igaz lehet.

Az akadályok között kerül megemlítésre a minden tanuló számára kihívást jelentő feladatok kiválasztásának vagy kidolgozásának nehézsége. Emellett felmerül annak a kérdése is, hogy hogyan egyeztethetö össze az egyéni előrehaladásra fókuszáló értékelés az osztályzással. Például minden esetben igazságosnak éreznék-e a tanulók az erőfeszítésen és az egyéni fejlődésen alapuló értékelést. A tanulók egyéni előrehaladásához igazodó oktatás során nehezen képzelhető el, hogy sikerül az előírt tartalmat mindenki számára megtanítani. További kérdés, hogy a hagyományos órarend milyen mértékü fellazítására lenne szükség, hogy a tanulók egyéni üteméhez igazodó tanulás megvalósítható legyen.

Az iskolát körülölelő környezet sok szempontból ugyancsak nem kedvez az elsajátítási célstruktúrával jellemezhető környezet kialakításának, helyette a viszonyító célstruktúrához járul hozzá. Ennek talán az iskolai életet leginkább meghatározó szegmense az egyre eröteljesebb elszámoltathatóság és ezzel párhuzamosan a standardizált tesztek alkalmazása, amely egyértelmüen a végeredményre fokuszáló tanári gyakorlatot eredményez, hiszen a pedagógus megítélése mellett akár az állás biztonságát is veszélyeztetheti. A tanulói teljesítményteszteken alapuló elszámoltathatóság az Egyesült Államok oktatási rendszerében kifejezetten szigorúnak számít a No Child Left Behind jogszabály 2002-es bevezetése óta (magyarul 1. Tóth, 2010; Zsigmond, 2005).

A pedagógusok ki vannak téve egy társadalmi nyomásnak, amelyek az iskolával kapcsolatban állók közvetítenek, így a szülök a tanulók vagy az oktatási szféra egyéb alkalmazottai, aki iskolával kapcsolatos meggyőződéseivel (pl. meritokráciában való hit) valószínűleg nehezen egyeztethető össze a célorientáció elméleten alapuló oktatás, például a külső jutalmak elhagyása vagy a nyilvános elismerés. Az sem világos, hogy az esetleges otthoni viszonyító és az iskolai elsajátítási célstruktúra együttes hatása milyen következményekkel jár.

Végezetül lényeges lehet minden innováció szempontjából, hogy az új stratégiák megtanulása, ennek megfelelően az osztálytermi gyakorlat átalakítása, illetve a tapasztalatok értékelése időigényes, ami nehezen egyeztethető össze a mindennapi tanári munkával. Ráadásul a célorientációs elmélet számos tanulással kapcsolatos korábbi nézet megváltoztatását, új szakzsargon és új fogalmak elsajátítását igényli.

\section{A célorientációkat mérő kérdőívek}

\section{Általános jellemzök}

A célokat kognitív reprezentációknak, vagyis tudatosult, könnyen hozzáférhető személyiségkomponenseknek tekintik (Kaplan és Maehr, 2007; Pintrich, 2000a), így a célokról való információgyüjtés legáltalánosabban használt eszközei a kérdőívek, amelyeken általában a Likert-skálás megoldást alkalmazzák. Megemlíthetőek azonban kivételek is, például Patrick és Ryan (2008) a Likert-skálás kérdőívtételek mellett nyílt 
végű kérdéseket alkalmazott, hogy információt gyüjtsön a tételmondatok megítélését befolyásoló tényezőkről. Van Yperen (2006) állításpárokkal váltotta ki a Likert-skálát, e megoldás mögött azonban a már túlhaladott célokat szembe állító, polarizáló nézet tapintható ki.

A rendelkezésre álló méröeszközök többsége a felnőtt korosztályt, föként a felsőoktatásban tanulókat célozza, alacsony azon kérdőívek száma, amelyek általános iskolás tanulók körében is alkalmazhatók (1. Kaplan és Maehr, 2007 áttekintését). Az oktatás területén a leggyakrabban alkalmazott mérőeszközök közé tartozik a PALS (Patterns of Adaptive Learning Scales), melyet általános iskola negyedik osztályától ajánlanak használatra készítői (Midgley és mtsai, 2000), illetve az Elliot és McGregor (2001) nevéhez köthető, és a felsőoktatásban használt AGQ (Achievement Goal Questionnaire), illetve továbbfejlesztett változata, az AGQ-R (Elliot és Murayama, 2008). Az általános iskolás korosztály kapcsán megemlíthető a GOALS-S (Goal Orientation and Learning Strategies Survey), mely egy ausztrál kutatóközösséghez kötődő, szűkebb körben használt mérőeszköz (Dowson és McInerney, 2004). Emellett egy finn kutatóközösség középiskolás korú tanulók körében gyüjt információkat célorientációkról a Niemivirta (2002b) által kifejlesztett kérdőív segítségével. Az oktatás területén kívül a célorientációkhoz kapcsolódóan elsősorban a munkavállalók (pl. Vandewalle, 1997), valamint a sportolók (pl. Conroy, Elliot és Hofer, 2003) motivációjának megismerése érdekében kifejlesztett mérőeszközökkel találkozhatunk.

\section{Gyakori problémák}

A továbbiakban azokat a fontosabb kritikákat tekintjük át, amelyek az oktatás területén alkalmazott kérdőívekkel kapcsolatban felmerülnek. Ennek célja egyrészről, hogy megindokoljuk, miért tarjuk szükségesnek a célorientációk mérésére saját fejlesztésü mérőeszköz kidolgozását, másrészről, hogy bemutassuk azokat az eredményeket, amelyekre kérdőívünk létrehozása során támaszkodunk.

\section{A 2x2-es felosztás újszerúsége}

A teljesítménykereső-teljesítménykerülő viselkedésre vonatkozó teóriának és a célorientációs elmélet összekapcsolásának hatására a dichotóm célelméletet először egy hármas megközelítés váltotta fel, mely az elsajátítási cél mellett egy teljesítménykeresőviszonyító és egy teljesítménykerülö-viszonyító célt különböztetett meg, de hamarosan megfogalmazódott a teljesítménykereső-teljesítménykerülő megkülönböztetés az elsajátítási céllal kapcsolatban is (Elliot, 1999; Pintrich, 2000a).

A szakirodalomban egyetértés mutatkozik a célok 2x2-es felosztásával kapcsolatban, ugyanakkor a jelenleg alkalmazott kérdöívek jelentős része még a hármas felosztáson alapul, vagyis az elsajátítási cél esetében a teljesítménykeresőteljesítménykerülő dimenziót nem különbözteti meg. Bár jól azonosítható a törekvés a kérdőívek továbbfejlesztésére (1. Baranik, Barron, és Finney, 2007 áttekintését), jelenleg a nemzetközi szakirodalomban alig találunk olyan mérőeszközt, mely a célok négyes felosztását követi, és nem áll rendelkezésre olyan, amely széles körben elfogadott, és alkalmas általános iskolások céljainak feltérképezésére.

\section{A célok és az egyéb, célokkal összefüggő változók elkülönítése}

A célok értelmezését illetően nincs konszenzus, mely természetesen a mérőeszközök kidolgozása területén is érezteti hatását, hiszen így hiányzik az egyetértés a célok 
operacionalizálását illetően. Míg a kutatók egy része kizárólag a célok két dimenzióját (szándék és viszonyítási kritérium) kívánja megjeleníteni a kérdőívtételekben (pl. Elliot és McGregor, 2001), mások tágabban értelmezve, számos egyéb változót is felhasználnak a mérések során. Az egyes céltípusokat eltérö motivációs rendszerek központi elemeinek tekintik, amelyek eltérő kognitív, affektív és viselkedési folyamatokat indítanak el (Elliott és Dweck, 1988). A kutatók egy része, különösen a célelmélet formálódásának korai szakaszában, számos olyan tényezőt is megjelenít a mérőeszközökön, amelyeket más szakemberek nem tekintenek a célorientációk összetevőinek, hanem azok következményeként értelmeznek. Talán a leggyakoribb példa a siker megjelenítése a célokat mérő kérdőíveken (pl. Niemivirta, 2002b; Skaalvik, 1997). Bár bizonyítható, hogy a siker értelmezése összefügg a követett célokkal, általában a sikert nem értelmezik a célok összetevőjeként. Dowson és McInerney (2004) mérőeszközén az elsajátítási cél egyik tételmondatában az érdeklödés kifejezés szerepel, ami így egy további motivációs konstruktummal köti össze a célorientációkat, ugyancsak kritikára adva okot. Kaplan és Maehr (2007) arra hívja fel a figyelmet, hogy a különböző kutatók a gondolkodásra, az érzelmekre és a viselkedésre irányuló megfogalmazások eltérő kombinációit alkalmazzák kérdőíveiken. A célok tágabban értelmezett megközelítésmódja minden bizonnyal a túlzottan általános, „neutrális” megfogalmazásokból adódó hibákat kívánja elkerülni.

Megjegyezzük, hogy a célok tartalmában konszenzust kereső, a célok operacionalizálásával foglalkozó elméleti munkák is megjelentek (pl. Elliot és Fryer, 2008), így a jövőben valószínüleg egyre ritkábban merül majd fel e kérdés. Azonban az alkalmazott kérdőívek megújítása e szempontot figyelembe véve még várat magára.

\section{Kontextushoz kötöttség}

A kutatók egy része a kontextus szerepét hangsúlyozza, vagyis úgy tekint a célorientációkra, melyek a különböző szituációkban jelentős eltérést mutathatnak adott személy esetében is (pl. Ames, 1992), míg mások az egyéni jellemzőket helyezik elötérbe, vagyis az előbbi megközelítéssel szemben a környezeti feltételektől viszonylag független, stabil személyiségjellemzőként kezelik a célorientációkat ( $\mathrm{pl}$. Dweck és Leggett, 1988). Ebből következően a kérdőívek egy része specifikus megfogalmazást alkalmaz, és meghatározott szituációkra vonatkoztatva, elsősorban adott tantárgyhoz, kurzushoz kötődően fogalmazza meg állításait (pl. Elliot és McGregor, 2001). Ezzel szemben a mérőeszközök egy másik csoportja általánosabb megfogalmazással az iskolai tanulás egészére vonatkozóan szerepeltetnek kérdöívtételeket (Niemivirta, 2002b).

E ponton érdemesnek tartjuk megemlíteni Limón (2006) eszmefuttatását, amely a specifikusság-általánosság kérdéskörét járja körül az episztemlógiai meggyőződések vizsgálatához kötődően, de az oktatáskutatás további területeire általában érvényes megállapításokat tartalmaz. Az első kérdés, amit ennek alapján feltehetünk, hogy egyáltalán lehetséges-e nem kontextushoz kötődően felmérni adott konstruktumot. Esetünkben a tantárgyhoz nem kötődő kérdések kontextusa például az iskola, ami eltérhet a munka világában tapasztalható vagy a sporthoz kapcsolódó teljesítményszituációk értelmezésétől, azaz ebben az esetben is kontextusfüggőnek tekinthető. A Limón további lényeges felvetése, hogy az általános jellemzők megismerésének egyik útja éppen az lehet, ha feltárjuk a különböző kontextusokhoz, tantárgyakhoz kapcsolódó hasonlóságokat és eltéréseket.

A 2x2-es felosztás a faktoranalízisek eredményei alapján az általános és a tantárgyakhoz, kurzusokhoz kapcsolódó állítások esetében egyaránt kirajzolódik. A kutatások elindultak ebbe az irányba is, Finney, Pieper és Barron (2004) kutatásukban a kontextushoz kötöttség eltérő szintjeit célzó kérdőív két változatát hasonlította össze, és 
arra a megállapításra jutott, hogy egyazon kérdőív esetében is megjelenik a $2 \times 2$-es felosztás a kontextushoz kötöttség eltérő szintjein. Egy másik vizsgálatban Baranik, Barron és Finney (2010) ugyanazon mérőeszköz általános és a kontextushoz kötött tételeit vetette össze, kapcsolatot keresve néhány további motivációs konstruktummal. Munkájuk lényeges eredménye, hogy a kontextus eltérő módon befolyásolja az elsajátítási és viszonyító célokat, úgy tűnik, hogy előbbiek sokkal inkább függenek a tanulási környezettöl.

A mérőeszköz kontextushoz kötöttségét az elméleti nézőpont mellett a mérés célja is befolyásolhatja. Amennyiben a célorientációk és egyéb személyiségjellemzők közötti összefüggések jelentik a kutatás tárgyát, az általános, kontextustól független (pl. tantárgyat, kurzust nem tartalmazó) állítások megfogalmazása javasolható, míg ha a tanulási környezet és a célorientációk kapcsolatát kívánjuk feltárni, célszerü kontextushoz kötődő kérdőívtételeket alkalmazni. Az osztálytermi gyakorlat motivációs hatásának feltárása esetében a kontextushoz erösen kötődő mérőeszközök használata kívánatos, hiszen az általános megközelítés elfedheti a tantárgyak, a pedagógusok és számos további tényezők eltérését.

\section{A kérdőívtételek megfogalmazásának problémái}

Elliot és Murayama (2008) az egyik leggyakrabban alkalmazott mérőeszköz (AGQ) továbbfejlesztett változatának (AGQ-R) ismertetése során részletesen elemzi a széles körben alkalmazott célorientációs kérdöívek megfogalmazásának lehetséges hibáit, melyek egy része a korábban bemutatott problémák megjelenéseként értelmezhető.

Elsőként arra hívják fel a figyelmet, hogy a cél olyan szándékra utal, amely a jövőbeni viselkedést irányítja, ez azonban gyakran nem jelenik meg a kérdöívtételekben. Így sok esetben például inkább az értékekre, mint a célokra utalnak a megfogalmazások (pl. „Fontos nekem, hogy jobban teljesitsek a többi tanulónál”). A szerzők az AGQ-R esetében ezt úgy oldották meg, hogy a kérdőívtételek mindegyike egy olyan formulával kezdődik, amely a jövőre utal (, $A z$ a célom...”, , $A z$ a szándékom”..., „Arra törekszem...”).

Gyakori probléma, hogy a szándék mögött álló okot vagy okokat is megjelenítik a kérdöíven, vagyis a szándék és az ok nem különül el, miközben utóbbi nem képezi a célorientációk részét ( $\mathrm{pl}$. „A gyenge teljesitménytöl való félelem gyakran motivál az osztályteremben").

$\mathrm{Az}$ elsajátítási és viszonyító cél mérésére irányuló megfogalmazásokban általában különböző tartalom jelenik meg, vagyis a tanuló saját teljesítményének megítéléséhez választott kritériumokra eltérő példákat alkalmaznak a mérőeszközökben. Ugyanakkor az alkalmazott kritériumokra utaló tartalmak kiválasztása gyakran nem elég körültekintő, mivel ezek sok esetben nem köthetők kizárólagosan az adott tétellel mérni kívánt célhoz. A viszonyító célra utaló kérdéseknél például általában az osztályzatokat szerepeltetik, mint a normatív kritériumot (,Az a célom, hogy jobb jegyet szerezzek, mint a tanulók többsége”). A jegyek fontosságának tanulók általi megítélése azonban nem biztos, hogy a viszonyító célra utal, hiszen az értékelés során az osztályzatok egyaránt lehetnek normaorientáltak és kritériumorientáltak.

A többszörös célelmélet alapján széles körben elfogadott, hogy adott tanuló több cél esetében is magas értéket ér el, a kérdőívek egy része mégis tartalmaz olyan mondatokat, mely egy cél választása során egy másik cél követését kizárja (pl. „,Bár nem szivesen ismerem be, néha inkább jól akarok teljesiteni az osztályban, mint sokat tanulni").

A normatív összehasonlítás a viszonyító cél esetében mind a teljesítménykereső, mind a teljesítménykerülő összetevő jellemzője, ugyanakkor a megfogalmazásokban 
gyakran eltérő ennek hangsúlyozása a két komponens esetében. Gyakran ugyanazon mérőeszköz tekintetében is tapasztalható, hogy míg az egyik összetevőre utaló tételben egyértelmüen kifejeződik a normatív viszonyítás, addig a másikban nem jelenik meg (pl. „Az a célom, hogy a gyenge teljesitményt elkerüljem az osztályteremben”).

További problémaként merül fel a viszonyító célokra utaló tételekben, hogy a megfogalmazások gyakran extrém csoportokra irányulnak, ami azzal a veszéllyel fenyeget, hogy csak az osztály legjobb vagy legrosszabb tanulói számára adekvát a megfogalmazás. Saját észlelt kompetenciájuktól függően a tanulóknak ugyanaz a kérdőívtétel eltérő viszonyítási pontokat kínálhat (pl. „jobban teljesiteni másoknál” vagy „másoknál nem rosszabbul teljesiteni”), a jelenleg alkalmazott méröeszközök pedig ezt figyelmen kívül hagyva az észlelt kompetencia tekintetében fóként a legerősebb, illetve leggyengébb tanulókra fókuszálnak.

Utolsóként az egyes skálákban szerepeltetett érzelmekkel kapcsolatos tartalmak eltérő mennyiségére hívják fel a figyelmet a szerzők (pl. „A gyenge teljesítménytől való félelem gyakran motivál az osztályteremben"). Bár az érzelmek szorosan kötődnek a célokhoz, az egyes célok melletti elköteleződés a jövőbeli lehetőségeket tekintve érzelmi állapotot is képvisel, ugyanakkor ezek nem központi összetevői a célorientációknak. Vagyis ideális esetben nem jelennek meg érzelmekre utaló megfogalmazások, de ha mégis, elvárásként fogalmazható meg, hogy a különböző célokat tekintve azonos arányban jelenjenek meg.

\section{A tanulási környezet megismerését célzó kérdőívek}

\section{Holisztikus megközelítésü kérdöívek}

A célorientációs elmélethez kapcsolódóan a tanulási környezet megismerésére elsősorban olyan kérdőíveket alkalmaznak, amelyek a pedagógusokra, az osztálytermi légkörre, esetleg az iskola légkörére (célstruktúrájára) vonatkozó általános állításokat tartalmaznak, amelyeket a továbbiakban összefoglalóan holisztikus megközelítésü eszközökként emlegetünk. Mint korábban említettük, az elsajátítási célstruktúra az elsajátítást, megértést, a korábbi teljesítmény túlszárnyalását ösztönzi az osztályteremben, míg a viszonyitó célstruktúra a képességek összevetésére és a versenyre ösztönöz. E konstruktumok létezését egyetlen körülmény igazolja, mégpedig a statisztikailag kimutatható összefüggésük a különböző célokkal. Bár a viszonyító teljesítménykereső és teljesítménykerülő dimenziók megkülönböztetése több vizsgálatban is előfordul, ennek használata nem általános a célstruktúrák feltárásában. A tanulási környezet esetében eddig viszonylag kevés figyelem irányult a teljesítménykereső és teljesítménykerülő dimenziókra, azaz tulajdonképpen kevés bizonyíték áll rendelkezésre abban a tekintetben, hogy a tanulási környezet esetében e dimenziók megjelenhetnek. E dimenziók elterjedésének további akadálya abban keresendő, hogy a mérőeszközök fejlesztése e területen ritka. Egyrészről azért, mert a célorientációs elméletet alkalmazók gyakran nem a környezettel, hanem a tanulók más jellemzőivel keresnek kapcsolatot, másrészről a tanulási környezet és a célorientációk összefüggését vizsgáló kérdőívek egy része nem holisztikusan, inkább a tanári gyakorlat egy-egy elemével összefüggésben vizsgálja a cél és környezet viszonyát (1. a következő pontban). Továbbá valószínüsíthető, hogy a környezetet illetően jóval nehezebb olyan állításokat megfogalmazni, amelyek a teljesítménykereső-teljesítménykerülő dimenziókra vonatkoznak. Utóbbit támaszthatja alá, hogy a viszonyító teljesítménykerülő skála pszichometriai mutató bizonyos esetekben nem érték el azt a 
szintet, amellyel elemzéseket lehetett volna végezni (pl. Kaplan, Gheen és Midgley, 2002; Wolters, 2004).

A leggyakrabban Midgley és munkatársai (2000) általi kifejlesztett, korábban már említett PALS-t alkalmazzák, amely utolsó változatában a tanári és az osztálytermi célstruktúrára vonatkozóan is tartalmaz állításokat (13. táblázat). Utóbbi konstruktumok használata terjedt el szélesebb körben, mivel elméletileg a tanári célstruktúrát is magában foglalja, ugyanakkor a kutatás céljától függően a pedagógusokkal kapcsolatos konstruktumot is alkalmazzák. Megkülönböztetik az osztálytermi és iskolai szintet is a célstruktúrák esetében, utóbbi szint vizsgálatára azonban kevés példát találunk (kivételként 1. Ames, 1992; Matos, Lens és Vansteenkiste, 2009). Ezekben ugyancsak a PALS-t alkalmazzák, a kérdőívtételeken az osztályunkban („In our class...”) megfogalmazást az ebben az iskolában („In this school...”) formulára cserélve. A PALS mérőeszköz egyik skálájának továbbfejlesztett változata használatos még, amely Urdan (2004b) nevéhez köthető.

Holisztikus megközelítésük miatt kizárólag e kérdőívek által gyüjtött eredményekből természetesen nem tudunk következtetni azokra a környezeti összetevőkre, tanári tevékenységekre, amelyek fontos szerepet játszanak a tanulók motivációjában, ugyanakkor a globális kérdőívek jelentik az alapját azon kvalitatív kutatások többségének, amelyek az osztálytermi folyamatok részletesebb feltárására irányulnak. Ezekben a tanulók által észlelt célstruktúrákra vonatkozó kérdőívek alapján az osztályokat különböző kategóriákba sorolják (pl. átlagosnál magasabb az elsajátítási cél és alacsonyabb a viszonyító cél észlelése), majd kvalitatív módszerek, elsősorban osztálytermi megfigyelések és interjúk segítségével kísérlik meg megragadni a tanári gyakorlatban, illetve az egyéb környezeti összetevőkben azokat a különbségeket, amelyek valószínüsíthetően az adott kategóriába tartozó osztályokra jellemzőek. Az osztálytermi megfigyelések során vizsgált szegmensek kiválasztásában e megoldás esetében is általában a TARGET dimenziókra támaszkodnak, ami nem függetlenül attól, hogy az osztálytermi megfigyelésekre kidolgozott egyetlen eszköz is a TARGET dimenziókon alapul, bár három további kategóriát is megjelenít (1. Patrick, Ryan, Anderman, Middleton, Linnenbrink, Hruda, Edelin, Kaplan és Midgley, 1997). 


\begin{tabular}{|c|c|c|c|}
\hline $\begin{array}{c}\text { Skálák (állítások száma, } \\
\text { Cronbach- } \alpha \text { ) }\end{array}$ & Forrás & Évf. & Megjegyzés \\
\hline $\begin{array}{l}\text { Osztálytermi célstruktúrák } \\
\text { (1) osztálytermi elsajátítási } \\
(6 ; 0,67-0,79) \\
\text { (2) osztálytermi viszonyító } \\
(5 ; 0,67-0,82)\end{array}$ & $\begin{array}{c}\text { Midgley és } \\
\text { mtsai } \\
\text { (1996) idézi } \\
\text { Anderman } \\
\text { és Midgley } \\
\text { (1997) }\end{array}$ & $5 ., 6$. & $\begin{array}{l}\text { Az osztályterem általános } \\
\text { légkörére fókuszál. }\end{array}$ \\
\hline $\begin{array}{l}\text { Osztálytermi célstruktúrák } \\
\text { (1) osztálytermi elsajátítási } \\
(5 ; 0,85) \\
\text { (2) osztálytermi viszonyító } \\
\text { teljesítménykereső (5; } \\
0,89) \\
\text { (3) osztálytermi viszonyító } \\
\text { teljesítménykerülő (4; } \\
0,74)\end{array}$ & $\begin{array}{c}\text { Midgley és } \\
\text { mtsai } \\
(2000)\end{array}$ & 7. & $\begin{array}{l}\text { Az osztályterem általános } \\
\text { légkörére fókuszál. A } \\
\text { továbbfejlesztése oka a } \\
\text { teljesítménykereső- } \\
\text { teljesítménykerülő dimenzió } \\
\text { megjelenítése, a } \\
\text { pedagógusokra és további } \\
\text { motivációs konstruktumokra } \\
\text { utaló állítások átfogalmazása. }\end{array}$ \\
\hline $\begin{array}{l}\text { Tanári célstruktúrák } \\
\text { (1) tanári elsajátítási }(5 ; 0,83) \\
\text { (2) tanári viszonyító } \\
\text { teljesítménykereső }(3 ; \\
0,79) \\
\text { (3) tanári viszonyító } \\
\text { teljesítménykerülő (4; } \\
0,71)\end{array}$ & $\begin{array}{c}\text { Midgley és } \\
\text { mtsai } \\
(2000)\end{array}$ & 9. & $\begin{array}{l}\text { A tanári gyakorlat általános } \\
\text { jellemzőire fókuszál. }\end{array}$ \\
\hline $\begin{array}{l}\text { Osztálytermi célstruktúrák } \\
\text { (1) osztálytermi viszonyító } \\
\text { célstruktúra ( } 7 ; 0,87 \text { és } \\
0,89)\end{array}$ & $\begin{array}{l}\text { Urdan } \\
(2004 b)\end{array}$ & $\begin{array}{l}9- \\
11 . \\
10- \\
12 .\end{array}$ & $\begin{array}{l}\text { Az osztályterem általános } \\
\text { légkörére fókuszál, amely } \\
\text { alakításában a tanulók } \\
\text { szerepét helyezi előtérbe. }\end{array}$ \\
\hline
\end{tabular}

\section{Analitikus megközelítésü kérdöivek}

A tanulási környezet és a célorientációk közötti kapcsolatot tanulói kérdöíveken keresztül feltáró munkák további megoldását az analitikusnak nevezhető megközelítés jelenti. E kutatásokban a tanulási környezet társas jellemzőire, illetve a tanári tevékenységekre vonatkozó kérdőívtételeket alkalmaznak. Ezek ugyancsak a TARGET dimenziót veszik alapul, ugyanakkor további változókkal is kísérleteznek (14. táblázat).

Bár e kérdőívekkel is feltártak kapcsolatot a tanulói célok és a tanulási környezet között összetevői között, viszonylag ritkán alkalmazzák az analitikus megközelítésü kérdőíveket. Ennek oka minden bizonnyal az, hogy az összefüggésekből nehezen következtethetünk ok-okozati összefüggésre, így az eredmények félrevezethetök lehetnek. A kontextus megismerésére mindenképpen további, elsősorban kvalitatív megközelítésü kutatások szükségesek. 
14. táblázat. A tanulási környezet összetevőinek megismerése érdekében alkalmazott kérdöivek a célelmélettel összefüggésben

\begin{tabular}{|c|c|c|c|}
\hline $\begin{array}{c}\text { Skálák (állítások száma, } \\
\text { Cronbach-a) }\end{array}$ & Forrás & $\dot{E} \boldsymbol{v} f$ & Megjegyzés \\
\hline $\begin{array}{l}\text { Osztálytermi környezet } \\
\text { (1) érdekesség }(4 ; 0,91) \\
\text { (2) értékelés szigora }(4 ; 0,65) \\
\text { (3) értékelés hangsúlya }(3 ; 0,74)\end{array}$ & $\begin{array}{l}\text { Church, } \\
\text { Elliot és } \\
\text { Gable } \\
(2001)\end{array}$ & $\begin{array}{l}\text { Felső- } \\
\text { oktatás }\end{array}$ & $\begin{array}{l}\text { A TARGET értékelés } \\
\text { dimenziójához kötődően } \\
\text { készült a 2. és 3. skála. }\end{array}$ \\
\hline $\begin{array}{l}\text { Osztályterem észlelése } \\
\text { (1) tanulás hangsúlyozása }(8 ; \\
0,80) \\
\text { (2) képesség és értékelés } \\
\text { hangsúlyozása }(5 ; 0,73) \\
\text { (3) autonómia és választás } \\
\text { hangsúlyozása }(6 ; 0,60) \\
\text { (4) egyéni munka hangsúlyozása } \\
\text { (5;0,51) } \\
\text { (5) feladatok változatosságának } \\
\text { hangsúlyozása }(4 ; 0,66)\end{array}$ & $\begin{array}{l}\text { Tapola és } \\
\text { Niemivirta } \\
\quad(2008)\end{array}$ & 6. & $\begin{array}{l}\text { A TARGET dimenziókat } \\
\text { felhasználva készült, bár } \\
\text { más elvet alkalmaz a } \\
\text { kérdőívtételek } \\
\text { csoportosításában. }\end{array}$ \\
\hline $\begin{array}{l}\text { Osztálytermi társas környezet } \\
\text { (1) tanári támogatás }(4 ; 0,82) \\
\text { (2) kölcsönös tisztelet } \\
\text { támogatása }(5 ; 0,82) \\
\text { (3) tanulók közötti interakció } \\
\text { támogatása }(6 ; 0,90)\end{array}$ & $\begin{array}{l}\text { Ryan és } \\
\text { Patrick } \\
(2001)\end{array}$ & $7 ., 8$. & $\begin{array}{l}\text { Nem a TARGET } \\
\text { dimenziókra épül, a társas } \\
\text { környezet korábban nem } \\
\text { vizsgált elemeire kívánja } \\
\text { felhívni a figyelmet. }\end{array}$ \\
\hline $\begin{array}{l}\text { Tanulóközpontú tanítási } \\
\text { gyakorlat } \\
\text { (1) pozitív tanár-diák viszonyra } \\
\text { törekvés }(7 ; 0,92) \\
\text { (2) tanulói vélemények } \\
\text { tiszteletben tartása }(7 ; 0,84) \\
\text { (3) tudásszervezés támogatása } \\
(6 ; 0,86) \\
\text { (4) egyéni különbségekhez } \\
\text { igazodás }(5 ; 0,69)\end{array}$ & $\begin{array}{l}\text { Meece, } \\
\text { Herman és } \\
\text { McCombs } \\
\text { (2003) }\end{array}$ & $5-12$. & $\begin{array}{l}\text { A pedagógusok tanítási } \\
\text { gyakorlatának } \\
\text { vizsgálatára kifejlesztett } \\
\text { kérdőív nem kezel } \\
\text { kiemelten egyetlen } \\
\text { motivációs elméletet sem. }\end{array}$ \\
\hline
\end{tabular}

\section{A kérdőíves adatgyưjités korlátai és a továbblépés irányai}

A célorientációs elmélethez kötődően általában olyan önbeszámolón alapuló tanulói kérdőíveket alkalmaznak, amelyek az attitüdskálák közé sorolhatók. E méröeszközök általános korlátai jól ismertek (pl. Fishbein, 2002; Paulhus, 1991; Szokolszky, 2004), ezek részletes kifejtését nem tekintjük feladatunknak. Mindössze megemlítjük, hogy a tanulók szubjektív értékelése saját motivációjukról nyilvánvalóan „torzított” képet ad, miközben arra is felhívjuk a figyelmet, hogy a különbözö információforrások közül a tanulási motiváció és a tanulási környezet összefüggésének feltárásában ez tekinthető a leggyümölcsözőbbnek (1. „A kontextuális nézöpont a tanulási motiváció kutatásában” címü pontban). A célelmélet keretei között végzett kérdőíves vizsgálatokhoz kapcsolódó kritikák és megoldási lehetőségek áttekintését eredményeink értékelése, értelmezése, majd a további kutatási irányok kijelölése szempontjából lényegesnek 
tartjuk, így a következőkben áttekintjük a kérdőíves adatfelvétellel kapcsolatos bírálatokat, valamint a továbbfejlesztés lehetőségeit.

Az első probléma, amit meg kell említenünk a kérdőíves adatgyüjtés kapcsán, az annak megkérdőjelezhetősége, hogy a kutatók „logikája” szerint megfogalmazott állítások ugyanazzal a jelentéssel bírnak a tanulók számára (Dowson és McInerney, 2003). További probléma, hogy a különböző, például más szocioökonómiai vagy kulturális háttérrel, esetleg tanulási úttal rendelkező tanulói csoportok számara sem biztos, hogy azonos jelentést hordoznak a kérdések, állítások (Kaplan és Maehr, 2007). Ezen a gondolatmeneten tovább haladva pedig eljuthatunk addig, hogy feltegyük a kérdést: vajon milyen tapasztalatokra, eseményekre támaszkodnak a tanulók, amikor választ adnak a feltett kérdésekre (Maehr és Meyer, 1997). Korábban - A kontextuális nézöpont hatása az osztálytermi gyakorlatra címü pontban - említettük, hogy a környezetről kérdőívekkel gyüjtött adatok a tanulók szubjektumán átszürve a tanulók sajátosságaitól függően jelentős eltéréseket mutathatnak, ami nyilvánvalóan az eredmények értelmezésére, gyakorlati felhasználására is hatással van.

A méröeszközök fejlesztésének hangsúlyos irányát jelentik a kérdőívek validitásának ellenőrzése, továbbfejlesztése érdekében szervezett kvalitatív vizsgálatok. Például Dowson és McInerney (2003) célokat mérő kérdőívük fejlesztése érdekében tanulói interjúkra és osztálytermi megfigyelésekre egyaránt támaszkodik, az elsajátítási, a viszonyító és a tanulást kerülő cél kapcsán. A PALS elsajátítási célstruktúrát mérő skálájának esetében hasonló megoldással találkozhatunk Koskey, Karabenick, Woolley, Bonney és Dever (2010), akik kognitív interjús technikával vállalkoztak a skála müködésének ellenőrzésére, továbbfejlesztésére. A kvalitatív módszerek alkalmazását emellett azért sürgetik, mert segítségükkel jobban megismerhetők a célok különböző kontextushoz kötődő megnyilvánulásai, a jelentéskonstruálás folyamata (pl. videóval támogatott felidézés alkalmazásával), valamint lehetőséget kínálhatnak a kérdőíveken alapuló eredmények ellentmondásainak tisztázására (Kaplan és Maehr, 2007; Turner és Patrick, 2008).

A célokat mérő eszközök alapjául szolgáló elméleti konstrukciók nem egyeznek, így a különböző kérdöívek segítségével gyüjtött információk összevethetőségének kérdése a kezdetektől foglalkoztatja a célelmélettel foglalkozókat. Ennek ellenére viszonylag kevés kutatás vállalkozik a célorientációk megismerését célzó eszközök különbségeinek szisztematikus feltárására (pl. Jagacinski és Duda, 2001; Hulleman, Schrager, Bodman és Harackiewicz, 2010). E vizsgálatok a méröeszközök továbbfejlesztéséhez jelentősen hozzájárulhatnak, amit Elliot és Murayama (2008) - A kérdöivtételek megfogalmazásának problémái címü pontban kivonatolt - fogalmazási problémákat érintő összegzése kiválóan példáz.

A célokat vizsgáló eszközökkel kapcsolatban egyre gyakrabban találkozhatunk modern tesztelméletre épülő elemzésekkel is, amelyek elsősorban a mérőeszközök tulajdonságait vizsgálják a klasszikus tesztelmélet kínálta lehetőségekhez képest néhány új szempont szerint (pl. Adesope, Gress és Nesbit, 2008; Hafsteinsson, Donovan és Breland, 2007; Martin, Marsh, Debhus és Malmberg, 2007; Muis, Winne és Edwards, 2009). A modern tesztelmélet többek között abban kínál elörelépést, hogy alkalmazásával a Likert-skálák esetében megvizsgálható, hogy az egyes állításokhoz tartozó skálafokok mennyiben fedik le a tanulók motivációs szintje alapján meghatározható intervallumot. 


\section{Összegzés}

A célorientációs elmélet a tanulási motiváció kutatásának egy intenzíven fejlődő területét képviseli, melyben a tanulók motivációs jellemzőire utaló konstruktumok, a célorientációk, a korábbiaknál talán érzékenyebbek a tanulási környezet sajátosságaira, emellett jóval nagyobb hangsúllyal jelenik meg az elemzésekben a tanulók és környezetük kapcsolatának vizsgálata. Ebböl következően e megközelítés alkalmas lehet a motívumfejlesztésre irányuló beavatkozások empirikus megalapozására. Bár a célorientációk pedagógiai jelentősége a célok és egyéb tanuláshoz kötődő változók, személyiségjellemzők összefüggésének tükrében nem kétséges, az elmélet keretei között több alapvető jelentőségű kérdés megválaszolása várat még magára. Ezek közül kiemelkedik a célorientációk stabilitása, az elsajátítási cél és a tanulói teljesítmények összefüggésével kapcsolatos inkonzisztens eredmények magyarázata, illetve a célorientációk manipulálási lehetőségei.

Az osztálytermi gyakorlatot leginkább az utóbbi kérdésre adott válaszok befolyásolhatják. Konszenzus mutatkozik abban, hogy mind iskolai, mind osztálytermi szinten az elsajátítási célstruktúra kialakítása jár a legkedvezőbb következményekkel, ugyanakkor a gyakorlati megvalósítás lépései még korántsem kidolgozottak. Az elsajátítási célt hangsúlyozó környezet kialakításának valószínüleg számos módja létezik, a kérdés, hogy melyek ezek közül a legegyszerübben kivitelezhető megoldások. A kérdés megválaszolásának nehézségét föként az jelenti, hogy a motiváló tanulási környezet kialakításához a tanulók szubjektív észlelését kell figyelembe vennünk, azonban a helyzetek, körülmények tanulók általi megítélése, értelmezése között jelentős különbségek adódnak. Így a motívumfejlesztés érdekében kidolgozott stratégiák esetében vizsgálatra szorul az is, hogy ezek milyen tanulói, környezeti jellemzők mellett hatékonyak.

$\mathrm{Az}$ intervenciós kísérletek mérsékelt eredményei alapján, úgy tünik, túlzottan optimista az a várakozás, mely szerint a megfelelö tanulási környezet létrehozása önmagában elegendő lehet a tanulók többségénél a célorientációk jelentős manipulálásához. Figyelembe véve a tanulók egyéni interpretációjából adódó különbségeket és a többszörös célelméletet, várhatóan egyre nagyobb hangsúlyt kap a jövőben a motivációs szempontból problémás tanulók azonosítása, illetve a különböző motivációs mintázattal jellemezhető tanulói csoportok párhuzamos vizsgálata, ami azzal a reménnyel kecsegtet, hogy a különböző motivációs profilokhoz jobban illeszkedő beavatkozások talán hatékonyabbak lehetnek. 


\section{AZ EMPIRIKUS VIZSGÁLATOK KONCEPCIÓJA}

\section{Célok}

\section{Méröeszköz-fejlesztés}

Egy olyan mérőeszköz-család létrehozása a célunk, amellyel a célorientációs elmélet alapján a tanulók motivációs jellemzőiről, valamint a tanulási környezet motivációs sajátosságairól egyaránt információk szerezhetők, és amely alkalmas a tanuló és a környezete közötti összefüggések kvantitatív megközelítésü feltárására, illetve a jövőben orientálhatja a kvalitatív kutatásokat e területen.

\section{Tanulói célok kérdőív}

A célorientációs megközelítés nem tartozik a hangsúlyos kutatási irányok közé hazánkban, így a területhez kapcsolódó mérőeszközökkel sem rendelkezünk. Bár több angol nyelvü kérdőívet is találhatunk a célorientációk mérésére a nemzetközi szakirodalomban (pl. Dowson és McInerney, 2004; Midgley és mtsai, 2000), részben az elméleti koncepcióval kapcsolatos konszenzus hiányából, részben a terület gyors fejlődéséből következően jelenleg nem találhatunk olyan eszközt, amely az utóbbi évek kutatásai alapján támasztott követelményeket figyelembe véve alkalmas lenne általános iskolás tanulók céljainak feltérképezésére. Mivel nem létezik az említett korosztály számára adaptálható kérdőív, saját mérőeszköz kidolgozása mellett döntöttünk, amelyet a továbbiakban Tanulói célok kérdöív elnevezéssel említünk.

\section{Osztálytermi környezet kérdőív}

A célstruktúrák mérése napjainkig szinte kizárólagosan a PALS mérőeszközhöz (Midgley és mtsai, 2000) köthető. E mérőeszköz utolsó változatában a viszonyító célstruktúrára vonatkozóan egy teljesítménykereső és egy teljesítménykerülő dimenzió egyaránt szerepel. A jelenleg elérhető eredmények, felmerült kritikák fényében azonban kétséges e dimenziók létezése (pl. Kaplan és Maehr, 2007). Emellett az eltérő pedagógiai gyakorlat okán a széles körben elfogadott elsajátítási célstruktúrára vonatkozó skála adaptálásának sikere is bizonytalan. Az elöbbiekből következően a célstruktúrák esetében ugyancsak saját kérdőív fejlesztése látszik célszerünek.

A célstruktúrák mellett az osztálytermi környezet alig néhány összetevőjét vizsgálták eddig kérdőívek segítségével a célorientációs elmélet keretei között, miközben ezek azonosítása kulcsfontosságú lehet a motívumfejlesztés szempontjából. E területen a külföldi kérdőíves vizsgálatok eredményeinek figyelembe vétele mellett, de elsődlegesen a hazai körülményeket és osztálytermi gyakorlatot szem előtt tartó mérőeszközök kidolgozása javasolható.

A korábbi kvantitatív (pl. Church, Elliot és Gable, 2001; Meece, Herman és McCombs, 2003) és kvalitatív kutatások (pl. Anderman és mtsai, 2002; Patrick és mtsai, 2001) egyaránt a tanári tevékenységek néhány elemére és a társas közeg, társas kapcsolatok sajátosságaira hívták fel a figyelmet, így mérőeszközünket a hazai körülményekhez igazítva az osztálytermi környezet említett összetevőire, valamint a célstruktúrákra kíséreljük meg kifejleszteni. Az Osztálytermi környezet kérdöív elnevezésű mérőeszközt tehát a célstruktúrák, a tanári tevékenységek és a társas közeg néhány jellemző vonásának megismerése érekében kívántuk kifejleszteni. 


\section{Összefüggések feltárása}

\section{A célorientációk összefüggése}

Az egyes célorientációk közötti kapcsolatok hasonló mintázatát számos alkalommal megerősítették az Egyesült Államokban végzett vizsgálatok (1. Ross, Shannon, Sailsbury-Glennon és Guarino, 2002), ugyanakkor egyes ázsiai és európai országok tanulói, hallgatói körében ettől eltérő összefüggéseket tártak fel (pl. Lau és Lee, 2008; Niemivirta, Rijavec és Yamauchi, 2001). Ezek az eredmények a célok és a tanulást befolyásoló egyéb motivációs és kognitív változók közötti kapcsolatok univerzalitását kérdőjelezik meg. E kapcsolatok megismerése tanulóink esetében mindenekelőtt az Egyesült Államokban feltárt összefüggések hazai kontextusra való adaptálhatósága tekintetében bővíthetik ismereteink.

\section{A célstruktúrák összefüggése}

A célstruktúrákat a korábbi vizsgálatokban elsősorban arra használták fel, hogy eredményeik alapján kvalitatív módszerekkel derítsék fel, mi jellemzi a különböző célokat hangsúlyozó tanulási környezeteket (pl. Anderman és mtsai, 2002; Patrick és mtsai, 2001). A szakirodalom alapján azt mondhatjuk, hogy kapcsolatuk a kontextustól függőnek tekinthető, összefüggésük széles határok között mozog (vö. Anderman és Midgley, 1997; Wolters, 2004). A célstruktúrák viszonyának vizsgálata kapcsán arról szerezhetünk információkat, hogy milyenek, valamint hogy mennyiben hasonlóak vagy különbözőek motivációs szempontból a kutatásunkban szereplő osztályok.

\section{A célorientációk és az osztályzatok összefüggése}

Tudvalevő, hogy a tudásszintmérő tesztekhez viszonyítva az osztályzatok kevésbé nyújtanak pontos képet a tanulók tudásáról (Csapó, 2002b; Sáska, 1991). Ugyanakkor mint korábban rámutattunk - az osztályzatok erős összefüggést mutatnak a tanulók tantárgyi tudásával, képességeivel, és a tanulási motivációval összefonódva kölcsönösen alakítják egymást. A tanulók jegyei az iskolai sikeresség központi jelentőségü mutatói, emellett a teljesítmények egyik legegyszerübben összegyüjthető információforrását jelentik. A célorientációk és az osztályzatok kapcsolatának vizsgálata alapján bizonyos következtetések fogalmazhatók meg a különböző célorientációk teljesítményre gyakorolt hatásáról, amelyek az eddigi vizsgálatok által feltárt összefüggések hazai kontextusra való átültetését tekintve ugyancsak lényegesek lehetnek.

\section{A célorientációk és a célstruktúrák összefüggése}

Széles körben elfogadott, számos empirikus kutatás által alátámasztott, hogy a tanulók célorientációi és az osztálytermi célstruktúrák összefüggenek egymással, minden bizonnyal kölcsönösen formálják egymást (pl. Anderman és Midgley, 1997; Linnenbrink, 2005). A célorientációk és a célstruktúrák közötti kapcsolatok feltárása mindenekelőtt a mérőeszközök müködéséről kínál tájékoztatást. Összefüggésükkel megerősíthetik, hogy mind a célorientációk, mind a célstruktúrák megismerésére érdekében kifejlesztett kérdőívek az általunk megcélzott konstruktumokat mérik, és alkalmasak arra, hogy a tanulók motivációs jellemzőinek és a tanulási környezet lényeges sajátosságainak interakciójáról következtetéseket fogalmazzunk meg. Kapcsolataik feltárása ezen túl az osztálytermi környezet általános jellemzőinek azonosításához járulhat hozzá, amely a további elemzéseket orientálhatja jelen kutatás keretei között. 


\section{A célorientációk összefüggése a tanári tevékenységekkel, társas környezettel}

A tanulási motiváció különböző konstruktumainak esetében számos kérdőíves vizsgálat jelzett összefüggést a tanulási motívumok és a tanulási környezet között (pl. OECD, 2004b; Willms, 2003). A célorientációs elmélet keretei között ugyancsak megerősítette több kvalitatív kutatás (pl. Anderman és mtsai, 2002; Patrick és mtsai, 2001) és néhány kérdőíves vizsgálat (pl. Church, Elliot és Gable, 2001; Meece, Herman és McCombs, 2003), hogy a tanulók személyes céljai és a tanulási környezet bizonyos összetevői kapcsolatban állnak. A kvalitatív módszerekkel gyüjtött eredményeket nagyobb mintán nem ellenőrizték, de emellett a tanulási környezet számos további összetevőjének célorientációkkal való összefüggése is feltételezhető. Az összetevők azonosítása iránymutatást kínálhat a későbbi kutatások fókuszálásához, majd a motívumfejlesztés gyakorlati megvalósításához.

\section{A célstruktúrák összefüggése a tanári tevékenységekkel, társas környezettel}

A célorientációk és a célstruktúrák között kapcsolatot kereső jelenlegi, akár holisztikus, akár analitikus megközelítést választó kérdőíveken keresztül nehezen léphetünk tovább a motívumfejlesztés irányba. Egyrészröl mert a kurrens kutatások alapján úgy tünik, hogy a célorientációk viszonylag stabil személyiségjellemzők, a várakozásokhoz képest nehezebben manipulálhatók (pl. Linnenbrink, 2005; Miller és Meece, 1997), másrészről világossá vált, hogy a célstruktúrák nem csak a célorientációkon keresztül fejhetik ki hatásukat a teljesítményre (Murayama és Elliot, 2009). A továbblépés egy lehetséges iránya, ha a célorientációk helyett a célstruktúrák megismerésére, a célstruktúrákat befolyásoló környezeti elemekre helyezzük át a hangsúlyt a célorientációkról.

Az osztályokat holisztikus megközelítéssel a célstruktúrák szerint kategorizáló, majd az osztálytermi gyakorlat különbségeit kvalitatív módszereken keresztül feltáró megoldások tulajdonképpen a felvázolt logikára, azaz a célstruktúrák és a tanulási környezet jellemzői közötti kapcsolatok feltárására épülnek. Ugyanakkor következtetéseik általánosíthatósága - többek között a minta alacsony elemszáma miatt - problematikus. Az analitikus megközelítésü tanulói kérdőívek segítségével bár közvetlen kapcsolatot teremtenek a tanulók célorientációi és a tanulási környezet között, e megoldással a célstruktúrákról nem szerzünk információkat, amelyek vélhetően érzékenyebbek a tanulási környezet változására, manipulálására.

Előrelépést jelenthet a holisztikus és analitikus kérdőívek kombinálása, amelynek segítségével feltételezhetően eljuthatunk a tanulási környezet olyan elemeihez, amelyek statisztikailag igazolható módon fontos szerepet játszanak a tanulási motivációban. A kvalitatív módszerek természetesen így sem mellőzhetőek, ugyanakkor e megoldás segítségével megvizsgálható, hogy a kvalitatív módon feltárt tanári gyakorlat elemei általánosíthatók-e, vagy az, hogy milyen jelentőséget képviselnek egymáshoz képest ezek az elemek. A motiváló tanári tevékenységek összetevőiről kérdőívek segítségével gyüjtött adatok emellett orientálhatják a kvalitatív módszerekkel dolgozó kutatásokat is. Vagyis a kvantitatív és kvalitatív adatgyüjtési ciklusok váltakozása előrelendítheti a tanulási környezet motivációs szempontú feltárását, melyben a holisztikus és analitikus megközelítésű kérdőívek kombinációjának kulcsszerepe lehet. 


\section{Kérdések}

Kutatási kérdéseink a következők:

- Létrehozható-e olyan magyar nyelvü mérőeszköz-család, amely alkalmas a célorientációk és az osztálytermi környezet kapcsolatának feltérképezésére felső tagozatos tanulók körében?

- Milyen összefüggések tárhatók fel a célorientációk között?

- Milyen összefüggések tárhatók fel a célstruktúrák között?

- Milyen összefüggések tárhatók fel a tanári tevékenységek és a társas közeg jellemzői között?

- Milyen összefüggések tárhatók fel a célorientációk és az osztályzatok között?

- Milyen összefüggések tárhatók fel a célorientációk és a célstruktúrák között?

- Mi jellemzi a célorientációk összefüggését a tanári tevékenységekkel és a társas közeg jellemzőivel?

- Mi jellemzi a célstruktúrák összefüggését a tanári tevékenységekkel és a társas közeg jellemzőivel?

\section{Hipotézisek}

Hipotéziseinket az alábbiakban foglaljuk össze:

- Létrehozható olyan magyar nyelvü méröeszköz-rendszer, amely alkalmas a célorientációk, a célstruktúrák, valamint a tanári tevékenységek és a társas környezet összefüggéseinek megismerésére felső tagozatos tanulók körében.

- A célstruktúrák összefüggése a tanári tevékenységekkel és a társas környezettel kérdőívek segítségével vizsgálható.

- A célstruktúrák közvetítő szerepet töltenek be a célorientációk, valamint a tanári tevékenységek és a társas környezet jellemzői között.

- Az elsajátítási célok és a viszonyító teljesítménykereső cél között közel azonos erösségü összefüggések adódnak.

- Az elsajátítási teljesítménykereső cél és a viszonyító teljesítménykerülő cél közötti összefüggés nem számottevő.

- A tanulást kerülő cél összefüggése a további célokkal nem számottevő.

- Az elsajátítási célok összefüggést mutatnak az elsajátítási célstruktúrával.

- A viszonyító célok összefüggést mutatnak a viszonyító célstruktúrával.

- A célorientációk összefüggése a tanári tevékenységekkel és a társas közeg jellemzőivel nem számottevő.

- A célstruktúrák összefüggése a tanári tevékenységekkel és a társas közeg jellemzőivel jelentőségteljes.

- A társas környezet pozitív jellemzői összefüggést mutatnak az elsajátítási célstruktúrával.

- A TARGET javaslatoknak megfelelö tanári tevékenységek összefüggést mutatnak az elsajátítási célstruktúrával.

A tanulást kerülő cél osztályzatokkal és célstruktúrákkal való összefüggésére nem tudunk hipotéziseket megfogalmazni e cél ritka alkalmazása miatt. A 9. ábra szemlélteti azokat a konstruktumokat, amelyek megismerésére alkalmas mérőeszköz-család létrehozását tüztük ki célul, jelölve, hogy az egyes konstruktumok melyik kérdőíven kaptak helyet. Az ábrán feltüntettük az egyes konstruktumok várakozásainknak megfelelö kapcsolatait is, amely összefüggéseik feltárását illető hipotéziseink áttekintését hívatott megkönnyíteni. 
Osztálytermi környezet kérdöív

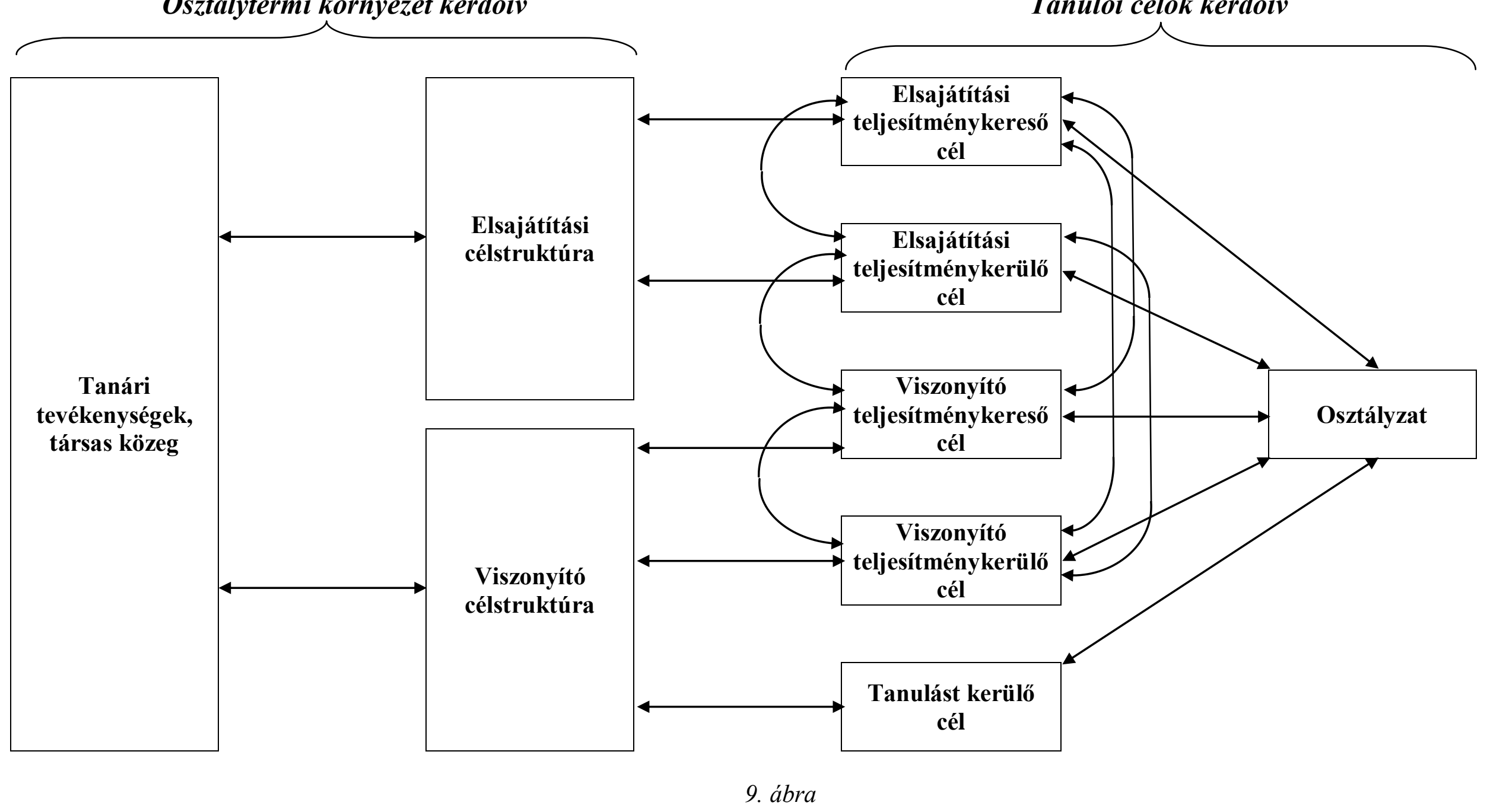

A vizsgálatsorozat keretében felmért konstruktumok és fontosabb feltételezett összefüggéseik 


\section{A vizsgálatsorozat menete}

A vizsgálatokra 2009 tavaszán, 2011 tavaszán és 2011 őszén került sor. Az első alkalommal a Tanulói célok kérdöív és az Osztálytermi környezet kérdöív felvétele egyaránt megtörtént, mindkettő egy-egy tanóra felhasználását igényelte. Egy tanórás mérés keretében a második alkalommal kizárólag a Tanulói célok kérdöiv továbbfejlesztésére fókuszáltunk, mivel e kérdőív esetében világossá vált, hogy jelentős átdolgozásra van szükség. A harmadik alkalommal a mérőeszközök további fejlesztése ugyancsak céljaink között szerepelt, de e mérés egyúttal az összefüggések vizsgálatához szükséges végső adatfelvételt is jelentette. Így mind a Tanulói célok kérdőivet és mind az Osztálytermi környezet kérdöívet kitöltettük egy-egy tanórán. A 10. ábrán foglaltuk össze a vizsgálatsorozat menetét, fontosabb részleteit.

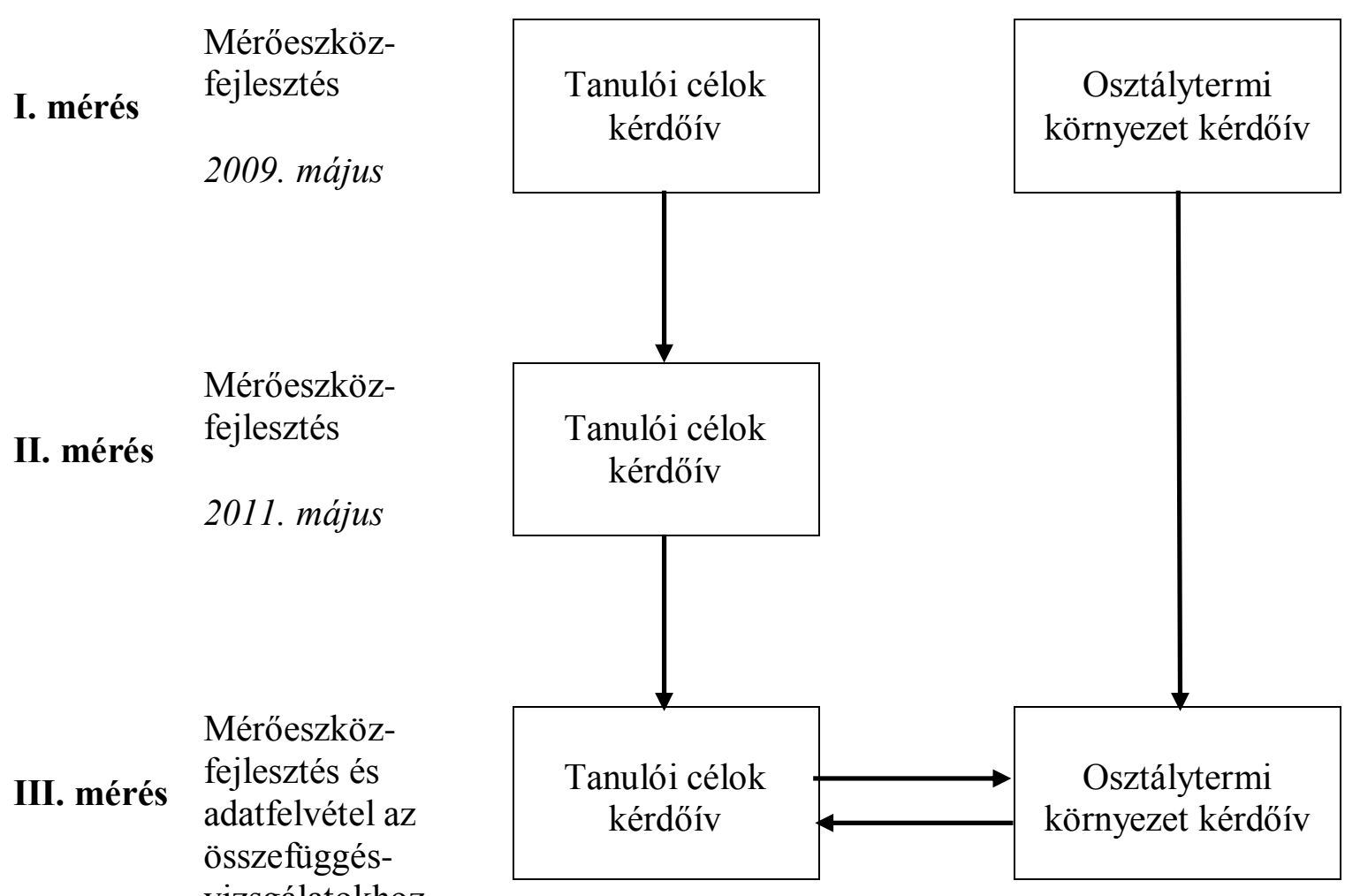

vizsgálatokhoz

2011. november

10. ábra

A vizsgálatsorozat menete

\section{A minták összeállításának szempontjai}

A vizsgálatsorozat mintájának kiválasztását az életkort tekintve két tényező befolyásolta: (1) korábban mely életkortól sikerült kérdőívek segítségével információt gyüjteni a tanulók személyes céljairól; (2) tanulóink motivációs jellemzőit figyelembe véve, mely életkor igényel kitüntetett figyelmet hazánkban. A nemzetközi szakirodalom szerint a legkorábban 4. osztályos tanulók körében alkalmaztak sikerrel célorientációk 
mérésére kérdőívet, míg a magyar tanulók motivációs sajátosságait tekintve a felső tagozat jelentősége kiemelkedő az ötödik osztálytól kezdődő jelentős mértékü csökkenés miatt.

Az első mérés során központi kérdés volt, hogy a személyes célok megismerése érdekében fejlesztett eszköz müködésének mi az alsó életkori határa. Ezt 4 és 7. évfolyam között becsültünk, ami alapján történt a minta összeállítása is. Az első mérés eredményeire támaszkodva a mérőeszköz továbbfejlesztett változatának alkalmazhatóságáról az életkort tekintve már pontosabb feltételezéseket fogalmazhattunk meg. A kipróbálásba ezért csak 4. és 5. osztályos diákokat vontunk be, ugyanis e két évfolyam között jeleztek jelentősebb különbséget adataink a kérdőív müködésében. A második adatfelvételt követően azonban egyértelmüvé vált, hogy a kérdőív végső változata 4. évfolyamon nem használható, így 5-8. évfolyamon került sor a végső adatfelvételre. Az egyes mérések mintájának fontosabb jellemzői a 15. táblázatban láthatók. A táblázatban az első és harmadik mérés esetében azon tanulók létszámát tüntettük fel, akik a két kérdőív közül bármelyiket vagy mindkettőt kitöltötték. A minták további részleteire az adott mérőeszközökkel gyüjtött adatokról elemzéseket közlő szövegrészek elött térünk ki.

\section{5. táblázat. A vizsgálatsorozat mintáinak évfolyamok szerinti megoszlása}

\begin{tabular}{lcccccc}
\hline \multirow{2}{*}{ Mérés } & \multicolumn{7}{c}{ Évfolyamok } & \multirow{2}{*}{ Összesen } \\
\cline { 2 - 6 } & $\mathbf{4 .}$ & $\mathbf{5 .}$ & $\boldsymbol{6 .}$ & $\mathbf{7 .}$ & $\mathbf{8 .}$ & \\
\hline I. & 207 & 193 & 133 & 96 & - & 629 \\
II. & 187 & 126 & - & - & - & 313 \\
III. & - & 209 & 226 & 257 & 256 & 898 \\
\hline
\end{tabular}

Megj.: a II. mérésben csak a Tanulói célok kérdőív felvételére került sor.

Adatfelvételeink során nem lehetett cél semmilyen szempontból a reprezentativitás, hiszen a tanulási motiváció általunk vizsgált konstruktumainak kontextusfüggő jellegét tekintve a reprezentativitás alapegységei esetünkben nem az egyes tanulók, hanem az egyes osztályok lennének. Ha a finanszírozási problémáktól eltekintünk, akkor sem tudnánk választ adni arra a kérdésre, hogy a reprezentativitáshoz milyen szempontot válasszunk. Az előzőekből következően a minta nagysága tekintetében mindössze azt tüztük ki célul, hogy a mérőeszközök müködésének vizsgálatához, illetve az egyes tényezők közötti kapcsolatok feltárásához évfolyamonként elegendő tanuló töltse ki a kérdőíveket. A végső adatfelvétel során a minta nagyságát túlterveztük, hiszen itt figyelembe kellett vennünk azt is, hogy megfelelő létszámban töltsék ki mindkét kérdőívünket tanulók.

Bár korábban kitértünk arra, hogy a családi háttér és a tanulási motiváció között legfeljebb gyenge kapcsolatot jeleztek az eddigi kutatások, rámutattunk arra is, hogy ez vélhetően - a tanulási motiváció kontextusfüggő jellegéből adódóan - nem jelenti az összefüggés teljes hiányát. A minta összeállítása során arra törekedtünk, hogy a tanulók családi hátterét tekintve méréseinkben egyaránt szerepeljen kedvezőtlen, átlagos és előnyös helyzetben lévő intézmény is. Ezt elsősorban a tanulók szociokulturális háttere és szövegértési teljesítménye között feltárt összefüggés indokolja (pl. Cs. Czachesz és Vidákovich, 1996; Molnár Gy. és Józsa, 2006; OECD, 2010a), ami befolyásolhatja a kérdőíveken szereplő állítások megértését. A családi háttér fontosabb sajátosságainak összefoglaló mutatójaként az oktatáskutatásban leggyakrabban a szülők iskolai végzettségét használják, amely az olvasási teljesítményt tekintve is kiemelkedik a háttérváltozók közül. 
A vizsgálatsorozat utolsó felmérésében részt vevő tanulók szüleinek iskolai végzettség szerinti megoszlását a 16. táblázat mutatja. Az országos reprezentatív adatok és mintánk jellemzőinek összehasonlítása alapján megállapítható, hogy a kutatásunkba bevont tanulói kör nem tér el jelentősen az országos jellemzőktől, mindössze a szakmunkás végzettséggel és érettségivel rendelkező szülők arányában láthatunk említésre méltó különbséget. Míg előbbi csoportba tartozó szülők valamivel magasabb, az utóbbiba sorolhatók valamivel alacsonyabb arányban jelennek meg mintánkban. A minta tehát céljainknak megfelelően a tanulók szüleinek iskolai végzettsége szempontjából heterogénnek tekinthető.

16. táblázat. A tanulók megoszlása a szülők iskolai végzettsége szerinti bontásban (\%)

\begin{tabular}{lccccc}
\hline & $\begin{array}{c}\text { Legfeljebb } \\
\text { általános } \\
\text { iskola }\end{array}$ & $\begin{array}{c}\text { Szakmunkás } \\
\text { végzettség }\end{array}$ & Érettségi & Föiskola & Egyetem \\
\hline III. mérés & & & & & \\
Anya & 10 & 27 & 26 & 21 & 16 \\
Apa & 8 & 37 & 23 & 15 & 17 \\
\hline Országos* & & & & & \\
Anya & 8 & 22 & 40 & 22 & 18 \\
Apa & 5 & 38 & 32 & 13 & 12 \\
\hline *Országos reprezentatív minta (Józsa, 2003). & &
\end{tabular}

\section{Adatgyüjtés és -rögzítés}

A minta összeállítását és az adatfelvételt fơként gyakorló pedagógusok segítették, akik különbözö, a Szegedi Tudományegyetem Neveléstudományi Intézete által hirdetett képzésekben vettek részt. A személyes tájékoztatás után önként jelentkező pedagógusok iskoláikban általában maguk töltették ki a kérdőíveket, illetve néhány esetben kollégáik segítségét kérték ebben.

A felmérésekben segédkező pedagógusok minden alkalommal írásban kaptak tájékoztatást a kérdőívek kitöltésének céljáról egy felkérő levélben, valamint részletes iránymutatást kitöltési útmutatók formájában. Az adatfelvételt végző személyek esetében egyetlen kikötéssel éltünk, mégpedig azzal, hogy azokat a kérdőíveket, amelyeken a matematikát oktató pedagógussal kialakított viszonyra, illetve a pedagógus tevékenységeire vonatkozó kérdések szerepelnek, ne az adott osztálynak matematikát oktató pedagógus töltesse ki. A célunk ezzel az volt, hogy kiküszöböljük az adott pedagógus jelenlétéből adódó esetleges torzító hatásokat. Az említett kitételnek megfelelően az első mérésben mindkét kérdőív, míg a végső adatgyüjtés során az Osztálytermi környezet kérdöiv esetében tüntettük ezt fel a kitöltési útmutatókban.

A tanulók a kérdőíveket név nélkül töltötték ki, a két tanórás mérések során a tanulói kérdőívek összekapcsolását sorszámok segítségével oldottuk meg. A tanulási motivációra és tanulási környezetre utaló állítások mellett minden mérésben rákérdeztünk a tanulók matematika, szorgalom és magatartás osztályzatára. Az utolsó mérésben emellett a tanulók nemére és a szülők iskolai végzettségére vonatkozóan is szerepeltettünk kérdéseket.

Korábbi tapasztalatokból tudjuk, hogy a tanulók egy része gyakran nem, vagy csak részben veszi komolyan a mérést. Az adatok megbízhatósága érdekében ezért az adatok rögzítése során amennyiben a kérdőíven látszott, hogy a tanuló minden tételnél 
azonos számot karikázott be vagy valamilyen mintát rajzolt ki a bekarikázásokkal, az adott kérdöív vagy annak bizonyos skálái nem kerültek rögzítésre.

\section{Adatelemzés: a modern tesztelmélet lehetőségei}

A modern tesztelmélet vagy valószínüségi tesztelmélet (Item Response Theory, IRT) modelljeit (pl. Andrich, 1978; Masters, 1982; Rasch, 1960) egyre gyakrabban alkalmazzák a hazai tudásszintmérésekben és képességvizsgálatokban (pl. Molnár Gy., 2003, 2005, 2007; Molnár Gy. és Józsa, 2006; Vigh, 2008, 2010), azonban a motivációkutatás ez idáig kevéssé élt az IRT kínálta lehetőségekkel (kivételként 1. Kontra, 2009). A célorientációs elmélet kutatásának nemzetközi gyakorlatában egyre gyakrabban alkalmaznak modern tesztelméletre épülő elemzésekkel, amelyek főként a széles körben használt mérőeszközök tulajdonságainak vizsgálatában játszanak növekvő szerepet (pl. Adesope, Gress és Nesbit, 2008; Hafsteinsson, Donovan és Breland, 2007; Martin, Marsh, Debhus és Malmberg, 2007; Muis, Winne és Edwards, 2009).

A Tanulói célok kérdőiv fejlesztése során azt tüztük ki célul, hogy lehetőség szerint a klasszikus és a modern tesztelmélet által támasztott követelményeknek egyaránt megfelelő mérőeszközt hozzunk létre. E cél elérése érdekében az eddigi gyakorlattól eltérően már a fejlesztési folyamat során felhasználtuk a modern tesztelmélet kínálta lehetőségeket. A továbbiakban a modern tesztelmélet kutatási céljainkat érintő jellemzőit foglaljuk össze.

A valószínűségi tesztelméleti modellek olyan esetekben alkalmazhatók, amikor a választ olyan látens tulajdonság magyarázza, amely a válasz konzisztenciájáért felelős. Ez a látens tulajdonság azt is meghatározza, hogy egy személy az adott itemre milyen választ ad (Rasch, 1960). Ez a feltétel a motivációs konstruktumoknál is teljesül, mert folytonos tulajdonságúak, így különböző szintek definiálhatók (l. Muis és mtsai, 2009).

A valószínüségi tesztelméleti modellek egyszerre követik nyomon a tanuló válaszát, valamint, hogy milyen válasz lett volna a legvalószínűbb. Ezeket a modellek folyamatosan összehasonlítják, meghatározzák az eltéréseket és így eljutnak a szisztematikus tényezők mintafüggetlen becsléséig és a tanulók motivációs szintjének a mérőeszköztől független meghatározásáig. A valószínűségi tesztelméleti modellek alkalmazásának eredményeként egy intervallumon belül számszerüsíthető és jellemezhető a tanulók motivációs szintje. Esetünkben az egyéneket az alacsonyabbtól a magasabb célorientáció szerint rangsorolhatjuk (1. Muis és mtsai, 2009). Mindezek mellett paraméterezhető az egyes kérdőívtételekkel való egyetértés mértéke is. Ezzel megállapítható, hogy az egyes itemek melyik szinten helyezkednek el, és vizsgálhatjuk ezek tulajdonságait. A modellek alkalmazásával továbbá e két paramétert közös skálán lehet kifejezni, amely alapján megállapítható, hogy az egyes kérdőívtételek mennyire jól fedik le a tanulók motivációs szintjei alapján meghatározott intervallumot. Mindezek mellett pedig az is vizsgálható, hogy az egyes itemek mennyire illeszkednek a modell által elvárt, elöre jelzett adatokhoz. 


\section{A TANULÓI CÉLOK KÉRDŐÍV FEJLESZTÉSE}

A tanulói célorientációk megismerése érdekében létrehozott Tanulói célok kérdöiv fejlesztése három fázisban történt. Elömérést végeztünk 2009 tavaszán és 2011 tavaszán, ugyanakkor a végső adatfelvétel során, 2011 őszén is céljaink között szerepelt a mérőeszköz müködésének javítása.

A következőkben a három adatgyüjtés alapján a mérőeszköz-fejlesztés főbb lépéseit és eredményeit ismertetjük. Klasszikus tesztelméletre építve a kérdőívváltozatok validitását és reliabilitását jellemezzük. A modern tesztelmélet alkalmazása során vizsgálatunk célja az egyes kérdőívtételek müködésének pontosabb megismerése, a motivációs szintek meghatározása az egyes dimenziók esetében, és az ezekből levonható következtetések megfogalmazása a kérdöív továbbfejlesztése szempontjából. Mérőeszközünk müködésének ellenőrzésekor az esetleges évfolyamok szerint eltérésekre külön figyelmet fordítunk.

\section{Az első adatfelvétel}

\section{Minta}

Első felmérésünk keretében a résztvevők egy tanórás kérdőívet töltöttek ki. Vizsgálatunkban 9 iskola 31 osztályának 625 tanulója vett részt, 4-7. évfolyamon. A minta fontosabb adatait a 17. táblázat közli. A minta életkorának meghatározását érintő részleteiről „A minták összeállitásának szempontjai” címü pont kínál részletes leírást.

17. táblázat. A Tanulói célok kérdöívet kitöltők az elsö adatfelvétel során

\begin{tabular}{lccccc}
\hline \multirow{2}{*}{ Minta } & \multicolumn{5}{c}{ Évfolyamok } \\
\cline { 2 - 6 } & $\mathbf{4 .}$ & $\mathbf{5 .}$ & $\boldsymbol{6 .}$ & 7. & Összesen \\
\hline Tanulók & 206 & 182 & 128 & 94 & 610 \\
Osztályok & 10 & 10 & 6 & 5 & 31 \\
\hline
\end{tabular}

\section{Méröeszköz}

A tanulói célokra vonatkozó kérdőív 57 állítást tartalmazott, a tanulóknak ötfokú Likertskálán kellett kifejezniük, hogy egy-egy állítást mennyire éreznek igaznak önmagukra nézve. A célok vizsgálata során az oktatással kapcsolatban a kontextushoz kötődő megközelítést választottuk, amely adott tantárgyhoz kapcsolódó kérdőívtételek megfogalmazását jelenti. E megközelítés mellett szóló érv, hogy a célokkal kapcsolatos eredményeket össze kívánjuk kapcsolni az osztálytermi környezet észlelésének (pl. a pedagógusok értékelési szokásainak) vizsgálatával, amely esetében tantárgyanként jelentős eltérések feltételezhetők. Az egyes céltípusokra 10-12 kérdőívtétel vonatkozott, a 18. táblázat céltípusonként egy-egy példát közöl. A kérdőív skálák szerint rendezett állításai a 3. mellékletben láthatók. 
18. táblázat. A Tanulói célok kérdöív skáláinak jellemzöi az elsö adatfelvétel során

\begin{tabular}{|c|c|c|}
\hline Skálák & $\begin{array}{l}\text { Tételek } \\
\text { száma }\end{array}$ & Példatétel \\
\hline $\begin{array}{l}\text { Elsajátítási } \\
\text { teljesítménykereső cél }\end{array}$ & 10 & $\begin{array}{l}\text { Arra törekszem matekból, hogy teljesen } \\
\text { megértsem a tananyagot. }\end{array}$ \\
\hline $\begin{array}{l}\text { Elsajátítási } \\
\text { teljesítménykerülő cél }\end{array}$ & 12 & $\begin{array}{l}\text { Arra törekszem matekból, hogy elkerüljem a } \\
\text { tananyag hiányos megértését. }\end{array}$ \\
\hline $\begin{array}{l}\text { Viszonyító } \\
\text { teljesítménykereső cél }\end{array}$ & 12 & $\begin{array}{l}\text { Fontos célom matekból, hogy másokhoz képest } \\
\text { jól teljesítsek. }\end{array}$ \\
\hline $\begin{array}{l}\text { Viszonyító } \\
\text { teljesítménykerülő cél }\end{array}$ & 12 & $\begin{array}{l}\text { Az egyik célom elkerülni annak látszatát, hogy a } \\
\text { matek nehezen megy nekem. }\end{array}$ \\
\hline Tanulást kerülő cél & 11 & $\begin{array}{l}\text { Az egyik célom, hogy minél hamarabb végezzek } \\
\text { a matekfeladatokkal. }\end{array}$ \\
\hline
\end{tabular}

\section{Érvényesség}

A kérdőív érvényességéről informáló faktoranalízis eredményei az előzetes elméleti struktúrába illeszkedő állítások feltüntetésével a 19. táblázatban láthatók. A faktorok legjobb interpretálhatóságának figyelembe vételével, a legmagasabb faktorsúllyal szereplő tételek megtartásával, Varimax rotáció alkalmazásával jutottunk az eredményekhez.

Mindössze 12 tételt tartottunk meg az 57 állításból, az egyes dimenziókhoz 2-4 tétel tartozik. Az állítások a megcélzott öt skála helyett négybe rendeződnek, a viszonyító teljesítménykerülő cél mérésére megfogalmazott kérdőívtételek nem illeszkedtek a struktúrába. A változórendszer faktoranalízisre való alkalmasságát a Kaiser-Meyer-Olkin-mutató (továbbiakban KMO-mutató) jelzi, amely a megtartott 12 kérdőívtétel esetében 0,79. Kaiser (1974, Ketskeméty és Izsó, 1996) a KMO-mutató alapján a faktoranalízis módszerének alkalmazását a 0,5 feletti érték esetén javasolja, a 0,7 és 0,8 közötti értéket közepesnek, míg a 0,8 és 0,9 közöttit megfelelönek tekinti. A kapott érték alapján tehát azt mondhatjuk, hogy a változórendszer hátterében joggal feltételezünk látens változókat.

A kérdőív faktoranalízisét évfolyamok szerinti bontásban is elvégeztük. A 6 . évfolyam kivételével minden évfolyamon egyértelmüen elkülöníthető az elméleti koncepciónak megfelelően a négy faktor. Évfolyamok szerint növekvő sorrendben a KMO-mutató értéke a következőképpen alakult: 0,$69 ; 0,75 ; 0,74$ és 0,72 (4-7. melléklet). A 6. évfolyamon a többi évfolyamtól eltéröen négy faktor helyett három faktorba rendeződtek a kérdőívtételek, az elsajátítási teljesítménykereső cél és a viszonyító teljesítménykereső cél egy faktorba került. E jelenség feltehetően a minta sajátosságához köthető, hiszen mind az alacsonyabb, mind a magasabb évfolyamok esetében igazolták az eredmények az előzetesen feltételezett látens változók létezését. 
19. táblázat. A Tanulói célok kérdöív faktoranalizise a teljes mintán az elsö adatfelvétel alapján

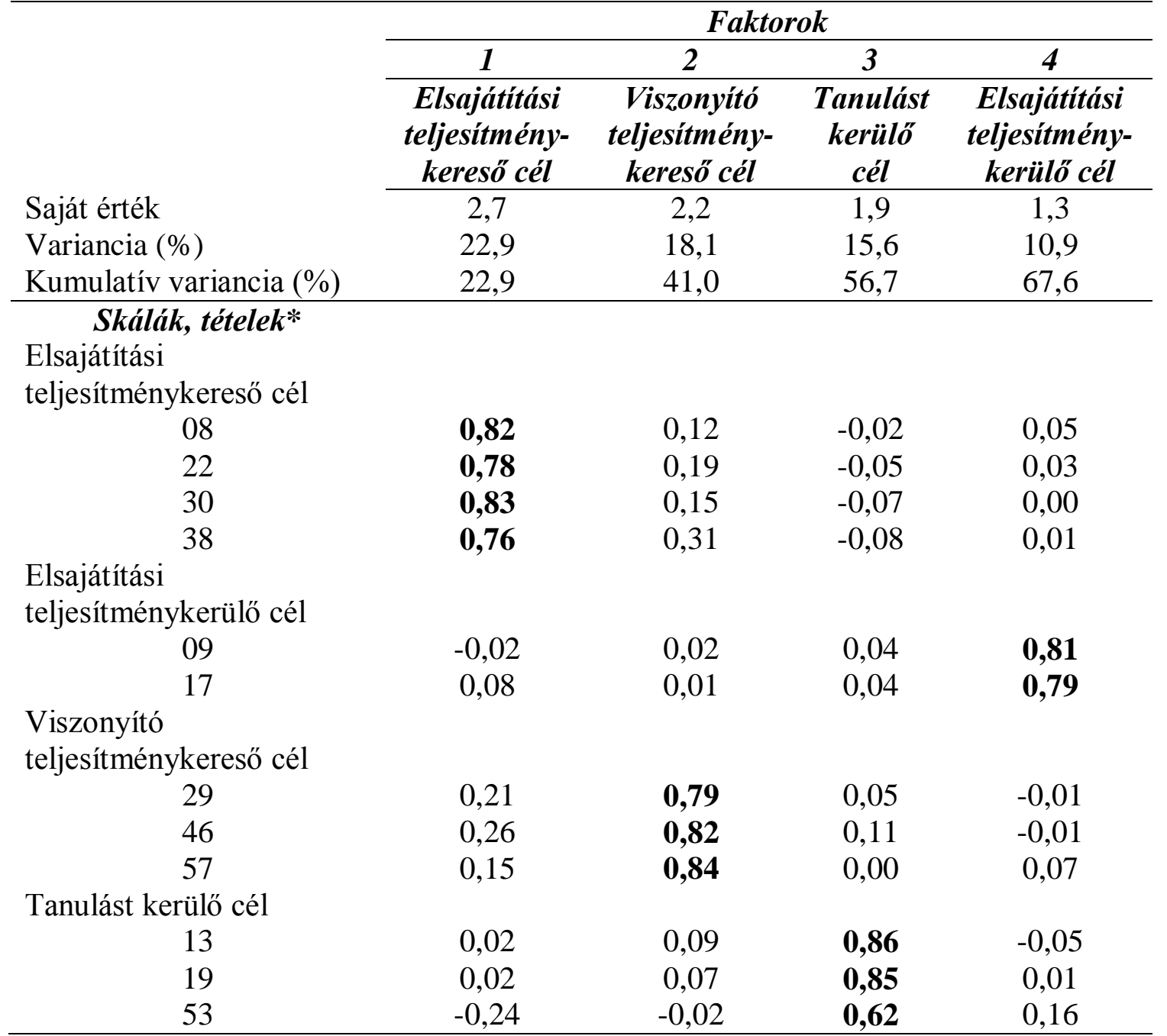

Megj.: főkomponens analízis Varimax rotációval, forgatás előtt 1-nél nagyobb sajátértékủ faktorok, a 0,4nél nagyobb faktorsúlyokat félkövér szedés jelzi; * a számok a kérdőívtétel sorszámát jelzik.

\section{Megbízhatóság}

A kérdőív skáláinak megbízhatóságát az 20. táblázat közli. Az adatok azt jelzik, hogy elsajátítási teljesítménykereső cél, valamint a viszonyító teljesítménykereső cél reliabilitásmutatói kifejezetten jónak mondhatók (vö. B. Németh és Habók, 2006; Józsa, 2002, 2007; Józsa és Fazekasné, 2008; Molnár É., 2003). Ugyanakkor az elsajátítási teljesítménykerülő cél és a tanulást kerülő cél további állítások megfogalmazását igénylik a megbízhatóság növelése érdekében, illetve általánosságban elmondható, hogy a kérdöívtételek száma alacsony.

Mivel a mérőeszköz vizsgálata során arra is választ keresünk, hogy a kérdőív milyen életkortól alkalmazható, az egyes skálák reliabilitását évfolyamok szerinti bontásban is megvizsgáljuk. Az elsajátítási teljesítménykerülő cél kivételével az skálák megbízhatósága megfelelö, e cél esetében azonban érdemes figyelembe vennünk, hogy mindössze két kérdőívtételről van szó. A 6. évfolyam esetében a többi évfolyamtól eltérően müködik a kérdőív, ami - a faktoranalízis eredményét megerősítve ugyancsak értelmezhető a minta sajátosságaként. Láthatjuk továbbá, hogy a 4 . és 5. évfolyam között a legjelentősebbek a különbségek, ami egyrészről utalhat a tanulók 
kevésbé fejlett olvasási képességére, másrészről ezeknek az évfolyamoknak eltérő motivációs jellemzőit is megjelenítheti, hiszen - mint korábban rámutattunk - nagyjából ekkor kezdődik a tanulási motivációs általános visszaesése (1. „A tanulási motiváció életkori változása" címü pontban).

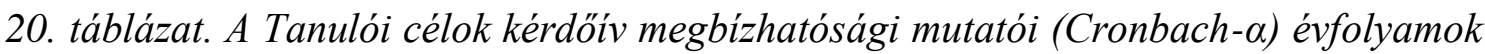
szerinti és a teljes mintán az elsö adatfelvétel alapján

\begin{tabular}{lcccccc}
\hline \multirow{2}{*}{ Skálák } & Tételek & \multicolumn{5}{c}{ Évfolyamok } \\
\cline { 3 - 7 } & száma & $\mathbf{4 .}$ & $\mathbf{5 .}$ & $\mathbf{6 .}$ & $\mathbf{7 .}$ & Összes \\
\hline Elsajátítási teljesítménykereső cél & 4 & 0,78 & 0,86 & 0,77 & 0,85 & 0,83 \\
Elsajátítási teljesítménykerülő cél & 2 & 0,33 & 0,60 & 0,37 & 0,61 & 0,46 \\
Viszonyító teljesítménykereső cél & 3 & 0,72 & 0,80 & 0,81 & 0,80 & 0,79 \\
Tanulást kerülö cél & 3 & 0,64 & 0,70 & 0,73 & 0,73 & 0,68 \\
\hline
\end{tabular}

\section{Modern tesztelméletre épülö elemzések}

A modern tesztelméleti modellek közül Masters (1982) parciális kredit modelljét alkalmazzuk, az elemzések elvégzéséhez ConQuest programmal ( $W u$, Adams és Wilson, 1998) kalibráljuk közös skálára az adatokat. Megvizsgáljuk az egyes kérdőívtételek átlagos támogatottságának mértékét, modellilleszkedését, az egyes állításokhoz tartozó egyetértés mértékét kifejező küszöbértékeket összekapcsoljuk a tanulók motivációs szintjével és személy-item térképen ábrázoljuk céltípusok szerint. Mielött a modern tesztelmélet alapján végzett elemzéseink eredményeit bemutatjuk, bevezetünk néhány terminológiai újítást, illetve röviden definiálunk néhány fogalmat, amelyek elemzéseink követéséhez szükségesek.

Már említettük, hogy a valószínüségi tesztelmélet az oktatástudományon belül föként a tudásszintmérésekhez és a képességvizsgálatokhoz kötődik, ami a fogalomhasználatában is megmutatkozik. Eredményeink adekvátabb értelmezése érdekében szükséges a terminológiának a motivációkutatás jellemzőinek megfelelő kiegészítése. A modern tesztelmélet egyik leggyakrabban használt fogalma a feladatok legkisebb, önállóan értékelhető részét jelentő item, ami számos összetett szó tagjaként is előfordul. A kérdőíves vizsgálatok kontextusában azonban az item kifejezés nem szokványos, így ahol lehetséges, ezt a kérdőívtétel, tétel vagy állítás szavakkal helyettesítjük. Azonban a modern tesztelmélet néhány széles körben elterjedt szóösszetétele (pl. személy-item térkép) kapcsán úgy véljük, hogy az item szó felcserélése a megértést nehezítené, így néhány esetben továbbra is az itemet használjuk. További terminológiai változtatás, hogy a képességszint helyett a motivációs szint kifejezést, itemnehézség helyett pedig az egyetértés mértékét használjuk.

Elemzéseink a parciális kredit modellel végeztük, amelynek eredményeként adódó logit kifejezés a képességmérésben a képességszintek és az itemnehézségi paraméterek közös skálájának egységét jelöli. Az itemek nehézségét az a képességszint reprezentálja, ahol a helyes válasz valószínüsége 50 százalék. Ennek analógiájára esetünkben a logit a tanulók motivációs szintjének és a kérdőívtételek támogatottságának mértékét jelző paraméterek közös skálájának egységét jelöli, vagyis azt a motivációs szintet, ahol az adott állítás támogatottságának valószínúsége 50 százalék. A középérték logitok jelölik az adott kérdőívtétel átlagos támogatottságának mértékét. A pozitív logitérték átlag feletti motivációs szintet jelöl, ahol a személyek az adott motivációs konstruktum esetében erősebb motívumokkal rendelkeznek, így a 
kérdőívtételek magasabb skálafokának választása valószínü. A negatív logitértékek jelzik az átlag alatti, míg a 0 értékek az átlagos motivációs szintet.

$\mathrm{Az}$ egyes itemek modellilleszkedését az infit MNSQ paraméterek jelölik. Ezekkel számszerüsíthető a modell által előre jelzett és a valós eredmény különbsége (Molnár Gy., 2008). Felhasználásával esetünkben elsősorban arról kaphatunk információt, hogy adott célkategórián belül a kérdőív egyes tételeire adott válaszok mennyiben fedik le ugyanazt a látens változót. Az itemek modellilleszkedését mutató paraméter elfogadhatóságát a vizsgálat céljainak és a minta elemszámának függvényében állapíthatjuk meg. Molnár Gyöngyvér (2006) szerint 200 fös mintánál 0,8 és 1,2 közötti, 2000 fösnél pedig 0,94 és 1,06 közötti elfogadhatósági sáv ajánlott. Mintáink méretét figyelembe véve a 0,8 és 1,2 közötti elfogadási sávot alkalmazzuk, vagyis a 0,8 alatti kérdöívtételek túlilleszkednek, míg az 1,2 felettiek nem illeszkednek a modellhez. Minél közelebb van egy item infit MNSQ-ja 1,0-hoz, annál jobb a modellilleszkedése.

Minden állításhoz ötfokozatú Likert-skála tartozik, de az egyes állítások között négy küszöbérték (vagy lépésparaméter) helyezkedik el. Az egyes küszöbszint a 2-es skálafok, a kettes küszöbszint a 3-as, a hármas küszöbszint a 4-es és a négyes küszöbszint az 5-ös skálafok 50 százalékos választásának valószínüségét mutatja a tanulók motivációs szintje alapján. A küszöbértékek általában akkor müködnek az elvártnak megfelelöen, ha a motivációs szint növekedésével emelkednek.

21. táblázat. A Tanulói célok kérdöív tételeinek empirikus paraméterei a teljes mintán az elsö adatfelvétel alapján

\begin{tabular}{|c|c|c|c|c|c|c|}
\hline \multirow{2}{*}{ Skálák, tételek } & \multirow{2}{*}{$\begin{array}{c}\text { Középérték } \\
\text { logit }\end{array}$} & \multirow{2}{*}{$\begin{array}{c}\text { Infit } \\
\text { MNSQ } \\
\end{array}$} & \multicolumn{4}{|c|}{ Küszö̈bértékek (logit) } \\
\hline & & & 1 & 2 & 3 & 4 \\
\hline \multicolumn{7}{|c|}{$\begin{array}{l}\text { Elsajátítási } \\
\text { teliesítménykereső cél }\end{array}$} \\
\hline 08 & $-0,692$ & 0,99 & $-2,78$ & $-1,93$ & 0,10 & 1,82 \\
\hline 22 & 0,386 & 1,11 & $-1,39$ & $-0,60$ & 1,04 & 2,48 \\
\hline 30 & $-0,033$ & 1,10 & $-1,81$ & $-0,91$ & 0,60 & 1,98 \\
\hline 38 & 0,339 & 1,13 & $-1,52$ & $-0,59$ & 0,92 & 2,52 \\
\hline \multicolumn{7}{|l|}{$\begin{array}{l}\text { Elsajátítási } \\
\text { teljesítménykerülő cél }\end{array}$} \\
\hline 09 & 0,013 & 1,00 & $-0,69$ & $-0,36$ & 0,24 & 0,81 \\
\hline 17 & $-0,013$ & 1,07 & $-0,79$ & $-0,41$ & 0,25 & 0,86 \\
\hline \multicolumn{7}{|c|}{$\begin{array}{l}\text { Viszonyító } \\
\text { teljesítménykereső cél }\end{array}$} \\
\hline 29 & 0,238 & 1,07 & $-1,29$ & $-0,36$ & 0,68 & 1,91 \\
\hline 46 & $-0,228$ & 0,87 & $-1,87$ & $-0,99$ & 0,34 & 1,59 \\
\hline 57 & $-0,010$ & 1,06 & $-1,63$ & $-0,76$ & 0,47 & 1,86 \\
\hline \multicolumn{7}{|l|}{ Tanulást kerülő cél } \\
\hline 13 & $-0,188$ & 0,91 & $-1,46$ & $-0,78$ & 0,32 & 1,15 \\
\hline 19 & $-0,122$ & 0,88 & $-1,34$ & $-0,65$ & 0,29 & 1,19 \\
\hline 53 & 0,310 & 1,15 & $-0,88$ & $-0,23$ & 0,81 & 1,54 \\
\hline
\end{tabular}

A 21. táblázat szerint mérőeszközünk esetében az összes kérdöívtételnél teljesül, hogy a küszöbértékek a motivációs szint növekedésével emelkednek, vagyis a kérdőívtételek ebböl a szempontból megfelelően müködnek. Jellemző, hogy az 1-es és 2-es küszöbérték az átlagos motivációs szint alatt, illetve az átlagosnál (logitérték=0), míg a 3-as és 4-es küszöbérték az átlag feletti szintnél helyezkedik el. A magasabb 
célorientációval rendelkező tanulók körében a magasabb skálafokok bejelölése valószínü. Ebböl következik, hogy ezeknek az állításoknak a felhasználása indokolt a további mérésekben. Az item-illeszkedés vizsgálat eredményei szerint az egyes dimenziók olyan kérdőívtételeket tartalmaznak, amelyek megfelelően illeszkednek a modell által elvárt, előre jelzett eredményekhez.

A tanulók motivációs szint szerinti eloszlása és az egyetértés mértéke a parciális kredit modell segítségével közös logitskálán kifejezve személy-itemtérképen ábrázolható (11. és 12. ábra). Mindegyik ábra bal oldalán a diákok motivációs szint szerinti eloszlása, a jobb oldalon a kérdöívtételekhez tartozó skálapontok küszöbértékei láthatók, amelyeket a 21. táblázat számszerüsítve is tartalmaz. A továbbiakban elöször a logitskálát jellemezzük, majd az egyes dimenziók szerint a minta összetételét, végül a kérdőívtételek müködését elemezzük.

A logitskálán nem határozhatjuk meg a motivációs szintek és az egyetértés mértékét jellemző küszöbértékek abszolút helyét, hanem a relatív távolságokat jellemezhetjük a motivációs szinteken és a küszöbértékeken belül, valamint ezek között. A logitskálán a negatív értékek átlag alatti motivációs szintet jelölnek, ahol azon állítások skálapontjainak küszöbértékei láthatók, amelyeknél a Likert-skálán az alacsonyabb érték bejelölése valószínü, míg az átlag feletti motivációs szinten a magasabb skálapontok küszöbértékei helyezkednek el. Például az elsajátítási teljesítménykereső dimenzióban a 38.4. azt a motivációs szintet jelöli, ahol 50 százalék annak a valószínüsége, hogy a tanuló az ötfokozatú skálán a legmagasabb értéket (11. ábra) választja a 38. kérdőívtételnél. Ez az érték nem hasonlítható össze a többi dimenzióval, mert nem kalibráltuk közös skálára az adatokat. Ennek oka, hogy az elméleti háttér alapján a négy dimenzió nem vezethető vissza egy közös konstruktumra.

Ezzel a grafikus ábrázolással jellemezhető a minta összetétele is. A 11. és 12. ábrán minden ' $x$ ' négy tanulót reprezentál. Ugyanakkor az ábrázolt 'x'-eken kívül is vannak tanulók, csak négynél kevesebben vannak, ezért az ábrák nem tartalmazzák az adataikat. A mintatérkép alapján megállapítható, hogy a tanulók az elsajátítási teljesítménykereső cél tekintetében különböznek a leginkább: a motivációs szintben mutatkozó eltérés megközelítőleg 9 logit. Ehhez hasonlóan a viszonyító teljesítménykereső célnál is heterogén a csoport: a -3 és a 4 logit között helyezkedik el a tanulók többsége. Az elsajátítási teljesítménykerülő és a tanulást kerülő célnál láthatóan homogénebb a minta összetétele.

A személy-itemtérképről azt is leolvashatjuk, hogy a kérdőív skálapontjai mennyiben felelnek meg a vizsgált korosztály motivációs jellemzőinek. A mintához jól illesztett kérdőívnél a motivációs szinteket jelölő 'x'-ek és az állítások küszöbértékei egymással párhuzamosan futnak. Az ettől eltérő működés releváns információkat nyújt a mérőeszköz-fejlesztési folyamatban, ez alapján megállapítható, hogy milyen tulajdonságú kérdőívtételek hiányoznak. A kérdőívtételek skálái az elsajátítási teljesítménykereső cél magas motivációs szintjének mérésére kevésbé alkalmasak a teljes mintán (11. ábra). Az elsajátítási teljesítménykerülö dimenzióhoz tartozó két állítás nem elégséges a minta lefedéséhez. A minta homogenitása viszont arra utal, hogy e dimenzióhoz kevesebb kérdöívtétel is elegendő lehet. A viszonyító teljesítménykerülö és a tanulást kerülö célnál a kérdőívtételek skálapontjainak küszöbértékei az előző két dimenzióhoz képest megfelelően fedik a tanulók motivációs szintjeit, ugyanakkor e két dimenzióban is indokolt a további kérdőívtételek fejlesztése (12. ábra).

A személy-item térképeket évfolyamonként is elemeztük (8-15. melléklet). Az azonos céldimenzióban az évfolyamok adatait nem kalibráltuk közös skálára, vagyis az eredmények nem hasonlíthatók össze közvetlenül. Célunk mindössze az volt, hogy évfolyamonként külön vizsgálhassuk meg, hogy az egyes kérdöívtételek mennyire fedik 
le a tanulók motivációs szintjét. A személy-item térképek alapján az elsajátítási teljesítménykereső célnál a 4. évfolyamon müködnek a legkevésbé a kérdőívtételek, a magasabb motivációs szintet kevéssé fedik le a skálapontok küszöbértékei, de az életkor előrehaladtával egyre inkább megfelelő ebben a dimenzióban a skála müködése. Ehhez hasonló tendencia figyelhető meg a viszonyító teljesítménykereső cél dimenziójában is. Az elsajátítási teljesítménykerülő célnál a 4. évfolyamon az átlag alatti, míg a többi évfolyamnál az átlagos szintről hiányoznak kérdőívtételek minden évfolyam esetében. Ehhez a dimenzióhoz tehát további kérdőívtételek szükségesek. A tanulást kerülő cél dimenziójában a négy évfolyamnál nincs jelentősebb eltérés a mérőeszköz müködésében. 


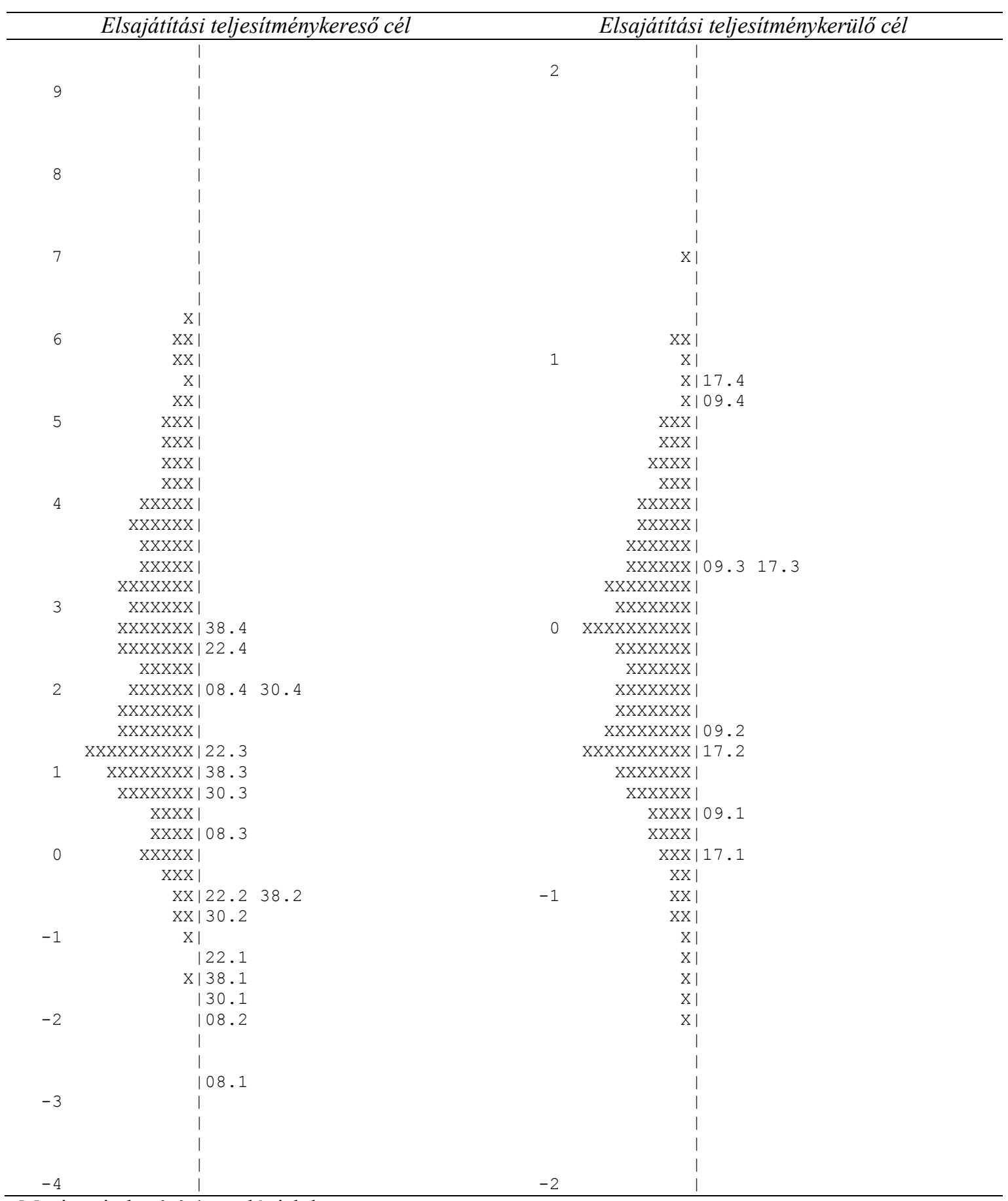

Megj.: minden 'x' 4 tanulót jelöl.

11. ábra

Az elsajátitási célok személy-item térképei a teljes mintán az elsö adatfelvétel alapján 


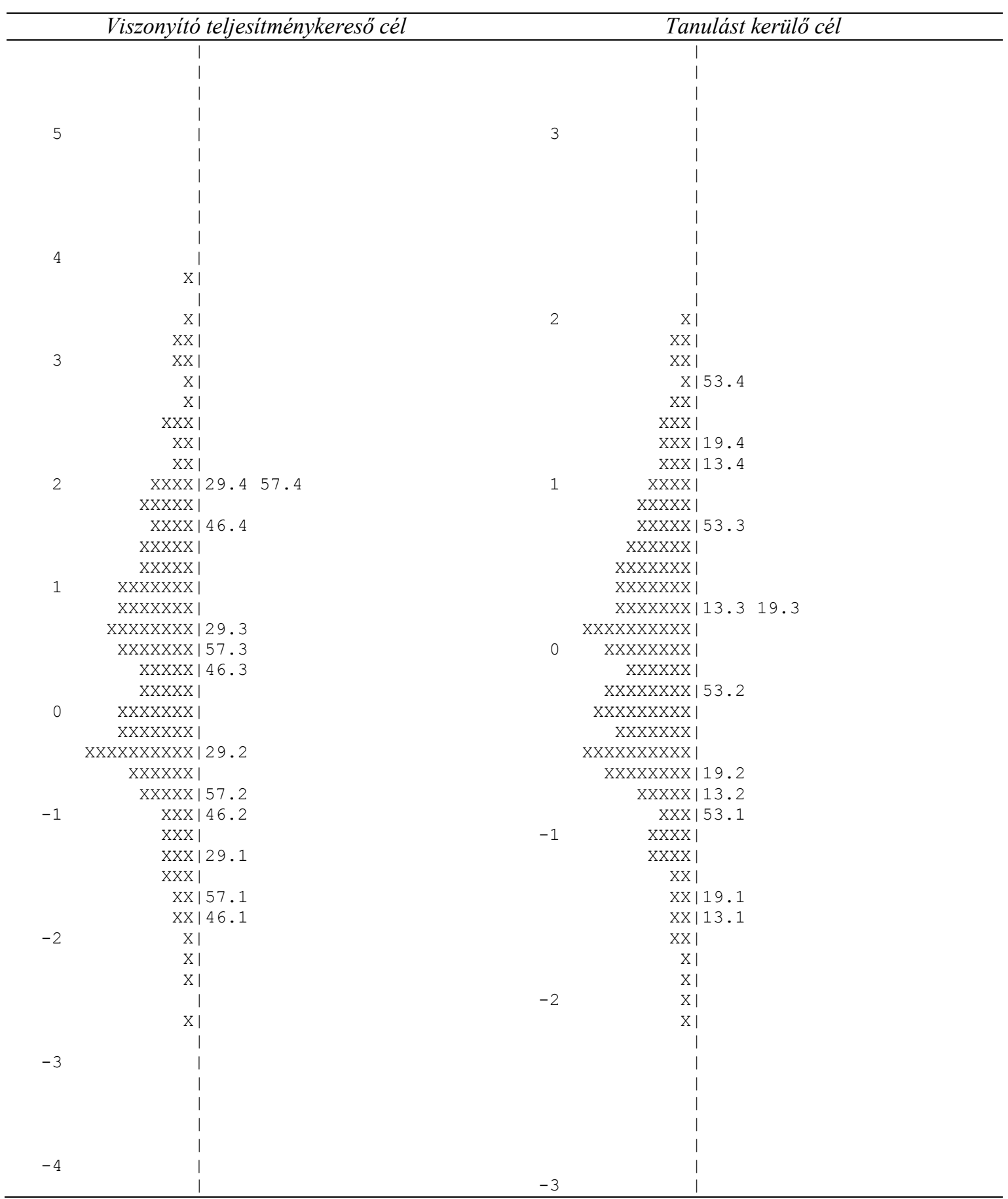

Megj.: minden 'x' 4 tanulót jelöl.

12. ábra

A viszonytó teljesitménykeresö és a tanulást kerülö cél személy-item térképei a teljes mintán az elsö adatfelvétel alapján 


\section{A továbbfejlesztés irányai}

A faktoranalízis eredményei szerint az előzetesen feltételezett öt látens változó közül négyet sikerült lefednünk 12 állítás segítségével, a viszonyító teljesítménykerülő célhoz azonban nem tudtunk kérdőívtételeket rendelni. Az egyes céltípusok reliabilitásmutatói szerint az elsajátítási teljesítménykerülő célhoz tartozó két állítás megbízhatósága nem éri el az alkalmazáshoz szükséges értéket. Bár a felhasználás követelményének a tanulást kerülő cél reliabilitása eleget tesz, e cél megbízhatóságának emelése is javasolható. Emellett általánosságban is megfogalmazható, hogy a kérdőívtételek számának emelésére van szükség.

A modern tesztelmélet felhasználásával végzett elemzések arra mutattak rá, hogy több skála nem illeszkedik megfelelően a tanulók motivációs jellemzőihez. Az elsajátítási teljesítménykereső cél magasabb tartományában elhelyezkedő tanulók motivációs szintjét a kérdőívtételek nem fedik, föként 4-6. évfolyamon láthatók lefedettségi problémák. Az elsajátítási teljesítménykerülő cél csak a 4. évfolyamon nem illeszkedik az alacsony tartományban található tanulókhoz, ugyanakkor a kérdőívtételek alacsony száma miatt az átlagos motivációs szinttel rendelkező tanulók lefedettsége is hiányos. A viszonyító teljesítménykereső célnál a jelenlegi formában is alkalmazható skáláról van szó. A tanulást kerülő cél állításai 4. és 5. évfolyamon többnyire megfelelően illeszkednek a tanulók motivációs jellemzőihez, azonban 6. és 7 . évfolyamon az átlagos motivációs szintről hiányoznak kérdőívtételek.

Összegezve, a mérőeszköz müködése az évfolyam emelkedésével párhuzamosan egyre megbízhatóbb. A Cronbach- $\alpha$ értékében a 4. és 5. évfolyam között láthatóak a legnagyobb különbségek, és a lefedettség is a 4. évfolyamon a leginkább problematikus, bár az 5. évfolyam esetében is jelentős hiányosságok tapasztalhatók. Azonban az eredmények alapján nem vethetjük el, hogy a kérdöív végső változata akár 4. évfolyamon is alkalmazható lesz, vagyis a kérdőív későbbi változatának kipróbálásakor érdemes továbbra is bevonni 4. osztályos tanulókat.

A modern tesztelmélet kínálta lehetőségek segítségével láthatjuk, hogy milyen motivációs szintre vonatkozó állítások hiányoznak a mérőeszközről, kérdéses azonban, hogy sikerül-e megfogalmazni a megcélzott motivációs tartományoknak megfelelö mondatokat. Bár a képesség- és tudásszint-mérő tesztek esetében gyakran alkalmazzák a modern tesztelmélet modelljeit, hogy különböző nehézségü feladatokat fejlesszenek, a Likert-skálás állítások esetében erre nem találtunk kísérletet, a nemzetközi szakirodalomban kizárólag a modern tesztelmélet ellenőrző szerepére támaszkodnak. Ennek oka valószínüleg, hogy az állítások megfogalmazása közötti különbségek jóval nehezebben hozhatók összefüggésbe az átlagos támogatottság eltéréseivel. Ennek személtetése érdekében az elsajátítási teljesítménykereső cél kérdőívtételeit állítottuk növekvő sorrendbe az átlagos támogatottság szerint a 22. táblázatban. Megjegyezzük, hogy az átlagos támogatottság mellett az egyes skálapontok küszöbértékei közötti távolságok is befolyásolják, hogy adott kérdőívtétel mennyire fedi a mintát, a skálapontok közötti távolságokra azonban nem tudunk előzetes feltételezéseket megfogalmazni, vagyis új mondatok megfogalmazásánál az állítások e tulajdonsága nem tervezhetö. 
22. táblázat. Az elsajátitási teljesitménykereső cél kérdöivtételei és átlagos támogatottságuk a teljes mintán az elsö adatfelvétel alapján

\begin{tabular}{llc}
\hline & \multicolumn{1}{c}{ Kérdöivtételek } & $\begin{array}{c}\text { Középérték- } \\
\text { logit }\end{array}$ \\
\hline 8. & Arra törekszem matekból, hogy teljesen megértsem a tananyagot. & $-0,692$ \\
30. & Matekból arra törekszem, hogy amennyire csak lehet, megértsem a & $-0,033$ \\
& & \\
tananyagot. & 0,339 \\
38. & Arra törekszem, hogy egyre többet tudjak matekból. & 0,386 \\
\hline
\end{tabular}

Megj.: az állítások elötti számok a tétel kérdőívben elfoglalt helyére utalnak.

A kérdőív továbbfejlesztése érdekében minden céltípusnál további állításokat fogalmaztunk meg. Azon skálák esetében, ahol jelentősebb lefedettségi hiányosságot tapasztaltunk, kísérletet tettünk arra, hogy viszonyítási pontként használjuk a rendelkezésre álló kérdőívtételek közül azokat, amelyek átlagos támogatottsága a lefedni kívánt tartományhoz a legközelebbi értéket vette fel. Az elsajátítási teljesítménykereső céldimenzióban a magasabb motivációs tartományt, míg az elsajátítási teljesítménykerülő célnál az alacsonyabb motivációs tartományt megcélozva arra törekedtünk, hogy a korábbiaknál „markánsabb” megfogalmazású mondatokat alkossunk. A viszonyítási pontként használt állítások és példaként néhány új kérdőívtétel a 23. táblázatban látható. Az átlagos támogatottság értékeit az első mérés eredményei alapján zárójelben közöljük.

23. táblázat. A lefedettség növelése érdekében viszonyitási pontként használt és néhány új kérdöivtétel az elsö adatfelvétel alapján

\begin{tabular}{|c|c|c|}
\hline Skálák & Megtartott kérdöívtételek & Új kérdöívtételek \\
\hline \multirow{2}{*}{$\begin{array}{l}\text { Elsajátítási } \\
\text { teljesítmény- } \\
\text { kereső cél }\end{array}$} & \multirow{2}{*}{$\begin{array}{l}\text { Fontos célom matekból, hogy } \\
\text { teljesen megtanuljam a } \\
\text { tananyagot. }(22 . ; 0,386)\end{array}$} & $\begin{array}{l}\text { Fontos célom matekból, hogy } \\
\text { minden részletét megtanuljam a } \\
\text { tananyagnak. }\end{array}$ \\
\hline & & $\begin{array}{l}\text { Matekból a célom, hogy } \\
\text { megtanuljak annyit, amennyit } \\
\text { csak lehet. }\end{array}$ \\
\hline \multirow{2}{*}{$\begin{array}{l}\text { Elsajátítási } \\
\text { teljesítmény- } \\
\text { kerülő cél }\end{array}$} & \multirow{2}{*}{$\begin{array}{l}\text { Fontos célom elkerülni, hogy } \\
\text { matekból kevesebbet tanuljak } \\
\text { meg annál, mint amennyit } \\
\text { lehetne. }(9 . ;-0,013)\end{array}$} & $\begin{array}{l}\text { Arra törekszem matekból, hogy } \\
\text { egyre kevesebb olyan részlet } \\
\text { legyen, amit nem értek. }\end{array}$ \\
\hline & & $\begin{array}{l}\text { Arra törekszem matekból, hogy } \\
\text { elkerüljem a hiányos tudást. }\end{array}$ \\
\hline
\end{tabular}

Megj.: a zárójelben az első szám a tétel kérdőívben elfoglalt helyére utal, majd az átlagos támogatottság értéke látható.

\section{A második adatfelvétel}

\section{Minta}

A korábbi próbamérés eredménye alapján megfogalmazható, hogy a mérőeszköz pszichometriai mutatói 4. és 5. évfolyam között jelentősen javulnak, valamint, hogy az 5. évfolyamon mért adatok további kedvező változást mutatnak a magasabb évfolyamokon, bár az eltérések nem számottevőek. Ebből következően, ha a 4. és 5. évfolyamon megfelelő a kérdőív müködése, feltételezhető, hogy magasabb 
évfolyamokon is használható, így a második próbamérés keretében kizárólag az említett két évfolyam tanulóinak körében töltettük ki kérdöívünket. A tanulók és az osztályok évfolyamok szerinti megoszlását a 24 . táblázat közli.

24. táblázat. A Tanulói célok kérdölvet kitöltök a második adatfelvétel során

\begin{tabular}{lccc}
\hline \multirow{2}{*}{ Minta } & \multicolumn{3}{c}{ Évfolyamok } \\
\cline { 2 - 4 } & $\mathbf{4 .}$ & $\mathbf{5 .}$ & Összesen $^{\text {S. }}$ \\
\hline Tanulók & 187 & 126 & 313 \\
Osztályok & 8 & 7 & 15 \\
\hline
\end{tabular}

\section{Méröeszköz}

Az első próbamérés 16 megfelelően működő tételmondatát megtartva, összesen 64 kérdőívtételt tartalmazott a kérdőív a kipróbálás második szakaszában. A tanulóknak továbbra is ötfokú Likert-skálán kellett kifejezniük, hogy egy-egy állítást mennyire éreznek igaznak önmagukra nézve. Az új állítások megfogalmazásánál arra törekedtünk, hogy a hiányzó viszonyító teljesítménykerülő célra vonatkozóan, a megbízhatóság javítása miatt az elsajátítási teljesítménykereső és a tanulást kerülő célra, valamint a lefedettségi problémák miatt minden céltípus tekintetében megfelelő állításokat találjunk. A kérdőív újabb változatának skálák szerint rendezett állításait a 16. melléklet tartalmazza.

\section{Érvényesség}

A kérdőív szerkezetét évfolyamok szerint és a két évfolyamot összevonva egyaránt ellenőriztük. A faktoranalízis eredményei szerint azonban kizárólag az 5. évfolyam esetén rajzolódik ki az elméleti koncepciónak megfelelő struktúra, amely mind az öt célra vonatkozóan tartalmaz tételeket, egymástól jól elkülönülő faktorokba rendeződve (25. táblázat). A KMO-mutató a megtartott 20 kérdőívtétel esetében 0,75 , amely az első mérés során kapott eredményhez hasonlóan ugyancsak a közepes kategóriába sorolható (Kaiser, 1974, idézi Ketskeméty és Izsó, 1996). Az első mérés 12 kérdőívtétele közül nem illeszkedett minden állítás az új mérőeszköz alapján kirajzolódó struktúrába, így 9 olyan állítást tartottunk meg, amely a korábbi kérdőíven is szerepelt, vagyis kénytelenek voltunk az első adatfelvétel alapján megfelelően müködő állításokat elhagyni.

Az eredmények alapján tehát megfogalmazható, hogy a kérdőív e formája 4. évfolyamon nem alkalmazható, míg 5. évfolyamon az eszköz validitása megfelelő. Ebből következően a további elemzéseket kizárólag az 5. évfolyamra vonatkozóan végezzük el. 
25. táblázat. A Tanulói célok kérdöív faktoranalizise 5. évfolyamon a második adatfelvétel alapján

\begin{tabular}{|c|c|c|c|c|c|}
\hline & \multicolumn{5}{|c|}{ Faktorok } \\
\hline & 1 & 2 & 3 & 4 & 5 \\
\hline & $\begin{array}{c}\text { Elsajátítási } \\
\text { teljesítmény- } \\
\text { keresö cél }\end{array}$ & $\begin{array}{c}\text { Tanulást } \\
\text { kerïlö } \\
\text { cél } \\
\end{array}$ & $\begin{array}{c}\text { Viszonyító } \\
\text { teljesítmény- } \\
\text { kereső cél } \\
\end{array}$ & $\begin{array}{c}\text { Elsajátítási } \\
\text { teljesítmény- } \\
\text { kerülö cél }\end{array}$ & $\begin{array}{c}\text { Viszonyitó } \\
\text { teljesítmény- } \\
\text { kerülö cél }\end{array}$ \\
\hline Saját érték & 3,1 & 2,6 & 2,4 & 2,4 & 2,2 \\
\hline Var. $(\%)$ & 15,3 & 13,1 & 11,9 & 11,8 & 10,9 \\
\hline K. var. (\%) & 15,3 & 28,4 & 40,3 & 52,0 & 62,1 \\
\hline $\begin{array}{c}\text { Skálák, } \\
\text { tételek* } \\
\text { Elsajátítási } \\
\text { teljesítmény- } \\
\text { kereső cél }\end{array}$ & & & & & \\
\hline 38 & 0,72 & $-0,08$ & 0,31 & 0,05 & 0,07 \\
\hline 27 & 0,72 & $-0,29$ & 0,27 & $-0,01$ & $-0,05$ \\
\hline 32 & 0,84 & $-0,16$ & $-0,09$ & $-0,02$ & 0,19 \\
\hline 8 & 0,81 & $-0,08$ & 0,21 & 0,10 & 0,12 \\
\hline $\begin{array}{l}\text { Elsajátítási } \\
\text { teljesítmény- } \\
\text { kerülö cél }\end{array}$ & & & & & \\
\hline 44 & 0,04 & 0,11 & 0,18 & 0,61 & 0,26 \\
\hline 17 & $-0,05$ & $-0,07$ & 0,01 & 0,71 & 0,14 \\
\hline 50 & 0,32 & 0,11 & 0,08 & 0,56 & 0,30 \\
\hline 53 & 0,12 & $-0,22$ & 0,26 & 0,71 & 0,02 \\
\hline 9 & $-0,10$ & 0,25 & $-0,14$ & 0,68 & $-0,10$ \\
\hline $\begin{array}{l}\text { Viszonyító } \\
\text { teljesítmény- } \\
\text { kereső cél }\end{array}$ & & & & & \\
\hline 6 & 0,07 & 0,14 & $\mathbf{0 , 8 3}$ & 0,04 & 0,20 \\
\hline 46 & 0,36 & $-0,06$ & 0,73 & 0,18 & $-0,02$ \\
\hline 29 & 0,36 & 0,04 & 0,69 & 0,08 & 0,23 \\
\hline $\begin{array}{l}\text { Viszonyító } \\
\text { teljesítmény- } \\
\text { kerülö cél }\end{array}$ & & & & & \\
\hline 5 & $-0,05$ & $-0,03$ & 0,04 & 0,06 & $\mathbf{0 , 8 0}$ \\
\hline 10 & 0,04 & $-0,02$ & 0,18 & 0,18 & 0,71 \\
\hline 29 & 0,27 & 0,16 & 0,30 & $-0,02$ & 0,58 \\
\hline 35 & 0,24 & 0,19 & $-0,09$ & 0,26 & $\mathbf{0 , 5 8}$ \\
\hline $\begin{array}{l}\text { Tanulást } \\
\text { kerülő cél }\end{array}$ & & & & & \\
\hline 53 & $-0,26$ & $\mathbf{0 , 5 3}$ & 0,40 & 0,10 & 0,00 \\
\hline 13 & 0,01 & $\mathbf{0 , 8 1}$ & 0,14 & $-0,05$ & 0,09 \\
\hline 19 & $-0,19$ & 0,78 & 0,03 & $-0,03$ & $-0,02$ \\
\hline 46 & $-0,16$ & 0,84 & $-0,15$ & 0,17 & 0,13 \\
\hline
\end{tabular}

Megj.: fökomponens analízis Varimax rotációval, forgatás előttt 1-nél nagyobb sajátértékű faktorok, a 0,4nél nagyobb faktorsúlyokat félkövér szedés jelzi; var.=variancia, $K$. var.=kumulatív variancia; * a számok a kérdőivtétel sorszámát jelzik, dőlt és félkövér szedés jelzi azon kérdőívtételek számát, amelyek a kérdőív korábbi változatában nem szerepeltek. 


\section{Megbízhatóság}

A mérőeszköz reliabilitása a 26. táblázat adatai szerint megfelelő, az egyes skálákat vizsgálva láthatjuk, hogy a teljesítménykerülő célok megbízhatósági mutatói a legalacsonyabbak, ugyanakkor a 0,6-os szintet meghaladják, vagyis használhatónak tekinthetők. Ezzel szemben a teljesítménykereső célok 0,8 feletti reliabilitásmutatói kifejezetten jónak mondhatók. Megjegyezzük, hogy az első mérés alapján feltételezhetően a kérdőív megbízhatósága a magasabb évfolyamokon egyre inkább növekszik. Összességében a mérőeszköz egyes skáláinak megbízhatósági mutatói elérik azt a szintet, amely lehetővé teszi a kérdőív alkalmazását 5. évfolyamtól kezdődően, ugyanakkor nem lehetünk elégedettek a tételek számával a viszonyító teljesítménykereső cél esetében.

26. táblázat. A Tanulói célok kérdőiv megbizhatósági mutatói (Cronbach- $\alpha$ ) 5. évfolyamon a második adatfelvétel alapján

\begin{tabular}{lcc}
\hline \multicolumn{1}{c}{ Skálák } & Tételek száma & Cronbach- $\boldsymbol{\alpha}$ \\
\hline Elsajátítási teljesítménykereső cél & 4 & 0,82 \\
Elsajátítási teljesítménykerülő cél & 5 & 0,67 \\
Viszonyító teljesítménykereső cél & 3 & 0,81 \\
Viszonyító teljesítménykerülő cél & 4 & 0,67 \\
Tanulást kerülő cél & 4 & 0,81 \\
\hline
\end{tabular}

\section{Modern tesztelméletre épülö elemzések}

A második mérésben a kérdőív empirikus mutatóit az elöző mérésnek megfelelően vizsgáltuk. Először a faktoranalízis alapján megmaradt kérdőívtételek átlagos támogatottságát és modellilleszkedését tanulmányozzuk, majd a célkategóriák szerinti müködést az 5. évfolyamosok körében, végül ellenörizzük a kérdöív továbbfejlesztésére tett kísérletünk eredményét.

Az egyes kérdőívtételek célkategóriánkénti müködésének paramétereit a 27. táblázat tartalmazza. Ez alapján megállapítható, hogy a kérdőívtételek többsége az átlagos motivációs szintnél helyezkedik el. Minden kérdőívtétel skálapontjának küszöbértéke a motivációs szint emelkedésével kivétel nélkül növekszik. A modellilleszkedést jelölő infit paraméter értéke minden esetben megfelelö. Ennek a paraméternek az értéke függ a minta elemszámától is (1. Molnár Gy., 2008), ezért ez befolyásolja az elfogadhatósági tartományt is. Esetünkben 0,7 és 1,3 közötti értékkel rendelkező paramétereket tekintettünk elfogadhatónak. Ezt figyelembe véve láthatjuk, hogy elöző mérésből hiányzó viszonyító teljesítménykereső cél dimenziójához tartozó kérdőívtételek is megfelelően működnek. 
27. táblázat. A Tanulói célok kérdöív tételeinek empirikus paraméterei 5. évfolyamon a második adatfelvétel alapján

\begin{tabular}{|c|c|c|c|c|c|c|}
\hline \multirow{2}{*}{ Skálák, tételek* } & \multirow{2}{*}{$\begin{array}{c}\text { Középérték } \\
\text { logit }\end{array}$} & \multirow{2}{*}{$\begin{array}{c}\text { Infit } \\
M N S Q\end{array}$} & \multicolumn{4}{|c|}{ Küszöbértékek (logit) } \\
\hline & & & 1 & 2 & 3 & 4 \\
\hline \multicolumn{7}{|l|}{$\begin{array}{l}\text { Elsajátítási } \\
\text { teljesítménykereső cél }\end{array}$} \\
\hline 38 & $-0,361$ & 0,88 & $-3,06$ & $-1,27$ & 0,59 & 2,29 \\
\hline 27 & 0,830 & 1,07 & $-1,13$ & $-0,13$ & 1,54 & 3,02 \\
\hline 32 & $-0,548$ & 0,90 & $-2,85$ & $-1,68$ & 0,24 & 2,09 \\
\hline 8 & 0,079 & 0,91 & $-1,84$ & $-1,41$ & 0,97 & 2,56 \\
\hline \multicolumn{7}{|c|}{$\begin{array}{l}\text { Elsajátítási teljesítmény- } \\
\text { kerülő cél }\end{array}$} \\
\hline 44 & 0,061 & 1,08 & $-0,75$ & $-0,26$ & 0,34 & 0,89 \\
\hline 17 & 0,279 & 0,82 & $-0,39$ & 0,04 & 0,49 & 0,97 \\
\hline 50 & $-0,511$ & 0,93 & $-1,65$ & $-1,03$ & $-0,30$ & 0,91 \\
\hline 53 & $-0,106$ & 1,03 & $-0,86$ & $-0,68$ & $-0,04$ & 1,02 \\
\hline 9 & 0,277 & 1,12 & $-0,64$ & $-0,29$ & 0,50 & 1,47 \\
\hline \multicolumn{7}{|c|}{$\begin{array}{l}\text { Viszonyító teljesítmény- } \\
\text { kereső cél }\end{array}$} \\
\hline 6 & 0,075 & 1,21 & $-1,18$ & $-0,70$ & 0,42 & 1,70 \\
\hline 46 & $-0,316$ & 1,08 & $-2,06$ & $-1,14$ & 0,17 & 1,74 \\
\hline 29 & 0,241 & 0,89 & $-1,38$ & $-0,55$ & 0,70 & 2,18 \\
\hline \multicolumn{7}{|c|}{$\begin{array}{l}\text { Viszonyító teljesítmény- } \\
\text { kerülö cél }\end{array}$} \\
\hline 5 & 0,537 & 0,96 & 0,07 & 0,17 & 0,55 & 1,20 \\
\hline 10 & $-0,387$ & 0,94 & $-1,52$ & $-0,76$ & $-0,04$ & 0,77 \\
\hline 29 & $-0,100$ & 1,11 & $-0,95$ & $-0,59$ & 0,01 & 1,06 \\
\hline 35 & $-0,050$ & 1,03 & $-1,01$ & $-0,42$ & 0,06 & 1,14 \\
\hline \multicolumn{7}{|l|}{ Tanulást kerülő cél } \\
\hline 53 & 0,012 & 1,33 & $-0,95$ & $-0,42$ & 0,25 & 1,13 \\
\hline 13 & $-0,265$ & 1,11 & $-1,15$ & $-0,60$ & 0,02 & 0,66 \\
\hline 19 & $-0,009$ & 1,06 & $-1,06$ & $-0,51$ & 0,32 & 1,18 \\
\hline 46 & 0,262 & 0,94 & $-0,93$ & $-0,43$ & 0,47 & 1,88 \\
\hline
\end{tabular}

Megj.: * a számok a tétel kérdőívben elfoglalt helyére utalnak, dőlt és félkövér szedés jelzi azon kérdőívtételek számát, amelyek a kérdőív korábbi változatában nem szerepeltek.

Az 5. évfolyamosok körében azt is megvizsgáltuk, hogy az egyes kérdőívtételek skálapontjai mennyire jól fedik a célkategóriák szerinti motivációs szintek alapján meghatározott intervallumot (13-15. ábra). Az elsajátítási teljesítménykereső cél alapvető problémája az első mérés alapján az volt, hogy a magasabb tartományból hiányoztak kérdőívtételek. Ez a probléma továbbra is fennáll, de összességében jobban müködnek a jelenlegi állítások (13. ábra). Különösen az új 27. kérdőívtétel müködik a fejlesztés céljainak megfelelően, a többi kérdőívtételhez képest a magasabb motivációs szinteken jellemzőek a skálapontok küszöbértékei. A 13. kérdőívtétel a faktoranalízis alapján nem maradt a mérésben, ezért nem tudtuk ellenőrizni a müködését. 


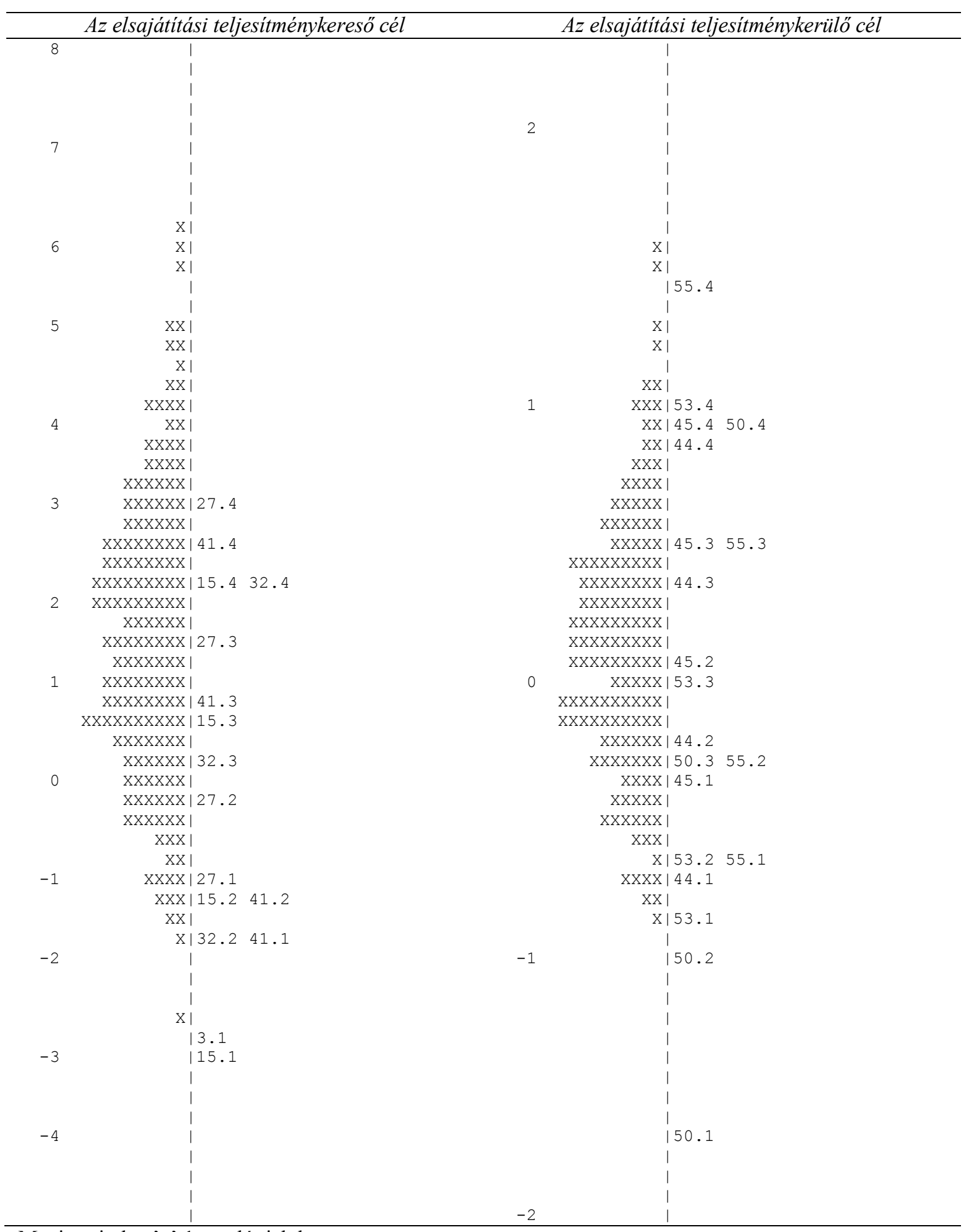

Megj.: minden 'x' 1 tanulót jelöl.

13. ábra

Az elsajátitási célok személy-item térképei a teljes mintán a második adatfelvétel alapján 


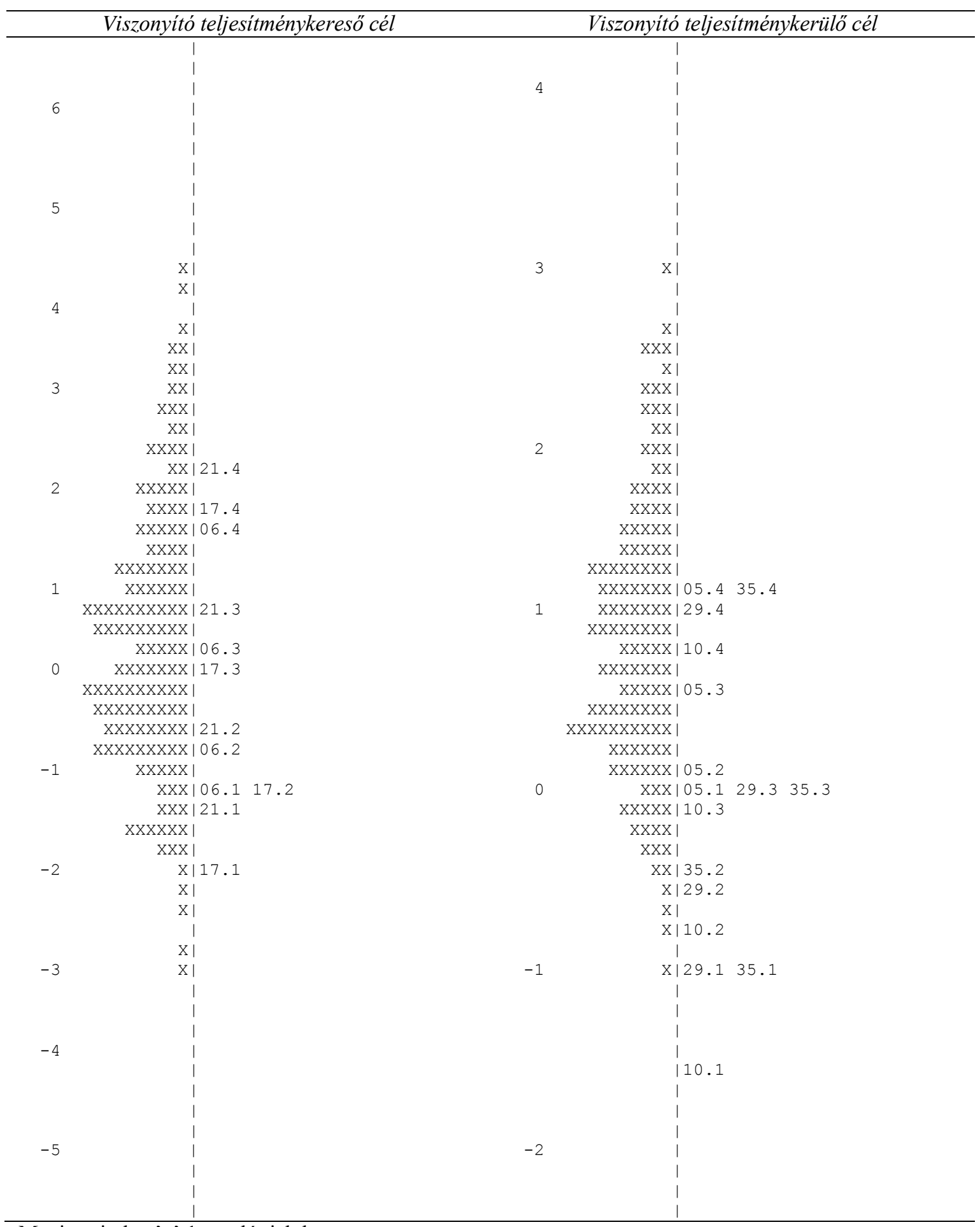

Megj.: minden 'x' 1 tanulót jelöl.

14. ábra

A viszonyitó célok személy-item térképei a teljes mintán a második adatfelvétel alapján 


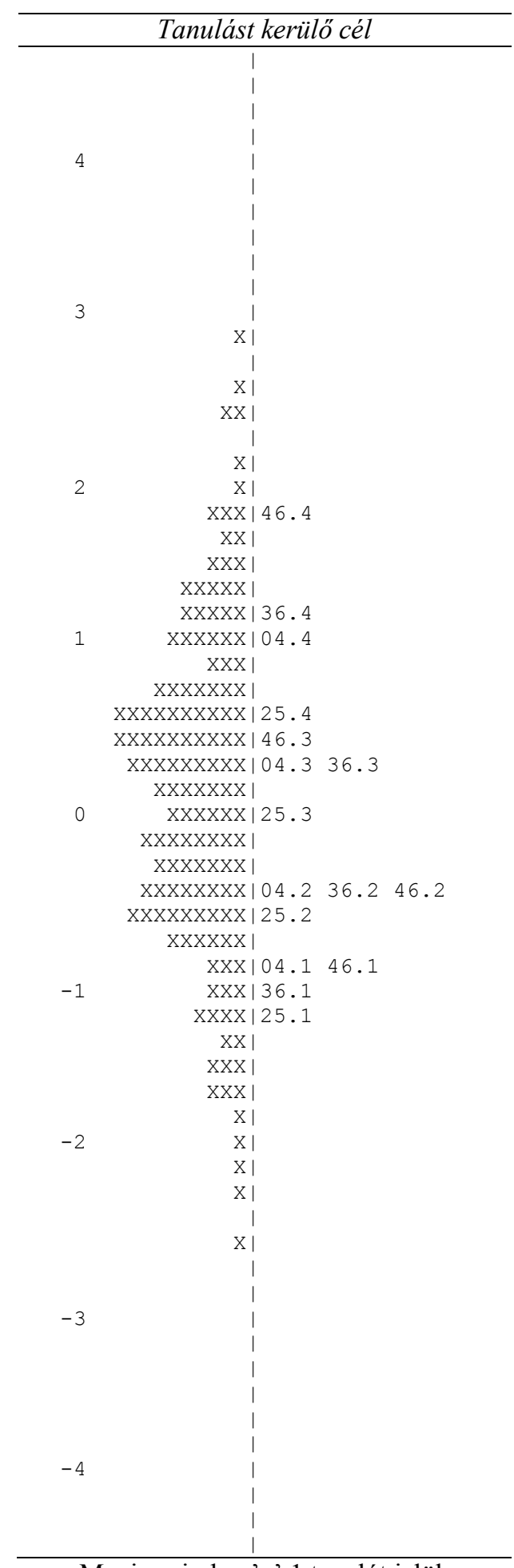

Megj.: minden 'x' 1 tanulót jelöl.

15. ábra

A tanulást kerülö cél személy-item térképe a teljes mintán a második adatfelvétel alapján 
Az elsajátítási teljesítménykerülő célhoz az első mérésben kevés kérdőívtétel tartozott, ezért nem fedte a tanulók motivációs szintjeit sem a teljes mintán (11. ábra) sem évfolyamok szerint. A két, korábbi mérésben is szereplő kérdőívtétel középérték logitjai az átlagos szintnél helyezkednek el (27. táblázat). Bár vannak lefedettségi problémák ennél a célnál is (13. ábra), összességében ebben a mérésben sikerült olyan kérdőívtételeket fejleszteni, amelyek az alacsonyabb motivációs szintre jellemzőek. Ez egyezik a kérdőívfejlesztés céljaival. Az 50. kérdőívtételt a 9. kérdőívtétel alapján hoztuk létre (23. táblázat) és elvárásainknak megfelelően a skálapontok küszöbértékei az átlag alatti és az átlagos motivációs szinten jellemzőek. Ugyanakkor a küszöbértékek közül az 1-es és a 2-es az átlag alatti motivációs szinten csak nagyon kevés diákra jellemző.

A viszonyító teljesítménykereső céldimenzióban a három kérdőívtétel többnyire megfelelően fedi a tanulók motivációs szintjei alapján meghatározott intervallumot (14. ábra). Ennek oka, hogy e három kérdőívtétel egymástól elkülönülve az átlag alatti (17.), az átlagos (6.) és az átlag feletti (21.) szintekre jellemző (1. 27. táblázat). Ugyanakkor szükséges még további kérdőívtétel fejlesztése, mert a tanulók motivációs szintjei között ebben a dimenzióban jelentősebb eltérések vannak: megközelítőleg 7 logitegységnyi különbség jellemzi az ötödikes tanulók többségét. A továbbfejlesztés számára fontos információ, hogy különösen az alacsonyabb és a magasabb motivációs tartományból hiányoznak további kérdőívtételek.

A viszonyító teljesítménykerülő cél esetében a kérdőív a magasabb motivációs tartományban nem megfelelő (14. ábra). Ennek hátterében az áll, hogy három kérdőívtétel (10., 29. és 35.) hasonlóan müködik. A kérdőív továbbfejlesztése szempontjából viszont az 5. kérdőívtétel alapján lehetne újabb állításokat megfogalmazni a jobb lefedettség elérése érdekében.

A tanulást kerülő célnál az első mérés alapján a kérdőívfejlesztés célja az volt, hogy az átlagos motivációs szintre készítsünk kérdőívtételeket. Ennek elérése többnyire megfelelően valósult meg: ennél a dimenziónál egyeznek meg leginkább az egyes kérdőívtételek skálapontjai a tanulók motivációs szintjeivel, bár a legalacsonyabb és a legmagasabb motivációs tartományból hiányoznak még a kérdőívtételek skálapontjai (15. ábra).

\section{A továbbfejlesztés irányai}

A klasszikus tesztelmélet segítségével végzett elemzések szerint 5. osztályos tanulók körében a mérőeszköz validitása és reliabilitása eleget tesz azoknak az általános elvárásoknak, amelyek alapján a kérdőív használatra javasolható. Ugyanakkor megjegyezzük, hogy két skála, az elsajátítási teljesítménykerülő cél és a viszonyító teljesítménykerülő cél megbízhatósága némiképp elmarad a többi skáláétól, ez azonban a csoport homogenitásával is magyarázható. A modern tesztelmélet által végzett elemzések arra hívták fel a figyelmet, hogy a kérdőív egyes skálái nem fedik megfelelően a tanulók motivációs jellemzőit. Az elsajátítási teljesítménykereső cél és a viszonyító teljesítménykerülő cél magasabb tartományában elhelyezkedő tanulók motivációs szintjét e skálák kérdőívtételei nem fedik. Emellett a viszonyító teljesítménykereső és a tanulást kerülő cél legalacsonyabb és legmagasabb tartományaiban tapasztalható a lefedettségben kevésbé jelentős hiányosság.

Minden céltípus esetében rendelkezésre állnak megfelelően müködő kérdőívtételek, így az említett problémák orvoslásakor lehetőségünk van arra, hogy ezekre támaszkodjunk. A megfelelöen müködő kérdéseket mintaként kívánjuk használni, bízva abban, hogy e tételek kisebb módosításaival, például egyes szavak, kifejezések szinonímákkal való felcserélésével megoldhatjuk a felsorolt problémák egy 
részét. Tehát míg az első mérés alapján inkább intuitív módon fogalmaztunk meg új állításokat, itt a jól müködő tételek analógiájára támaszkodva kívánjuk ezt megtenni a nagyobb siker reményében.

A reliabilitás növelése érdekében az alacsonyabb megbízhatóságú skáláknál egyrészről megvizsgálhatjuk, hogy a meglévő kérdőívtételek közül melyek képviselik a legnagyobb súlyt a jelenlegi Cronbach- $\alpha$ mutatókban, másrészről az állítások átlagos támogatottságát és a skálapontok küszöbértékeit felhasználva kiválaszthatjuk azokat a tételeket, amelyek a leginkább illeszkednek a mintához, valamint a legmagasabb logitegységnyi lefedéssel rendelkeznek. A mérőeszköz fejlesztéséhez szükséges adatokat a 28. táblázat foglalja össze.

28. táblázat. Az elsajátítási teljesitménykerülö és viszonyitó teljesitménykerülö cél

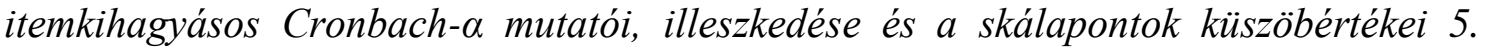
évfolyamon a második adatfelvétel alapján

\begin{tabular}{|c|c|c|c|c|c|c|}
\hline \multirow[b]{2}{*}{ Skálák, tételek* } & \multirow{2}{*}{$\begin{array}{c}\text { Cronbach-a } \\
\text { adott tétel } \\
\text { törlése után }\end{array}$} & \multirow{2}{*}{$\begin{array}{c}\text { Középérték- } \\
\text { logit }\end{array}$} & \multicolumn{4}{|c|}{ Skálapontok küszöbértékei (logit) } \\
\hline & & & 2 & 3 & 4 & 5 \\
\hline \multicolumn{7}{|l|}{$\begin{array}{l}\text { Elsajátítási } \\
\text { teljesítménykerülő } \\
\text { cél }\end{array}$} \\
\hline 44 & 0,60 & 0,168 & $-0,75$ & $-0,26$ & 0,34 & 0,89 \\
\hline 45 & 0,61 & 0,338 & $-0,39$ & 0,04 & 0,49 & 0,97 \\
\hline 50 & 0,61 & $-0,524$ & $-1,65$ & $-1,03$ & $-0,30$ & 0,91 \\
\hline 53 & 0,61 & $-0,238$ & $-0,86$ & $-0,68$ & $-0,04$ & 1,02 \\
\hline 55 & 0,59 & 0,257 & $-0,64$ & $-0,29$ & 0,50 & 1,47 \\
\hline \multicolumn{7}{|l|}{$\begin{array}{l}\text { Viszonyító } \\
\text { teljesítménykerülő } \\
\text { cél }\end{array}$} \\
\hline 5 & 0,54 & 0,547 & 0,07 & 0,17 & 0,55 & 1,20 \\
\hline 10 & 0,59 & $-0,331$ & $-1,52$ & $-0,76$ & $-0,04$ & 0,77 \\
\hline 29 & 0,61 & $-0,228$ & $-0,95$ & $-0,59$ & 0,01 & 1,06 \\
\hline 35 & 0,60 & 0,012 & $-1,01$ & $-0,42$ & 0,06 & 1,14 \\
\hline
\end{tabular}

Megj.: * a számok a tétel kérdőívben elfoglalt helyére utalnak.

Az elsajátítási teljesítménykerülő cél esetében a reliabilitást tekintve az 55 . tétel emelkedik ki, míg a viszonyító teljesítménykerülő cél esetében az 5. kérdőívtétel, így ezek analógiájára fogalmazunk meg új állításokat. Mivel mindkét céltípus esetében további három-négy tétel megbízhatósága tulajdonképpen azonosnak tekinthető, a további kérdések megfogalmazásához viszonyítási pontként az átlagos támogatottság értékét és a skálapontok által lefedett logitegység nagyságát vettük figyelembe, így mintaként az 53. és 35. állításokat használjuk. A reliabilitás növelése mellett természetesen törekedtünk arra is, hogy a megfogalmazások változatosságát növeljük. A mintaként használt és új állításokat a 29. táblázat közli. 
29. táblázat. A reliabilitás növelése érdekében viszonyitási pontként használt és új kérdöivtételek a második adatfelvétel alapján

\begin{tabular}{|c|c|c|}
\hline Skálák & Megtartott kérdöivtételek & Új kérdöivtételek \\
\hline \multirow{2}{*}{$\begin{array}{l}\text { Elsajátítási } \\
\text { teljesítmény- } \\
\text { kerülő cél }\end{array}$} & $\begin{array}{l}\text { Fontos célom elkerülni, hogy } \\
\text { matekból kevesebbet tanuljak } \\
\text { meg annál, mint amennyit meg } \\
\text { tudnék tanulni.(55.) }\end{array}$ & $\begin{array}{l}\text { Matekból a célom elkerülni, hogy } \\
\text { kevesebbet értsek meg annál, } \\
\text { mint amennyit meg tudnék } \\
\text { érteni. }\end{array}$ \\
\hline & $\begin{array}{l}\text { El akarom kerülni matekból, } \\
\text { hogy legyen olyan részlet, amit } \\
\text { nem értek. (53.) }\end{array}$ & $\begin{array}{l}\text { Fontos célom elkerülni matekból, } \\
\text { hogy legyen olyan részlet, amit } \\
\text { nem tudok. }\end{array}$ \\
\hline \multirow{2}{*}{$\begin{array}{l}\text { Viszonyító } \\
\text { teljesítmény- } \\
\text { kerülő cél }\end{array}$} & $\begin{array}{l}\text { Fontos célom elkerülni, hogy a } \\
\text { többieknél gyengébb legyek } \\
\text { matekból. (5.) }\end{array}$ & $\begin{array}{l}\text { Az egyik célom elkerülni, hogy a } \\
\text { többieknél rosszabb legyek } \\
\text { matekból. }\end{array}$ \\
\hline & $\begin{array}{l}\text { El akarom kerülni, hogy } \\
\text { gyengének lássanak matekból. } \\
(35 .)\end{array}$ & $\begin{array}{l}\text { El akarom kerülni, hogy gyenge } \\
\text { matekosnak gondoljanak. }\end{array}$ \\
\hline
\end{tabular}

Megj.: az állítások előtti számok a tétel kérdőívben elfoglalt helyére utalnak.

Az elsajátítási teljesítménykereső és a viszonyító teljesítménykerülő cél skáláinál a lefedettségi problémák kiküszöbölésére teszünk kísérletet. A meglévő állítások segítségével egyrészröl azt kerülhetjük el, hogy a mintához kevésbé illeszkedő mondatok analógiájára fogalmazunk meg újabb tételeket. Így az előbbi dimenziónál a 15. és 32. állítás, míg utóbbinál a 10. és 29. tételek követése kerülendő. Másrészről viszonyítási pontot jelenthetnek a legmagasabb tartományban mérő állítások (27. és 5.), figyelembe véve, hogy ezeknél „erősebb” megfogalmazásokra van szükség. E gondolatmenetet követve az egyik skálához kettő, míg a másikhoz három új állítást dolgoztunk ki, amelyeket a 30. táblázatban tüntettünk fel.

30. táblázat. A magasabb motivációs tartományok lefedettségének növelése érdekében viszonyitási pontként használt és új kérdöivtételek a második adatfelvétel alapján

\begin{tabular}{|c|c|c|}
\hline Skálák & Megtartott kérdőivtételek & Új kérdöívtételek \\
\hline \multirow{2}{*}{$\begin{array}{l}\text { Elsajátítási } \\
\text { teljesítmény- } \\
\text { keresó cél }\end{array}$} & \multirow{2}{*}{$\begin{array}{l}\text { Matekból a célom, hogy } \\
\text { megtanuljak annyit, amennyit } \\
\text { csak lehet. (27.) }\end{array}$} & $\begin{array}{l}\text { Fontos célom, hogy matekból } \\
\text { annyit tudjak, amennyit csak } \\
\text { lehet. }\end{array}$ \\
\hline & & $\begin{array}{l}\text { Fontos célom matekból, hogy a } \\
\text { lehető legtöbb részletet } \\
\text { megtanuljam. }\end{array}$ \\
\hline \multirow{3}{*}{$\begin{array}{l}\text { Viszonyító } \\
\text { teljesítmény- } \\
\text { kerülő cél }\end{array}$} & \multirow{3}{*}{$\begin{array}{l}\text { Fontos célom elkerülni, hogy a } \\
\text { többieknél gyengébb legyek } \\
\text { matekból. (5.) }\end{array}$} & $\begin{array}{l}\text { Fontos célom, hogy ne tartsanak } \\
\text { túl gyenge matekosnak. }\end{array}$ \\
\hline & & $\begin{array}{l}\text { El akarom kerülni, hogy matekból } \\
\text { túl gyenge legyek. }\end{array}$ \\
\hline & & $\begin{array}{l}\text { El akarom kerülni matekból, hogy } \\
\text { a többieknél jóval gyengébb } \\
\text { legyek. }\end{array}$ \\
\hline
\end{tabular}

Megj.: az állítások előtti számok a tétel kérdőívben elfoglalt helyére utalnak.

A viszonyító teljesítménykereső és a tanulást kerülő cél legalacsonyabb és legmagasabb tartományaiban tapasztalható a lefedettségben kisebb hiányosság. E probléma megoldásában ugyancsak az állítások átlagos támogatottsága és a skálapontok 
küszöbértékei kínálhatnak segítséget, bár kérdéses, hogy sikerülhet-e e kisebb különbségeket új tételek megfogalmazásaiban kifejezni. Mintaként azokat a mondatokat használhatjuk, amelyeknek átlagos támogatottsága, valamint skálapontjai a le nem fedett területekhez a legközelebb esnek. Ezek a viszonyító teljesítménykereső cél esetében a 21-es és 17-es, míg a tanulást kerülő cél esetében a 25-ös és 46-os tétel. Az említett állításokat, és az ezek alapján létrehozott új kérdőívtételeket a 31. táblázatban közöljük.

31. táblázat. A legalacsonyabb és legmagasabb motivációs tartományok lefedettségének növelése érdekében viszonyitási pontként használt és új kérdöivtételek a második adatfelvétel alapján

\begin{tabular}{|c|c|c|}
\hline Skálák & Megtartott kérdöivtételek & Új kérdöívtételek \\
\hline \multirow{2}{*}{$\begin{array}{l}\text { Viszonyító } \\
\text { teljesítmény- } \\
\text { keresó cél }\end{array}$} & $\begin{array}{l}\text { Fontos célom matekból, hogy } \\
\text { jobb legyek, mint a többiek. } \\
(21 .)\end{array}$ & $\begin{array}{l}\text { Egyik célom, hogy a többieknél } \\
\text { jobb legyek matekból. }\end{array}$ \\
\hline & $\begin{array}{l}\text { Egyik célom, hogy az } \\
\text { osztálytársaimhoz képest jó } \\
\text { matekosnak tartsanak. (17.) }\end{array}$ & $\begin{array}{l}\text { Matekból a célom, hogy az } \\
\text { osztálytársaimnál jobbnak } \\
\text { tartsanak. }\end{array}$ \\
\hline \multirow{2}{*}{$\begin{array}{l}\text { Tanulást } \\
\text { kerülö cél }\end{array}$} & $\begin{array}{l}\text { Az egyik célom, hogy minél } \\
\text { hamarabb végezzek a } \\
\text { matekfeladatokkal. (25.) }\end{array}$ & $\begin{array}{l}\text { Arra törekszem, hogy a lehetö } \\
\text { leghamarabb végezzek a } \\
\text { matekfeladatokkal. }\end{array}$ \\
\hline & $\begin{array}{l}\text { Próbálom minél kevesebb } \\
\text { munkával megoldani a } \\
\text { matekfeladatokkal. (46.) }\end{array}$ & $\begin{array}{l}\text { Minél kevesebb időt akarok } \\
\text { matekfeladatok megoldásával } \\
\text { tölteni. }\end{array}$ \\
\hline
\end{tabular}

Megj.: az állítások előtti számok a tétel kérdőívben elfoglalt helyére utalnak.

\section{A harmadik adatfelvétel}

\section{Minta}

A második mérés alapján világossá vált, hogy a mérőeszköz negyedik évfolyamon nem alkalmazható, hiszen a skálák érvényességét csak az ötödik évfolyamon sikerült igazolnunk. Ebböl következően a felmérésünkbe 5. osztálytól vontunk be tanulókat, és a felső tagozat egészére kiterjesztettük az adatfelvételt annak érdekében, hogy mérőeszközünk évfolyamok szerinti müködéséről is ismereteket szerezhessünk. A harmadik mérés keretében, 2011 novemberében 885 tanuló töltötte ki kérdöívünket 5-8. évfolyamon. A vizsgálatba bevont tanulók és osztályok évfolyamok szerinti megoszlását a 32. táblázat közli.

32. táblázat. A Tanulói célok kérdöívet kitöltök a harmadik adatfelvétel során

\begin{tabular}{lccccc}
\hline \multicolumn{1}{c}{ Minta } & 5. évfolyam & 6. évfolyam & 7. évfolyam & 8. évfolyam & Összesen \\
\hline Tanulók & 207 & 219 & 254 & 205 & 885 \\
Osztályok & 9 & 10 & 11 & 10 & 40 \\
\hline
\end{tabular}

\section{Méröeszköz}

A második mérés alapján megtartott 20 kérdőívtételt elemzéseink alapján továbbiakkal egészítettük ki, így összesen 33, skálánként 5-9 kérdőívtételt szerepeltettünk kérdőívünkön. Az új tételek megfogalmazásának célja a reliabilitás javítása, a 
lefedettségi problémák megoldása, valamint a viszonyító teljesítménykereső cél esetében a kérdőívtételek számának emelése volt. A kérdőív e változatának skálák szerint rendezett állításait a 17. melléklet tartalmazza.

\section{Érvényesség}

A kérdőívtételek előzetes elvárásainknak megfelelő skálába rendeződését ismételten ellenőriztük faktoranalízis használatával. A faktoranalízis lefuttatása utána a várakozásainknak nem megfelelő faktorba kerülő állításokat kihagytuk, így az eredeti 33 állításból 20-at, skálánként 4-4 állítást tartottunk meg. A változórendszer faktorizációra való alkalmasságát jelező KMO-mutató értéke 0,88, ami kevéssel marad el a kiváló kategória 0,90-es alsó határától (Kaiser, 1974, idézi Ketskeméty és Izsó, 1996). A faktoranalízis eredményeit a megtartott kérdőívtételek feltüntetésével a 33. táblázat közli. Az érvényesség vizsgálatát évfolyamok szerint is elvégeztük. Ennek eredményei nem mutattak emlitésre méltó eltérést a teljes mintához képest. A KMO mutató értéke az évfolyamok növekvő sorrendjében a következőképpen alakult: 0,81; 0,$83 ; 0,85$ és 0,88 (18-21. melléklet). 
33. táblázat. A célorientációk faktoranalízise a teljes mintán a végső mérés alapján

\begin{tabular}{|c|c|c|c|c|c|}
\hline & \multicolumn{5}{|c|}{ Faktorok } \\
\hline & 1. & 2. & 3. & 4. & 5. \\
\hline Variancia (\%) & 17,1 & 15,5 & 13,0 & 12,3 & 10,9 \\
\hline
\end{tabular}

\section{Skálák, tételek}

\section{Elsajátítási teljesítménykereső cél}

Arra törekszem matekból, hogy teljesen megértsem a tananyagot.

Matekból a célom, hogy megértsek annyit, amennyit csak lehet.

Fontos célom, hogy matekból annyit tudjak, amennyit csak lehet.

Fontos célom matekból, hogy a lehető legtöbb részletet megtanuljam.

\section{Elsajátítási teljesítménykerülő cél}

El akarom kerülni matekból, hogy ne értsem a tananyag minden részletét.

Egyik célom elkerülni, hogy matekból kevesebbet tudjak annál, mint amennyit lehetne.

Fontos célom elkerülni, hogy matekból kevesebbet tanuljak meg annál, mint amennyit meg tudnék tanulni.

Fontos célom elkerülni matekból, hogy legyen olyan részlet, amit nem tudok.

$\begin{array}{lllll}0,13 & \mathbf{0 , 7 7} & -0,08 & 0,20 & 0,09 \\ 0,10 & \mathbf{0 , 8 3} & -0,03 & 0,21 & 0,12 \\ 0,16 & \mathbf{0 , 8 3} & -0,07 & 0,19 & 0,06 \\ 0,22 & \mathbf{0 , 8 1} & -0,09 & 0,07 & 0,09\end{array}$

$0,01 \quad 0,08 \quad 0,07 \quad 0,11-\mathbf{0 , 7 2}$

$\begin{array}{lllll}0,12 & 0,08 & 0,08 & 0,02 & \mathbf{0 , 7 9}\end{array}$

$\begin{array}{lllll}0,11 & -0,02 & 0,05 & 0,08 & \mathbf{0 , 7 4}\end{array}$

$\begin{array}{lllll}0,07 & 0,32 & 0,08 & 0,20 & \mathbf{0 , 5 7}\end{array}$ 


\section{Viszonyító teljesítménykereső cél}

Matekból a célom, hogy az osztálytársaimnál jobbnak tartsanak.

$\begin{array}{lllll}\mathbf{0 , 8 6} & 0,13 & 0,06 & 0,21 & 0,13 \\ \mathbf{0 , 8 8} & 0,18 & 0,08 & 0,17 & 0,09 \\ \mathbf{0 , 8 8} & 0,17 & 0,05 & 0,26 & 0,08 \\ \mathbf{0 , 8 6} & 0,19 & 0,06 & 0,24 & 0,08\end{array}$

Arra törekszem matekból, hogy az osztálytársaimnál jobb legyek.

\section{Viszonyító teljesítménykerülő cél}

El akarom kerülni, hogy gyengének lássanak matekból.

$\begin{array}{lllll}0,18 & 0,04 & -0,05 & \mathbf{0 , 7 6} & 0,21 \\ 0,30 & 0,26 & -0,03 & \mathbf{0 , 6 1} & 0,08 \\ 0,18 & 0,19 & 0,03 & \mathbf{0 , 8 0} & 0,09 \\ 0,28 & 0,34 & 0,02 & \mathbf{0 , 7 0} & 0,05\end{array}$

Arra törekszem, hogy a többieknél ne legyek gyengébb matekos.

\section{Tanulást kerülő cél}

A matekfeladatokat próbálom a lehető legkevesebb munkával elvégezni.

$\begin{array}{lllll}-0,05 & -0,09 & \mathbf{0 , 7 2} & -0,09 & 0,16\end{array}$

Próbálom minél kevesebb munkával megoldani a matekfeladatokat.

$\begin{array}{lllll}-0,02 & -0,15 & \mathbf{0 , 8 0} & -0,02 & 0,11\end{array}$

A matekfeladatokat próbálom a lehető leggyorsabban befejezni.

$\begin{array}{lllll}0,15 & 0,00 & \mathbf{0 , 8 2} & 0,05 & -0,03\end{array}$

Az egyik célom, hogy minél hamarabb végezzek a matekfeladatokkal.

$0,12 \quad 0,02 \quad \mathbf{0 , 8 4}$

Megj.: főkomponens analízis Varimax rotációval, forgatás előtt 1-nél nagyobb sajátértékű faktorok, a 0,4-nél nagyobb faktorsúlyokat félkövér szedés jelzi. 


\section{Megbízhatóság}

Az érvényes skálák megbízhatósági mutatóit a 34. táblázatban foglaljuk össze, a teljes mintára és az egyes évfolyamokra vonatkozóan egyaránt feltüntettük az adatokat. A méröeszköz megbízhatósága az egyes céltípusokat tekintve a teljes mintán 0,71 és 0,93 között változik, a legalacsonyabb értékek a teljesítménykerülő célok kapcsán, illetve az 5. évfolyamos tanulók körében tapasztalhatók, azonban ezen az évfolyamon is meghaladják minden skála esetében a 0,7-es értéket. Összességében megállapítható, hogy az egyes céltípusokat mérő állításcsoportok minden vizsgált évfolyamon megfelelö pontossággal müködnek.

34. táblázat. A Tanulói célok kérdöív megbizhatósági mutatói (Cronbach- $\alpha$ ) évfolyamok szerinti és a teljes mintán a harmadik adatfelvétel alapján

\begin{tabular}{lcccccc}
\hline \multirow{2}{*}{ Skálák } & Tételek & \multicolumn{5}{c}{ Évfolyamok } \\
\cline { 3 - 7 } & száma & $\mathbf{5 .}$ & $\mathbf{6 .}$ & $\mathbf{7 .}$ & $\mathbf{8 .}$ & Összes \\
\hline Elsajátítási teljesítménykereső cél & 4 & 0,84 & 0,88 & 0,88 & 0,85 & 0,87 \\
Elsajátítási teljesítménykerülő cél & 4 & 0,71 & 0,70 & 0,70 & 0,73 & 0,71 \\
Viszonyító teljesítménykereső cél & 4 & 0,93 & 0,93 & 0,92 & 0,95 & 0,93 \\
Viszonyító teljesítménykerülő cél & 4 & 0,72 & 0,78 & 0,78 & 0,86 & 0,80 \\
Tanulást kerülő cél & 4 & 0,73 & 0,79 & 0,86 & 0,83 & 0,81 \\
\hline
\end{tabular}

\section{Modern tesztelméletre épülö elemzések}

A kérdőív pszichometriai mutatóit a modern tesztelmélet eszközeivel először a teljes mintán, majd részmintánként is elvégeztük. Először bemutatjuk az egyes céltípusokhoz tartozó, a faktoranalízis alapján megmaradt kérdőívtételek átlagos támogatottságát, modellilleszkedését, a skálapontok küszöbértékeit, majd a minta-itemtérképeket elemezzük. Végül a kérdőív fejlesztésére tett kísérletünket ellenőrizzük.

A 35. táblázat tartalmazza a kérdőívtételek pszichometriai mutatóit a parciális kredit modellel végzett elemzés alapján. Minden kérdőívtétel modellilleszkedése megfelelő, a skálapontok küszöbértékei a motivációs szint növekedésével kivétel nélkül emelkednek. 
35. táblázat. A Tanulói célok kérdöív tételeinek empirikus paraméterei a teljes mintán a harmadik adatfelvétel alapján

\begin{tabular}{|c|c|c|c|c|c|c|}
\hline \multirow{2}{*}{ Skálák, tételek* } & \multirow{2}{*}{$\begin{array}{c}\text { Középérték } \\
\text { logit }\end{array}$} & \multirow{2}{*}{$\begin{array}{c}\text { Infit } \\
\text { MNSQ }\end{array}$} & \multicolumn{4}{|c|}{ Küszöbértékek (logit) } \\
\hline & & & 1 & 2 & 3 & 4 \\
\hline \multicolumn{7}{|l|}{$\begin{array}{l}\text { Elsajátítási } \\
\text { teljesítménykereső cél }\end{array}$} \\
\hline 16 & $-0,465$ & 1,12 & $-3,29$ & $-1,67$ & 0,33 & 2,77 \\
\hline 21 & $-0,200$ & 1,04 & $-2,61$ & $-1,45$ & 0,41 & 2,83 \\
\hline 25 & 0,217 & 1,01 & $-2,16$ & $-1,08$ & 0,90 & 3,20 \\
\hline 31 & 0,448 & 1,12 & $-2,08$ & $-1,02$ & 1,41 & 3,48 \\
\hline \multicolumn{7}{|l|}{$\begin{array}{l}\text { Elsajátítási } \\
\text { teljesítménykerülő cél }\end{array}$} \\
\hline 8 & 0,025 & 1,08 & $-0,54$ & $-0,28$ & 0,04 & 0,78 \\
\hline 14 & 0,105 & 0,91 & $-0,55$ & $-0,23$ & 0,20 & 0,93 \\
\hline 19 & 0,202 & 1,03 & $-0,60$ & $-0,20$ & 0,36 & 1,19 \\
\hline 27 & $-0,332$ & 1,05 & $-1,20$ & $-0,77$ & $-0,13$ & 0,72 \\
\hline \multicolumn{7}{|c|}{$\begin{array}{l}\text { Viszonyító teljesítmény- } \\
\text { kereső cél }\end{array}$} \\
\hline 12 & 0,151 & 0,92 & $-2,16$ & $-1,01$ & 0,98 & 2,79 \\
\hline 15 & 0,129 & 0,89 & $-2,09$ & $-0,99$ & 0,91 & 2,67 \\
\hline 20 & 0,079 & 0,82 & $-2,10$ & $-1,02$ & 0,89 & 2,54 \\
\hline 28 & 0,050 & 0,99 & $-2,16$ & $-0,95$ & 0,76 & 2,54 \\
\hline \multicolumn{7}{|c|}{$\begin{array}{l}\text { Viszonyító teljesítmény- } \\
\text { kerülő cél }\end{array}$} \\
\hline 5 & 0,199 & 1,17 & $-0,70$ & $-0,36$ & 0,32 & 1,45 \\
\hline 7 & $-0,146$ & 1,09 & $-1,48$ & $-0,86$ & 0,13 & 1,59 \\
\hline 24 & $-0,025$ & 1,07 & $-0,92$ & $-0,50$ & 0,09 & 1,16 \\
\hline 26 & $-0,028$ & 0,99 & $-1,17$ & $-0,67$ & 0,15 & 1,52 \\
\hline \multicolumn{7}{|l|}{ Tanulást kerülő cél } \\
\hline 1 & 0,400 & 1,10 & $-1,55$ & $-0,68$ & 1,24 & 2,58 \\
\hline 11 & 0,114 & 0,95 & $-1,69$ & $-0,69$ & 0,79 & 2,03 \\
\hline 18 & $-0,357$ & 1,01 & $-2,10$ & $-1,14$ & 0,39 & 1,42 \\
\hline 29 & $-0,156$ & 1,02 & $-1,71$ & $-0,88$ & 0,47 & 1,48 \\
\hline
\end{tabular}

Megj.: * a számok a tétel kérdöívben elfoglalt helyére utalnak.

A skálapontok küszöbértékeit minta-itemtérképen ábrázolva megvizsgáltuk, hogy a teljes mintán mennyire fedik célkategóriánként a tanulók motivációs szintjei alapján definiálható intervallumot (16-18. ábra). A továbbiakban az egyes dimenziók eredményeit értelmezzük és jellemezzük a kérdőívfejlesztés eredményességét.

A korábbi mérésekhez hasonlóan az elsajátítási teljesítménykereső és a viszonyító teljesítménykerülő célok magasabb motivációs tartományából hiányoznak kérdöívtételek, valamint ez utóbbi dimenzióban az átlagos szint is kevésbé lefedett. Az elsajátítási teljesítménykereső célnál a két újabb kérdőívtétel $(25 ., 31$.$) előzetes$ elvárásainknak megfelelően az átlag feletti motivációs szintre jellemző (22. táblázat). A viszonyító teljesítménykerülő célkategória esetében a magasabb motivációs szint lefedése érdekében létrehozott 9., 17. és 30. kérdőívtétel a harmadik mérésben a faktoranalízis alapján sem a teljes mintán, sem a részmintán nem müködött megfelelően, ezért ezeknél nem vizsgáljuk a kérdőívfejlesztés eredményességét. Ugyanakkor a második mérésben az 5. kérdőívtétel analógiájára létrehozott 24. 
kérdőívtétel megfelelően müködik, de önmagában kevéssé járul hozzá a lefedettség biztosításához (17. ábra).

Az első és a második mérésben a többi dimenzióhoz képest jól müködő viszonyító teljesítménykereső és tanulást kerülő céloknál ebben a mérésben jelentősebb eltérést tapasztalunk. A viszonyító teljesítménykereső cél dimenziójában az egyes kérdőívtételek átlagos támogatottsága hasonló, a küszöbértékek is többnyire azonos motivációs szintre jellemzőek. Ebből következik, ebben a dimenzióban a skálapontok küszöbértékei kevéssé fedik a tanulók motivációs szintjét: mind az átlag alatti, az átlagos és az átlag feletti szintről hiányoznak küszöbértékek. A második mérés alapján létrehozott új kérdőívtételek (12., 20.) a már meglévőkhöz hasonlóan müködnek. Ennek hátterében az állhat, hogy a négy kérdőívtételből a 15. és a 20. kérdöívtétel megfogalmazása nagyon hasonló és ez mind a középérték logitokban, mind az egyes skálapontok küszöbértékeiben látható. A tanulást kerülő céldimenzióban az első méréshez hasonlóan az átlagos motivációs szintről hiányoznak küszöbértékek. A faktoranalízis alapján egyik új kérdőívtétel sem került ehhez a dimenzióhoz, ezért nem tudjuk vizsgálni a parciális kredit modellel ezeknek az állításoknak a pszichometriai mutatóit.

Az elsajátítási teljesítménykerülő céldimenzióban a faktoranalízis alapján az első mérésben kettő, a másodikban három, ebben a mérésben négy kérdőívtétel szerepel. Ezek müködése megfelelö, a többi dimenzióhoz képest leginkább ebben a célkategóriában fedik a skálapontok küszöbértékei a teljes mintán a tanulók motivációs szintjeit (16. ábra).

$\mathrm{Az}$ első méréshez hasonlóan a harmadik mérésben is megvizsgáltuk a céltípusokat évfolyamonként. Ezzel azt elemeztük, hogy az egyes dimenzióknál van-e eltérés évfolyamok szerint. Az első mérés tanulságai alapján azt feltételezzük, hogy a kérdöív az egyes céloknál egyre inkább megfelel a tanulók motivációs szintjeinek. Ezért külön skálára kalibrálva a személy-itemtérképeket vizsgáltuk meg egyenként és összevetettük a tanulságokat (22-31. melléklet).

Az elsajátítási teljesítménykereső célnál az évfolyamok előrehaladásával egyre inkább előnyös a kérdőív müködése, ugyanakkor mindegyik évfolyam esetében a magasabb motivációs tartományból hiányoznak a kérdőívtételek küszöbértékei. Az elsajátítási teljesítménykereső célnál minden évfolyamon a diákok motivációs szintjeit a küszöbértékek többnyire megfelelően fedik. A viszonyító teljesítménykereső célnál minden évfolyam esetében a kérdőívtételek skálapontjai azonos motivációs szinteken jellemzőek, ezért nem fedik a küszöbértékek a tanulók motivációs szintjei szerinti intervallumot. A viszonyító teljesítménykereső célnál az elsajátítási teljesítménykereső dimenzióhoz hasonlóan az 5. évfolyamon a magasabb tartományból hiányoznak kérdőívtételek, amelyek azonban az életkor előrehaladásával egyre inkább fedik a tanulók motivációs szintjét. Ugyanakkor a többi évfolyam esetében az átlagos és az átlag feletti motivációs szintről hiányoznak küszöbértékek. A tanulást kerülő célnál minden évfolyamon két elkülönülő skálapont-csoportot találunk, amelyek egyik része az átlagos motivációs szint alatt és felett lévő diákok motivációs szintjét mérik.

\section{Összegzés}

\section{A Tanulói célok kérdőiv jellemzői}

Összességében 20, céltípusonként 4-4 állítás érvényességét erősítették meg a faktorelemzések a teljes mintára és az egyes évfolyamokra vonatkozóan egyaránt. Az egyes céltípusokat leképző faktorok minden vizsgált évfolyamon megfelelő 
pontossággal müködnek a használathoz, a teljes mintán egyetlen cél kivételével a skálák Cronbach- $\alpha$ értékei elérik vagy meghaladják a 0,80 -as értéket. A klasszikus tesztelmélet által támasztott követelményeknek tehát minden szempontból megfelel a Tanulói célok kérdőiv, a tervezett konstruktumok felmérésére alkalmas eszközt hoztunk létre.

A modern tesztelmélet kínálta elemzési lehetőségek felhasználásával megállapítható, hogy a skálák jóságmutatói, az infit MNSQ értékek szerint a kérdőívtételek modellilleszkedése megfelelö, ugyanakkor a dimenziónkénti négy kérdőívtétel nem elégséges ahhoz, hogy teljes mértékben le tudjuk fedni az egyes évfolyamokon a tanulók motivációs szintjei alapján meghatározott intervallumok egészét. Az elsajátítási teljesítménykerülő célnál müködnek legjobban a kérdőívtételek, a többi esetben további kérdőívtételekre lenne szükség. A lefedettség szempontjából a legkevésbé az elsajátítási teljesítménykereső cél tételeivel lehetünk elégedettek.

$\mathrm{Az}$ eredmények értelmezésekor felhívjuk a figyelmet, hogy a célok mérésére leggyakrabban alkalmazott mérőeszközök esetében sem jellemző a kifogástalan lefedettség (vö. Adesope, Gress és Nesbit, 2008; Martin, Marsh, Debus és Malmberg, 2008; Muis és mtsai, 2009). Muis és munkatársainak (2009) a két leggyakrabban használt mérőeszközről (AGQ, PALS) közölt elemzése ugyancsak az elsajátítási teljesítménykereső cél magasabb motivációs szintjeit illetően jelez problémákat mindkét eszköznél. Bár az említett munkában a lefedettségi hiányosságok kevésbé voltak látványosak, fontos megjegyeznünk, hogy a kérdőíveket felnőttekkel vették fel, eredményeink pedig az életkor növekedésével egyre jobb lefedettséget jeleznek.

\section{Kutatásmódszertani reflexió}

A Tanulói célok kérdöiv kifejlesztése során a klasszikus tesztelmélet szempontjait kiegészítve a modern tesztelmélet követelményeinek való megfelelésre is törekedtünk. A legnagyobb kihívást utóbbi tekintetében egyértelmüen a tanulók motivációs szintjei alapján meghatározott intervallumok lefedése jelentette. Az első mérést követően e probléma megoldása érdekében inkább intuitív módon kíséreltünk meg állításokat megfogalmazni, míg a második mérésben a rendelkezésre álló kérdőívtételek analógiája alapján alkottunk újabb tételeket. Adataink arra utalnak, hogy e kísérletek néhány alkalommal sikeresnek bizonyultak, azonban a legtöbb esetben nem sikerült e próbálkozások eredményeinek pontos értékelését elvégeznünk. Ennek oka az, hogy a mérőeszköz egyes skáláinak összetétele a mérések között jelentősen változott. Minden alkalommal elhagytuk azoknak az állításoknak a szerepeltetését a kérdőíven, amelyek az új faktorstruktúrába nem az elvárásoknak megfelelően illeszkedtek. Ebből következik, hogy az új mérésekben több esetben elvesztettük az újonnan megfogalmazott kérdőívtételek viszonyítási pontjait. A mérőeszköz fejlesztésében elsősorban tehát a faktoranalízisre támaszkodtunk, a parciális kredit modellt a létrejött faktorstruktúrában lévő kérdőívtételek ellenőrzésére használtuk, valamint az eredmények alapján törekedtünk a kérdöív továbbfejlesztésére, de több esetben nem vizsgálhattuk ennek sikerességét.

A lefedettség növelése érdekében megfontolandó lehet további kérdőívfejlesztési stratégia alkalmazásaként a skálapontok számának emelése. Ellenérvként merülhet fel egyrészről az, hogy érdemes szem előtt tartanunk a kérdőív egységességét, vagyis a kérdőív egészét tekintve nem indokolt mindenhol a skálabeosztás növelése, illetve ennek hatása nehezen megjósolható. Másrészről fontos lehet, hogy a hazai iskolai értékelési gyakorlat ötfokú osztályzásra épül, amely minden bizonnyal megkönnyíti a válaszadást a tanulók számára. Lényeges kutatási kérdésként merül fel az említett stratégia előnyeinek és hátrányainak empirikus felderítése a motivációs szintek lefedése szempontjából. 


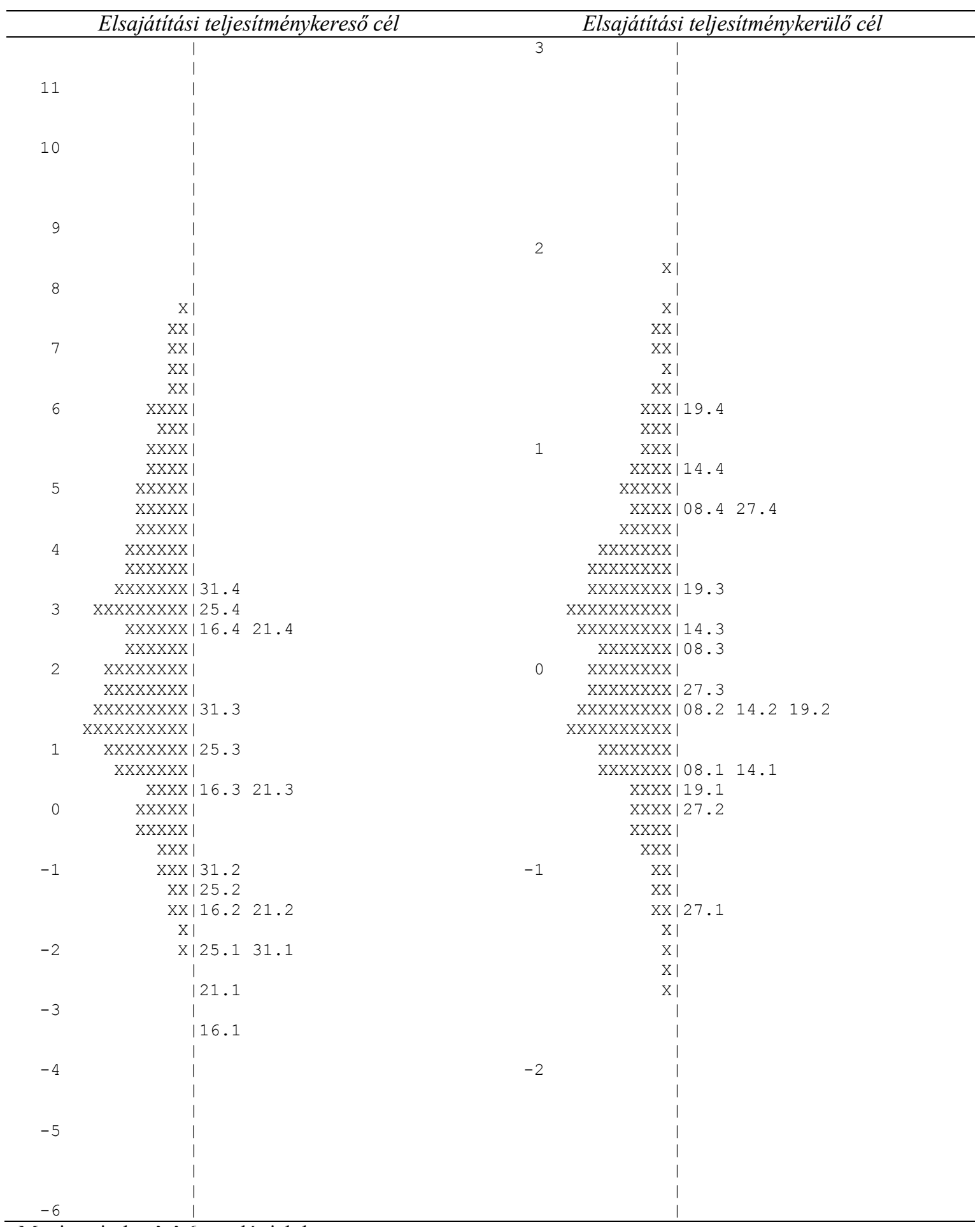

Megj.: minden 'x' 6 tanulót jelöl.

16. ábra

Az elsajátitási célok személy-item térképei a teljes mintán a harmadik adatfelvétel alapján 


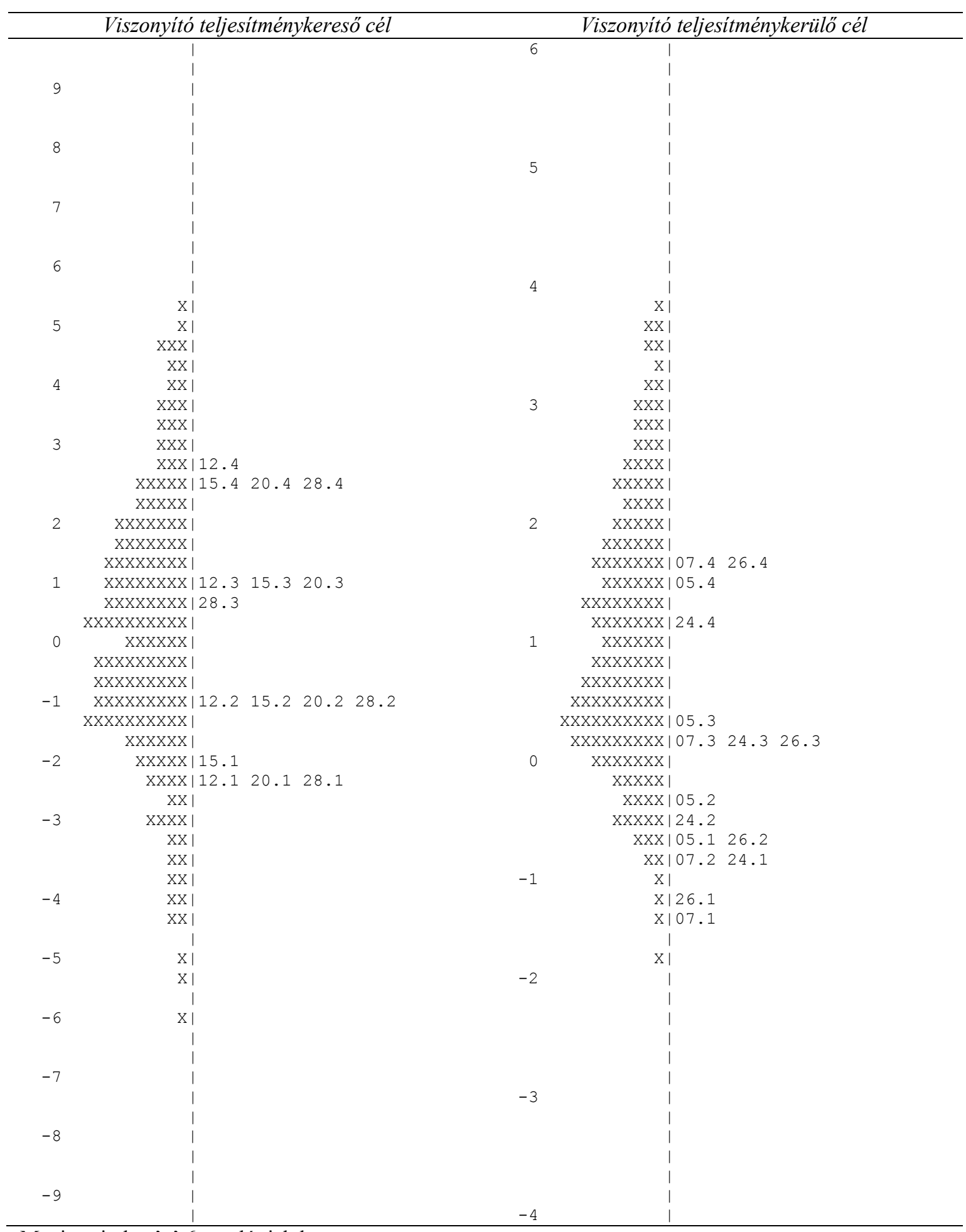

Megj.: minden 'x' 6 tanulót jelöl.

17. ábra

A viszonyitó célok személy-item térképei a teljes mintán a harmadik adatfelvétel alapján 


\begin{tabular}{|c|c|c|}
\hline \multicolumn{3}{|c|}{ Tanulást kerülö cél } \\
\hline \multirow{7}{*}{5} & I & \\
\hline & I & \\
\hline & i & \\
\hline & i & \\
\hline & I & \\
\hline & i & \\
\hline & i & \\
\hline \multirow[t]{6}{*}{4} & I & \\
\hline & । & \\
\hline & $\mathrm{X} \mid$ & \\
\hline & I & \\
\hline & $\mathrm{XI}$ & \\
\hline & । & \\
\hline \multirow[t]{6}{*}{3} & $\mathrm{XI}$ & \\
\hline & XX| & \\
\hline & $\mathrm{XX} \mid 01.4$ & \\
\hline & $\mathrm{XX}$ & \\
\hline & $\mathrm{XX} \mid$ & \\
\hline & $\mathrm{XXX}$ & \\
\hline \multirow[t]{6}{*}{2} & $\mathrm{XXX} \mid 11.4$ & \\
\hline & $\mathrm{XXX} \mid$ & \\
\hline & XXXI & \\
\hline & XXXXXX|18.4 & 29.4 \\
\hline & XXXX|01.3 & \\
\hline & XXXXXX| & \\
\hline \multirow[t]{6}{*}{1} & XXXXXXX| & \\
\hline & XXXXXXX|11.3 & \\
\hline & $\mathrm{XXXXXXX1}$ & \\
\hline & XXXXXXXXX|18.3 & 29.3 \\
\hline & XXXXXXXX| & \\
\hline & XXXXXXX| & \\
\hline \multirow[t]{6}{*}{0} & XXXXXXXX| & \\
\hline & XXXXXXXXX| & \\
\hline & XXXXXXXXX| & \\
\hline & XXXXXXXXXX| & \\
\hline & XXXXXXXX|01.2 & 11.2 \\
\hline & XXXXXX|29.2 & \\
\hline \multirow[t]{5}{*}{-1} & XXXX|18.2 & \\
\hline & $\mathrm{XXXX}$ & \\
\hline & XXXX| & \\
\hline & $\mathrm{XX} \mid 01.1$ & \\
\hline & $\mathrm{XX} \mid 11.1$ & 29.1 \\
\hline \multirow[t]{6}{*}{-2} & $\mathrm{XX}$ & \\
\hline & $\mathrm{X} \mid 18.1$ & \\
\hline & $\mathrm{X} \mid$ & \\
\hline & $\mathrm{X} \mid$ & \\
\hline & $\mathrm{XI}$ & \\
\hline & $\mathrm{X} \mid$ & \\
\hline \multirow[t]{6}{*}{-3} & I & \\
\hline & I & \\
\hline & I & \\
\hline & I & \\
\hline & । & \\
\hline & I & \\
\hline \multirow[t]{3}{*}{-4} & 1 & \\
\hline & i & \\
\hline & I & \\
\hline
\end{tabular}

Megj.: minden 'x' 6 tanulót jelöl.

18. ábra

A tanulást kerülö cél személy-item térképei a teljes mintán a harmadik adatfelvétel alapján 


\section{AZ OSZTÁLYTERMI KÖRNYEZET KÉRDŐÍV FEJLESZTÉSE}

Az osztálytermi környezet motivációs sajátosságainak megismerését célzó kérdöív létrehozása érdekében próbamérést végeztünk 2009 tavaszán, ugyanakkor a végső adatfelvétel során, 2011 öszén is céljaink között szerepelt a mérőeszköz fejlesztése. Az első mérés során a kérdőív összeállításának alapját a célstruktúrák, valamint a TARGET dimenziók (1. „A tanulási környezet lényeges összetevői a célorientációs elmélet alapján" címü pontban) szerinti tanári gyakorlatra vonatkozó skálák jelentették. A második mérésben az említett skálák egyes állításait elhagytuk, illetve újakat fogalmaztunk meg az eredmények alapján, valamint további, elsősorban az osztálytermi környezet társas jellemzőinek leírására alkalmas skálákkal egészítettük ki mérőeszközünk.

A következőkben vizsgálatsorozatunk két mérésének részleteit ismertetjük az Osztálytermi környezet kérdöiv létrehozásának folyamatával összefüggésben. Az adatok alapján minden esetben megvizsgáljuk a kérdöív érvényességét és megbízhatóságát, kiemelt figyelmet fordítva az évfolyamok közötti eltérések feltárására.

\section{Az első adatfelvétel}

\section{Minta}

Első mérésünkben az Osztálytermi környezet kérdőiv első változatát 595 tanuló töltötte ki 4-7. évfolyamon. A résztvevő tanulók évfolyamonkénti megoszlását, illetve az egyes évfolyamokon bevont osztályok számát a 36. táblázatban közöljük. A tanulók életkorának kiválasztását a Tanulói célok kérdöív életkori alkalmazhatósága határozta meg (1. „A minták összeállításának szempontjai” a címü pontban).

36. táblázat. Az Osztálytermi környezet kérdöivet kitöltők az első adatfelvétel során

\begin{tabular}{lccccc}
\hline \multirow{2}{*}{ Minta } & \multicolumn{5}{c}{ Évfolyamok } \\
\cline { 2 - 6 } & $\mathbf{4 .}$ & $\mathbf{5 .}$ & $\boldsymbol{6 .}$ & 7. & Összesen \\
\hline Tanulók & 192 & 179 & 132 & 92 & 595 \\
Osztályok & 10 & 10 & 6 & 5 & 31 \\
\hline
\end{tabular}

\section{Méröeszköz}

Az Osztálytermi környezet kérdöív első változata 65 Likert-skálás állítást tartalmazott. Minden állítás kapcsán ötfokú skálán kellett értékelnie a tanulóknak, hogy az adott állítást mennyiben érzik jellemzőnek osztályukra vagy a matematikát oktató pedagógusra nézve.

Holisztikus megközelítéssel a tanulási környezet motivációs sajátosságait két dimenzióval kívántuk feltárni, így az elsajátítási és a viszonyító célstruktúrára egy-egy skála vonatkozott. A további analitikus megközelítésü állítások szerepeltetését a TARGET dimenziók határozták meg, amelyek mindegyike esetében korábbi vizsgálatok kapcsolatot tártak fel a célorientációkkal (1. „A tanulási környezet lényeges összetevői a célorientációs elmélet alapján" címü pontot). Az eredeti koncepciótól mindössze annyiban tértünk el, hogy az értékeléssel összefüggésben a Church, Elliot és Gable (2001) által alkalmazott, a célorientációk és értékelési gyakorlat között összefüggést feltáró két skálával kiegészítve, az értékelés dimenzióját három részre 
osztottuk. Így a TARGET eredeti értékelés dimenzióját leíró normaorientált értékelés mellett az értékelés szigora és az értékelés jelentősége elnevezéssel az állítások további két csoportját hoztuk létre.

A kérdőíven szerepeltett skálákkal kapcsolatos fontosabb információkat a 37. táblázat közli, a teljes kérdőív skálák szerint rendezett állításai pedig a 32. mellékletben megtalálhatók. A 37. táblázatban feltüntettük azokat a fontosabb mérőeszközöket is, amelyekre kérdöívtételeink megfogalmazása során támaszkodtunk. Hangsúlyozzuk ugyanakkor, hogy néhány állítástól eltekintve, nem fordításról van szó. A fordítás egyrészről az eltérő pedagógiai gyakorlat miatt ütközne nehézségekbe, másrészről a mintaként használt kérdőívek általában idősebb korosztály számára készültek (1. az „Analitikus megközelitésü kérdőivek” címü pontban). A TARGET összetevők közül egyedül az idő dimenzió kapcsán nem támaszkodhattunk egyetlen korábbi mérőeszközre sem, így ennek esetében az interjúkutatások megállapításaira alapoztuk mondataink (1. a ,A tanulási környezet lényeges összetevői a célorientációs elmélet alapján" címü pontban). A kérdőív tételeinek megfogalmazásakor emellett Brophy (2004), valamint Kaplan és Maehr (2007) egyes TARGET dimenziókhoz tartozó leírásait vettük figyelembe (1. és 2. melléklet).

A tanár-diák kapcsolatról is információt gyüjtöttünk, mivel - mint szakirodalmi áttekintésünkben rámutattunk - ez mind a tanulók motivációs jellemzőit, mind a tanulási környezetröl alkotott véleményt befolyásolhatja (1. „Kötődés a pedagógushoz” a címü pontban). E skála helytakarékossági okokból a Tanulói célok kérdöiven szerepelt az első mérésben, de logikailag a tanulási környezet elemzéséhez illeszkedik, ezért itt tárgyaljuk.

\section{7. táblázat. Az Osztálytermi környezet kérdöív skálái az elsö adatfelvétel során}

\begin{tabular}{|c|c|c|c|}
\hline Skálák & $\begin{array}{l}\text { Tételek } \\
\text { száma }\end{array}$ & Példatétel & Minta \\
\hline $\begin{array}{l}\text { Elsajátítási } \\
\text { célstruktúra }\end{array}$ & 7 & $\begin{array}{l}\text { Az új dolgok tanulása matekból fontos cél } \\
\text { az osztályunkban. }\end{array}$ & $\begin{array}{l}\text { Midgley és mtsai } \\
\text { (2000), Urdan } \\
\text { (2004b) }\end{array}$ \\
\hline $\begin{array}{l}\text { Viszonyító } \\
\text { célstruktúra }\end{array}$ & 14 & $\begin{array}{l}\text { Az osztályunkban fontos cél, hogy a } \\
\text { többieknél jobb jegyet szerezzünk } \\
\text { matekból. }\end{array}$ & $\begin{array}{l}\text { Midgley és mtsai } \\
\text { (2000), Urdan } \\
(2004 \mathrm{~b})\end{array}$ \\
\hline Feladat & 6 & $\begin{array}{l}\text { Érdekes feladatokat oldunk meg } \\
\text { matekórán. }\end{array}$ & $\begin{array}{c}\text { Tapola és Niemivirta } \\
\text { (2008) }\end{array}$ \\
\hline Irányítás & 9 & $\begin{array}{l}\text { Matekórán a tanulók beleszólhatnak abba, } \\
\text { hogy milyen feladaton dolgozzanak. }\end{array}$ & $\begin{array}{c}\text { Tapola és Niemivirta } \\
(2008)\end{array}$ \\
\hline Elismerés & 6 & $\begin{array}{l}\text { A matektanár észreveszi, ha sokat } \\
\text { készülünk az órára. }\end{array}$ & $\begin{array}{c}\text { Tapola és Niemivirta } \\
(2008)\end{array}$ \\
\hline Csoportmunka & 4 & $\begin{array}{l}\text { A matektanár megengedi, hogy több } \\
\text { tanuló együtt dolgozzon egy feladaton. }\end{array}$ & $\begin{array}{c}\text { Tapola és Niemivirta } \\
\text { (2008) }\end{array}$ \\
\hline $\begin{array}{l}\text { Normaorientált } \\
\text { értékelés }\end{array}$ & 7 & $\begin{array}{l}\text { A tanulóknak gyakran kell versenyezniük } \\
\text { a jó jegyért matekból. }\end{array}$ & $\begin{array}{l}\text { Church, Elliot és } \\
\text { Gable (2001), Tapola } \\
\text { és Niemivirta (2008) }\end{array}$ \\
\hline $\begin{array}{l}\text { Értékelés } \\
\text { szigora }\end{array}$ & 3 & $\begin{array}{l}\text { A magas követelmények miatt nehéz jó } \\
\text { jegyet szerezni matekból. }\end{array}$ & $\begin{array}{l}\text { Church, Elliot és } \\
\text { Gable (2001) }\end{array}$ \\
\hline $\begin{array}{l}\text { Értékelés } \\
\text { jelentősége }\end{array}$ & 5 & Sok dolgozatot írunk matekból. & $\begin{array}{l}\text { Church, Elliot és } \\
\text { Gable (2001) }\end{array}$ \\
\hline Idő & 4 & $\begin{array}{l}\text { A matektanár kevés időt ad órán a } \\
\text { feladatok megoldására. }\end{array}$ & \\
\hline $\begin{array}{l}\text { Tanár-diák } \\
\text { kapcsolat }\end{array}$ & 5 & Jóban vagyok a matektanárral. & \\
\hline
\end{tabular}




\section{Érvényesség}

A mérőeszköz érvényességét faktoranalízisek segítségével ellenőriztük. Külön-külön, a holisztikus és az analitikus megközelítésbe illeszkedő kérdőívtételek bevonásával végeztünk faktoranalízist, azaz a két célstruktúrát külön kezeltük. Az állítások ily módon történő elkülönítésének indoka, hogy a tanári gyakorlatra vonatkozó kérdöívtételek esetében nem egyszerüen azonos látens változókat reprezentáló állításokat kívántunk skálákba rendezni, hanem olyan skálákat kerestünk, amelyek összefüggésbe hozhatók a célstruktúrákkal. Ezért elsőként a két célstruktúrát leíró összetartozó kérdőívtételekből kellett változókat létrehoznunk.

A célstruktúrákra vonatkozó konstruktumok érvényességéről informáló faktoranalízis eredményeit az előzetes elméleti struktúrába illeszkedő állítások feltüntetésével a négy évfolyamra lefuttatva a 38. táblázatban közöljük. Az előzetes 21ből 10 állítást tartottunk meg. A faktorok legjobb interpretálhatóságának figyelembe vételével, a legmagasabb faktorsúllyal szereplő tételek megtartásával, Varimax rotáció alkalmazásával jutottunk az eredményekhez. A változórendszer faktoranalízisre való alkalmasságát jelző KMO-mutató a teljes mintára vonatkoztatva 0,85, ami jónak tekinthető (Kaiser, 1974, idézi Ketskeméty és Izsó, 1996). Fontosnak tartjuk megemlíteni, hogy a két konstruktum varianciája szinte megegyezik, ami a későbbi elemzések tekintetében lényeges lesz.

Az érvényesség vizsgálatát évfolyamonként is elvégeztük, az évfolyamok között azonban nem tapasztaltunk jelentős eltéréseket. Minden évfolyamon egyértelműen megfeleltethetők a faktorok a célstruktúráknak. A KMO-mutató az évfolyamok növekvő sorrendjében a következőképpen alakult: 0,76; 0,86;0,75;0,78 (33. melléklet).

38. táblázat. A célstruktúrák faktoranalízise a teljes mintán az elsö adatfelvétel alapján

\begin{tabular}{|c|c|c|}
\hline & \multicolumn{2}{|c|}{ Faktorok } \\
\hline & 1. & 2. \\
\hline & Elsajátítási célstruktúra & Viszonyító célstruktúra \\
\hline Saját érték & 2,9 & 2,8 \\
\hline Variancia $(\%)$ & 28,9 & 27,8 \\
\hline Kumulatív variancia (\%) & 28,9 & 56,7 \\
\hline \multicolumn{3}{|l|}{ Skálák, tételek* } \\
\hline \multicolumn{3}{|l|}{ Elsajátítási célstruktúra } \\
\hline 26 & 0,78 & 0,03 \\
\hline 6. & $\mathbf{0 , 7 2}$ & 0,03 \\
\hline 50. & 0,76 & 0,21 \\
\hline 42. & $\mathbf{0 , 7 7}$ & 0,15 \\
\hline 34. & $\mathbf{0 , 7 3}$ & 0,01 \\
\hline \multicolumn{3}{|l|}{ Viszonyító célstruktúra } \\
\hline 36 & 0,15 & 0,74 \\
\hline 28. & 0,09 & $\mathbf{0 , 7 8}$ \\
\hline 16. & 0,02 & $\mathbf{0 , 7 2}$ \\
\hline 65. & 0,13 & 0,72 \\
\hline 41. & 0,01 & $\mathbf{0 , 7 2}$ \\
\hline
\end{tabular}

Megj.: fökomponens analízis Varimax rotációval, forgatás elött 1-nél nagyobb sajátértékü faktorok, a 0,4nél nagyobb faktorsúlyokat félkövér szedés jelzi; * a számok a tétel kérdőívben elfoglalt helyére utalnak.

A tanári gyakorlatra vonatkozó kérdőívtételek érvényességének vizsgálata előtt összefüggéseket kerestünk a célstruktúrák és a TARGET összetevőkre vonatkozó 
tételek közötti korrelációk segítségével, amelyet elvégeztünk a teljes mintára és évfolyamok szerint is (34. melléklet). Ezután kiválogattuk azokat a kérdöívtételeket, amelyek a többi állításhoz viszonyítva kiemelkedö, szignifikáns összefüggést mutattak valamely célstruktúrával, és az összefüggések évfolyamonként is azonos irányúak, illetve hasonló erősségűek voltak. Ez legalább két évfolyamon hasonló erősségü és azonos irányú összefüggést jelentett. Így az eredeti 44 tétel 15-re csökkent. Nem tartottunk meg további két olyan állítást, amelyek korrelációs értékei a célstruktúrákkal összefüggésben viszonylag magasak voltak (,A matektanár elég időt szokott hagyni arra, hogy az osztály megértse az anyagot." „A matektanárnak fontos, hogy a tanultak szerint oldjuk meg a feladatokat."). Elöbbi mondat esetében a döntés indoka, hogy a PISA-mérésből átvenni szándékozott egyik skálán egy hasonló mondat szerepel $(, A$ tanár addig magyarázza az anyagot, amíg mindenki meg nem érti."). Utóbbi mondat a várakozásokhoz képest ellentétesen müködött, nem a viszonyító, hanem az elsajátításai célstruktúrával mutatott együtt járást, így nem tudunk további skálát létrehozni az állítással összefüggésben. Ezek alapján 13 kérdőívtételt tartottunk meg, amelyek hat skálához tartoztak (34. melléklet).

Faktoranalízis elvégzésével ellenőriztük, hogy az előzetes elméleti struktúrába illeszkednek-e a tanári tevékenységekre vonatkozó állítások. A faktoranalízist 11 kérdöívtétel bevonásával végeztük. Nem vontuk be a csoportmunka és az értékelés jelentősége elnevezésű skálákat, mivel ezekhez mindössze egy-egy állítást tartozott. A 0,77-es KMO-mutató a változórendszer faktorizációra való alkalmasságáról tájékoztat (Kaiser, 1974, idézi Ketskeméty és Izsó, 1996). Bár az elismerés és a normaorientált értékelés skálája kiemelkedik a faktorstruktúrából, az egyes skálákhoz tartozó kérdőívtételek száma alacsonynak tekinthető (39. táblázat).

A Tanulói célok kérdőíven szereplő tanár-diák kapcsolatról érdeklődő állítások érvényességét a célokkal közös faktoranalízis segítségével vizsgáltuk. Az eredeti öt állításból hármat tartottunk meg, amely mindhárom évfolyamon egyértelmüen azonos faktorba rendeződött (35. melléklet). 
39. táblázat. A tanári tevékenységek faktoranalizise a teljes mintán az elsö adatfelvétel alapján

\begin{tabular}{lcccc}
\hline & \multicolumn{4}{c}{ Faktorok } \\
\cline { 2 - 5 } & $\mathbf{1 .}$ & $\mathbf{2 .}$ & $\mathbf{3 .}$ & $\mathbf{4 .}$ \\
\cline { 2 - 5 } Saját érték & 2,7 & 1,7 & 1,5 & 1,3 \\
Variancia (\%) & 20,8 & 13,0 & 11,7 & 10,0 \\
Kumulatív variancia (\%) & 20,8 & 33,7 & 45,5 & 55,5 \\
\hline
\end{tabular}

Feladat

\section{Skálák, tételek*}

$\begin{array}{rrrrr}27 . & \mathbf{0 , 5 7} & 0,12 & \mathbf{0 , 4 3} & 0,09 \\ 60 . & \mathbf{- 0 , 6 4} & 0,06 & 0,06 & 0,21 \\ 15 . & 0,36 & 0,03 & \mathbf{0 , 6 9} & -0,09\end{array}$

Elismerés

$\begin{array}{ccccc}59 . & \mathbf{0 , 6 9} & 0,25 & 0,09 & -0,03 \\ 9 . & \mathbf{0 , 7 1} & 0,08 & 0,05 & -0,01 \\ 54 . & \mathbf{0 , 6 7} & 0,11 & 0,21 & 0,06\end{array}$

Normaorientált értékelés

$\begin{array}{rrrrr}64 . & -0,28 & 0,09 & 0,38 & \mathbf{0 , 4 5} \\ 4 . & 0,02 & 0,06 & 0,02 & \mathbf{0 , 7 4} \\ 23 . & 0,07 & -0,07 & -0,09 & \mathbf{0 , 6 9}\end{array}$

Felelösség

$\begin{array}{rrrrr}31 . & 0,08 & \mathbf{0 , 9 1} & 0,04 & 0,06 \\ 46 . & 0,27 & \mathbf{0 , 8 6} & 0,05 & -0,05\end{array}$

Megj.: főkomponens analízis Varimax rotációval, forgatás előtt 1-nél nagyobb sajátértékủ faktorok, a 0,4nél nagyobb faktorsúlyokat félkövér szedés jelzi; * a számok a tétel kérdőívben elfoglalt helyére utalnak.

\section{Megbízhatóság}

A 40. táblázatban a célstruktúrák és a tanár-diák kapcsolat skáláinak reliabilitásmutatói láthatók, az eredményeket évfolyamok szerinti bontásban is feltüntettük. Az adatok szerint a célstruktúrákra vonatkozó öt-öt állítás belső konzisztenciája minden évfolyamon megfelel a skálák pontosságával kapcsolatos követelményeknek. A tanárdiák kapcsolatra vonatkozó három kérdőívtétel megbízhatósága ugyancsak minden évfolyamon meghaladja a használhatóság szokásos 0,6-os kritériumát. Az eredmények alapján tehát megfogalmazható, hogy a célstruktúrák és a tanár-diák viszonyra vonatkozó skálák jelenlegi formájukban már 4. évfolyamtól kezdődően alkalmazhatók. Bár az elismerés és a normaorientált értékelés kérdéscsoportjainak érvényességét alátámasztotta a faktoranalízis, célszerü a skálákhoz tartozó kérdőívtételek számát emelni, így e skálák megbízhatóságára nem térünk ki.

40. táblázat. A célstruktúrák skáláinak és a tanár-diák kapcsolat skála megbizhatósági mutatói (Cronbach- $\alpha$ ) évfolyamok szerinti és a teljes mintán az elsö adatfelvétel alapján

\begin{tabular}{lcccccc}
\hline \multirow{2}{*}{\multicolumn{1}{c}{ Skála }} & Tételek & \multicolumn{5}{c}{ Évfolyamok } \\
\cline { 3 - 7 } & száma & $\mathbf{4 .}$ & $\mathbf{5 .}$ & $\mathbf{6 .}$ & $\mathbf{7 .}$ & Összes \\
& 5 & 0,72 & 0,84 & 0,72 & 0,79 & 0,81 \\
Elsajátítási célstruktúra & 5 & 0,82 & 0,80 & 0,69 & 0,76 & 0,80 \\
Viszonyító célstruktúra & 3 & 0,69 & 0,90 & 0,76 & 0,87 & 0,85 \\
Tanár-diák kapcsolat & & & & &
\end{tabular}




\section{A továbbfejlesztés irányai}

Eredményeink szerint a tanári tevékenységekre utaló skálákhoz tartozó állítások száma általában alacsony, két skála, a csoportmunka és az értékelés jelentősége esetében mindössze egy-egy állítást tartottunk. Emellett megoldásra váró probléma, hogy a kérdőívtételek egy része nem az előzetes elvárásoknak megfelelően rendeződött skálákba. Mérőeszközünk továbbfejlesztéséhez így egyrészről az egyes skálákhoz kapcsolódóan fogalmaztunk meg további állításokat, másrészről az állítások újrarendezésével, valamint új állítások megfogalmazásával új skálákat hoztunk létre. A kérdőív első változatán nem szerepeltett tanulók csoportositása és egyéni felelösséget hangsúlyozó értékelés elnevezéssel soroltunk összetartozó csoportokba mondatokat. A 41. táblázatban közöljük az új skálák szerint rendezve a megtartott és új kérdőívtételeket. 
41. táblázat. A tanári tevékenységekre vonatkozó megtartott és új kérdöivtételek az elsö adatfelvétel alapján

\begin{tabular}{|c|c|c|}
\hline Skálák & Megtartott kérdöivtételek & Új kérdöívtételek \\
\hline \multirow[b]{3}{*}{ Feladat } & $\begin{array}{l}\text { Érdekes feladatokat oldunk meg } \\
\text { matekórán. (27.) }\end{array}$ & $\begin{array}{l}\text { Változatos feladatokat oldunk meg } \\
\text { matekórán. }\end{array}$ \\
\hline & A matekóráink unalmasak. (60.) & $\begin{array}{l}\text { Hasznos feladatokat oldunk meg } \\
\text { matekórán. }\end{array}$ \\
\hline & $\begin{array}{l}\text { Matekórán olyan játékokat is játszani } \\
\text { szoktunk, amibool tanulni lehet. } \\
\text { (15.) }\end{array}$ & $\begin{array}{l}\text { A matekóráink gyorsan eltelnek. } \\
\text { Olyan feladatokat oldunk meg } \\
\text { matekórán, amelyek az iskolán } \\
\text { kívül is hasznosak. }\end{array}$ \\
\hline
\end{tabular}

A matektanár észreveszi, ha jobban tudunk valamit, mint korábban. (59.)

Elismerés

A matektanár tényleg komolyan gondolja, ha megdicsér egy tanulót.

A matektanár elismeri, ha valaki (9.) rendesen dolgozik.

A matektanár észreveszi, ha sokat készülünk az órára. (54.)

Matekórán az kaphat jó jegyet, aki a

Matekórán versenyezni kell a többieknél jobb volt. (64.) tanulóknak a jó jegyért.

Normaorientált értékelés
A matektanár példaként állítja elénk azokat a tanulókat, akik jó jegyet kaptak. (4.)
A matektanár versenyezteti a tanulókat a jó jegyért.

A matektanár példaként állítja elénk azokat a tanulókat, akik jó dolgozatot írtak.

A matektanár el szokta mondani, hogy milyen típusú feladatok lesznek a dolgozatban.

Tudni szoktuk előre, ha matekból dolgozatot írunk.

Váratlanul írunk dolgozatot matekból. javításra. (46.)

A jobb matekosok nehezebb feladatokat szoktak kapni.

A gyengébb matekosok könnyebb feladatokat szoktak kapni.

A matektanár adni szokott, olyan feladatot, amit több tanulónak kell megoldania együtt.

Matekórán vannak olyan feladatok, amin a tanulók közösen dolgozhatnak.

Matekórán minden feladatot egyedül kell megoldanunk.

Megj.: a számok a tétel kérdőívben elfoglalt helyére utalnak. 


\section{A harmadik adatfelvétel}

\section{Minta}

Az utolsó adatfelvétel során az osztálytermi környezet kérdőív továbbfejlesztett változatát 861 tanuló töltötte ki 5-8. évfolyamon. A résztvevő tanulók évfolyamonkénti megoszlását, illetve az egyes évfolyamokon bevont osztályok számát a 42. táblázatban közöljük. A tanulók életkorának kiválasztását a célorientációkat vizsgáló kérdőív életkori alkalmazhatósága határozta meg (1. „A minták összeállitásának szempontjai” címü pontban).

42. táblázat. Az Osztálytermi környezet kérdöívet kitöltök a harmadik adatfelvétel során

\begin{tabular}{lccccc}
\hline \multirow{2}{*}{ Minta } & \multicolumn{5}{c}{ Évfolyamok } \\
\cline { 2 - 6 } & $\mathbf{5 .}$ & $\mathbf{6 .}$ & $\mathbf{7 .}$ & $\mathbf{8 .}$ & Összesen \\
\hline Tanulók & 203 & 218 & 245 & 195 & 861 \\
Osztályok & 9 & 10 & 11 & 10 & 40 \\
\hline
\end{tabular}

\section{Méröeszköz}

Utolsó felmérésünkben az osztálytermi környezet megismerése érdekében egyrészről a próbamérés alapján továbbfejlesztett kilenc skálát alkalmaztuk. Ezeket olyan továbbiakkal egészítettük, amelyek az osztályterem társas közegéröl szolgálnak információkkal. A kérdőív utolsó változatán így hat új skála szerepelt. Összesen 78 Likert-skálás állítás vonatkozott az osztálytermi légkörre, amelyből 16-ot a Tanulói célok kérdöíven jelenítettünk meg, törekedve arra, hogy közel azonos, 40 percet nem meghaladó időt vegyen igénybe mindkét kérdöív kitöltése. Az új skálák közül egyet angol nyelvröl fordítottunk magyarra, ötöt pedig korábbi hazai vizsgálatokban használt kérdőívekből emeltük át. A továbbiakban röviden bemutatjuk az állításcsoportokat, valamint indokoljuk, hogy miért szerepeltetjük ezeket mérőeszközünkön. A skálák elnevezését és fontosabb jellemzőit a 43. táblázatban foglaltuk össze, a teljes kérdöív skálák szerint rendezett állításai a 36. mellékletben láthatók.

Az új skálák egyike a tanulók közötti kölcsönös tisztelet támogatása elnevezést viseli, és öt magyarra fordított kérdőívtételből áll. Az eredeti angol nyelvü skálát Ryan és Patrick (2001) dolgozta ki és alkalmazta a célelmélethez kötődően 10-14 éves tanulók körében. A tanulók közötti kölcsönös tisztelet támogatása a biztonság érzésének, a szorongás csökkentésének és a hibázással kapcsolatos alacsony fenyegetettség légkörének megteremtésére való tanári törekvést fejezi ki, és többek között a tanulók egymás közötti kigúnyolásával kapcsolatosan tartalmaz állításokat. A konstruktum a viszonyító célstruktúrával minden bizonnyal összefügg, hiszen például a tanulók közötti teljesítményre vonatkozó gúny a teljesítmények nyilvános összevetésének egy formájaként is értelmezhető. A tanári viszonyító célstruktúrával való összefüggését Ryan és Patrick (2001) munkája igazolta.

További három skála a 2003-as PISA-vizsgálat magyar kérdőívén szerepelt tanári támogatás, fegyelmezési problémák és odatartozás érzése elnevezéssel. Hasonló állításokból álló, ugyancsak tanári támogatásnak nevezett skálájával Ryan és Patrick (2001) negatív irányú összefüggést fedezett fel a tanári viszonyító célstruktúrával. A skála ezen kívül a Meece, Herman és McCombs (2003) által felvett pozitív tanár-diák viszonyra törekvés és a tanulói vélemények tiszteletben tartása elnevezésű skálákkal is átfedést mutat, ami pozitív kapcsolatban áll a célorientációkkal. Ezen állításcsoport esetében fordítás helyett a PISA-mérésben korábban már kipróbált skála alkalmazása mellett döntöttünk. A fegyelmezési problémákat az osztály társas klímájának globális 
mutatójaként értelmezzük, ami minden bizonnyal összefügg a tanár-diák viszonnyal is. Jelentőségét emellett az adja, hogy a PISA-mérésben az osztálytermi folyamatokat leíró változók közül a legszorosabb kapcsolatban állt az iskolától való elfordulás mértékével (Willms, 2003). Az odatartozás érzése arra utal, hogy mennyire érzi magát a tanuló az osztályában magányosnak, kívülállónak. E változó osztályszintü aggregátuma ugyancsak az osztály társas klímájának egy átfogó mutatója, továbbá azt feltételezzük, hogy az osztálytermi környezet észlelését befolyásolja, hiszen az - mint korábban rámutattunk a „A kontextuális nézőpont a tanulási motiváció kutatásában” címü pontban - társas konstrukció eredménye. A tanári támogatásra és a fegyelmezési problémákra vonatkozó állításcsoportokat a PISA-mérésben a matematikaórákkal kapcsolatban fogalmazták meg, ezért e skálákat a PISA-kérdőívvel megegyező módon, négyfokú skálabeosztással vettük fel, figyelembe véve saját mintánk és a PISA-mérés reprezentatív mintájának összehasonlításban rejlő lehetőségeket. Az odatartozás érzése skála eredetileg az iskolára vonatkozott, így annyi módosítással éltünk, hogy az iskola szavakat osztályra cseréltük a mondatokban.

A pozitiv osztálylégkör és a tanárok szabályorientált viselkedése állításcsoportokat Dalbert és Stöber (2002) munkája alapján Jámbori Szilvia (2007) adaptálta. A pozitív osztálylégkör az osztály tanulói közötti kapcsolatokra utaló globális mutatóként értelmezhető, ami feltételezhetően a kölcsönös tisztelethez hasonló kapcsolatban áll a célstruktúrákkal, ugyanakkor attól eltérően nem a pedagógushoz kötődő jellemzőként értelmezhető. A tanárok szabályorientált viselkedéséhez kapcsolódó kérdőívtételek korábbi használatáról a célelmélettel összefüggésben nem tudunk, ugyanakkor Anderman, Patrick, Hruda és Linnenbrink (2002) osztálytermi megfigyelések alapján gyengébb elsajátítási célstruktúráról számolt be azokban az osztályokban, amelyekben a pedagógus nagy hangsúlyt fektetett a szabályok, bevett eljárásmódok követésére. Mindkét konstruktum esetében a hatfokú skálabeosztás helyett ötfokút alkalmaztunk, hozzáigazítva az általunk használt többi kérdőívtételhez. A tanárok szabályorientált viselkedése tekintetében további változtatást tettünk, a pedagógusokra általánosságban utaló állításokat konkretizáltuk, és a matematikatanárra vonatkozóan fogalmaztuk át.

\section{Érvényesség}

Az Osztálytermi környezet kérdőiv továbbfejlesztett változatának validitását faktoranalízis segítségével ellenőriztük a teljes mintán. A legelőnyösebb faktorstruktúrába rendeződött kérdőívtételek faktoranalízisének eredményeit a 44. táblázat közli. A KMO-mutató 0,90-es értéke a mutató osztályozásában a legjobb kategória alsó határát képviseli, vagyis a változórendszer kiválóan alkalmas a faktorizációra (Kaiser, 1974, idézi Ketskeméty és Izsó, 1996).

A legjobb interpretálhatóságra törekedve egyes skálákat, illetve állításokat elhagytunk. Így meg kellett válnunk több teljes skálától, így az odatartozás érzése, a tanár-diák kapcsolat, az elismerés és a csoportmunka elnevezésü állításcsoportoktól. A PISA-mérőeszközről átvett tanári támogatás és fegyelmezési problémák skálái mellett a célstruktúrák és a tanulók csoportosítása maradtak változatlanul. A normaorientált értékelés skála mindhárom megtartott mondata a tanulók közötti versenyhez kötődik, így a skála elnevezését versenyeztetésre változtattuk. A tanár-diák kapcsolat a tanári támogatással került egy faktorba, így a több állítást tartalmazó tanári támogatás skála megtartása mellett döntöttünk. Több skála mindössze három kérdőívtételből áll, ezek használatát megbízhatóságuktól tesszük függővé, ugyanakkor a megfelelö reliabilitásértékek mellett is megfontolandó később mérőeszköz-fejlesztésénél a tételek számának növelése. 
43. táblázat. Az Osztálytermi környezet kérdöiv skálái a harmadik adatfelvétel során

\begin{tabular}{|c|c|c|c|c|c|}
\hline Skálák & $\begin{array}{l}\text { Tételek } \\
\text { száma }\end{array}$ & Példatétel & Forrás & $\begin{array}{c}\text { Életkor } \\
\text { (év) }\end{array}$ & Megjegyzés \\
\hline Tanári támogatás & 6 & $\begin{array}{l}\text { A tanár külön segítséget nyújt, ha a } \\
\text { diákoknak szükségük van rá. }\end{array}$ & PISA (2003) & 15 & $\begin{array}{l}\text { A 2003-as PISA-mérés magyar kérdőívével } \\
\text { megegyező formában került felhasználásra } \\
\text { (négyfokú skálabeosztás). }\end{array}$ \\
\hline Fegyelmezési problémák & 5 & $\begin{array}{l}\text { A diákok az óra kezdete után még sokáig } \\
\text { nem látnak munkához. }\end{array}$ & PISA (2003) & 15 & $\begin{array}{l}\text { A 2003-as PISA-mérés magyar kérdőívével } \\
\text { megegyező formában került felhasználásra } \\
\text { (négyfokú skálabeosztás). }\end{array}$ \\
\hline Odatartozás érzése & 6 & $\begin{array}{l}\text { Az osztályomban kívülállónak érzem } \\
\text { magam (kimaradok a dolgokból). }\end{array}$ & PISA (2003) & 15 & $\begin{array}{l}\text { Az iskola helyett az osztályra vonatkozóan } \\
\text { fogalmaztuk meg az állításokat. }\end{array}$ \\
\hline Pozitív osztálylégkör & 10 & $\begin{array}{l}\text { Nálunk az osztályban inkább egymás ellen } \\
\text { dolgoznak a diákok, mintsem együtt. }\end{array}$ & $\begin{array}{l}\text { Dalbert és Stöber (2002) } \\
\text { alapján Jámbori (2007) }\end{array}$ & $15-18$ & $\begin{array}{l}\text { A hatfokú skálabeosztás helyett ötfokút } \\
\text { alkalmaztunk. }\end{array}$ \\
\hline $\begin{array}{l}\text { A matematikatanár } \\
\text { szabályorientált viselkedése }\end{array}$ & 4 & $\begin{array}{l}\text { A matektanár pontosan meghatározza, } \\
\text { hogy mit tehetek és mit nem. }\end{array}$ & $\begin{array}{c}\text { Dalbert és Stöber (2002) } \\
\text { alapján Jámbori (2007) }\end{array}$ & $15-18$ & $\begin{array}{l}\text { A skála eredetileg a tanulót oktató összes } \\
\text { tanárra vonatkozott. A hatfokú } \\
\text { skálabeosztás helyett ötfokút alkalmaztunk. }\end{array}$ \\
\hline $\begin{array}{l}\text { Tanulók közötti kölcsönös } \\
\text { tisztelet támogatása }\end{array}$ & 5 & $\begin{array}{l}\text { A matektanár nem engedi, hogy } \\
\text { kinevessük azt, aki rossz választ ad. }\end{array}$ & Ryan és Patrick (2001) & $10-14$ & $\begin{array}{l}\text { Korábban magyar nyelven nem használt } \\
\text { skála fordítására tettünk kísérletet. }\end{array}$ \\
\hline Tanár-diák kapcsolat & 3 & Kedvelem a matektanárt. & Próbamérés & $10-14$ & \\
\hline Elismerés & 4 & $\begin{array}{l}\text { A matektanár tényleg komolyan gondolja, } \\
\text { ha megdicsér egy tanulót. }\end{array}$ & Próbamérés & $10-14$ & $\begin{array}{l}\text { Egy további állítást fogalmaztunk meg e } \\
\text { skála esetében a próbamérés után. }\end{array}$ \\
\hline Normaorientált értékelés & 5 & $\begin{array}{l}\text { A matektanár példaként állítja elénk } \\
\text { azokat a tanulókat, akik jó jegyet kaptak. }\end{array}$ & Próbamérés & $10-14$ & $\begin{array}{l}\text { Három további állítást fogalmaztunk meg e } \\
\text { skála esetében a próbamérés után. }\end{array}$ \\
\hline Feladat & 7 & $\begin{array}{l}\text { Változatos feladatokat oldunk meg } \\
\text { matekórán. }\end{array}$ & Próbamérés & $10-14$ & $\begin{array}{l}\text { Négy további állítást fogalmaztunk meg e } \\
\text { skála esetében a próbamérés után. }\end{array}$ \\
\hline Tanulók csoportosítása & 3 & $\begin{array}{l}\text { Ha csoportban kell dolgozni a jó és rossz } \\
\text { matekosok külön csoportba kerülnek. }\end{array}$ & Próbamérés & $10-14$ & $\begin{array}{l}\text { Két további állítást fogalmaztunk meg e } \\
\text { skála esetében a próbamérés után. }\end{array}$ \\
\hline Csoportmunka & 4 & $\begin{array}{l}\text { A matektanár megengedi, hogy több tanuló } \\
\text { együtt dolgozzon egy feladaton. }\end{array}$ & Próbamérés & $10-14$ & $\begin{array}{l}\text { Három további állítást fogalmaztunk meg e } \\
\text { skála esetében a próbamérés után. }\end{array}$ \\
\hline $\begin{array}{l}\text { Egyéni felelősséget } \\
\text { hangsúlyozó értékelés }\end{array}$ & 6 & $\begin{array}{l}\text { Ha valakinek rosszul sikerül a } \\
\text { matekdolgozata megpróbálhatja újra. }\end{array}$ & Próbamérés & $10-14$ & $\begin{array}{l}\text { Három további állítást fogalmaztunk meg e } \\
\text { skála esetében a próbamérés után. }\end{array}$ \\
\hline Elsajátítási célstruktúra & 5 & $\begin{array}{l}\text { A tananyag megértése matekból fontos cél } \\
\text { az osztályunkban. }\end{array}$ & Próbamérés & $10-14$ & \\
\hline Viszonyító célstruktúra & 5 & $\begin{array}{l}\text { Az osztályunkban fontos, hogy ne tünjünk } \\
\text { butának matekból. }\end{array}$ & Próbamérés & $10-14$ & \\
\hline
\end{tabular}


44. táblázat. Az Osztálytermi környezet kérdöiv faktoranalizise a teljes mintán a harmadik adatfelvétel alapján

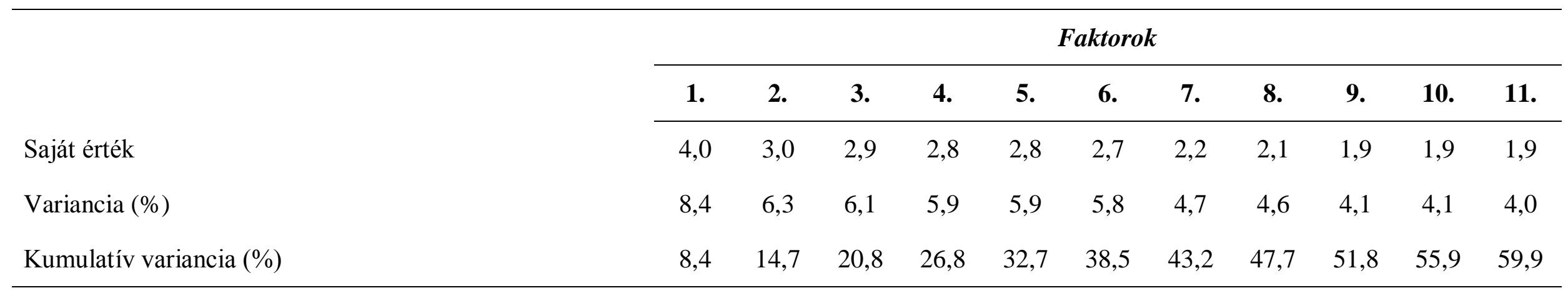

\section{Skálák, tételek}

\section{Tanári támogatás}

A tanár érdeklődést mutat minden diák tanulása iránt.

$\begin{array}{ccccccccccc}0,26 & -0,08 & 0,15 & 0,04 & 0,13 & \mathbf{0 , 6 5} & 0,18 & -0,01 & 0,04 & 0,00 & 0,02 \\ 0,19 & -0,03 & -0,06 & 0,05 & 0,24 & \mathbf{0 , 6 7} & 0,05 & 0,25 & 0,01 & 0,12 & 0,04 \\ -0,12 & -0,23 & 0,15 & 0,09 & -0,04 & 0,39 & 0,12 & -0,02 & 0,14 & -0,14 & 0,12 \\ 0,18 & -0,08 & 0,14 & 0,04 & 0,15 & \mathbf{0 , 7 0} & 0,15 & 0,18 & 0,10 & -0,03 & 0,02 \\ 0,37 & -0,03 & -0,06 & 0,09 & 0,18 & \mathbf{0 , 5 2} & 0,02 & 0,23 & 0,10 & -0,06 & 0,01 \\ 0,37 & -0,07 & 0,02 & 0,17 & 0,12 & \mathbf{0 , 5 3} & 0,11 & 0,01 & -0,03 & 0,01 & 0,01\end{array}$

A tanár külön segítséget nyújt, ha a diákoknak szükségük van rá.

A tanulók könyvekből és egyéb nyomtatott anyagból dolgoznak. (N)

A tanár segít a diákoknak a tanulásban.

A tanár addig magyarázza az anyagot, amíg mindenki meg nem érti.

A tanár lehetővé teszi a diákok számára, hogy kifejtsék véleményüket.

\section{Fegyelmezési problémák}

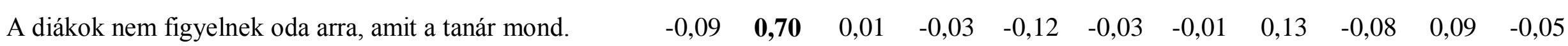


Az órán zaj és fegyelmezetlenség van.

A tanárnak sokáig kell várnia arra, hogy az osztály elcsendesedjen.

A diákok nem tudnak jól dolgozni.

A diákok az óra kezdete után még sokáig nem látnak munkához.

\section{Pozitív osztálylégkör}

Nálunk az osztályban ... megbízunk egymásban.

Nálunk az osztályban ... segítünk osztálytársainknak, ha valakinek segítségre van szüksége.

Nálunk az osztályban ... senkit sem zárunk ki az osztályközösségböl.

Nálunk az osztályban ... szívesen vagyunk együtt.

Nálunk az osztályban ... a legtöbb diák jól kijön egymással

\section{A matematikatanár szabályorientált viselkedése}

A matektanárnak világos szabályai és elő́rásai vannak arról, hogy hogyan viselkedjünk.

A matektanár az akarja, hogy mindig az ő szabályait kövessük.

A matektanár pontosan meghatározza, hogy mit tehetünk és mit nem.

\section{Tanulók közötti kölcsönös tisztelet támogatása}

A matektanár nem engedi, hogy a tanulók kinevessék

$\begin{array}{ccccccccccc}-0,03 & \mathbf{0 , 8 0} & -0,02 & -0,03 & 0,03 & -0,09 & -0,13 & -0,02 & -0,10 & 0,08 & 0,06 \\ -0,01 & \mathbf{0 , 7 9} & 0,00 & -0,10 & 0,05 & -0,09 & -0,06 & -0,01 & 0,05 & -0,07 & 0,18 \\ -0,08 & \mathbf{0 , 6 6} & 0,05 & -0,09 & -0,17 & -0,13 & 0,02 & -0,04 & 0,06 & 0,06 & 0,02 \\ -0,08 & \mathbf{0 , 6 9} & 0,05 & -0,09 & -0,07 & 0,04 & -0,02 & -0,19 & 0,03 & 0,03 & 0,18 \\ & & & & & & & & & & \\ 0,05 & -0,07 & 0,03 & \mathbf{0 , 7 5} & 0,03 & 0,00 & 0,03 & 0,02 & 0,09 & -0,01 & 0,02 \\ -0,05 & -0,09 & 0,06 & \mathbf{0 , 7 4} & 0,14 & 0,03 & -0,06 & 0,10 & -0,02 & 0,02 & 0,04 \\ 0,06 & -0,05 & -0,04 & \mathbf{0 , 5 9} & 0,09 & 0,12 & -0,08 & -0,01 & -0,06 & -0,04 & -0,06 \\ 0,07 & -0,03 & 0,07 & \mathbf{0 , 7 7} & -0,02 & 0,11 & 0,06 & -0,08 & -0,08 & -0,03 & -0,07 \\ 0,16 & -0,07 & 0,02 & \mathbf{0 , 7 1} & 0,02 & 0,00 & 0,08 & 0,03 & -0,02 & 0,01 & 0,02\end{array}$

$\begin{array}{lllllllllll}0,15 & -0,10 & 0,10 & -0,05 & 0,04 & 0,18 & 0,11 & 0,11 & \mathbf{0 , 7 3} & 0,10 & 0,03\end{array}$

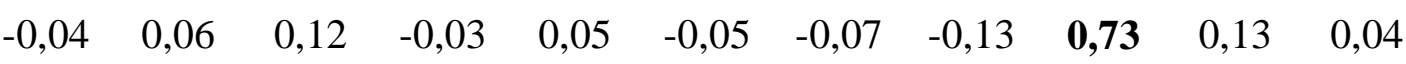

$\begin{array}{lllllllllll}0,15 & -0,01 & 0,14 & -0,02 & 0,12 & 0,10 & 0,14 & 0,09 & \mathbf{0 , 7 8} & 0,05 & 0,05\end{array}$

$\begin{array}{lllllllllll}0,12 & -0,05 & -0,03 & -0,01 & 0,19 & 0,11 & \mathbf{0 , 7 9} & 0,08 & 0,07 & 0,07 & 0,01\end{array}$ 
egymás ötleteit, elképzeléseit.

A matektanár nem engedi, hogy kinevessük azt, aki rossz választ ad.

$\begin{array}{lllllllllll}0,15 & -0,03 & 0,04 & 0,00 & 0,14 & 0,21 & \mathbf{0 , 7 7} & 0,14 & -0,01 & -0,04 & 0,01 \\ 0,28 & -0,15 & 0,06 & 0,05 & 0,12 & 0,17 & \mathbf{0 , 6 8} & 0,18 & 0,14 & -0,06 & 0,00\end{array}$
mondjanak egymásról.

\section{Versenyeztetés}

Matekórán az kaphat jó jegyet, aki a többieknél jobb volt.

Matekórán versenyezni kell a tanulóknak a jó jegyért.

A matektanár versenyezteti a tanulókat a jó jegyért.

$\begin{array}{ccccccccccc}0,01 & 0,10 & 0,16 & 0,05 & 0,06 & 0,04 & -0,10 & 0,17 & 0,17 & \mathbf{0 , 6 3} & 0,10 \\ -0,05 & 0,04 & 0,10 & -0,01 & 0,04 & -0,07 & 0,01 & -0,11 & 0,08 & \mathbf{0 , 7 9} & 0,09 \\ 0,04 & 0,05 & 0,11 & -0,10 & -0,11 & 0,00 & 0,07 & -0,11 & 0,05 & \mathbf{0 , 7 4} & 0,13\end{array}$

\section{Feladat}

Érdekes feladatokat oldunk meg matekórán.

Matekórán olyan játékokat is játszani szoktunk, amiből tanulni lehet.

Olyan feladatokat oldunk meg matekórán, amelyek az iskolán kívül is hasznosak.

A matekóráink gyorsan eltelnek.

Hasznos feladatokat oldunk meg matekórán.

Változatos feladatokat oldunk meg matekórán.

\section{Tanulók csoportosítása}

Ha csoportban kell dolgozni a jó és rossz matekosok külön csoportba kerülnek.

$\begin{array}{ccccccccccc}\mathbf{0 , 7 0} & -0,05 & -0,06 & 0,16 & -0,05 & -0,20 & -0,15 & 0,09 & -0,05 & 0,00 & 0,19 \\ \mathbf{0 , 5 8} & 0,10 & -0,12 & 0,17 & 0,07 & -0,12 & -0,20 & -0,02 & -0,27 & -0,07 & 0,13 \\ \mathbf{0 , 6 3} & 0,11 & -0,05 & 0,07 & -0,01 & -0,25 & -0,05 & 0,05 & -0,24 & -0,06 & 0,24 \\ \mathbf{0 , 5 5} & -0,05 & -0,03 & 0,03 & -0,19 & -0,21 & -0,23 & 0,13 & -0,14 & -0,12 & 0,03 \\ \mathbf{0 , 7 1} & -0,08 & -0,07 & 0,09 & -0,20 & -0,07 & -0,15 & 0,11 & -0,15 & -0,08 & 0,06 \\ \mathbf{0 , 6 3} & -0,04 & -0,14 & 0,09 & -0,02 & -0,08 & -0,12 & 0,09 & -0,22 & -0,13 & 0,22 \\ & & & & & & & & & & \\ -0,08 & 0,09 & 0,08 & 0,03 & 0,02 & 0,06 & -0,08 & -0,12 & -0,04 & 0,24 & \mathbf{0 , 5 4}\end{array}$


A jobb matekosok nehezebb feladatokat szoktak kapni.

A gyengébb matekosok könnyebb feladatokat szoktak kapni.

\section{Egyéni felelősséget hangsúlyozó számonkérés}

Matekórán gyakran beszélünk arról, hogy milyen feladatok lesznek a dolgozatban.

A matektanár el szokta mondani, hogy milyen típusú feladatok lesznek a dolgozatban.

Tudni szoktuk elöre, ha matekból dolgozatot írunk.

\section{Elsajátítási célstruktúra}

Az osztályunkban fontos a kitartó munka matekból.

A tananyag megértése matekból fontos cél az osztályunkban.

Az új dolgok tanulása matekból fontos cél az osztályunkban.

A matekfeladatok megértése fontos cél az osztályunkban.

Az osztályunkban fontos, hogy értsük is az anyagot matekból, ne csak bemagoljuk.

\section{Viszonyító célstruktúra}

Az osztályunkban fontos cél, hogy a többieknél jobb jegyet szerezzünk matekból.

Az osztályunkban fontos megmutatni, hogy a többieknél nem vagyunk rosszabbak matekból.

$\begin{array}{lllllllllll}0,14 & 0,13 & 0,06 & -0,05 & 0,10 & 0,00 & 0,04 & 0,12 & 0,08 & 0,07 & \mathbf{0 , 8 2} \\ 0,20 & 0,13 & 0,12 & -0,04 & 0,03 & 0,06 & 0,06 & 0,09 & 0,08 & 0,06 & \mathbf{0 , 8 1}\end{array}$

$\begin{array}{lllllllllll}0,26 & -0,03 & -0,03 & 0,06 & 0,17 & 0,12 & 0,10 & \mathbf{0 , 7 3} & 0,07 & 0,04 & 0,06\end{array}$

$\begin{array}{lllllllllll}0,21 & -0,01 & 0,05 & 0,00 & 0,15 & 0,18 & 0,09 & \mathbf{0 , 7 9} & 0,02 & 0,01 & 0,00\end{array}$

$\begin{array}{lllllllllll}0,09 & -0,07 & 0,22 & -0,02 & -0,05 & 0,13 & 0,22 & \mathbf{0 , 6 1} & -0,05 & -0,21 & 0,05\end{array}$

$\begin{array}{lllllllllll}0,32 & -0,10 & 0,29 & 0,15 & \mathbf{0 , 5 8} & 0,10 & 0,12 & 0,13 & 0,11 & 0,02 & 0,06\end{array}$

$\begin{array}{lllllllllll}0,20 & -0,12 & 0,22 & 0,01 & \mathbf{0 , 6 8} & 0,20 & 0,14 & 0,05 & 0,08 & 0,01 & 0,01\end{array}$

$\begin{array}{lllllllllll}0,31 & -0,07 & 0,21 & 0,09 & \mathbf{0 , 6 6} & 0,12 & 0,16 & 0,08 & 0,06 & 0,06 & 0,10\end{array}$

$\begin{array}{lllllllllll}0,24 & -0,07 & 0,26 & 0,11 & \mathbf{0 , 6 6} & 0,27 & 0,15 & 0,04 & 0,08 & -0,04 & 0,05\end{array}$

$\begin{array}{lllllllllll}0,39 & -0,07 & 0,07 & 0,18 & \mathbf{0 , 5 3} & 0,23 & 0,16 & 0,21 & 0,01 & -0,09 & 0,06\end{array}$

$\begin{array}{lllllllllll}-0,01 & 0,01 & \mathbf{0 , 7 0} & 0,10 & 0,18 & 0,04 & 0,02 & -0,01 & 0,13 & 0,17 & 0,17\end{array}$

$\begin{array}{lllllllllll}0,22 & 0,01 & \mathbf{0 , 7 4} & 0,03 & 0,11 & 0,04 & 0,00 & -0,01 & 0,08 & 0,01 & -0,02\end{array}$ 
Az osztályunkban fontos, hogy mások előtt ne hibázzunk matekból.

$\begin{array}{lllllllllll}0,08 & 0,07 & \mathbf{0 , 7 7} & 0,00 & 0,04 & 0,07 & -0,13 & 0,08 & 0,08 & 0,10 & -0,02\end{array}$

Az osztályunkban fontos, hogy ne tünjünk butának matekból.

$\begin{array}{lllllllllll}0,09 & -0,02 & \mathbf{0 , 6 2} & 0,03 & 0,34 & 0,07 & 0,13 & 0,06 & 0,12 & 0,07 & 0,17\end{array}$

$\begin{array}{cllllllllllllll}\mathrm{Az} & \text { osztályunkban fontos, hogy ne tünjön úgy, a } & 0,28 & 0,04 & \mathbf{0 , 5 0} & -0,02 & 0,19 & 0,06 & 0,14 & 0,08 & 0,01 & 0,13 & 0,10\end{array}$ matekfeladatok nehezek.

Megj.: fökomponens analízis Varimax rotációval, forgatás előtt 1-nél nagyobb sajátértékü faktorok, a 0,4-nél nagyobb faktorsúlyokat félkövér szedés jelzi; az $\mathrm{N}$ negatív megfogalmazású tételt jelöl. 


\section{Megbízhatóság}

A 45. táblázatban láthatók a faktoranalízis alapján azonos látens változót reprezentáló kérdőívtételek csoportjainak reliabilitásmutatói mind a teljes mintára, mind az egyes évfolyamokra vonatkoztatva. A magasabb évfolyamokon többnyire pontosabban mérnek a skálák, ugyanakkor a 7. évfolyam esetében a megbízhatóság a skálák többségét tekintve valamivel meghaladja a 8. évfolyam értékeit. A mindössze három állítást tartalmazó állításcsoportok reliabilitása a várakozásoknak megfelelően a többi skálához viszonyítva általában alacsonyabb. Ez alól ugyanakkor a tanulók közötti kölcsönös tisztelet támogatása skála kivételt jelent, ennek pontossága 6 . évfolyamtól kezdődően jónak mondható.

$\mathrm{Az}$ itemkihagyásos reliabilitást minden skála tekintetében évfolyamonként is ellenőriztük. Az eredmények alapján egyetlen skála esetében sem láttuk indokoltnak, hogy kérdőívtételtől váljunk meg.

45. táblázat. Az Osztálytermi környezet kérdöív érvényes skáláinak megbizhatósági mutatói (Cronbach- $\alpha$ ) évfolyamok szerinti és a teljes mintán a harmadik adatfelvétel alapján

\begin{tabular}{|c|c|c|c|c|c|c|}
\hline \multirow{2}{*}{ Skálák } & \multirow{2}{*}{$\begin{array}{l}\text { Tételek } \\
\text { száma }\end{array}$} & \multicolumn{5}{|c|}{ Évfolyamok } \\
\hline & & 5. & 6. & 7. & 8. & Összes \\
\hline Tanári támogatás & 6 & 0,66 & 0,70 & 0,73 & 0,77 & 0,79 \\
\hline Fegyelmezési problémák & 5 & 0,71 & 0,79 & 0,84 & 0,80 & 0,79 \\
\hline Pozitív osztálylégkör & 5 & 0,73 & 0,73 & 0,82 & 0,79 & 0,77 \\
\hline $\begin{array}{l}\text { A matematikatanár } \\
\text { szabályorientált viselkedése }\end{array}$ & 3 & 0,68 & 0,64 & 0,74 & 0,66 & 0,69 \\
\hline $\begin{array}{l}\text { Tanulók közötti kölcsönös } \\
\text { tisztelet támogatása }\end{array}$ & 3 & 0,70 & 0,80 & 0,82 & 0,79 & 0,79 \\
\hline Feladat & 6 & 0,74 & 0,73 & 0,84 & 0,84 & 0,81 \\
\hline Versenyeztetés & 3 & 0,68 & 0,65 & 0,70 & 0,65 & 0,67 \\
\hline Tanulók csoportosítása & 3 & 0,63 & 0,60 & 0,74 & 0,65 & 0,66 \\
\hline $\begin{array}{l}\text { Egyéni felelősséget hangsúlyozó } \\
\text { számonkérés }\end{array}$ & 3 & 0,60 & 0,64 & 0,74 & 0,80 & 0,72 \\
\hline Elsajátítási célstruktúra & 5 & 0,80 & 0,79 & 0,84 & 0,83 & 0,85 \\
\hline Viszonyító célstruktúra & 5 & 0,82 & 0,70 & 0,79 & 0,77 & 0,79 \\
\hline
\end{tabular}

\section{Összegzés}

Adataink arról tájékoztattak, hogy az egyes skálákhoz tartozó kérdőívtételekből létrehozhatók összevont mutatók. A következőkben ezekre az aggregált mutatókra kívánunk támaszkodni az osztálytermi környezet motivációs jellemzőnek leírásához, illetve a tanulók motivációs jellemzői és az osztálytermi környezet közötti összefüggések feltárásához.

Megállapítható, hogy az évfolyamok mindegyikén minden vizsgált skála Cronbach- $\alpha$ mutatója eléri a használhatóság 0,6-os értékét, vagyis a skálák ötödik osztálytól kezdve alkalmazhatók. Bár e skálák alkalmasak a munkánk céljaival összefüggő elemzésekhez, az eredmények alapján lényegesnek bizonyuló, ugyanakkor mindössze három tételből álló skálákhoz a jövőben további kérdőívtételek fejlesztése szükséges. 


\section{A VIZSGÁLT KONSTRUKTUMOK JELLEMZÖI}

Ebben a fejezetben a harmadik adatfelvétel alapján azoknak a konstruktumoknak az általános jellemzőit ismertetjük, amelyek esetében mérőeszközeink megfelelöen müködtek. Elöször a célorientációkat, majd a célstruktúrákat jellemezzük, végül a tanári tevékenységek és a társas közeg megismerésére létrehozott változóinkat vizsgáljuk meg. E konstruktumok sajátosságainak ismerete a későbbiekben egyrészről összefüggéseik értelmezéséhez járulhat hozzá, másrészről az említett változócsoportok belső kapcsolatainak feltárása információt kínál tanulónk, iskoláink motivációs sajátosságáról, választ kínálva egyes kutatási kérdéseinkre.

\section{Célorientációk}

\section{Általános jellemzök}

Ebben a pontban a célorientációk általános jellemzőit vizsgáljuk meg, elsősorban olyan jellemzők, összefüggések után kutatva, amelyek lényegesek lehetnek további elemzéseink szempontjából. A tanulók motívumainak jellemzésekor általánosan használt fejlettség kifejezést szándékosan kerüljük, hiszen ez a motívumok kedvező következményeire utal, ami a célorientációk esetében félreértésekre adhat okot. A viszonyító teljesítménykerülő és a tanulást kerülő cél esetében a magasabb értékek kedvezőtlen motivációs jellemzőkre utalnak, míg az elsajátítási teljesítménykereső cél kapcsán éppen ellentétesen értelmezhetők a magasabb értékek. A képet tovább árnyalja, hogy a másik két cél következményei kevésbé egyértelmüek, vagyis elönyös vagy előnytelen hatásuk a tanulás eredményességével összefüggő különböző változók esetében eltérő lehet.

A célorientációs elmélettel foglalkozó szakirodalomban konszenzus alakult ki arra vonatkozóan, hogy a célokat a tanulási környezet formálja, vagyis kontextusfüggő konstruktumokként értelmezhetők. Azonban nincs egyetértés abban a tekintetben, hogy a környezet szerepe mekkora jelentőséggel bír. Míg egyesek a célok környezet általi befolyásolhatóságát, mások viszonylagos stabilitását emelik. A különböző életkorú tanulók céljainak vizsgálata keresztmetszeti adatfelvételek tükrében nem jellemző. Amennyiben egy mérési pont alapján eltérő életkorú tanulók céljait vetik egybe, általában különböző iskolafokozatra járó tanulókról van szó, a feltárt különbségeket pedig az eltérö tanulási környezeteknek tulajdonítják, és nem a tanulók fejlődéséhez kötődően értelmezik (pl. Anderman és Midgley, 1997; Meece, Herman és McCombs, 2003).

Annak ellenére, hogy az évfolyamok összehasonlítása ritkán alkalmazott megoldás, a következőkben ilyen jellegü összevetéseket is végzünk. Tesszük ezt egyrészről azért, mert úgy véljük, az eredmények lényeges jellemzőit tárhatják fel mintánknak, amely a további elemzéseinket befolyásolhatja, másrészről úgy gondoljuk, hogy a tanulási környezet változása nem kizárólag az iskolafokozatok között, de adott iskolafokozaton belül, évfolyamok szerint is jelentős eltéréseket rejthet magában. Például a képesség jellegü tudásról egyre inkább az ismeret jellegü tudásra helyeződik a hangsúly vagy a továbbtanuláshoz közeledve egyre erősebb lesz a teljesítményre irányuló nyomás.

A 46. táblázatban foglaltuk össze a célok átlagait és szórásait évfolyamok szerint, és varianciaanalízist végeztünk, hogy kiderítsük, az évfolyamok között adódó eltérések szignifikánsak-e. Mivel nem rendelkezünk viszonyítási pontokkal a célokat 
mérő kérdőívünkkel kapcsolatban, a minta egészére vonatkozó adatokból nem tudunk következtetéseket levonni, ezen adatokat a 37. mellékletben tüntettük fel.

A varianciaanalízis eredményei három célnál jeleznek szignifikáns különbségeket az évfolyamok között, az elsajátítási teljesítménykereső és a viszonyító mindkét dimenziójában. Mindhárom esetben az 5. évfolyam jellemzői eltérőek $(\{5\}<$ $\{6,7,8\})$. A szórások jól láthatóan alig különböznek, egyetlen esetben, az elsajátítási teljesítménykerülő cél tekintetében mutatkozott különbség, itt is az 5. osztályosok különböztek a minta többi részétől. Tehát az elsődleges eredmények arról tanúskodnak, hogy az ötödikesek kivételével mintánk évfolyamok szerinti bontásban hasonlónak tekinthető.

46. táblázat. A célorientációk összehasonlitása évfolyamok szerint

\begin{tabular}{|c|c|c|c|c|c|c|c|c|c|c|}
\hline \multirow{3}{*}{ Célok } & \multicolumn{10}{|c|}{ Évfolyamok } \\
\hline & \multicolumn{2}{|c|}{5.} & \multicolumn{2}{|c|}{6.} & \multicolumn{2}{|c|}{7} & \multicolumn{2}{|c|}{8.} & \multicolumn{2}{|c|}{$A N O V A$} \\
\hline & Átlag & Szórás & Átlag & Szórás & Átlag & Szórás & Átlag & Szórás & $\mathrm{F}$ & $\mathrm{p}$ \\
\hline $\begin{array}{l}\text { Elsajátítási } \\
\text { teljesítmény- } \\
\text { kereső cél }\end{array}$ & 4,34 & 0,74 & 4,03 & 0,83 & 4,02 & 0,80 & 3,92 & 0,84 & 10,44 & $<0,01$ \\
\hline $\begin{array}{l}\text { Elsajátítási } \\
\text { teljesítmény- } \\
\text { kerülő cél }\end{array}$ & 3,10 & 1,21 & 3,10 & 1,03 & 3,20 & 1,02 & 3,32 & 1,01 & 2,02 & 0,11 \\
\hline $\begin{array}{l}\text { Viszonyító } \\
\text { teljesítmény- } \\
\text { kereső cél }\end{array}$ & 3,42 & 1,29 & 3,06 & 1,21 & 2,86 & 1,13 & 2,85 & 1,21 & 10,34 & $<0,01$ \\
\hline $\begin{array}{l}\text { Viszonyító } \\
\text { teljesítmény- } \\
\text { kerülő cél }\end{array}$ & 4,16 & 0,89 & 3,80 & 0,92 & 3,74 & 0,93 & 3,72 & 1,04 & 10,24 & $<0,01$ \\
\hline $\begin{array}{l}\text { Tanulást } \\
\text { kerülő cél }\end{array}$ & 3,12 & 0,94 & 3,20 & 0,94 & 3,20 & 0,97 & 3,08 & 0,94 & 0,95 & 0,42 \\
\hline
\end{tabular}

\section{Belsö összefüggések}

A következőkben a célorientációk belső összefüggéseit vizsgáljuk meg. A célorientációk közötti kapcsolatok megismerése tanulóink körében önmagában is informatív, a különböző célok együtt járásáról, kombinációjáról kínál tájékoztatást. Emellett bizonyos összevetéseket tehetünk az Egyesült Államokban feltárt kapcsolatokkal, amelyek mérőeszközünk müködéséről és az eddig megismert összefüggések hazai kontextusra való adaptálhatósága tekintetében bővítik tudásunk. A célorientációk közötti kapcsolatokat jó ideig univerzálisnak tekintették, hiszen az összefüggések hasonló mintázata rajzolódott ki a - többségében az Egyesült Államokban végzett - kutatások alapján. Az utóbbi években azonban több olyan beszámoló is napvilágot látott, amelyekben nem egyesült államokbeli tanulókat vizsgáltak, és amelyek eredményei szerint e kapcsolatok a korábbiaktól bizonyos pontokon eltértek (1. a „Kulturális különbségek” címü pontban.). Vagyis amennyiben jelentős eltéréseket fedezünk fel, úgy kulturális különbségekre gyanakodhatunk, továbbá valószínüsíthetjük azt is, hogy a célorientációk összefüggése a tanulást befolyásoló egyéb tényezőkkel ugyancsak különbözhet. Például az egyes céltípusok teljesítményre gyakorolt hatásában, ha a célok az eddigiektől eltérő kombinációban fordulnak elö. 
A célorientációk közötti korrelációkat kiszámítottuk a teljes mintára (47. táblázat) és az egyes évfolyamokra (48-51. táblázat) vonatkozóan egyaránt. A teljes mintát tekintve láthatjuk, hogy a tanulást kerülö cél kivételével minden céltípus között szignifikáns az összefüggés, a legmagasabb korrelációs értékeket a viszonyító teljesítménykerülő cél esetében kaptuk. Ha évfolyamok szerint vizsgáljuk meg az összefüggések mintázatát, kevés lényegi eltérést találunk. Egyrészről az elsajátítási cél két típusa között az 5. évfolyamon nincs szignifikáns összefüggés, másrészről ugyanezen az évfolyamon a tanulást kerülő cél a viszonyító teljesítménykerülővel is szignifikáns kapcsolatban áll. A z-próba eredményei szerint egyetlen szignifikáns különbség sem adódott az évfolyamok között. Külön kiemelendő, hogy minden évfolyamon a viszonyító teljesítménykerülö célhoz kapcsolódik legerösebben minden további cél, vagyis e cél a célok különféle kombinációjában jelentős súlyt képvisel. Megjegyezzük, hogy e célorientáció a tanulást befolyásoló egyéb változókra és a teljesítményre is kedvezőtlenül hatást gyakorol az eddigi eredmények szerint.

47. táblázat. A célorientációk korrelációi a teljes mintán

\begin{tabular}{lccccc}
\hline & $\mathbf{1 .}$ & $\mathbf{2 .}$ & $\mathbf{3 .}$ & $\mathbf{4 .}$ & $\mathbf{5 .}$ \\
\hline 1. Elsajátítási teljesítménykereső cél & - & & & & \\
2. Elsajátítási teljesítménykerülő cél & $\mathbf{0 , 2 8}$ & - & & & \\
3. Viszonyító teljesítménykereső cél & $\mathbf{0 , 3 7}$ & $\mathbf{0 , 2 7}$ & - & & \\
4. Viszonyító teljesítménykerülő cél & $\mathbf{0 , 4 9}$ & $\mathbf{0 , 3 4}$ & $\mathbf{0 , 5 4}$ & - & - \\
5. Tanulást kerülő cél & $-0,08$ & $\mathbf{0 , 2 1}$ & 0,16 & 0,05 & -
\end{tabular}

Megj.: félkövér szedés jelzi a 0,01 alatti szinten szignifikáns összefüggéseket.

48. táblázat. A célorientációk korrelációi 5. évfolyamon

\begin{tabular}{lccccc}
\hline & $\mathbf{1 .}$ & $\mathbf{2 .}$ & $\mathbf{3 .}$ & $\mathbf{4}$. & $\mathbf{5 .}$ \\
\hline 1. Elsajátítási teljesítménykereső cél & - & & & & \\
2. Elsajátítási teljesítménykerülö cél & 0,13 & - & & & \\
3. Viszonyító teljesítménykereső cél & $\mathbf{0 , 3 1}$ & $\mathbf{0 , 2 6}$ & - & & \\
4. Viszonyító teljesítménykerülő cél & $\mathbf{0 , 4 1}$ & $\mathbf{0 , 2 8}$ & $\mathbf{0 , 5 0}$ & - & \\
5. Tanulást kerülő cél & 0,13 & $\mathbf{0 , 2 7}$ & $\mathbf{0 , 3 4}$ & 0,22 & - \\
\hline
\end{tabular}

Megj.: félkövér szedés jelzi a 0,01 alatti szinten szignifikáns összefüggéseket.

49. táblázat. A célorientációk korrelációi 6. évfolyamon

\begin{tabular}{lccccc}
\hline & $\mathbf{1 .}$ & $\mathbf{2 .}$ & $\mathbf{3 .}$ & $\mathbf{4}$ & $\mathbf{5 .}$ \\
\hline 1. Elsajátítási teljesítménykereső cél & - & & & & \\
2. Elsajátítási teljesítménykerülő cél & $\mathbf{0 , 2 9}$ & - & & & \\
3. Viszonyító teljesítménykereső cél & $\mathbf{0 , 3 3}$ & $\mathbf{0 , 3 0}$ & - & & \\
4. Viszonyító teljesítménykerülő cél & $\mathbf{0 , 5 2}$ & $\mathbf{0 , 3 9}$ & $\mathbf{0 , 4 9}$ & - & \\
5. Tanulást kerülő cél & $-0,11$ & $\mathbf{0 , 2 5}$ & $-0,01$ & $-0,11$ & - \\
\hline
\end{tabular}

Megj.: félkövér szedés jelzi a 0,01 alatti szinten szignifikáns összefüggéseket. 


\begin{tabular}{lccccc}
\hline & $\mathbf{1 .}$ & $\mathbf{2 .}$ & $\mathbf{3 .}$ & $\mathbf{4 .}$ & $\mathbf{5 .}$ \\
\hline 1. Elsajátítási teljesítménykereső cél & - & & & & \\
2. Elsajátítási teljesítménykerülő cél & $\mathbf{0 , 3 4}$ & - & & & \\
3. Viszonyító teljesítménykereső cél & $\mathbf{0 , 3 4}$ & $\mathbf{0 , 2 8}$ & - & & \\
4. Viszonyító teljesítménykerülő cél & $\mathbf{0 , 4 0}$ & $\mathbf{0 , 3 1}$ & $\mathbf{0 , 5 4}$ & - & \\
5. Tanulást kerülö cél & $-0,09$ & $\mathbf{0 , 1 6}$ & $\mathbf{0 , 1 6}$ & 0,05 & - \\
\hline
\end{tabular}

Megj.: félkövér szedés jelzi a 0,01 alatti szinten szignifikáns összefüggéseket; dőlt és félkövér szedés jelzi a 0,01 és 0,05 közötti szinten szignifikáns összefüggéseket.

51. táblázat. A célorientációk korrelációi 8. évfolyamon

\begin{tabular}{lccccc}
\hline & $\mathbf{1 .}$ & $\mathbf{2 .}$ & $\mathbf{3 .}$ & $\mathbf{4 .}$ & $\mathbf{5 .}$ \\
\hline 1. Elsajátítási teljesítménykereső cél & - & & & & \\
2. Elsajátítási teljesítménykerülö cél & $\mathbf{0 , 4 4}$ & - & & & \\
3. Viszonyító teljesítménykereső cél & $\mathbf{0 , 4 5}$ & $\mathbf{0 , 3 1}$ & - & & \\
4. Viszonyító teljesítménykerülő cél & $\mathbf{0 , 5 6}$ & $\mathbf{0 , 4 6}$ & $\mathbf{0 , 5 7}$ & - & \\
5. Tanulást kerülő cél & $\mathbf{- 0 , 2 3}$ & $\mathbf{0 , 1 5}$ & $\mathbf{0 , 1 7}$ & 0,05 & - \\
\hline
\end{tabular}

Megj.: félkövér szedés jelzi a 0,01 alatti szinten szignifikáns összefüggéseket; dölt és félkövér szedés jelzi a 0,01 és 0,05 közötti szinten szignifikáns összefüggéseket.

A következőkben megkísérlünk következtetéseket levonni a célorientációk amerikai és hazai mintán feltárt kapcsolatainak összevetéséből. Szem elött kell tartanunk, hogy a célorientációk mintázatának összehasonlítását több tényező is akadályozza. Az első, hogy az azonosságokról és különbözőségekről biztos következtetéseket azonos életkorban felvett ekvivalens kérdőívek alapján vonhatnánk le, ami esetünkben nem teljesül. További akadály, hogy 2x2-es célfelosztást követő kérdőívet tudomásunk szerint alig alkalmaztak még általános iskolás korosztály körében. Az egyetlen általunk ismert kivételt Lau és Lee (2008) munkája jelenti, amelynek elemzésünk szempontjából releváns eredményeire a későbbiekben kitérünk. A négyes felosztás esetében viszonyítási pontként felnőtt korosztály eredményeit használhatjuk. Az előbbiek mellett meg kell jegyeznünk azt is, hogy a tanulást kerülö célt csak szük körben alkalmazzák, így e cél esetében alig találhatunk igazodási pontként alkalmazott munkákat.

A 2x2-es felosztás korrelációit Baranik és munkatársainak (2010) tanulmánya alapján mutatjuk be, amely 54 ( $\mathrm{n}=9014)$, föként az AGQ kérdőívet alkalmazó adatgyüjtés eredményeiből számol becsült értékeket metaanalízis-technikával. A Baranik és munkatársai (2010) által számolt célok közötti korrelációkat, valamint jelen felmérés teljes mintára vonatkozó korrelációit az 52. táblázatban foglaltuk össze az összevetés megkönnyítése érdekében. Természetesen a korrelációkat a minta mérete is befolyásolja, ugyanakkor az összefüggések mintázata lényeges információkat rejthet. 
52. táblázat. A célorientációk korrelációi (Baranik és mtsai, 2010, 274. o. részlet)

\begin{tabular}{|c|c|c|c|c|c|c|c|c|}
\hline \multirow{2}{*}{ Célok } & \multicolumn{4}{|c|}{ Amerikai minta* } & \multicolumn{4}{|c|}{ Magyar minta** } \\
\hline & 1. & 2. & 3. & 4. & 1. & 2. & 3. & 4. \\
\hline $\begin{array}{l}\text { 1. Elsajátítási } \\
\text { teljesítménykereső cél }\end{array}$ & - & & & & - & & & \\
\hline $\begin{array}{l}\text { 2. Elsajátítási } \\
\text { teljesítménykerülő cél }\end{array}$ & 0,29 & - & & & 0,28 & - & & \\
\hline $\begin{array}{l}\text { 3. Viszonyító } \\
\text { teljesítménykereső cél }\end{array}$ & 0,34 & 0,23 & - & & $\mathbf{0 , 3 7}$ & 0,27 & - & \\
\hline $\begin{array}{l}\text { 4. Viszonyító } \\
\text { teljesítménykerülő cél }\end{array}$ & $\mathbf{0 , 1 3}$ & $\mathbf{0 , 4 6}$ & $\mathbf{0 , 5 1}$ & - & 0,49 & $\mathbf{0 , 3 4}$ & 0,54 & - \\
\hline
\end{tabular}

Az eredmények összevetése alapján láthatjuk, hogy a viszonyító teljesítménykerülő célt nem számítva, mindössze néhány századnyi különbségeket láthatunk a korrelációk között, de a viszonyító cél két típusa között ugyancsak jelentéktelen a különbség. A viszonyító teljesítménykerülő cél esetében adódnak említésre méltó eltérések, kisebb az elsajátítási teljesítménykerülő céllal való kapcsolat erősségében, és rendkívül jelentős az elsajátítási teljesítménykereső céllal való kapcsolatban. Utóbbi jelentőségét talán az jelzi leginkább, hogy míg az amerikai mintán itt találjuk a leggyengébb összefüggést, a magyar mintán ez a második legerősebb.

Megjegyezzük, hogy az elsajátítási teljesítménykereső és a viszonyító teljesítménykerülő cél kapcsolatában Lau és Lee (2008) hasonlót tapasztalt az adaptált négyes felosztású AGQ-kérdőív adatait elemezve kínai 7-10. évfolyamos tanulók körében $(\mathrm{r}=0,49 ; \mathrm{p}<0,01 ; \mathrm{n}=270)$. Dela Rosa (2010) ugyancsak e kérdőív adaptációja alapján filippínó középiskolások körében tapasztalt hasonlót $(r=0,38 ; p<0,01 ; n=682)$. Shih (2005) hatodikos tajvani diákok körében hármas felosztású kérdőívével a viszonyító teljesítménykerülő és az elsajátítási cél között kapott a vártnál erősebb összefüggést $(\mathrm{r}=0,24 ; \mathrm{p}<0,01 ; \mathrm{n}=242)$. Az említett kutatási eredmények alapján a magyar és amerikai minta között észlelt különbségekből így nem mérőeszközünk esetleges problémáira, hanem a magyar minta eltérő jellemzőire következtetünk.

A legkevesebb viszonyítási lehetőség a tanulást kerülő cél esetében adódik, hiszen e céltípus alkalmazása nem általános. Meece, Herman és McCombs (2003) két életkori csoportot vizsgált (fiatalabb: $n=2649$; idösebb $n=1966$ ). A szerzők csak az iskolafokozatot közlik, a tanulók pontos életkorát nem. A kutatásban említett middle school és a high school elnevezésü iskolafokozatok az életkort tekintve megközelítőleg a hazai felső tagozatnak és középiskolának felelnek meg (U. S. Department of State, é. n.). Mindkét korcsoport körében ugyanazt az eredményt kapta, az elsajátítási és tanulást kerülö cél között $-0,14(\mathrm{p}<0,01)$, míg a viszonyító és tanulást kerülő cél között 0,37 $(\mathrm{p}<0,01)$ volt a korreláció értéke. Niemivirta (2002) 9. évfolyamosok körében $(\mathrm{n}=143)$ végzett felmérésében az elsajátítási céllal -0,27-es $(\mathrm{p}<0,01)$, míg a viszonyító teljesítménykerülö céllal 0,15-ös $(\mathrm{p}<0,05)$ korrelációkat kapott. Brdar, Rijavec és Loncaric (2006) ugyancsak középiskolások körében $(\mathrm{n}=1131)$ az elsajátítási céllal 0,24-es $(\mathrm{p}<0,01)$, míg a viszonyító céllal 0,10 -es $(\mathrm{p}<0,01)$ korrelációs értékeket kaptak. Mivel a célok teljesítménykereső-teljesítménykerülő dimenzióra nem osztott konstruktumai a 2x2-es felosztásban leginkább a teljesítménykereső célokkal azonosíthatók (vö. Midgley és mtsai, 2000; Murayama és Elliot, 2008), az eredményekből azt az elvárást fogalmazhatjuk meg mintánkra vonatkozóan, hogy a tanulást kerülő cél az elsajátítási teljesítménykereső céllal negatív előjelü gyenge 
korrelációt mutat, míg a viszonyító teljesítménykereső céllal közepes erősségü korrelációt. Adataink nem térnek ettől lényegesen, bár a korrelációk erősségei általában gyengébbek (47-51. táblázat).

További igazodási pontot kínálhat az az elméleti megfontolás, mely szerint a tanulást kerülő célt követő tanulóknál az erőfeszítés hiánya nem a hiányos képességek elrejtését célozza, vagyis a tanulást kerülő és a viszonyító teljesítménykerülő cél között csak alacsony korreláció fogadható el (Kaplan és Maehr, 2007). Bár mérőeszközünk e kritériumnak megfelel, felhívjuk a figyelmet arra, hogy az imént idézett kutatások, valamint saját eredményeink éppen azt támasztották alá, hogy a célorientációk belső összefüggései jelentősen függenek a mintától.

\section{Osztályok közötti különbségek}

A következőkben azt vizsgáljuk, hogy a célok jellemzői mennyiben kontextusfüggőek, vagyis mennyiben eltérőek az egyes osztályok esetében. E cél érdekében az átlagokat osztályonként, évfolyamok szerinti bontásban vetjük össze. Először a legalacsonyabb és legmagasabb osztályátlagokat vizsgáljuk meg, majd az osztályok átlagai közötti különbségek mértékét számszerüsítjük.

Az 53. táblázatban közöljük az egyes célok legkisebb és legnagyobb osztályátlagát évfolyamok szerinti bontásban. Az adatokból az látszik, hogy a legkisebb különbségek a tanulást kerülő cél kapcsán adódnak, vagyis az adott osztályok motivációs légkörét az osztály tanulóinak e jellemzője befolyásolja a legkevésbé. Ez kissé meglepő, hiszen azt várnánk, hogy elsősorban e jellemző mentén lehet megkülönböztetni a motivált és motiválatlan közösségeket. Úgy tünik, leginkább abban jelentkezik a különbség, hogy adott osztály tanuló mennyiben törekszenek az átlagtól való lemaradás elkerülésére, azaz milyen a viszonyító teljesítménykerülő cél követése. $\mathrm{Az}$ elsajátítási teljesítménykerülő cél évfolyamok közötti különbségei valamivel kisebbek a többi céllal összevetve, ami arra utalhat, hogy a cél kevésbé függ a tanulási környezettől. Az évfolyamok közötti különbségek tendenciáit megfigyelve, azt mondhatjuk, hogy a magasabb évfolyamok felé haladva egyre inkább elkülönülnek az osztályok a korábbi vizsgálatok alapján legkedvezőbbnek tekintett elsajátítási teljesítménykereső, és a legelőnytelenebb viszonyító teljesítménykerülő cél alapján. 
53. táblázat. A célorientációk osztályonként: a legkisebb és a legnagyobb osztályátlagok évfolyamonként feltüntetve

\begin{tabular}{lcccc}
\hline \multicolumn{1}{c}{ Osztályok } & \multicolumn{4}{c}{ Évfolyam } \\
\cline { 2 - 5 } & $\mathbf{5 .}$ & $\mathbf{6 .}$ & $\mathbf{7 .}$ & $\mathbf{8 .}$ \\
\hline Elsajátítási teljesítménykereső cél & & & & \\
$\quad$ Legkisebb átlagú osztály & 4,02 & 3,69 & 3,57 & 3,05 \\
$\quad \begin{array}{l}\text { Legnagyobb átlagú osztály } \\
\text { Elsajátítási teljesítménykerülő cél }\end{array}$ & 4,74 & 4,43 & 4,38 & 4,41 \\
$\quad$ Legkisebb átlagú osztály & 2,42 & 2,38 & 2,39 & 2,03 \\
$\quad$ Legnagyobb átlagú osztály & 3,57 & 3,61 & 3,38 & 3,94 \\
$\quad$ Viszonyító teljesítménykereső cél & & & & \\
$\quad$ Legkisebb átlagú osztály & 3,11 & 2,25 & 2,09 & 2,28 \\
$\quad$ Legnagyobb átlagú osztály & 3,96 & 3,61 & 3,25 & 3,34 \\
$\quad$ Viszonyító teljesítménykerülő cél & & & & \\
$\quad$ Legkisebb átlagú osztály & 3,96 & 3,13 & 3,02 & 2,47 \\
$\quad$ Legnagyobb átlagú osztály & 4,32 & 4,13 & 4,53 & 4,45 \\
$\quad$ Tanulást kerülő cél & & & & \\
$\quad$ Legkisebb átlagú osztály & 2,88 & 2,94 & 2,75 & 2,96 \\
$\quad$ Legnagyobb átlagú osztály & 3,64 & 4,06 & 3,81 & 3,38 \\
\hline
\end{tabular}

Az osztályok közötti különbségek számszerüsítésére gyakran alkalmazott megoldás az $\mathrm{F}$ értékek kiszámítása, amely azt mutatja meg, hogy az osztályok közötti különbség hányszorosa az osztályokon belül létező átlagos különbségeknek (pl. B. Németh és Habók, 2006; Csapó, 2002c, 2004; Csapó, Molnár Gy. és Kinyó, 2009; Tóth, Csapó és Székely, 2010). Ha az osztályok közötti és az osztályokon belüli variancia hányadosaként kapott $\mathrm{F}$ érték 1-nél nagyobb és szignifikáns, akkor az osztályközösségek között valódi eltérések léteznek. Minél nagyobb az F értéke, annál nagyobbak az osztályok közötti különbségek.

Az „Osztályközösség hatása” címü pontban már kitértünk arra, hogy a hazai iskolarendszer szélsőségesen szelektív, ami az egyes tanulóközösségek tanulási motivációra is hatással lehet, így arra számítunk, hogy az F értékek meghaladják az 1-et a célok kapcsán is, bár a korábbi munkák alapján túl nagy eltérésekre nem számítunk. Csapó (2002c) munkájában néhány tantárgyi attitüd esetében számolt $\mathrm{F}$ értéket, eredményei szerint ezek nagyságrendileg alacsonyabbak voltak, mint amelyek a diákok kognitív jellemzői alapján adódtak. A hetedikesek körében nem haladták meg a 4-et a tantárgyi attitüdök F értékei, míg egyes kognitív tesztek kapcsán 20-nál magasabbak voltak. B. Németh és Habók (2006) hetedikesek körében affektív változókat vizsgálva a matematika iránti érdeklődés és az olvasási énkép kapcsán jutott a legmagasabb $\mathrm{F}$ értékekhez, azonban ezek 2-nél nem voltak magsabbak.

Adataink szerint az osztályok közötti különbségek összességében nem jelentősek a céloknál sem (54. táblázat). Viszonyítási pontként használhatjuk a matematika osztályzatok $\mathrm{F}$ értékét a teljes mintára, amely 4,57. A legmagasabb értékeket a tanulást kerülö célnál kaptuk, azonban az eredmények évfolyamok szerint nagyon különböznek, így nehezen vonhatók le következtetések, vagyis e ponton mintánk valamilyen sajátosságára is gyanakodhatunk. A többi cél esetében hasonló értékeket láthatunk minden évfolyamon. Bár egy-egy évfolyam $\mathrm{F}$ értéke bizonyos célok esetében nem szignifikáns, úgy tünik a legkisebb eltérések a viszonyító teljesítménykereső célnál adódnak, míg az osztályok közötti különbségekben nagyobb szerep jut a viszonyító teljesítménykerülő célnak, megerősítve a korábbi elemzéseink, de az elsajátítási célok értékei alig alacsonyabbak ennél. Azt mondhatjuk tehát, hogy elsőssorban az elsajátítási 
célok és a viszonyító teljesítménykerülő cél rejti leginkább a diákoknak azokat a sajátosságait, amelyek mentén az osztályközösségek megkülönböztethetök, de ezek egyike sem kap a többinél nagyobb jelentőséget.

54. táblázat. A célorientációk osztályok közötti különbségét jellemzö F értékek

\begin{tabular}{|c|c|c|c|c|c|c|c|c|c|c|}
\hline \multirow{3}{*}{ Célok } & \multicolumn{10}{|c|}{ Évfolyamok } \\
\hline & \multicolumn{2}{|c|}{5.} & \multicolumn{2}{|c|}{6.} & \multicolumn{2}{|c|}{7.} & \multicolumn{2}{|c|}{8.} & \multicolumn{2}{|c|}{ Összes } \\
\hline & $\mathrm{F}$ & $\mathrm{p}$ & $\mathrm{F}$ & $\mathrm{p}$ & $\mathrm{F}$ & $\mathrm{p}$ & $\mathrm{F}$ & $\mathrm{p}$ & $\mathrm{F}$ & $\mathrm{p}$ \\
\hline $\begin{array}{l}\text { Elsajátítási } \\
\text { teljesítmény- } \\
\text { kereső cél }\end{array}$ & 2,42 & $<0,01$ & 1,65 & 0,09 & 2,43 & $<0,01$ & 2,27 & $<0,01$ & 2,77 & $<0,01$ \\
\hline $\begin{array}{l}\text { Elsajátítási } \\
\text { teljesítmény- } \\
\text { kerülő cél }\end{array}$ & 2,37 & $<0,01$ & 2,58 & $<0,01$ & 2,53 & $<0,01$ & 2,55 & $<0,01$ & 2,45 & $<0,01$ \\
\hline $\begin{array}{l}\text { Viszonyító } \\
\text { teljesítmény- } \\
\text { kereső cél }\end{array}$ & 1,11 & 0,36 & 2,84 & $<0,01$ & 0,87 & 0,58 & 1,43 & 0,16 & 2,10 & $<0,01$ \\
\hline $\begin{array}{l}\text { Viszonyító } \\
\text { teljesítmény- } \\
\text { kerülő cél }\end{array}$ & 1,00 & 0,44 & 2,78 & $<0,01$ & 3,02 & $<0,01$ & 2,67 & $<0,01$ & 3,04 & $<0,01$ \\
\hline $\begin{array}{l}\text { Tanulást } \\
\text { kerülő cél }\end{array}$ & 3,53 & $<0,01$ & 3,68 & $<0,01$ & 2,04 & 0,02 & 0,37 & 0,97 & 2,15 & $<0,01$ \\
\hline
\end{tabular}

Megj.: félkövér szedés jelzi a 0,05 alatti szinten szignifikáns összefüggéseket.

\section{Néhány háttértényezö szerepe}

Mivel az eddigi kutatások során leginkább a tanulási környezet jellemzői bizonyultak meghatározónak a célorientációk formálódásában, adatfelvételeink során nem volt hangsúlyos az oktatáskutatásokban általánosan alkalmazott háttértényezőknek az összegyüjtése. Egyedül a tanulók neméről és szüleinek iskolai végzettségéről állnak rendelkezésre adatok, a következőkben e változók és a célorientációk között keresünk kapcsolatot.

Mint már említettük, a tanulási motiváció különböző konstruktumai és a családi hátteret jellemző változók között a korábbi kutatások nem tártak fel lényeges kapcsolatot, ami a célorientációkra is igaz. A célorientációs elmélettel összefüggésben a nemek szerepének vizsgálata nem gyakori. A tanulási motivációban nemek szerint tapasztalható különbségeket áttekintő munkájukban Meece, Glienke és Askew (2009) alig néhány olyan kutatást talált, amelyben eltérésekről számoltak be, ám ezek főképp természettudományokkal összefüggésben vizsgálták a tanulók céljait, így elképzelhető, hogy a tantárgy szerepe jelenik meg ezekben a különbségekben. Következtetésük szerint nem állapítható meg egyértelmü kapcsolat a nemi hovatartozás és célok alakulása között.

A kutatási eredmények szerint tehát nem várjuk, hogy a célokkal számottevő összefüggését mutat a diákok neme vagy a diákok szüleinek iskolázottsága. Az 55. táblázatban látható korrelációs értékek megerősíteni látszanak feltételezéseink. Egyedül a tanulást kerülő célnál kaptunk említésre érdemes kapcsolatot, miszerint a lányok körében e cél követése valamivel gyakoribb. Az, hogy ritkábban értelmezik a lányok teljesítményszituációként a matematikai feladatokat némiképp meglepö, hiszen a korábbi felmérések adatai arra utalnak, hogy általában erősebben érzékelik az iskolai teljesítménykényszert mind általánosságban (Zsiros és Örkényi, 2011), mind a 
matematikával összefüggésben $(O E C D, 2004)$, emellett a matematikához kapcsolódó motivációs konstruktumokban sem tártak fel jelentős eltéréseket eddig (Csapó, 2000; $O E C D, 2004 b)$.

55. táblázat. A célorientációk korrelációi a tanulók nemével és a szülök iskolai végzettségével a teljes mintán

\begin{tabular}{lccc}
\hline \multicolumn{1}{c}{ Célok } & Nem & $\begin{array}{c}\text { Anya iskolai } \\
\text { végzettsége }\end{array}$ & $\begin{array}{c}\text { Apa iskolai } \\
\text { végzettsége }\end{array}$ \\
\hline Elsajátítási teljesítménykereső cél & $\mathbf{- 0 , 1 5}$ & $\mathbf{0 , 1 0}$ & $\mathbf{0 , 0 9}$ \\
Elsajátítási teljesítménykerülő cél & $-0,03$ & $\mathbf{0 , 1 7}$ & $\mathbf{0 , 1 5}$ \\
Viszonyító teljesítménykereső cél & 0,06 & $\mathbf{0 , 0 8}$ & $\mathbf{0 , 0 9}$ \\
Viszonyító teljesítménykerülő cél & $\mathbf{- 0 , 0 8}$ & $\mathbf{0 , 1 1}$ & $\mathbf{0 , 1 4}$ \\
Tanulást kerülő cél & $\mathbf{0 , 2 5}$ & 0,06 & $\mathbf{0 , 0 8}$ \\
\hline
\end{tabular}

Megj.: félkövér szedés jelzi a 0,01 alatti szinten szignifikáns összefüggéseket; dőlt és félkövér szedés jelzi a 0,01 és 0,05 közötti szinten szignifikáns összefüggéseket.

Az elemzéseket a nemekkel kapcsolatban évfolyamok szerint is elvégeztük, a korrelációs együtthatók az évfolyamok növekvő sorrendjében a következőképpen alakultak: 0,$30 ; 0,26 ; 0,16 ; 0,31$. A nemek szerinti különbségek létezését a tanulást kerülő cél kapcsán a kétmintás t-próba eredményei minden évfolyamon és a minta egészén egyaránt megerősítették (56. táblázat).

56. táblázat. A tanulást kerülö cél jellemzői a fiúk és lányok körében évfolyamok szerint és a teljes mintán

\begin{tabular}{lcccccccc}
\hline \multirow{2}{*}{ Évfolyamok } & \multicolumn{2}{c}{ Fiúk } & \multicolumn{2}{c}{ Lányok } & \multicolumn{2}{c}{ Levene } & \multicolumn{2}{c}{ Kétmintás t/d } \\
\cline { 2 - 9 } & átlag & szórás & átlag & szórás & F & p & t/d & $\mathrm{p}$ \\
\hline 5. & 2,80 & 0,90 & 3,39 & 0,93 & 0,68 & 0,41 & $-4,47$ & $<0,01$ \\
6. & 3,03 & 0,93 & 3,33 & 0,97 & 0,66 & 0,42 & $-2,41$ & 0,02 \\
7. & 2,95 & 0,88 & 3,45 & 0,94 & 2,14 & 0,14 & $-3,95$ & $<0,01$ \\
8. & 2,80 & 0,89 & 3,37 & 0,89 & 0,03 & 0,87 & $-4,45$ & $<0,01$ \\
Összes & 2,91 & 0,90 & 3,38 & 0,93 & 2,53 & 0,11 & $-7,57$ & $<0,01$ \\
\hline
\end{tabular}

\section{Célstruktúrák}

\section{Általános jellemzök}

A célstruktúrák leíró statisztikáinak áttekintése egy általános képet kínálhat arról, hogy milyen a felmérésben szereplö osztályok környezete motivációs szempontból. Mint említettük, az feltételezzük, hogy a magasabb évfolyamok felé haladva általában változnak a környezet jellemzői. İgy például a pedagógusok osztálytermi gyakorlatában a teljesítmény hangsúlyozása vagy a normaorientált értékelés nagyobb szerepet kaphat.

$\mathrm{Az}$ 57. táblázatban foglaltuk össze a célstruktúrák átlagait és szórásait évfolyamok szerint, emellett varianciaanalízist végeztünk, hogy megvizsgáljuk, az évfolyamok között adódó eltérések számottevőek-e. A célokhoz hasonlóan itt is főként az 5. évfolyam kapcsán tapasztaltunk különbségeket, mindkét célstruktúrát magasabbra értékelték, ugyanakkor a viszonyító célstruktúra 6. osztályban is eltér mind az alacsonyabb, mind a magasabb évfolyamon kapott válaszoktól (elsajátítási: $\{5\}<$ $\{6,7,8\}$; viszonyító: $\{5\}<\{6\}<\{7,8\})$. Ez kissé meglepő, hiszen azt várnánk, hogy 
továbbtanulási döntés felé közeledve a viszonyításra orientáló környezetnek egyre jelentősebb a szerepe.

57. táblázat. A célstruktúrák összehasonlitása évfolyamok szerint

\begin{tabular}{|c|c|c|c|c|c|c|c|c|c|c|}
\hline \multirow{3}{*}{ Célstruktúrák } & \multicolumn{8}{|c|}{ Évfolyamok } & \multirow{2}{*}{\multicolumn{2}{|c|}{$A N O V A$}} \\
\hline & \multicolumn{2}{|c|}{5.} & \multicolumn{2}{|c|}{6.} & \multicolumn{2}{|c|}{7.} & \multicolumn{2}{|c|}{8.} & & \\
\hline & Átl. & Szór. & Átl. & Szór. & Átl. & Szór. & Átl. & Szór. & $\mathrm{F}$ & $\mathrm{p}$ \\
\hline Elsajátítási & 4,15 & 0,74 & 3,63 & 0,77 & 3,55 & 0,93 & 3,47 & 0,81 & 28,67 & $<0,01$ \\
\hline Viszonyító & 3,39 & 0,99 & 3,16 & 0,81 & 2,93 & 0,85 & 2,93 & 0,81 & 13,25 & $<0,01$ \\
\hline
\end{tabular}

\section{Belsö összefüggések}

A szakirodalom alapján nem tudunk hipotéziseket megfogalmazni a célstruktúrák összefüggésére, hiszen az osztálytermi célstruktúrák felmérésének egyik gyakori célja éppen az, hogy a kontextus különbségeiröl tájékoztasson. Példaként néhány, a felmérésünkben részt vevő diákokhoz hasonló életkorú tanulókkal végzett korábbi kutatás eredményeit említhetjük meg. Anderman és Midgley (1997) 6. évfolyamon angol tantárgyhoz kapcsolódóan -0,63-as értéket kapott $(\mathrm{n}=341, \mathrm{p}<0,01)$, Turner és munkatársai (2002) szintén 6. osztályban -0,40-es értéket $(\mathrm{n}=1197, \quad \mathrm{p}<0,01)$ matematikához kötődően. Míg Wolters (2004) ugyancsak e tárggyal összefüggésben 7. és 8. évfolyamon nem talált kapcsolatot $(\mathrm{r}=0,02, \mathrm{n}=525)$, addig Freeman és Anderman (2005) 0,53-as korrelációs értéket tárt fel 6. évfolyamon $(n=1197, p<0,01)$ tantárgyhoz nem kötődő mérőeszköz segítségével.

A célstruktúrák korrelációit az 58. táblázat közli minden évfolyam és a teljes minta esetében. Az adatok első pillantásra nem mutatnak lényeges különbségeket az évfolyamok között. A célstruktúrák összefüggése szerint az osztálytermekben az elsajátítási és viszonyító célokra orientáló üzenetek általában egyszerre vannak jelen, és a tanulók véleménye évfolyamonként nem különbözik a z-próba szerint $(\mathrm{z}=0,1084)$ az 5. és 8. évfolyam korrelációinak összehasonlítása esetében, ami megint csak arra utal, hogy a felső tagozat viszonylag egységes a motivációs üzeneteket tekintve, legalábbis a mintánkba került osztályokban.

58. táblázat. A célstruktúrák korrelációi a teljes mintán

\begin{tabular}{lccccc}
\hline \multirow{2}{*}{ Célstruktúrák } & \multicolumn{5}{c}{ Évfolyamok } \\
\cline { 2 - 6 } Elsajátítási & $\mathbf{5 .}$ & $\mathbf{6 .}$ & $\mathbf{7 .}$ & $\mathbf{8 .}$ & $\ddot{O}_{\text {sszes }}$ \\
\cline { 2 - 6 } Viszonyító & 0,47 & 0,47 & 0,53 & 0,55 & 0,53
\end{tabular}

Megj.: a táblázatban minden korrelációs együttható $\mathrm{p}<0,01$ szinten szignifikáns.

\section{Osztályok közötti különbségek}

A következőkben megvizsgáljuk, hogy a célstruktúrák jellemzői, illetve összefüggései mennyiben kontextusfüggő sajátságok, vagyis mennyiben kötődnek az egyes osztályközösségekhez. E kérdés megválaszolására az átlagokat és a korrelációkat osztályonként, évfolyamok szerinti bontásban vesszük szemügyre. Elsőként a legalacsonyabb és legmagasabb osztályátlagokat vetjük össze, majd az osztályok átlagai közötti különbségek mértékét jellemezzük, ezután a célstruktúrák kapcsolatának erősségét nézzük meg, végül megpróbáljuk a nemzetközi szakirodalomban az osztályok motivációs jellemzőire alkalmazott kategóriák felhasználásával megvizsgálni mintánkat. 
Az 59. és 60. táblázatok közlik a legkisebb és a legnagyobb osztályátlagokat a két célstruktúra vonatkozásában. Az adatokból látható, hogy az évfolyamonkénti átlagok (57. táblázat) elfedik, hogy a magasabb évfolyamokon egyes osztályokban egyre kevésbé érzik az osztálytermi környezetet tanulásra ösztönzőnek a tanulók, míg kisebbek a különbségek a legmagasabb átlagú osztályokat tekintve. A társas összehasonlításra orientáló viszonyító célstruktúra esetében azt látjuk, hogy a tanulási környezet motivációs hatása a diákok véleménye szerint csökkenő tendenciát mutat mind a legalacsonyabb, mind a legmagasabb átlagok alapján, 8. évfolyamon azonban a csökkenés megáll, és némileg magasabbak az értékek, amelyek talán a továbbtanulással összefüggő társas összehasonlítás növekvő szerepével magyarázhatók. A legnagyobb eltérés egyértelmüen a tanulást hangsúlyozó elsajátítási célra orientáló környezet kapcsán a legalacsonyabb átlagú osztályok között adódik.

59. táblázat. Az elsajátitási célstruktúra osztályonként: a legkisebb és a legnagyobb osztályátlagok évfolyamonként feltüntetve

\begin{tabular}{ccccc}
\hline \multicolumn{1}{c}{ Oszatályok } & 5. évfolyam & 6. évfolyam & 7. évfolyam & 8. évfolyam \\
\hline Legkisebb átlagú osztály & 3,63 & 3,28 & 2,85 & 2,90 \\
Legnagyobb átlagú osztály & 4,69 & 4,20 & 4,45 & 4,22 \\
\hline
\end{tabular}

60. táblázat. A viszonyitó célstruktúra osztályonként: a legkisebb és a legnagyobb osztályátlagok évfolyamonként feltüntetve

\begin{tabular}{lcccc}
\hline \multicolumn{1}{c}{ Osztályok } & 5. évfolyam & 6. évfolyam & 7. évfolyam & 8. évfolyam \\
\hline Legkisebb átlagú osztály & 2,73 & 2,50 & 2,30 & 2,38 \\
Legnagyobb átlagú osztály & 3,91 & 3,63 & 3,47 & 3,59 \\
\hline
\end{tabular}

Az osztályátlagok közötti különbsége számszerü jellemzésére a célstruktúrák kapcsán is felhasználjuk az F értékeket (61. táblázat). Láthatjuk, hogy az F értékei magasabbak, vagyis a különbségek markánsabbak annál, amelyeket a céloknál megfigyelhettünk. Ha két célstruktúra eredményeit egybevetjük évfolyamonként, láthatjuk, hogy a legfiatalabbaknál ismételten eltérő eredményeket kapunk. Az eredmények szerint 5. osztályban nagyobbak az eltérések abban, hogy mennyiben érzékelik az önfejlesztéshez kötődő üzeneteket a tanulók, míg a társas összehasonlításra vonatkozók kisebb jelentőségüek az osztályok megkülönböztetésében.

61. táblázat. A célstruktúrák osztályok közötti különbségét jellemző F értékek

\begin{tabular}{|c|c|c|c|c|c|c|c|c|c|c|}
\hline \multirow{3}{*}{ Célstruktúrák } & \multicolumn{10}{|c|}{ Évfolyamok } \\
\hline & \multicolumn{2}{|c|}{5.} & \multicolumn{2}{|c|}{6.} & \multicolumn{2}{|c|}{7} & \multicolumn{2}{|c|}{8.} & \multicolumn{2}{|c|}{ Összes } \\
\hline & $\mathrm{F}$ & $\mathrm{p}$ & $\mathrm{F}$ & $\mathrm{p}$ & $\mathrm{F}$ & $\mathrm{p}$ & $\mathrm{F}$ & $\mathrm{p}$ & $\mathrm{F}$ & $\mathrm{p}$ \\
\hline Elsajátítási & 3,75 & $<0,01$ & 4,12 & $<0,01$ & 5,74 & $<0,01$ & 3,13 & $<0,01$ & 6,34 & $<0,01$ \\
\hline Viszonyító & 3,84 & $<0,01$ & 2,68 & $<0,01$ & 2,24 & $<0,01$ & 2,57 & $<0,01$ & 3,57 & $<0,01$ \\
\hline
\end{tabular}

A 62. táblázatban az osztályonként kapott legkisebb és legnagyobb korrelációs együtthatókat tüntettük fel. Láthatjuk, hogy a változók kapcsolatában szélsőséges eltérések mutatkoznak osztályonként, egyes osztályokban közelít az 1-hez a korreláció, míg máshol nincs szignifikáns összefüggés. Bár a szakirodalom szerint jelentős negatív korreláció is lehetséges, ilyen eredményt egyetlen osztályközösség esetében sem kaptunk. A legmagasabb korrelációs együtthatókat évfolyamonként összevetve itt ugyancsak azt láthatjuk, hogy az 5. évfolyam némileg eltér a többitől. 
62. táblázat. A célstruktúrák összefüggése osztályonként: a legkisebb és a legnagyobb összefüggést tükrözö korrelációs együtthatók évfolyamonként és a teljes mintán

\begin{tabular}{lcccccccc}
\hline \multirow{2}{*}{ Osztályok } & \multicolumn{2}{c}{$\mathbf{5 .}$ évfolyam } & \multicolumn{2}{c}{ 6. évfolyam } & \multicolumn{2}{c}{ 7. évfolyam } & \multicolumn{2}{c}{ 8. évfolyam } \\
\cline { 2 - 9 } & $\boldsymbol{r}$ & $\boldsymbol{n}$ & $\boldsymbol{r}$ & $\boldsymbol{n}$ & $\boldsymbol{r}$ & $\boldsymbol{n}$ & $\boldsymbol{r}$ & $\boldsymbol{n}$ \\
\hline Minimum & $-0,16$ & 18 & $-0,10$ & 24 & 0,31 & 14 & 0,24 & 22 \\
Maximum & $\mathbf{0 , 9 2}$ & 23 & $\mathbf{0 , 7 8}$ & 25 & $\mathbf{0 , 7 4}$ & 29 & $\mathbf{0 , 7 9}$ & 19 \\
\hline
\end{tabular}

Megj.: félkövér szedés jelzi a 0,01 alatti szinten szignifikáns összefüggéseket.

\section{Néhány háttértényezó szerepe}

A rendelkezésre álló háttérváltozóknak, a tanulók nemének és a szülők iskolázottságának hatását megvizsgáltuk a célstruktúrák kapcsán is. A tanulási környezet észlelésében nem ritka a nemek közötti különbség, általában a lányok pozitívabban ítélik meg az iskolai légkört, az iskolával való azonosulásuk erősebb, a pedagógusok és az osztályközösségről alkotott véleményük kedvezőbb képet mutat (pl. Jámbori, 2003; Várnai és Örkényi, 2007). Mint korábban rámutattunk - „Az elsődleges szocializációs színtér, a család szerepe" címü pontban - a szülőknek jelentős szerepe lehet a tanulási motiváció alakításában, amely nem függetlenek szocioökonómiai státuszuktól. Az elöbbiek alapján elméletileg az iskolai környezetröl alkotott tanulói véleményekben is megjelenhet a nemek és a szülök iskolázottságának hatása. Az említett változók korrelációs együtthatóit a teljes mintára vonatkozóan a 63. táblázatban közöljük, amelyek az összefüggések hiányáról tájékoztatnak.

63. táblázat. A célorientációk korrelációi a tanulók nemével és a szülők iskolai végzettségével a teljes mintán

\begin{tabular}{lccc}
\hline \multicolumn{1}{c}{ Célstruktúrák } & Nem & $\begin{array}{c}\text { Anya iskolai } \\
\text { végzettsége }\end{array}$ & $\begin{array}{c}\text { Apa iskolai } \\
\text { végzettsége }\end{array}$ \\
\hline Elsajátítási & 0,04 & 0,00 & 0,03 \\
Viszonyító & 0,06 & 0,03 & 0,08 \\
\hline
\end{tabular}

Megj.: a táblázatban látható korrelációs együtthatók nem szignifikánsak.

\section{Tanári tevékenységek, társas környezet}

\section{Általános jellemzök}

Ebben a pontban a tanári tevékenységek és a társas környezet megismerése érdekében használt változók leíró statisztikáit, valamint évfolyamok közötti különbségeit tekintjük át (64. táblázat). A varianciaanalízis szerint a legnagyobb különbség az évfolyamok között a feladat elnevezésű változó kapcsán adódik, ami az órai feladatok érdekességére, változatosságára utal. Nagyobb különbségeket figyelhetünk meg emellett a tanulók csoportosítása változó esetén, mely a tanulók teljesítményén alapuló csoportokba sorolását takarja. Továbbá az egyéni felelösséget hangsúlyozó számonkérés, a tanári támogatás és a tanulók közötti kölcsönös tisztelet támogatása emelkedik ki a sorból. A pozitív osztálylégkör kapcsán azonban nem találtunk eltérést az évfolyamok között. 
64. táblázat. A tanári tevékenységeket és a társas környezetet leiró változók összehasonlítása évfolyamok szerint

\begin{tabular}{|c|c|c|c|c|c|c|c|c|c|c|}
\hline \multirow[b]{2}{*}{ Tanári tevékenységek, társas környezet } & \multicolumn{8}{|c|}{ Évfolyamok } & \multirow{2}{*}{\multicolumn{2}{|c|}{$A N O V A$}} \\
\hline & \multicolumn{2}{|c|}{5.} & \multicolumn{2}{|c|}{6.} & \multicolumn{2}{|c|}{7.} & \multicolumn{2}{|c|}{8.} & & \\
\hline Tanári támogatás & 3,13 & 0,48 & 2,96 & 0,54 & 3,02 & 0,53 & 2,81 & 0,61 & 12,00 & $<0,01$ \\
\hline Pozitív osztálylégkör & 3,80 & 0,73 & 3,65 & 0,77 & 3,70 & 0,79 & 3,63 & 0,74 & 2,02 & 0,11 \\
\hline A matematikatanár szabályorientált viselkedése & 3,83 & 0,89 & 3,68 & 0,91 & 3,57 & 0,95 & 3,54 & 0,89 & 4,42 & $<0,01$ \\
\hline Tanulók közötti kölcsönös tisztelet támogatása & 4,18 & 0,95 & 3,83 & 1,10 & 3,77 & 1,06 & 3,69 & 1,07 & 8,42 & $<0,01$ \\
\hline Tanulók csoportosítása & 2,86 & 1,10 & 2,72 & 1,11 & 2,25 & 1,04 & 2,35 & 0,99 & 15,53 & $<0,01$ \\
\hline Egyéni felelősséget hangsúlyozó számonkérés & 4,44 & 0,70 & 4,05 & 0,87 & 4,05 & 0,87 & 4,01 & 0,96 & 11,67 & $<0,01$ \\
\hline
\end{tabular}

Megj.: félkövér szedés jelzi a varianciaanalízis 0,05 alatti szinten szignifikáns F értékeit.

65. táblázat. A tanári tevékenységeket és a társas környezetet leiró változók közötti korrelációk a teljes mintán

\begin{tabular}{|c|c|c|c|c|c|c|c|c|}
\hline Tanári tevékenységek, társas környezet & 1. & 2. & 3. & 4. & 5. & 6. & 7. & 8. \\
\hline 3. Pozitív osztálylégkör & $\mathbf{0 , 2 3}$ & $-0,17$ & - & & & & & \\
\hline 5. Tanulók közötti kölcsönös tisztelet támogatása & 0,43 & $-0,20$ & 0,09 & $\mathbf{0 , 2 3}$ & - & & & \\
\hline 6. Feladat & 0,56 & $-0,20$ & 0,23 & 0,25 & $\mathbf{0 , 4 5}$ & - & & \\
\hline 7. Versenyeztetés & 0,01 & $\mathbf{0 , 1 4}$ & $-0,05$ & $\mathbf{0 , 2 3}$ & $-0,04$ & 0,03 & - & \\
\hline 8. Tanulók csoportosítása & $\mathbf{0 , 1 1}$ & 0,24 & 0,00 & 0,15 & 0,06 & $\mathbf{0 , 1 8}$ & $\mathbf{0 , 3 1}$ & - \\
\hline
\end{tabular}

Megj.: félkövér szedés jelzi a 0,01 alatti szinten szignifikáns összefüggéseket; dőlt és félkövér szedés jelzi a 0,01 és 0,05 közötti szinten szignifikáns összefüggéseket. 
A korábbi eredményeket megerősítve jellemzően az 5. évfolyam további évfolyamoktól való különbözőségét tapasztalhatjuk. Ez jellemző a tanári támogatás $(\{5\}<\{6,7\}<$ $\{8\})$, tanulók közötti kölcsönös tisztelet támogatása $(\{5\}<\{6,7,8\})$, a feladat $(\{5\}<$ $\{6,7\}<\{7,8\})$ és az egyéni felelősséget hangsúlyozó számonkérés $(\{5\}<\{6,7,8\})$ kapcsán. Valamint az 5. és 6. évfolyam együttes elkülönülése figyelhető még meg a matematikatanár szabályorientált viselkedése $(\{5,6\}<\{6,7,8\})$, a versenyeztetés $(\{5,6\}$ $<\{6,7,8\})$ és a tanulók csoportosítása $(\{5,6\}<\{7,8\})$ változóknál. A fegyelmezési problémák esetében minimális csökkenést láthatunk a magasabb évfolyamok felé haladva $(\{5,6,7\}<\{7,8\})$.

Negatív irányú trendként értelmezhetők az eredmények a tanári támogatás, a tanulók közötti kölcsönös tisztelet támogatása, a feladat és az egyéni felelősséget hangsúlyozó számonkérés skálái tekintetében. Ugyanakkor kedvező tendencia látható a fegyelmezési problémák előfordulásában, a matematikatanár szabályorientált viselkedésében és a tanulók csoportosításában. A versenyeztetés kapcsán azonban nem tudjuk egyértelmüen megfogalmazni, hogy a csökkenés mit jelent (1. „A többszörös célok elmélete" címü pontban).

\section{Belsö összefüggések}

A tanári tevékenységeket és az osztályterem társas közegét leíró változók korrelációit a 65. táblázat tartalmazza. Megfigyelhetjük, hogy a változók közül központi jelentősége van a feladatnak, a legszorosabb, 0,40 feletti korrelációs együtthatókat e tényezö kapcsán láthatjuk. A tanári támogatással, a tanulók közötti kölcsönös tisztelet támogatásával és az egyéni felelősséget hangsúlyozó számonkéréssel korrelál a legerősebben, és csak egyetlen változóval, a versenyeztetéssel nincs kapcsolatban. Az adatokból természetesen nem tudunk következteti arra, hogy melyik változó gyakorol hatást a másikra, mégis megfogalmazhatjuk, hogy ahol változatosabbaknak, érdekesebbnek találják a feladatokat a diákok, ott az osztálytermi társas közeget is kedvezőbbnek látják a tanulók. A feladat változó negatívan korrelál a fegyelmezési problémákkal, ami statisztikai alátámasztását jelenti annak, hogy ha változatosabb a tanóra, a fegyelmezési problémák gyakorisága is csökken. A szociális közegröl információt kínáló változók közül a tanári támogatás emelhető ki, amely viszonylag jelentékeny kapcsolatot mutat más tényezőkkel, a feladat mellett leginkább a tanulók közötti kölcsönös tisztelet támogatásával és az egyéni felelősséget hangsúlyozó számonkéréssel. Érdekes módon a pozitív osztálylégkör a vizsgált változókkal alig mutat összefüggést, egyedül a tanári támogatással korrelál, de a korrelációs együttható nem jelentős.

$\mathrm{Az}$ összefüggéseket évfolyamok szerinti bontásban is megvizsgáltuk, az eredmények a 38-41. mellékletekben láthatók. Jó látható trend, hogy a tanulók közötti kölcsönös tisztelet támogatása a magasabb évfolyamokon egyre több változóval mutat kapcsolatot, amely közül a tanári támogatás változása a leglátványosabb. A jelenségre könnyen találunk magyarázatot: a társas összehasonlítás egyre fontosabb lesz serdülökorban (1. Fülöp, 2010). Ez egyben azt is mutatja, hogy a tanári támogatás nem ugyanazt jelenti a különbözö életkorokban. Emellett láthatjuk, hogy a matematikatanár szabályorientált viselkedése egyre kevésbé függ össze további tényezőkkel, nyolcadikban már nem kaptunk szignifikáns kapcsolatokat. Időbeli változást látunk még a pozitív osztálylégkörnél, míg ötödikben alig kapcsolódik össze más tényezőkkel, addig később egyre gazdagabb az összefüggése, a feladat és a kölcsönös tisztelet támogatása emelhető ki. 


\section{Osztályok közötti különbségek}

A következökben a legalacsonyabb és legmagasabb osztályátlagokat összevetjük a tanári tevékenységeket és a társas környezetet leíró változók esetében is, majd az osztályok átlagai közötti különbségeket mértékét az F értékkel is jellemezzük. A legkisebb és legnagyobb osztályátlagok évfolyamonkénti bontásban a 66. táblázatban láthatók. Az eredmények szerint néhány vizsgált környezeti jellemzö észlelésének osztályok közötti különbségei egyre szélsőségesebb képet mutatnak a magasabb évfolyamokon. Egyre csökkenő értékeket láthatunk a tanári támogatás és az egyéni felelősséget hangsúlyozó számonkérés tekintetében, a legmagasabb átlagok csökkennek a versenyeztetés kapcsán, a matematikatanár szabályorientált viselkedése és a feladat változó különbségei pedig egyre nagyobbak.

66. táblázat. A tanári tevékenységeket és a társas környezetet leiró változók osztályonként: a legkisebb és a legnagyobb osztályátlagok évfolyamonként feltüntetve

\begin{tabular}{|c|c|c|c|c|}
\hline \multirow{2}{*}{ Osztályok } & \multicolumn{4}{|c|}{ Évfolyam } \\
\hline & 5. & 6. & 7. & 8. \\
\hline \multicolumn{5}{|l|}{ Tanári támogatás } \\
\hline Legkisebb átlagú osztály & 2,91 & 2,63 & 2,64 & 2,22 \\
\hline Legnagyobb átlagú osztály & 3,48 & 3,21 & 3,52 & 3,43 \\
\hline \multicolumn{5}{|l|}{ Fegyelmezési problémák } \\
\hline Legkisebb átlagú osztály & 1,31 & 1,48 & 1,00 & 1,27 \\
\hline Legnagyobb átlagú osztály & 2,48 & 2,81 & 2,43 & 2,43 \\
\hline \multicolumn{5}{|l|}{ Pozitív osztálylégkör } \\
\hline Legkisebb átlagú osztály & 3,36 & 3,05 & 3,14 & 3,38 \\
\hline Legnagyobb átlagú osztály & 4,55 & 4,29 & 4,00 & 4,09 \\
\hline \multicolumn{5}{|c|}{ A matematikatanár } \\
\hline Legkisebb átlagú osztály & 3,27 & 3,17 & 2,93 & 2,73 \\
\hline Legnagyobb átlagú osztály & 4,43 & 4,19 & 4,15 & 4,16 \\
\hline \multicolumn{5}{|c|}{$\begin{array}{l}\text { Tanulók közötti kölcsönös tisztelet } \\
\text { támogatása }\end{array}$} \\
\hline Legkisebb átlagú osztály & 3,42 & 3,13 & 2,70 & 3,08 \\
\hline Legnagyobb átlagú osztály & 4,57 & 4,29 & 4,69 & 4,55 \\
\hline \multicolumn{5}{|l|}{ Feladat } \\
\hline Legkisebb átlagú osztály & 3,27 & 3,10 & 2,77 & 2,74 \\
\hline Legnagyobb átlagú osztály & 4,41 & 3,67 & 3,84 & 3,78 \\
\hline \multicolumn{5}{|l|}{ Versenyeztetés } \\
\hline Legkisebb átlagú osztály & 2,03 & 1,95 & 1,99 & 1,78 \\
\hline Legnagyobb átlagú osztály & 3,34 & 3,17 & 2,99 & 2,75 \\
\hline \multicolumn{5}{|l|}{ Tanulók csoportosítása } \\
\hline Legkisebb átlagú osztály & 1,81 & 1,57 & 1,51 & 1,56 \\
\hline Legnagyobb átlagú osztály & 3,76 & 4,08 & 3,25 & 3,03 \\
\hline \multicolumn{5}{|c|}{$\begin{array}{l}\text { Egyéni felelősséget hangsúlyozó } \\
\text { számonkérés }\end{array}$} \\
\hline Legkisebb átlagú osztály & 4,10 & 3,46 & 3,36 & 3,25 \\
\hline Legnagyobb átlagú osztály & 4,92 & 4,41 & 4,69 & 4,58 \\
\hline
\end{tabular}


Az F értékeket vizsgálva azt láthatjuk, hogy mindössze néhány változó kapcsán kapunk jelentősnek mondható osztályok közötti különbségeket (68. táblázat). A legnagyobb különbségek a fegyelmezési problémák előfordulásának gyakoriságához kötődnek, az eltérések mértékét talán azzal érzékeltethetjük leginkább, hogy 10-et meghaladó $\mathrm{F}$ értékeket korábban föként kognitív változók esetében tártak fel magyar mintán (1. Csapó, 2002c). Jelentősnek mondható továbbá a tanulók előzetes teljesítményen alapuló csoportosítása, ami szélsőségesen nagy különbségeket mutat e tanári tevékenység tekintetében. Mintánkban a 6. évfolyamon kiugró F értéket $(24,34)$ kaptunk, míg 8. évfolyamon ennek a különbségek mértéke $(3,88)$ nem számottevő. Emellett az osztályok a feladat változó, a tanári támogatás és a matematikatanár szabályorientált viselkedése mentén különböztethetök meg leginkább.

\section{Néhány háttértényezó szerepe}

A rendelkezésre álló háttérváltozók szerepét a korábbi konstruktumhoz hasonlóan a tanári tevékenységeket és a társas környezetet leíró változóknál is megvizsgáltuk. A 67. táblázatban láthatók az eredmények, amelyek szerint statisztikailag igazolható módon egyik változó észlelésében sem játszik jelentős szerepet a tanulók neme és szüleinek iskolai végzettsége.

67. táblázat. A célorientációk korrelációi a tanulók nemével és a szülők iskolai végzettségével a teljes mintán

\begin{tabular}{lrrr}
\hline & Nem & $\begin{array}{c}\text { Anya } \\
\text { iskolai } \\
\text { végzett- } \\
\text { sége }\end{array}$ & $\begin{array}{c}\text { Apa } \\
\text { iskolai } \\
\text { végzett- } \\
\text { sége }\end{array}$ \\
\hline Tanári támogatás & & 0,02 & 0,03 \\
Fegyelmezési problémák & $-0,05$ & $-\mathbf{0 , 1 3}$ & $\mathbf{- 0 , 1 0}$ \\
Pozitív osztálylégkör & 0,05 & 0,01 & 0,01 \\
A matematikatanár szabályorientált viselkedése & $\mathbf{0 , 0 8}$ & $-0,02$ & $-0,04$ \\
Tanulók közötti kölcsönös tisztelet támogatása & $-0,02$ & 0,07 & 0,06 \\
Feladat & $-0,04$ & $-0,03$ & 0,00 \\
Versenyeztetés & $\mathbf{0 , 1 0}$ & 0,00 & 0,03 \\
Tanulók csoportosítása & $\mathbf{0 , 1 3}$ & $\mathbf{- 0 , 1 9}$ & $\mathbf{- 0 , 1 1}$ \\
Egyéni felelösséget hangsúlyozó számonkérés & $-0,04$ & $\mathbf{- 0 , 1 1}$ & $\mathbf{- 0 , 0 9}$ \\
\hline
\end{tabular}

Megj.: félkövér szedés jelzi a 0,01 alatti szinten szignifikáns összefüggéseket; dőlt és félkövér szedés jelzi a 0,01 és 0,05 közötti szinten szignifikáns összefüggéseket. 
68. táblázat. A tanári tevékenységeket és a társas környezetet leiró változók osztályok közötti különbségét jellemzö F értékek

\begin{tabular}{|c|c|c|c|c|c|c|c|c|c|c|}
\hline \multirow[b]{2}{*}{ Tanári tevékenységek, társas környezet } & \multicolumn{10}{|c|}{ Évfolyamok } \\
\hline & \multicolumn{2}{|c|}{5.} & \multicolumn{2}{|c|}{6.} & \multicolumn{2}{|c|}{7.} & \multicolumn{2}{|c|}{8.} & \multicolumn{2}{|c|}{ Összes } \\
\hline Tanári támogatás & 3,47 & $<0,01$ & 2,37 & $<0,01$ & 5,37 & $<0,01$ & 3,38 & $<0,01$ & 4,34 & $<0,01$ \\
\hline Pozitív osztálylégkör & 3,21 & $<0,01$ & 4,16 & $<0,01$ & 1,99 & 0,02 & 1,08 & 0,38 & 2,46 & $<0,01$ \\
\hline A matematikatanár szabályorientált viselkedése & 2,98 & $<0,01$ & 2,92 & $<0,01$ & 4,20 & $<0,01$ & 4,06 & $<0,01$ & 3,69 & $<0,01$ \\
\hline Tanulók közötti kölcsönös tisztelet támogatása & 1,52 & 0,14 & 2,23 & 0,02 & 4,21 & $<0,01$ & 2,28 & $<0,01$ & 3,09 & $<0,01$ \\
\hline Tanulók csoportosítása & 8,43 & $<0,01$ & 24,34 & $<0,01$ & 5,45 & $<0,01$ & $3, \mathbf{8 8}$ & $<0,01$ & 9,88 & $<0,01$ \\
\hline Egyéni felelősséget hangsúlyozó számonkérés & 2,63 & $<0,01$ & 2,52 & $<0,01$ & 4,16 & $<0,01$ & 2,53 & $<0,01$ & $\mathbf{3 , 7 0}$ & $<0,01$ \\
\hline
\end{tabular}




\section{Összegzés}

A célorientációk közötti összefüggések vizsgálata megerősítette, hogy a célok feltárására kifejlesztett mérőeszközünk a megcélzott konstruktumokat méri, a belső kapcsolatok mintázata az egyesült államokbeli tanulók körében feltártaknak megfelel. Az egyetlen jelentősebb eltérést, amely az elsajátítási teljesítménykereső és a viszonyító teljesítménykereső cél viszonyában adódott, kulturális különbségként értelmezhetjük. Mivel a korábbi vizsgálatok az előbbi cél kedvező, míg az utóbbi kedvezőtlen következményeiről tájékoztattak, feltételezhetően tanulóink körében a célok kevésbé előnyös kombinációkban fordulnak elő. Az osztályok leginkább az elsajátítási célok és a viszonyító teljesítménykerülő cél alapján megkülönböztethetők, de ebben az említettek egyikének sem jut a többinél nagyobb jelentőségü szerep. Ugyancsak e célok alapján tapasztaltunk évfolyamok szerinti eltéréseket, az ötödikes korosztály céljai különböztek a magasabb évfolyamra járó tanulókétól.

Az elsajátítási és a viszonyító célstruktúrák általában egyszerre vannak jelen az osztálytermekben, kapcsolatuk erőssége alig különbözik évfolyamonként. Az osztályok motivációs üzeneteik szerinti elkülönítésében a viszonyító célstruktúránál valamivel nagyobb a jelentősége van az elsajátítási célstruktúrának. A célstruktúrák észlelése tekintetében ugyancsak az ötödikesek véleményében említhetünk eltéréseket.

A tanári tevékenységeket és a szociális közeget jellemző változók többsége ugyancsak az 5., néhány változónál az 5. és 6 . évfolyamon tér el a többitől. E tényezők közül a feladat és a kölcsönös tisztelet támogatása emelkedik ki, utóbbi jelentősége az idősebb korosztályban egyre fontosabb szerephez jut a további környezeti tényezők megítélése kapcsán. Az osztályok közötti különbségekben a fegyelmezési problémák előfordulása a legmeghatározóbb. 


\section{A VIZSGÁLT KONSTRUKTUMOK ÖSSZEFÜGGÉSE}

\section{A célorientációk és az osztályzatok közötti összefüggések}

A következőkben megvizsgáljuk a célorientációk kapcsolatát néhány rendelkezésre álló osztályzattal. Mint említettük, az osztályzatok csak közelítő képet kínálnak a tanulók tudásáról, ugyanakkor az iskolai teljesítmények legfontosabb mutatói, amelyek a tanulási motívumok alakulásával szoros kapcsolatban állnak. Az összefüggések tehát az célok és a teljesítmény közötti viszonyról tájékoztatnak.

A Tanulói célok kérdőiven arra kértük a diákokat, hogy adják meg az előző év végi matematika, szorgalom és magatartás osztályzataikat, az elemzéseket ezekkel az adatokkal végezzük. A célokkal kapcsolatos eredmények értelmezéséhez lényeges tisztában lennünk azzal, hogy a vizsgált osztályzatok milyen kapcsolatban állnak egymással. A 69. táblázatban évfolyamok szerint és a teljes mintára vonatkozóan is feltüntettük az osztályzatok korrelációit. Az adatokból láthatjuk, a matematika és szorgalom osztályzatok kapcsolatai, valamint a magatartás és szorgalom közöttiek hasonlóak, és valamivel erősebbek, mint a magatartás és matematika korrelációi. Az eredmények nem meglepőek, hiszen a szorgalom tulajdonképpen a jegyek összességére vonatkozik, illetve a tanulmányi eredmények és a magatartási problémák között kapcsolatok is jól ismertek (pl. Csapó, 2002b; Felleginé, 2004). A némiképp alacsonyabb korrelációt a magatartás és a matematika jegyek között az magyarázhatja, hogy e tantárgy osztályzatai nagyobb eltéréseket mutathatnak a szorgalom jegyhez viszonyítva, gondoljunk csak a reál és humán beállítottságú tanulókra. Láthatjuk továbbá, hogy nincsenek lényeges különbségek évfolyamok szerint.

69. táblázat. A matematika, a szorgalom és a magatartás osztályzatok korrelációi évfolyamok szerint és a teljes mintán

\begin{tabular}{lcccccccccc}
\hline \multirow{2}{*}{ Oszztályzatok } & \multicolumn{10}{c}{ Évfolyamok } \\
\cline { 2 - 11 } & MAT & SZO & MAT & SZO & MAT & SZO & MAT & SZO & MAT & SZO \\
\hline Szorgalom & 0,63 & - & 0,66 & - & 0,71 & - & 0,71 & - & 0,68 & - \\
Magatartás & 0,45 & 0,66 & 0,46 & 0,65 & 0,49 & 0,64 & 0,49 & 0,63 & 0,46 & 0,63 \\
\hline Megj.: MAT: \\
szignifikáns.
\end{tabular}

A 70-72. táblázatokban a célorientációk és az osztályzatok közötti korrelációs értékeket tüntettük fel évfolyamok szerint és a teljes mintán egyaránt. Először a három táblázatot elemezzük, majd a matematika osztályzatokra fókuszálunk, és a korrelációk erősségét összevetjük nemzetközi, valamint a tanulási motiváció más konstruktumaival végzett hazai elemzések eredményeivel.

Várakozásainknak megfelelően a magatartás jegyek esetében kaptunk alacsonyabb korrelációs értékeket. Bár a különbségek nem jelentősek, meglepő, hogy a matematikával kapcsolatos célok a matematika jegyeknél valamivel erősebb viszonyban állnak a szorgalom osztályzatokkal. A célok általános, vagyis egyszerüen a tanuláshoz, valamint a kontextushoz kötött, azaz tantárgyakhoz vagy kurzusokhoz kapcsolódó felmérése egyaránt bevett szokás a nemzetközi szakirodalomban, de a két megközelítés előnyeinek és hátrányainak számbavétele eddig alig kapott figyelmet (1. a „Kontextushoz kötöttség” címü pontban). Az eredményeink utalhatnak arra, hogy a 
felmért célok bár a matematikához kapcsolódóan kerültek felvételre, tulajdonképpen általánosságban fejezik ki a tanulók célorientációit, vagyis lehetséges, hogy más tárgyak esetében is hasonló célokat követnek a tanulók. Ez lényeges, jövőbeni kutatások által megválaszolandó kérdés lehet.

$\mathrm{Az}$ elsajátítási teljesítménykerülő cél kivételével adataink szerint a célorientációk és az osztályzatok összefüggése gyengébb az 5. évfolyamon. Ezt jelzi, hogy egyes esetekben ezen az évfolyamon nincs szignifikáns korreláció, de a szignifikáns összefüggések kapcsán is többször láthatjuk, hogy eltér a szignifikanciaszint a magasabb évfolyamokon tapasztaltaktól. Az azonos sziginfikanciaszintű korrelációkat z-próba alkalmazásával ellenőriztük. Az ötödikesek és a nyolcadikosok körében az elsajátítási teljesítménykereső cél és a matematika osztályzatok korrelációi szignifikáns eltérést mutatnak $(\mathrm{z}=3,4608 ; \mathrm{p}<0,01)$, de ugyanezen évfolyamok, illetve cél kapcsán a szorgalom jegyeknél is különbséget kaptunk $(\mathrm{z}=3,7930 ; \mathrm{p}<0,01)$. Emellett a szorgalom osztályzatok kapcsán eltérést találtunk a 7 . és 8 . évfolyam között a viszonyító teljesítménykereső cél $(\mathrm{z}=2,1231$; $\mathrm{p}<0,01)$, valamint 6 . és 8 . évfolyam között a viszonyító teljesítménykerülő célok kapcsán $(\mathrm{z}=2,4553 ; \mathrm{p}<0,01)$.

$\mathrm{Az}$ 5. évfolyamot követően tehát általában erösebbek az összefüggések, amit többféleképpen is értelmezhetünk: pontosabban érzékelik saját céljaikat a tanulók vagy fontosabb szerephez jutnak e célok a teljesítményt tekintve, de a két tényező egyszerre is teljesülhet. A rendelkezésre álló információk alapján jelen vizsgálat keretei között csupán e felvetésekig juthatunk.

Mindhárom osztályzat kapcsán megfogalmazható megállapítás, hogy a tanulást kerülő cél és a jegyek között nincs összefüggés. Ez első ránézésre megkérdőjelezi e konstruktum fontosságát a magyar tanulók körében, legalábbis az osztályzatokkal összefüggésben. Ugyanakkor a 2x2-es felosztás céljainak mindegyike összefüggést mutat az osztályzatokkal. Megjegyezzük, hogy ebböl még nem következtethetünk ezek tényleges összefüggéseire, hiszen az egyes célok is kapcsolatban állnak egymással.

70. táblázat. A célorientációk és a matematika osztályzatok korrelációi évfolyamok szerint és a teljes mintán

\begin{tabular}{lccccc}
\hline \multirow{2}{*}{ Célok } & \multicolumn{4}{c}{ Évfolyamok } \\
\cline { 2 - 6 } & $\mathbf{5 .}$ & $\mathbf{6 .}$ & $\mathbf{7 .}$ & $\mathbf{8 .}$ & Összes \\
\hline Elsajátítási teljesítménykereső cél & $\mathbf{0 , 1 9}$ & $\mathbf{0 , 3 1}$ & $\mathbf{0 , 4 2}$ & $\mathbf{0 , 4 7}$ & $\mathbf{0 , 3 7}$ \\
Elsajátítási teljesítménykerülő cél & $\mathbf{0 , 2 7}$ & $\mathbf{0 , 2 9}$ & $\mathbf{0 , 3 5}$ & $\mathbf{0 , 4 0}$ & $\mathbf{0 , 3 2}$ \\
Viszonyító teljesítménykereső cél & $\mathbf{0 , 1 7}$ & $\mathbf{0 , 2 2}$ & $\mathbf{0 , 2 5}$ & $\mathbf{0 , 3 6}$ & $\mathbf{0 , 2 6}$ \\
Viszonyító teljesítménykerülő cél & $\mathbf{0 , 1 4}$ & $\mathbf{0 , 2 5}$ & $\mathbf{0 , 3 2}$ & $\mathbf{0 , 3 9}$ & $\mathbf{0 , 2 9}$ \\
Tanulást kerülő cél & 0,06 & 0,05 & 0,06 & 0,08 & 0,06 \\
\hline
\end{tabular}

Megj.: félkövér szedés jelzi a 0,01 alatti szinten szignifikáns összefüggéseket; dőlt és félkövér szedés jelzi a 0,01 és 0,05 közötti szinten szignifikáns összefüggéseket. 
71. táblázat. A célorientációk és a szorgalom osztályzatok korrelációi évfolyamok szerint és a teljes mintán

\begin{tabular}{lccccc}
\hline \multirow{2}{*}{ Célok } & \multicolumn{5}{c}{ Évfolyamok } \\
\cline { 2 - 6 } & $\mathbf{5 .}$ & $\mathbf{6 .}$ & $\mathbf{7 .}$ & $\mathbf{8 .}$ & Összes \\
\hline Elsajátítási teljesítménykereső cél & $\mathbf{0 , 2 8}$ & $\mathbf{0 , 3 8}$ & $\mathbf{0 , 4 3}$ & $\mathbf{0 , 5 6}$ & $\mathbf{0 , 4 3}$ \\
Elsajátítási teljesítménykerülő cél & $\mathbf{0 , 2 6}$ & $\mathbf{0 , 2 0}$ & $\mathbf{0 , 1 6}$ & $\mathbf{0 , 4 0}$ & $\mathbf{0 , 2 4}$ \\
Viszonyító teljesítménykereső cél & 0,11 & $\mathbf{0 , 1 7}$ & $\mathbf{0 , 1 8}$ & $\mathbf{0 , 3 6}$ & $\mathbf{0 , 2 2}$ \\
Viszonyító teljesítménykerülő cél & $\mathbf{0 , 1 7}$ & $\mathbf{0 , 2 8}$ & $\mathbf{0 , 3 2}$ & $\mathbf{0 , 4 7}$ & $\mathbf{0 , 3 3}$ \\
Tanulást kerülő cél & 0,06 & 0,03 & 0,02 & $-0,05$ & 0,01 \\
\hline
\end{tabular}

Megj.: félkövér szedés jelzi a 0,01 alatti szinten szignifikáns összefüggéseket; dőlt és félkövér szedés jelzi a 0,01 és 0,05 közötti szinten szignifikáns összefüggéseket.

72. táblázat. A célorientációk és a magatartás osztályzatok korrelációi évfolyamok szerint és a teljes mintán

\begin{tabular}{lccccc}
\hline \multirow{2}{*}{ Célok } & \multicolumn{5}{c}{ Évfolyamok } \\
\cline { 2 - 6 } & $\mathbf{5 .}$ & $\mathbf{6 .}$ & $\mathbf{7 .}$ & $\mathbf{8 .}$ & Összes \\
\hline Elsajátítási teljesítménykereső cél & $\mathbf{0 , 1 6}$ & $\mathbf{0 , 3 8}$ & $\mathbf{0 , 3 2}$ & $\mathbf{0 , 4 4}$ & $\mathbf{0 , 3 0}$ \\
Elsajátítási teljesítménykerülő cél & $\mathbf{0 , 1 6}$ & 0,13 & 0,06 & $\mathbf{0 , 2 4}$ & $\mathbf{0 , 1 5}$ \\
Viszonyító teljesítménykereső cél & 0,00 & 0,05 & 0,08 & $\mathbf{0 , 1 5}$ & 0,05 \\
Viszonyító teljesítménykerülő cél & $\mathbf{0 , 1 5}$ & $\mathbf{0 , 2 0}$ & $\mathbf{0 , 1 9}$ & $\mathbf{0 , 3 2}$ & $\mathbf{0 , 1 9}$ \\
Tanulást kerülő cél & 0,06 & $-0,08$ & $\mathbf{- 0 , 1 4}$ & $\mathbf{- 0 , 1 5}$ & $\mathbf{- 0 , 0 8}$ \\
\hline
\end{tabular}

Megj.: félkövér szedés jelzi a 0,01 alatti szinten szignifikáns összefüggéseket; dőlt és félkövér szedés jelzi a 0,01 és 0,05 közötti szinten szignifikáns összefüggéseket.

A nemzetközi szakirodalom alapján a célorientációk és a jegyek kapcsolatát „A célorientációk és a tanulás eredményességét befolyásoló egyéb változók kapcsolata" címü pontban összegeztük a korábbiakban, melyből most azt emelnénk ki, hogy az egyesült államokbeli általános iskolások körében végzett kutatásokban az osztályzatok általában nem álltak kapcsolatban az elsajátítási céllal. A viszonyító teljesítménykereső céllal kapcsolatos eredmények nem konzisztensek, míg a viszonyító teljesítménykerülő és a tanulást kerülő cél a felmérések többsége szerint kedvezőtlen hatást gyakorol a jegyekre. Az adataink áttekintéséböl kirajzolódó kép számos ponton ellentmond az ismertetett eredményeknek, hiszen tanulóink körében egyértelmüen kimutatható az elsajátítási célok pozitív hatása, ugyanakkor a viszonyító teljesítménykerülő nem befolyásolja előnytelenül az osztályzatokat, a tanulást kerülő cél pedig nem gyakorol hatást az osztályzatokra.

Ha összehasonlítjuk az általunk feltárt kapcsolatokat hazai mintán más motivációs konstruktumok esetében tapasztalt összefüggésekkel, világosabb képet kaphatunk a célok és az osztályzatok viszonyáról. Viszonyítási pontként a nagyobb mintán, felső tagozatosok körében végzett vizsgálatok eredményit használjuk, a matematikához kötődőek mellett néhány általános motivációs konstruktummal kapcsolatos eredményt is közlünk. Józsa (2002) korábban már érintett kutatásában a Kozéki-féle tanulási motiváció kérdöívvel 7. évfolyamon $(\mathrm{n}=594)$ 0,34-es, az iskolai énképpel 0,38-as, míg a matematikai énképpel 0,52-es korrelációt kapott $(\mathrm{p}<0,01)$. Az elsajátítási motivációval összefüggésben Józsa (2007) ugyancsak közöl adatokat. A tanulói önjellemzések alapján 6. évfolyamon $(n=701)$ az értelmi elsajátítási motívummal 0,26-os, míg az elsajátítási motiváció összevont mutatójával 0,33-as értéket kapott $(\mathrm{p}<0,01)$. Megemlítjük továbbá Csapó (2000) elemzésének eredményeit, amely ötödikes $(n=2082)$ és hetedikes $(n=2228)$ tanulók matematika iránti attitűdje és matematika osztályzatainak kapcsolatáról közöl információkat, elöbbi korosztályban 
0,39-es, utóbbiban 0,37-es korreláció adódott $(\mathrm{p}<0,01)$. Ha a célorientációk és a matematika osztályzatok saját vizsgálatunkban kapott korrelációt egybevetjük ezekkel az eredményekkel, jól látszik, hogy az általunk vizsgált motivációs konstruktumok fontos előrejelzői az osztályzatoknak, egyedül a matematika énkép kapcsán mutattak ki erősebb kapcsolatot a korábbi vizsgálatok.

A korrelációk alapján úgy tűnik, hogy a célok fontossági sorrendjének elején az elsajátítási teljesítménykereső, majd az elsajátítási teljesítménykerülő cél következik, míg a viszonyító célok hasonló jelentőséget képviselnek a matematika jegyben. A szorgalom és magatartás osztályzat esetében adódó korrelációk szerint a viszonyító teljesítménykerülő cél nagyobb súllyal esik latba, mint teljesítménykereső dimenziója. Mivel a célok egymással is összefüggenek, a korrelációk erőssége a célok jegyeket befolyásoló szerepét tekintve elfedheti a valóságot.

A célok egymáshoz viszonyított fontosságának pontosabb feltárása érdekében regresszióanalízist végeztünk, az elemzéseket mindhárom osztályzatra, minden évfolyamra, valamint a teljes mintára vonatkoztatva is elvégeztük (73-75. táblázat). Ezek megerősítik az elsajátítási cél fontosságát, de a teljesítménykereső dimenzió markánsabb szerepét mutatják. A viszonyító teljesítménykereső cél a regresszióelemzés szerint nem magyarázza a tanulók osztályzatai közötti különbségeket, míg a viszonyító teljesítménykerülö hatása kizárólag 7 . és 8 . évfolyamon kimutatható. A megmagyarázott varianciák nagyobbak a magasabb évfolyamokon, azonban az elsajátítási teljesítménykerülő cél ez alól kivételt képez, a matematika jegy megmagyarázott varianciája nagyságrendileg alig különbözik az egyes évfolyamok között. Ezzel kapcsolatban a feltételezésünk, hogy e céltípus talán kevésbé függ a tanulási környezettől, föképp a teljesítménnyel kapcsolatos információktól, legalábbis azoktól, amelyek az osztályzatok által megszerezhetők. 
73. táblázat. A matematika osztályzattal mint függö változóval végzett regresszióanalizis évfolyamok szerint és a teljes mintán

\begin{tabular}{|c|c|c|c|c|c|c|c|c|c|c|}
\hline \multirow[b]{2}{*}{ Célok } & \multicolumn{10}{|c|}{ Évfolyamok } \\
\hline & \multicolumn{2}{|c|}{5.} & \multicolumn{2}{|c|}{6.} & \multicolumn{2}{|c|}{7.} & \multicolumn{2}{|c|}{8.} & \multicolumn{2}{|c|}{ Összes } \\
\hline Elsajátítási teljesítménykereső cél & 2,7 & 0,06 & 7,0 & $<0,01$ & 13,1 & $<0,01$ & 15,6 & $<0,01$ & 9,5 & $<0,01$ \\
\hline Viszonyító teljesítménykereső cél & 1,6 & 0,26 & 1,8 & 0,27 & 0,2 & 0,89 & 3,5 & 0,20 & 1,8 & 0,06 \\
\hline Viszonyító teljesítménykerülő cél & $-0,2$ & 0,86 & 0,5 & 0,82 & 4,6 & 0,04 & 1,6 & 0,61 & 1,8 & 0,12 \\
\hline Tanulást kerülő cél & $-0,3$ & 0,54 & 0,1 & 0,74 & 0,3 & 0,47 & 1,0 & 0,08 & 0,2 & 0,33 \\
\hline
\end{tabular}

Megj.: félkövér szedés jelzi a 0,05 alatti szinten szignifikáns összefüggéseket.

74. táblázat. A szorgalom osztályzattal mint függö változóval végzett regresszióanalízis évfolyamok szerint és a teljes mintán

\begin{tabular}{|c|c|c|c|c|c|c|c|c|c|c|}
\hline \multirow{3}{*}{ Célok } & \multicolumn{10}{|c|}{ Évfolyamok } \\
\hline & \multicolumn{2}{|c|}{5.} & \multicolumn{2}{|c|}{6.} & \multicolumn{2}{|c|}{7.} & \multicolumn{2}{|c|}{8.} & \multicolumn{2}{|c|}{ Összes } \\
\hline & $\mathrm{r} \beta(\%)$ & $\mathrm{p}$ & $\mathrm{r} \beta(\%)$ & $\mathrm{p}$ & $\mathrm{r} \beta(\%)$ & $\mathrm{p}$ & $\mathrm{r} \beta(\%)$ & $\mathrm{p}$ & $\mathrm{r} \beta(\%)$ & $\mathrm{p}$ \\
\hline Elsajátítási teljesítménykereső cél & 7,0 & $<0,01$ & 11,8 & $<0,01$ & 17,0 & $<0,01$ & 21,7 & $<0,01$ & 14,5 & $<0,01$ \\
\hline Viszonyító teljesítménykereső cél & $-0,3$ & 0,76 & 0,1 & 0,92 & $-1,2$ & 0,35 & 1,8 & 0,49 & $-0,2$ & 0,80 \\
\hline Viszonyító teljesítménykerülő cél & 0,6 & 0,70 & 2,8 & 0,23 & 7,1 & $<0,01$ & 7,8 & 0,04 & 4,9 & $<0,01$ \\
\hline Tanulást kerülő cél & $-0,1$ & 0,83 & 0,2 & 0,40 & 0,1 & 0,34 & 0,0 & 0,97 & 0,0 & 0,65 \\
\hline
\end{tabular}

Megj.: félkövér szedés jelzi a 0,05 alatti szinten szignifikáns összefüggéseket. 
75. táblázat. A magatartás osztályzattal mint függő változóval végzett regresszióanalízis évfolyamok szerint és a teljes mintán

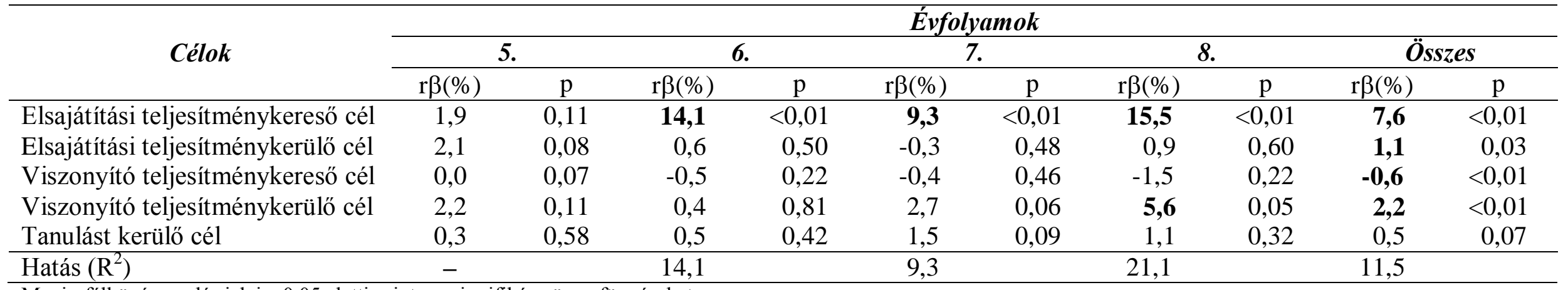

Megj.: félkövér szedés jelzi a 0,05 alatti szinten szignifikáns összefüggéseket. 
Ha összevetjük a matematika és a szorgalom osztályzatok megmagyarázott varianciáit, a korrelációszámításokat megerősítve azt láthatjuk, hogy a szorgalom jegyeket inkább magyarázzák a célorientációk, 8. évfolyamon a szorgalom kapcsán adódó 35 százalékos érték számottevően meghaladja a matematikához kötődő 24 százalékot. Ez a korábbiaknál is komolyabban veti fel, hogy a célorientációk általános és kontextushoz kötött mérésének összevetése, előnyeinek és hátrányainak felderítése lényeges kutatási kérdésként kezelendő.

Jól tudjuk, hogy az osztályzatok iskolánként, sőt, gyakran osztályonként sem összehasonlíthatók. Ami az egyik közösségben jó teljesítménynek számít, az máshol lehet, hogy csak középszerü, azaz ugyanaz a teljesítmény eltérő osztályzatot érhet (1. Csapó, 2002b). Az adott közösség teljesítménye fontos viszonyítási pontot jelenthet az eredmények értékelésében, ahogyan erre az énkép kapcsán rámutattunk (1. , $A z$ osztályközösség hatása" címü pontban). Lehetséges, hogy ez a célok és az osztályzatok összefüggését is befolyásolja. E kérdés megválaszolása érdekében az osztályzatok helyett a tanulók osztályzatának az osztályátlagtól való eltérésével is elemzéseket végzünk a matematika jegyre szükítve vizsgálatunk.

A célorientációk és a matematika jegyek átlagtól való eltérésének korreláció (76. táblázat) az egyes évfolyamokon hasonlóak, a z-próba nem jelzett szignifikáns eltéréseket. Az összefüggések erőssége a célok és az osztályzatok átlagtól való eltérése között közel azonosak, mint a célok és az osztályzatok között (vö. 73-75. táblázat), így ezekből az adatokból nem következtethetünk arra, hogy jegyeknek a közösség teljesítményéhez viszonyított értékei fontosabbak lennének, mint a jegyek abszolút értéke. A tanulást kerülö cél szerepe eredményeink szerint ebben az esetben sem meghatározó.

76. táblázat. A célorientációk és a matematika osztályzatok osztályátlagtól való eltérésének korrelációi évfolyamok szerint és a teljes mintán

\begin{tabular}{lccccc}
\hline \multirow{2}{*}{ Célok } & \multicolumn{5}{c}{ Évfolyamok } \\
\cline { 2 - 6 } & $\mathbf{5 .}$ & $\mathbf{6 .}$ & 7. & $\mathbf{8 .}$ & Összes \\
\hline Elsajátítási teljesítménykereső cél & $\mathbf{- 0 , 2 2}$ & $\mathbf{- 0 , 2 8}$ & $\mathbf{- 0 , 3 7}$ & $\mathbf{- 0 , 4 0}$ & $\mathbf{- 0 , 3 2}$ \\
Elsajátítási teljesítménykerülő cél & $\mathbf{- 0 , 3 0}$ & $\mathbf{- 0 , 2 5}$ & $\mathbf{- 0 , 2 5}$ & $\mathbf{- 0 , 3 3}$ & $\mathbf{- 0 , 2 8}$ \\
Viszonyító teljesítménykereső cél & $\mathbf{- 0 , 2 1}$ & $\mathbf{- 0 , 2 3}$ & $\mathbf{- 0 , 2 2}$ & $\mathbf{- 0 , 3 1}$ & $\mathbf{- 0 , 2 4}$ \\
Viszonyító teljesítménykerülő cél & $\mathbf{- 0 , 1 5}$ & $\mathbf{- 0 , 2 2}$ & $\mathbf{- 0 , 2 6}$ & $\mathbf{- 0 , 2 8}$ & $\mathbf{- 0 , 2 3}$ \\
Tanulást kerülő cél & $-0,13$ & $-0,11$ & $-0,03$ & $-0,07$ & $\mathbf{0 , 0 7}$ \\
\hline
\end{tabular}

Megj.: félkövér szedés jelzi a 0,01 alatti szinten szignifikáns összefüggéseket; dölt és félkövér szedés jelzi a 0,01 és 0,05 közötti szinten szignifikáns összefüggéseket.

A matematika osztályzatok átlagtól való eltérésével mint függő változóval regresszióelemzést végeztük, függő változóként a célokat alkalmazva (77. táblázat). A megmagyarázott varianciák valamivel alacsonyabbak a matematika jeggyel végzett regresszióanalízis eredményéhez képest (vö. 73. táblázat). Az eredmények alapján úgy tünik, hogy motivációs szempontból az osztályzatok abszolút értéke mintha valamivel fontosabb lenne, mint a relatív értéke. Ugyanakkor hiba lenne messzemenő következtetésként azt levonni, hogy a kevésbé szigorú osztályzással bizonyosan pozitív irányban befolyásolhatnánk a matematikával kapcsolatos motivációt. Csíkos (2012a) munkájában a tantárgy kedveltsége és az adott tantárgyból elért eredmény közötti összefüggések elemzésekor egyrészröl arra felhívja a figyelmet, hogy e kapcsolatot szélesebb kontextusba helyezve lenne érdemes vizsgálni (pl. a tananyag és az óraszámok hogyan változtak adott tantárgy esetében), másrészről arra mutat rá, hogy a szigor enyhítése az osztályzatok inflálódását okozhatja. 
77. táblázat. A matematika osztályzat osztályátlagtól való eltérésével mint függö változóval végzett regresszióanalizis évfolyamok szerint és a teljes mintán

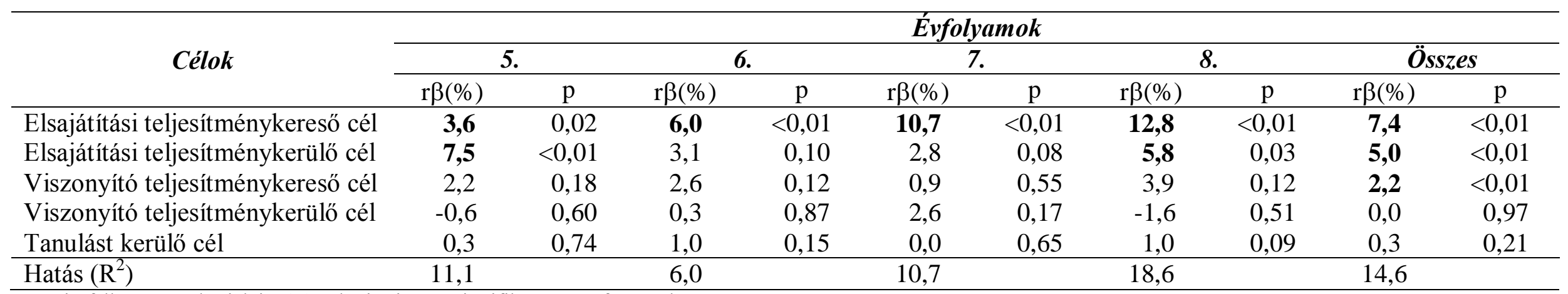

Megj.: félkövér szedés jelzi a 0,05 alatti szinten szignifikáns összefüggéseket. 


\section{A célorientációk és a célstruktúrák közötti összefüggések}

Ebben a pontban a tanulók motivációs jellemzőiről informáló célorientációk és az osztálytermi környezet motivációs sajátosságait holisztikusan kifejező célstruktúrák közötti kapcsolatokat vizsgáljuk. Korábbi elemzéseink e konstruktumok érvényességét és megbízhatóságát alátámasztották, azonban a tanulási motiváció és a tanulási környezet összefüggésének feltárására való alkalmasságukhoz hipotéziseinknek megfelelő összefüggésük igazolása is szükséges. Várakozásaink szerint az elsajátítási célstruktúra kapcsolatban áll az elsajátítási célokkal, és összefüggésük erősebb, mint a viszonyító célstruktúra kapcsolata az elsajátítási célokkal. És megfordítva, a viszonyító célstruktúra összefügg a viszonyító célokkal, és összefüggéseik erősebbek, mint az elsajátítási célstruktúra és a viszonyító célstruktúra közötti kapcsolatoknál. Megjegyezzük ugyanakkor, hogy az elsajátítási célstruktúra teljesítménykereső és teljesítménykerülő dimenzió kapcsolataira vonatkozóan nem rendelkezünk előzetes kutatási eredményekkel.

A célorientációk és a célstruktúrák korrelációit a 78. táblázatban közöljük évfolyamok szerinti bontásban és a minta egészére. A négy évfolyamot együtt tekintve várakozásaink teljesülnek az elsajátítási teljesítménykerülő cél kivételével, e cél esetében azonos a többi korrelációhoz viszonyítva alacsony értéket kaptunk. A tanulást kerülő cél esetében a korrelációs együtthatók alig térnek el a 0 -tól, vagyis nem jeleznek említésre érdemes kapcsolatot. Az adatok évfolyamok szerinti vizsgálatából ugyancsak az derül ki, hogy az összefüggések többségében a várakozásainknak megfelelően alakulnak. A z-probák eredményei nem jeleztek szignifikáns eltéréseket a korrelációs együtthatókban az évfolyamok között. A tanulást kerülő cél célstruktúrákkal való összefüggése meglepő képet mutat, hiszen a legtöbb évfolyamon vagy gyenge negatív kapcsolat adódik, vagy nem kaptunk kapcsolatot, addig az ötödikesek körében pozitív összefüggést mutat. 
78. táblázat. A célorientációk és a célstruktúrák korrelációi évfolyamok szerint és a teljes mintán

\begin{tabular}{|c|c|c|c|c|c|c|c|c|c|c|}
\hline \multirow{3}{*}{ Célok } & \multicolumn{10}{|c|}{ Évfolyamok } \\
\hline & \multicolumn{2}{|c|}{5.} & \multicolumn{2}{|c|}{6.} & \multicolumn{2}{|c|}{7.} & \multicolumn{2}{|c|}{8.} & \multicolumn{2}{|c|}{ Összes } \\
\hline & Els. & Visz. & Els. & Visz. & Els. & Visz. & Els. & Visz. & Els. & Visz. \\
\hline $\begin{array}{l}\text { Elsajátítási } \\
\text { teljesítmény- } \\
\text { kereső cél }\end{array}$ & 0,48 & 0,29 & $\mathbf{0 , 3 6}$ & $\mathbf{0 , 3 2}$ & 0,48 & 0,28 & 0,34 & $\mathbf{0 , 3 1}$ & 0,45 & $\mathbf{0 , 3 2}$ \\
\hline $\begin{array}{l}\text { Elsajátítási } \\
\text { teljesítmény- } \\
\text { kerülő cél }\end{array}$ & 0,15 & 0,27 & 0,12 & 0,13 & 0,21 & 0,03 & 0,19 & 0,18 & 0,14 & 0,14 \\
\hline $\begin{array}{l}\text { Viszonyító } \\
\text { teljesítmény- } \\
\text { kereső cél }\end{array}$ & 0,36 & $\mathbf{0 , 5 4}$ & 0,26 & 0,42 & 0,27 & $\mathbf{0 , 4 3}$ & 0,22 & $\mathbf{0 , 4 0}$ & $\mathbf{0 , 3 1}$ & 0,47 \\
\hline $\begin{array}{l}\text { Viszonyító } \\
\text { teljesítmény- } \\
\text { kerülő cél }\end{array}$ & 0,27 & $\mathbf{0 , 4 0}$ & 0,24 & $\mathbf{0 , 3 3}$ & 0,25 & 0,36 & 0,27 & $\mathbf{0 , 3 7}$ & $\mathbf{0 , 3 0}$ & $\mathbf{0 , 3 8}$ \\
\hline $\begin{array}{l}\text { Tanulást } \\
\text { kerülö cél }\end{array}$ & 0,16 & $\mathbf{0 , 4 0}$ & $-0,17$ & $-0,16$ & $-0,07$ & $-0,05$ & $-0,19$ & 0,00 & $-0,07$ & 0,05 \\
\hline
\end{tabular}

Megj.: félkövér szedés jelzi a 0,01 alatti szinten szignifikáns összefüggéseket; dőlt és félkövér szedés jelzi a 0,01 és 0,05 közötti szinten szignifikáns összefüggéseket. Els.: elsajátítási célstruktúra. Visz.: viszonyító célstruktúra.

Láthattuk korábbi elemzéseink során, hogy mind a célorientációk, mind a célstruktúrák összefüggenek, így a korrelációs együtthatók vizsgálata nem adhat világos képet a célok és célstruktúrák viszonyáról. E kapcsolatokból adódó torzításokat regresszióelemzés által szürjük ki. Függő változóként a célokat alkalmazó regressziós számításainkat a 7983. táblázatok közlik. Az elsajátítási teljesítménykereső cél alakításában az elsajátítási célstruktúra hatása jóval erőteljesebben megmutatkozik, a minta egészét, illetve az 5 . és 7. évfolyamot figyelembe véve jelentős 20 százalék körüli megmagyarázott varianciát kapunk, azonban 6 . és 8 . évfolyamon a viszonyító célstruktúra hatása is jelentős, alig marad el az elsajátításiétól (79. táblázat).

Az elsajátítási teljesítménykerülő cél esetében a korrelációszámításokhoz képest valamivel tisztább képet kapunk, de az elsajátítási célstruktúra hatása kizárólag a hetedikes körében mutatkozik meg (80. táblázat). A megmagyarázott hatás ugyanakkor csekélynek mondható, az 5. osztályok részmintája pedig ismételten másféle összefüggést jelez, hiszen itt a viszonyító célstruktúra szerepe mutatható ki.

A viszonyító célok mindkét típusa a várakozásaink szerint müködik, e célok követésében jelentkező tanulók közötti különbségeket a viszonyító célstruktúrák konzisztensen magyarázzák, míg az elsajátítási célstruktúrának nincs magyarázó ereje (81. és 82. táblázat). Az ötödikesek eredményi ismét eltérnek a többiekétől, itt a viszonyító célstruktúra hatása jóval jelentősebb mindkét viszonyító cél alakulásában.

A tanulást kerülö cél eredményei a regresszióanalízis kapcsán az 5. osztályosok ismét eltérőek, hiszen itt számottevő a megmagyarázott variancia értéke (83. táblázat). Ez azt jelenti, hogy amennyiben társas összehasonlítást hangsúlyozó, vagyis viszonyító célstruktúra jellemzi az osztályteremet, a tanulóknak kevéssé fontos a teljesítmény. 
79. táblázat. Az elsajátítási teljesitménykereső céllal mint függő változóval végzett regresszióanalízis évfolyamok szerint és a teljes mintán

\begin{tabular}{|c|c|c|c|c|c|c|c|c|c|c|}
\hline \multirow[b]{2}{*}{ Célstruktúrák } & \multicolumn{10}{|c|}{ Évfolyamok } \\
\hline & \multicolumn{2}{|c|}{5.} & \multicolumn{2}{|c|}{6.} & \multicolumn{2}{|c|}{7.} & \multicolumn{2}{|c|}{8.} & \multicolumn{2}{|c|}{ Összes } \\
\hline Elsajátítási & 21,6 & $<0,01$ & 9,8 & $<0,01$ & 22,6 & $<0,01$ & 8,4 & $<0,01$ & 17,3 & $<0,01$ \\
\hline Hatás $\left(\mathrm{R}^{2}\right)$ & 21,6 & & 15,7 & & 22,6 & & 14,0 & & 20,8 & \\
\hline
\end{tabular}

Megj.: félkövér szedés jelzi a 0,05 alatti szinten szignifikáns összefüggéseket.

80. táblázat. Az elsajátítási teljesitménykerülő céllal mint függő változóval végzett regresszióanalízis évfolyamok szerint és a teljes mintán

\begin{tabular}{|c|c|c|c|c|c|c|c|c|c|c|}
\hline \multirow{3}{*}{ Célstruktúrák } & \multicolumn{10}{|c|}{ Évfolyamok } \\
\hline & \multicolumn{2}{|c|}{5.} & \multicolumn{2}{|c|}{6.} & \multicolumn{2}{|c|}{7.} & \multicolumn{2}{|c|}{8.} & \multicolumn{2}{|c|}{ Összes } \\
\hline & $\mathrm{r} \beta(\%)$ & $\mathrm{p}$ & $\mathrm{r} \beta(\%)$ & $\mathrm{p}$ & $\mathrm{r} \beta(\%)$ & $\mathrm{p}$ & $\mathrm{r} \beta(\%)$ & $\mathrm{p}$ & $\mathrm{r} \beta(\%)$ & $\mathrm{p}$ \\
\hline Elsajátítási & 0,4 & 0,74 & 0,9 & 0,32 & 5,7 & $<0,01$ & 2,4 & 0,13 & 1,4 & 0,02 \\
\hline Viszonyító & 6,7 & $<0,01$ & 1,1 & 0,25 & $-0,3$ & 0,12 & 2,1 & 0,18 & 1,2 & 0,03 \\
\hline Hatás $\left(\mathrm{R}^{2}\right)$ & 6,7 & & - & & - & & - & & 2,6 & \\
\hline
\end{tabular}

Megj.: félkövér szedés jelzi a 0,05 alatti szinten szignifikáns összefüggéseket.

81. táblázat. A viszonyitó teljesitménykereső céllal mint függö változóval végzett regresszióanalízis évfolyamok szerint és a teljes mintán

\begin{tabular}{|c|c|c|c|c|c|c|c|c|c|c|}
\hline \multirow{3}{*}{ Célstruktúrák } & \multicolumn{10}{|c|}{ Évfolyamok } \\
\hline & \multicolumn{2}{|c|}{5.} & \multicolumn{2}{|c|}{6.} & \multicolumn{2}{|c|}{7.} & \multicolumn{2}{|c|}{8.} & \multicolumn{2}{|c|}{ Összes } \\
\hline & $\mathrm{r} \beta(\%)$ & $\mathrm{p}$ & $\mathrm{r} \beta(\%)$ & $\mathrm{p}$ & $\mathrm{r} \beta(\%)$ & $\mathrm{p}$ & $\mathrm{r} \beta(\%)$ & $\mathrm{p}$ & $\mathrm{r} \beta(\%)$ & $\mathrm{p}$ \\
\hline Elsajátítási & 4,5 & 0,06 & 1,9 & 0,29 & 1,6 & 0,41 & 0,3 & 0,88 & 2,7 & 0,02 \\
\hline Hatás $\left(\mathrm{R}^{2}\right)$ & 26,0 & & 16,4 & & 16,8 & & 15,4 & & 22,7 & \\
\hline
\end{tabular}

Megj.: félkövér szedés jelzi a 0,05 alatti szinten szignifikáns összefüggéseket. 
82. táblázat. A viszonyitó teljesitménykerülö céllal mint függő változóval végzett regresszióanalizis évfolyamok szerint és a teljes mintán

\begin{tabular}{|c|c|c|c|c|c|c|c|c|c|c|}
\hline \multirow{2}{*}{ Célstruktúrák } & \multicolumn{10}{|c|}{ Évfolyamok } \\
\hline & \multicolumn{2}{|c|}{5.} & \multicolumn{2}{|c|}{6.} & \multicolumn{2}{|c|}{7.} & \multicolumn{2}{|c|}{8.} & \multicolumn{2}{|c|}{ Összes } \\
\hline Elsajátítási & 2,9 & 0,16 & 2,7 & 0,13 & 2,1 & 0,25 & 2,4 & 0,27 & 3,8 & $<0,01$ \\
\hline Hatás $\left(\mathrm{R}^{2}\right)$ & 14,3 & & 9,1 & & 11,2 & & 12,2 & & 16,0 & \\
\hline \multicolumn{11}{|c|}{ Megj.: félkövér szedés jelzi a 0,05 alatti szinten szignifikáns összefüggéseket. } \\
\hline \multicolumn{11}{|c|}{ 83. táblázat. A tanulást kerülö céllal mint függö változóval végzett regresszióanalizis évfolyamok szerint és a teljes mintán } \\
\hline \multirow[t]{4}{*}{ Célstruktúrák } & \multicolumn{2}{|c|}{5.} & \multicolumn{2}{|c|}{6.} & \multicolumn{2}{|c|}{7.} & \multicolumn{2}{|c|}{8.} & \multicolumn{2}{|c|}{ Összes } \\
\hline & $\mathrm{r} \beta(\%)$ & $\mathrm{p}$ & $\mathrm{r} \beta(\%)$ & $\mathrm{p}$ & $\mathrm{r} \beta(\%)$ & $\mathrm{p}$ & $\mathrm{r} \beta(\%)$ & $\mathrm{p}$ & $\mathrm{r} \beta(\%)$ & $\mathrm{p}$ \\
\hline & $-0,6$ & 0,64 & 2,2 & 0,10 & 0,3 & 0,52 & 5,2 & $<0,01$ & 0,9 & $<0,01$ \\
\hline & 16,3 & $<0,01$ & 1,6 & 0,20 & 0,2 & 0,71 & $-0,1$ & 0,09 & 0,6 & $<0,01$ \\
\hline Hatás $\left(\mathrm{R}^{2}\right)$ & 16,3 & & - & & - & & 5,2 & & 1,5 & \\
\hline
\end{tabular}

Megj.: félkövér szedés jelzi a 0,05 alatti szinten szignifikáns összefüggéseket. 


\section{A célorientációk összefüggése a tanári tevékenységekkel és a társas környezettel}

A célorientációk kapcsolata az osztálytermi környezet jellemzőivel kevéssé feltárt területnek számít, mindössze néhány vizsgálat fokuszált ezen összefüggésekre. Viszonyítási pontot nem találunk elözetes feltételezések megfogalmazásához, hiszen a korábbi munkákban alkalmazott kérdőívek a célok eltérő felosztásán alapulnak, illetve a tanári gyakorlatra és szociális közegre vonatkozó mérőeszközök is eltérnek az általunk alkalmazottaktól.

A célorientációk összefüggését a tanári tevékenységekkel és a társas közeget leíró változókkal a teljes mintára vonatkozóan a 84. táblázatban tüntettük fel. Az adatok alapján elmondhatjuk, hogy az elsajátítási teljesítménykerülő és a tanulást kerülő cél esetében nem kaptunk említésre méltó kapcsolatot. Ez az osztályzatok esetében tapasztaltakat megerősítve arra utal, hogy e célok kevésbé érzékenyek a környezet sajátosságaira. Az eredményekből kiemelhető, hogy a tanári támogatás, a tanulók közötti kölcsönös tisztelet támogatása és a változatos, érdekes feladatok az elsajátítási teljesítménykereső céllal összefüggést mutatnak. Emellett a feladat változó hatása a viszonyító célokkal is kapcsolatban áll. A feladat változó központi szerepe így további megerősítést nyer, a későbbi kutatásokban érdemes lehet a feladat változót több skálára bontani az árnyaltabb információgyüjtés érdekében. Felmerülhet például a kérdés, hogy a feladatok változatosságának változója azért mutat kapcsolatot a viszonyító célokkal, mert a versenyhelyzettel kombinált feladatok változatosak, vagy más tényezők állnak az összefüggés hátterében.

A célorientációk korrelációit a tanári tevékenységekkel és a társas közeget leíró változókkal évfolyamok szerint is elemeztük (42-45. melléklet). Az adatokból kitünik, hogy a kapcsolatok általában egyre gyengébbek magasabb évfolyamokon, egyre kevesebb szignifikáns korrelációt láthatunk. Ez azt jelenti, hogy egyre nehezebb a környezet manipulálásával befolyásolni a célokat, legalábbis az általunk azonosított összetevőkön keresztül. A feladat változó jelentősége minden évfolyamon megmarad, ugyanakkor az ötödikesek körében az egyéni felelősséget hangsúlyozó értékelés kedvező és a fegyelmezési problémák kedvezőtlen szerepe látható az elsajátítási teljesítménykerülő célhoz kötődően. A tanulók előzetes teljesítményén alapuló csoportosításának hatása pedig a viszonyító célokkal mutat kapcsolatot, vagyis e tanári tevékenység negatív következményeire utalnak az adatok. 
84. táblázat. A célorientációk korrelációi a tanári tevékenységekkel és a társas környezetet leiró változókkal a teljes mintán

\begin{tabular}{|c|c|c|c|c|c|}
\hline \multirow[b]{2}{*}{$\begin{array}{c}\text { Tanári tevékenységek, társas } \\
\text { környezet }\end{array}$} & \multicolumn{5}{|c|}{ Célok } \\
\hline & $\begin{array}{c}\text { Els. telj. } \\
\text { keresö }\end{array}$ & $\begin{array}{l}\text { Els. telj. } \\
\text { kerülö }\end{array}$ & $\begin{array}{l}\text { Visz. telj. } \\
\text { keresö }\end{array}$ & $\begin{array}{l}\text { Visz. telj. } \\
\text { kerü̈lö }\end{array}$ & $\begin{array}{c}\text { Tan. } \\
\text { kerülö }\end{array}$ \\
\hline Tanári támogatás & 0,26 & 0,06 & $\mathbf{0 , 1 3}$ & $\mathbf{0 , 1 3}$ & $-0,05$ \\
\hline Fegyelmezési problémák & $-0,18$ & $-0,12$ & $-0,03$ & $-0,13$ & $\mathbf{0 , 1 7}$ \\
\hline Pozitív osztálylégkör & 0,19 & 0,02 & 0,07 & $\mathbf{0 , 1 3}$ & $-0,07$ \\
\hline $\begin{array}{l}\text { A matematikatanár } \\
\text { szabályorientált viselkedése }\end{array}$ & 0,16 & 0,08 & 0,16 & $\mathbf{0 , 1 4}$ & $\mathbf{0 , 1 0}$ \\
\hline $\begin{array}{l}\text { Tanulók közötti kölcsönös } \\
\text { tisztelet támogatása }\end{array}$ & $\mathbf{0 , 2 2}$ & $\mathbf{0 , 1 4}$ & $\mathbf{0 , 1 5}$ & $\mathbf{0 , 1 7}$ & $-0,04$ \\
\hline Feladat & $\mathbf{0 , 3 7}$ & 0,08 & 0,26 & 0,22 & $-0,10$ \\
\hline Versenyeztetés & $-0,09$ & $-0,04$ & $\mathbf{0 , 2 0}$ & 0,03 & $\mathbf{0 , 1 1}$ \\
\hline Tanulók csoportosítása & $-0,05$ & $-0,11$ & $\mathbf{0 , 1 6}$ & 0,04 & 0,09 \\
\hline $\begin{array}{l}\text { Egyéni felelősséget } \\
\text { hangsúlyozó számonkérés }\end{array}$ & $\mathbf{0 , 1 9}$ & 0,04 & $\mathbf{0 , 1 2}$ & $\mathbf{0 , 1 1}$ & 0,02 \\
\hline
\end{tabular}

Megj.: félkövér szedés jelzi a 0,01 alatti szinten szignifikáns összefüggéseket; dőlt és félkövér szedés jelzi a 0,01 és 0,05 közötti szinten szignifikáns összefüggéseket. Els. telj. kereső: elsajátítási teljesítménykereső; Els. telj. kerülő: elsajátítási teljesítménykerülő; Visz. telj. kereső: viszonyító teljesítménykereső; Visz. telj. kerülő: viszonyító teljesítménykerülő; Tan. kerülő: tanulást kerülő.

Az előzőekben láthattuk, hogy mind a célok, mind a környezetet leíró változók egymással is kapcsolatban állnak, így e kapcsolatok szerepét érdemes regresszióanalízis segítségével kiszürni. A célokat függő változóként kezelve végeztünk számításokat, melyeket a teljes mintára vonatkozóan a 85. táblázat közöl, a 46-49. mellékletekben pedig évfolyamok szerint láthatók az eredmények.

A minta egészét illetően a korrelációs együtthatók esetében látottakat erősítik meg adataink, így az elsajátítási teljesítménykerülő cél és a tanulást kerülő cél tanulók közötti különbségeit tudjuk megmagyarázni a vizsgált változókkal. Ugyanakkor a legmagasabb megmagyarázott varianciával rendelkező elsajátítási teljesítménykerülő célnál is alig 15 százalék az ismert hatás. Egyértelmủen a feladat változójának a hatása emelhető ki a regresszióanalízis alapján is.

A megmagyarázott varianciák értékét tekintve az évfolyamok szerinti elemzéseknél jelentős különbségeket kaptunk, a hetedik osztályosokat kivéve 10 százalék körüli értékeket kaptunk a tanulást kerülő célnál is a további évfolyamokon, illetve az egyes évfolyamokon rendkívül változó a megmagyarázott varianciák értéke (46-49. melléklet). Mindössze azt állapíthatjuk meg, hogy a különbségekért leginkább a feladat változó a felelős, és a legmagasabb ismert hatások általában az elsajátítási teljesítménykerülö cél esetében adódnak. 
85. táblázat. A célok mint függő változók regresszióanalízise a tanári tevékenységeket és társas környezetet leíró változókkal a teljes mintán

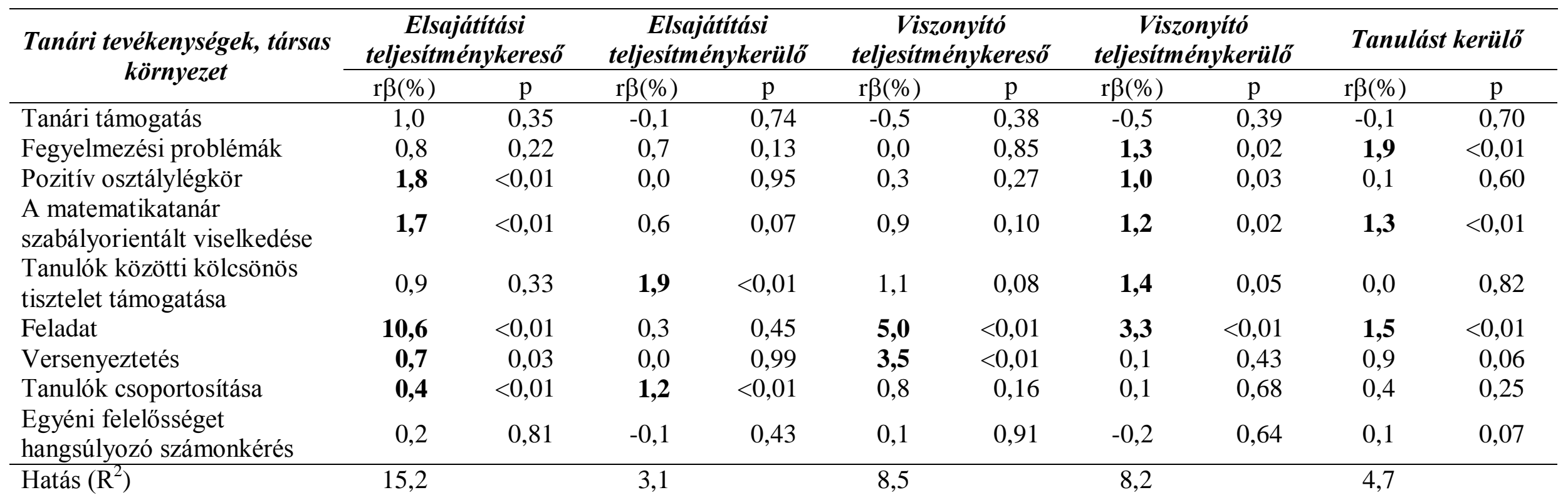

Megj.: félkövér szedés jelzi a 0,05 alatti szinten szignifikáns összefüggéseket. 


\section{A célstruktúrák összefüggése a tanári tevékenységekkel és a társas környezettel}

A célstruktúrák és az osztálytermi környezet további tényezői közötti kapcsolatokra vonatkozó feltételezéseink megfogalmazásánál elsősorban kvalitatív kutatásokra támaszkodhatunk (1. „A tanulási környezet lényeges összetevői a célorientációs elmélet alapján" címü pontban). Ezek alapján azt várjuk, hogy az elsajátítási célstruktúra kialakulását elősegíti a tanári támogatás és a pozitív osztálylégkör, a tanulók közötti kölcsönös tisztelet támogatása, ugyanakkor gyengíti a pedagógus szabályorientált viselkedése. A viszonyító célstruktúra feltételezhetően negatív kapcsolatot mutat a tanári támogatás érzésével, a kölcsönös tisztelet támogatásával.

Bár korábbi kutatásokra nem támaszkodhatunk, logikusnak tünik, hogy ha az alacsony tanári elvárások és az összehasonlítás negatív kontextusa a viszonyító célstruktúrát erősíti, akkor a korábbi teljesítményen alapuló csoportosítást kifejező változónk esetében is a viszonyító célstruktúra kialakulását feltételezhetjük.

A célstruktúrák korrelációi a tanári tevékenységekkel és a szociális környezet jellemzőivel a teljes mintát illetően a 86. táblázatban láthatók. A korrelációs együtthatók általában megerősítik várakozásaink, az eltérés elsősorban a viszonyító célstruktúra esetében mutatkozik, hiszen több változó kapcsán negatív összefüggést jósoltunk e célstruktúrával, amit eredményeink nem támasztanak alá. Említésre érdemes még a matematikatanár szabályorientált viselkedése, amely várakozásainkkal szemben erős kapcsolatot mutat az elsajátítási céllal is. Az osztálytermi környezet kedvező jellemzői motivációs szempontból a feladat, a tanári támogatás és a tanulók közötti kölcsönös tisztelet támogatásának változója. Az egyéni felelősséget hangsúlyozó számonkérés változóját a vizsgálatsorozat tapasztalatai alapján hoztuk létre, az adatok első pillantásra azt jelezik, hogy a környezet motivációs sajátosságainak leírásában fontos szerephez jut, az említettek után következik a fontossági sorban a korrelációs értékek alapján.

86. táblázat. A célstruktúrák korrelációi a tanári tevékenységekkel és a társas környezetet leíró változókkal a teljes mintán

\begin{tabular}{lcc}
\hline \multicolumn{1}{c}{ Tanári tevékenységek, társas környezet } & $\begin{array}{c}\text { Elsajátítási } \\
\text { célstruktúra }\end{array}$ & $\begin{array}{c}\text { Viszonyító } \\
\text { célstruktúra }\end{array}$ \\
\hline Tanári támogatás & $\mathbf{0 , 5 1}$ & $\mathbf{0 , 2 6}$ \\
Fegyelmezési problémák & $\mathbf{- 0 , 2 4}$ & $-0,05$ \\
Pozitív osztálylégkör & $\mathbf{0 , 2 5}$ & $\mathbf{0 , 1 0}$ \\
A matematikatanár szabályorientált viselkedése & $\mathbf{0 , 2 9}$ & $\mathbf{0 , 3 5}$ \\
Tanulók közötti kölcsönös tisztelet támogatása & $\mathbf{0 , 4 5}$ & $\mathbf{0 , 2 3}$ \\
Feladat & $\mathbf{0 , 6 6}$ & $\mathbf{0 , 4 1}$ \\
Versenyeztetés & 0,05 & $\mathbf{0 , 2 7}$ \\
Tanulók csoportosítása & $\mathbf{0 , 1 6}$ & $\mathbf{0 , 2 4}$ \\
Egyéni felelösséget hangsúlyozó számonkérés & $\mathbf{0 , 3 9}$ & $\mathbf{0 , 2 1}$ \\
\hline
\end{tabular}

Megj.: félkövér szedés jelzi a 0,01 alatti szinten szignifikáns összefüggéseket; dőlt és félkövér szedés jelzi a 0,01 és 0,05 közötti szinten szignifikáns összefüggéseket.

Az adatok általában évfolyamok szerinti összevetésben is konzisztensnek mondhatók, ugyanakkor kivételt jelent ez alól a tanulók csoportosítása, a fegyelmezési problémák és az pozitív osztálylégkör (50. melléklet). E tényezők hol az egyik, hol a másik célstruktúrával mutattak jelentős összefüggést. Úgy tünik a tanári támogatás magasabb évfolyamokon egyre fontosabb, míg a matematikatanár szabályorientált viselkedésének szerepe gyengül. 
A többszörös kapcsolatok kiszürése érdekében regresszióelemzést végeztünk a célstruktúrákkal mint függő változókkal. Az eredmények a 87. táblázatban láthatók, melyek szerint az elsajátítási célstruktúra észlelésében mutatkozó különbségek közel felét sikerült változóinkkal megmagyaráznunk, míg a viszonyító célstruktúra eltéréseinek megközelítőleg negyed részét ismerjük, legalábbis a teljes mintát tekintve. Változóink közül mindkét célstruktúra esetében kiemelkedik a feladat elnevezésü változó. Az elsajátítási célstruktúra kialakulásában adataink szerint a kulcsszerephez jut a feladat mellett a tanári támogatás és a tanulók közötti kölcsönös tisztelet támogatása. A viszonyító célstruktúrát támogató környezeti tényezők közül a matematikatanár szabályorientált viselkedése és a versenyeztetés emelkedik ki.

87. táblázat. A célstruktúrák mint függö változók regresszióanalizise a tanári tevékenységeket és társas környezetet leiró változókkal a teljes mintán

\begin{tabular}{lrrrr}
\hline \multirow{2}{*}{\multicolumn{1}{c}{ Tanári tevékenységek, társas környezet }} & \multicolumn{2}{c}{$\begin{array}{c}\text { Elsajátítási } \\
\text { célstruktúra }\end{array}$} & \multicolumn{2}{c}{$\begin{array}{c}\text { Viszonyitó } \\
\text { célstruktúra }\end{array}$} \\
\cline { 2 - 6 } & $\mathrm{r} \beta(\%)$ & $\mathrm{p}$ & $\mathrm{r} \beta(\%)$ & \multicolumn{1}{c}{$\mathrm{p}$} \\
\hline Tanári támogatás & $\mathbf{7 , 7}$ & $<0,01$ & 0,8 & 0,41 \\
Fegyelmezési problémák & $\mathbf{1 , 5}$ & $<0,01$ & 0,0 & 0,74 \\
Pozitív osztálylégkör & $\mathbf{2 , 2}$ & $<0,01$ & 0,4 & 0,25 \\
A matematikatanár szabályorientált viselkedése & $\mathbf{2 , 8}$ & $<0,01$ & $\mathbf{6 , 8}$ & $<0,01$ \\
Tanulók közötti kölcsönös tisztelet támogatása & $\mathbf{6 , 7}$ & $<0,01$ & 1,4 & 0,11 \\
Feladat & $\mathbf{2 7 , 0}$ & $<0,01$ & $\mathbf{1 0 , 2}$ & $<0,01$ \\
Versenyeztetés & 0,0 & 0,61 & $\mathbf{5 , 4}$ & $<0,01$ \\
Tanulók csoportosítása & 0,8 & 0,06 & $\mathbf{2 , 3}$ & $<0,01$ \\
Egyéni felelősséget hangsúlyozó számonkérés & 1,9 & 0,09 & 0,2 & 0,78 \\
\hline Hatás $\left(\mathrm{R}^{2}\right)$ & 47,9 & \multicolumn{4}{c}{24,7} \\
\hline
\end{tabular}

Megj.: félkövér szedés jelzi a 0,05 alatti szinten szignifikáns összefüggéseket.

Az eredményeket évfolyamok szerint vizsgálva azt láthatjuk, hogy az elsajátítási cél megmagyarázott varianciája viszonylag széles határok között mozog, az évfolyamok emelkedésével párhuzamosan egyre nő, míg 5. évfolyamon megközelítőleg a tanulók észlelésében adódó különbségek negyedét, addig 8. évfolyam a felét sikerült lefednünk a vizsgált változókkal (51. melléklet). Ezzel szemben a viszonyító célstruktúra megmagyarázott varianciája alig mutat évfolyamok közötti eltéréseket (52. melléklet). A feladat változatosságát, hasznosságát kifejező változó központi szerepét megerösítik az évfolyamok szerinti regresszióanalízisek. A további változók szerepét tekintve kissé furcsa, hogy mind a tanári támogatás, mind a tanulók közötti kölcsönös tisztelet támogatása két-két évfolyamon jelentős magyarázó erőt képvisel, míg a további két évfolyamon nem szignifikáns az összefüggésük az elsajátítási célstruktúrával. A viszonyító célstruktúra esetében említésre méltónak látszik még a tanulók előzetes teljesítményük alapján történő csoportosítása, mely két évfolyamon szignifikáns magyarázó erővel bír, 4-5 százalék körüli értékben. A matematikatanár szabályorientált viselkedése kapcsán az évfolyamok emelkedésével párhuzamos csökkenő tendencia kirajzolódását tapasztalhatjuk, vagyis ennek fontossága egyre kisebb. 


\section{Összegzés}

Az összefüggések áttekintésének megkönnyítése érdekében a 19. ábrán az egyes konstruktumok közötti kapcsolatokat ábrázoltuk a megmagyarázott varianciák feltüntetésével. Eredményeink szerint a matematika osztályzatokkal egyedül az elsajátítási célok hozhatók kapcsolatba. Ha a korrelációs együtthatók értékeit a korábbi hazai kutatásokkal egybevetjük, az elsajátítási teljesítménykereső cél kapcsán jelentős összefüggésről beszélhetünk.

A célorientációk és a célstruktúrák között kapcsolatot mutattak ki mérőeszközeink. Elemzésünk arról tanúskodik, hogy az elsajátítási célstruktúra általában erősebb kapcsolatot mutatat az elsajátítási célokkal, míg a viszonyító célstruktúra a viszonyító célokkal. Az eredmények egyedül az elsajátítási teljesítménykerülő cél esetében nem konzisztensek.

Az osztálytermi környezet célstruktúrákat befolyásoló elemei közül az órákon megoldott feladatok változatossága, hasznossága emelkedik ki. Az elsajátítási célstruktúra szempontjából emellett a tanári támogatás és a tanulók közötti kölcsönös tisztelet támogatása fontos, míg a viszonyító célstruktúrát támogató környezeti tényezők közül a matematikatanár szabályorientált viselkedése és a versenyeztetés jut lényeges szerephez. A regresszióanalízisek eredményei szerint az elsajátítási célstruktúra tekintetében a tanulók közötti különbségek nagy arányát, 47,9 százalékát, míg a viszonyító célstruktúra esetében a különbségek 24,7 százalékát magyarázzák az általunk felmért tényezők.

A célorientációk és az osztálytermi környezetet leíró változók viszonyát ugyancsak megvizsgáltuk, azonban a kapcsolatok általában kevésbé jelentősnek mutatkoztak, mint amelyeket a célorientációk és a célstruktúrák, vagy a célstruktúrák az osztálytermi környezet faktorai között tapasztaltunk. Ezek az eredmények arra utalnak, hogy az osztálytermi környezet motivációs tényezői és a célorientációk között a célstruktúrák konstruktumai teremtenek kapcsolatot.

A kapcsolatok általában évfolyamok szerint is hasonló mintázatot mutattak, ugyanakkor az 5. évfolyam esetében néhány ponton lényeges eltéréseket láthattunk. A tanulást kerülő cél és a viszonyító célstruktúra, a feladat elnevezésű változó és az elsajátítási teljesítménykereső cél összefüggésében, valamint a célstruktúrák megmagyarázott varianciáiban tapasztaltunk említésre méltó különbségeket. 


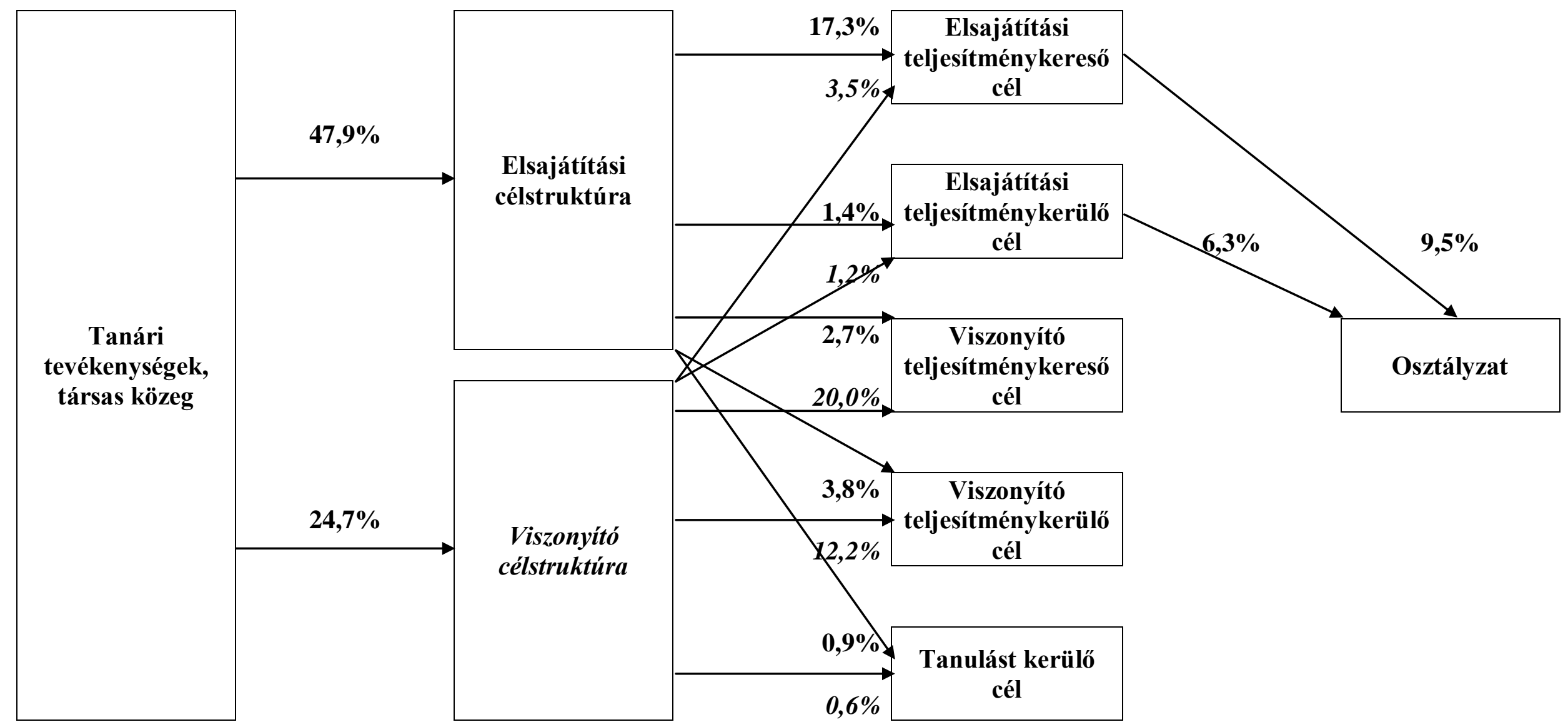

Megj.: az elsajátítási és a viszonyító célstruktúra célorientációkra gyakorolt hatásának elkülönítése érdekében a viszonyító célstruktúrához kapcsolódó megmagyarázott varianciákat félkövér szedés jelzi. 


\section{0. ÖSSZEGZÉS, KÖVETKEZTETÉSEK}

\section{Az eredmények összefoglalása, értelmezése}

A tanulási motiváció kontextusfüggő jellegét felismerve a motivációkutatás az utóbbi két évtizedben az alapkutatás irányából egyre inkább a használatorientált alapkutatás irányába látszik elmozdulni, vagyis a vizsgálatok a tudományos megértést és az ökológiai validitást egyaránt szem elött tartva valós iskolai környezetben folynak. E megközelítés széles körben elfogadott, alkalmazott elméleti keretét a célorientációs elmélet jelenti.

A tanulási motiváció osztálytermi folyamatait tekintve alig rendelkezünk ismeretekkel hazai kontextusban, ahogy ennek feltérképezésére alkalmas mérőeszközökkel sem. E dolgozat a célorientációs elmélet által felhalmozott tudás hazai felhasználásának megalapozására vállalkozott, egyrészt a célorientációs elméleten alapuló olyan mérőeszköz-család létrehozása által, amely alkalmas a tanulók motivációs sajátosságai és az osztálytermi környezet interakciójának feltárására; másrészről tanulóink céljainak, valamint a hazai osztálytermek néhány motivációs sajátosságainak feltárásával; harmadrészt a tanulók céljai és az osztálytermi környezet közötti összefüggések közül néhány alapvető jelentőségű azonosításával.

\section{A kifejlesztett méröeszköz-család müködése}

A tanulók célorientációinak megismerésére három felmérés eredményei alapján fejlesztettük ki a Tanulói célok kérdőívet. A fejlesztési folyamat során a klasszikus és a modern tesztelmélet kínálta lehetőségekre egyaránt támaszkodtunk. A faktoranalízis alapján az előzetes elméleti struktúrába 20, céltípusonként 4-4 Likert-skálás kérdőívtétel tartozik, a Kaiser-Meyer-Olkin mutató értéke a teljes mintán 0,88, ami egyértelmüen jelzi a változórendszer faktorizációra való alkalmasságát. A mérőeszköz megbízhatósága az egyes céltípusokat tekintve a teljes mintán 0,71 és 0,93 között változik, a legalacsonyabb értékek az 5 . évfolyamos tanulók körében tapasztalhatók, azonban minden esetben meghaladják a 0,7-es értéket.

A parciális kredit modellel végzett elemzés alapján a teljesítménykerülő célokhoz képest a teljesítménykereső céloknál nagyobb különbségeket azonosítottunk évfolyamok szerint a tanulók motivációjában. A kérdőívtételek modellilleszkedése minden részmintában és dimenzióban megfelelö, a skálapontok küszöbértékei a motivációs szint növekedésével párhuzamosan emelkednek. A teljes mintán a teljesítménykerülő céldimenziókhoz tartozó kérdöívtételek többnyire megfelelően fedik le a tanulók motivációs szintjét, ugyanakkor a teljesítménykereső céloknál azonosítható egy magasabb motivációs szint, amelyet az egyes skálapontok nem fednek le. Megjegyezzük, hogy a célok mérésére leggyakrabban alkalmazott kérdőívekre sem jellemző a kifogástalan lefedettség (pl. Martin és mtsai, 2008).

Egy további kérdőívet hoztunk létre, amely az osztályterem motivációs jellemzőit holisztikus megközelítéssel leíró célstruktúrákról, valamint az osztálytermi környezet néhány konkrétabb sajátosságáról, így a társas közegről és a tanári tevékenységekről informál. Két mérésre támaszkodva fejlesztettük ki az Osztálytermi környezet kérdöivet, amelynek mind érvényességét, mind megbízhatóságát megerősítették eredményeink. A 48 állításból álló Likert-skálás eszköz KMO-mutatója 0,90. A mérőeszköz a két célstruktúráról 5-5 kérdőívtételen keresztül (Cronbach- $\alpha$ : 0,79 és 0,85$)$, valamint a szociális közegről és a tanári tevékenységekröl kilenc skála 3-6 kérdőívtétele által (Cronbach- $\alpha: 0,66-0,85)$ tájékoztat. 
A célorientációk és a célstruktúrák közötti kapcsolatok általában elvárásainknak megfelelően alakultak. Leginkább a viszonyító célok hozhatók kapcsolatba a viszonyító célstruktúrával, a teljesítménykereső esetében 20,0, míg a teljesítménykerülö összetevőnél 12,2 százalék a megmagyarázott variancia. Ez az elsajátítási teljesítménykereső cél és az elsajátítási célstruktúra összefüggésében 17,3 százalék, míg a teljesítménykerülő esetében 1,4. Utóbbi konstruktum tekintetben nem rendelkezünk viszonyítási ponttal, az eredmények Baranik és munkatársainak (2010) metaelemzését megerősítve e céltípusnak a többitől jelentősen eltérő működéséről tájékoztatnak.

$\mathrm{Az}$ elsajátítási célstruktúra tekintetében a regresszióanalízisek eredményei szerint a tanulók közötti különbségek közel felét (47,9\%), míg a viszonyító célstruktúra esetében a különbségek nagyjából negyedét (24,7\%) magyarázzák az általunk kiválasztott osztálytermi társas környezethez és tanári tevékenységekhez kapcsolódó tényezők. Vagyis az osztálytermi környezet különböző jellemzői és a célstruktúrák kapcsolatba hozhatók kérdőíveink által, továbbá a környezeti tényezők közül néhány lényegeset sikerült azonosítanunk.

A célorientációk különbségének viszonylag kis részét tudtuk a tanári tevékenységeket és a társas közeget leíró változókkal összefüggésbe hozni, az elsajátítási teljesítménykereső cél kapcsán adódott a legmagasabb megmagyarázott variancia, ennek értéke 15,2 százalék volt. Az eredmények tehát arra utalnak, hogy a célorientációk és az osztálytermi környezet motivációs tényezői között a célstruktúrák töltenek be közvetítő szerepet. Összességében megállapítható, hogy a kifejlesztett mérőeszköz-család konstruktumainak kapcsolata megfelel a várakozásoknak, és alkalmas a célorientációk és az osztálytermi környezet összefüggéseinek feltérképezésére.

\section{A célorientációk jellemzöi tanulóink körében}

Adataink arra utalnak, hogy tanulóink körében a legkedvezőtlenebb következményekkel kísért viszonyító teljesítménykerülő cél a legkedvezőbbként számon tartott elsajátítási teljesítménykereső céllal jelentősen összefügg $(0,49 ; p<0,01)$. Ez az összefüggés az Egyesült Államokban végzett vizsgálatok alapján nem várt jelenség $(0,13 ; p<0,01$; $\mathrm{n}=9014$ ), és arra enged következtetni, hogy a célok kombinációja esetén kevéssé valószínű előnyös összetételek előfordulása tanulóink körében. E kapcsolat minden bizonnyal kulturális eltérésként értelmezhető, több nem egyesült államokbeli tanulókkal végzett vizsgálat ugyancsak ezen a ponton talált eltérést (pl. Dela Rosa, 2010; Lau és Lee, 2008; Shih, 2005).

Elemzéseink szerint az osztályzatok és a célorientációk kapcsolata nem felel meg a nemzetközi szakirodalom alapján megfogalmazott elvárásainknak, mely szerint leginkább a viszonyító teljesítménykereső cél felelős a tanulók osztályzatai közötti eltérésekért. Tanulóink körében az elsajátítási cél két dimenziójával hozhatók összefüggésbe a jegyek, míg a teljesítménykereső céltípus az osztályzatok közötti különbségek 9,5, a teljesítménykerülő a 6,3 százalékát magyarázza. Ugyanakkor az a célorientációs elméletből következő kívánalom teljesül, miszerint az elsajátítási cél előnyös hatása megmutatkozik az osztályzatokkal összefüggésben. Magyarázatként tanáraink egyesült államokbeli kollégáitól eltérő - például feleletválasztó tesztekre vélhetően ritkábban támaszkodó - értékelési gyakorlata merülhet fel.

A tanulást kerülő cél belső összefüggéseit tekintve megfelelt az elözetes várakozásoknak. Bár az osztályok közötti különbségek magyarázatában hasonló súlyt képviselt, mint a többi cél, ezen kívül mindössze a tanulók nemével mutatott kapcsolatot $(0,25 ; \mathrm{p}<0,01)$, a lányok körében valamivel gyakoribb e cél követése. 
Vagyis felmérésünkben e céltípuson keresztül nem jutottunk lényeges információkhoz, azonban nem kizárható, hogy a tanulók kognitív teljesítményével összefügg.

Az osztályok között az elsajátítási célok és a viszonyító teljesítménykerülő cél alapján tehetünk különbségeket, melyek jelentősége közel azonosnak tekinthető. Az elsajátítási teljesítménykereső és a két viszonyító cél alapján tapasztaltunk évfolyamok szerinti eltéréseket, az ötödikes korosztály céljai magasabbak voltak, mint a 6-8. évfolyamra járó tanulóké. E ponton meg kell jegyeznünk, hogy a viszonyító teljesítménykereső cél - legalábbis a nemzetközi kutatási eredmények szerint kedvezőtlen kognitív és motivációs folyamatokhoz is kapcsolódik, így ez az eltérés ellentmond annak a korábbi hazai kutatásokban tapasztalt általánosnak mondható tendenciának, hogy diákjaink motivációs jellemzői egyre kedvezőtlenebbek.

\section{Az osztálytermi környezet jellemzöi}

Az önfejlesztésre irányuló elsajátítási célstruktúra és az összehasonlításra fókuszáló viszonyító célstruktúra észlelése általában egyidejűleg jelenik meg tanulóink körében, ugyanakkor az osztályok között szélsőséges különbségek adódnak. Találtunk olyan osztályt, ahol 0,92 volt korrelációs együttható $(\mathrm{p}<0,01)$, ugyanakkor más tanulóközösségekben nem kaptunk szignifikáns kapcsolatot. Az egyes osztályok általában valamivel élesebben különülnek el az elsajátítási célstruktúra tekintetében, ugyanakkor az 5. évfolyamon az osztályok közötti különbségekben a viszonyító célstruktúrának van nagyobb, a magasabb évfolyamokon tapasztaltakat meghaladó szerepe. Ez talán a tanulók közötti társas összehasonlítás gyakoribb előfordulására utal, és magyarázatot kínálhat arra, hogy az ötödikesek viszonyító céljai miért erősebbek.

A tanári tevékenységeket és a szociális közeget jellemző változók többsége ugyancsak az 5., néhány változónál az 5. és 6 . évfolyamon tér el a többitől. E tényezők közül a feladat és a kölcsönös tisztelet támogatása emelkedik ki, utóbbi jelentősége az idősebb korosztályban egyre fontosabb szerephez jut a további környezeti tényezők megítélése kapcsán. Az osztályok közötti különbségekben a fegyelmezési problémák előfordulása a legmeghatározóbb.

Eredményeink alapján úgy tünik, hogy a 6., 7. és 8. évfolyamos tanulók az osztálytermi környezetet hasonlóan ítélik meg, viszonylag egységes ezen évfolyamok környezete a motivációs üzeneteket tekintve, legalábbis a mintánkba került osztályokban. Ezzel szemben az ötödikes tanulók tapasztalatai az osztályterem motivációs közegét illetően több ponton eltérnek az idősebb tanulókétól. Talán az alsó és felső tagozat közötti átmenetet, a felső tagozathoz még kevésbé igazodó környezetet, egy átállást megkönnyítő tanári magatartást tükröznek az adatok.

\section{Az osztálytermi környezet motivációs hatása}

Mivel adataink szerint az elsajátítási teljesítménykereső cél összefüggésbe hozható az osztályzatokkal, az elsajátítási célstruktúra pedig az elsajátítási teljesítménykereső cél tanulók közötti különbségeinek számottevő részérét felelős, az osztálytermi környezet azon elemeinek azonosítása, amelyek hatást gyakorolnak az elsajátítási célstruktúrára, tulajdonképpen közvetett módon megmutatja, hogy a tanulók osztályzatai a környezet mely elemeinek manipulálásával befolyásolhatók.

Az elsajátítási célstruktúra tekintetben kiemelkedik a feladat elnevezésű változó, emellett a tanári támogatás és a tanulók közötti kölcsönös tisztelet támogatása jut kulcsszerephez $(\mathrm{r}=0,45-0,66 ; \mathrm{p}<0,01)$. Vagyis amennyiben ezeket az osztálytermi jellemzőket sikerül pozitív irányba befolyásolni, feltételezhetjük a tanulók motivációjának kedvező irányú alakulását, és a teljesítményük növekedését. A 
viszonyító célstruktúrák alakulásában ugyancsak a feladat változó a legfontosabb, emellett a matematikatanár szabályorientált viselkedése és a versenyeztetés meghatározó $(\mathrm{r}=0,27-0,41 ; \mathrm{p}<0,01)$.

Az adatokból az is kitünik, hogy az említett környezeti tényezők jelentősége évfolyamok szerint is különbözik. Az eredmények arra utalnak, hogy mind a feladat változatossága, hasznossága, mind a tanulók közötti kölcsönös tisztelet támogatása, mind a tanári támogatás szerepe a magasabb évfolyamokon egyre fontosabb lesz.

\section{Az eredmények hasznosíthatósága}

Alig rendelkezünk ismeretekkel osztálytermeink motivációs hatásáról, tulajdonképpen a beavatkozási pontok feltárása sem történt még meg, így az empírián alapuló motívumfejlesztő stratégiák hiányoznak a magyar neveléstudományi szakirodalomból. A munkánk eredményeként kifejlesztett mérőeszköz-család elsősorban e téren kínál elörelépést. Kérdőíveink segítségével azonosítható a tanári tevékenység és a társas közeg néhány tanulási motivációt befolyásoló összetevője. A tanulási környezetet holisztikusan jellemző célstruktúrák viszonyítási pontként szolgálhatnak a környezet motivációs elemeinek részletesebb feltérképezésére indított további, akár kvalitatív, akár kvantitatív módszerekre támaszkodó kutatásokhoz. Emellett a feltárt összefüggések a további vizsgálatokhoz jelentős iránymutatást kínálnak. Bár rendelkezésünkre áll a tanulási motiváció több konstruktumának felmérésére magyar nyelvű mérőeszköz, a környezet motivációs sajátosságainak feltérképezésére jelenleg az Osztálytermi környezet kérdöív az egyetlen.

A kidolgozott mérőeszközök intervenciós programok értékelése során is jól hasznosíthatók lehetnek. Úgy tűnik, a motivációs konstruktumok jó része, így a célorientációk is viszonylag stabil személyiségjellemzők, vagyis rövid távon csak korlátozott mértékben alkalmasak a különböző beavatkozások motivációs hatásának értékelésére. Ugyanakkor a célstruktúrák talán érzékenyebbek, így a környezet motivációs üzeneteiben bekövetkező - akár pozitív, akár negatív - változásokat még azelött jelezhetik, mielött a tanulók motivációs jellemzőben bekövetkezne bármiféle átalakulás.

A korábbi kutatások szerint bár a viszonyító célok, illetve a viszonyító célstruktúra hozzájárulhat a teljesítmény növekedéséhez, valószínüsíthető, amennyiben ez nem párosul elsajátítási célokkal, illetve elsajátítási célstruktúrával, hosszú távon inkább károsan befolyásolja az önfejlesztésre irányuló célokat. Vagyis a célorientációs elméleten alapuló mérések magukban rejtik annak lehetőségét, hogy a tanulási környezet motivációs jellemzőinek változásáról a korábbiaknál részletesebb, a tanulási motivációt rövid távon előnyösen, hosszú távon előnytelenül érintő jellemzőiről is információkat szerezhessünk.

Az előzőekben bemutatott megközelítéssel gyüjtött eredményeken keresztül eljuthatunk olyan - a tanulási motivációt, az ismeret vagy képesség jellegü tudást, esetleg ezek különféle kombinációját célzó - fejlesztő programok tervezéséhez, amelyek a tanulási motiváció alakulására az empirikus eredmények felhasználásával az eddigieknél lényegesen nagyobb figyelmet fordíthatnak.

\section{További kutatási lehetőségek}

A célorientációk teljesítményre gyakorolt hatásáról a nemzetközi szakirodalom alapján fogalmaztunk meg feltételezéseket, e kérdéskört munkánkban mindössze néhány 
osztályzattal összefüggésben vizsgálhattuk. Mivel a tanulási motiváció kontextusfüggő jelenség, illetve saját fejlesztésü mérőeszközt alkalmaztunk, elengedhetetlen, hogy az egyes célokhoz kapcsolódó következményeket a tanulói teljesítmények tekintetében további területeken ellenőrizzük. Ennek fontosságára hívják fel figyelmünket azok az eredményeink is, amelyek a célorientációk, valamint a célorientációk és az osztályzatok között az amerikai mintákon feltártakhoz képest eltérő összefüggéseket jeleztek. A további vizsgálódást a teljesítmények és a célok kapcsolatát illetően az is megköveteli, hogy tudvalevő, az osztályzatokat a tanulók tudása mellett számos körülmény befoláyolhatja (1. Csapó, 2002b; Sáska, 1991). A jövőbeni felmérésekben érdemes a diákok kognitív teljesítményéről más forrásokból is információt gyüjteni. Ennek legegyszerübben kivitelezhetö - a nemzetközi szakirodalomban gyakran alkalmazott megoldásaként a tanulás stratégiák felmérése kínálkozik. Ennél azonban jóval megbízhatóbb információkhoz juthatunk, ha az induló tudás- valamint képességszintet kontroláló longitudinális vizsgálatokkal kapcsoljuk össze a célorientációk, illetve célstruktúrák felmérését.

Mérőeszközünk továbbfejlesztésére több okot is találhatunk. Az elsajátítási teljesítménykereső és a viszonyító teljesítménykerülő cél személy-item térképen, fơképp az alacsonyabb évfolyamokon, kisebb lefedettségi problémák azonosíthatók, valamint az osztálytermi környezet egyes tényezőihez tartozó kérdöívtételek száma alacsony. Ha a célstruktúrák és az osztálytermi környezet összefüggéseit vesszük szemügyre, láthatjuk, hogy az egyik célstruktúra esetében a tanulók közötti különbségek nagyjából felét, míg a másiknál a negyedét sikerült lefednünk a felmért környezeti jellemzőkkel. Célszerü lenne ebbe az irányba is lépéseket tenni, vagyis a megmagyarázott variancia értékét tovább növelni, egyéb környezeti tényezőkkel összekapcsolni a célstruktúrákat. Számos további osztálytermi környezetet leíró tényező esetében feltételezhető összefüggés a célstruktúrákkal. Példaként említhető a teljesítményre irányuló nyomás, amely a PISA-mérés adatai szerint jelentős mértékben meghaladja hazánkban a nemzetközi átlagot (Willms, 2003), és akár magyarázatot is kínálhat a viszonyító teljesítménykerülö cél és az elsajátítási teljesítménykereső cél kapcsolatára tanulóink körében. De az általunk felmért korosztályban nem müködö odatartozás érzése is megemlíthető, amely a környezet motivációs sajátosságainak tanulók közötti eltéréseit magyarázhatja. Láthatjuk, hogy e megközelítés a környezet motivációs sajátosságainak részletesebb megismerése felé vezet. Ebben a kvantitatív és kvalitatív egységekből álló adatgyüjtés ciklikus alkalmazása javasolható, amelyben tanulói interjúkra, nyílt végü írásbeli kikérdezésre és osztálytermi megfigyelésekre támaszkodva történhet meg a kérdőívtételek bővítése, amit az eredmények szélesebb körü kvantitatív megközelítésü ellenőrzése követhet.

A vizsgálat kontextusaként a matematika tantárgyat választottuk, azonban az azonosított összefüggések ellenőrzése más tantárgyakhoz kötődően is szükségesnek látszik, hiszen jelen pillanatban nem tudjuk, hogy eredményeink csak a matematika esetében helytállóak, vagy további, például humán tárgyak kapcsán is jellemzőek. E ponton megemlíthetjük még, hogy a célok által megmagyarázott varianciák a szorgalom jegy estében magasabbak voltak, mint a matematika jegynél, ami a célorientációkat mérő kérdőívtételek kontextushoz kötődő és általános megfogalmazásai közötti különbségek részletesebb vizsgálatára hívja fel a figyelmet. Tehát elképzelhető, hogy a tanulók célorientációi a különböző tantárgyakhoz kapcsolódóan tulajdonképpen azonosnak tekinthetők. Ugyanakkor felmerülhet annak a problémája e megközelítés követése esetén, hogy az általános megfogalmazású állítások kevésbé hozhatók kapcsolatba adott tárgy órai légkörével, tanári tevékenységeivel. Azaz, még ha nem szorosan tantárgyakhoz kötődő tanulói jellemzőkről van is szó, akkor is előnyösebb 
lehet a tantárgyakhoz kötődő mérőeszközök alkalmazása, amennyiben a tanulási környezet motivációs hatásának megismerése a célunk.

Eredményeink szerint a feladat elnevezést viselő változó részletesebb megismerése kulcsfontosságú lehet a motívumfejlesztő stratégiák kidolgozásában. Vagyis a diákok véleményének részletes feltárása e területen központi jelentőségü feladatként jelentkezik. A gyakorlati alkalmazás szempontjából lőrelépést jelenthet olyan fejlesztő programok elindítása, amelyek felhasználják a célokkal kapcsolatban jelenleg rendelkezésre álló eredményeket, akár a tanulási motiváció, akár egyéb személyiségkomponensek fejlesztésére fókuszálva.

A célorientációs elmélet motívumfejlesztés céljából alkalmazható javaslatainak gyakorlati megvalósítását a tanári nézetek jelentős mértékben befolyásolhatják, így a pedagógusok körében érdemes lehet feltárni az elmélettel kapcsolatos nézeteket (pl. a teljesítmények összevetésével kapcsolatos vélekedéseket), ami a tanulói kérdőívek által gyüjtött információk értelmezéséhez is jelentősen hozzájárulhat.

Korábban rámutattunk arra, hogy a célorientációs elmélet által javasolt motívumfejlesztő stratégiák között egyetlen olyan sincs, amely más elmélet keretei között ne tünne fel. Ebből következően az Osztálytermi környezet kérdőiven szereplő környezeti összetevőket érdemes lehet további motivációs konstruktumokkal összefüggésben is megvizsgálni, ami az egyes tényezök jelentőségét illetően bővítheti tudásunk. 


\section{KÖSZÖNETNYILVÁNÍTÁS}

Először is témavezetőmnek, Józsa Krisztiánnak szeretném kifejezni a hálámat, akire egyetemista éveimtől kezdődően mindig számíthattam, aki segített a tanulási motiváció jelenségének megértésében, akitől megtanulhattam a kutatásmódszertan alapjait, és aki gyakran az elvárhatónál is nagyobb gondossággal segítette nemcsak a dolgozathoz kapcsolódó, de egyéb munkáim megszületését is.

Csapó Benö támogatása, magas szintü elvárásai, és az általa létrehozott inspiráló szellemi közeg ugyancsak egyetemista éveimtől kezdődően meghatározó. Emellett köszönöm, hogy lehetővé tette a Neveléstudományi Intézet és a Doktori Iskola infrastruktúrájának használatát.

Köszönetet mondok Molnár Edit Katalinnak, akitől a tanulási motiváció témakörét érintő első szemináriumi dolgozatom kapcsán kaptam bátorítást, folyamatos támogatást, és akitől sokat tanulhattam a tudományos munkához szükséges alaposságról és gondolataim szöveggé formálásáról.

A Tanulói célok kérdöiven közösen dolgoztam Vigh Tiborral, akinek ezúton köszönöm hozzájárulását, kritikai észrevételeit, és a rendkívül hasznos szakmai beszélgetéseket. Szenczi Beátával a motiváció témakörében folytatott beszélgetéseink szintén formálták e munkát, köszönetet mondok érte.

$\mathrm{Az}$ adatrögzítések során nyújtott segítőkészségéért, fáradhatatlan munkájáért Csomorné Benkovics Ágnesnek tartozom köszönettel. A harmadik fejezet ábráinak szerkesztésében Börcsökné Soós Edit segítségét köszönöm. Balázsi Ildikónak köszönöm, hogy rendelkezésemre bocsátotta a 2003-as PISA-vizsgálat magyar nyelvü tanulói kérdőívét.

Köszönöm Bárányné Jámbori Szilviának és Csíkos Csabának a disszertáció házi védésre benyújtott változatához füzött értékes megjegyzéseit, javaslatait.

A minta összeállításában, a mérések megszervezésében és az adatfelvétel lebonyolításában számos kolléga, intézményvezető, pedagógus munkájáért tartozom köszönettel. Szeretném kifejezni a hálámat Antal Jánosnénak, Béresné Majoros Ildikónak, Bucsai Ferencnének, Budásné Kis Editnek, Csikós Erzsébetnek, Csináthné Bakó Évának, Dani Tibornénak, Dézsi Erzsébetnek, Hegyi Györgynének, Ignáczné Ribarics Editnek, Kovács Beátának, Kovács Tündének, Ladányi Gábornénak, Miklós Anikónak, Paróczai Zoltánnak, Patócs Anikónak, Szádvári Lászlónak, Sziget Györgynek, Szücs Norbertnek, Takács Istvánnak, Takács Sándornak, Thamó Emökének, Tomasev Marinnénak, Tóthné Kecskeméti Katalinnak, Tóthné Lengyel Máriának, Turcsányiné Kertész Ilonának, Weiner Andrásnak, Zsemberiné Futó ldikónak, Zsohárné Szenczy Liliannának. Köszönöm továbbá a felmérésekben részt vevő tanulók közremüködését.

Köszönettel tartozom barátaim közül Csempesz Péternek, Kasik Lászlónak, Kelemen Valériának és Szücs Norbertnek, akik a dolgozat megírásának utolsó szakaszában segítségemre voltak abban, hogy feladataim egy része alól mentesülhessek.

Végezetül pedig a legnagyobb köszönettel szeretteimnek tartozom. A szüleimnek, akik tanulmányaimban mindig támogattak, és kedvesemnek, Varga Andreának, aki nagy-nagy türelemmel viselte e dolgozat megszületését.

Az értekezés az OTKA K68798 és K83850 pályázatok támogatásával valósult meg. 


\section{IRODALOM}

Adelman, H. S. és Taylor, L. (2005): Classroom climate. In: Lee S. W. (szerk.): Encyclopedia of school psychology. Sage, Thousand Oaks, CA. 88-90.

Adesope, O. O., Gress, C. L. Z. és Nesbit, J. (2008): Examining the Psychometric Properties of Achievement Goal Questionnaire using Item Response Theory. Canadian Society for the Study of Education, Vancouver, BC.

Ames, C. (1992): Classrooms: Goals, structures, and student motivation. Journal of Educational Psychology, 84. 3. sz. 261-271.

Ames, C. és Archer, J. (1988): Achievement Goals in the Classroom: Students' Learning Strategies and Motivation Processes. Journal of Educational Psychology, 80. 3. sz. 260-267.

Anderman, E. M. és Maehr, M. L. (1994): Motivation and schooling in the middle grades. Review of Educational Research, 64. 2. sz. 287-309.

Anderman, E. M. és Midgley, C. (1997): Changes in achievement goal orientations, perceived academic competence, and grades across the transition to middle level schools. Contemporary Educational Psychology, 22. 3. sz. 269-298.

Anderman, E. M. és Midgley, C. (2004): Changes in self-reported academic cheating across the transition from middle school to high school. Contemporary Educational Psychology, 29. 4. sz. 499-514.

Anderman, E. M., Griesinger, T. és Westerfield, G. (1998): Motivation and cheating during early adolescence. Journal of Educational Psychology, 90. 1. sz. 84-93.

Anderman, L. H. (1999): Classroom goal orientation, school belonging and social goals as predictors of students' positive and negative affect following the transition to middle school. Journal of Research and Development in Education, 32. 2. sz. 89-103.

Anderman, L. H. és Anderman, E. M. (1999): Social predictors of changes in students' achievement goal orientations. Contemporary Educational Psychology, 25. 1. sz. $21-37$.

Anderman, L. H. és Anderman, E. M. (2000): Considering contexts in educational psychology: Introduction to the special issue. Educational Psychologist, 35. 2. sz. 67-68.

Anderman, L. H., Patrick, H., Hruda, L. Z. és Linnenbrink, E. A. (2002): Observing classroom goal structures to clarify and expand goal theory. In: Midgley, C. (szerk.): Goals, goal structures, and patterns of adaptive learning. Mahwah, NJ: Lawrence Erlbaum Associates. 243-278.

Andor Mihály (2001): Társadalmi egyenlőtlenség és oktatás. Educatio, 10. 1. sz. 11-30.

Andrich, D. A. (1978): A rating formulation for ordered response categories. Psychometrika, 43. 4. sz. 561-573.

Artelt, C., Baumert, J., Julius-Mc-Elvany, N. és Peschar, J. (2003): Learners for life. Student approaches to learning. Results from PISA 2000. OECD, Paris. 
Arts, J. A. R., Gijselaers, W. H. és Segers, M. S. R. (2002): Cognitive effects of an authentic computer-supported problem-based learning enviroment. Instructional Science, 30. 6. sz. 465-495.

Atkinson, J. W. (1966/1988): A kockázatvállaló viselkedés motivációs meghatározói. In: Barkóczi Ilona és Séra László (szerk.): Az emberi motiváció I-II. Tankönyvkiadó, Budapest. 179-201.

Atkinson, R. L., Atkinson, R. C., Smith, E. E. és Bem, D. J. (1993/1994): Pszichológia. Osiris-Századvég Kiadó, Budapest.

Austin, J. T. és Vancouver, J. B. (1996): Goal constructs in psychology: Structure, process, and content. Psychological Bulletin, 120. 3. sz. 338-375.

B. Németh Mária és Habók Anita (2006): A 13 és 17 éves magyar tanulók viszonya a tanuláshoz. Magyar Pedagógia, 103. 2. sz. 83-105.

Babad, E. (1993): Pygmalion - 25 years after interpersonal expectations in the classroom. In: Blanck, P. D. (szerk.): Interpersonal expectations: Theory, research, and application. Cambridge University Press, London. 125-153.

Babad, E. (2009): The social psychology of the classroom. Routledge, New York.

Bacsa Éva (2008): A tanulási célok vizsgálata az angol nyelvtanulás tükrében. Iskolakultúra, 18. 7-8. sz. 33-49.

Ballér Endre (1973): Tanulói attitüdök vizsgálata. Pedagógiai Szemle, 23. 7-8. sz. 644657.

Bánfi Ilona (1999): Az iskolai teljesítményt befolyásoló háttértényezők. Új Pedagógiai Szemle, 49. 6. sz. 14-28.

Baranik, L. E., Barron, K. E. és Finney, S. J. (2007): Measuring goal orientation in a work domain: Construct validity evidence for the 2 x 2 framework. Educational and Psychological Measurement, 67. 4. sz. 697-718.

Baranik, L. E., Barron, K. E. és Finney, S. J. (2010): Examining general versus specific measures of achievement goals. Human Performance, 23. 2. sz. 155-172.

Baranik, L. E., Bynum, B. H., Stanley, L. J. és Lance, C. E. (2010): Examining the construct validity of mastery-avoidance achievement goals: A meta-analysis. Human Performance, 23. 3. sz. 265-282.

Barkóczi Ilona és Putnoky Jenő (1980): Tanulás és motiváció. Tankönyvkiadó, Budapest.

Barrett, K. C. és Morgan, G. A. (1995): Continuities and discontinuities in mastery motivation during infancy and toddlerhood: a conceptualization and review. In: MacTurk, R. H. és Morgan, G. A. (szerk.): Mastery motivation: Origins, conceptualizations and applications. Vol. 12. Advances in applied developmental psychology. Ablex Publishing Corporation, Norwood, New Jersey. 57-94.

Barron, K. E. és Harackiewicz, J. M. (2001): Achievement goals and optimal motivation: Testing multiple goal models. Journal of Personality and Social Psychology, 80. 5. sz. 706-722.

Báthory Zoltán (1989): Tanulói kötődések vizsgálata négy tanulói korosztály körében. Pedagógiai Szemle, 12. sz. 1162-1172. 
Bempechat, J. és Mirny, A. (2005): Contemporary theories of achievement motivation. In: Farenga, S. J. és Ness, D. (szerk.): Encyclopedia of education and human development. M. E. Sharpe, Armonk, NY. 433-443.

Berényi Eszter, Berkovits Balázs és Erőss Gábor (2008, szerk.): Iskolarend. Kiváltság és különbségtétel a közoktatásban. Gondolat, Budapest.

Bernardo, A. B. I. és Ismail, R. (2010): Social perceptions of achieving students and achievement goals of students in Malaysia and the Philippines. Social Psychology of Education, 13. 3. sz. 385-407.

Bickhard, M. H. (2003): An Integration of Motivation and Cognition. In: Smith, L., Rogers, C. és Tomlinson, P. (szerk.): Development and motivation: joint perspectives. Leicester: British Psychological Society, Monograph Series II. 41-56.

Biehler, R. F. és Snowman, J. (1986/1994): Motiváció. In: Csapó Benő, Csirikné Czachesz Erzsébet, Pukánszky Béla és Vidákovich Tibor (szerk.): Neveléselméleti szöveggyüjtemény. JATEPress, Szeged. 301-350.

Bishop, J. H., Bishop, M., Bishop, M., Gelbwasser, L., Green, S., Peterson, E., Rubinsztaj, A. és Zuckerman, A. (2004): Why we harass nerds and freaks: A formal theory of student culture and norms. Journal of School Health, 74. 7. sz. $235-251$.

Blumenfeld, P. C., Kempler, T. M. és Krajcik, J. S. (2006): Motivation and Cognitive Engagement in Learning Environments. In: Sawyer, R. K. (szerk.): The Cambridge handbook of the learning sciences. New York, Cambridge. 475-488.

Boekaerts, M. és Martens, R. (2006): Motivated learning: What it is and How it can be enhanced. In: Verschaffel, L., Dochy, F., Boekaerts, M. és Vosniadou, S. (szerk.): Instructional psychology: Past, present and future trends. Elsevier, Amsterdam. 113-129.

Boekaerts, M. és Niemivirta, M. (2000): Self-regulated learning: Finding a balance between learning goals and ego-protective goals. In: Boekaerts, M., Pintrich, P. $\mathrm{R}$ és Zeidner, M. (szerk.): Handbook of Self-Regulation. San Diego, CA: Academic Press. 417-450.

Bognár József, Géczi Gábor, Vincze Géza és Szabó Attila (2009): Coping skills, motivational profiles and perceived motivational climate in young elite ice hockey and soccer players. International Quarterly of Sport Science, 1. 1. sz. 111.

Bong, M. (2008): Effects of parent-child relationships and classroom goal structures on motivation, help-seeking avoidance, and cheating. The Journal of Experimental Education, 76. 2. sz. 191-217.

Brdar, I., Rijavec, M. és Loncaric, D. (2006): Goal orientation, coping with school failure and school achievement. European Journal of Psychology of Education, 21. 1. sz. 53-70.

Brophy, J. (2004): Motivating student to learn. Lawrence Erlbaum Associates, New Jersey.

Brophy, J. E. és Good, T. L. (1970): Teachers communication of differential expectations of children's classroom performance: some behavioural data. Journal of Educational Psychology, 61. 5. sz. 365-375. 
Brophy, J. E. és Good, T. L. (1974): Teacher-student relationships: Causes and consequences. Holt, Rinehart \& Winston, New York.

Busch-Rossnagel, N. A., Knauf-Jensen, D. E. és DesRosiers, F. S. (1995): Mothers and others: the role of the socializing environment in the development of mastery motivation. In: MacTurk, R. H. és Morgan, G. A. (szerk.): Mastery motivation: Origins, conceptualizations and applications. Vol. 12. Advances in applied developmental psychology. Ablex Publishing Corporation, Norwood, New Jersey. 117-145.

Butterfield, P. M. és Miller, L. (1984): Read your baby: A follow up intervention program for parents with NICU infants. Infant Mental Health, 5. 2. sz. 107-116.

Cantor, N., Norem, J. K., Niedenthal, P. M., Langston, C. A. és Brower, A. M. (1987): Life tasks and cognitive strategies in a life transition. Journal of Personality and Social Psychology, 53. 6. sz. 1178-1191.

Carver, C. S. és Scheier, M. F. (1998): Személyiségpszichológia. Osiris, Budapest.

Carver, C. S. és Scheier, M. F. (2000): On the structure of behavioral self-regulation. In: Boekaerts, M., Pintrich, P. R. és Zeidner, M. (szerk.): Handbook of selfregulation: Theory, research, applications. Academic Press, San Diego. 41-84.

Church, M. A., Elliot A. J. és Gable, S. L. (2001): Perceptions of classroom environment, achievement goals, and achievement outcomes. Journal of Educational Psychology, 93. 1. sz. 43-54.

Collins, A., Joseph, D. és Bielaczyc, K. (2004): Design research: Theoretical and methodological issues. Journal of the Learning Sciences, 13. 1. sz. 15-42.

Coulombe, S., Tremblay, J. és Marchand, S. (2004): International Adult Literacy Survey. Literacy scores, human capital and growth across fourteen OECD countries. Statistics Canada, Ottawa.

Cury, F., Elliot, A. J., Da Fonseca, D. és Moller, A. C. (2006): The social-cognitive model of achievement motivation and the $2 \times 2$ achievement goal framework. Journal of Personality and Social Psychology, 90. 5. sz. 666-679.

Cs. Czachesz Erzsébet és Vidákovich Tibor (1996): A családi-kulturális tényezők hatása az olvasás elsajátítására. Magyar Pedagógia, 96. 1. sz. 35-57.

Csapó Benő (2000): A tantárgyakkal kapcsolatos attitüdök összefüggései. Magyar Pedagógia, 100. 3. sz. 343-366.

Csapó Benő (2002a): A tudáskoncepció változása: nemzetközi tendenciák és a hazai helyzet. Új Pedagógia Szemle, 52. 2. sz. 38-45.

Csapó Benő (2002b): Az iskolai tudás felszíni rétegei: mit tükröznek az osztályzatok? In: Csapó Benő (szerk.): Az iskolai tudás. Osiris Kiadó, Budapest. 45-90.

Csapó Benő (2002c): Az osztályok közötti különbségek és a pedagógiai hozzáadott érték. In: Csapó Benő (szerk.): Az iskolai müveltség. Osiris Kiadó, Budapest. 269-297.

Csapó Benő (2003): A képességek fejlődése és iskolai fejlesztése. Akadémiai Kiadó, Budapest. 
Csapó Benő (2004): Az iskolai osztályok közötti különbségek és az oktatási rendszer demokratizálása. In: Csa-pó Benő: Tudás és iskola. Müszaki Könyvkiadó, Budapest. 225-241.

Csapó Benő (2011): Az oktatás tudományos hátterének fejlődése. Magyar Tudomány, 172. 9. sz. 1065-1076.

Csapó Benő, Molnár Gyöngyvér és Kinyó László (2009): A magyar oktatási rendszer szelektivitása a nemzetközi összehasonlító vizsgálatok eredményeinek tükrében. Iskolakultúra, 19. 3-4. sz. 3-13.

Cserné Ádermann Gizella (1991): Az „önmagát beteljesítő jóslat” (Pygmalion-hatás) pedagógiai vizsgálata. In: Kósáné Ormai Vera (szerk.): A pedagógus. Neveléslélektan V. Szöveggyüjtemény. Tankönyvkiadó, Budapest. 162-173.

Csíkos Csaba (2006): Nemzetközi rendszerszintű felmérések tanulságai az olvasástanítás számára. In: Józsa Krisztián (szerk.): Az olvasási képesség fejlődése és fejlesztése. Dinasztia Tankönyvkiadó, Budapest. 175-186.

Csíkos Csaba (2012a): Melyeik a kedvenc tantárgyad? Iskolakultúra, 22. 13. sz. 3-16.

Csíkos Csaba (2012b): Pedagógiai kisérletek kutatásmódszertana. Gondolat Kiadó, Budapest. (megjelenés alatt)

Csíkos Csaba és Dobi János (2001): Matematikai nevelés. In: Báthory Zoltán és Falus Iván (szerk.) Tanulmányok a neveléstudomány köréböl. Osiris Kiadó, Budapest. $355-372$.

Csíkszentmihályi Mihály (2001): Flow. Az áramlat. A tökéletes élmény pszichológiája. Akadémiai Kiadó, Budapest.

D. Molnár Éva (2010): A tanulás értelmezése a 21. században. Iskolakultúra, 20. 11. sz. 3-16.

D. Molnár Éva (2012): A tanulás önszabályozása. Nemzeti Tankönyvkiadó, Budapest. (megjelenés alatt)

Dai, D. Y. és Sternberg, R. J. (2004, szerk.): Motivation, emotion, and cognition: Integrative perspectives on intellectual functioning and development. Lawrence Erlbaum Associates, Inc. Publishers, Mahwah, NJ.

De Corte, E. (2001): Az iskolai tanulás: A legfrissebb eredmények és a legfontosabb tennivalók. Magyar Pedagógia, 101. 4. sz. 413-434.

De Corte, E., Verschaffel, L., Entwistle, N. és Merriënboer, J. van (2003, szerk.): Powerful Learning Environments: Unravelling Basic Components and Dimensions. Pergamon, Oxford.

Deemer, S. A. (2004): Using achievement goal theory to translate psychological principles into practice in the secondary classroom. American Secondary Education, 32. 3. sz. 4-15.

Dela Rosa, E. (2010):The 2 × 2 achievement goal framework and intrinsic motivation among Filipino students: A validation study. The Educational Measurement and Evaluation Review, 1. 2. sz. 48-58.

Demetrovics Zsolt és Nagy Gyöngyi (2001): Személyes törekvések és egészség. Magyar Pszichológiai Szemle, 56. 4. sz. 513-538. 
Dermitzaki, I., és Efklides, A. (2001): Age and gender effects on students' evaluations regarding the self and task-related experiences in mathematics. In: Volet, S. és Järvelä, S. (szerk.): Motivation in learning contexts: Theoretical and methodological implications. Elsevier, Amsterdam. 271-293.

Dobi János (2001): A matematika tanulásának affektív feltételei. In: Csapó Benő és Vidákovich Tibor (szerk.): Neveléstudomány az ezredfordulón. Nemzeti Tankönyvkiadó, Budapest. 268-279.

Dowson, M. és McInerney, D. M. (2001): Psychological parameters of students' social and work avoidance goals: A qualitative investigation. Journal of Educational Psychology, 93. 1. sz. 35-42.

Dowson, M. és McInerney, D. M. (2003): What do students say about their motivational goals? Towards a more complex and dynamic perspective on student motivation. Contemporary Educational Psychology, 28. 1. sz. 91-113.

Dowson, M. és McInerney, D. M. (2004): The development and validation of the Goal Orientation and Learning Strategies Survey (GOALS-S). Educational and Psychological Measurement, 64. 2. sz. 290-310.

Dweck, C. S. (1986): Motivational processes affecting learning. American Psychologist, 41. 10. sz. $1040-1048$.

Dweck, C. S. (2002): The development of ability conceptions. In: Wigfield, A. és Eccles, J. (szerk.): The development of achievement motivation. Academic Press, New York. 57-90.

Dweck, C. S. és Leggett, E. L. (1988): A social-cognitive approach to motivation and personality. Psychological Review, 95. 2. sz. 256-273.

Eaton, M. J. és Dembo, M. H. (1997): Differences in the motivational beliefs of AsianAmerican and Non-Asian students. Journal of Educational Psychology, 89. 3. sz. $433-440$.

Eccleston, C. (2007): Self-Fulfilling Prophecy. In: Baumeister, R. F. és Vohs, K. D. (szerk.): Encyclopedia of social psychology. Sage Publications, Thousand Oaks. 1586.

Elliot, A. J. (1997): Integrating the "classic" and "contemporary" approaches to achievement motivation: A hierarchical model of approach and avoidance achievement motivation. In: Maehr, M. L. és Pintrich, P. R. (szerk.): Advances in motivation and achievement. JAI Press Inc., Greenwich, Connecticut. 143179.

Elliot, A. J. (1999): Approach and avoidance motivation and achievement goals. Educational Psychologist, 34. 3. sz. 149-169.

Elliot, A. J. (2005): A conceptual history of the achievement goal construct. In: Elliot, A. J. és Dweck, C. S. (szerk.): Handbook of competence and motivation. Guilford Press, New York. 52-72.

Elliot, A. J. és Church, M. A. (1997): A hierarchical model of approach and avoidance achievement motivation. Journal of Personality and Social Psychology, 72. 1. sz. 218-232.

Elliot, A. J. és Friedman, R. (2007): Approach-avoidance: A central characteristic of personal goals. In: Little, B. R., Salmela-Aro, K. és Phillips, S. D. (szerk.): 
Personal project pursuit: Goals, action, and human flourishing. Lawrence Erlbaum Associates Publishers, Mahwah. 97-118.

Elliot, A. J. és Fryer, J. W. (2008): The goal construct in psychology. In: Shah, J. és Gardner, W. (szerk.): Handbook of Motivation Science. The Guilford Press, New York. 235-250.

Elliot, A. J. és Harackiewicz, J. M. (1996): Approach and avoidance achievment goals and intrinsic motivation: A mediational analysis. Journal of Personality and Social Psychology, 70. 3. sz. 461-475.

Elliot, A. J. és McGregor, H. A. (2001): A 2 X 2 achievement goal framework. Journal of Personality \& Social Psychology, 80. 3. sz. 501-519.

Elliot, A. J. és Murayama, K. (2008): On the measurement of achievement goals: Critique, illustration, and application. Journal of Educational Psychology, 100. 3. sz. 613-628.

Elliot, A. J. és Zahn, I. (2008): Motivation. In: Salkind, N. (szerk.): Encyclopedia of educational psychology. Sage Publications, Thousand Oaks, CA. 686-692.

Elliot, A. J., Chirkov, V., Kim, Y. és Sheldon, K. M. (2001): A cross-cultural analysis of avoidance (relative to approach) personal goals. Psychological Science, 12. 6. sz. 505-510.

Elliott, E. S. és Dweck, C. S. (1988): Goals: An approach to motivation and achievement. Journal of Personality and Social Psychology, 54. 1. sz. 5-12.

Emmons, R. A. (1986): Personal strivings: An approach to personality and subjective well-being. Journal of Personality and Social Psychology, 51. 5. sz. 1058-1068.

Farsang Andrea (1993): Motiváció a földrajzoktatásban. A földrajz tanítása, 1. 5. sz. 3 7.

Fejes József Balázs (2005): Roma tanulók motivációját befolyásoló tényezők. Iskolakultúra, 15. 11. sz. 3-13.

Fejes József Balázs (2006): Miért (nem) fontosak a hátrányos helyzetű tanulók? Új Pedagógiai Szemle, 56. 7-8. sz. 17-26.

Fejes József Balázs (2010a): A mentorálás hatása a tanulási motivációra hátrányos helyzetü tanulók körében. In: Csíkos Csaba és Kinyó László (szerk.): $X$. Országos Neveléstudományi Konferencia, Budapest, 2010. november 4-6. Új törekvések és lehetöségek a 21. századi neveléstudományokban. Szegedi Tudományegyetem, Szeged. 206.

Fejes József Balázs (2010b): A tanulási motiváció fejlesztésének lehetőségei a célorientációs elmélet alapján. In: Vajda Zoltán (szerk.): Bölcsészmühely 2009. JatePress, Szeged. 43-53.

Fejes József Balázs (2011): A tanulási motiváció kutatásának új iránya: a célorientációs elmélet. Magyar Pedagógia, 111. 1. sz. 25-51.

Fejes József Balázs és Józsa Krisztián (2005): A tanulási motiváció jellegzetességei hátrányos helyzetü tanulók körében. Magyar Pedagógia, 105. 2. sz. 185-205.

Fejes József Balázs és Józsa Krisztián (2007): Az iskolai eredményesség és a tanulási motiváció kulturális jellemzői: roma és többségi tanulók összehasonlítása. Iskolakultúra, 17. 6-7. sz. 83-96. 
Fejes József Balázs és Szenczi Beáta (2010): Tanulási korlátok a magyar és az amerikai szakirodalomban. Gyógypedagógiai Szemle, 38. 4. sz. 273-287.

Fejes József Balázs és Vígh Tibor (2011): A célorientációk kérdőív müködésének vizsgálata klasszikus és modern tesztelméleti eszközök felhasználásával. In: Vidákovich Tibor és Habók Anita (szerk.): PÉK 2011 - IX. Pedagógiai Értékelési Konferencia: Program - Elöadás-összefoglalók. Szegedi Tudományegyetem, Szeged. 30.

Fejes József Balázs és Vígh Tibor (2012): A Tanulói célok kérdőív müködésének vizsgálata matematika tantárgyhoz kötődően 5-8. évfolyamon In: Csapó Benő és Tóth Edit (szerk.): PÉK 2012 - X. Pedagógiai Értékelési Konferencia: Program - Elöadás-összefoglalók. Szegedi Tudományegyetem, Szeged. (elfogadva)

Fejes, J. B. (2012): Learning motivation of disadvantaged students. In: Seel, N. M. (szerk.): Encyclopedia of the Sciences of Learning. Springer, New York. 19351937.

Felleginé Takács Anna (2004): Problémás tanulók, okok és megoldási javaslatok. In: N. Kollár Katalin és Szabó Éva (szerk.): Pszichológia pedagógusoknak. Osiris Kiadó, Budapest. 472-496.

Figlio, D. N. (2007): Boys Named Sue: Disruptive Children and Their Peers. Education Finance and Policy, 2. 4. sz. 376-94.

Finney, S. J., Pieper, S., L. és Barron, K. E. (2004): Examining the psychometric properties of the Achievement Goal Questionnaire in a general academic context. Educational and Psychological Measurement, 64. 2. sz. 365-382.

Fishbein, M. (2002): Az attitűd és a viselkedés predikciója. In: Lengyel Zsuzsanna (szerk.): Szociálpszichológia. Szöveggyüjtemény. Osiris Kiadó, Budapest. 147163.

Ford, M. E. (1992): Motivating humans: Goals, emotions and personal agency beliefs. Thousand Oaks, CA: Sage.

Forray R. Katalin és Hegedűs T. András (1998): Cigány gyermekek szocializációja. Aula, Budapest.

Freeman, T. M. és Anderman, L. H. (2005): Changes in mastery goals in urban and rural middle school students. Journal of Research in Rural Education, 20. 1. sz. $1-12$.

Fuchs, L. S., Fuchs, D., Karns, K., Hamlett, C. L., Katzaroff, M. és Dutka, S. (1997): Effects of task-focused goals on low-achieving students with and without learning disabilities. American Educational Research Journal, 34. 3. sz. 513544.

Fülöp Márta (2001): A versengés szerepe. Új Pedagógiai Szemle, 51. 11. sz. 3-17.

Fülöp Márta (2008): Paradigmaváltás a versengéskutatásban. Pszichológia. 28. 2. sz. $113-140$.

Fülöp Márta (2010a): A társas viselkedés szociálpszichológiája: a társas összehasonlítás. In: Zsolnai Anikó és Kasik László (szerk.): A szociális kompetencia fejlesztésének elméleti és gyakorlati alapjai. Tankönyvkiadó, Budapest. 48-77. 
Fülöp Márta (2010b): Tanulási motiváció és versengés: barátok vagy ellenségek? In: Molnár Éva és Kasik László (szerk.): PÉK 2010 - VIII. Pedagógiai Értékelési Konferencia: Program - Tartalmi összefoglalók. Szegedi Tudományegyetem, Szeged. 73.

Gage, N. L. és Berliner, D. C. (1991): Educational Psychology. Houghton Mifflin Company, Boston.

Galasi Péter és Varga Júlia (2005): Munkaeröpiac és oktatás. MTA Közgazdaságtudományi Intézet, Budapest.

Geen, R. G. (1995): Human Motivation: A Social Psychological Approach. Brooks/Cole Publishing Company, Pacific Grove, California.

Gonida, E. N., Kiosseoglou, G. és Voulala, K. (2007): Perceptions of parental goals and their contribution to student achievement goal orientation and engagement in the classroom: Grade-level differences across adolescence. European Journal of Psychology of Education, 22. 1. sz. 23-39.

Good, T. L. és Brophy, J. E. (2008): Nyissunk be a tanterembe! 2. kötet. Educatio Kht., Budapest.

Gordon Győri János (2004): A kulturális összehasonlító pedagógia alapjai, eredményei, valamint jelentősége a mai magyar pedagógiában. Iskolakultúra, 14. 2. sz. 66-75.

Gordon Győri János (2006): Az oktatás világa Kelet-és Délkelet-Ázsiában. Japán és Szingapúr. Gondolat Kiadó, Budapest.

Gordon Győri János (2009): Kulturális különbségek a tanulási motivációban. Magyar Pszichológiai Szemle, 64. 1. sz. 203-228.

Gottfried, A. E., Flaming, J. S. és Gottfried, A. W. (1998): Role of cognitively stimulating home environment in children academic intrinsic motivation: A longitudinal study. Child Development, 69. 5. sz. 1448-1460.

Graham, S. és Golan, S. (1991): Motivational influences on cognition: Task involvement, ego orientation, and depth of information processing. Journal of Educational Psychology, 83. 2. sz. 187-194.

Grant, H. és Dweck, C. S. (2003): Clarifying achievement goals and their impact. Journal of Personality and Social Psychology, 85. 3. sz. 541-553.

Gulikers, J., Bastiaens, Th. és Martens, R. (2005): The Surplus Value of an Authentic Learning Environment. Computers in Human Behaviour, 21. 3. sz. 509-521.

Gurtner, J. L., Monnard, I. és Genoud, P. A. (2001): Towards a multilayer model of context. and its impact on motivation. In: Volet, S. és Järvelä, S. (szerk.): Motivation in learning contexts: Theoretical and methodological implications. Elsevier, Amsterdam. 189-208.

Guthrie, J. T., Wigfield, A., és Vonsecker, C. (2000): Effects of integrated instruction on motivation and strategy use in reading. Journal of Educational Psychology, 92. 331-341.

Haahr, J. H., Nielsen, T. K., Hansen, M. E. és Jakobsen, S. T. (2005): Explaining Student Performance. Evidence from the international PISA, TIMSS and PIRLS surveys. Danish Technological Institute. 2010. május 10-i megtekintés, http://ec.europa.eu/education/pdf/doc282_en.pdf 
Hafsteinsson, L. G., Donovan, J. J., és Breland, B. T. (2007): An IRT Examination of Two Popular Goal Orientation Measures. Educational and Psychological Measurement, 67. 4. sz. 719-739.

Hanushek, E. A. és Kimko, D. D. (2000): Schooling, labor-force quality, and the growth of nations. The American Economic Review, 90. 5. sz. 1184-1208.

Harackiewicz, J. M., Barron, K. E., Tauer, J. M., Carter, S. M., és Elliot, A. J. (2000): Short-term and long-term consequences of achievement goals: Predicting interest and performance over time. Journal of Educational Psychology, 92. 2. sz. 316-330.

Harackiewicz, J. M., Barron, K. M., Pintrich, P. R., Elliot, A. J. és Thrash, T. M. (2002): Revision of achievement goal theory: necessery and illuminating. Journal of Educational Psychology, 94. 3. sz. 638-645.

Harris, M. J. és Rosenthal, R. (1986): Four factors in the mediation of teacher expectancy effects. In: Feldman, R. S. (szerk.): The Social Psychology of Education: Current Research and Theory. Cambridge University Press, New York. 91-114.

Harsányi Eszter és Radó Péter (1997): Cigány tanulók a magyar iskolákban. Educatio, 6. 1. sz. $48-59$.

Harter, S. (1981): A model of mastery motivation in children. In: Collins, W. A. (szerk.): Minnesota Symposia on Child Psychology. Vol. 14. Lawrence Erlbaum Associates, Hillsdale, New Jersey. 215-255.

Hegedűs T. András (1993): Motiválhatók-e a cigány gyerekek. Educatio, 2. 2. sz. 211220.

Heine, S. J., Kitayama, S., Lehman, D. R., Takata, T., Ide, E., Lueng, C. és Matsumoto, H. (2001): Divergent Consequences of Success and Failure in Japan and North America: An Investigation of Self-Improving Motivations and Malleable Selves. Journal of Personality and Social Psychology, 81. 4. sz. 599-615.

Hickey, D. T. (2003): Engaged participation vs. marginal non-participation: A stridently sociocultural model of achievement motivation. Elementary School Journal, 103. 4. sz. 401-429.

Hickey, D. T., Moore, A. L. és Pellegrino, J. W. (2001): The motivational and academic consequences of elementary mathematics environments: Do constructivist innovations and reforms make a difference? American Educational Research Journal, 38. 3. sz. 611-652.

Hidi, S. (2000): An interest researcher's perspective: the effect of extrinsic and intrinsic factors on motivation. Intrinsic and extrinsic motivation. In: Sansone, C. és Harackiewicz, J. M. (szerk.): Intrinsic and extrinsic motivation: the search for optimal motivation and performance. Academic Press, San Diego, California. 309-339.

Hidi, S. és Harackiewicz, J. M. (2000): Motivating the academically unmotivated: A critical issue for the 21th century. Review of Educational Research. 70. 2. sz. 151-179.

Higgins E. T. (1987): Self-discrepancy: A theory relating self and affect. Psychological Review, 94. 3. sz. 319-340. 
Ho, I. T. és Hau, K.-T. (2008): Academic achievement in Chinese context: The role of goals, strategies, and effort. International Journal of Psychology, 43. 5. sz. 892897.

Howse, R. B., Lange, G., Farran, D. C. és Boyles, C. D. (2003): Motivation and selfregulation as predictors of achievement in economically disadvantaged young children. Journal of Experimental Education, 71. 2. sz. 151-174.

Hulleman, C. S., Schrager, S. M., Bodman, S. M. és Harackiewicz, J. M. (2010): A meta-analytic review of achievement goal measures: Different labels for the same constructs or different constructs with similar labels? Psychological Bulletin, 136. 3. sz. 422-449.

Husman, J. és Lens, W. (1999). The role of the future in student motivation. Educational Psychologist, 34. 2. sz. 113-125.

Ireson, J. és Hallam, S. (2001): Ability grouping in education. Chapman, London.

Ireson, J., Hallam, S. és Plewis, I. (2001): Ability grouping in secondary schools: Effects on pupil's self-concepts. The British Journal of Educational Psychology, 71. 2. sz. $315-327$.

Jacobs, J. E. és Osgood, D. W. (2002): The use of multi-level modeling to study individual change and context effects in achievement motivation. In: Pintrich, P. R. és Maehr, M. L. (szerk.): New directions in measures and methods. Vol. 12. Elsevier Sciences, New York. 277-318.

Jámbori Szilvia (2003a): Az iskola szerepe a serdülők jövő-orientációjának alakulásában. Magyar Pedagógia, 103. 4 sz. 481-497.

Jámbori Szilvia (2003b): Serdülők jövő-orientációját befolyásoló szülői nevelési stílusok vizsgálata. Serdülö-és gyermekpszichoterápia, 1. 3. sz. 221-231.

Jámbori Szilvia (2007): Hogyan tervezik a serdülők a jövőjüket? Juhász Gyula Felsőoktatási Kiadó, Szeged.

Jánosa András (2011): Adatelemzés SPSS használatával. ComputerBooks Kiadó, Budapest.

Järvelä, S. és Niemivirta, M. (1999): The changes in learning theory and topicality of recent research on motivation. Learning and Instruction, 9. 1. sz. 57-65.

Järvelä, S. és Salovaara, A. (2004): The Interplay of Motivational Goals and Cognitive Strategies in a New Pedagogical Culture. Educational Psychologist, 9. 4. sz. 232-244.

Järvelä, S. és Volet, S. (2004): Motivation in real-life, dynamic, and interactive learning environments: Streching constructs and methodologies. European Psychologist, 9. 4. sz. 241-250.

Jennings, K. D. (1996): Mastery motivation and the formation of self-concept from infancy through early childhood. In: Messer, D. J. (szerk.): Mastery motivation in early childhood: Development, measurement and social processes. Routledge, London and New York. 36-54.

Józsa Krisztián (1999): Mi alakítja az énértékelésünket fizikából? Iskolakultúra, 9. 10. sz. $72-80$. 
Józsa Krisztián (2000): Az iskola és a család hatása a tanulási motiváció alakulására. Iskolakultúra, 10. 8. sz. 69-82.

Józsa Krisztián (2001): Az elsajátítási motiváció és a kognitív kompetencia fejlesztése. In: Csapó Benő és Vidákovich Tibor (szerk.): Neveléstudomány az ezredfordulón. Tankönyvkiadó, Budapest. 162-174.

Józsa Krisztián (2002): Tanulási motiváció és humán műveltség. In: Csapó Benő (szerk.): Az iskolai müveltség. Osiris Kiadó, Budapest. 239-268.

Józsa Krisztián (2003): Idegen nyelvi készségek fejlettsége angol és német nyelvböl a 6. és 10. évfolyamon a 2002/2003-as tanévben. Függelék: országos adatok, statisztikák. Országos Közoktatási Értékelési és Vizsgaközpont, Budapest.

Józsa Krisztián (2004): Az első osztályos tanulók elemi alapkészségeinek fejlettsége. Egy longitudinális kutatás első mérési pontja. Iskolakultúra, 14. 11. sz. 3-16.

Józsa Krisztián (2005): A képességek és motívumok kölcsönös fejlesztésének lehetősége. In: Kelemen Elemér és Falus Iván (szerk.): Tanulmányok a neveléstudomány köréből. Müszaki Könyvkiadó, Budapest. 283-302.

Józsa Krisztián (2007): Az elsajátítási motiváció. Müszaki Kiadó, Budapest.

Józsa Krisztián (2008): Az olvasásképesség fejlődése tanulásban akadályozott és többségi gyermekek esetében (szimpózium). In: Perjés István és Ollé János (szerk.): VIII. Országos Neveléstudományi Konferencia, 2008. November 11-13. Hatékony tudomány, pedagógiai kultúra, sikeres iskola. Magyar Tudományos Akadémia Pedagógiai Bizottság, Budapest. 56-62.

Józsa Krisztián (2009a): A longitudinal analysis of learning motivation between the ages of 10 and 14. Paper presented at the 13th Biennial Conference for Research on Learning and Instruction, Amsterdam, August 25-29, 2009.

Józsa Krisztián (2009b): Matematikai készségek, képességek és attitüdök tanulásban akadályozott és többségi gyermekek esetében (szimpózium). In: Bárdos Jenő és Sebestyén József (szerk.): IX. Országos Neveléstudományi Konferencia Veszprém, 2009. november 19-21. Neveléstudomány - Integritás és integrálhatóság. Pannon Egyetem, Veszprém. 62-67.

Józsa Krisztián (2010): Az elsajátítási motiváció változása 10-14 éves kor között. In: Csíkos Csaba és Kinyó László (szerk.): X. Országos Neveléstudományi Konferencia: Új törekvések és lehetöségek a 21. századi neveléstudományokban. Program és Összefoglalók. SZTE Neveléstudományi Intézet, Szeged. 203.

Józsa Krisztián és Bratinkáné Magyar Éva (2007): A tanulási motiváció változásának longitudinális elemzése 4-8. osztály között. In: Vidákovich Tibor és Molnár Éva (szerk.): VII. Országos Neveléstudományi Konferencia Budapest, 2007. október 25-27. Változó tanulási környezetek, változó pedagógusszerepek. Magyar Tudományos Akadémia Pedagógiai Bizottság, Budapest. 68.

Józsa Krisztián és Fazekasné Fenyvesi Margit (2008): Tanulásban akadályozott gyermekek tanulási motivációja. In: Szabó Ákosné (szerk.): Tanulmányok a tanulásban akadályozottak pedagógiája és határtudományai köréből. Educatio, Budapest, 157-179.

Józsa Krisztián és Fejes József Balázs (2010): A szociális környezet szerepe a tanulási motiváció alakulásában: a család, az iskola és a kultúra hatása. In: Zsolnai Anikó 
és Kasik László (szerk.): A szociális kompetencia fejlesztésének elméleti és gyakorlati alapjai. Tankönyvkiadó, Budapest. 134-162.

Józsa Krisztián és Fejes József Balázs (2012): A tanulás affektív tényezői. In: Csapó Benő (szerk.): Mérlegen a magyar iskola. Nemzeti Tankönyvkiadó, Budapest. 367-406.

Józsa Krisztián és Nikolov Marianne (2005): Az angol és német nyelvi készségek fejlettségét befolyásoló tényezők. Magyar Pedagógia, 105. 3. sz. 307-337.

Józsa Krisztián és Pap-Szigeti Róbert (2006): Az olvasási képesség és az anyanyelvhasználat fejlődése 14-18 éves korban. In: Józsa Krisztián (szerk.): $A z$ olvasási képesség fejlödése és fejlesztése, Dinasztia Tankönyvkiadó, Budapest. 131-153.

Józsa Krisztián és Székely Györgyi (2004): Kísérlet a kooperatív tanulás alkalmazására a matematika tanítása során. Magyar Pedagógia, 104. 3. sz. 339-362.

Józsa Krisztián és Zentai Gabriella (2007): Hátrányos helyzetü óvodások DIFER Programcsomagra alapozott játékos fejlesztése. Új Pedagógiai Szemle, 57. 5. sz. 3-17.

Józsa Krisztián, Szenczi Beáta és Hricsovinyi Julianna (2011): A tanulási motiváció számítógép-alapú mérési lehetőségei. In: Csapó Benő és Zsolnai Anikó (szerk.): Kognitív és affektív fejlődési folyamatok diagnosztikus értékelésének lehetőségei az iskola kezdő szakaszában. Nemzeti Tankönyvkiadó, Budapest. 147-171.

Kaplan, A. és Maehr, M. L. (1999): Achievement goals and student well-being. Contemporary Educational Psychology, 24. 4. sz. 330-358.

Kaplan, A. és Maehr, M. L. (2007): The contributions and prospects of goal orientation theory. Educational Psychology Review, 19. 2. sz. 141-184.

Kaplan, A. és Middleton, M. (2002): Should childhood be a journey or a race? Response to Harackiewicz et al. (2002). Journal of Educational Psychology, 94. 3. sz. 646-648.

Kaplan, A. és Midgley, C. (1999): The relationship between perceptions of the classroom goal structure and early adolescents' affect in school: The mediating role of coping strategies. Learning and Individual Differences, 11. 2. sz. 187212.

Kaplan, A., Gheen, M. és Midgley, C. (2002): Classroom goal structure and student disruptive behaviour. British Journal of Educational Psychology, 72. 2. sz. 191211.

Karabenick, S. A. (2003): Seeking help in large college classes: A person-centered approach. Contemporary Educational Psychology, 28. 1. sz. 37-58.

Karabenick, S. A. (2004): Perceived achievement goal structure and college student help seeking. Journal of Educational Psychology, 96. 3. sz. 569-581.

Kasik László (2011): A szociálisérdek-érvényesítés néhány dimenziójának müködése és érzelmi háttere 8-18 évesek körében. Magyar Pedagógia, 111. 2. sz. (megjelenés alatt)

Kaufman, L. és Rousseeuw, P. J. (1990): Finding groups in data: An introduction to cluster analysis. John Wiley and Sons, New York. 
Keller, J. M. (1987): Development and use of the ARCS model of motivational design. Journal of Instructional Development, 10. 3. sz. 2-10.

Kertesi Gábor és Kézdi Gábor (2005): Általános iskolai szegregáció. Okok és következmények. In: Kertesi Gábor (szerk.): A társadalom peremén. Osiris Kiadó, Budapest. 377-387.

Kertesi Gábor és Varga Júlia (2005): Foglalkoztatás és iskolázottság Magyarországon. Közgazdasági szemle, 52. 7-8. sz. 633-662.

Ketskeméty László és Izsó Lajos (1996): Az SPSS for Windows programrendszer alapjai. Felhasználói útmutató és oktatási segédlet. SPSS Partner Bt., Budapest.

Kirschner, P. A. (2005): Learning in innovative learning environments. Computers in Human Behavior, 21. 4. sz. 547-554.

Kiss Judit és Gordos Ágnes (2003): Családi és kortárskapcsolatok jellemzői általános iskolás roma és nem roma gyermekek körében IV. Egészségnevelés, 44. 3. sz. 100-108.

Kock, A. de, Sleegers, P. és Voeten, M. J. M. (2004): New learning and the classification of learning environments in secondary education. Review of Educational Research, 74. 2. sz. 141-170.

Kocsis Mihály (2000): Egy Baranya megyei iskolai tudásmérés néhány vizsgálati területéről. Iskolakultúra, 10. 8. 3-13.

Kontra József (2009): A parciális kredit modell egy alkalmazása. In: Pšenáková Ildikó, Mezı Ferenc és Viczayová Ildikó (szerk.): Képzés és gyakorlat II. Konstantin Filozófus Egyetem, Nyitra. 99-108.

Koskey, L. K., Karabenick, S. A., Woolley, M. E., Bonney, C. R. és Dever, B. V. (2010): „Cognitive Validity of Students Self-Reports of Classroom Mastery Goal Structure: What Students Are Thinking and Why It Matters". Contemporary Educational Psychology, 35. 4. sz. 254-263.

Kozéki Béla (1985): Személyiségfejlesztés az iskolában. Békés megyei Pedagógiai Intézet, Békéscsaba.

Kozéki Béla (1991): Az iskolaethosz és a személyiségstruktúra kölcsönhatása. Akadémiai Kiadó, Budapest.

Körössy Judit (1997): Az énkép és összefüggése az iskolai teljesítménnyel. In: Mészáros Aranka (szerk.): Az iskola szociálpszichológiai jelenségvilága. Budapest, ELTE Eötvös Kiadó. 67-85.

Kőrössy Judit (2004): Az "én" fogalma, az énfejlődés elméletei. In: N. Kollár Katalin és Szabó Éva (szerk.): Pszichológia pedagógusoknak. Budapest, Osiris Kiadó. 5173.

Kumar, R. (2006): Students' experiences of home-school dissonance: The role of school academic culture and perceptions of classroom goal structures. Contemporary Educational Psychology, 31. 3. sz. 253-279.

Lau, K. L. és Lee, J. C. K. (2008): Validation of a Chinese achievement goal orientation questionnaire. British Journal of Educational Psychology, 78. 2. sz. 331-353. 
Lee, C., Tinsley, C. H. és Bobko, P. (2003): Cross-cultural variance in goal orientation and their effects. Applied Psychology: An International Review, 52. 2. sz. 272297.

Lee, J. Q., McInerney, D. M., Liem, G. A. D. és Ortiga, Y. P. (2010): The relationships between future goals and achievement goal orientations: An intrinsic-extrinsic motivation perspective. Contemporary Educational Psychology, 35. 4. sz. 264279.

Lemos, M. S. (1996): Students' and teachers' goals in the classroom. Learning and Istruction, 6. 2. sz. 151-171.

Lemos, M. S. de és Gonçalves, C. (2004): Students' Management of Goalsin the Natural Classroom Setting: Methodological Implications. Educational Psychologist, 9. 4. sz. 198-209.

Levy-Tossman, I., Kaplan, A. és Assor, A. (2007): Academic goal orientations, multiple goal profiles, and friendship intimacy among early adolescents. Contemporary Educational Psychology, 32. 2. sz. 231-252.

Lewalter D. és Krapp, A. (2004): The Role of Contextual Conditions of Vocational Education for Motivational Orientations and Emotional Experiences. Educational Psychologist, 9. 4. sz. 210-221.

Lewin, K., Lippitt, R. és White, R. (1939): Patterns of aggressive behavior in experimentally created social climates. Journal of Social Psychology, 10. 2. sz. 271-299.

Limón, M. (2006): The domain generality-specificity of epistemological beliefs: A theoretical problem, a methodological problem or both? International Journal of Educational Research, 45. 1-2. sz. 7-27.

Linnenbrink, E. A. (2004): Person and context: Theoretical and practical concerns in achievement goal theory. In: Pintrich, P. R. és Maehr, M. L. (szerk.): Advances in motivation and achievement: Motivating students, improving schools: The legacy of Carol Midgley. Elsevier, Stamford.159-184.

Linnenbrink, E. A. (2005): The dilemma of performance-approach goals: The use of multiple goal contexts to promote students' motivation and learning. Journal of Educational Psychology, 97. 2. sz. 197-213.

Linnenbrink, E. A. és Pintrich, P. R. (2001): Multiple goals, multiple contexts: The dynamic interplay between personal goals and contextual goal stresses. In: Volet, S. és Järvelä, S. (szerk.): Motivation in learning contexts: Theoretical and methodological implications. Elsevier, Amsterdam. 251-269.

Linnenbrink, E. A. és Pintrich, P. R. (2002a): Motivation as an enabler for academic success. School Psychology Review, 31. 3. sz. 313-327.

Linnenbrink, E. A. és Pintrich, P. R. (2002b): The role of motivational beliefs in conceptual change. In: Limon, M. és Mason, L. (szerk.): Reconsidering conceptual change: Issues in theory and practice. Kluwer Academic, Dordrecht. $115-135$.

Liskó Ilona (2001): A cigány tanulók és a pedagógusok. Iskolakultúra, 11. 12. sz. 3-14. 
Locke, E. A. és Latham, G. P. (1994/1999): Célkitüzés-elmélet. In: O’Neil, H. F. Jr. és Drillings, M. (szerk.): Motiváció: elmélet és kutatás. Vince Kiadó, Budapest. 23-40.

Lodewyk, K. R. és Winne, Ph. H. (2005): Relations among the structure of learning tasks, achievement, and changes in self-efficacy in secondary students. Journal of Education Psychology, 97. 1. sz. 3-12.

MacTurk, R. H., Morgan, G. A. és Jennings, K. D. (1995): The assessment of mastery motivation in infants and young children. In: MacTurk, R. H. és Morgan, G. A. (szerk.): Mastery motivation: Origins, conceptualizations and applications. Advances in applied developmental psychology, Vol. 12. Ablex Publishing Corporation, Norwood, New Jersey. 19-56.

Madon, S., Jussim, L. és Eccles, J. S. (1997): In search of the powerful self-fulfilling prophecy. Journal of Personality and Social Psychology, 72. 4. sz. 791-809.

Maehr, M. L. és Meyer, H. A. (1997): Understanding motivation and schooling: Where we've been, where we are, and where we need to go. Educational Psychology Review, 9. 4. sz. 371-409.

Maehr, M. L. és Midgley, C. (1991): Enhancing student motivation: a school wide approach. Educational Psychology, 26. 3-4. sz. 399-427.

Maehr, M. L. és Sjogren, D. D. (1971/1997): Atkinson elmélete a teljesítmény motivációról. In: Oláh Attila és Pléh Csaba (szerk.): Szöveggyüjtemény az általános és a személyiségpszichológiához. Nemzeti Tankönyvkiadó, Budapest. 214-229.

Markus, H. és Kitayama, S. (1991): Culture and the self: Implications for cognition, emotion, and motivation. Psychological Review, 98. 2. sz. 224-253.

Markus, H. és Nurius, P. (1986): Possible selves. American Psychologist, 41. 9. sz. 954-969.

Marr, A. J. (2005): Intrinsic/Extrinsic Motivation: The Phony Controversy. Themanager.org, $2010.205 . \quad 16-\mathrm{i} \quad$ megtekintés www.themanager.org/HR/Motivation.htm

Marsh, H. W. és Craven, R. (2002): The Pivotal Role of Frames of Reference in Academic Self-concept Formation: The Big Fish Little Pond Effect. In: Pajares, F. és Urdan, T. (szerk.): Adolescence and Education, Volume 2. Information Age Publishing, Greenwich. 83-123.

Marsh, H. W. és Rowe, K. J. (1996): The negative effects of school average ability on academic self-concept: An application of multilevel modelling. Australian Journal of Education, 40. 1. sz. 65-87.

Marsh, H. W., Chessor, D., Craven, R. G. és Roche, L. (1995): The effects of the gifted and talented program on academic self-concept: the big fish strikes again, American Educational Research Journal, 32. 2. sz. 285-319.

Martin, A., Marsh, H., Debus, R. és Malmberg, L. (2008): Performance and mastery orientation of high school and university/college students: A Rasch perspective. Educational and Psychological Measurement, 68. 3. sz. 464-487.

Marton Ferenc (2004a): A tanulás tárgya. Magyar Pedagógia, 104. 4. sz. 381-392. 
Marton Ferenc (2004b): A tudásalapú társadalom két illúziója. Iskolakultúra, 14. 10. sz. $31-36$.

Marton Magda (1998): Útban az éntudat kialakulása felé II. A tudat testérzékleti eredete. Pszichológia, 18. 4. sz. 379-435.

Martos Tamás (2009a): Célok, tervek, törekvések. I. Elméleti megfontolások és alkalmazási lehetőségek. Magyar Pszichológiai Szemle, 64. 2. sz. 337-358.

Martos Tamás (2009b): Célok, tervek, törekvések. II. A személyes célok és életcélok kapcsolata - módszertani kérdések és demonstráció. Magyar Pszichológiai Szemle, 64. 3. sz. 573-592.

Masters, G. N. (1982): A Rasch model for partial credit scoring. Psychometrika, 47. 2. sz. $149-174$.

Matos, L., Lens, W. és Vansteenkiste, M. (2009): School culture matters for teachers' and students' achievement goals. In: Kaplan, A., Karabenick, S. és De Groot, E. (szerk.): Culture, self, and motivation: Essays in honor of Martin L. Maehr. Greenwich, CN, Information Age. 161-181.

Mau, W. és Lynn R. (1999): Racial and ethnic differences in motivation for educational achievement in the United States. Personality and Individual Differences, 27. 6. sz. 1091-1096.

McCombs, B. L. és Marzano, R. J. (1990): Putting the self in self-regulated learning: The self as agent in integrating will and skill. Educational Psychologist, 25. 1. sz. 51-69.

McInerney, D. M. (2012): Shool motivation. In: Seel, N. M. (szerk.): Encyclopedia of the Sciences of Learning. Springer, New York. 2966-2972.

McInerney, D. M. és Liem, A. D. (2009): Achievement motivation in cross-cultural context: Application of Personal Investment Theory in educational settings. In: Kaplan, A., Karabenick, S. és De Groot, E. (szerk.): Culture, self, and motivation: Essays in honor of Martin L. Maehr. Greenwich, CN, Information Age. 213-241.

Meece, J. L. Anderman, E. M. és Anderman, L. H. (2006): Classroom goal structure, student motivation, and academic achievement. Annual Review of Psychology, 57. 1. sz. 487-504.

Meece, J. L. és Holt, K. (1993): A pattern analysis of students' achievement goals. Journal of Educational Psychology, 85. 4. sz. 582-590.

Meece, J. L. és Miller, S. D. (2001): Longitudinal analysis of elementary school students' achievement goals in literacy activities. Contemporary Educational Psychology, 26. 4. sz. 454-480.

Meece, J. L., Glienke, B. B. és Askew, K. (2009): Gender and motivation. In: Wentzel, K. és Wigfield, A. (szerk.): Handbook on motivation at school. Routledge, Taylor \& Francis Group, New York. 411-432.

Meece, J. L., Herman, P. és McCombs, B. (2003): Relations of learner-centered teaching practices to adolescents' achievement goals. International Journal of Educational Research, 39. 4-5. sz. 457-475.

Mészáros Aranka (2002, szerk.): Az iskola szociálpszichológiai jelenségvilága. Eötvös Kiadó, Budapest. 
Midgley, C., Kaplan, A. és Middleton, M. J. (2001): Performance-approach goals: Good for what, for whom, under what circumstances, and at what cost? Journal of Educational Psychology, 93. 1. sz. 77-86.

Midgley, C., Maehr, M. L., Hruda, L. Z., Anderman, E., Anderman, L., Freeman, K. E., Gheen, M., Kaplan, A., Kumar, R., Middleton, M. J., Nelson, J., Roeser, R., és Urdan, T. (2000): Manual for the Patterns of Adaptive Learning Scales (PALS). University of Michigan, Ann Arbor.

Miller, A. D. és Murdock, T. B. (2007): Modeling latent true scores to determine the utility of aggregate student perceptions as classroom indicators in HLM: The case of classroom goal structures. Contemporary Educational Psychology, 32. 1. sz. 83-104.

Miller, R. B., Greene, B. A., Montalvo, G. P, Ravindran, B. és Nichols, J. D. (1996): Engagement in Academic Work: The role of learning goals, future consequences, pleasing others and perceived ability. Contemporary Educational Psychology, 21. 4. sz. 388-422.

Miller, S. D. és Meece, J. L. (1997): Enhancing elementary students' motivation to read and write: A classroom intervention study. Journal of Educational Research, 90. 5. sz. 286-300.

Moller, A. C. és Elliot, A. J. (2006): The 2 x 2 achievement goal framework: An overview of empirical research. In: Mittel, A. (szerk.): Focus on educational psychology. Nova Science Publishers, New York. 307-326.

Molnár Éva (2002): Önszabályozó tanulás: nemzetközi kutatási irányzatok és tendenciák. Magyar Pedagógia, 102. 1. sz. 63-79.

Molnár Éva (2003): Néhány személyes motívum szerepe az önszabályozó tanulásban. Magyar Pedagógia, 103. 2. sz. 155-175.

Molnár Éva (2009): Az önszabályozás értelmezései és elméleti megközelítései. Magyar Pedagógia, 109. 4. sz. 343-364.

Molnár Éva és B. Németh Mária (2006): Az olvasási képesség fejlettsége az iskoláskor elején. In: Józsa Krisztián (szerk.): Az olvasási képesség fejlődése és fejlesztése. Dinasztia Tankönyvkiadó, Budapest. 107-129.

Molnár Gyöngyvér (2003): Az ismeretek alkalmazásának vizsgálata modern tesztelméleti eszközökkel. Magyar Pedagógia, 103. 4. sz. 423-446.

Molnár Gyöngyvér (2005): Az objektív mérés megvalósításának lehetısége: a Raschmodell. Iskolakultúra, 15. 3. sz. 71-80.

Molnár Gyöngyvér (2006): A Rasch-modell alkalmazása a társadalomtudományi kutatásokban. Iskolakultúra, 16. 12. sz. 99-113.

Molnár Gyöngyvér (2007): Hátrányos helyzetü diákok problémamegoldó gondolkodásának longitudinális követése. Magyar Pedagógia, 107. 4. sz. 277293.

Molnár Gyöngyvér (2008): A Rasch-modell kiterjesztése nem dichotóm adatok elemzése: a rangskálás és parciális kredit modell. Iskolakultúra, 18. 1-2. sz. 6677. 
Molnár Gyöngyvér és Józsa Krisztián (2006): Az olvasási képesség értékelésnek tesztelméleti megközelítései. In: Józsa Krisztián (szerk.): Az olvasási képesség fejlődése és fejlesztése. Dinasztia Tankönyvkiadó, Budapest. 155-174.

Morgan, G. A. és Yang, R. K. (1995): Toward a multifaceted conceptualization of mastery motivation: an organized summary of research. In: MacTurk, R. H. és Morgan, G. A. (szerk.): Mastery motivation: Origins, conceptualizations and applications. Vol. 12. Advances in applied developmental psychology. Ablex Publishing Corporation, Norwood, New Jersey. 317-337.

Morgan, G. A., MacTurk, R. H. és Hrncir E. J. (1995): Mastery motivation: overview, definitions and conceptual issues. In: MacTurk, R. H. és Morgan, G. A. (szerk.): Mastery motivation: Origins, conceptualizations and applications. Vol. 12. Advances in applied developmental psychology. Ablex Publishing Corporation, Norwood, New Jersey. 1-18.

Morgan, G. A., Maslin-Cole, C., Harmon, R. J., Busch-Rossnagel, N. A., Jennings, K. D., Hauser-Cram, P. és Brockman, L. (1996): Parent and teacher perceptions of young children's mastery motivation: Assesment and review of research. In: Messer, D. J. (szerk.): Mastery motivation in early childhood: Development, measurement and social processes. Routledge, London and New York, 109-131.

Muis, K. R., Winne, P. H. és Edwards, O. V. (2009): Alternative psychometrics for assessing achievement goal orientation: A Rasch analysis. British Journal of Educational Psychology, 79. 3. sz. 547-576.

Murayama, K. és Elliot, A. J. (2009): The joint influence of personal achievement goals and classroom goal structures on achievement-related outcomes. Journal of Educational Psychology, 101. 2. sz. 432-447.

Murdock, T. B. (2000): Incorporating economic context into educational psychology: Methodological and conceptual challenges. Educational Psychologist, 35. 2. sz. $113-124$.

Murphy, P. K. és Alexander, P. A. (2000): A Motivated Exploration of Motivation Terminology. Contemporary Educational Psychology, 25. 2. sz. 3-53.

Nagy József (1994): Én(tudat) és pedagógia. Magyar Pedagógia, 94. 1-2. sz. 3-26.

Nagy József (2000): A XXI. század és nevelés. Osiris Kiadó, Budapest.

Nagy Mária (2002): Cigány tanulók az iskolában. A tanárok beszélnek. Magyar Pedagógia, 102. 3. sz. 301-331.

Nahalka István (2002): Hogyan alakul ki a tudás a gyermekben? Konstruktivizmus és pedagógia. Nemzeti Tankönyvkiadó, Budapest.

Németh Erzsébet (1998): A külső ösztönzők hatásra kialakuló viselkedés és attitüd változás komplex vizsgálata. Magyar Pedagógia, 98. 4. sz. 313-338.

Nguyen Luu, L. A. (2003): Lehet-e összehasonlító a pszichológia, ha kulturális? In: Nguyen Luu Lan Anh és Fülöp Márta (szerk.): Kultúra és pszichológia. Osiris Kiadó, Budapest. 15-53.

Nicholls, J. G. (1978): The development of the concepts of effort and ability, perception of own attainment, and the understanding that difficult tasks require more ability. Child Development, 49. 4. sz. 800-814. 
Nicholls, J. G. (1984): Achievement motivation: Conceptions of ability, subjective experience, task choice, and performance. Psychological Review, 91. 3. sz. 328346.

Niemivirta, M. (2002a): Individual differences and developmental trends in motivation: Integrating person-centered and variable-centered methods. In: Pintrich, P. R. és Maehr, M. L. (szerk.): Advances in motivations and achievement: New directions in measures and methods. JAI Press, Amsterdam. 241-275.

Niemivirta, M. (2002b): Motivation and performance in context: the influence of goal orientations and instructional setting on situational appraisals and task performance. Psychologia: An International Journal of Psychology in the Orient, 45. 250-270.

Niemivirta, M., Rijavec, M. és Yamauchi, H. (2001): Goal orientations and actioncontrol beliefs: A cross-cultural comparison among croatian, finnish, and japanese students. In: Efklides, A., Kuhl, J. és Sorrentino, R. M. (szerk.): Trends and prospects in motivation reserach. Kluwer, Dordrecht. 163-183.

Niles, F. S. (1995): Cultural differences in learning motivation and learning strategies: A comparison of overseas and Australian students at an Australian university. International Journal of Intercultural Relations, 19. 2. sz. 369-385.

OECD (2000): Motivating Students for Lifelong Learning. OECD, Paris.

OECD (2004a): Knowledge management. Innovation in the Knowledge Economy: Implications for Education and Learning. OECD, Paris.

OECD (2004b): Learning for Tomorrow's World. First Result from PISA 2003. OECD, Paris.

OECD (2007): PISA 2006. Sciences Competencies for Tomorrow's World. OECD, Paris.

OECD (2010a): PISA 2009 Results: Learning to Learn. OECD, Paris.

OECD (2010b): The High Costs of Low Educational Performance. The Long-run Economic Impact of Improving PISA Outcomes. OECD, Paris.

Oka, E. R. (2005): Motivation. In: Lee, S. W. (szerk.): Encyclopedia of school psychology. Sage, Thousand Oaks, CA. 330-335.

Orosz Sándor (2001): Az általános iskolából kilépő tanulók tudásának alakulása a rendszerváltozás után. In: Csapó Benő és Vidákovich Tibor (szerk.): Neveléstudomány az ezredfordulón. Nemzeti Tankönyvkiadó, Budapest. 328338.

Paulhus, D. L. (1991): Measurement and control of response bias. In: Robinson, J. P., Shaver P. R. és Wrightsman, L. S. (szerk.): Measures of personality and social psychological attitudes. Academic Press, New York. 17-59.

Papp Katalin és Józsa Krisztián (2000): Legkevésbé a fizikát szeretik a diákok? Fizikai Szemle, 50. 2. sz. 61-67.

Papp Katalin és Nagy Anett (2004): Tanár szakos hallgatók komplex természettudományos ismereteinek fejlesztése. Iskolakultúra, 14. 4. sz. 29-41.

Papp Katalin és Nagy Anett (2007): Public Relations és a fizikatanítás: avagy hogyan tegyük vonzóvá a fizika tantárgyat. Fizikai Szemle, 57. 1. sz. 18-24. 
Papp Zoltán és Pappné Patai Anikó (2000): Mit tehetnénk a fizika attitűd javításáért? Fizikai Szemle, 50. 7. sz. 234-241.

Patrick, H. és Ryan, A. M. (2008): What do students think about when evaluating their classroom's mastery goal structure? An examination of young adolescents' explanations. Journal of Experimental Education, 77. 2. sz. 99-123.

Patrick, H., Anderman, L. H., Ryan, A. M., Edelin, K. és Midgley, C. (2001): Teachers' communication of goal orientations in four fifth-grade classrooms. The Elementary School Journal, 102. 1. sz. 35-58.

Patrick, H., Ryan, A. M., Anderman, L. H., Middleton, M., Linnenbrink, L., Hruda, L. Z., Edelin, K., Kaplan, A. és Midgley, C. (1997): OPAL. Observing patterns of adaptive learning: A protocol for Classroom Observations. University of Michigan, Ann Arbor.

Patrick, H., Turner, J. C., Meyer, D. K és Midgley, C. (2003): How teachers establish psychological environments during the first days of school: Associations with avoidance in mathematics. Teachers College Record, 105. 8. sz. 1521-1558.

Pintér Henriett (2009): Téma és motivációs lehetőség fogalmazásórán. Tanító, 47. 8. sz. $20-23$.

Pintrich, P. R. (2000a): An achievement goal theory perspective on issues in motivation terminology, theory, and research. Contemporary Educational Psychology, 25. 1. sz. 92-104.

Pintrich, P. R. (2000b): Multiple goals, multiple pathways: The role of goal orientation in learning and achievement. Journal of Educational Psychology, 92. 3. sz. 544555.

Pintrich, P. R. (2003): A motivational sciences perspective on the role of student motivation in learning and teaching context. Journal of Educational Psychology, 95. 4. sz. 667-686.

Pintrich, P. R. és DeGroot, E. (1990): Motivational and self-regulated learning components in classroom academic performance. Journal of Educational Psychology, 82. 1. sz. 33-40.

Pomerantz, E. M., Grolnick, W. S. és Price, C. E. (2005): The role of parents in how children approach achievement: A dynamic process perspective. In: Elliot, A. és Dweck, C. (szerk.): Handbook of motivation and competence. Guilford, New York. 259-278.

Radnóti Katalin (2004): Gyenge kezdés után erős visszaesés. Avagy: miért nem szeretik a diákok a fizikát. Iskolakultúra, 14. 1. sz. 50-68.

Radnóti Katalin (2005): A fizika tantárgy helyzete egy vizsgálat tükrében. Iskolakultúra, 15. 3. sz. 81-94.

Radó Péter (1997): Jelentés a magyarországi cigány tanulók oktatásáról: Szakértői tanulmány a Nemzeti és Etnikai Kisebbségi Hivatal számára. Budapest.

Ranschburg Jenő (2001): A család anyagi helyzetének szerepe a gyermekkori magatartási zavarok kialakulásában. Fejlesztö Pedagógia, 2. 6. sz. 26-34.

Rasch, G. (1960): Probabilistic models for some intelligence and attainment tests. Danish Institute for Educational Research, Copenhagen. 
Raudenbush, S. W. (1984): Magnitude of teacher expectancy effects on Pupil IQ as a function of the credibility of expectancy induction: A synthesis of findings from 18 experiments. Journal of Educational Psychology, 76. 1. sz. 85-97.

Rawsthorne, L. J. és Elliot, A. J. (1999): Achievement goals and intrinsic motivation: A meta-analytic review. Personality and Social Psychology Review, 3. 4. sz. 326344.

Réthy Endréné (1989): Teljesitményértékelés és tanulási motiváció. Tankönyvkiadó, Budapest.

Réthy Endréné (1999): Motiváció: felfogások, elképzelések, hitek. Iskolakultúra, 9. 9. sz. 56-59.

Réthy Endréné (2001a): A tanulási motiváció elemzése. In: Csapó Benő és Vidákovich Tibor (szerk.): Neveléstudomány az ezredfordulón: Tanulmányok Nagy József tiszteletére. Tankönyvkiadó, Budapest. 153-161.

Réthy Endréné (2001b): Motivációs elképzelések. In: Golnhofer Erzsébet és Nahalka István (szerk.): Pedagógusok pedagógiája. Nemzeti Tankönyvkiadó, Budapest. 177-201.

Réthy Endréné (2003): Motiváció, tanulás, tanitás. Miért tanulunk jól vagy rosszul? Nemzeti Tankönyvkiadó, Budapest.

Réthy Endréné (2004): Motivációs eljárások, pedagógiai kirekesztődés. In: Nahalka István és Torgyik Judit (szerk.): Megközelitések. Roma gyermekek nevelésének egyes kérdései. Eötvös József Könyvkiadó, Budapest. 246-267.

Réthy Endréné és Vámos Ágnes (2006): Esélyegyenlötlenség és méltányos pedagógia. Bölcsész Konzorcium, Budapest.

Revákné Markóczi Ibolya (2002): Motiváció a biológiatanításban. A biológia tanitása, 10. 4 sz. $7-12$.

Roeser, R. W., Midgley, C. és Urdan, T. C. (1996): Perceptions of school psychological environment and early adolescents' psychological and behavioural functioning in school: The mediating role of goals and belonging. Journal of Educational Psychology, 88. 3. sz. 408-422.

Rosenthal, R. (2002): The Pygmalion effect and its mediating mechanisms. In: Aronson, J. (szerk.): Improving academic achievement. Elseviser, New York. 25-36.

Ross, M. E., Shannon, D. M., Salisbury-Glennon, J. D. és Guarino, A. (2002): The patterns of adaptive learning survey: A comparison across grade levels. Educational and Psychological Measurement, 62. 3. sz. 483-497.

Rubie-Davies, C. M. (2006): Teacher expectations and student self-perceptions: Exploring relationships. Psychology in the Schools, 43. 5. sz. 537-552.

Rueda, R. és Moll L. C. (1999): A motiváció szociokulturális megközelítése. In: O’Neil H. F. Jr. és Drillings M. (szerk.): Motiváció: elmélet és kutatás. Vince Kiadó, Budapest. 129-148.

Ryan, A. M. és Patrick, H. (2001): The classroom social environment and changes in adolescents' motivation and engagement during middle school. American Educational Research Journal, 38. 2. sz. 437-460. 
Ryan, A. M., Gheen, M. H. és Midgley, C. (1998): Why do some students avoid asking for help? An examination of the interplay among students' academic efficacy, teachers' social-emotional role, and the classroom goal structure. Journal of Educational Psychology, 90. 3. sz. 528-535.

Ryan, A. M., Kiefer, S. M. és Hopkins, N. B. (2004): Young adolescents' social motivation: An achievement goal perspective. In: Pintrich, P. R. és Maehr, M. L. (szerk.): Advances in motivation and achievement: Motivating students, improving schools: The legacy of Carol Midgley. Elsevier, Stamford. 310-330.

Ryan, R. M. (2000): Peer groups as a context for the socialisation of adolescents' motivation, engagement and achievement in school. Educational Psychologist, 35. 2. sz.101-111.

Ryan, R. M. és Deci, E. L. (2000): Self-determination theory and the facilitation of intrinsic motivation, social development, and well-being. American Psychologist, 55. 1. sz. 68-78.

Sallay Hedvig (1997): Tanári elvárások, visszajelentések és a tanulók ezekre adott reakciói: érvényesül-e, s miként fejti ki hatását a Pygmalion-effektus? In: Mészáros Aranka (szerk.): Az iskola szociálpszichológiai jelenségvilága. ELTE Eötvös Kiadó, Budapest. 102-112.

Sallay Hedvig (2003): Serdülők jövő-orientációja: a szülői nevelés hatásai. Magyar Pedagógia, 103. 3. sz. 389-404.

Sáska Géza (1991): Mit osztályoznak a tanárok? Új Pedagógiai Szemle, 41. 12. sz. $22-$ 29.

Schoenfeld, A. H. (2006): Design Experiments. In: Elmore, P. B., Camilli, G. és Green, J. (szerk.): Handbook of Complementary Methods in Education Research. American Educational Research Association and Lawrence Erlbaum Associates, Washington, DC \& Mahwah, NJ. 193-206.

Schunk, D. H. (2000): Motivation for achievement: Past, present, and future. Issues in Education: Contributions from Educational Psychology, 6. 1. sz. 161-165.

Schutz, P. A. és Pekrun, R. (2007, szerk.): Emotion in education. Academic Press, San Diego, CA.

Schwinger, M. és Wild, E. (2012): Prevalence, stability, and functionality of achievement goal profiles in mathematics from third to seventh grade. Contemporary Educational Psychology, 37. 1. sz. 1-13

Seifer, R. és Vaughn, B. E. (1995): Mastery motivation within a general organizational model of competence. In: MacTurk, R. H. és Morgan, G. A. (szerk.): Mastery motivation: Origins, conceptualizations and applications. Vol. 12. Advances in applied developmental psychology. Ablex Publishing Corporation, Norwood, New Jersey. 95-115.

Senko, C. és Miles, K. M. (2008): Pursuing their own learning agenda: How masteryoriented students jeopardize their class performance. Contemporary Educational Psychology, 33. 4. sz. 561-583.

Shih, S. S. (2005): Taiwanese sixth graders' achievement goals and their motivation, strategy use, and grades: An examination of the multiple goal perspective. Elementary School Journal, 106. 1. sz. 39-58. 
Simons, J., Vansteenkiste, M., Lens, W. és Lacante, M. (2004): Placing motivation and future time perspective theory in a temporal perspective. Educational Psychology Review, 16. 2. sz. 121-139.

Skaalvik, E. M. (1997): Self-enhancing and self-defeating ego orientation: Relations with task and avoidance orientation, achievement, self-perceptions, and anxiety. Journal of Educational Psychology, 89. 1. sz. 71-81.

Stevenson, D. L. és Baker, D. P. (1992): Shadow education and allocation in formal schooling: Transition to university in Japan. American Journal of Sociology, 97. 6. sz. 1639-1657.

Stigler, J. W., Gallimore, R. és Hiebert, J. (2000): Using video surveys to compare classrooms and teaching across cultures: Examples and lessons from the TIMSS Video Studies. Educational Psychologist, 35. 2. sz. 87-100.

Stipek, D. és Ryan, R. (1997): Economically disadvantaged preschoolers: Ready to learn by further to go. Developmental Psychology, 33. 4. sz. 711-723.

Stipek, D. J. (1993): Motivation to Learn: From Theory to Practice. Allyn and Bacon, Needham Heights, Massachusetts.

Stipek, D., Givvin, K., Salmon, J. és MacGyvers, V. (1998): Can a teacher intervention improve classroom practices and student motivation in mathematics? Journal of Experimental Education, 66. 4. sz. 319-337.

Stokes, D. E. (1997): Pasteur's Quadrant: basic science and technological innovation. The Brookings Institution, Washington.

Szabó Ákosné (2003): Velük vagy rajtuk? A roma gyermekek és szüleik szükségletei. Gyógypedagógiai Szemle, 31. 2. sz. 97-110.

Szabó Mónika (2003): Társas kapcsolatok: család, barátok, iskola. In: Aszmann Anna (szerk.): Iskolás gyermekek egészségmagatartása 1986-1993. Anonymus Kiadó, Budapest. 109-124.

Szabó Mónika (2004): Motiváció. In: N. Kollár Katalin és Szabó Éva (szerk.): Pszichológia pedagógusoknak. Osiris Kiadó, Budapest. 169-191.

Szenczi Beáta (2008): Énkép és tanulás: Nemzetközi kutatási irányzatok és tendenciák. Iskolakultúra Online, 1. 2. sz. 104-118.

Szenczi Beáta (2010a): Az olvasási motiváció mérése kisiskolás korban: Egy pilot vizsgálat eredményei. In: Csíkos Csaba és Kinyó László (szerk.): X. Országos Neveléstudományi Konferencia, Budapest, 2010. november 4-6. Uj törekvések és lehetőségek a 21. századi neveléstudományokban. Szegedi Tudományegyetem, Szeged. 204.

Szenczi Beáta (2010b): Az olvasási motiváció: definíciók és kutatási irányok. Magyar Pedagógia, 110. 2. sz. 119-147.

Szenczi Beáta (2011): Leendő és gyakorló tanítók meggyőződései az olvasási motivációról. In: Vidákovich Tibor és Habók Anita (szerk.): PÉK 2011 - IX. Pedagógiai Értékelési Konferencia: Program - Elöadás-összefoglalók. Szegedi Tudományegyetem, Szeged. 73.

Szenczi Beáta és Józsa Krisztián (2008): Az énképet vizsgáló SDQI kérdőív hazai adaptációja (előadás). In: Perjés István (szerk.): VIII. Országos 
Neveléstudományi Konferencia: Hatékony tudomány, pedagógiai kultúra, sikeres iskola, Budapest. Tartalmi Összefoglalók, 328.

Szenczi Beáta és Józsa Krisztián (2009): A tanulási énkép összefüggése a tanulmányi eredményekkel és a képességfejlettséggel. In: Molnár Gyöngyvér és Kinyó László (szerk.): PÉK 2009 - VII. Pedagógiai Értékelési Konferencia: Program Tartalmi összefoglalók. Szegedi Tudományegyetem, Szeged. 103.

Szenczi, B. és Józsa, K. (2010): Moderating effects of achievement measures on the relationship between academic self-concept and academic achievement. Presented at the 12th International Conference on Motivation, Porto, Portugalia, September 2-4, 2010. In: Lemos M., Goncalves, T., Verissimo, L. és Meneses, H. (szerk.): Motivation: New Directions in Mind. Book of Abstracts. 150-151.

Szitó Imre (1991): Az ökológiai megközelítés a pszichológiában. Magyar Pszichológiai Szemle, 47. 2. sz. 215-232.

Szűcs Norbert és Fejes József Balázs (2011): A deszegregáció lehetőségei többiskolás településeken. Hódmezővásárhely példája. In: Németh Szilvia (szerk.): $H H-s$ gyermekek a közoktatásban. Kézikönyv hátrányos és halmozottan hátrányos helyzetü gyermekek neveléséhez és oktatásához. RAABE Kiadó.

Szokolszky Ágnes (2004): Kutatómunka a pszichológiában. Budapest, Osiris Kiadó.

Takács Gábor (2009): A motiváció szükségessége, lehetősége matematikaórán. Tanitó, 47. 5. sz. $10-12$.

Tamás Pál (2006, szerk.): A tudásalapú társadalom kialakulása Magyarországon. Új Mandátum Könyvkiadó, Budapest.

Tapola, A. és Niemivirta, M. (2008): The role of achievement goal orientations in students' perceptions of and preferences for classroom environment. British Journal of Educational Psychology, 78. 2. sz. 291-312.

Tátrai Szilárd (2004): A kontextus fogalmáról. Magyar nyelvőr, 128. 4. sz. 479-494.

Thrash, T. M. és Elliot, A. J. (2001): Delimiting and integrating the goal and motive constructs in achievement motivation. In: Efklides, A., Kuhl, J. és Sorrentino, R. (szerk.): Trends and prospects in motivation research. Kluwer Academic Publishers, Amsterdam. 3-21.

Tímár Éva (1994): Városi és községi iskolák tanítási klímájának sajátosságai. Magyar Pedagógia, 94. 3-4. sz. 253-274.

Tóth Edit (2010): Teszt alapú elszámoltathatóság a közoktatásban. Iskolakultúra. 20.1. sz. 60-79.

Tóth Edit és Székely László (2011): Háttértényezők hatásának vizsgálata hierarchikus lineáris modellekkel. A 2007-es TIMSS-mérés matematika eredményeinek másodelemzése. Magyar Pedagógia, 111. 1. sz. 5-24.

Tóth Edit, Csapó Benő és Székely László (2010): Az iskolák és osztályok közötti különbségek alakulása a magyar iskolarendszerben. Egy longitudinális vizsgálat eredményei. Közgazdasági Szemle, 57.9. sz. 798-814.

Tuominen-Soini, H., Salmela-Aro, K. és Niemivirta, M. (2008): Achievement goal orientations and well-being: A person-centred analysis. Learning and Instruction, 18. 3. sz. 251-266. 
Tuominen-Soini, H., Salmela-Aro, K. és Niemivirta, M. (2011): Stability and change in achievement goal orientations: A person-centred approach. Contemporary Educational Psychology, 36. 2. sz. 82-100.

Turner, J. C. (2001): Using context to enrich and challenge our understanding of motivational theory. In: Volet, S. és Järvelä, S. (szerk.): Motivation in learning contexts: Theoretical and methodological implications. Elsevier, Amsterdam. 85-104.

Turner, J. C. és Meyer, D. K. (1999): Integrating classroom context into motivation theory and research: Rationales, methods, and implications. In: Urdan, T., Maehr, M. és Pintrich, P. R. (szerk.): Advances in motivation. Vol. 11. Greenwich CT: JAI Press. 87-121.

Turner, J. C. és Meyer, D. K. (2000): Studying and understanding the instructional contexts of classrooms: Using our past to forge our future. Educational Psychologist, 35. 2. sz. 69-85.

Turner, J. C. és Patrick, H. (2008): How does motivation develop and why does it change? Reframing motivation research. Educational Psychologist, 43. 3. sz. 119-131.

Turner, J. C. és Patrick, H. (2009): The cultural situatedness of motivation: In: Kaplan, A., Karabenick, S. és DeGroot, E. (szerk.): Culture, Self, and, Motivation: Essays in Honor of Martin L. Maehr. 243-265.

Turner, J. C., Meyer, D. K., Midgely, C. és Patrick, H. (2003): Teacher discourse and sixth graders' reported affect and achievement behaviors in two highmastery/high-performance mathematics classrooms. Elementary School Journal, 103. 4. sz. 357-382.

Turner, J. C., Midgley, C., Meyer, D. K., Gheen, M., Anderman, E. és Kang, Y. (2002): The classroom environment and students' reports of avoidance strategies in mathematics: A multimethod study. Journal of Educational Psychology, 94. 1. sz. 88-106.

U. S. Department of State (é. n.): The U. S. Education System. 2012. 01. 08-i megtekintés, http://usinfo.org/enus/education/overview/edlite-structure-us1.html

Urdan, T. (1999, szerk.): Advances in motivation and achievement. Volume 11: Motivation in context. Stamford, CT: JAI Press.

Urdan, T. (2004a): Can achievement goal theory guide school reform? In: Pintrich, P. R. és Maehr, M. L. (szerk.): Advances in motivation and achievement: Motivating students, improving schools: The legacy of Carol Midgley. Elsevier, Stamford. 361-392.

Urdan, T. (2004b): Predictors of academic self-handicapping and achievement: Examining achievement goals, classroom goal structures, and culture. Journal of Educational Psychology, 96. 2. sz. 251-264.

Urdan, T. (2004c): Using multiple methods to assess students' perceptions of classroom goal structures. European Psychologist, 9. 4. sz. 222-231.

Urdan, T. (2010a): The challenges and promise of research on classroom goal structures. Meece, J. L. és Eccles, J. S. (szerk.): Handbook of Research on 
Schooling, Schools, \& Human Development. Routledge, Taylor \& Francis Group, New York. 92-108.

Urdan, T. (2010b): Unfinished business: putting motivation theory to the "classroom test". In: Urdan, T. és Karabenick, S. A. (szerk.): Advances in Motivation and Achievement: The Decade Ahead: Applications and contexts of motivation and achievement. Emerald, Bingley, U.K. 109-138.

Urdan, T. és Midgley, C. (2003): Changes in the perceived classroom goal structure and patterns of adaptive learning during early adolescence. Contemporary Educational Psychology, 28. 4. sz. 524-551.

Urdan, T. és Schoenfelder, E. (2006): Classroom effects on student motivation: Goal. structures, social relationships, and competence beliefs. Journal of School Psychology, 44. 5. sz. 331-349.

Urdan, T. és Turner, J. C. (2005): Competence motivation in the classroom. In: Elliot, A. J. és Dweck, C. S. (szerk.): Handbook of competence and motivation. Guilford Press, New York. 297-317.

Urdan, T., Kneisel, L. és Mason, V. (1999): The effect of particular instructional practices on student motivation: An exploration of teachers' and students' perceptions. In: Urdan, T. (szerk.): Advances in motivation and achievement. Volume 11: Motivation in context. Stamford, CT: JAI Press. 123-158.

Urdan, T., Midgley, C. és Anderman, E. (1998): The role of classroom goal structure in students' use of self-handicapping strategies. American Educational Research Journal, 35. 1. sz. 101-122.

Urdan, T., Solek, M. és Schoenfelder, E. (2007): Students' perceptions of family influences on their academic motivation: A qualitative analysis. European Journal of Psychology of Education, 22. 1. sz. 7-21.

Usher, E. L. és Morris, D. B. (2012): Academic motivation. In: Seel, N. M. (szerk.): Encyclopedia of the Sciences of Learning. Springer, New York. 36-39.

Vajda Zsuzsanna és Kósa Éva (2005): Neveléslélektan. Osiris Kiadó, Budapest.

Van Yperen, N. W. (2006): A novel approach to assessing achievement goals in the context of the $2 \times 2$ framework: identifying distinct profiles of individuals with different dominant achievemnt goals. Personality and Social Psychology Bulletin, 32. 11. sz. 1432-1445.

Várnai Dóra és Örkényi Ágota (2007): Iskola, kortárs kapcsolatok, kortárs bántalmazás. In: Németh Ágnes (szerk.): Serdülőkorú fiatalok egészsége és életmódja. Országos Gyermekegészségügyi Intézet, Budapest. 158-170.

Vauras, M., Salonen, P., Lehtinen E. és Lepola, J. (2001): Long-term development of motivation and cognition in family and school contexts. In: Volet, S. és Järvelä, S. (szerk.): Motivation in learning contexts: Theoretical advances and methodological implications. Pergamon Press, Amsterdam. 295-315.

Veczkó József (1986): Gyerekek, tanárok, iskolák. Gyerekeink viszonya az iskolához. Tankönyvkiadó, Budapest.

Veidner János (2003): A motiváció, az érzékelés, az észlelés, az emlékezet, a megfigyelés szerepe a fizikatanításban II. Módszertani közlemények, 43. 4. sz. $147-151$. 
Vígh Tibor (2008): Egy IRT-alapú nyelvi feladatbank létrehozásának módszertani kérdései: A német érettségi vizsgafeladatok elemzésének eredményei. Magyar Pedagógia, 108. 1. sz. 29-51.

Vígh Tibor (2010): Az idegen nyelvi érettségi müködése és hatása a tanulói teljesitmények és a tanári nézetek tükrében. PhD-értekezés. Szegedi Tudományegyetem, Bölcsészettudományi Kar, Neveléstudományi Doktori Iskola, Szeged.

Vigotszkij, L. Sz. (1967): Gondolkodás és beszéd. Akadémiai Kiadó, Budapest.

Vigotszkij, L. Sz. (1971): A magasabb pszichikus funkciók fejlödése. Gondolat Kiadó, Budapest.

Volet, S. (2001): Learning and motivation in context: A multi-dimensional and multilevel, cognitive-situative perspective. In: Volet, S. és Järvelä, S. (szerk.): Motivation in learning contexts: Theoretical advances and methodological implications. Pergamon Press, Amsterdam. 57-82.

Volet, S. és Järvelä, S. (2001, szerk.): Motivation in learning contexts: Theoretical and methodological implications. Elsevier, Amsterdam.

Walker, R. A., Pressick-Kilborn, K. J., Sainsbury, E. és MacCallum, J. (2010): A sociocultural approach to motivation: A long time coming but here at last. In: Timothy C. Urdan és Stuart A. Karabenick (szerk.): Advances in Motivation and Achievement: The Decade Ahead: Applications and contexts of motivation and achievement. Emerald, Bingley, U.K. 1-42.

Weinstein, R.S. és McKown, C. (1998): Expectancy effects "in context": Listening to the voices of students and teachers. In: Brophy, J. (szerk.): Advances in research on teaching. JAI Press, Greenwich. 215-242.

Wentzel, K. R. (1993): Social and academic goals at school: Motivation and achievement in early adolescence. Journal of Early Adolescence, 13. 1. sz. 4-20.

Wentzel, K. R. (1998): Social relationships and motivation in middle school: The role of parents, teachers, and peers. Journal of Educational Psychology, 90. 2. sz. 202-209.

Wentzel, K. R. (2000): What is it that I'm trying to achieve? Classroom goals from a content. perspective. Contemporary Educational Psychology, 25. 1. sz. 105-115.

Wentzel, K. R. és Wigfield, A. (2009, szerk.): Handbook of Motivation at School. Routledge, Taylor \& Francis Group, New York.

Willms, J. D. (2003): Student engagement at school: A sense of belonging and participation (Results from PISA 2000). OECD, Paris.

Wolters, C. A. (1999): The relationship between high school students' motivational regulation and their use of learning strategies, effort, and classroom performance. Learning and Individual Differences, 3. 3. sz. 281-299.

Wolters, C. A. (2004): Advancing achievement goal theory: using goal structures and goal orientations to predict students' motivation, cognition and achievement. Journal of Educational Psychology, 96. 2. sz. 236-250.

Wolters, C. A. és Daugherty, S. G. (2007): Goal structures and teachers' sense of efficacy: their relation and association to teaching experience and academic level. Journal of Educational Psychology, 99. 1. sz. 181-193. 
Wolters, C. A., Yu, S. és Pintrich, P. R. (1996): The relation between goal orientation and students' motivational beliefs and self-regulated learning. Learning and Individual Differences, 11. 3. sz. 281-299.

Wu, M., Adams, R. J. és Wilson, M. R. (1998): ACER ConQuest. Generalised Item Response Modelling Software. ACER Press, Australia.

Zeidner, M. és Schleyer, E. (1999): The big-fish-little-pond effect for academic selfconcept, test anxiety, and school grades in gifted children. Contemporary Educational Psychology, 24. 4. sz. 305-329.

Zusho, A., Pintrich, P. R. és Cortina, K. S. (2005): Motives, goals, and adaptive patterns of performance in Asian American and Anglo American students. Learning and Individual Differences, 15. 2. sz. 141-158.

Zsigmond Anna (2005): Amerika: Társadalom és oktatás. Fordulópontok az amerikai oktatáspolitikában. Gondolat, Budapest.

Zsiros Emese és Örkényi Ágota (2011): Iskola, kortársbántalmazás. In: Németh Ágnes és Költö András (szerk.): Serdülőkorú fiatalok egészsége és életmódja 2010. Országos Gyermekegészségügyi Intézet, Budapest. 103-112.

Zsolnai Anikó (2001a): A gyermekkori kötődések szerepe a szociális kompetencia fejlődésében. In: Csapó Benő és Vidákovich Tibor (szerk.): Neveléstudomány az ezredfordulón: Tanulmányok Nagy József tiszteletére. Tankönyvkiadó, Budapest, 143-152.

Zsolnai Anikó (2001b): Kötődés és nevelés. Eötvös József Könyvkiadó, Budapest. 


\section{ÁBRÁK JEGYZÉKE}

1. ábra. A szociális közeg hatása az elsajátítási motívumok fejlődésére (Geen, 1995,

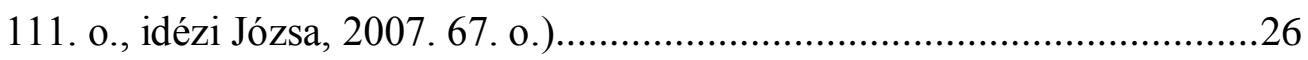

2. ábra. A tantárgyakkal kapcsolatos attitüdök az iskolai évek függvényében (Csapó, 2000, 351. o.)

3. ábra. Olvasási és matematikai énkép (Forrás: OECD PISA 2001 database, Table C.3.2.; Józsa és Fejes, 2012, 395. o.)

4. ábra. A jó teljesítmény fontossága természettudományok, olvasás és matematika területén (\%) (Forrás: OECD PISA 2006 database, Table 3.7.; Józsa és Fejes, 2012, 397. o.)

5. ábra. Az elsajátítási motiváció életkori változása (Józsa, 2007 alapján) ...............44

6. ábra. A tanulási környezet különböző összetevőire utaló fogalmak áttekintése a célorientációs elmélet alapján.

7. ábra. Az osztálytermi célstruktúrákat befolyásoló előzetes változók és hatások lehetséges modellje (Urdan, 2010a, 99. o.)

8. ábra. Elemzési keret a célorientációk és a célstruktúrák együttes, teljesítménnyel kapcsolatos változókra kifejtett hatásának vizsgálatához (Murayama és Elliot, 2009, 433. o.)

9. ábra. A vizsgálatsorozat keretében felmért konstruktumok és fontosabb feltételezett összefüggéseik

10. ábra. A vizsgálatsorozat menete

11. ábra. Az elsajátítási célok személy-item térképei a teljes mintán az első adatfelvétel alapján

12. ábra. A viszonytó teljesítménykereső és a tanulást kerülő cél személy-item térképei a teljes mintán az első adatfelvétel alapján

13. ábra. Az elsajátítási célok személy-item térképei a teljes mintán a második adatfelvétel alapján

14. ábra. A viszonyító célok személy-item térképei a teljes mintán a második adatfelvétel alapján

15. ábra. A tanulást kerülő cél személy-item térképe a teljes mintán a második adatfelvétel alapján

16. ábra. Az elsajátítási célok személy-item térképei a teljes mintán a harmadik adatfelvétel alapján

17. ábra. A viszonyító célok személy-item térképei a teljes mintán a harmadik adatfelvétel alapján

18. ábra. A tanulást kerülő cél személy-item térképei a teljes mintán a harmadik adatfelvétel alapján

19. ábra. A vizsgált konstruktumok összefüggése a megmagyarázott varianciák alapján 


\section{TÁBLÁZATOK JEGYZÉKE}

1. táblázat. A személyes befektetés dimenziói (Maehr és Meyer, 1997, 374-375. o.)

2. táblázat. A motivációtudomány különböző típusú kutatásai (Pintrich, 2003, 669.

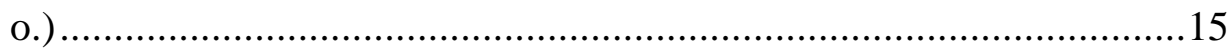

3. táblázat. A tantárgyak kedveltségének változása: az elő- és utómérés korrelációi (Józsa és Pap-Szigeti, 2006, 147. o.) .................................................39

4. táblázat. A tanulók iskola iránti attitüdje évfolyam szerint (\%) (Zsiros és Örkényi,

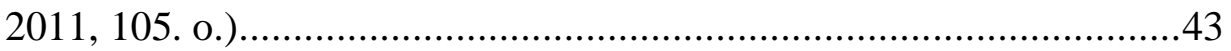

5. táblázat. Az iskola percepciója (\%) (Szabó, 2003, 121. o.) ..............................46

6. táblázat. A tanári magatartás percepciója (\%) (Várnai és Örkény, 2007, 164. o.)47

7. táblázat. A tanári magatartás percepciója (\%) (Várnai és Örkény, 2007, 164. o.) 47

8. táblázat. A tanulási motiváció és az osztályzatok, teszteredmények összefüggése (Józsa, 2002, 258. o.) ..................................................................49

9. táblázat. Az alapkészségek, az intelligencia és az értelmi elsajátítási motívum regresszióanalízise a tanulmányi átlaggal mint függő változóval (r $\beta \%)$ (Józsa, 2007 alapján)...............................................................50

10. táblázat. Az elsajátítási és a viszonyító cél meghatározásai (Maehr és Meyer,

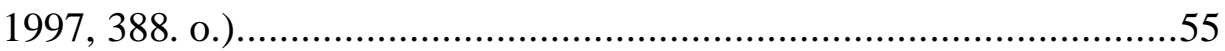

11. táblázat. A célok teljesítménykereső és teljesítménykerülő formái (Linnenbrink és Pintrich, 2001, 254. o.).....

12. táblázat. A célorientációkat befolyásoló körülmények szempontjai (TARGET) (Kaplan és Maehr, 2007, 159. o., részlet) .........................................70

13. táblázat. A célstruktúrák megismerését célzó kérdőívek .................................83

14. táblázat. A tanulási környezet összetevőinek megismerése érdekében alkalmazott kérdőívek a célelmélettel öszefüggésben ........................................8 84

15. táblázat. A vizsgálatsorozat mintáinak évfolyamok szerinti megoszlása .............93

16. táblázat. A tanulók megoszlása a szülök iskolai végzettsége szerinti bontásban $(\%)$

17. táblázat. A Tanulói célok kérdőívet kitöltők az első adatfelvétel során...............96

18. táblázat. A Tanulói célok kérdőív skáláinak jellemzői az első adatfelvétel során 97

19. táblázat. A Tanulói célok kérdőív faktoranalízise a teljes mintán az első adatfelvétel alapján

20. táblázat. A Tanulói célok kérdőív megbízhatósági mutatói (Cronbach- $\alpha$ ) évfolyamok szerinti és a teljes mintán az első adatfelvétel alapján

21. táblázat. A Tanulói célok kérdőív tételeinek empirikus paraméterei a teljes mintán az első adatfelvétel alapján.

22. táblázat. Az elsajátítási teljesítménykereső cél kérdőívtételei és átlagos támogatottságuk a teljes mintán az első adatfelvétel alapján.

23. táblázat. A lefedettség növelése érdekében viszonyítási pontként használt és néhány új kérdőívtétel az első adatfelvétel alapján

24. táblázat. A Tanulói célok kérdőívet kitöltők a második adatfelvétel során. 107 
25. táblázat. A Tanulói célok kérdőív faktoranalízise 5. évfolyamon a második adatfelvétel alapján

26. táblázat. A Tanulói célok kérdőív megbízhatósági mutatói (Cronbach- $\alpha) 5$. évfolyamon a második adatfelvétel alapján

27. táblázat. A Tanulói célok kérdőív tételeinek empirikus paraméterei 5. évfolyamon a második adatfelvétel alapján

28. táblázat. Az elsajátítási teljesítménykerülő és viszonyító teljesítménykerülő cél itemkihagyásos Cronbach- $\alpha$ mutatói, illeszkedése és a skálapontok küszöbértékei 5. évfolyamon a második adatfelvétel alapján

29. táblázat. A reliabilitás növelése érdekében viszonyítási pontként használt és új kérdőívtételek a második adatfelvétel alapján

30. táblázat. A magasabb motivációs tartományok lefedettségének növelése érdekében viszonyítási pontként használt és új kérdőívtételek a második adatfelvétel alapján

31. táblázat. A legalacsonyabb és legmagasabb motivációs tartományok lefedettségének növelése érdekében viszonyítási pontként használt és új kérdőívtételek a második adatfelvétel alapján

32. táblázat. A Tanulói célok kérdőívet kitöltők a harmadik adatfelvétel során

33. táblázat. A célorientációk faktoranalízise a teljes mintán a végső mérés alapján

34. táblázat. A Tanulói célok kérdőív megbízhatósági mutatói (Cronbach- $\alpha$ ) évfolyamok szerinti és a teljes mintán a harmadik adatfelvétel alapján

35. táblázat. A Tanulói célok kérdőív tételeinek empirikus paraméterei a teljes mintán a harmadik adatfelvétel alapján

36. táblázat. Az Osztálytermi környezet kérdőívet kitöltők az első adatfelvétel során

37. táblázat. Az Osztálytermi környezet kérdőív skálái az első adatfelvétel során .. 129

38. táblázat. A célstruktúrák faktoranalízise a teljes mintán az első adatfelvétel alapján

39. táblázat. A tanári tevékenységek faktoranalízise a teljes mintán az első adatfelvétel alapján

40. táblázat. A célstruktúrák skáláinak és a tanár-diák kapcsolat skála megbízhatósági mutatói (Cronbach- $\alpha$ ) évfolyamok szerinti és a teljes mintán az első adatfelvétel alapján

41. táblázat. A tanári tevékenységekre vonatkozó megtartott és új kérdőívtételek az első adatfelvétel alapján

42. táblázat. Az Osztálytermi környezet kérdőívet kitöltők a harmadik adatfelvétel során.....

43. táblázat. Az Osztálytermi környezet kérdőív skálái a harmadik adatfelvétel során

44. táblázat. Az Osztálytermi környezet kérdőív faktoranalízise a teljes mintán a harmadik adatfelvétel alapján 
45. táblázat. Az Osztálytermi környezet kérdőív érvényes skáláinak megbízhatósági mutatói (Cronbach- $\alpha$ ) évfolyamok szerinti és a teljes mintán a harmadik adatfelvétel alapján

46. táblázat. A célorientációk összehasonlítása évfolyamok szerint........................ 145

47. táblázat. A célorientációk korrelációi a teljes mintán........................................146

48. táblázat. A célorientációk korrelációi 5. évfolyamon .....................................146

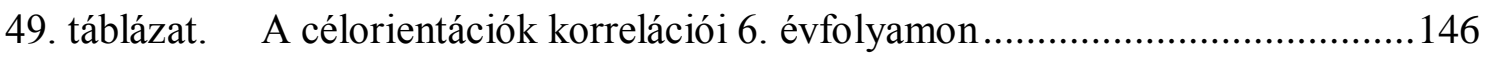

50. táblázat. A célorientációk korrelációi 7. évfolyamon ...................................... 147

51. táblázat. A célorientációk korrelációi 8. évfolyamon......................................147

52. táblázat. A célorientációk korrelációi (Baranik és mtsai, 2010, 274. o. részlet). 148

53. táblázat. A célorientációk osztályonként: a legkisebb és a legnagyobb osztályátlagok évfolyamonként feltüntetve.

54. táblázat. A célorientációk osztályok közötti különbségét jellemző F értékek ....151

55. táblázat. A célorientációk korrelációi a tanulók nemével és a szülők iskolai végzettségével a teljes mintán

56. táblázat. A tanulást kerülő cél jellemzői a fiúk és lányok körében évfolyamok szerint és a teljes mintán

57. táblázat. A célstruktúrák összehasonlítása évfolyamok szerint ........................153

58. táblázat. A célstruktúrák korrelációi a teljes mintán .....................................153

59. táblázat. Az elsajátítási célstruktúra osztályonként: a legkisebb és a legnagyobb osztályátlagok évfolyamonként feltüntetve.

60. táblázat. A viszonyító célstruktúra osztályonként: a legkisebb és a legnagyobb osztályátlagok évfolyamonként feltüntetve.

61. táblázat. A célstruktúrák osztályok közötti különbségét jellemző F értékek......154

62. táblázat. A célstruktúrák összefüggése osztályonként: a legkisebb és a legnagyobb összefüggést tükröző korrelációs együtthatók évfolyamonként és a teljes mintán

63. táblázat. A célorientációk korrelációi a tanulók nemével és a szülők iskolai végzettségével a teljes mintán

64. táblázat. A tanári tevékenységeket és a társas környezetet leíró változók összehasonlítása évfolyamok szerint

66. táblázat. A tanári tevékenységeket és a társas környezetet leíró változók osztályonként: a legkisebb és a legnagyobb osztályátlagok évfolyamonként feltüntetve.

67. táblázat. A célorientációk korrelációi a tanulók nemével és a szülők iskolai végzettségével a teljes mintán

68. táblázat. A tanári tevékenységeket és a társas környezetet leíró változók osztályok közötti különbségét jellemző F értékek 160

69. táblázat. A matematika, a szorgalom és a magatartás osztályzatok korrelációi évfolyamok szerint és a teljes mintán.

70. táblázat. A célorientációk és a matematika osztályzatok korrelációi évfolyamok szerint és a teljes mintán

71. táblázat. A célorientációk és a szorgalom osztályzatok korrelációi évfolyamok szerint és a teljes mintán . 
72. táblázat. A célorientációk és a magatartás osztályzatok korrelációi évfolyamok szerint és a teljes mintán

73. táblázat. A matematika osztályzattal mint függő változóval végzett regresszióanalízis évfolyamok szerint és a teljes mintán. 166

74. táblázat. A szorgalom osztályzattal mint függő változóval végzett regresszióanalízis évfolyamok szerint és a teljes mintán

75. táblázat. A magatartás osztályzattal mint függő változóval végzett regresszióanalízis évfolyamok szerint és a teljes mintán.

76. táblázat. A célorientációk és a matematika osztályzatok osztályátlagtól való eltérésének korrelációi évfolyamok szerint és a teljes mintán

77. táblázat. A matematika osztályzat osztályátlagtól való eltérésével mint függő változóval végzett regresszióanalízis évfolyamok szerint és a teljes mintán

78. táblázat. A célorientációk és a célstruktúrák korrelációi évfolyamok szerint és a teljes mintán

79. táblázat. Az elsajátítási teljesítménykereső céllal mint függő változóval végzett regresszióanalízis évfolyamok szerint és a teljes mintán

80. táblázat. Az elsajátítási teljesítménykerülő céllal mint függő változóval végzett regresszióanalízis évfolyamok szerint és a teljes mintán

81. táblázat. A viszonyító teljesítménykereső céllal mint függő változóval végzett regresszióanalízis évfolyamok szerint és a teljes mintán

82. táblázat. A viszonyító teljesítménykerülő céllal mint függő változóval végzett regresszióanalízis évfolyamok szerint és a teljes mintán

83. táblázat. A tanulást kerülő céllal mint függő változóval végzett regresszióanalízis évfolyamok szerint és a teljes mintán.

84. táblázat. A célorientációk korrelációi a tanári tevékenységekkel és a társas környezetet leíró változókkal a teljes mintán

85. táblázat. A célok mint függő változók regresszióanalízise a tanári tevékenységeket és társas környezetet leíró változókkal a teljes mintán

86. táblázat. A célstruktúrák korrelációi a tanári tevékenységekkel és a társas környezetet leíró változókkal a teljes mintán

87. táblázat. A célstruktúrák mint függő változók regresszióanalízise a tanári tevékenységeket és társas környezetet leíró változókkal a teljes mintán 


\section{MELLÉKLETEK JEGYZÉKE}

1. melléklet. A célorientációkat befolyásoló körülmények szempontjai (TARGET) (Kaplan és Maehr, 2007, 159. o.)

2. melléklet. A TARGET ajánlásainak összehasonlítása a hagyományos osztálytermi környezettel (Brophy, 2004, 104-105. o.) ....

3. melléklet. A Tanulói célok kérdőív skálák szerint rendezett állításai az első adatfelvétel során

4. melléklet. A Tanulói célok kérdőív faktoranalízise 4. évfolyamon az első adatfelvétel alapján

5. melléklet. A Tanulói célok kérdőív faktoranalízise 5. évfolyamon az első adatfelvétel alapján

6. melléklet. A Tanulói célok kérdőív faktoranalízise 6. évfolyamon az első adatfelvétel alapján

7. melléklet. A Tanulói célok kérdőív faktoranalízise 7. évfolyamon az első adatfelvétel alapján

8. melléklet. Az elsajátítási teljesítménykereső cél személy-item térképe 4. és 5. évfolyamon az első adatfelvétel alapján

9. melléklet. Az elsajátítási teljesítménykereső cél személy-item térképe 6. és 7. évfolyamon az első adatfelvétel alapján

10. melléklet. Az elsajátítási teljesítménykerülő cél személy-item térképe 4. és 5. évfolyamon az első adatfelvétel alapján .

11. melléklet. Az elsajátítási teljesítménykerülő cél személy-item térképe 6 . és 7 . évfolyamon az első adatfelvétel alapján ....

12. melléklet. A viszonyító teljesítménykereső cél személy-item térképe 4 . és 5. évfolyamon az első adatfelvétel alapján

13. melléklet. A viszonyító teljesítménykereső cél személy-item térképe 6 . és 7. évfolyamon az első adatfelvétel alapján

14. melléklet. A tanulást kerülő cél személy-item térképe 4. és 5. évfolyamon az első adatfelvétel alapján

15. melléklet. A tanulást kerülő cél személy-item térképe 6. és 7. évfolyamon az első adatfelvétel alapján

16. melléklet. A Tanulói célok kérdőív skálák szerint rendezett állításai a második adatfelvétel során.

17. melléklet. A Tanulói célok kérdőív skálák szerint rendezett állításai a harmadik adatfelvétel során

18. melléklet. A Tanulói célok kérdőív faktoranalízise 5. évfolyamon a harmadik adatfelvétel alapján

19. melléklet. A Tanulói célok kérdőív faktoranalízise 6. évfolyamon a harmadik adatfelvétel alapján

20. melléklet. A Tanulói célok kérdőív faktoranalízise 7. évfolyamon a harmadik adatfelvétel alapján 
21. melléklet. A Tanulói célok kérdőív faktoranalízise 8. évfolyamon a harmadik adatfelvétel alapján

22. melléklet. Az elsajátítási teljesítménykereső cél személy-item térképe 5. és 6. évfolyamon a harmadik adatfelvétel alapján.

23. melléklet. Az elsajátítási teljesítménykereső cél személy-item térképe 7. és 8 . évfolyamon a harmadik adatfelvétel alapján.

24. melléklet. Az elsajátítási teljesítménykerülő cél személy-item térképe 5. és 6. évfolyamon a harmadik adatfelvétel alapján.

25. melléklet. Az elsajátítási teljesítménykerülő cél személy-item térképe 7. és 8 . évfolyamon a harmadik adatfelvétel alapján.

26. melléklet. A viszonyító teljesítménykereső cél személy-item térképe 5. és 6. évfolyamon a harmadik adatfelvétel alapján.

27. melléklet. A viszonyító teljesítménykereső cél személy-item térképe 7. és 8 . évfolyamon a harmadik adatfelvétel alapján.

28. melléklet. A viszonyító teljesítménykerülő cél személy-item térképe 5. és 6 . évfolyamon a harmadik adatfelvétel alapján.

29. melléklet. A viszonyító teljesítménykerülö cél személy-item térképe 7. és 8 . évfolyamon a harmadik adatfelvétel alapján.

30. melléklet. A tanulást kerülő cél személy-item térképe 5. és 6 . évfolyamon a harmadik adatfelvétel alapján.

31. melléklet. A tanulást kerülő cél személy-item térképe 7. és 8. évfolyamon a harmadik adatfelvétel alapján.

32. melléklet. Az Osztálytermi környezet kérdőív skálák szerint rendezett állításai az első adatfelvétel során.

33. melléklet. A célstruktúrák kérdőívtételeinek faktoranalízise évfolyamonként a próbamérés alapján

34. melléklet. Az Osztálytermi környezet kérdőív tételeinek korrelációi a célstruktúrákkal évfolyamonként az első adatfelvétel alapján

35. melléklet. A célorientációk és tanár-diák kapcsolat faktoranalízise az első mérés alapján

36. melléklet. Az Osztálytermi környezet kérdőív skálák szerint rendezett állításai a harmadik adatfelvétel során

37. melléklet. A célorientációk jellemzői a teljes mintán 269

38. melléklet. A tanári tevékenységeket és a társas környezetet leíró változók közötti korrelációk 5. évfolyamon

39. melléklet. A tanári tevékenységeket és a társas környezetet leíró változók közötti korrelációk 6. évfolyamon

40. melléklet. A tanári tevékenységeket és a társas környezetet leíró változók közötti korrelációk 7. évfolyamon

41. melléklet. A tanári tevékenységeket és a társas környezetet leíró változók közötti korrelációk 8. évfolyamon

42. melléklet. A célorientációk korrelációi a tanári tevékenységekkel és a társas környezetet leíró változókkal 5. évfolyamon 
43. melléklet. A célorientációk korrelációi a tanári tevékenységekkel és a társas környezetet leíró változókkal 6 . évfolyamon .

44. melléklet. A célorientációk korrelációi a tanári tevékenységekkel és a társas környezetet leíró változókkal 7. évfolyamon .

45. melléklet. A célorientációk korrelációi a tanári tevékenységekkel és a társas környezetet leíró változókkal 8. évfolyamon

46. melléklet. A célok mint függő változók regresszióanalízise a tanári tevékenységeket és társas környezetet leíró változókkal 5. évfolyamon

47. melléklet. A célok mint függő változók regresszióanalízise a tanári tevékenységeket és társas környezetet leíró változókkal 6. évfolyamon

48. melléklet. A célok mint függő változók regresszióanalízise a tanári tevékenységeket és társas környezetet leíró változókkal 7. évfolyamon

49. melléklet. A célok mint függő változók regresszióanalízise a tanári tevékenységeket és társas környezetet leíró változókkal 8. évfolyamon

50. melléklet. A célstruktúrák korrelációi a tanári tevékenységekkel és a társas környezetet leíró változókkal évfolyamok szerint

51. melléklet. Az elsajátítási célstruktúrával mint függő változóval végzett regresszióanalízis évfolyamok szerint 279

52. melléklet. A viszonyító célstruktúrával mint függő változóval végzett regresszióanalízis évfolyamok szerint 280 
MELLÉKLETEK 
1. melléklet. A célorientációkat befolyásoló körülmények szempontjai (TARGET) (Kaplan és Maehr, 2007, 159. o.)

\begin{tabular}{|c|c|c|c|}
\hline $\begin{array}{l}\text { Környezeti } \\
\text { dimenziók }\end{array}$ & Leírás & Az elsajátítási cél fejlesztése & A viszonyító cél fejlesztése \\
\hline Feladat & $\begin{array}{l}\text { Mit kérnek a tanulótól? Mi } \\
\text { a végeredmény? Milyen } \\
\text { lehetőségei vannak } \\
\text { tanulónak a feladat } \\
\text { befolyásolásra? Mennyire } \\
\text { tủnik hasznosnak, } \\
\text { jelentéssel bírónak a } \\
\text { feladat az egyén } \\
\text { számára? }\end{array}$ & $\begin{array}{l}\text { A tanulót olyan feladat } \\
\text { elvégzésére kérik, amelynek } \\
\text { célja számára világos, és } \\
\text { amely kihívást jelent. } \\
\text { Lehetősége van a feladat } \\
\text { befolyásolásra. A } \\
\text { végeredmény hasznos és } \\
\text { jelentéssel bír. Különböző } \\
\text { tanulók különböző } \\
\text { feladatokat teljesíthetnek. }\end{array}$ & $\begin{array}{l}\text { A tanulót olyan feladat } \\
\text { elvégzésére kérik, amely túl } \\
\text { könnyü, így rutinszerü, } \\
\text { vagy túl nehéz, így jól } \\
\text { strukturált. A produktum } \\
\text { célja az értékelés. A } \\
\text { feladatok minden tanuló } \\
\text { számára hasonlóak. }\end{array}$ \\
\hline Irányítás & $\begin{array}{l}\text { Az egyénnek mennyire } \\
\text { van beleszólása abba, } \\
\text { hogy hogyan és mikor } \\
\text { végezze el a feladatait? } \\
\text { Meg lehet-e változtatni a } \\
\text { szabályokat? Ki vesz } \\
\text { részt a döntéshozatalban, } \\
\text { és hogyan? }\end{array}$ & $\begin{array}{l}\text { A tanuló részt vesz a } \\
\text { döntéshozatalban, amely } \\
\text { befolyásolja saját } \\
\text { tevékenységét, és } \\
\text { beleszólhat abba, hogyan és } \\
\text { milyen stratégiák } \\
\text { segítségével végezze el a } \\
\text { feladatot. }\end{array}$ & $\begin{array}{l}\text { A tanulónak külsőleg } \\
\text { meghozott, szigorú } \\
\text { szabályoknak kell } \\
\text { megfelelnie, nem választhat } \\
\text { alternatív utakat a feladat } \\
\text { elvégzéséhez. }\end{array}$ \\
\hline Elismerés & $\begin{array}{l}\text { Milyen eredménnyel és } \\
\text { viselkedéssel } \\
\text { foglalkozunk, és milyen } \\
\text { eredményt és viselkedést } \\
\text { ismernek el? }\end{array}$ & $\begin{array}{l}\text { Az elismert viselkedési } \\
\text { formák közé tartoznak } \\
\text { többek között a következők: } \\
\text { erőfeszítés, } \\
\text { kockázatvállalás, } \\
\text { kreativitás, ötletek } \\
\text { megosztása, a hibákból való } \\
\text { tanulás. Az elismerés } \\
\text { személyesen, nem a } \\
\text { közösség előtt történik. }\end{array}$ & $\begin{array}{l}\text { Többek között a következő } \\
\text { viselkedést ismerjük el: kis } \\
\text { erőfeszítéssel kiváló } \\
\text { teljesítmény, hibátlan } \\
\text { munka, a külsőleg } \\
\text { meghozott szabályok } \\
\text { betartása. Az elismerés } \\
\text { nyilvános. }\end{array}$ \\
\hline $\begin{array}{l}\text { Csoport- } \\
\text { munka }\end{array}$ & $\begin{array}{l}\text { Melyek a csoportba } \\
\text { rendezés kritériumai? } \\
\text { Milyenek a csoporton } \\
\text { belüli interakció normái, } \\
\text { szabályai? }\end{array}$ & $\begin{array}{l}\text { A csoportba rendezés } \\
\text { kritériumai többek között a } \\
\text { következők: az érdeklődés, } \\
\text { az olyan különbségek a } \\
\text { tanulók között, amelyek } \\
\text { elősegítik a tanulást, } \\
\text { valamint a csoporton belüli } \\
\text { és csoportok közötti } \\
\text { interakciókat és az ötletek } \\
\text { megosztását. }\end{array}$ & $\begin{array}{l}\text { Többek között a következő } \\
\text { szempontok szerint zajlik a } \\
\text { csoportba rendezés: } \\
\text { képességszint, teljesítmény, } \\
\text { társadalmi státusz. A } \\
\text { tanulók közötti interakció } \\
\text { korlátozva van, a csoportok } \\
\text { versenyeznek egymással. }\end{array}$ \\
\hline Értékelés & $\begin{array}{l}\text { Mit közvetít a feladat } \\
\text { értékelése a feladat } \\
\text { céljairól? Hogyan zajlik } \\
\text { az értékelés? }\end{array}$ & $\begin{array}{l}\text { A fejlődést, a kreativitást és a } \\
\text { készségek elsajátítását } \\
\text { értékelik. Az értékelés } \\
\text { személyesen, nem a } \\
\text { közösség elött történik. }\end{array}$ & $\begin{array}{l}\text { Az értékelés alapja, a feladat } \\
\text { végeredménye. Az értékelés } \\
\text { során a tanulók } \\
\text { teljesítményét } \\
\text { összehasonlítják egymással. } \\
\text { Az értékelés nyilvános. }\end{array}$ \\
\hline Idő & $\begin{array}{l}\text { Milyen az idővel való } \\
\text { gazdálkodás? Mennyire } \\
\text { rugalmas a menetrend? } \\
\text { Mi az üzenete az } \\
\text { időkorlátoknak? }\end{array}$ & $\begin{array}{l}\text { Az idő nem kötött, a tanulók } \\
\text { saját tempójuknak } \\
\text { megfelelően haladhatnak, a } \\
\text { menetrend úgy változik, } \\
\text { hogy segítse a feladat } \\
\text { elvégzését és a tanuló } \\
\text { szükségleteit. A hangsúly a } \\
\text { tanuláson van. }\end{array}$ & $\begin{array}{l}\text { Az idő kötött, időkorlátok } \\
\text { vannak, a tanulóknak időre } \\
\text { kell teljesíteniük, a } \\
\text { menetrend betartása } \\
\text { fontosabb, mint a feladat } \\
\text { teljesítése és a megértés. }\end{array}$ \\
\hline
\end{tabular}


Feladat Tankönyvalapú tanterv követése, a hangsúly a tankönyvből való olvasáson, az ismétlö órákon, a munkafüzet feladatain és a teszteken van. Minden tanuló ugyanazt az inputot kapja, és ugyanazt a feladatot végzi el. A hangsúly a tartalom lefedésén és a memorizáláson van. A motiváció eszköze elsősorban az osztályozás, amelyet kiegészíthetnek a külső jutalmazás különböző formái.

Irányítás A pedagógus diktálja a szabályokat, hozza meg egyoldalúan a tantervvel és a tantervi munkával kapcsolatos döntéseket. A tanulók viselkedése az iskola és a tanterem szigorú szabályaihoz kötött, tanulási lehetőségeiket a pedagógus és a tankönyv határozza meg.

Elismerés Ha nincs is kimondva, de a tanulók között állandó a verseny az elismerésért és a jutalomért. Bizonyos tanulók állandóan jó osztályzatokat kapnak, munkájukat dicsérettel illetik és nyilvánosan bemutatják. Ezek a tanulók minden rendelkezésre álló versenyt vagy díjat megnyernek. Más tanulókat ritkán vagy soha nem ismernek el vagy jutalmaznak, mivel az elismerés elsősorban vagy teljes mértékben a teljesítmény abszolút szintjétől függ, és nincs tekintettel arra, milyen egyéni különbségek vannak a tanulók között a tekintetben, hogy mekkora erőfeszítésükbe kerül az adott eredmény elérése.

Csoport- Az osztály egyének összessége, nem pedig egy koherens közösség. A anulók gyakran lépnek interakcióba a pedagógussal, egymással azonban ritkán, a feladatokon többnyire egyedül dolgoznak. Ha egyáltalán van csoportba rendezés, akkor annak a versenyzés, a képességek vagy eredmények szerinti megkülönböztetés a célja.
Változatos feladatok alkalmazása, amelyeket a tanulók érdekesnek találnak, és amelyek a tanulók belső motivációjára, tapasztalataira és hátterére építenek. A feladatok bevezetése során hangsúlyozzák, hogy azok milyen célokat szolgálnak. Az alkalmazott feladatokkal törekszenek arra, hogy maximalizálják a tanulók belső motivációját, segítsék a tanulókat abban, hogy értékeljék azt, amit tanulnak. (A hangsúly tehát nem a teszteken, az osztályzatokon vagy a külső jutalmakon van.) Annak érdekében, hogy biztosítsák a feladatok optimális kihívást jelentő voltát, olyan készségeket tanítanak, amelyek segítik a célok kitűzését az önszabályozást, és, ha szükséges, információforrásokat és különböző nehézségü feladatokat adnak a tanulóknak.

Hatalommegosztás érvényesül a tanulók és a pedagógus között, a tanulók szükségleteit és érzéseit, valamit a tananyaggal kapcsolatos kérdéseiket és érdeklődését figyelembe veszik. A tanulóknak gyakran van lehetőségük arra, hogy eldönthessék, mit csináljanak és hogyan. A tanulók beleszólhatnak az osztálytermi szabályok vagy a tanulási lehetőségek kialakításába.

Minden tanuló elismerésben részesül, aki valamilyen haladást ér el, azaz nemcsak a legjobban teljesítők kapnak elismerést. Nemcsak a teszteken elért jó eredményeket, hanem a tanulók sokféle más teljesítményét is elismerik. Az elismerés alapja az egyénileg kitüzött cél elérése érdekében mutatott fejlődés. Az elismerés leggyakoribb formája az erőfeszítések és a haladás elismerése, amely négyszemközt történik. Itt tehát nem a legjobban teljesítők nyilvános ünnepléséről beszélünk.

Az osztály olyan tanulóközösség, amely közösen kialakított normák és elvárások szerint müködik. A tanulók gyakran dolgoznak párokban vagy kis csoportokban, ennek megfelelően a tudás társas konstruktum. A csoportoknak adott feladatok változatosak, és a barátságon, a közös érdeklődésen vagy egyéb tényezőkön alapulnak, de nem a teljesítményszinten. A tanulókat a kooperációra ösztönzik nem, pedig a versengésre. 
Értékelés Minden tanulót ugyanazokkal az értékelési eszközökkel értékelnek (általában hagyományos tesztek segítségével). A visszajelzés gyakran nyilvános, és a teljesítmény abszolút szintjét hangsúlyozza (a helyesen megválaszolt itemek száma vagy százaléka egy teszt során). Az értékelés lehet normatív összehasonlítás is (egy diák relatív teljesítménye az osztályon vagy egy nagyobb mintán belül). Az értékelést gyakran úgy kapják a tanulók, hogy azt érezzék, egy-egy alkalommal a teljesítménykapacitásuk fix szintjét értékelték a képességfejlesztéshez vezető út egy értékes állomása helyett.

A tanár és a tanulók szigorú menetrendet követnek. Minden nap 30-60 perces időintervallumokra van beosztva. Az olyan feladatokat, amelyek több időt igényelnek, kihagyják a tantervböl, sőt még a tervezett feladatokat is gyakran lerövidítik vagy félbeszakítják, és egy másik nap folytatják, hogy beleférjenek az időbe.
Az értékelés különböző eszközök segítségével zajlik, a hangsúly azon van, hogy segítsenek a tanulóknak felismerni és értékelni fejlödésüket az egyéni céljaik elérése felé vezető úton. Ezen értékelés osztályzatokra történő váltása úgy történik, hogy a tanulóknak lehetőségük van javitótesztet írni, átdolgozni munkájukat egy-egy feladat esetében, vagy más módon javítani az eredetileg rossz eredményeken

Az idő kezelése rugalmas, így többféle feladat bevehető a tantervbe. Söt, ahelyett, hogy mindig megmondanák a tanulóknak, mit csináljanak és mikor, gyakran elöfordul, hogy a tanulók nagyobb projekteken dolgoznak. Ezen munka során önállóan kell beosztaniuk az idejüket, és önállóan kell kezelniük a különböző tanulási forrásaikat (ilyen lehet például az információs forrásokkal való interakció vagy az együttmüködés az osztálytársakkal). Ha szükségük van rá, a tanulók kaphatnak plusz időt egy-egy feladat teljesítésére. 
3. melléklet. A Tanulói célok kérdöiv skálák szerint rendezett állitásai az elsö adatfelvétel során

\section{Elsajátítási teljesítménykereső cél}

Fontos célom matekból, hogy teljesen megtanuljam a tananyagot.

Matekból arra törekszem, hogy amennyire csak lehet, megértsem a tananyagot.

Fontos célom, hogy matekból megtanuljak annyit, amennyit csak lehet.

Fontos célom matekból, hogy új dolgokat tanuljak.

Keresem azokat a feladatokat matekórán, amelyekböl újat tanulhatok.

Fontos célom, hogy egyre jobb legyek matekból.

Arra törekszem, hogy egyre többet tudjak matekból.

Matekdolgozat írásakor fontos célom, hogy jobban sikerüljön, mint korábban.

Egyik célom, hogy úgy érezzem, egyre többet tudok matekból.

Arra törekszem matekból, hogy teljesen megértsem a tananyagot.

\section{Elsajátítási teljesítménykerüló cél}

Fontos célom elkerülni, hogy matekból kevesebbet tanuljak meg annál, mint amennyit meg tudnék tanulni.

Arra törekszem matekból, hogy elkerüljem a tananyag hiányos megértését.

Fontos célom elkerülni, hogy matekból kevesebbet tanuljak meg annál, mint amennyit lehetne.

Fontos célom, hogy matekból ne legyen olyan feladat, amit nem értek.

Arra törekszem matekból, hogy egyre többet pótoljak hiányzó tudásomból.

Keresem azokat a feladatokat matekórán, amiket hibátlanul meg tudok oldani.

Fontos célom matekból, hogy egyre kevesebbet hibázzak.

Fontos célom matekból, hogy ne legyek rosszabb, mint korábban.

Fontos célom, hogy ne kövessek el hibát a matekfeladatokban.

Fontos célom, hogy egyre kevesebbet hibázzak a matekfeladatokban.

Matekdolgozat írásakor fontos célom, hogy ne kövessek el semmiféle hibát.

Matekdolgozat írásakor fontos célom, hogy kevés hibát kövessek el.

\section{Viszonyító teljesítménykeresö cél}

Fontos célom matekból, hogy másokhoz képest jól teljesítsek.

Arra törekszem, hogy másokkal összehasonlítva jó legyek matekból.

Fontos célom matekból, hogy jobb legyek, mint a többiek.

Fontos célom a matekfeladatok megoldásakor, hogy másoknál jobb legyek.

Egyik célom, hogy mások azt gondolják rólam, jó vagyok matekból.

Fontos célom, hogy matekórán jól teljesítsek a többiek elött.

Keresem azokat a feladatokat matekórán, amelyekben jó eszűnek tünhetek.

Az egyik célom, hogy megmutassam másoknak, jól megy nekem a matek.

Az egyik célom, hogy megmutassam másoknak, a matek számomra könnyü.

Az egyik célom, hogy az osztálytársaimhoz képest jó matekosnak tartsanak.

Fontos célom, hogy matektudásomat mások megismerjék.

Matekdolgozat írásakor fontos célom, hogy a jobbak közé tartozzak az osztályban.

\section{Viszonyító teljesítménykerülö cél}

Fontos célom elkerülni, hogy matekból rosszabbul teljesítsek az osztálytársaimnál.

Fontos célom elkerülni, hogy az osztálytársaimnál gyengébb legyek matekból.

Arra törekszem, hogy a többieknél ne legyek gyengébb matekból.

Az egyik célom, hogy elkerüljem azokat a feladatokat matekórán, amikor butának tünhetek.

Fontos célom matekórán, hogy ne hibázzak mások elött.

Azokat a feladatokat választom matekórán, melyeket biztosan meg tudok oldani. 
Fontos célom, hogy matekból ne tűnjek gyengének az osztályban.

Fontos, hogy mások azt gondolják rólam, nem vagyok rossz matekból.

Az egyik célom elkerülni annak látszatát, hogy a matek nehezen megy nekem.

Kerülöm azokat a matekfeladatokat, amelyekben valószínüleg gyengén teljesítenék.

Fontos célom, hogy ne a legrosszabbak közé tartozzak a matekfeladatok megoldásában.

Matekdolgozat írásakor fontos célom, hogy ne a gyengébbek közé tartozzak az osztályban.

\section{Tanulást kerü̈lö cél}

A matekfeladatokat próbálom a lehető legkevesebb erőfeszítéssel elvégezni.

Matekórán a lehető legkevesebb feladatot akarom megoldani.

Csak a kötelező feladatokat végzem el matekból.

Nem szoktam szorgalmi feladatot vállalni matekból.

Az egyik célom, hogy minél hamarabb végezzek a matekfeladatokkal.

Csak annyit akarok matekozni, amennyit kötelező.

A matekfeladatokat próbálom a lehető legkevesebb munkával elvégezni.

A matekfeladatokat próbálom a lehető leggyorsabban befejezni.

Nem zavar, ha rossz matekosnak tartanak.

Nem zavar, ha nem tanulok semmit matekból.

Nem zavar, ha nem értem a matekot. 
4. melléklet. A Tanulói célok kérdöív faktoranalizise 4. évfolyamon az elsö adatfelvétel alapján

\begin{tabular}{|c|c|c|c|c|}
\hline & \multicolumn{4}{|c|}{ Faktorok } \\
\hline & 1. & 2. & 3. & 4. \\
\hline Saját érték & 2,5 & 2,0 & 1,8 & 1,3 \\
\hline Variancia $(\%)$ & 20,7 & 16,4 & 15,1 & 10,5 \\
\hline Kumulatív variancia (\%) & 20,7 & 37,1 & 52,3 & 62,7 \\
\hline \multicolumn{5}{|l|}{ Skálák, tételek* } \\
\hline \multicolumn{5}{|c|}{$\begin{array}{l}\text { Elsajátítási teljesítménykereső } \\
\text { cél }\end{array}$} \\
\hline 08 & 0,76 & 0,04 & $-0,01$ & 0,01 \\
\hline 22 & 0,74 & 0,09 & 0,04 & 0,02 \\
\hline 30 & $\mathbf{0 , 8 2}$ & 0,11 & $-0,03$ & $-0,08$ \\
\hline 38 & $\mathbf{0 , 7 3}$ & 0,25 & $-0,19$ & $-0,11$ \\
\hline \multicolumn{5}{|c|}{$\begin{array}{l}\text { Elsajátítási teljesítménykerülő } \\
\text { cél }\end{array}$} \\
\hline 09 & $-0,14$ & $-0,05$ & 0,11 & $\mathbf{0 , 7 0}$ \\
\hline 17 & 0,07 & 0,09 & $-0,06$ & $\mathbf{0 , 8 1}$ \\
\hline \multicolumn{5}{|c|}{$\begin{array}{l}\text { Viszonyító teljesítménykereső } \\
\text { cél }\end{array}$} \\
\hline 29 & 0,17 & $\mathbf{0 , 7 6}$ & 0,06 & 0,08 \\
\hline 46 & 0,16 & 0,78 & 0,16 & $-0,13$ \\
\hline 57 & 0,06 & $\mathbf{0 , 8 0}$ & 0,10 & 0,09 \\
\hline \multicolumn{5}{|l|}{ Tanulást kerülő cél } \\
\hline 13 & 0,08 & 0,04 & $\mathbf{0 , 8 7}$ & $-0,05$ \\
\hline 19 & $-0,05$ & 0,14 & $\mathbf{0 , 8 6}$ & 0,00 \\
\hline 53 & $-0,23$ & 0,17 & 0,46 & 0,23 \\
\hline
\end{tabular}

Megj.: fökomponens analízis Varimax rotációval, forgatás előtt 1-nél nagyobb sajátértékủ faktorok, a 0,4nél nagyobb faktorsúlyokat félkövér szedés jelzi; * a számok a kérdőívtétel sorszámát jelzik; $\mathrm{KMO}=0,69$. 
5. melléklet. A Tanulói célok kérdöiv faktoranalizise 5. évfolyamon az elsö adatfelvétel alapján

\begin{tabular}{|c|c|c|c|c|}
\hline & \multicolumn{4}{|c|}{ Faktorok } \\
\hline & 1. & 2. & 3. & 4. \\
\hline Saját érték & 2,8 & 2,3 & 1,9 & 1,5 \\
\hline Variancia $(\%)$ & 23,7 & 18,9 & 15,9 & 12,1 \\
\hline Kumulatív variancia (\%) & 23,7 & 42,7 & 58,5 & 70,7 \\
\hline \multicolumn{5}{|l|}{ Skálák, tételek* } \\
\hline \multicolumn{5}{|c|}{$\begin{array}{l}\text { Elsajátítási teljesítménykereső } \\
\text { cél }\end{array}$} \\
\hline 08 & $\mathbf{0 , 8 3}$ & 0,09 & 0,00 & 0,08 \\
\hline 22 & $\mathbf{0 , 8 2}$ & 0,15 & $-0,06$ & 0,09 \\
\hline 30 & $\mathbf{0 , 8 2}$ & 0,09 & $-0,13$ & 0,05 \\
\hline 38 & $\mathbf{0 , 8 2}$ & 0,32 & $-0,07$ & 0,03 \\
\hline \multicolumn{5}{|c|}{$\begin{array}{l}\text { Elsajátítási teljesítménykerülő } \\
\text { cél }\end{array}$} \\
\hline 09 & 0,03 & 0,02 & 0,07 & 0,84 \\
\hline 17 & 0,14 & $-0,01$ & $-0,01$ & $\mathbf{0 , 8 3}$ \\
\hline \multicolumn{5}{|c|}{$\begin{array}{l}\text { Viszonyító teljesítménykereső } \\
\text { cél }\end{array}$} \\
\hline 29 & 0,16 & $\mathbf{0 , 8 0}$ & 0,07 & $-0,14$ \\
\hline 46 & 0,20 & $\mathbf{0 , 8 7}$ & 0,04 & 0,03 \\
\hline 57 & 0,15 & 0,84 & $-0,01$ & 0,12 \\
\hline \multicolumn{5}{|l|}{ Tanulást kerülő cél } \\
\hline 13 & $-0,05$ & 0,14 & $\mathbf{0 , 8 5}$ & $-0,01$ \\
\hline 19 & 0,04 & 0,04 & $\mathbf{0 , 8 1}$ & 0,07 \\
\hline 53 & $-0,19$ & $-0,08$ & $\mathbf{0 , 7 0}$ & 0,00 \\
\hline
\end{tabular}

Megj.: főkomponens analízis Varimax rotációval, forgatás előtt 1-nél nagyobb sajátértékű faktorok, a 0,4nél nagyobb faktorsúlyokat félkövér szedés jelzi; * a számok a kérdőívtétel sorszámát jelzik, $\mathrm{KMO}=0,75$. 
6. melléklet. A Tanulói célok kérdöív faktoranalizise 6. évfolyamon az elsö adatfelvétel alapján

\begin{tabular}{|c|c|c|c|}
\hline \multirow[b]{3}{*}{ Saját érték } & \multicolumn{3}{|c|}{ Faktorok } \\
\hline & 1. & 2. & 3. \\
\hline & 3,6 & 2,1 & 1,4 \\
\hline Variancia $(\%)$ & 29,6 & 17,5 & 11,6 \\
\hline Kumulatív variancia (\%) & 29,6 & 47,1 & 58,7 \\
\hline \multicolumn{4}{|l|}{ Skálák, tételek* } \\
\hline \multicolumn{4}{|l|}{$\begin{array}{l}\text { Elsajátítási } \\
\text { teljesítménykereső cél }\end{array}$} \\
\hline 08 & $\mathbf{0 , 6 3}$ & $-0,14$ & 0,34 \\
\hline 22 & $\mathbf{0 , 5 7}$ & $-0,26$ & $-0,01$ \\
\hline 30 & 0,69 & $-0,13$ & 0,29 \\
\hline 38 & $\mathbf{0 , 7 3}$ & $-0,21$ & 0,27 \\
\hline \multicolumn{4}{|l|}{$\begin{array}{l}\text { Elsajátítási } \\
\text { teljesítménykerülő cél }\end{array}$} \\
\hline 09 & 0,17 & 0,03 & $\mathbf{0 , 7 4}$ \\
\hline 17 & $-0,11$ & 0,12 & 0,71 \\
\hline \multicolumn{4}{|l|}{$\begin{array}{l}\text { Viszonyító } \\
\text { teljesítménykereső cél }\end{array}$} \\
\hline 29 & 0,74 & 0,07 & $-0,11$ \\
\hline 46 & $\mathbf{0 , 7 9}$ & 0,13 & $-0,07$ \\
\hline 57 & 0,78 & 0,12 & $-0,15$ \\
\hline \multicolumn{4}{|l|}{ Tanulást kerülő cél } \\
\hline 13 & 0,00 & 0,86 & $-0,03$ \\
\hline 19 & $-0,01$ & 0,87 & $-0,02$ \\
\hline 53 & $-0,10$ & 0,65 & 0,18 \\
\hline
\end{tabular}

Megj.: fökomponens analízis Varimax rotációval, forgatás előtt 1-nél nagyobb sajátértékű faktorok, a 0,4nél nagyobb faktorsúlyokat félkövér szedés jelzi; * a számok a kérdőívtétel sorszámát jelzik, $\mathrm{KMO}=0,74$. 
7. melléklet. A Tanulói célok kérdöív faktoranalizise 7. évfolyamon az elsö adatfelvétel alapján

\begin{tabular}{|c|c|c|c|c|}
\hline & \multicolumn{4}{|c|}{ Faktorok } \\
\hline & 1. & 2. & 3. & 4. \\
\hline Saját érték & 2,9 & 2,1 & 2,1 & 1,5 \\
\hline Variancia $(\%)$ & 24,1 & 17,9 & 17,4 & 12,5 \\
\hline Kumulatív variancia (\%) & 24,1 & 41,9 & 59,3 & 71,8 \\
\hline \multicolumn{5}{|l|}{ Skálák, tételek* } \\
\hline \multicolumn{5}{|c|}{$\begin{array}{l}\text { Elsajátítási teljesítménykereső } \\
\text { cél }\end{array}$} \\
\hline 08 & $\mathbf{0 , 8 3}$ & 0,22 & $-0,05$ & $-0,01$ \\
\hline 22 & $\mathbf{0 , 8 7}$ & 0,08 & $-0,12$ & 0,19 \\
\hline 30 & $\mathbf{0 , 8 2}$ & 0,27 & $-0,04$ & $-0,10$ \\
\hline 38 & 0,74 & 0,21 & 0,04 & 0,15 \\
\hline \multicolumn{5}{|c|}{$\begin{array}{l}\text { Elsajátítási teljesítménykerülő } \\
\text { cél }\end{array}$} \\
\hline 09 & 0,09 & 0,11 & 0,06 & 0,84 \\
\hline 17 & 0,05 & 0,09 & 0,14 & $\mathbf{0 , 8 1}$ \\
\hline \multicolumn{5}{|c|}{$\begin{array}{l}\text { Viszonyító teljesítménykereső } \\
\text { cél }\end{array}$} \\
\hline 29 & 0,31 & $\mathbf{0 , 7 3}$ & 0,11 & 0,00 \\
\hline 46 & 0,28 & $\mathbf{0 , 8 1}$ & 0,18 & 0,17 \\
\hline 57 & 0,15 & $\mathbf{0 , 8 3}$ & $-0,26$ & 0,15 \\
\hline \multicolumn{5}{|l|}{ Tanulást kerülő cél } \\
\hline 13 & $-0,06$ & 0,22 & $\mathbf{0 , 8 2}$ & 0,05 \\
\hline 19 & 0,07 & $-0,01$ & $\mathbf{0 , 8 3}$ & 0,11 \\
\hline 53 & $-0,13$ & $-0,16$ & 0,76 & 0,07 \\
\hline
\end{tabular}

Megj.: főkomponens analízis Varimax rotációval, forgatás előtt 1-nél nagyobb sajátértékű faktorok, a 0,4nél nagyobb faktorsúlyokat félkövér szedés jelzi; * a számok a kérdőívtétel sorszámát jelzik, $\mathrm{KMO}=0,72$. 
8. melléklet. Az elsajátitási teljesitménykeresö cél személy-item térképe 4. és 5. évfolyamon az elsö adatfelvétel alapján

\begin{tabular}{|c|c|c|c|}
\hline \multicolumn{2}{|r|}{ 4. évfolyam } & \multicolumn{2}{|r|}{ 5. évfolyam } \\
\hline & 1 & & 1 \\
\hline \multirow[t]{4}{*}{9} & I & 11 & 1 \\
\hline & 1 & & 1 \\
\hline & I & & 1 \\
\hline & 1 & 10 & 1 \\
\hline \multirow[t]{5}{*}{8} & i & & i \\
\hline & I & & I \\
\hline & I & & 1 \\
\hline & 1 & 9 & I \\
\hline & 1 & & I \\
\hline \multirow[t]{4}{*}{7} & 1 & & $\mathrm{x} \mid$ \\
\hline & I & 8 & $\mathrm{x} \mid$ \\
\hline & $\mathrm{x} \mid$ & & $\mathrm{x} \mid$ \\
\hline & $\mathrm{xX} \mid$ & & I \\
\hline \multirow[t]{5}{*}{6} & $\mathrm{xXI}$ & 7 & $\mathrm{xx} \mid$ \\
\hline & $\mathrm{xXI}$ & & $\mathrm{xXI}$ \\
\hline & $\mathrm{xX} \mid$ & & $\mathrm{x} \mid$ \\
\hline & $\mathrm{x} \times 1$ & & $\mathrm{xx} \mid$ \\
\hline & $\mathrm{xxxx|}$ & 6 & $\mathrm{xxx|}$ \\
\hline \multirow[t]{4}{*}{5} & XXX| & & $\mathrm{xxX} \mid$ \\
\hline & XXXX1 & & $\mathrm{xxx} 1$ \\
\hline & $\mathrm{xxxx|}$ & 5 & XXXXX| \\
\hline & XXXXXXI & & XXXXX| \\
\hline \multirow[t]{5}{*}{4} & XXXXXXI & & xxxxI \\
\hline & XXXXX & & XXXXX| \\
\hline & XXXXXXX| & 4 & XXXXXXI \\
\hline & Xxxxxxxxxx| & & XXXXXXXI \\
\hline & XXXXXXx| & & XXXXXXxx|22.4 \\
\hline \multirow[t]{4}{*}{3} & XXXXXXXXXX| & 3 & $\operatorname{XXXXXXXX|38.4}$ \\
\hline & Xxxxxxxxx| & & xxxxxxxx| \\
\hline & Xxxxxxx| & & XXXXXX|08.4 30.4 \\
\hline & XXXXXX| & 2 & XXXXXXX| \\
\hline \multirow[t]{4}{*}{2} & Xxxxxxxxx| & & XxxxxxI \\
\hline & XXXXXXXXXX|38.4 & & 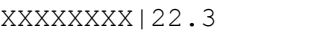 \\
\hline & XXXXXXXXXX|22.4 30.4 & & XXXXXXXX| \\
\hline & XXXXXXXXX|08.4 & 1 & XXXXXXX|30.3 38.3 \\
\hline & 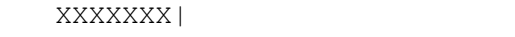 & & XXXXXXXI \\
\hline \multirow[t]{4}{*}{1} & XXXXX| & & $\mathrm{XXX1}$ \\
\hline & 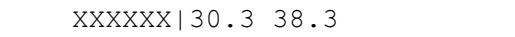 & 0 & $\mathrm{XXXXX} 108.3$ \\
\hline & XXXXXXX| & & XXXXX| \\
\hline & $x x x \mid 22.3$ & & $\mathrm{xX} \mid$ \\
\hline \multirow[t]{4}{*}{0} & $x \times x \times 108.3$ & & $\mathrm{xxx} \mid 30.2$ \\
\hline & $\mathrm{XXX1}$ & -1 & $\operatorname{XXXX|22.2\quad 38.2}$ \\
\hline & $\mathrm{XX} \mid$ & & $\mathrm{x} \mid$ \\
\hline & $\mathrm{x} \mid$ & & $x \mid 22.130 .1$ \\
\hline & $x \mid 22.2 \quad 30.2 \quad 38.138 .2$ & -2 & $\mathrm{x} \mid 08.2$ \\
\hline \multirow[t]{3}{*}{-1} & $\mid 22.1$ & & 38.1 \\
\hline & 30.1 & -3 & 1 \\
\hline & 108.2 & & 108.1 \\
\hline \multirow[t]{4}{*}{-2} & I & & I \\
\hline & I & & I \\
\hline & I & -4 & I \\
\hline & । & & I \\
\hline \multirow[t]{5}{*}{-3} & 1 & & I \\
\hline & I & -5 & I \\
\hline & 1 & & I \\
\hline & 1 & & 1 \\
\hline & I & & I \\
\hline-4 & 108.1 & -6 & I \\
\hline
\end{tabular}

Megj.: minden 'x' 1 tanulót jelöl. 
9. melléklet. Az elsajátítási teljesitménykereső cél személy-item térképe 6. és 7. évfolyamon az elsö adatfelvétel alapján

\begin{tabular}{|c|c|c|c|}
\hline \multicolumn{2}{|r|}{ 6. évfolyam } & \multicolumn{2}{|r|}{ 7. évfolyam } \\
\hline & I & & I \\
\hline \multirow[t]{5}{*}{7} & 1 & & 1 \\
\hline & i & 8 & i \\
\hline & 1 & & 1 \\
\hline & 1 & & 1 \\
\hline & i & & i \\
\hline \multirow[t]{6}{*}{6} & I & 7 & I \\
\hline & 1 & & $\mathrm{XI}$ \\
\hline & 1 & & I \\
\hline & I & & I \\
\hline & 1 & & I \\
\hline & $\mathrm{X} \mid$ & 6 & $\mathrm{x} 1$ \\
\hline \multirow[t]{5}{*}{5} & 1 & & $\mathrm{x} \mid$ \\
\hline & $\mathrm{XI}$ & & $\mathrm{XI}$ \\
\hline & $\mathrm{X} \mid$ & & $\mathrm{xx}$ \\
\hline & $\mathrm{xX} \mid$ & 5 & $\mathrm{xX} \mid$ \\
\hline & $\mathrm{x} \mid$ & & $\mathrm{x} \mid$ \\
\hline \multirow[t]{6}{*}{4} & $\mathrm{x} \times \mathrm{x}$ & & $\mathrm{x} \mid$ \\
\hline & $\mathrm{XXX1}$ & & $\mathrm{x} \mid$ \\
\hline & XXXXx| & 4 & $\mathrm{xX} \mid$ \\
\hline & $\mathrm{xx} \mid$ & & $\mathrm{xxx}$ \\
\hline & XXXX| & & $\mathrm{XXXX|}$ \\
\hline & XXXXX| & & $\operatorname{xxxxxx|} \mid 38.4$ \\
\hline \multirow[t]{5}{*}{3} & XXXXI & 3 & XXXXX| \\
\hline & $\mathrm{XXXX1}$ & & $x X X X X \mid 22.4$ \\
\hline & $x x x x \mid 22.4 \quad 38.4$ & & XXXXXXX| \\
\hline & Xxx| & & XXXXX|08.4 \\
\hline & XXXXXXI & 2 & XXXXXXXX|30.4 \\
\hline & XXXXXXXXX1 & & 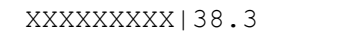 \\
\hline & xxxxxx & & Xxxxxxxx| \\
\hline & $\operatorname{XXXXX|08.4} 30.4$ & & XXXXx|22.3 \\
\hline & XXXXXXXXXX| & 1 & XXXXXXXXX| \\
\hline & XXXXXX| & & Xxxxxxxx| \\
\hline & 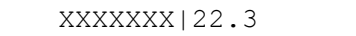 & & 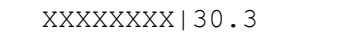 \\
\hline \multirow[t]{5}{*}{1} & XXXXXXXXXX| & & XXXXXXXXXX|38.2 \\
\hline & XXXXXXXXX| & 0 & XXXXX1 \\
\hline & 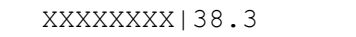 & & XXXXX|08.3 22.2 \\
\hline & XXX| & & XXXXXX1 \\
\hline & $\operatorname{xxxxx|30.3}$ & & $\mathrm{xxx} 1$ \\
\hline \multirow[t]{5}{*}{0} & $\mathrm{XXXX} \mid 08.3$ & -1 & $\mathrm{XXX} \mid$ \\
\hline & XXX| & & $\mathrm{xX} \mid$ \\
\hline & $x x x \mid 22.2$ & & $x x \mid 30.2 \quad 38.1$ \\
\hline & $\mathrm{XX} \mid$ & & 12208.1 \\
\hline & $x \mid 30.238 .2$ & -2 & $\mathrm{x} \mid$ \\
\hline \multirow[t]{6}{*}{-1} & $x \mid 22.1$ & & $x \mid 30.1$ \\
\hline & $\mathrm{XI}$ & & $\mathrm{x} \mid$ \\
\hline & $\mathrm{X} \mid$ & & $x \mid 08.2$ \\
\hline & 38.1 & -3 & $\mathrm{x} 108.1$ \\
\hline & 108.2 & & 1 \\
\hline & 1 & & $\mathrm{xI}$ \\
\hline \multirow[t]{5}{*}{-2} & 30.1 & & 1 \\
\hline & $\mathrm{X} \mid 08.1$ & -4 & I \\
\hline & I & & I \\
\hline & । & & I \\
\hline & I & & I \\
\hline \multirow[t]{5}{*}{-3} & I & -5 & I \\
\hline & 1 & & I \\
\hline & 1 & & 1 \\
\hline & I & & I \\
\hline & 1 & -6 & 1 \\
\hline
\end{tabular}

Megj.: minden 'x' 1 tanulót jelöl. 
10. melléklet. Az elsajátitási teljesitménykerülö cél személy-item térképe 4. és 5. évfolyamon az elsö adatfelvétel alapján

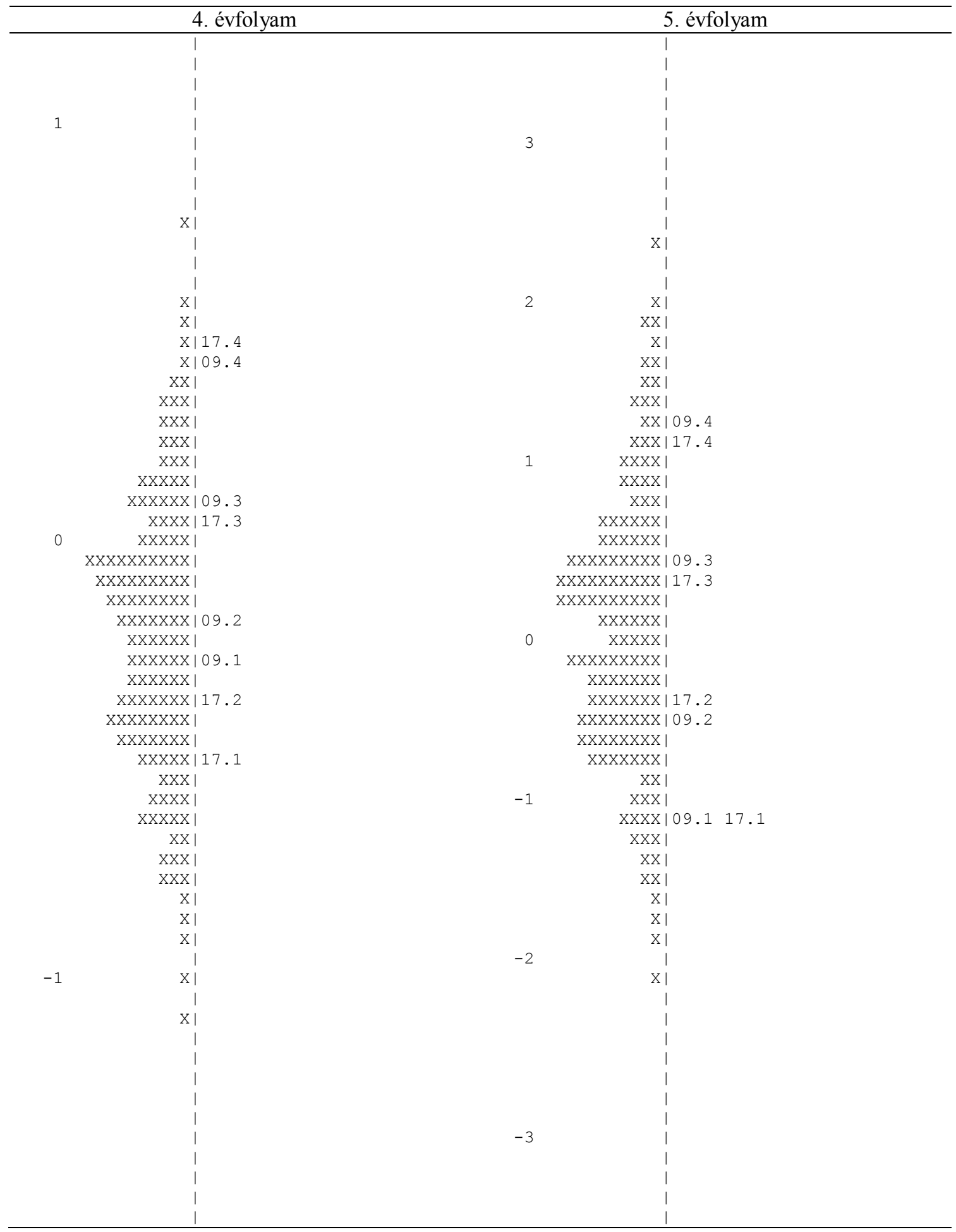

Megj.: minden 'x' 1 tanulót jelöl. 
11. melléklet. Az elsajátitási teljesitménykerülö cél személy-item térképe 6. és 7. évfolyamon az elsö adatfelvétel alapján

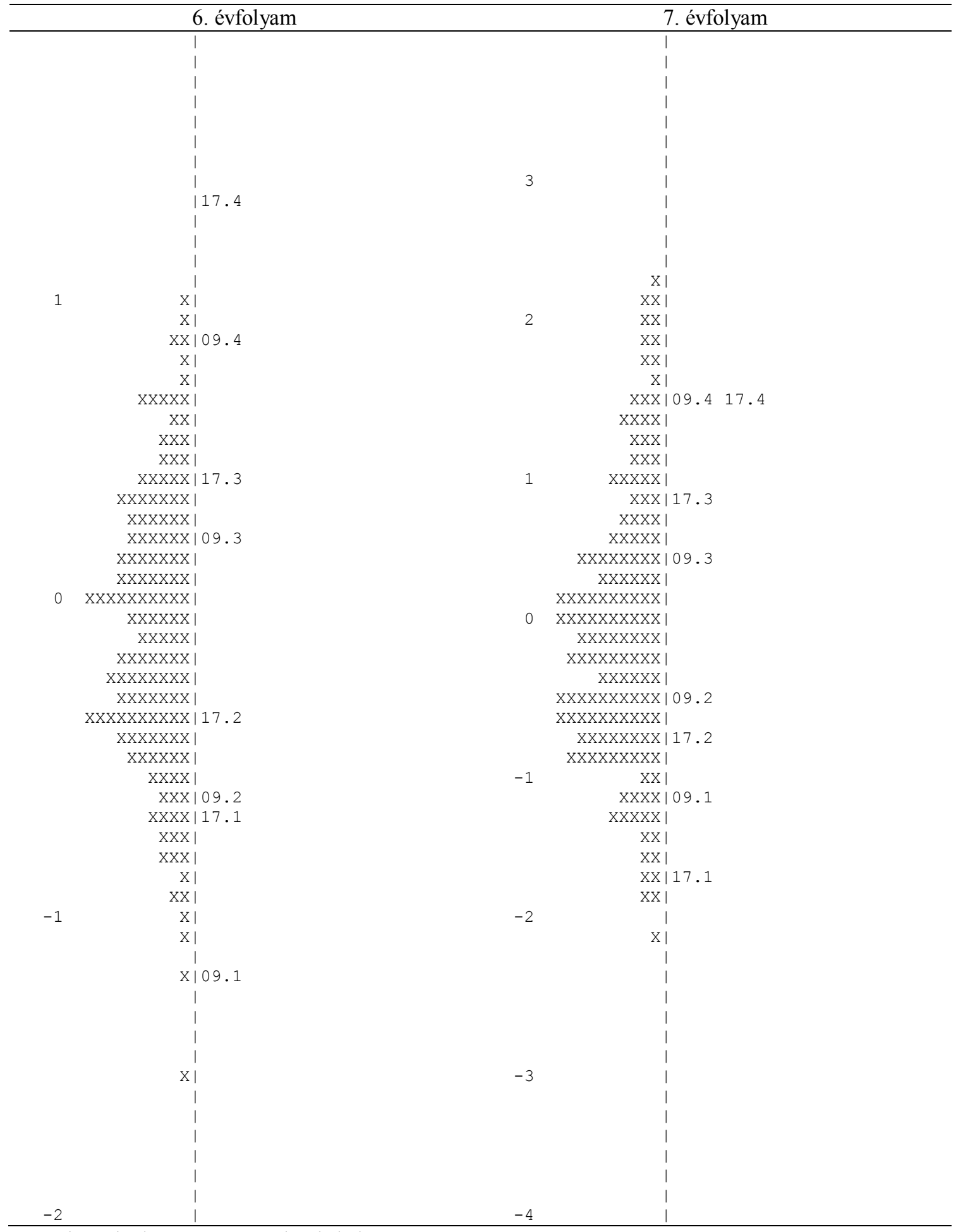

Megj.: minden 'x' 1 tanulót jelöl. 
12. melléklet. A viszonyitó teljesitménykereső cél személy-item térképe 4. és 5. évfolyamon az elsö adatfelvétel alapján

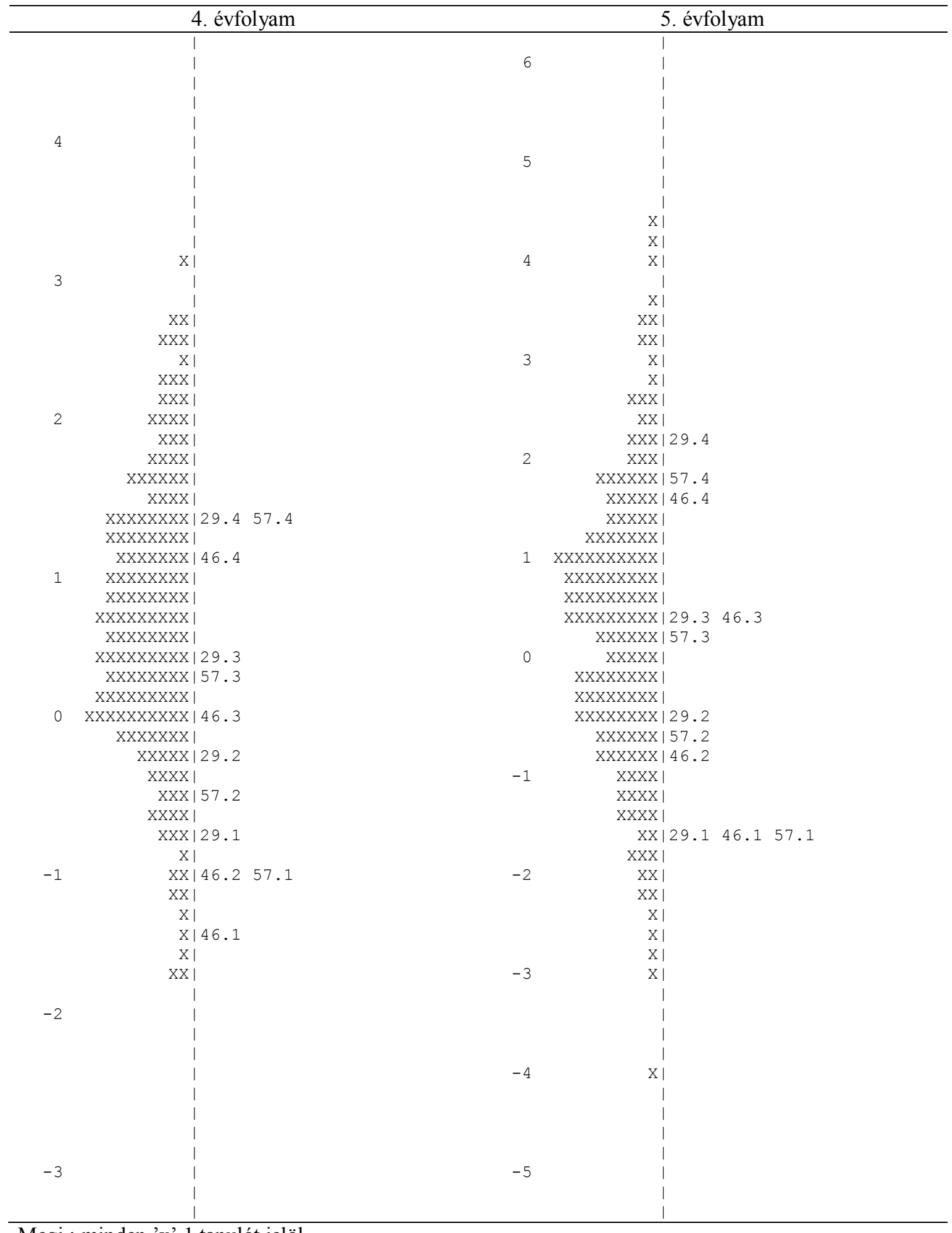

Megj.: minden 'x' 1 tanulót jelöl. 
13. melléklet. A viszonyitó teljesítménykereső cél személy-item térképe 6. és 7. évfolyamon az elsö adatfelvétel alapján

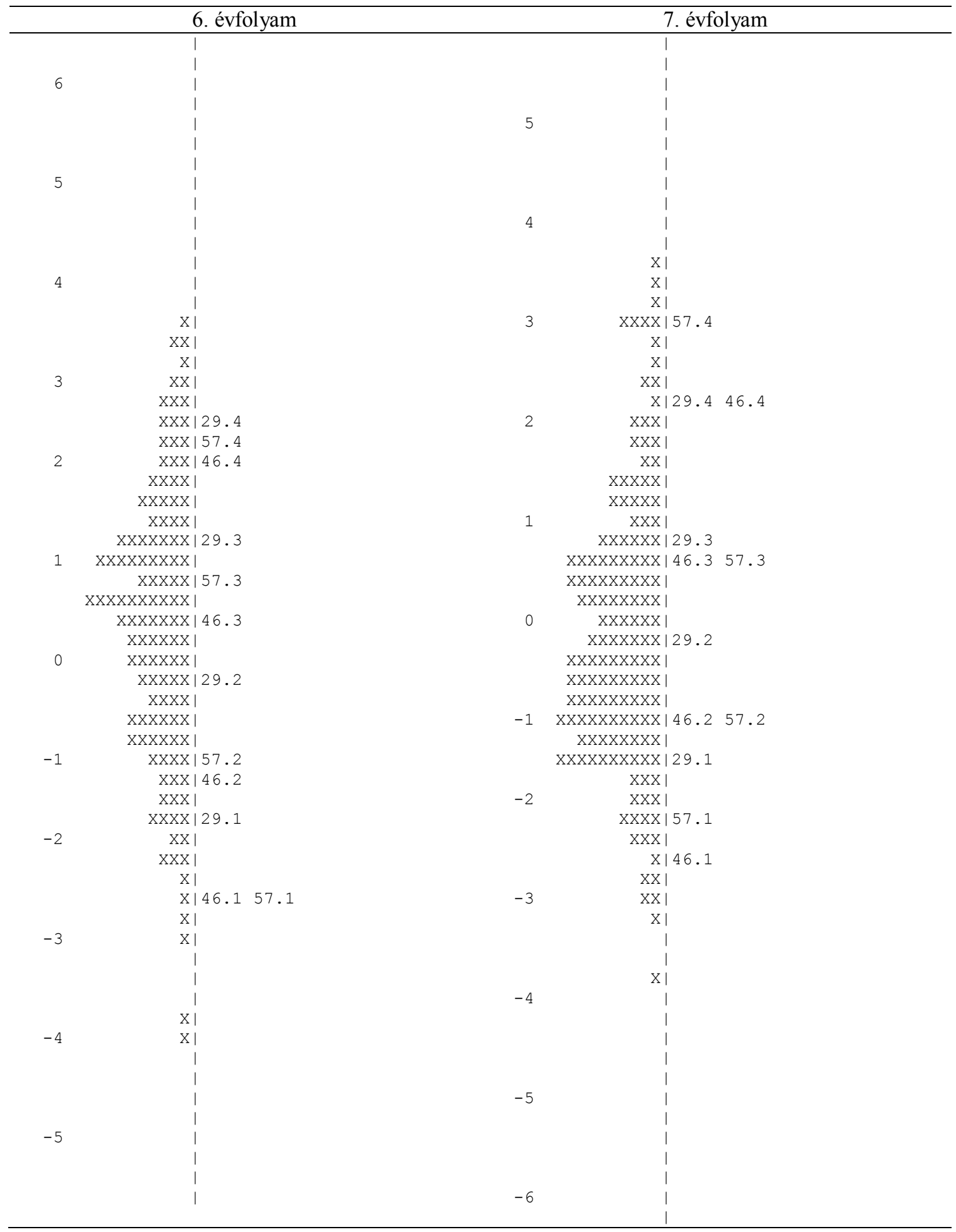

Megj.: minden 'x' 1 tanulót jelöl. 
14. melléklet. A tanulást kerülö cél személy-item térképe 4. és 5. évfolyamon az elsö adatfelvétel alapján

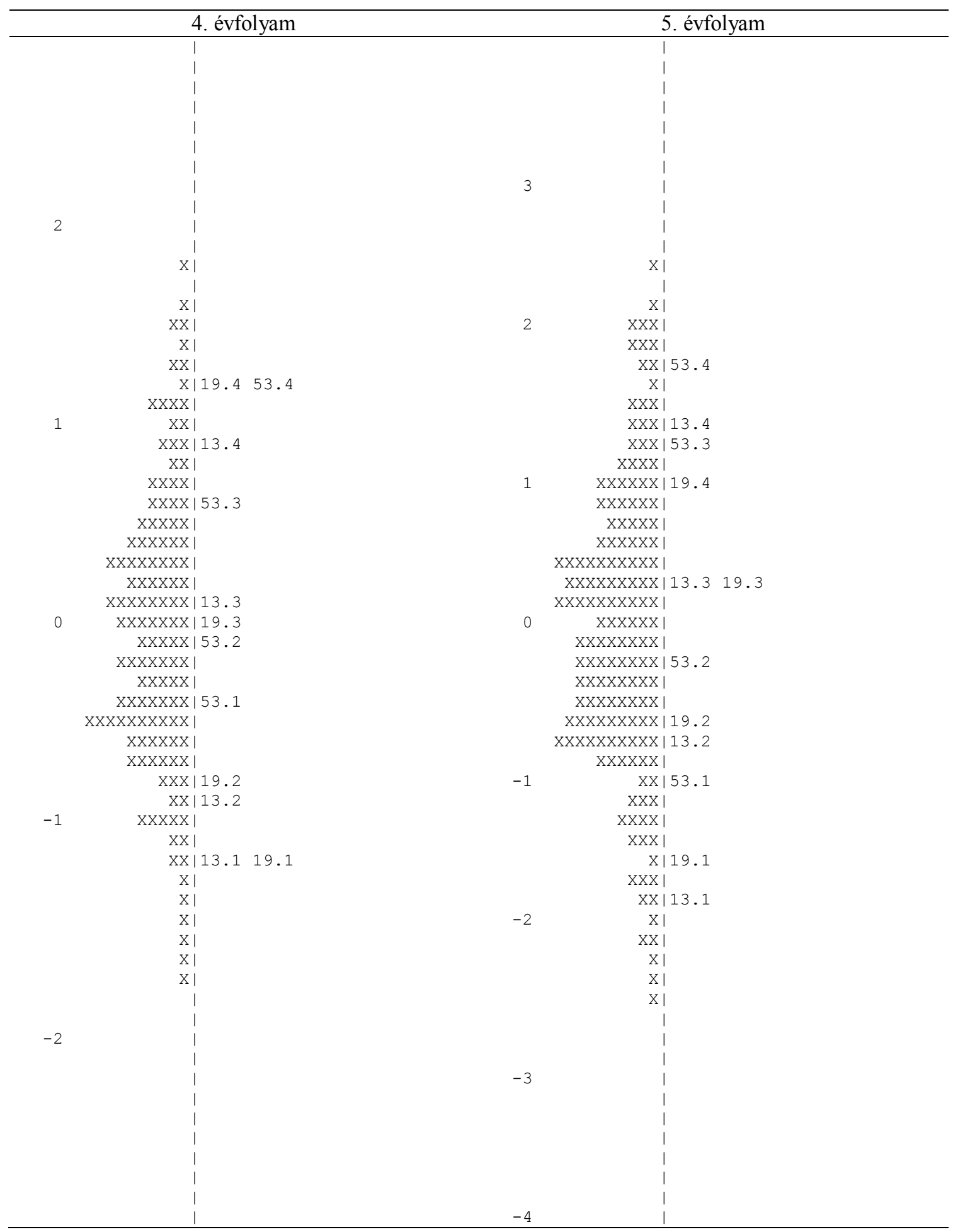

Megj.: minden 'x' 1 tanulót jelöl. 
15. melléklet. A tanulást kerülö cél személy-item térképe 6. és 7. évfolyamon az elsö adatfelvétel alapján

\begin{tabular}{|c|c|c|c|}
\hline \multicolumn{2}{|r|}{ 6. évfolyam } & \multicolumn{2}{|r|}{ 7. évfolyam } \\
\hline \multirow{8}{*}{4} & I & & I \\
\hline & 1 & & I \\
\hline & । & & 1 \\
\hline & i & 4 & I \\
\hline & । & & । \\
\hline & 1 & & i \\
\hline & । & & I \\
\hline & । & & । \\
\hline \multirow[t]{7}{*}{3} & i & & i \\
\hline & । & & $\mathrm{X} \mid$ \\
\hline & $\mathrm{X} \mid$ & 3 & I \\
\hline & $\mathrm{X} \mid$ & & $\mathrm{X} \mid$ \\
\hline & i & & $\mathrm{XI}$ \\
\hline & 153.4 & & $\mathrm{X} \mid$ \\
\hline & $\mathrm{XX} \mid$ & & $\mathrm{XX} \mid$ \\
\hline \multirow[t]{7}{*}{2} & $\mathrm{XX} \mid$ & & $\mathrm{X} \mid$ \\
\hline & I & & $\mathrm{XI}$ \\
\hline & $\mathrm{XXX} \mid$ & 2 & $\mathrm{XXX}$ \\
\hline & $\mathrm{XX} \mid$ & & $\mathrm{X} \mid 19.4$ \\
\hline & $\mathrm{XX} \mid$ & & $x X \mid 13.4$ \\
\hline & $X X \mid 19.4$ & & $x \mid 53.4$ \\
\hline & $X X \mid 13.4$ & & $\mathrm{XX} \mid$ \\
\hline \multirow[t]{7}{*}{1} & XXXXXX| & & $\mathrm{XX} \mid$ \\
\hline & XXXX|53.3 & & $\mathrm{XXX}$ \\
\hline & XXXXX|13.3 19.3 & 1 & $\mathrm{XXX}$ \\
\hline & XXXXX| & & XXXXXXX| \\
\hline & XXXXXXXX| & & XXXXXXX|53.3 \\
\hline & XXXXXX| & & XXXXXXX|19.3 \\
\hline & XXXXXXXXXX| & & XXXXXXXX|13.3 \\
\hline \multirow{2}{*}{0} & XXXXXXX| & & XXXXXX| \\
\hline & XXXXX| & & $\mathrm{XXX1}$ \\
\hline & XXXXXXXXX|53.2 & 0 & XXXXXX| \\
\hline & XXXXXXXXXX| & & XXXX| \\
\hline & $\operatorname{XXXXXXX|19.2}$ & & $\mathrm{XXXXXX|}$ \\
\hline & XXXXXXXXX| & & XXXXXXXXXX|19.2 \\
\hline \multirow{7}{*}{-1} & XXXXX|13.2 & & XXXXX|13.2 53.2 \\
\hline & XXXXXX| & & XXXX| \\
\hline & $\mathrm{XX} \mid$ & -1 & XXXX| \\
\hline & XXXX| & & $\mathrm{XXX1}$ \\
\hline & XXXX|19.1 53.1 & & $X X X \mid 19.1$ \\
\hline & $\mathrm{X} \mid 13.1$ & & $\mathrm{XXX} \mid$ \\
\hline & $\mathrm{X} \mid$ & & $x X \mid 13.1$ \\
\hline \multirow{7}{*}{-2} & $\mathrm{XXX}$ & & $\mathrm{X} \mid$ \\
\hline & $\mathrm{X} \mid$ & & $\mathrm{XX} \mid$ \\
\hline & i & -2 & $\mathrm{X} \mid$ \\
\hline & 1 & & $x x \mid 53.1$ \\
\hline & । & & I \\
\hline & $\mathrm{X} \mid$ & & i \\
\hline & । & & I \\
\hline \multirow[t]{7}{*}{-3} & 1 & & i \\
\hline & । & & i \\
\hline & । & -3 & i \\
\hline & i & & $x \mid$ \\
\hline & । & & I \\
\hline & । & & i \\
\hline & i & & 1 \\
\hline \multirow[t]{4}{*}{-4} & । & & i \\
\hline & i & & i \\
\hline & i & -4 & i \\
\hline & 1 & & | \\
\hline
\end{tabular}

Megj.: minden 'x' 1 tanulót jelöl. 
16. melléklet. A Tanulói célok kérdöív skálák szerint rendezett állításai a második adatfelvétel során

\section{Elsajátítási teljesítménykereső cél}

Fontos célom matekból, hogy teljesen megtanuljam a tananyagot.

Matekból arra törekszem, hogy amennyire csak lehet, megértsem a tananyagot.

Arra törekszem, hogy egyre többet tudjak matekból.

Arra törekszem matekból, hogy teljesen megértsem a tananyagot.

Matekdolgozat írásakor fontos célom, hogy jobban sikerüljön, mint korábban.

Fontos célom matekból, hogy minden részletét tudjam a tananyagnak.

Fontos célom matekból, hogy minden részletét megtanuljam a tananyagnak.

Matekból a célom, hogy megtanuljak annyit, amennyit csak lehet.

Matekból a célom, hogy megértsek annyit, amennyit csak lehet.

Matekból arra törekszem, hogy minden részletét értsem a tananyagnak.

Arra törekszem matekból, hogy egyre többet részletét értsem a tananyagnak.

Matekfeladatok megoldásakor a célom, hogy jobban sikerüljön, mint korábban.

Matekfeladatok megoldásakor a célom, hogy minden részletet értsek.

Matekfeladatok megoldásakor a célom, hogy minden részlet hibátlan legyen.

\section{Elsajátítási teljesítménykerülö cél}

Fontos célom elkerülni, hogy matekból kevesebbet tanuljak meg annál, mint amennyit meg tudnék tanulni.

Arra törekszem matekból, hogy elkerüljem a tananyag hiányos megértését.

Egyik célom elkerülni, hogy matekból kevesebbet tudjak annál, mint amennyit lehetne.

Arra törekszem matekból, hogy elkerüljem a hiányos tudást.

El akarom kerülni matekból, hogy legyen olyan részlet, amit nem tudok.

El akarom kerülni matekból, hogy legyen olyan részlet, amit nem értek.

Arra törekszem matekból, hogy egyre kevesebb olyan részlet legyen, amit nem értek.

Fontos célom matekból, hogy egyre kevesebb olyan részlet legyen, amit nem tudok.

El akarom kerülni matekból, hogy ne értsem a tananyag minden részletét.

El akarom kerülni matekból, hogy ne tudjam a tananyag minden részletét.

Matekfeladatok megoldásakor fontos célom elkerülni, hogy hibázzak.

Matekfeladatok megoldásakor el akarom kerülni, hogy legyen olyan részlet, ami nem tökéletes.

Matekfeladatok megoldásakor el akarom kerülni, hogy legyen olyan részlet, ami hiányos.

Matekfeladatok megoldásakor fontos célom elkerülni, hogy legyen olyan részlet, amit nem értek.

Matekfeladatok megoldásakor el akarom kerülni, hogy többet hibázzak, mint korábban. Matekdolgozat írásakor el akarom kerülni, hogy legyen olyan feladat, ami nem teljes.

Matekdolgozat írásakor fontos célom elkerülni, hogy legyen olyan részlet, ami hiányos.

Matekdolgozat írásakor fontos célom elkerülni, hogy többet hibázzak, mint korábban.

\section{Viszonyító teljesítménykeresö cél}

Fontos célom matekból, hogy jobb legyek, mint a többiek.

Egyik célom, hogy mások azt gondolják rólam, jó vagyok matekból.

Egyik célom, hogy az osztálytársaimhoz képest jó matekosnak tartsanak.

Fontos célom a matekfeladatok megoldásakor, hogy másoknál jobb legyek.

Arra törekszem matekból, hogy az osztálytársaimnál jobb legyek.

Arra törekszem, hogy a jó matekosok közé tartozzak az osztályban.

Fontos célom matekból, hogy a többiekhez képest jó legyek.

Matekfeladatok megoldásakor a célom túlteljesíteni a többieket. 


\section{Viszonyító teljesítménykerïlö cél}

Az egyik célom, hogy elkerüljem azokat a feladatokat matekórán, amikor butának tünhetek.

Azokat a feladatokat választom matekórán, melyeket biztosan meg tudok oldani.

Kerülöm azokat a matekfeladatokat, amelyekben valószínűleg gyengén teljesítenék.

El akarom kerülni matekból, hogy butának tünjek.

El akarom kerülni matekból, hogy rosszabb legyek a többieknél.

Fontos célom elkerülni, hogy a többieknél gyengébb legyek matekból.

Fontos célom matekból, hogy ne legyek rosszabb, mint a többiek.

Arra törekszem, hogy a többieknél ne legyek gyengébb matekos.

Fontos célom, hogy mások azt gondolják, nem vagyok rossz matekból.

Fontos célom elkerülni, hogy valaki azt gondolja, a többiek jobbak nálam matekból.

El akarom kerülni, hogy valaki azt gondolja, a többieknél rosszabb vagyok matekból.

El akarom kerülni, hogy gyengének lássanak matekból.

Fontos célom, hogy ne a rossz matekosok közé tartozzak az osztályban.

El akarom kerülni azokat a matekfeladatokat, amelyekben a többiek jobban teljesítenek.

Egyik célom, hogy elkerüljem azokat a matekfeladatokat, amelyekben valószínüleg gyengén teljesítenék.

\section{Tanulást kerïlö cél}

Az egyik célom, hogy minél hamarabb végezzek a matekfeladatokkal.

A matekfeladatokat próbálom a lehető legkevesebb munkával elvégezni.

A matekfeladatokat próbálom a lehető leggyorsabban befejezni.

Próbálom minél kevesebb munkával megoldani a matekfeladatokkal.

A matekfeladatokkal csak annyit foglalkozok, amennyit kötelező.

A matekfeladatokra csak annyi időt szánok, amennyit kötelező.

Nem csinálom meg a matekfeladatokat, ha nehéznek látszanak.

A nehéz matekfeladatokat nem szoktam megoldani.

A matekfeladatokat próbálom a lehetö leggyorsabban befejezni. 
17. melléklet. A Tanulói célok kérdöiv skálák szerint rendezett állitásai a harmadik adatfelvétel során

\begin{tabular}{l} 
Kérdöivtételek \\
\hline Elsajátítási teljesítménykeresö cél \\
Arra törekszem, hogy egyre többet tudjak matekból. \\
Arra törekszem matekból, hogy teljesen megértsem a tananyagot. \\
Matekból a célom, hogy megtanuljak annyit, amennyit csak lehet. \\
Matekból a célom, hogy megértsek annyit, amennyit csak lehet. \\
Fontos célom, hogy matekból annyit tudjak, amennyit csak lehet. \\
Fontos célom matekból, hogy a lehető legtöbb részletet megtanuljam. \\
\hline
\end{tabular}

Elsajátítási teljesítménykerüló cél

Fontos célom elkerülni, hogy matekból kevesebbet tanuljak meg annál, mint amennyit meg tudnék tanulni.

Egyik célom elkerülni, hogy matekból kevesebbet tudjak annál, mint amennyit lehetne.

El akarom kerülni matekból, hogy legyen olyan részlet, amit nem értek.

Arra törekszem matekból, hogy egyre kevesebb olyan részlet legyen, amit nem értek.

El akarom kerülni matekból, hogy ne értsem a tananyag minden részletét.

Matekból a célom elkerülni, hogy kevesebbet értsek meg annál, mint amennyit meg tudnék érteni.

Fontos célom elkerülni matekból, hogy legyen olyan részlet, amit nem tudok.

Viszonyító teljesítménykeresö cél

Fontos célom matekból, hogy jobb legyek, mint a többiek.

Egyik célom, hogy az osztálytársaimhoz képest jó matekosnak tartsanak.

Arra törekszem matekból, hogy az osztálytársaimnál jobb legyek.

Egyik célom, hogy a többieknél jobb legyek matekból.

Matekból a célom, hogy az osztálytársaimnál jobbnak tartsanak.

\section{Viszonyító teljesítménykerülö cél}

Fontos célom elkerülni, hogy a többieknél gyengébb legyek matekból.

Fontos célom matekból, hogy ne legyek rosszabb, mint a többiek.

Arra törekszem, hogy a többieknél ne legyek gyengébb matekos.

El akarom kerülni, hogy gyengének lássanak matekból.

Az egyik célom elkerülni, hogy a többieknél rosszabb legyek matekból.

El akarom kerülni, hogy gyenge matekosnak gondoljanak.

Fontos célom, hogy ne tartsanak túl gyenge matekosnak.

El akarom kerülni, hogy matekból túl gyenge legyek.

El akarom kerülni matekból, hogy a többieknél jóval gyengébb legyek.

\section{Tanulást kerülö cél}

Az egyik célom, hogy minél hamarabb végezzek a matekfeladatokkal.

A matekfeladatokat próbálom a lehető legkevesebb munkával elvégezni.

A matekfeladatokat próbálom a lehető leggyorsabban befejezni.

Próbálom minél kevesebb munkával megoldani a matekfeladatokat.

Arra törekszem, hogy a lehető leghamarabb végezzek a matekfeladatokkal.

Minél kevesebb időt akarok matekfeladatok megoldásával tölteni. 
18. melléklet. A Tanulói célok kérdöív faktoranalizise 5. évfolyamon a harmadik adatfelvétel alapján

\begin{tabular}{|c|c|c|c|c|c|}
\hline & \multicolumn{5}{|c|}{ Faktorok } \\
\hline & 1. & 2. & 3. & 4. & 5. \\
\hline Saját érték & 3,5 & 2,9 & 2,4 & 2,3 & 2,0 \\
\hline Var. $(\%)$ & 17,3 & 14,3 & 11,8 & 11,3 & 9,9 \\
\hline K. var. $(\%)$ & 17,3 & 31,7 & 43,4 & 54,7 & 64,6 \\
\hline $\begin{array}{l}\text { Skálák, } \\
\text { tételek* }\end{array}$ & & & & & \\
\hline $\begin{array}{l}\text { Elsajátítási } \\
\text { teljesítmény- } \\
\text { kereső cél }\end{array}$ & & & & & \\
\hline 16 & 0,09 & 0,78 & 0,11 & 0,01 & 0,10 \\
\hline 21 & 0,10 & $\mathbf{0 , 8 0}$ & $-0,02$ & 0,15 & 0,17 \\
\hline 25 & 0,10 & $\mathbf{0 , 8 0}$ & $-0,01$ & 0,00 & 0,14 \\
\hline 31 & 0,21 & $\mathbf{0 , 8 0}$ & 0,01 & $-0,09$ & $-0,03$ \\
\hline $\begin{array}{l}\text { Elsajátítási } \\
\text { teljesítmény- } \\
\text { kerülő cél }\end{array}$ & & & & & \\
\hline 8 & 0,02 & 0,08 & 0,66 & 0,05 & 0,00 \\
\hline 14 & 0,16 & $-0,01$ & 0,79 & 0,00 & 0,06 \\
\hline 19 & 0,12 & $-0,08$ & 0,76 & 0,05 & 0,04 \\
\hline 27 & 0,04 & 0,13 & 0,58 & 0,18 & 0,30 \\
\hline $\begin{array}{l}\text { Viszonyító } \\
\text { teljesítmény- } \\
\text { kereső cél }\end{array}$ & & & & & \\
\hline 12 & 0,86 & 0,10 & 0,14 & 0,16 & 0,14 \\
\hline 15 & $\mathbf{0 , 8 7}$ & 0,15 & 0,08 & 0,16 & 0,14 \\
\hline 20 & 0,90 & 0,18 & 0,10 & 0,10 & 0,19 \\
\hline 28 & $\mathbf{0 , 8 5}$ & 0,14 & 0,07 & 0,06 & 0,22 \\
\hline $\begin{array}{l}\text { Viszonyító } \\
\text { teljesítmény- } \\
\text { kerülő cél }\end{array}$ & & & & & \\
\hline 5 & 0,13 & 0,00 & 0,05 & 0,00 & $\mathbf{0 , 8 2}$ \\
\hline 7 & 0,32 & 0,33 & 0,19 & 0,04 & $\mathbf{0 , 3 7}$ \\
\hline 24 & 0,16 & 0,13 & 0,04 & 0,05 & 0,71 \\
\hline 26 & 0,30 & 0,28 & 0,11 & 0,07 & 0,60 \\
\hline $\begin{array}{l}\text { Tanulást } \\
\text { kerülő cél }\end{array}$ & & & & & \\
\hline 1 & 0,02 & 0,09 & $\mathbf{0 , 4 2}$ & 0,60 & $-0,09$ \\
\hline 11 & 0,03 & 0,00 & 0,28 & 0,67 & $-0,01$ \\
\hline 18 & 0,23 & 0,00 & $-0,13$ & $\mathbf{0 , 8 1}$ & 0,07 \\
\hline 29 & 0,14 & $-0,01$ & $-0,04$ & $\mathbf{0 , 8 1}$ & 0,13 \\
\hline
\end{tabular}

Megj.: fơkomponens analízis Varimax rotációval, forgatás előtt 1-nél nagyobb sajátértékủ faktorok, a 0,4nél nagyobb faktorsúlyokat félkövér szedés jelzi; var.=variancia, $K$. var.=kumulatív variancia; * a számok a kérdőívtétel sorszámát jelzik, $\mathrm{KMO}=0,81$. 
19. melléklet. A Tanulói célok kérdöív faktoranalizise 6. évfolyamon a harmadik adatfelvétel alapján

\begin{tabular}{lccccc}
\hline & \multicolumn{5}{c}{ Faktorok } \\
\cline { 2 - 6 } & $\mathbf{1 .}$ & $\mathbf{2 .}$ & $\mathbf{3 .}$ & $\mathbf{4 .}$ & $\mathbf{5 .}$ \\
\cline { 2 - 6 } Saját érték & 3,5 & 3,3 & 2,6 & 2,3 & 2,1 \\
Var. (\%) & 17,7 & 16,6 & 12,8 & 11,3 & 10,6 \\
K. var. (\%) & 17,7 & 34,3 & 47,1 & 58,5 & 69,0 \\
\hline \multicolumn{1}{c}{ Skálák, } & & & &
\end{tabular}

Elsajátítási

teljesítmény-

kereső cél

$\begin{array}{llllll}16 & 0,11 & \mathbf{0 , 7 7} & -0,07 & 0,11 & 0,27 \\ 21 & 0,06 & \mathbf{0 , 8 7} & -0,09 & 0,14 & 0,08 \\ 25 & 0,15 & \mathbf{0 , 8 6} & -0,08 & 0,12 & 0,12 \\ 31 & 0,22 & \mathbf{0 , 7 8} & -0,12 & 0,03 & 0,06\end{array}$

Elsajátítási

teljesítmény-

kerülő cél

$\begin{array}{cccccc}8 & 0,04 & 0,11 & 0,16 & \mathbf{0 , 6 9} & 0,17 \\ 14 & 0,14 & -0,03 & 0,08 & \mathbf{0 , 7 7} & 0,03 \\ 19 & 0,05 & 0,07 & 0,09 & \mathbf{0 , 6 8} & 0,04 \\ 27 & 0,14 & 0,21 & 0,04 & \mathbf{0 , 6 3} & 0,14\end{array}$

Viszonyító

teljesítmény-

kereső cél

$\begin{array}{llllll}12 & \mathbf{0 , 8 8} & 0,13 & -0,06 & 0,13 & 0,13 \\ 15 & \mathbf{0 , 8 7} & 0,15 & 0,01 & 0,12 & 0,07 \\ 20 & \mathbf{0 , 8 6} & 0,13 & -0,02 & 0,11 & 0,18 \\ 28 & \mathbf{0 , 8 9} & 0,19 & 0,00 & 0,09 & 0,19\end{array}$

Viszonyító

teljesítmény-

kerülő cél

$\begin{array}{cccccc}5 & 0,08 & 0,01 & -0,11 & 0,41 & \mathbf{0 , 7 2} \\ 7 & 0,35 & \mathbf{0 , 4 3} & -0,06 & 0,04 & \mathbf{0 , 4 6} \\ 24 & 0,19 & 0,20 & -0,08 & 0,14 & \mathbf{0 , 8 3} \\ 26 & 0,29 & \mathbf{0 , 4 3} & 0,01 & 0,00 & \mathbf{0 , 6 7}\end{array}$

Tanulást

kerülő cél

$\begin{array}{cccccc}1 & -0,13 & -0,12 & \mathbf{0 , 7 1} & 0,07 & 0,01 \\ 11 & -0,14 & -0,18 & \mathbf{0 , 8 0} & 0,02 & -0,02 \\ 18 & 0,07 & -0,09 & \mathbf{0 , 8 0} & 0,17 & -0,09 \\ 29 & 0,14 & 0,06 & \mathbf{0 , 8 1} & 0,11 & -0,07\end{array}$

Megj.: főkomponens analízis Varimax rotációval, forgatás előtt 1-nél nagyobb sajátértékủ faktorok, a 0,4nél nagyobb faktorsúlyokat félkövér szedés jelzi; var.=variancia, $K$. var.=kumulatív variancia; * a számok a kérdőívtétel sorszámát jelzik, $\mathrm{KMO}=0,83$. 
20. melléklet. A Tanulói célok kérdöív faktoranalizise 7. évfolyamon a harmadik adatfelvétel alapján

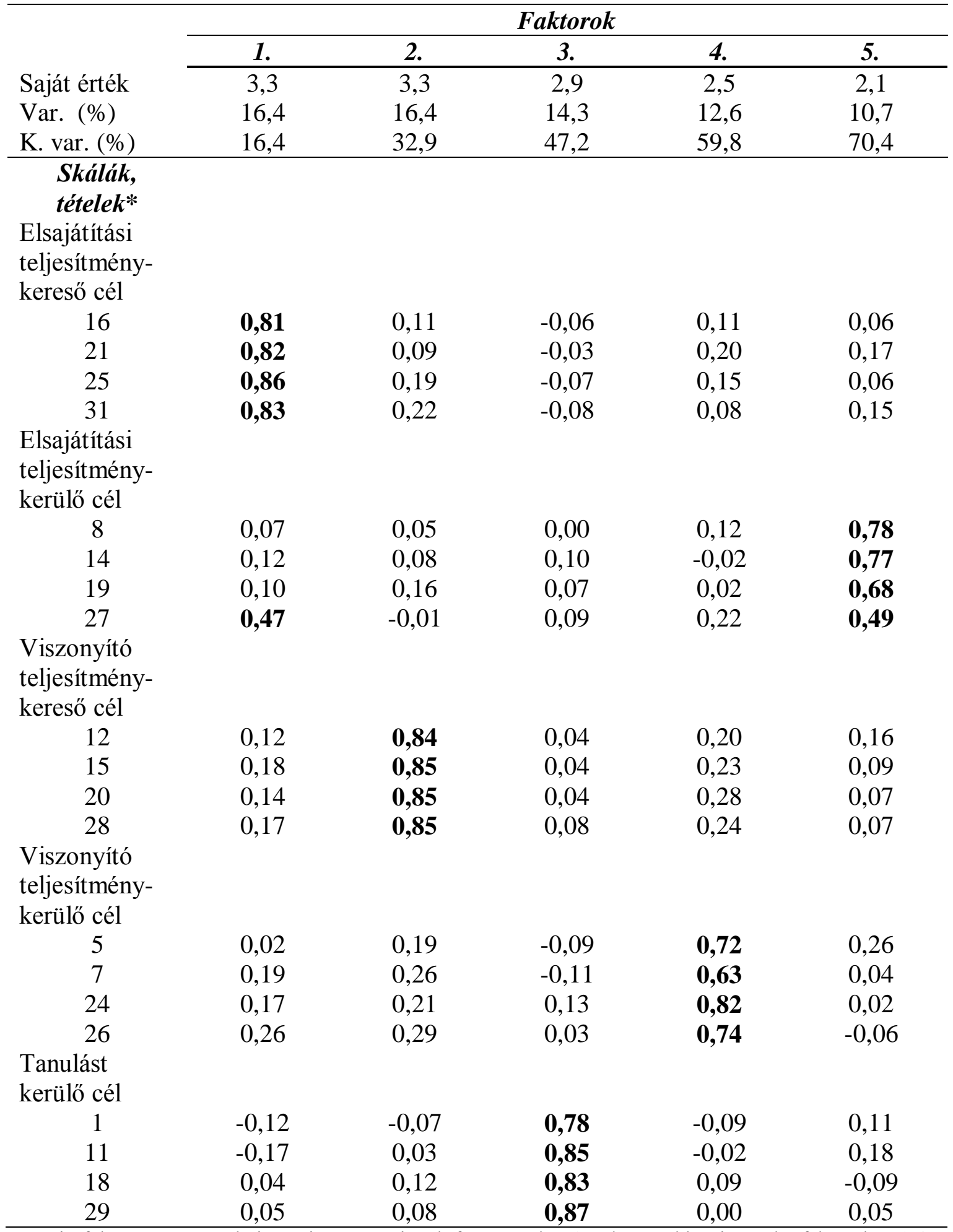

Megj.: fökomponens analízis Varimax rotációval, forgatás előtt 1-nél nagyobb sajátértékủ faktorok, a 0,4nél nagyobb faktorsúlyokat félkövér szedés jelzi; var.=variancia, $K$. var.=kumulatív variancia; * a számok a kérdőívtétel sorszámát jelzik, $\mathrm{KMO}=0,85$. 
21. melléklet. A Tanulói célok kérdöív faktoranalizise 8. évfolyamon a harmadik adatfelvétel alapján

\begin{tabular}{lccccc}
\hline & \multicolumn{5}{c}{ Faktorok } \\
\cline { 2 - 6 } & $\mathbf{1 .}$ & $\mathbf{2 .}$ & $\mathbf{3 .}$ & $\mathbf{4 .}$ & $\mathbf{5 .}$ \\
\cline { 2 - 6 } Saját érték & 3,5 & 3,4 & 2,8 & 2,8 & 2,1 \\
Var. (\%) & 17,7 & 17,0 & 14,2 & 14,0 & 10,4 \\
K. var. (\%) & 17,7 & 34,6 & 48,9 & 62,9 & 73,2 \\
\hline \multicolumn{1}{c}{ Skálák, } & & \multicolumn{5}{c}{} &
\end{tabular}

Elsajátítási

teljesítmény-

kereső cél

$\begin{array}{llllll}16 & 0,20 & \mathbf{0 , 7 2} & 0,16 & -0,20 & 0,04 \\ 21 & 0,13 & \mathbf{0 , 7 6} & 0,29 & -0,11 & 0,14 \\ 25 & 0,18 & \mathbf{0 , 7 8} & 0,27 & -0,14 & 0,04 \\ 31 & 0,20 & \mathbf{0 , 7 7} & 0,07 & -0,13 & 0,14\end{array}$

Elsajátítási

teljesítmény-

kerülő cél

$\begin{array}{cccccc}8 & -0,07 & 0,17 & 0,17 & 0,12 & \mathbf{0 , 7 1} \\ 14 & 0,14 & 0,35 & -0,02 & 0,12 & \mathbf{0 , 7 4} \\ 19 & 0,18 & -0,06 & 0,22 & -0,03 & \mathbf{0 , 8 2} \\ 27 & 0,13 & \mathbf{0 , 5 8} & 0,18 & -0,01 & \mathbf{0 , 4 3}\end{array}$

Viszonyító

teljesítmény-

kereső cél

$\begin{array}{llllll}12 & \mathbf{0 , 8 5} & 0,14 & 0,29 & 0,11 & 0,07 \\ 15 & \mathbf{0 , 8 9} & 0,20 & 0,17 & 0,11 & 0,10 \\ 20 & \mathbf{0 , 8 6} & 0,21 & 0,32 & 0,09 & 0,07 \\ 28 & \mathbf{0 , 8 7} & 0,26 & 0,19 & 0,11 & 0,08\end{array}$

Viszonyító

teljesítmény-

kerülő cél

$\begin{array}{cccccc}5 & 0,29 & 0,14 & \mathbf{0 , 7 7} & 0,00 & 0,14 \\ 7 & 0,26 & 0,16 & \mathbf{0 , 7 9} & 0,00 & 0,11 \\ 24 & 0,18 & 0,30 & \mathbf{0 , 7 6} & 0,01 & 0,16 \\ 26 & 0,27 & \mathbf{0 , 4 6} & \mathbf{0 , 6 8} & 0,01 & 0,14\end{array}$

Tanulást

kerülő cél

\begin{tabular}{cccccc}
1 & 0,00 & $-0,14$ & $-0,12$ & $\mathbf{0 , 7 4}$ & 0,04 \\
11 & 0,03 & $-0,19$ & $-0,04$ & $\mathbf{0 , 8 2}$ & 0,03 \\
18 & 0,16 & $-0,01$ & 0,10 & $\mathbf{0 , 8 4}$ & 0,00 \\
29 & 0,14 & $-0,09$ & 0,08 & $\mathbf{0 , 8 5}$ & 0,11 \\
\hline
\end{tabular}

Megj.: főkomponens analízis Varimax rotációval, forgatás előtt 1-nél nagyobb sajátértékű faktorok, a 0,4nél nagyobb faktorsúlyokat félkövér szedés jelzi; var.=variancia, $K$. var.=kumulatív variancia; * a számok a kérdőívtétel sorszámát jelzik, $\mathrm{KMO}=0,88$. 
22. melléklet. Az elsajátitási teljesitménykeresö cél személy-item térképe 5. és 6. évfolyamon a harmadik adatfelvétel alapján

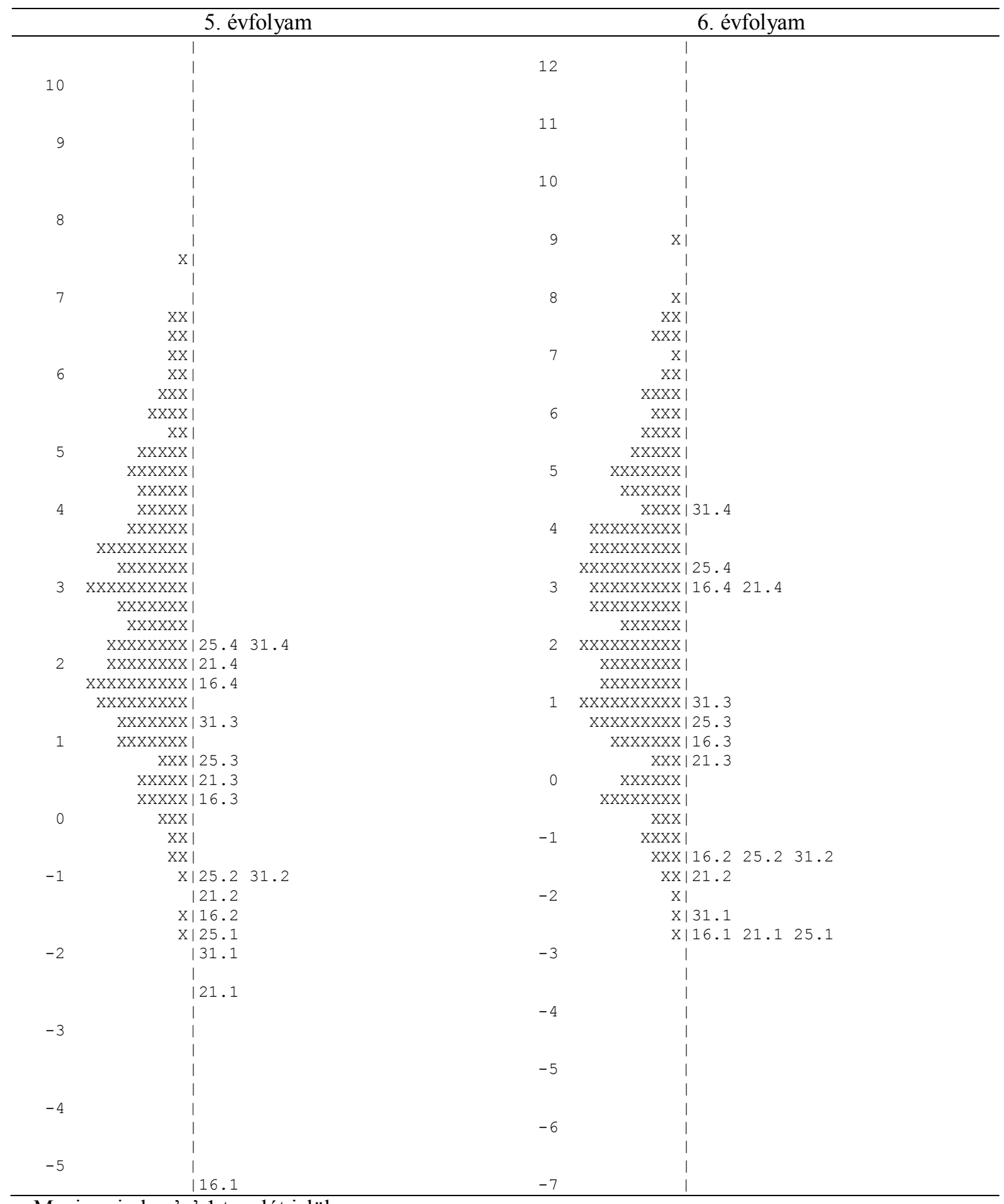

Megj.: minden 'x' 1 tanulót jelöl. 
23. melléklet. Az elsajátitási teljesitménykeresö cél személy-item térképe 7. és 8. évfolyamon a harmadik adatfelvétel alapján

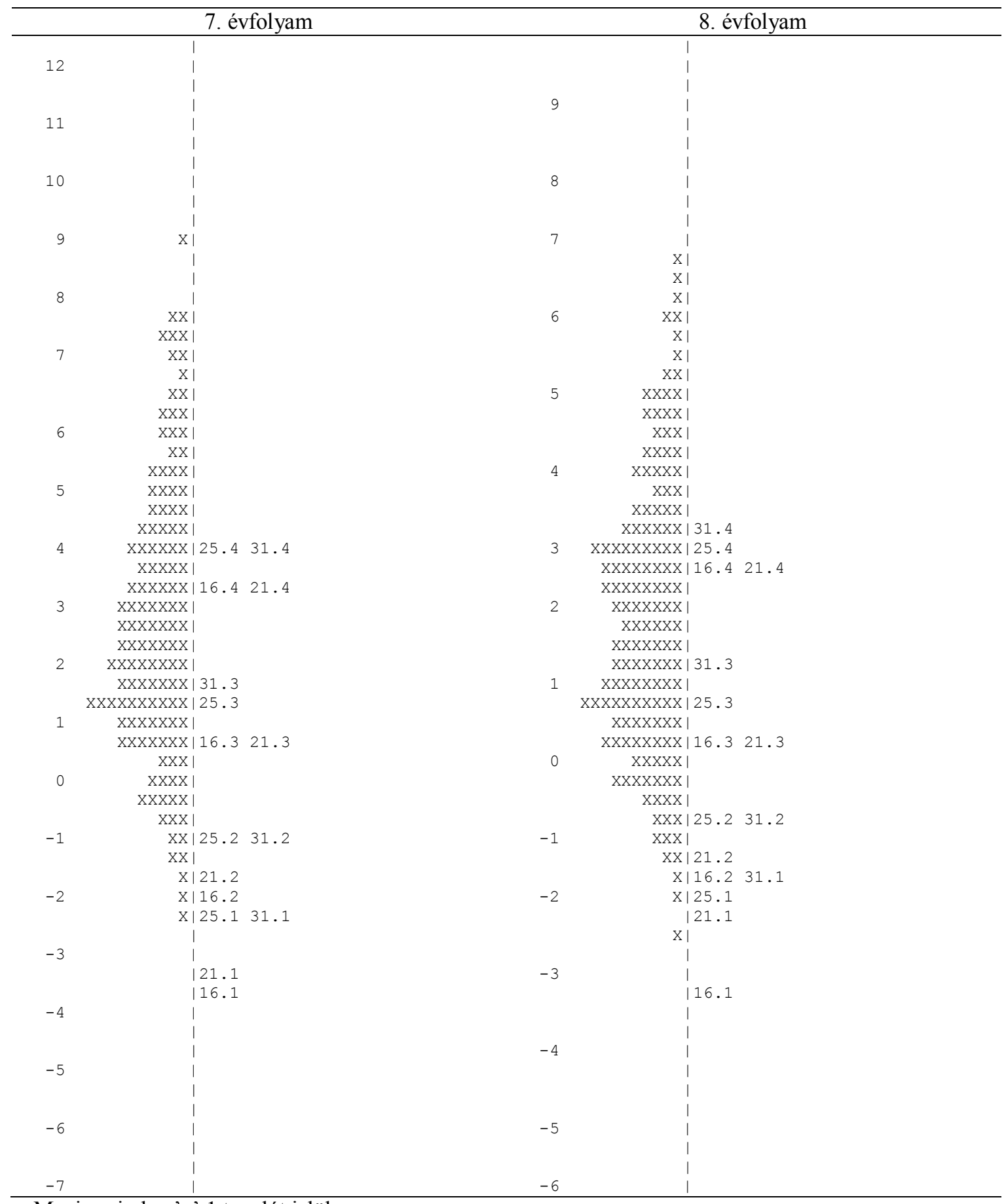

Megj.: minden 'x' 1 tanulót jelöl. 
24. melléklet. Az elsajátitási teljesitménykerülö cél személy-item térképe 5. és 6. évfolyamon a harmadik adatfelvétel alapján

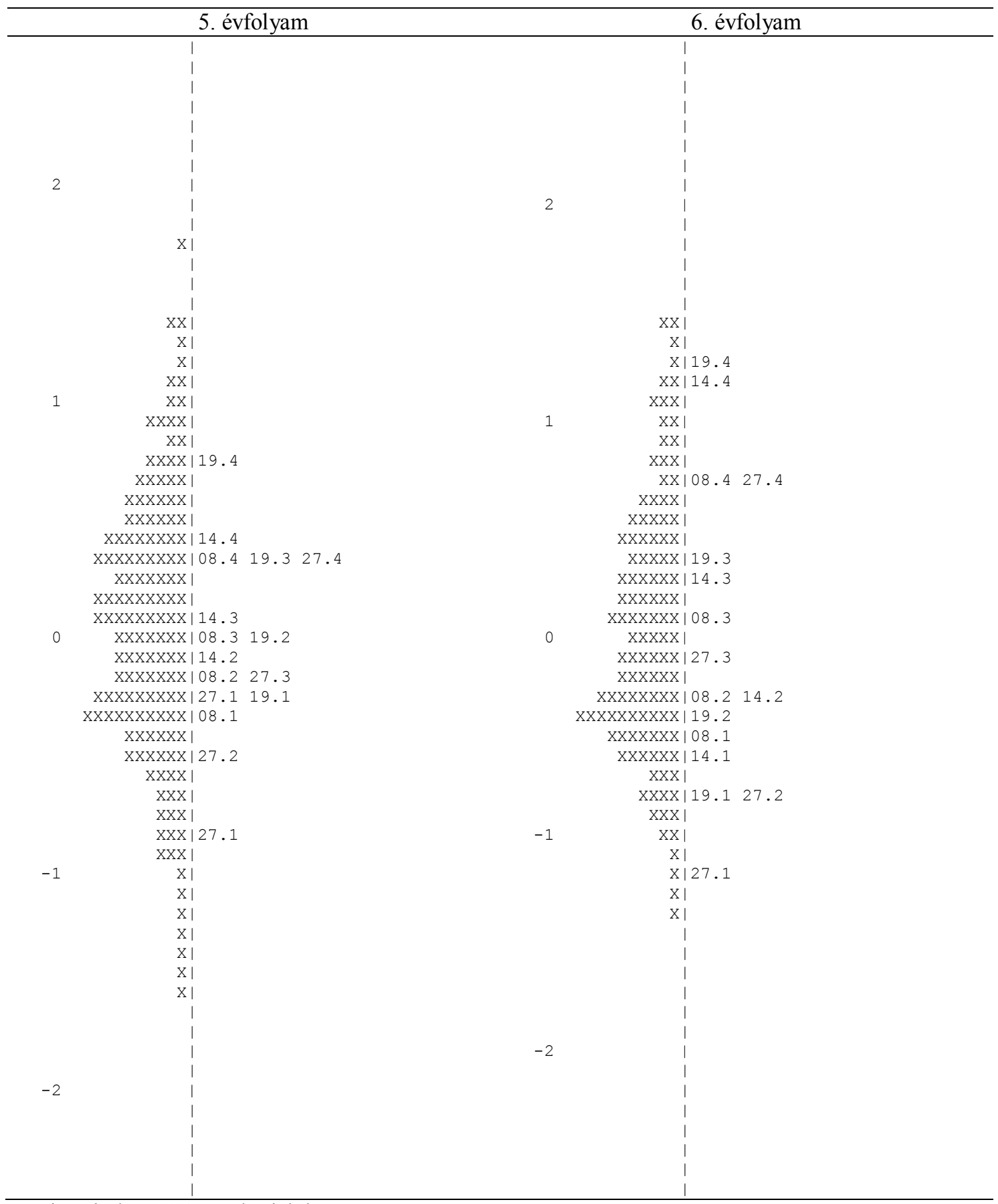

Megj.: minden 'x' 2 tanulót jelöl. 
25. melléklet. Az elsajátitási teljesitménykerülö cél személy-item térképe 7. és 8. évfolyamon a harmadik adatfelvétel alapján

\begin{tabular}{|c|c|c|c|}
\hline \multicolumn{2}{|r|}{ 7. évfolyam } & \multicolumn{2}{|r|}{ 8. évfolyam } \\
\hline 3 & 1 & 4 & 1 \\
\hline & । & & i \\
\hline & i & & i \\
\hline & I & & | \\
\hline & I & & i \\
\hline & I & & 1 \\
\hline & 1 & & 1 \\
\hline & i & & i \\
\hline & i & 3 & i \\
\hline & i & & $x \mid$ \\
\hline 2 & $x \mid$ & & । \\
\hline & $\mathrm{X} \mid$ & & $x \mid$ \\
\hline & I & & $x \mid$ \\
\hline & i & & $x \mid$ \\
\hline & $\mathrm{X} \mid$ & & $\mathrm{XX} \mid$ \\
\hline & $\mathrm{XX} \mid$ & & $\mathrm{X} \mid$ \\
\hline & $\mathrm{X} \mid$ & 2 & $\mathrm{X} \mid$ \\
\hline & $\mathrm{XX} \mid$ & & $\mathrm{XX} \mid$ \\
\hline & $\mathrm{XX} \mid$ & & $\mathrm{XX} \mid 19.4$ \\
\hline & XXXX|14.4 19.4 & & $\mathrm{XX}$ \\
\hline & $\mathrm{XX} \mid$ & & $\mathrm{XX} \mid 08.4$ \\
\hline 1 & $\mathrm{XXX}$ & & $\mathrm{XXX} \mid 14.4$ \\
\hline & XXXXX|08.4 27.4 & & $\mathrm{XXXX}$ \\
\hline & $\operatorname{xxxxx}$ & & $\mathrm{XXXX} \mid 27.4$ \\
\hline & XXXXXX| & 1 & $\operatorname{XXXX1}$ \\
\hline & XXXXX| & & XXXXXXX| \\
\hline & XXXXXXXXX| & & XXXXXX| \\
\hline & XXXXXXX|19.3 & & XXXXXXX| \\
\hline & XXXXXXXXX|14.3 & & XXXXXXXX|19.3 \\
\hline & XXXXXXXX| & & XXXXXXXXX| \\
\hline & XXXXXXX|08.3 & & XXXXXXX|14.3 \\
\hline 0 & XXXXXXXXXX| & & XXXXXXXXX| \\
\hline & $\operatorname{XXXXXXXXXX|27.3}$ & 0 & $\begin{array}{lll}\mathrm{XXXXXXX} \mid 08.327 .3\end{array}$ \\
\hline & XXXXXXXX|19.2 & & $\operatorname{XXXXXXX|}$ \\
\hline & XXXXXXXXXX|08.2 14.2 & & XXXXXXXXXX|14.2 19.2 \\
\hline & XXXXXXXX| & & $\operatorname{xxxxxxx|08.2}$ \\
\hline & XXXXXX| & & $\operatorname{XXXXX|}$ \\
\hline & XXX|08.1 19.1 & & XXXX| \\
\hline & $\mathrm{XXXXX} \mid 14.1$ & & $\begin{array}{lllll}X X X X \mid 08.1 & 14.1 & 19.1\end{array}$ \\
\hline & $\mathrm{XXXXX|}$ & & $\mathrm{XXX} \mid$ \\
\hline & $x \mid 27.2$ & -1 & $x x \mid 27.2$ \\
\hline-1 & $\mathrm{X} \mid$ & & $\mathrm{XX}$ \\
\hline & $\mathrm{xX}$ & & $\mathrm{xX}$ \\
\hline & $\mathrm{X} \mid$ & & $\mathrm{XX} 1$ \\
\hline & $x \mid$ & & | 27.1 \\
\hline & $\mathrm{X} \mid 27.1$ & & $\mathrm{X} \mid$ \\
\hline & $\mathrm{XI}$ & & । \\
\hline & $\mathrm{X} \mid$ & -2 & $x \mid$ \\
\hline & I & & | \\
\hline & I & & $x \mid$ \\
\hline & i & & । \\
\hline & । & & 1 \\
\hline-2 & । & & i \\
\hline & । & & i \\
\hline & i & & i \\
\hline & I & -3 & । \\
\hline & I & & । \\
\hline & i & & i \\
\hline & । & & 1 \\
\hline
\end{tabular}

Megj.: minden 'x' 2 tanulót jelöl. 
26. melléklet. A viszonyitó teljesítménykereső cél személy-item térképe 5. és 6. évfolyamon a harmadik adatfelvétel alapján

\begin{tabular}{|c|c|c|c|}
\hline \multicolumn{2}{|r|}{ 5. évfolyam } & \multicolumn{2}{|r|}{ 6. évfolyam } \\
\hline \multirow[t]{4}{*}{8} & 1 & 8 & 1 \\
\hline & I & & 1 \\
\hline & I & & I \\
\hline & I & & I \\
\hline \multirow[t]{3}{*}{7} & i & 7 & i \\
\hline & I & & 1 \\
\hline & I & & i \\
\hline \multirow[t]{4}{*}{6} & I & & 1 \\
\hline & I & 6 & I \\
\hline & 1 & & 1 \\
\hline & I & & I \\
\hline \multirow[t]{3}{*}{5} & $\mathrm{x} \mid$ & 5 & I \\
\hline & 1 & & $\mathrm{x} \mid$ \\
\hline & $\mathrm{xI}$ & & $\mathrm{x} \mid$ \\
\hline \multirow[t]{4}{*}{4} & $\mathrm{x} \mid$ & & $\mathrm{xx} \mid$ \\
\hline & $\mathrm{xI}$ & 4 & $\mathrm{xI}$ \\
\hline & $\mathrm{x} \times 1$ & & $\mathrm{x} \mid$ \\
\hline & $\mathrm{x} \times 1$ & & $\mathrm{xx} 1$ \\
\hline \multirow[t]{3}{*}{3} & $\mathrm{xxx} 1$ & & $\mathrm{x} \mid$ \\
\hline & $\mathrm{xxI}$ & 3 & $\mathrm{xxx} 1$ \\
\hline & $\mathrm{x} \times 1$ & & $\mathrm{xxx} 1$ \\
\hline \multirow[t]{4}{*}{2} & Xxxxi & & XXX|12.4 28.4 \\
\hline & $\mathrm{xxxx|}$ & 2 & XXXXX|15.4 20.4 \\
\hline & $\mathrm{xxxx|}$ & & xxxxx1 \\
\hline & xxxxxi & & 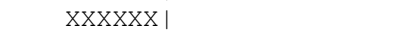 \\
\hline \multirow[t]{3}{*}{1} & XXXXX|12.4 20.4 & & XXXXXX1 \\
\hline & XXXXX|15.4 28.4 & 1 & xxxxxxxx1 \\
\hline & xxxxxxx| & & 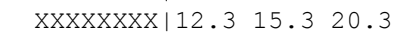 \\
\hline & xxxxxxxxx| & & xxXXXXXXXX|28.3 \\
\hline & XXXXxxx|12.3 & 0 & XXXXXXXX| \\
\hline & XXxx|15.3 20.3 & & XXXXxx \\
\hline & 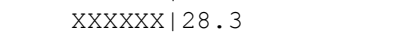 & & XXXXXX1 \\
\hline \multirow{2}{*}{-1} & xxxxxxxxx| & & $x \times x x x x x x \mid 2$ \\
\hline & XXXXXXXXXX| & -1 & 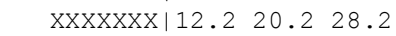 \\
\hline & XXXXXXX| & & Xxxxxxxx|15.2 \\
\hline & Xxxxxxx|15.2 & & xxxxxx \\
\hline \multirow[t]{3}{*}{-2} & $\begin{array}{llll}\text { XXXX|12.2 } & 20.2 & 28.2\end{array}$ & & XXXXX1 \\
\hline & 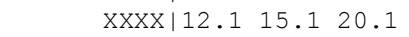 & -2 & XXX|15.1 $20.1 \quad 28.1$ \\
\hline & $\operatorname{xxxx|28.1}$ & & $\mathrm{xxxx|12.1}$ \\
\hline \multirow[t]{4}{*}{-3} & $x \mathrm{x}$ & & $x \times 1$ \\
\hline & XXI & -3 & XXX1 \\
\hline & XXX1 & & XXX1 \\
\hline & $\mathrm{xl}$ & & $\mathrm{x} \times 1$ \\
\hline \multirow[t]{3}{*}{-4} & XI & & $x \times 1$ \\
\hline & XI & -4 & $\mathrm{xi}$ \\
\hline & $\mathrm{XI}$ & & XI \\
\hline \multirow[t]{4}{*}{-5} & XI & & XI \\
\hline & i & -5 & XI \\
\hline & I & & 1 \\
\hline & i & & i \\
\hline \multirow[t]{3}{*}{-6} & I & & $\mathrm{XI}$ \\
\hline & i & -6 & i \\
\hline & i & & I \\
\hline-7 & i & & i \\
\hline & i & & i \\
\hline & i & -7 & i \\
\hline & i & & i \\
\hline-8 & i & & i \\
\hline & i & -8 & i \\
\hline & i & & I \\
\hline
\end{tabular}

Megj.: minden 'x' 2 tanulót jelöl. 
27. melléklet. A viszonyitó teljesitménykereső cél személy-item térképe 7. és 8. évfolyamon a harmadik adatfelvétel alapján

\begin{tabular}{|c|c|c|c|}
\hline \multicolumn{2}{|r|}{ 7. évfolyam } & \multicolumn{2}{|r|}{ 8. évfolyam } \\
\hline \multirow[t]{3}{*}{9} & I & & 1 \\
\hline & i & 12 & | \\
\hline & i & & i \\
\hline \multirow[t]{3}{*}{8} & i & 11 & i \\
\hline & । & & i \\
\hline & I & 10 & । \\
\hline \multirow[t]{4}{*}{7} & I & & | \\
\hline & i & & i \\
\hline & i & 9 & i \\
\hline & i & & i \\
\hline \multirow[t]{3}{*}{6} & $x \mid$ & 8 & i \\
\hline & । & & | \\
\hline & । & 7 & $\mathrm{X} \mid$ \\
\hline \multirow[t]{3}{*}{5} & $\mathrm{X} \mid$ & & । \\
\hline & $\mathrm{XX} \mid$ & & $x \mid$ \\
\hline & $\mathrm{XX} \mid$ & 6 & $\mathrm{X} \mid$ \\
\hline \multirow[t]{3}{*}{4} & $\mathrm{XI}$ & & $\mathrm{XX} \mid$ \\
\hline & $\mathrm{XX} \mid$ & 5 & $\mathrm{X} \mid$ \\
\hline & $\mathrm{XX} \mid$ & & $\mathrm{X} \mid$ \\
\hline \multirow[t]{4}{*}{3} & $\mathrm{XX} \mid 12.4 \quad 15.4$ & 4 & $X X X \mid 12.4 \quad 15.4$ \\
\hline & $X X X X \mid 20.428 .4$ & & $X X \mid 20.4$ \\
\hline & $\mathrm{XXXX}$ & & $\mathrm{X} \mid 28.4$ \\
\hline & $\mathrm{XXXXX}$ & 3 & $\operatorname{xxxX}$ \\
\hline \multirow[t]{3}{*}{2} & XXXXXX| & & XXXX| \\
\hline & XXXXXX| & 2 & XXXXXI \\
\hline & $\operatorname{XXXXXX|15.3} 20.3 \quad 28.3$ & & XXXXXX| \\
\hline \multirow[t]{3}{*}{1} & $\mathrm{xxxxx} \mid 12.3$ & 1 & $\mathrm{XXXXX1}$ \\
\hline & 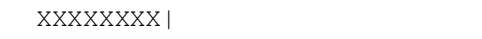 & & $x \times x x \mid 12.3 \quad 15.3 \quad 20.3$ \\
\hline & XXXXXXXX| & & 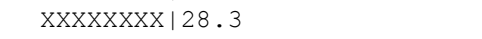 \\
\hline \multirow[t]{3}{*}{0} & XXXXXXXX| & 0 & $\mathrm{XXXXX|}$ \\
\hline & XXXXXXXX| & & XXXXXXX| \\
\hline & 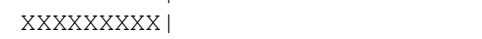 & -1 & XXXXXXXX| \\
\hline \multirow{4}{*}{-1} & $\operatorname{XXXXXXXXX|12.2} \quad 15.2 \quad 28.2$ & & 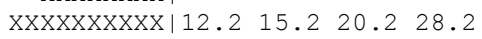 \\
\hline & 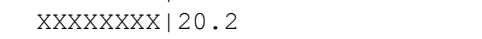 & -2 & 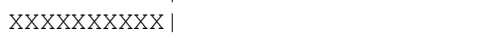 \\
\hline & XXXXXXXXXX| & & XXXXXX| \\
\hline & $\operatorname{XXXXXXX|}$ & & $\operatorname{XXXXXX|}$ \\
\hline \multirow[t]{3}{*}{-2} & XXXX| & -3 & XXXX|15.1 20.128 .1 \\
\hline & \begin{tabular}{l|llll}
$X X$ & 12.1 & 15.1 & 20.1 & 28.1
\end{tabular} & & $\mathrm{xxxxxx} \mid 12.1$ \\
\hline & $\mathrm{xxx} \mid$ & -4 & $\mathrm{XX} \mid$ \\
\hline \multirow[t]{3}{*}{-3} & $\mathrm{XXX} \mid$ & & $\mathrm{xxX} \mid$ \\
\hline & XI & -5 & $\mathrm{XX} \mid$ \\
\hline & $\mathrm{XXX}$ & & $\mathrm{XX}$ \\
\hline \multirow[t]{4}{*}{-4} & XXI & & $\mathrm{XX}$ \\
\hline & XXI & -6 & XI \\
\hline & 1 & & $x \mid$ \\
\hline & XI & -7 & XI \\
\hline \multirow[t]{3}{*}{-5} & XI & & $\mathrm{XI}$ \\
\hline & XI & -8 & I \\
\hline & I & & $\mathrm{XI}$ \\
\hline-6 & XI & & 1 \\
\hline & | & -9 & I \\
\hline & I & & I \\
\hline-7 & I & -10 & I \\
\hline & I & & i \\
\hline & i & -11 & i \\
\hline-8 & I & & i \\
\hline & I & & 1 \\
\hline & i & -12 & i \\
\hline & i & & i \\
\hline-9 & | & -13 & 1 \\
\hline
\end{tabular}

Megj.: minden 'x' 2 tanulót jelöl. 
28. melléklet. A viszonyitó teljesitménykerülö cél személy-item térképe 5. és 6. évfolyamon a harmadik adatfelvétel alapján

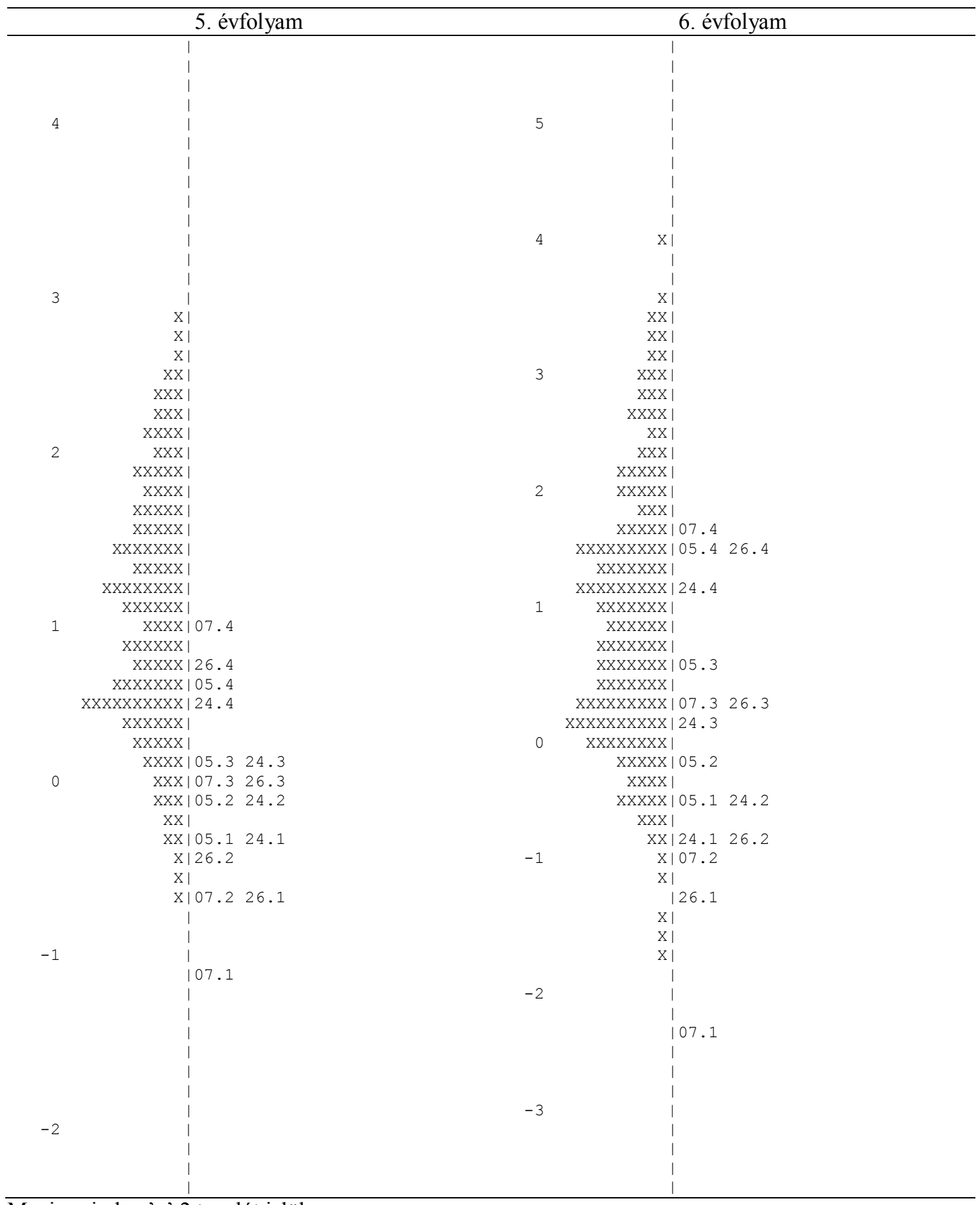

Megj.: minden 'x' 2 tanulót jelöl. 
29. melléklet. A viszonyitó teljesitménykerülö cél személy-item térképe 7. és 8. évfolyamon a harmadik adatfelvétel alapján

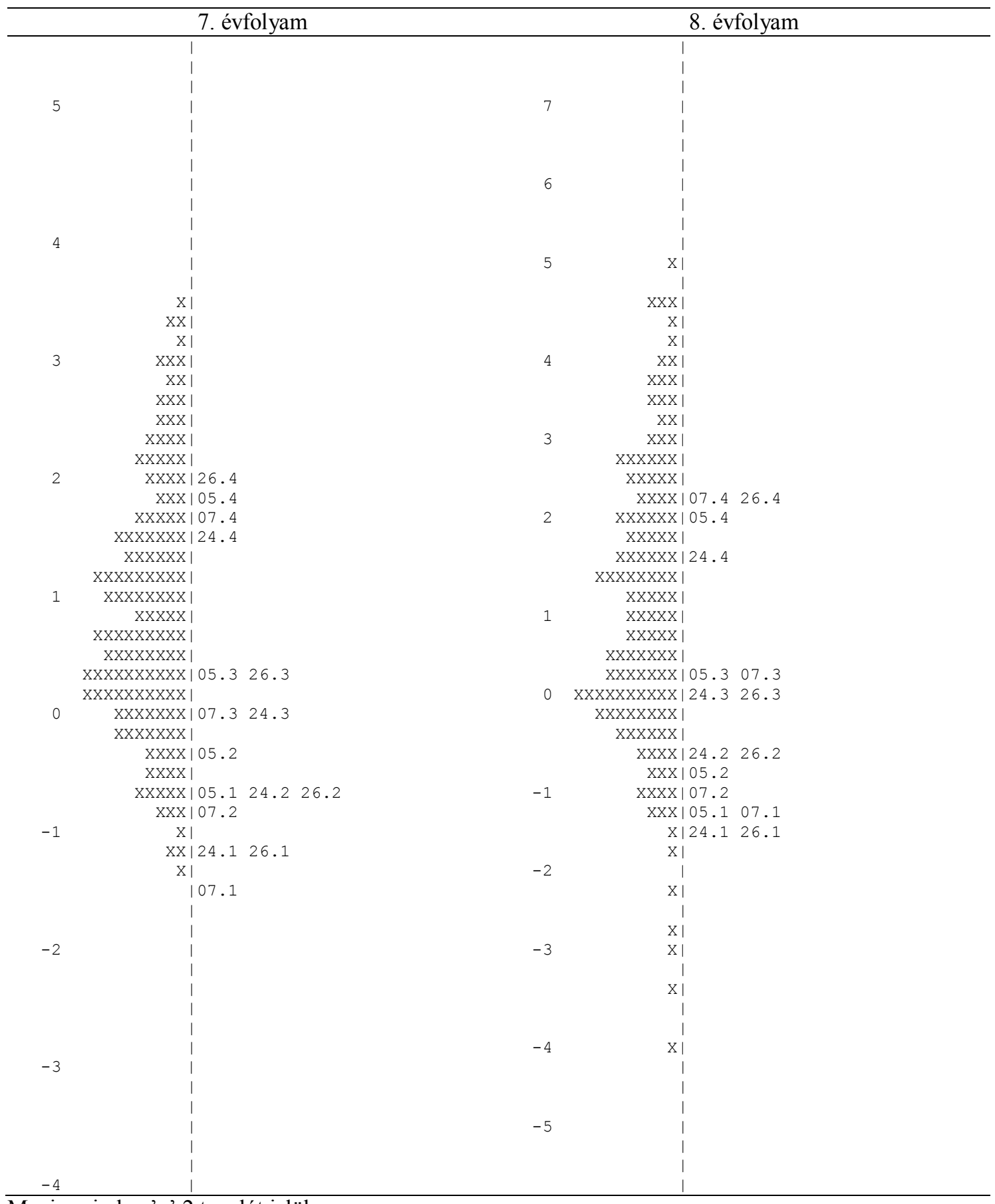

Megj.: minden 'x' 2 tanulót jelöl. 
30. melléklet. A tanulást kerülö cél személy-item térképe 5. és 6. évfolyamon a harmadik adatfelvétel alapján

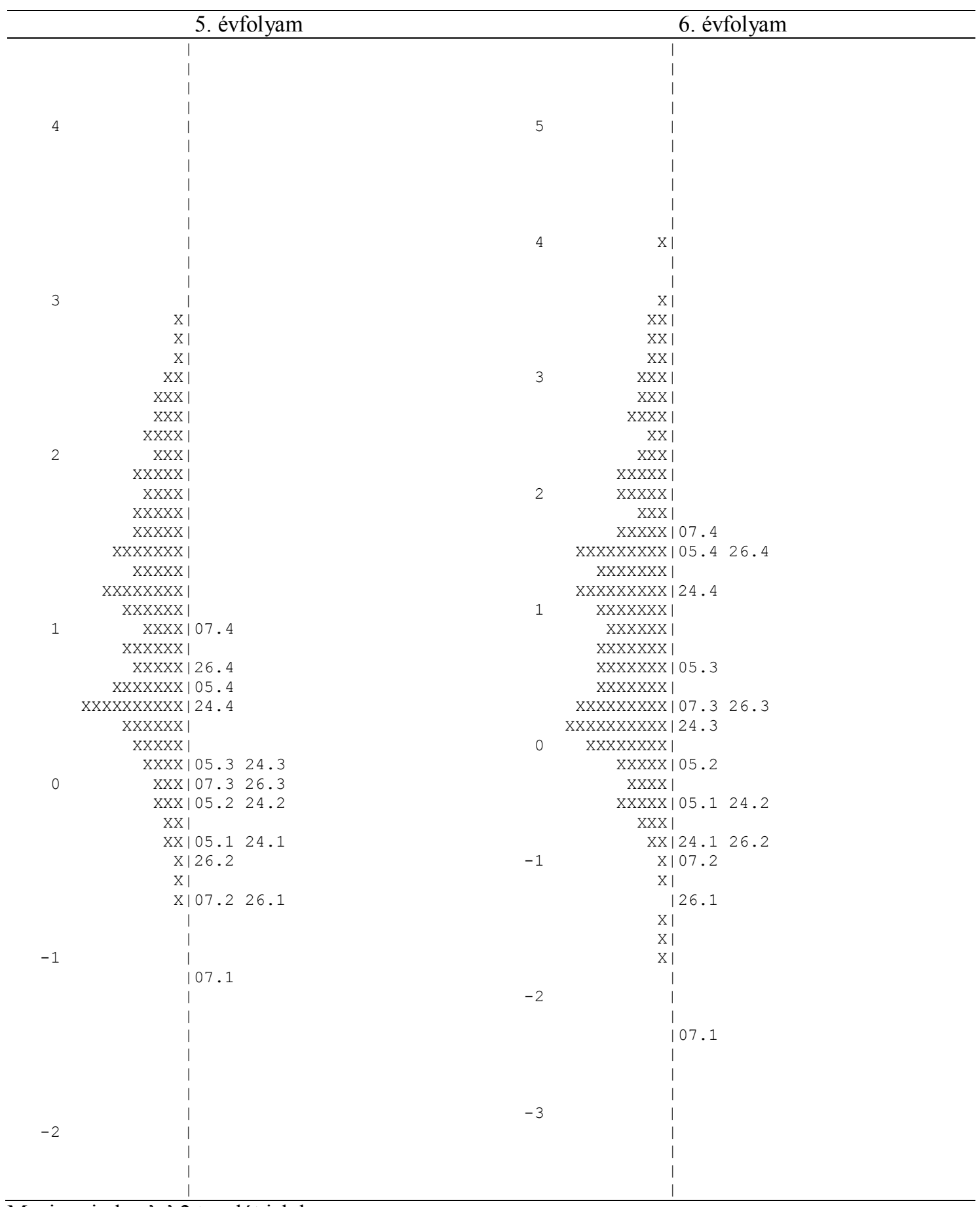

Megj.: minden 'x' 2 tanulót jelöl. 
31. melléklet. A tanulást kerülö cél személy-item térképe 7. és 8. évfolyamon a harmadik adatfelvétel alapján

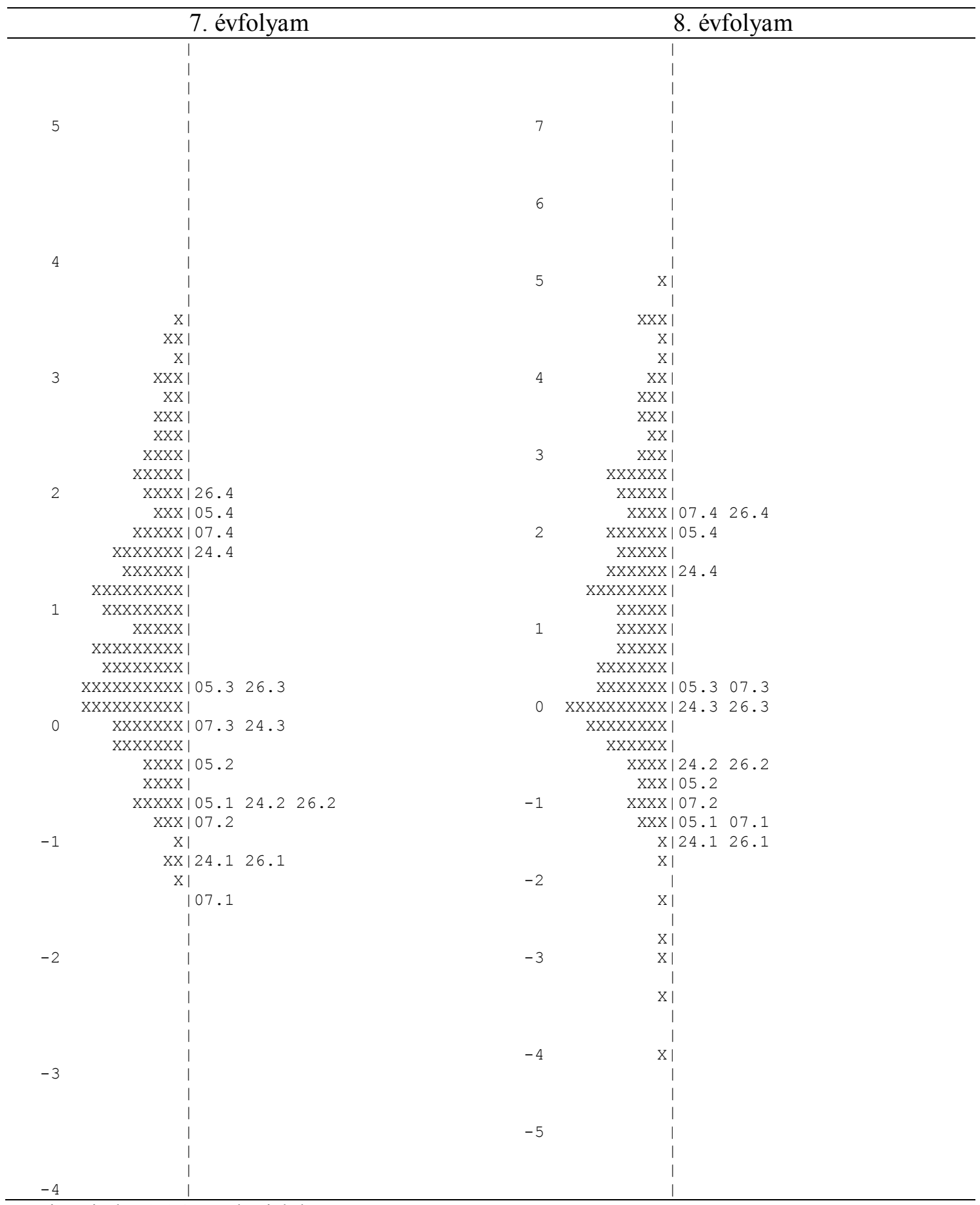

Megj.: minden 'x' 2 tanulót jelöl. 
32. melléklet. Az Osztálytermi környezet kérdöiv skálák szerint rendezett állitásai az elsö adatfelvétel során

\section{Kérdöivtételek}

\section{Elsajátítási célstruktúra}

Az osztályunkban fontos a kitartó munka matekból.

A tananyag megértése matekból fontos cél az osztályunkban.

Az új dolgok tanulása matekból fontos cél az osztályunkban.

A matekfeladatok megértése fontos cél az osztályunkban.

Az osztályunkban nem szégyen, ha gyakorlás közben hibázunk matekból.

Az osztályunkban nem baj, ha matekórán gyakorlás közben hibázunk.

Az osztályunkban fontos, hogy értsük is az anyagot matekból, ne csak bemagoljuk.

\section{Viszonyító célstruktúra}

Az osztályunkban fontos cél, hogy a többieknél jobb jegyet szerezzünk matekból.

Matekórán fontos az osztályunkban, hogy helyesen válaszoljunk a kérdésekre.

Az osztályunkban fontos, hogy magas pontszámot érjünk el a matekdolgozatban.

Az osztályunkban a tanulók próbálják megmutatni a többieknek, hogy jók matekból.

Az osztályunkban gyakran alakul ki verseny matekból.

Az osztályunkban a többség próbál a jó matekosok közé kell tartozni.

A jó jegy megszerzése matekból fontos cél az osztályunkban.

Az osztályunkban fontos megmutatni, hogy a többieknél nem vagyunk rosszabbak matekból.

Az osztályunkban fontos, hogy mások elött ne hibázzunk matekból.

Az osztályunkban fontos, hogy másoknál ne teljesítsünk rosszabbul matekból.

Az osztályunkban fontos, hogy ne tünjünk butának matekból.

Az osztályunkban fontos elkerülni annak látszatát, hogy nem tudjuk megoldani a matekfeladatokat.

Az osztályunkban fontos, hogy ne tünjön úgy, a matekfeladatok nehezek.

Matekórán az osztályunk ügyel arra, hogy ne látszódjon, ha valamit nem ért.

\section{Feladat}

Matekórán gyakran oldunk meg olyan feladatot, amivel iskolán kívül is találkozhatunk.

A matektanár számítógépet is használ az órákon.

Érdekes feladatokat oldunk meg matekórán.

$\mathrm{N} \quad$ A matekóráink unalmasak.

Matekórán olyan játékokat is játszani szoktunk, amiből tanulni lehet.

Matekórán előfordul, hogy nem ugyanazon a feladaton dolgozik minden tanuló.

\section{Irányítás}

Matekórán a tanulók beleszólhatnak abba, hogy milyen feladaton dolgozzanak.

Matekórán a tanulók maguk ellenőrzik le a feladatok megoldását.

A matektanár szorgalmi feladatot is szokott adni.

Matekórán megengedett, hogy saját gyorsaságuk szerint haladjanak a tanulók.

Ha valakinek rosszul sikerül a matekdolgozata megpróbálhatja újra.

Ha rossz jegyet kap valaki, a matektanár lehetőséget ad a javításra.

$\mathrm{N}$ A matektanárnak fontos, hogy a tanultak szerint oldjuk meg a feladatokat.

Matekórán a tanulók elmondhatják véleményüket.

N A matekóráinkon általában a tanár beszél, és a tanulók hallgatják.

\section{Csoportmunka}

A matektanár megengedi, hogy több tanuló együtt dolgozzon egy feladaton. 
N Matekórán a tanulók csak egyedül dolgozhatnak.

N Matekórán nem kérhetnek segítséget egymástól a tanulók.

$\mathrm{N}$ Matekórákon a tanulók nem beszélgethetnek egymással.

\section{Elismerés}

A matektanár értékelésnél elmondja, hogy miben vagyunk jobbak, mint korábban.

A matektanár észreveszi, ha jobban tudunk valamit, mint korábban.

A matektanár tényleg komolyan gondolja, ha megdicsér egy tanulót.

A matektanár a dolgozatban akkor is ad pontot egy feladatra, ha nem jó a végeredménye.

A matektanár figyelembe veszi a tanulók szorgalmát is az értékelésnél.

A matektanár észreveszi, ha sokat készülünk az órára.

\section{Értékelés szigora}

Szigorú az osztályzás matekból.

A magas követelmények miatt nehéz jó jegyet szerezni matekból.

Matekból kevés jó jegy születik az osztályunkban.

\section{Értékelés jelentösége}

Matekórán a tanulásnál fontosabb, hogy ellenőrizzük a feladatok megoldását.

Matekórán sok idő megy el a feladatok megoldásának ellenőrzésével.

Matekórán gyakran beszélünk arról, hogy milyen feladatok lesznek a dolgozatban.

Matekórákon általában a következő matekdolgozatra készíti fel az osztályt a tanár.

Sok dolgozatot írunk matekból.

\section{Normaorientált értékelés}

Ha csoportban kell dolgozni a jó és rossz matekosok külön csoportba kerülnek.

A tanulóknak gyakran kell versenyezniük a jó jegyért matekból.

Matekórán az kaphat jó jegyet, aki a többieknél jobb volt.

A matektanár példaként állítja elénk azokat a tanulókat, akik jó jegyet kaptak.

A matektanár el szokta mondani az osztály előtt, hogy kinek sikerült jól a dolgozata.

A matektanár rossz példaként állítja elénk azokat a tanulókat, akik rossz jegyet kaptak.

A matektanár el szokta mondani az osztály előtt, hogy kinek sikerült rosszul a dolgozata.

\section{Idö}

N Matekórán olyan gyorsan haladunk, hogy általában nincs idő a kérdezésre.

N Matekórán olyan gyorsan haladunk, hogy alig lehet érteni a tananyagot.

N A matektanár kevés időt ad órán a feladatok megoldására.

A matektanár elég időt szokott hagyni arra, hogy az osztály megértse az anyagot.

\section{Tanár-diák kapcsolat}

Jóban vagyok a matektanárral.

Úgy érzem, a matektanár szeret engem.

Kedvelem a matektanárt.

A matektanár az egyik kedvenc tanárom.

$\mathrm{N}$ Nem vagyok jóban a matektanárral.

Megj.: az N negatív megfogalmazású tételt jelöl. 
33. melléklet. A célstruktúrák kérdöivtételeinek faktoranalízise évfolyamonként a próbamérés alapján

\begin{tabular}{|c|c|c|c|c|c|c|c|c|}
\hline \multirow{2}{*}{$\mathrm{KMO}$} & \multirow{2}{*}{\multicolumn{2}{|c|}{$\frac{4 . \text { évf. }}{0,76}$}} & \multirow{2}{*}{\multicolumn{2}{|c|}{$\frac{\text { 5. évf. }}{0,86}$}} & \multicolumn{2}{|c|}{ 6. évf. } & \multicolumn{2}{|c|}{ 7. évf. } \\
\hline & & & & & & & & \\
\hline & \multicolumn{8}{|c|}{ Faktorok } \\
\hline & 1. & 2. & 1. & 2. & 1. & 2. & 1. & 2. \\
\hline & Els. & Visz. & Els. & Visz. & Els. & Visz. & Els. & Visz. \\
\hline Saját érték & 3,0 & 2,4 & 3,1 & 2,8 & 2,4 & 2,3 & 2,8 & 2,7 \\
\hline Variancia $(\%)$ & 30,1 & 24,4 & 31,4 & 27,8 & 23,9 & 22,6 & 27,9 & 26,6 \\
\hline Kumulatív var. (\%) & 30,1 & 54,5 & 31,4 & 59,2 & 23,9 & 46,5 & 27,9 & 54,5 \\
\hline \multicolumn{9}{|l|}{ Kérdőívtételek* } \\
\hline \multicolumn{9}{|l|}{$\begin{array}{l}\text { Elsajátítási } \\
\text { célstruktúra }\end{array}$} \\
\hline 26. & $-0,22$ & 0,68 & 0,78 & 0,19 & 0,67 & 0,10 & 0,71 & 0,13 \\
\hline 6. & $-0,14$ & 0,63 & 0,73 & 0,07 & 0,61 & 0,18 & 0,68 & 0,28 \\
\hline 50. & 0,18 & 0,75 & $\mathbf{0 , 8 0}$ & 0,25 & 0,67 & 0,25 & 0,67 & 0,31 \\
\hline 42. & 0,08 & 0,67 & $\mathbf{0 , 8 0}$ & 0,24 & 0,79 & 0,07 & 0,71 & 0,29 \\
\hline 34. & $-0,07$ & 0,71 & 0,75 & 0,11 & 0,62 & $-0,11$ & $\mathbf{0 , 8 1}$ & $-0,02$ \\
\hline \multicolumn{9}{|l|}{$\begin{array}{l}\text { Viszonyító } \\
\text { célstruktúra }\end{array}$} \\
\hline 36. & 0,78 & 0,09 & 0,20 & 0,72 & 0,24 & 0,64 & 0,35 & 0,67 \\
\hline 28. & $\mathbf{0 , 8 4}$ & $-0,07$ & 0,29 & $\mathbf{0 , 6 6}$ & 0,15 & $\mathbf{0 , 7 0}$ & 0,24 & 0,64 \\
\hline 16. & 0,72 & $-0,10$ & 0,11 & 0,73 & $-0,07$ & 0,67 & 0,11 & $\mathbf{0 , 7 0}$ \\
\hline 65. & $\mathbf{0 , 7 7}$ & 0,06 & 0,16 & $\mathbf{0 , 7 3}$ & 0,00 & 0,68 & 0,13 & 0,75 \\
\hline 41. & $\mathbf{0 , 7 0}$ & $-0,15$ & 0,07 & 0,76 & 0,14 & $\mathbf{0 , 5 8}$ & 0,10 & 0,69 \\
\hline
\end{tabular}

Megj.: fökomponens analízis Varimax rotációval, forgatás előtt 1-nél nagyobb sajátértékü faktorok, a 0,4nél nagyobb faktorsúlyokat félkövér szedés jelzi; * a számok a kérdőívtétel sorszámát jelzik; var.=variancia. 
34. melléklet. Az Osztálytermi környezet kérdőiv tételeinek korrelációi a célstruktúrákkal évfolyamonként az elsö adatfelvétel alapján

\begin{tabular}{|c|c|c|c|c|c|c|c|c|c|c|c|c|}
\hline \multirow{3}{*}{ Skálák } & \multirow{3}{*}{ Kérdőivitételek } & \multirow{3}{*}{$\begin{array}{l}\text { Tétel- } \\
\text { szám }\end{array}$} & \multicolumn{10}{|c|}{ Évfolyam } \\
\hline & & & \multicolumn{2}{|c|}{4.} & \multicolumn{2}{|c|}{5.} & \multicolumn{2}{|c|}{6.} & \multicolumn{2}{|c|}{7.} & \multicolumn{2}{|c|}{ Összes } \\
\hline & & & Els. & Visz. & Els. & Visz. & Els. & Visz. & Els. & Visz. & Els. & Visz. \\
\hline \multirow{6}{*}{ Feladat } & $\begin{array}{l}\text { Matekórán gyakran oldunk meg olyan feladatot, } \\
\text { amivel iskolán kívül is találkozhatunk. }\end{array}$ & 1. & $\mathbf{0 , 3 4}$ & $-\mathbf{0 , 2 3}$ & $\mathbf{0 , 3 2}$ & 0,14 & 0,00 & $\mathbf{0 , 3 2}$ & $\mathbf{0 , 2 8}$ & 0,11 & $\mathbf{0 , 2 2}$ & $\mathbf{0 , 1 9}$ \\
\hline & A matektanár számítógépet is használ az órákon. & 19. & 0,02 & $-0,16$ & $-0,10$ & 0,02 & 0,11 & $\mathbf{0 , 3 0}$ & 0,11 & $\mathbf{0 , 3 2}$ & $-0,02$ & 0,15 \\
\hline & Érdekes feladatokat oldunk meg matekórán. & 27. & $\mathbf{0 , 4 5}$ & 0,03 & 0,51 & 0,36 & 0,28 & 0,13 & $\mathbf{0 , 4 0}$ & $\mathbf{0 , 3 2}$ & 0,48 & $\mathbf{0 , 3 3}$ \\
\hline & A matekóráink unalmasak. & 60. & $-0,23$ & 0,12 & $-0,25$ & $-0,02$ & $-0,21$ & $-0,08$ & $-0,32$ & $-0,32$ & $-0,31$ & $-0,14$ \\
\hline & $\begin{array}{l}\text { Matekórán olyan játékokat is játszani } \\
\text { szoktunk, amiból tanulni lehet. }\end{array}$ & 15. & $\mathbf{0 , 2 6}$ & $-0,13$ & $\mathbf{0 , 3 4}$ & $\mathbf{0 , 3 5}$ & 0,17 & 0,07 & $\mathbf{0 , 3 1}$ & 0,22 & $\mathbf{0 , 3 0}$ & $\mathbf{0 , 2 7}$ \\
\hline & $\begin{array}{l}\text { Matekórán előfordul, hogy nem ugyanazon a } \\
\text { feladaton dolgozik minden tanuló. }\end{array}$ & 5 & $\mathbf{0 , 2 1}$ & 0,16 & $\mathbf{0 , 2 9}$ & 0,16 & 0,02 & 0,04 & 0,03 & $-0,08$ & 0,16 & 0,09 \\
\hline \multirow{9}{*}{ Irányítás } & $\begin{array}{l}\text { Matekórán a tanulók beleszólhatnak abba, hogy } \\
\text { milyen feladaton dolgozzanak. }\end{array}$ & 2 & -( & 0,05 & 0,04 & 0,03 & 0,08 & 0,19 & 00 & 0,08 & 0,02 & 0,08 \\
\hline & $\begin{array}{l}\text { Matekórán a tanulók maguk ellenőrzik le a } \\
\text { feladatok megoldását. }\end{array}$ & 29. & 0,01 & 0,02 & 0,14 & 0,18 & $-0,04$ & $-0,04$ & 0,05 & 0,23 & 0,06 & 0,14 \\
\hline & A matektanár szorgalmi feladatot is szokott adni. & 2. & 0,29 & 0,03 & $\mathbf{0 , 2 3}$ & $\mathbf{0 , 3 4}$ & 0,14 & 0,09 & 0,23 & 0,04 & $\mathbf{0 , 1 9}$ & $\mathbf{0 , 1 9}$ \\
\hline & $\begin{array}{l}\text { Matekórán megengedett, hogy saját gyorsaságuk } \\
\text { szerint haladjanak a tanulók. }\end{array}$ & 58. & 0,19 & 0,26 & $\mathbf{0 , 2 9}$ & 0,29 & 0,16 & $-0,05$ & 0,28 & 0,16 & $\mathbf{0 , 2 0}$ & $\mathbf{0 , 2 0}$ \\
\hline & $\begin{array}{l}\text { Ha valakinek rosszul sikerül a matekdolgozata } \\
\text { megpróbálhatja újra. }\end{array}$ & 31. & 0,12 & 0,12 & $\mathbf{0 , 2 7}$ & $\mathbf{0 , 2 8}$ & 0,07 & 0,15 & $-0,04$ & $-0,21$ & 0,15 & 0,16 \\
\hline & $\begin{array}{l}\text { Ha rossz jegyet kap valaki, a matektanár } \\
\text { lehetóséget ad a javításra. }\end{array}$ & 46. & 0,13 & 0,05 & $\mathbf{0 , 3 8}$ & $\mathbf{0 , 2 8}$ & 0,10 & 0,11 & 0,02 & $-0,20$ & $\mathbf{0 , 2 3}$ & $\mathbf{0 , 1 6}$ \\
\hline & $\begin{array}{l}\text { A matektanárnak fontos, hogy a tanultak szerint } \\
\text { oldjuk meg a feladatokat. }\end{array}$ & 53. & $\mathbf{0 , 3 4}$ & $\mathbf{0 , 2 8}$ & $\mathbf{0 , 5 4}$ & $\mathbf{0 , 3 1}$ & $\mathbf{0 , 2 7}$ & $-0,06$ & $\mathbf{0 , 4 2}$ & 0,18 & $0, \mathbf{4 4}$ & $\mathbf{0 , 2 0}$ \\
\hline & Matekórán a tanulók elmondhatják véleményüket. & 47. & $\mathbf{0 , 2 3}$ & $-0,14$ & $\mathbf{0 , 3 3}$ & $\mathbf{0 , 2 7}$ & 0,15 & $-0,03$ & $-0,01$ & $-0,10$ & $\mathbf{0 , 1 8}$ & 0,10 \\
\hline & $\begin{array}{l}\text { A matekóráinkon általában a tanár beszél és a } \\
\text { tanulók hallgatják. }\end{array}$ & 21. & $-0,12$ & $\mathbf{0 , 3 7}$ & $\mathbf{0 , 3 2}$ & $\mathbf{0 , 2 2}$ & 0,06 & $-0,11$ & 0,10 & $-0,16$ & $\mathbf{0 , 2 3}$ & 0,06 \\
\hline \multirow{2}{*}{$\begin{array}{l}\text { Csoport- } \\
\text { munka }\end{array}$} & $\begin{array}{l}\text { A matektanár megengedi, hogy több tanuló } \\
\text { együtt dolgozzon egy feladaton. }\end{array}$ & 22. & 0,11 & $-0,15$ & $\mathbf{0 , 3 0}$ & $\mathbf{0 , 1 9}$ & $\mathbf{0 , 2 3}$ & $\mathbf{0 , 3 0}$ & 0,09 & 0,02 & $\mathbf{0 , 2 6}$ & 0,19 \\
\hline & Matekórán a tanulók csak egyedül dolgozhatnak. & 33. & $-0,04$ & $\mathbf{0 , 2 7}$ & 0,10 & $-0,03$ & $-0,07$ & 0,14 & 0,01 & 0,03 & 0,01 & 0,03 \\
\hline
\end{tabular}


Matekórán nem kérhetnek segítséget egymástól a tanulók.

Matekórákon a tanulók nem beszélgethetnek

egymással.

A matektanár értékelésnél elmondja, hogy miben vagyunk jobbak, mint korábban.

A matektanár észreveszi, ha jobban tudunk valamit, mint korábban.

A matektanár tényleg komolyan gondolja, ha megdicsér egy tanulót.

Elismerés A matektanár a dolgozatban akkor is ad pontot egy feladatra, ha nem jó a végeredménye.

A matektanár figyelembe veszi a tanulók szorgalmát is az értékelésnél.

A matektanár észreveszi, ha sokat készülünk az órára.

\begin{tabular}{|c|c|c|c|c|c|c|c|c|c|c|c|c|}
\hline & $\begin{array}{l}\text { A matektanár észreveszi, ha sokat készülünk } \\
\text { az órára. }\end{array}$ & 54. & $\mathbf{0 , 5 0}$ & $-0,23$ & $\mathbf{0 , 6 0}$ & 0,43 & 0,18 & 0,01 & $\mathbf{0 , 4 0}$ & 0,14 & 0,45 & $\mathbf{0 , 2 6}$ \\
\hline \multirow{3}{*}{$\begin{array}{l}\text { Értékelés } \\
\text { szigora }\end{array}$} & Szigorú az osztályzás matekból. & 17. & 0,04 & $\mathbf{0 , 2 3}$ & $-0,02$ & 0,11 & 0,04 & 0,08 & $-0,07$ & $-0,07$ & $-0,01$ & 0,06 \\
\hline & $\begin{array}{l}\text { A magas követelmények miatt nehéz jó jegyet } \\
\text { szerezni matekból. }\end{array}$ & 10. & $-0,20$ & $\mathbf{0 , 1 9}$ & $-0,25$ & 0,06 & $-0,01$ & 0,13 & $-0,19$ & $-0,02$ & $-0,16$ & 0,07 \\
\hline & Matekból kevés jó jegy születik az osztályunkban. & 44. & $-0,03$ & 0,24 & 0,03 & 0,08 & 0,03 & 0,06 & $-0,07$ & $-0,04$ & $-0,01$ & 0,04 \\
\hline \multirow{5}{*}{$\begin{array}{l}\text { Értékelés } \\
\text { jelentő- } \\
\text { sége }\end{array}$} & $\begin{array}{l}\text { Matekórán a tanulásnál fontosabb, hogy } \\
\text { ellenőrizzük a feladatok megoldását. }\end{array}$ & 55. & 0,12 & 0,08 & 0,15 & 0,29 & 0,21 & 0,20 & 0,19 & 0,06 & $\mathbf{0 , 1 8}$ & 0,22 \\
\hline & $\begin{array}{l}\text { Matekórán sok idő megy el a feladatok } \\
\text { megoldásának ellenőrzésével. }\end{array}$ & 11. & $-0,09$ & $\mathbf{0 , 3 8}$ & 0,13 & 0,20 & 0,12 & 0,18 & $-0,31$ & $-0,18$ & $-0,04$ & 0,07 \\
\hline & $\begin{array}{l}\text { Matekórán gyakran beszélünk arról, hogy } \\
\text { milyen feladatok lesznek a dolgozatban. }\end{array}$ & 62. & $\mathbf{0 , 3 2}$ & $-0,02$ & 0,42 & 0,40 & $\mathbf{0 , 3 2}$ & 0,12 & 0,24 & 0,01 & $\mathbf{0 , 3 5}$ & 0,24 \\
\hline & $\begin{array}{l}\text { Matekórákon általában a következő } \\
\text { matekdolgozatra készíti fel az osztályt a tanár. }\end{array}$ & 3. & $-0,06$ & 0,44 & 0,24 & $\mathbf{0 , 3 3}$ & 0,11 & 0,04 & 0,25 & 0,01 & 0,23 & 0,19 \\
\hline & Sok dolgozatot írunk matekból. & 37. & 0,12 & $\mathbf{0 , 2 0}$ & 0,02 & 0,17 & 0,03 & $-0,11$ & 0,18 & $-0,17$ & $-0,01$ & 0,11 \\
\hline \multirow{2}{*}{$\begin{array}{l}\text { Norma- } \\
\text { orientált } \\
\text { értékelés }\end{array}$} & $\begin{array}{l}\text { Ha csoportban kell dolgozni a jó és rossz } \\
\text { matekosok külön csoportba kerülnek. }\end{array}$ & 23 & $-0,34$ & $\mathbf{0 , 3 9}$ & 0,12 & 0,15 & $-0,08$ & 0,14 & 0,14 & 0,28 & 0,10 & 0,19 \\
\hline & $\begin{array}{l}\text { A tanulóknak gyakran kell versenyezniük a jó } \\
\text { jegyért matekból. }\end{array}$ & 40 & $-0,26$ & $\mathbf{0 , 4 7}$ & 0,07 & $-0,36$ & 0,03 & $\mathbf{0 , 3 9}$ & 0,04 & $\mathbf{0 , 3 7}$ & 0,08 & 0,38 \\
\hline
\end{tabular}




\begin{tabular}{|c|c|c|c|c|c|c|c|c|c|c|c|}
\hline $\begin{array}{l}\text { Matekórán az kaphat jó jegyet, aki a } \\
\text { többieknél jobb volt. }\end{array}$ & 64. & $-0,03$ & $\mathbf{0 , 4 0}$ & 0,08 & 0,25 & 0,01 & 0,24 & $-0,07$ & 0,10 & 0,01 & 0,20 \\
\hline $\begin{array}{l}\text { A matektanár példaként állítja elénk azokat a } \\
\text { tanulókat, akik jó jegyet kaptak. }\end{array}$ & 4. & $-0,01$ & $\mathbf{0 , 3 6}$ & $\mathbf{0 , 1 9}$ & $\mathbf{0 , 2 8}$ & 0,22 & 0,24 & $-0,24$ & $-0,03$ & 0,09 & 0,19 \\
\hline $\begin{array}{l}\text { A matektanár el szokta mondani az osztály előtt, } \\
\text { hogy kinek sikerült jól a dolgozata. }\end{array}$ & 35. & 0,24 & $\mathbf{0 , 3 2}$ & 0,44 & $\mathbf{0 , 2 2}$ & 0,20 & 0,20 & $-0,17$ & $-0,03$ & 0,24 & $\mathbf{0 , 1 7}$ \\
\hline $\begin{array}{l}\text { A matektanár rossz példaként állítja elénk azokat } \\
\text { a tanulókat, akik rossz jegyet kaptak. }\end{array}$ & 25 & $-0,25$ & $\mathbf{0 , 3 2}$ & $-0,01$ & 0,14 & 0,01 & 0,22 & $-\mathbf{- 0 , 3 3}$ & $-0,18$ & $-0,11$ & 0,07 \\
\hline $\begin{array}{l}\text { A matektanár el szokta mondani az osztály előtt, } \\
\text { hogy kinek sikerült rosszul a dolgozata. }\end{array}$ & 12. & 0,18 & $\mathbf{0 , 2 5}$ & 0,18 & 0,11 & 0,14 & 0,13 & $-0,21$ & $-0,16$ & 0,09 & 07 \\
\hline $\begin{array}{l}\text { Matekórán olyan gyorsan haladunk, hogy } \\
\text { általában nincs idő a kérdezésre. }\end{array}$ & 49. & $-0,14$ & $\mathbf{0 , 2 3}$ & 0,00 & 0,06 & $-0,13$ & 0,12 & $-0,03$ & 0,06 & $-0,06$ & 0,08 \\
\hline $\begin{array}{l}\text { Matekórán olyan gyorsan haladunk, hogy alig } \\
\text { lehet érteni a tananyagot. }\end{array}$ & 63. & $-0,37$ & $\mathbf{0 , 2 8}$ & $-0,08$ & $-0,01$ & $-0,16$ & 0,04 & $-0,02$ & 0,10 & $-0,13$ & 0,00 \\
\hline $\begin{array}{l}\text { A matektanár kevés időt ad órán a feladatok } \\
\text { megoldására. }\end{array}$ & 24. & $-0,27$ & $\mathbf{0 , 3 7}$ & $-0,02$ & 0,04 & $-0,03$ & $-0,05$ & $-0,15$ & $-0,05$ & $-0,08$ & $-0,00$ \\
\hline $\begin{array}{l}\text { A matektanár elég időt szokott hagyni arra, hogy } \\
\text { Iz osztály megértse az anyagot. }\end{array}$ & 56. & $\mathbf{0 , 5 2}$ & 0,00 & $\mathbf{0 , 5 5}$ & $\mathbf{0 , 3 5}$ & $\mathbf{0 , 3 3}$ & 0,13 & $\mathbf{0 , 2 8}$ & 0,05 & $\mathbf{0 , 4 5}$ & $\mathbf{0 , 2 4}$ \\
\hline
\end{tabular}

az osztály megértse az anyagot.

Megj.: félkövér szedés jelzi azokat az értékeket, ahol az összefüggés 0,01 alatti szinten szignifikáns; dőlt és félkövér szedés jelzi azokat az értékeket, ahol az összefüggés 0,01 és 0,05 közötti szinten szignifikáns; félkövér szedés jelzi azokat az állításokat, amelyeket megtartottunk a próbamérés után; Els.=elsajátítási célstruktúra, Visz.=viszonyító célstruktúra. 
35. melléklet. A célorientációk és tanár-diák kapcsolat faktoranalizise az elsö mérés alapján

\begin{tabular}{|c|c|c|c|c|c|}
\hline & \multicolumn{5}{|c|}{ Faktorok } \\
\hline & 1. & 2. & 3. & 4. & 5. \\
\hline & $\begin{array}{c}\text { Elsajátítási } \\
\text { teljesítmény- } \\
\text { kereső cél }\end{array}$ & $\begin{array}{c}\text { Tanár- } \\
\text { diák } \\
\text { kapcsolat }\end{array}$ & $\begin{array}{c}\text { Tanulást } \\
\text { kerülő } \\
\text { cél }\end{array}$ & $\begin{array}{c}\text { Elsajátítási } \\
\text { teljesítmény- } \\
\text { kerülő cél }\end{array}$ & $\begin{array}{c}\text { Viszonyító } \\
\text { teljesítmény- } \\
\text { kereső cél }\end{array}$ \\
\hline Saját érték & 2,8 & 2,3 & 2,2 & 1,9 & 1,3 \\
\hline Var. (\%) & 18,5 & 15,6 & 14,6 & 12,5 & 8,8 \\
\hline $\begin{array}{l}\text { Kumulatív } \\
\text { var. }(\%)\end{array}$ & 18,5 & 34,1 & 48,7 & 61,2 & 70,0 \\
\hline $\begin{array}{l}\text { Kérdőív- } \\
\text { tételek* } \\
\text { Elsajátítási } \\
\text { teljesítmény- } \\
\text { kereső cél }\end{array}$ & & & & & \\
\hline 08 & $\mathbf{0 , 8 2}$ & 0,14 & 0,14 & $-0,01$ & 0,05 \\
\hline 22 & 0,76 & 0,24 & 0,17 & $-0,06$ & 0,03 \\
\hline 30 & $\mathbf{0 , 8 0}$ & 0,20 & 0,15 & $-0,06$ & 0,00 \\
\hline 38 & 0,72 & 0,27 & 0,30 & $-0,08$ & 0,02 \\
\hline $\begin{array}{l}\text { Elsajátítási } \\
\text { teljesítmény- } \\
\text { kerülő cél }\end{array}$ & & & & & \\
\hline 09 & 0,01 & $-0,06$ & 0,04 & 0,04 & $\mathbf{0 , 8 1}$ \\
\hline 17 & 0,05 & 0,05 & 0,00 & 0,03 & $\mathbf{0 , 8 0}$ \\
\hline $\begin{array}{l}\text { Viszonyító } \\
\text { teljesítmény- } \\
\text { kereső cél }\end{array}$ & & & & & \\
\hline 29 & 0,20 & 0,11 & 0,78 & 0,05 & $-0,02$ \\
\hline 46 & 0,24 & 0,10 & $\mathbf{0 , 8 2}$ & 0,10 & $-0,01$ \\
\hline 57 & 0,13 & 0,10 & $\mathbf{0 , 8 3}$ & 0,01 & 0,08 \\
\hline $\begin{array}{l}\text { Tanulást } \\
\text { kerülő cél }\end{array}$ & & & & & \\
\hline 13 & 0,03 & $-0,03$ & 0,10 & $\mathbf{0 , 8 5}$ & $-0,06$ \\
\hline 19 & 0,03 & $-0,05$ & 0,08 & $\mathbf{0 , 8 5}$ & 0,01 \\
\hline 53 & $-0,23$ & $-0,07$ & $-0,05$ & 0,62 & 0,15 \\
\hline $\begin{array}{l}\text { Tanár-diák } \\
\text { kapcsolat }\end{array}$ & & & & & \\
\hline 10 & 0,20 & $\mathbf{0 , 8 8}$ & 0,08 & $-0,01$ & 0,01 \\
\hline 44 & 0,30 & $\mathbf{0 , 7 7}$ & 0,14 & $-0,10$ & $-0,03$ \\
\hline 16 & 0,23 & $\mathbf{0 , 8 6}$ & 0,11 & $-0,07$ & 0,00 \\
\hline
\end{tabular}

Megj.: fökomponens analízis Varimax rotációval, forgatás előtt 1-nél nagyobb sajátértékü faktorok, a 0,4nél nagyobb faktorsúlyokat félkövér szedés jelzi, $\mathrm{KMO}=0,83$; * a számok a kérdőívtétel sorszámát jelzik; var.=variancia. 
36. melléklet. Az Osztálytermi környezet kérdöív skálák szerint rendezett állításai a harmadik adatfelvétel során

\section{Tanári támogatás}

\section{Kérdöivtételek}

A tanár érdeklődést mutat minden diák tanulása iránt.

A tanár külön segítséget nyújt, ha a diákoknak szükségük van rá.

N A tanulók könyvekből és egyéb nyomtatott anyagból dolgoznak.

A tanár segít a diákoknak a tanulásban.

A tanár addig magyarázza az anyagot, amíg mindenki meg nem érti.

A tanár lehetővé teszi a diákok számára, hogy kifejtsék véleményüket.

\section{Fegyelmezési problémák}

A diákok nem figyelnek oda arra, amit a tanár mond.

Az órán zaj és fegyelmezetlenség van.

A tanárnak sokáig kell várnia arra, hogy az osztály elcsendesedjen.

A diákok nem tudnak jól dolgozni.

A diákok az óra kezdete után még sokáig nem látnak munkához.

\section{Odatartozás érzése}

$\mathrm{N}$ Az osztályomban ... kívülállónak érzem magam (kimaradok a dolgokból).

Az osztályomban ... könnyen barátkozom.

Az osztályomban ... úgy érzem, tartozom valahová.

$\mathrm{N}$ Az osztályomban ... feszélyezve érzem magam és nem találom a helyem.

Az osztályomban ... úgy érzem, az osztálytársaim szeretnek engem.

$\mathrm{N}$ Az osztályomban ... magányos vagyok.

\section{Pozitív osztálylégkör}

Nálunk az osztályban ... megbízunk egymásban.

Nálunk az osztályban ... segítünk osztálytársainknak, ha valakinek segítségre van szüksége.

Nálunk az osztályban ... senkit sem zárunk ki az osztályközösségből.

Nálunk az osztályban ... szívesen vagyunk együtt.

N Nálunk az osztályban ... a közösség klikkekre bomlik.

Nálunk az osztályban ... sok tanuló szabadidejében is találkozik egymással.

N Nálunk az osztályban ... a gyenge képességü tanulókat kevésbé fogadják el.

N Nálunk az osztályban ... inkább egymás ellen dolgoznak a diákok, mintsem együtt.

N Nálunk az osztályban ... vannak olyanok, akik másokról rosszakat mondanak.

Nálunk az osztályban ... a legtöbb diák jól kijön egymással.

\section{A matematikatanár szabályorientált viselkedése}

A matektanárnak világos szabályai és elöírásai vannak arról, hogy hogyan viselkedjünk.

A matektanár figyel arra, hogy az iskolában érvényes szabályokat kövessük.

A matektanár az akarja, hogy mindig az ő szabályait kövessük.

A matektanár pontosan meghatározza, hogy mit tehetünk és mit nem.

\section{Kölcsönös tisztelet támogatása}

A matektanár azt akarja, hogy a tanulók tartsák tiszteletben egymás ötleteit, elképzeléseit.

A matektanár nem engedi, hogy a tanulók kinevessék egymás ötleteit, elképzeléseit.

A matektanár nem engedi, hogy kinevessük azt, aki rossz választ ad.

A matektanár nem engedi, hogy a tanulók rosszat mondjanak egymásról.

A matektanár azt akarja, hogy a tanulók tiszteljék egymást. 


\section{Tanár-diák kapcsolat}

Jóban vagyok a matektanárral.

Úgy érzem, a matektanár szeret engem.

Kedvelem a matektanárt.

\section{Elsajátítási célstruktúra}

Az osztályunkban fontos a kitartó munka matekból.

A tananyag megértése matekból fontos cél az osztályunkban.

Az új dolgok tanulása matekból fontos cél az osztályunkban.

A matekfeladatok megértése fontos cél az osztályunkban.

Az osztályunkban fontos, hogy értsük is az anyagot matekból, ne csak bemagoljuk.

\section{Viszonyító célstruktúra}

Az osztályunkban fontos cél, hogy a többieknél jobb jegyet szerezzünk matekból. Az osztályunkban fontos megmutatni, hogy a többieknél nem vagyunk rosszabbak matekból.

Az osztályunkban fontos, hogy mások elött ne hibázzunk matekból.

Az osztályunkban fontos, hogy ne tünjünk butának matekból.

Az osztályunkban fontos, hogy ne tünjön úgy, a matekfeladatok nehezek.

\section{Elismerés}

A matektanár észreveszi, ha jobban tudunk valamit, mint korábban.

A matektanár tényleg komolyan gondolja, ha megdicsér egy tanulót.

A matektanár észreveszi, ha sokat készülünk az órára.

A matektanár elismeri, ha valaki rendesen dolgozik.

\section{Normaorientált értékelés}

A matektanár példaként állítja elénk azokat a tanulókat, akik jó jegyet kaptak.

Matekórán az kaphat jó jegyet, aki a többieknél jobb volt.

Matekórán versenyezni kell a tanulóknak a jó jegyért.

A matektanár versenyezteti a tanulókat a jó jegyért.

A matektanár példaként állítja elénk azokat a tanulókat, akik jó dolgozatot írtak.

\section{Feladat}

Érdekes feladatokat oldunk meg matekórán.

$\mathrm{N} \quad$ A matekóráink unalmasak.

Matekórán olyan játékokat is játszani szoktunk, amiből tanulni lehet.

Olyan feladatokat oldunk meg matekórán, amelyek az iskolán kívül is hasznosak.

A matekóráink gyorsan eltelnek.

Hasznos feladatokat oldunk meg matekórán.

Változatos feladatokat oldunk meg matekórán.

\section{Tanulók csoportosítása}

Ha csoportban kell dolgozni a jó és rossz matekosok külön csoportba kerülnek.

A jobb matekosok nehezebb feladatokat szoktak kapni.

A gyengébb matekosok könnyebb feladatokat szoktak kapni.

\section{Csoportmunka}

A matektanár megengedi, hogy több tanuló együtt dolgozzon egy feladaton.

A matektanár adni szokott, olyan feladatot, amit több tanulónak kell megoldania együtt.

Matekórán vannak olyan feladatok, amin a tanulók közösen dolgozhatnak.

$\mathrm{N} \quad$ Matekórán minden feladatot egyedül kell megoldanunk.

\section{Egyéni felelösséget hangsúlyozó számonkérés}

Ha valakinek rosszul sikerül a matekdolgozata megpróbálhatja újra.

Ha rossz jegyet kap valaki, a matektanár lehetőséget ad a javításra.

Matekórán gyakran beszélünk arról, hogy milyen feladatok lesznek a dolgozatban. 
A matektanár el szokta mondani, hogy milyen típusú feladatok lesznek a dolgozatban.

Tudni szoktuk elöre, ha matekból dolgozatot írunk.

$\mathrm{N}$ Váratlanul írunk dolgozatot matekból.

Megj.: az N negatív megfogalmazású tételt jelöl.

37. melléklet. A célorientációk jellemzöi a teljes mintán

\begin{tabular}{lcc}
\hline \multicolumn{1}{c}{ Célok } & Átlag & Szórás \\
\hline Elsajátítási teljesítmény-kereső cél & 4,07 & 0,82 \\
Elsajátítási teljesítmény-kerülö cél & 3,18 & 1,07 \\
Viszonyító teljesítmény-kereső cél & 3,04 & 1,22 \\
Viszonyító teljesítmény-kerülő cél & 3,85 & 0,96 \\
Tanulást kerülö cél & 3,15 & 0,95 \\
\hline
\end{tabular}


38. melléklet. A tanári tevékenységeket és a társas környezetet leiró változók közötti korrelációk 5. évfolyamon

\begin{tabular}{|c|c|c|c|c|c|c|c|c|}
\hline Tanári tevékenységek, társas környezet & 1. & 2. & 3. & 4. & 5. & 6. & 7. & 8. \\
\hline 3. Pozitív osztálylégkör & 0,22 & $-0,19$ & - & & & & & \\
\hline 5. Tanulók közötti kölcsönös tisztelet támogatása & $\mathbf{0 , 3 2}$ & $-0,09$ & $-0,02$ & $\mathbf{0 , 2 8}$ & - & & & \\
\hline 6. Feladat & 0,44 & $-0,29$ & 0,05 & 0,40 & $\mathbf{0 , 3 4}$ & - & & \\
\hline 7. Versenyeztetés & 0,02 & $\mathbf{0 , 2 7}$ & $-0,11$ & 0,28 & $-0,09$ & 0,01 & - & \\
\hline 8. Tanulók csoportosítása & 0,06 & 0,25 & $-0,04$ & $\mathbf{0 , 2 3}$ & 0,07 & 0,12 & 0,42 & - \\
\hline
\end{tabular}

Megj.: félkövér szedés jelzi a 0,01 alatti szinten szignifikáns összefüggéseket; dőlt és félkövér szedés jelzi a 0,01 és 0,05 közötti szinten szignifikáns összefüggéseket.

39. melléklet. A tanári tevékenységeket és a társas környezetet leiró változók közötti korrelációk 6. évfolyamon

\begin{tabular}{|c|c|c|c|c|c|c|c|c|}
\hline Tanári tevékenységek, társas környezet & 1. & 2. & 3. & 4. & 5. & 6. & 7. & 8. \\
\hline 3. Pozitív osztálylégkör & $\mathbf{0 , 2 3}$ & $-0,17$ & - & & & & & \\
\hline 5. Tanulók közötti kölcsönös tisztelet támogatása & $\mathbf{0 , 3 7}$ & $-0,24$ & 0,03 & $\mathbf{0 , 3 3}$ & - & & & \\
\hline 6. Feladat & $\mathbf{0 , 5 6}$ & $-0,16$ & $\mathbf{0 , 2 4}$ & $\mathbf{0 , 2 0}$ & $\mathbf{0 , 4 0}$ & - & & \\
\hline 7. Versenyeztetés & $-0,03$ & 0,09 & 0,09 & 0,15 & $-0,02$ & $-\mathbf{0 , 0 2}$ & - & \\
\hline 8. Tanulók csoportosítása & 0,14 & $\mathbf{0 , 3 2}$ & 0,03 & 0,03 & 0,05 & 0,17 & 0,15 & - \\
\hline
\end{tabular}

Megj.: félkövér szedés jelzi a 0,01 alatti szinten szignifikáns összefüggéseket; dőlt és félkövér szedés jelzi a 0,01 és 0,05 közötti szinten szignifikáns összefüggéseket. 
40. melléklet. A tanári tevékenységeket és a társas környezetet leiró változók közötti korrelációk 7. évfolyamon

\begin{tabular}{|c|c|c|c|c|c|c|c|c|}
\hline Tanári tevékenységek, társas környezet & 1. & 2. & 3. & 4. & 5. & 6. & 7. & 8. \\
\hline 3. Pozitív osztálylégkör & 0,24 & $-0,15$ & - & & & & & \\
\hline 4. A matematikatanár szabályorientált viselkedése & 0,18 & $-0,27$ & 0,01 & - & & & & \\
\hline 5. Tanulók közötti kölcsönös tisztelet támogatása & 0,46 & $-0,24$ & 0,15 & 0,11 & - & & & \\
\hline 6. Feladat & 0,59 & $-0,28$ & $\mathbf{0 , 3 3}$ & 0,23 & 0,45 & - & & \\
\hline 7. Versenyeztetés & 0,01 & $-0,01$ & $-0,16$ & 0,35 & $-0,03$ & 0,04 & - & \\
\hline 8. Tanulók csoportosítása & 0,14 & 0,11 & 0,08 & 0,19 & 0,00 & 0,19 & 0,24 & - \\
\hline
\end{tabular}

41. melléklet. A tanári tevékenységeket és a társas környezetet leiró változók közötti korrelációk 8. évfolyamon

\begin{tabular}{|c|c|c|c|c|c|c|c|c|}
\hline Tanári tevékenységek, társas környezet & 1. & 2. & 3. & 4. & 5. & 6. & 7. & 8. \\
\hline 1. Tanári támogatás & - & & & & & & & \\
\hline 3. Pozitív osztálylégkör & $\mathbf{0 , 2 1}$ & $-0,18$ & - & & & & & \\
\hline 5. Tanulók közötti kölcsönös tisztelet támogatása & 0,48 & $-0,25$ & 0,16 & 0,14 & - & & & \\
\hline 6. Feladat & $\mathbf{0 , 5 8}$ & $-0,26$ & 0,22 & 0,06 & $\mathbf{0 , 4 7}$ & - & & \\
\hline 7. Versenyeztetés & 0,00 & $\mathbf{0 , 2 3}$ & $-0,03$ & 0,07 & $-0,11$ & $-0,02$ & - & \\
\hline
\end{tabular}

Megj.: félkövér szedés jelzi a 0,01 alatti szinten szignifikáns összefüggéseket; dőlt és félkövér szedés jelzi a 0,01 és 0,05 közötti szinten szignifikáns összefüggéseket. 
42. melléklet. A célorientációk korrelációi a tanári tevékenységekkel és a társas környezetet leíró változókkal 5. évfolyamon

\begin{tabular}{lccccc}
\hline \multirow{2}{*}{$\begin{array}{c}\text { Tanári tevékenységek, társas } \\
\text { környezet }\end{array}$} & $\begin{array}{c}\text { Els. telj. } \\
\text { keresö }\end{array}$ & $\begin{array}{c}\text { Els. telj. } \\
\text { kerülö }\end{array}$ & $\begin{array}{c}\text { Visz. telj. } \\
\text { keresó }\end{array}$ & $\begin{array}{c}\text { Visz. telj. } \\
\text { kerülö }\end{array}$ & $\begin{array}{c}\text { Tan. } \\
\text { kerülö }\end{array}$ \\
\hline Tanári támogatás & $\mathbf{0 , 2 7}$ & 0,08 & 0,14 & $\mathbf{0 , 1 7}$ & 0,01 \\
Fegyelmezési problémák & $\mathbf{- 0 , 3 4}$ & 0,05 & $-0,07$ & $-0,08$ & $\mathbf{0 , 1 7}$ \\
Pozitív osztálylégkör & 0,11 & $-0,06$ & 0,00 & 0,13 & $-0,01$ \\
A matematikatanár & $\mathbf{0 , 1 6}$ & $\mathbf{0 , 1 4}$ & $\mathbf{0 , 2 2}$ & $\mathbf{0 , 1 6}$ & $\mathbf{0 , 2 1}$ \\
szabályorientált viselkedése & & & & & \\
Tanulók közötti kölcsönös & $\mathbf{0 , 1 9}$ & $\mathbf{0 , 3 0}$ & 0,12 & 0,06 & 0,06 \\
tisztelet támogatása & $\mathbf{0 , 3 7}$ & 0,11 & $\mathbf{0 , 2 7}$ & $\mathbf{0 , 2 1}$ & 0,05 \\
Feladat & $-0,11$ & $-0,07$ & $\mathbf{0 , 2 4}$ & 0,04 & $\mathbf{0 , 1 7}$ \\
Versenyeztetés & $-0,03$ & $-0,02$ & $\mathbf{0 , 2 0}$ & $\mathbf{0 , 2 3}$ & $\mathbf{0 , 2 6}$ \\
Tanulók csoportosítása & $\mathbf{0 , 3 4}$ & 0,09 & $\mathbf{0 , 1 8}$ & $\mathbf{0 , 1 6}$ & 0,02 \\
$\begin{array}{l}\text { Egyéni felelösséget } \\
\text { hangsúlyozó számonkérés }\end{array}$ & & &
\end{tabular}

Megj.: félkövér szedés jelzi a 0,01 alatti szinten szignifikáns összefüggéseket; dőlt és félkövér szedés jelzi a 0,01 és 0,05 közötti szinten szignifikáns összefüggéseket. Els. telj. kereső: elsajátítási teljesítménykereső; Els. telj. kerülő: elsajátítási teljesítménykerülő; Visz. telj. kereső: viszonyító teljesítménykereső; Visz. telj. kerülő: viszonyító teljesítménykerülő; Tan. kerülő: tanulást kerülő.

43. melléklet. A célorientációk korrelációi a tanári tevékenységekkel és a társas környezetet leíró változókkal 6. évfolyamon

\begin{tabular}{|c|c|c|c|c|c|}
\hline \multirow[b]{2}{*}{$\begin{array}{c}\text { Tanári tevékenységek, társas } \\
\text { környezet }\end{array}$} & \multicolumn{5}{|c|}{ Célok } \\
\hline & $\begin{array}{c}\text { Els. telj. } \\
\text { keresö }\end{array}$ & $\begin{array}{c}\text { Els. telj. } \\
\text { kerü̈lö }\end{array}$ & $\begin{array}{c}\text { Visz. telj. } \\
\text { keresö }\end{array}$ & $\begin{array}{l}\text { Visz. telj. } \\
\text { kerülö }\end{array}$ & $\begin{array}{l}\text { Tan. } \\
\text { kerüló }\end{array}$ \\
\hline Tanári támogatás & 0,18 & $-0,01$ & 0,10 & 0,08 & $-0,07$ \\
\hline Fegyelmezési problémák & $-0,16$ & $-0,21$ & 0,05 & $-0,18$ & 0,16 \\
\hline Pozitív osztálylégkör & 0,24 & 0,07 & 0,14 & 0,15 & $-0,09$ \\
\hline $\begin{array}{l}\text { A matematikatanár } \\
\text { szabályorientált viselkedése }\end{array}$ & 0,24 & 0,08 & 0,24 & 0,22 & 0,11 \\
\hline $\begin{array}{l}\text { Tanulók közötti kölcsönös } \\
\text { tisztelet támogatása }\end{array}$ & $\mathbf{0 , 1 8}$ & 0,12 & 0,15 & 0,22 & $-0,03$ \\
\hline Feladat & 0,26 & $-0,03$ & 0,21 & 0,14 & $-0,19$ \\
\hline Versenyeztetés & $-0,13$ & $-0,02$ & 0,20 & 0,03 & 0,02 \\
\hline Tanulók csoportosítása & $-0,10$ & $-0,14$ & 0,15 & $-0,13$ & 0,16 \\
\hline $\begin{array}{l}\text { Egyéni felelősséget } \\
\text { hangsúlyozó számonkérés }\end{array}$ & 0,18 & $-0,01$ & 0,10 & 0,04 & $-0,01$ \\
\hline
\end{tabular}

Megj.: félkövér szedés jelzi a 0,01 alatti szinten szignifikáns összefüggéseket; dőlt és félkövér szedés jelzi a 0,01 és 0,05 közötti szinten szignifikáns összefüggéseket. Els. telj. kereső: elsajátítási teljesítménykereső; Els. telj. kerülő: elsajátítási teljesítménykerülö; Visz. telj. kereső: viszonyító teljesítménykereső; Visz. telj. kerülő: viszonyító teljesítménykerülő; Tan. kerülő: tanulást kerülő. 
44. melléklet. A célorientációk korrelációi a tanári tevékenységekkel és a társas környezetet leíró változókkal 7. évfolyamon

\begin{tabular}{|c|c|c|c|c|c|}
\hline \multirow[b]{2}{*}{$\begin{array}{c}\text { Tanári tevékenységek, társas } \\
\text { környezet }\end{array}$} & \multicolumn{5}{|c|}{ Célok } \\
\hline & $\begin{array}{l}\text { Els. telj. } \\
\text { keresö }\end{array}$ & $\begin{array}{c}\text { Els. telj. } \\
\text { kerüulö }\end{array}$ & $\begin{array}{c}\text { Visz. telj. } \\
\text { keresö }\end{array}$ & $\begin{array}{l}\text { Visz. telj. } \\
\text { kerülöo }\end{array}$ & $\begin{array}{c}\text { Tan. } \\
\text { kerüllö }\end{array}$ \\
\hline Tanári támogatás & $\mathbf{0 , 3 0}$ & 0,13 & 0,08 & 0,10 & $-0,03$ \\
\hline Fegyelmezési problémák & $-0,17$ & $-0,12$ & $-0,07$ & $-0,13$ & 0,06 \\
\hline Pozitív osztálylégkör & 0,21 & 0,05 & 0,06 & 0,10 & $-0,08$ \\
\hline $\begin{array}{l}\text { A matematikatanár } \\
\text { szabályorientált viselkedése }\end{array}$ & 0,11 & 0,04 & 0,10 & 0,13 & 0,09 \\
\hline $\begin{array}{l}\text { Tanulók közötti kölcsönös } \\
\text { tisztelet támogatása }\end{array}$ & $\mathbf{0 , 3 2}$ & 0,14 & 0,17 & $\mathbf{0 , 1 9}$ & $-0,02$ \\
\hline Feladat & $\mathbf{0 , 4 3}$ & $\mathbf{0 , 1 8}$ & $\mathbf{0 , 2 3}$ & 0,13 & $-0,05$ \\
\hline Versenyeztetés & $-0,06$ & $-0,01$ & $\mathbf{0 , 1 8}$ & 0,06 & 0,16 \\
\hline Tanulók csoportosítása & 0,03 & $-0,09$ & $\mathbf{0 , 1 8}$ & 0,10 & $-0,07$ \\
\hline $\begin{array}{l}\text { Egyéni felelősséget } \\
\text { hangsúlyozó számonkérés }\end{array}$ & $\mathbf{0 , 1 7}$ & 0,01 & $-0,04$ & 0,05 & 0,00 \\
\hline
\end{tabular}

Megj.: félkövér szedés jelzi a 0,01 alatti szinten szignifikáns összefüggéseket; dőlt és félkövér szedés jelzi a 0,01 és 0,05 közötti szinten szignifikáns összefüggéseket. Els. telj. kereső: elsajátítási teljesítménykereső; Els. telj. kerülő: elsajátítási teljesítménykerülő; Visz. telj. kereső: viszonyító teljesítménykereső; Visz. telj. kerülő: viszonyító teljesítménykerülő; Tan. kerülő: tanulást kerülő.

45. melléklet. A célorientációk korrelációi a tanári tevékenységekkel és a társas környezetet leíró változókkal 8. évfolyamon

\begin{tabular}{|c|c|c|c|c|c|}
\hline \multirow[b]{2}{*}{$\begin{array}{c}\text { Tanári tevékenységek, társas } \\
\text { környezet }\end{array}$} & \multicolumn{5}{|c|}{ Célok } \\
\hline & $\begin{array}{c}\text { Els. telj. } \\
\text { keresö }\end{array}$ & $\begin{array}{l}\text { Els. telj. } \\
\text { kerülö }\end{array}$ & $\begin{array}{c}\text { Visz. telj. } \\
\text { keresöo }\end{array}$ & $\begin{array}{c}\text { Visz. telj. } \\
\text { kerülö }\end{array}$ & $\begin{array}{c}\text { Tan. } \\
\text { kerüló }\end{array}$ \\
\hline Tanári támogatás & $\mathbf{0 , 1 9}$ & 0,12 & 0,12 & 0,10 & $-0,12$ \\
\hline Fegyelmezési problémák & $-0,16$ & $-0,14$ & $-0,08$ & $-0,19$ & $\mathbf{0 , 3 0}$ \\
\hline Pozitív osztálylégkör & 0,13 & 0,02 & 0,02 & 0,12 & $-0,11$ \\
\hline $\begin{array}{l}\text { A matematikatanár } \\
\text { szabályorientált viselkedése }\end{array}$ & 0,07 & 0,10 & 0,01 & $-0,01$ & 0,01 \\
\hline $\begin{array}{l}\text { Tanulók közötti kölcsönös } \\
\text { tisztelet támogatása }\end{array}$ & 0,09 & 0,07 & 0,07 & 0,09 & $-0,15$ \\
\hline Feladat & 0,27 & 0,15 & 0,16 & $\mathbf{0 , 2 1}$ & $-0,23$ \\
\hline Versenyeztetés & $-0,13$ & $-0,01$ & 0,13 & $-0,07$ & 0,12 \\
\hline Tanulók csoportosítása & $-0,24$ & $-0,14$ & $-0,07$ & $-0,14$ & 0,03 \\
\hline $\begin{array}{l}\text { Egyéni felelősséget } \\
\text { hangsúlyozó számonkérés }\end{array}$ & 0,02 & 0,12 & 0,16 & 0,08 & 0,08 \\
\hline
\end{tabular}

Megj.: félkövér szedés jelzi a 0,01 alatti szinten szignifikáns összefüggéseket; dőlt és félkövér szedés jelzi a 0,01 és 0,05 közötti szinten szignifikáns összefüggéseket. Els. telj. kereső: elsajátítási teljesítménykereső; Els. telj. kerülő: elsajátítási teljesítménykerülő; Visz. telj. kereső: viszonyító teljesítménykereső; Visz. telj. kerülő: viszonyító teljesítménykerülő; Tan. kerülő: tanulást kerülő. 
46. melléklet. A célok mint függö változók regresszióanalizise a tanári tevékenységeket és társas környezetet leíró változókkal 5. évfolyamon

\begin{tabular}{|c|c|c|c|c|c|c|c|c|c|c|}
\hline $\begin{array}{c}\text { Tanári tevékenységek, társas } \\
\text { környezet }\end{array}$ & \multicolumn{2}{|c|}{$\begin{array}{c}\text { Elsajátítási } \\
\text { teljesítménykeresö }\end{array}$} & \multicolumn{2}{|c|}{$\begin{array}{c}\text { Elsajátítási } \\
\text { teljesítménykerülö }\end{array}$} & \multicolumn{2}{|c|}{$\begin{array}{c}\text { Viszonyító } \\
\text { teljesítménykereső }\end{array}$} & \multicolumn{2}{|c|}{$\begin{array}{c}\text { Viszonyító } \\
\text { teljesítménykerü̈lö }\end{array}$} & \multicolumn{2}{|c|}{ Tanulást kerüló } \\
\hline Tanári támogatás & 2,9 & 0,21 & $-0,2$ & 0,79 & 0,1 & 0,90 & 1,1 & 0,45 & 0,0 & 0,66 \\
\hline Pozitív osztálylégkör & 0,5 & 0,58 & 0,0 & 0,94 & 0,0 & 0,89 & 1,3 & 0,17 & 0,0 & 0,45 \\
\hline $\begin{array}{l}\text { A matematikatanár } \\
\text { szabályorientált viselkedése }\end{array}$ & 0,3 & 0,80 & 1,6 & 0,17 & 1,1 & 0,56 & 0,8 & 0,50 & 3,5 & 0,04 \\
\hline Feladat & 7,1 & 0,03 & 0,5 & 0,57 & 4,2 & 0,08 & 1,9 & 0,32 & $-0,1$ & 0,75 \\
\hline Versenyeztetés & 0,3 & 0,68 & 0,6 & 0,30 & 5,5 & $<0,01$ & $-0,2$ & 0,62 & 0,1 & 0,92 \\
\hline Tanulók csoportosítása & 0,1 & 0,88 & 0,1 & 0,35 & 1,9 & 0,25 & 4,7 & $<0,01$ & 4,9 & 0,02 \\
\hline $\begin{array}{l}\text { Egyéni felelősséget } \\
\text { hangsúlyozó számonkérés }\end{array}$ & 3,2 & 0,25 & $-0,9$ & 0,18 & 0,8 & 0,61 & 0,8 & 0,53 & 0,0 & 0,95 \\
\hline Hatás $\left(\mathrm{R}^{2}\right)$ & 12,9 & & 10,0 & & 5,5 & & 4,7 & & 8,4 & \\
\hline
\end{tabular}

Megj.: félkövér szedés jelzi a 0,05 alatti szinten szignifikáns összefüggéseket. 
47. melléklet. A célok mint függö változók regresszióanalizise a tanári tevékenységeket és társas környezetet leíró változókkal 6. évfolyamon

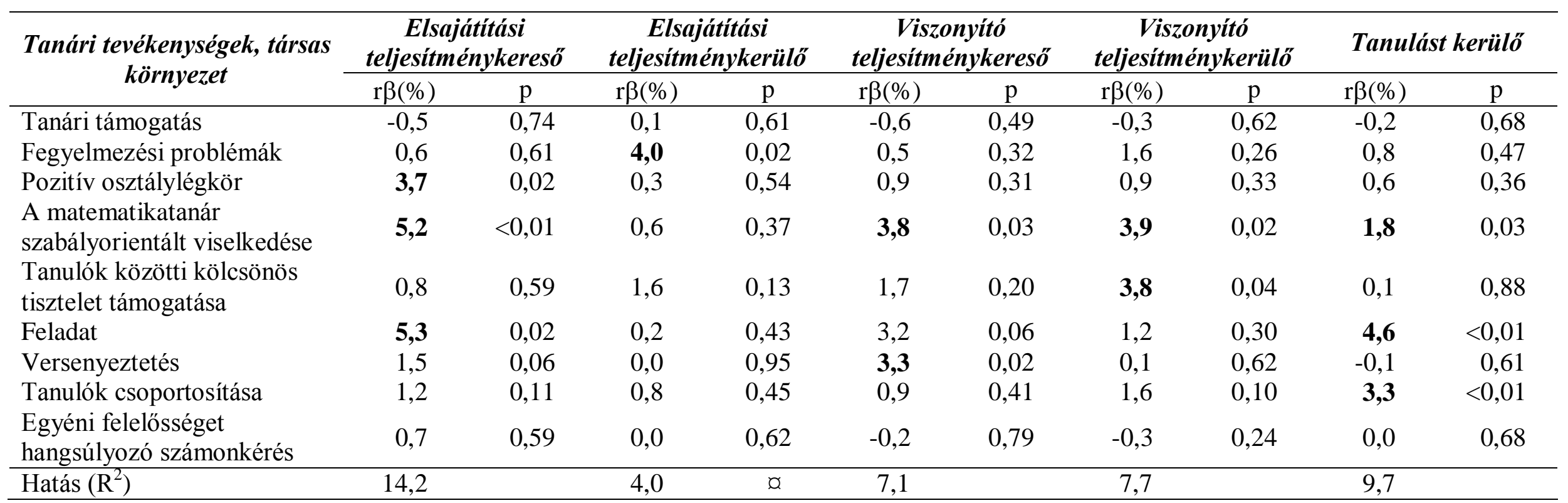

Megj.: félkövér szedés jelzi a 0,05 alatti szinten szignifikáns összefüggéseket. 
48. melléklet. A célok mint függö változók regresszióanalizise a tanári tevékenységeket és társas környezetet leíró változókkal 7. évfolyamon

\begin{tabular}{|c|c|c|c|c|c|c|c|c|c|c|}
\hline $\begin{array}{c}\text { Tanári tevékenységek, társas } \\
\text { környezet }\end{array}$ & \multicolumn{2}{|c|}{$\begin{array}{c}\text { Elsajátítási } \\
\text { teljesítménykeresö }\end{array}$} & \multicolumn{2}{|c|}{$\begin{array}{c}\text { Elsajátítási } \\
\text { teljesítménykerülö }\end{array}$} & \multicolumn{2}{|c|}{$\begin{array}{c}\text { Viszonyító } \\
\text { teljesítménykereső }\end{array}$} & \multicolumn{2}{|c|}{$\begin{array}{c}\text { Viszonyító } \\
\text { teljesítménykerü̈lö }\end{array}$} & \multicolumn{2}{|c|}{ Tanulást kerüló } \\
\hline Tanári támogatás & 1,5 & 0,55 & 0,1 & 0,94 & $-0,7$ & 0,35 & $-0,5$ & 0,50 & 0,0 & 0,96 \\
\hline Pozitív osztálylégkör & 1,4 & 0,33 & 0,0 & 0,94 & 0,3 & 0,63 & 0,4 & 0,49 & $-0,1$ & 0,76 \\
\hline $\begin{array}{l}\text { A matematikatanár } \\
\text { szabályorientált viselkedése }\end{array}$ & 0,4 & 0,58 & 0,0 & 0,92 & $-0,3$ & 0,71 & 1,3 & 0,25 & 1,4 & 0,11 \\
\hline Feladat & 12,2 & $<0,01$ & 3,9 & 0,03 & 4,8 & 0,02 & 0,2 & 0,88 & 0,5 & 0,43 \\
\hline Versenyeztetés & 0,5 & 0,32 & 0,0 & 0,92 & 2,7 & 0,04 & 0,2 & 0,67 & 3,1 & 0,02 \\
\hline Tanulók csoportosítása & $-0,1$ & 0,72 & 1,0 & 0,11 & 2,7 & 0,04 & 0,8 & 0,24 & 1,1 & 0,04 \\
\hline $\begin{array}{l}\text { Egyéni felelősséget } \\
\text { hangsúlyozó számonkérés }\end{array}$ & $-0,3$ & 0,80 & $-0,1$ & 0,28 & 0,8 & 0,02 & $-0,1$ & 0,83 & $-0,1$ & 0,47 \\
\hline Hatás $\left(\mathrm{R}^{2}\right)$ & 17,5 & & 3,9 & & 13,7 & & 3,4 & & 4,2 & \\
\hline
\end{tabular}

Megj.: félkövér szedés jelzi a 0,05 alatti szinten szignifikáns összefüggéseket. 
49. melléklet. A célok mint függö változók regresszióanalizise a tanári tevékenységeket és társas környezetet leíró változókkal 8. évfolyamon

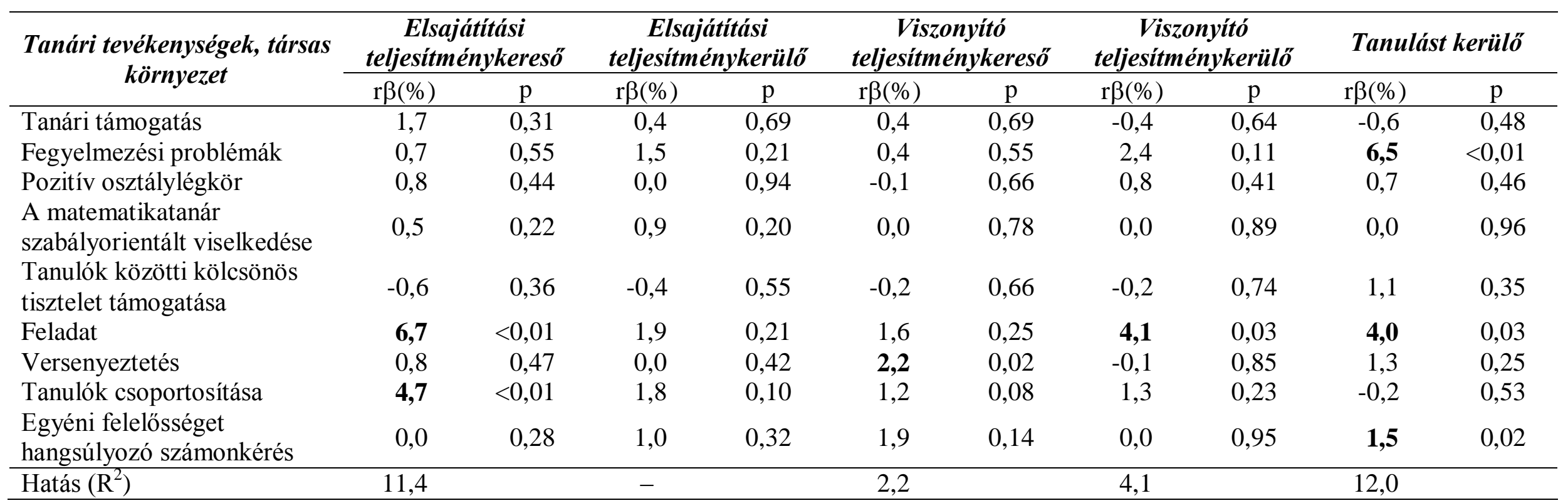

Megj.: félkövér szedés jelzi a 0,05 alatti szinten szignifikáns összefüggéseket. 
50. melléklet. A célstruktúrák korrelációi a tanári tevékenységekkel és a társas környezetet leiró változókkal évfolyamok szerint

\begin{tabular}{|c|c|c|c|c|c|c|c|c|}
\hline \multirow[b]{2}{*}{ Tanári tevékenységek, társas környezet } & \multicolumn{8}{|c|}{ Évfolyamok } \\
\hline & \multicolumn{2}{|c|}{5.} & \multicolumn{2}{|c|}{6.} & \multicolumn{2}{|c|}{7.} & \multicolumn{2}{|c|}{8.} \\
\hline Tanári támogatás & $\mathbf{0 , 3 7}$ & 0,18 & $\mathbf{0 , 5 3}$ & $\mathbf{0 , 3 1}$ & 0,47 & 0,16 & 0,60 & $\mathbf{0 , 3 3}$ \\
\hline Pozitív osztálylégkör & 0,17 & 0,07 & 0,22 & 0,22 & $\mathbf{0 , 3 4}$ & 0,03 & $\mathbf{0 , 1 9}$ & 0,05 \\
\hline A matematikatanár szabályorientált viselkedése & $\mathbf{0 , 3 6}$ & $\mathbf{0 , 4 3}$ & $\mathbf{0 , 2 3}$ & $\mathbf{0 , 3 5}$ & 0,32 & $\mathbf{0 , 3 3}$ & 0,16 & 0,21 \\
\hline Tanulók közötti kölcsönös tisztelet támogatása & $\mathbf{0 , 3 1}$ & $\mathbf{0 , 1 9}$ & $\mathbf{0 , 4 4}$ & $\mathbf{0 , 2 1}$ & $\mathbf{0 , 4 5}$ & 0,21 & $\mathbf{0 , 4 7}$ & 0,22 \\
\hline Feladat & $\mathbf{0 , 5 9}$ & $\mathbf{0 , 3 5}$ & $\mathbf{0 , 5 4}$ & 0,37 & 0,64 & 0,36 & $\mathbf{0 , 7 0}$ & $\mathbf{0 , 4 2}$ \\
\hline Tanulók csoportosítása & 0,06 & $\mathbf{0 , 3 1}$ & 0,23 & 0,16 & 0,15 & 0,23 & $-0,02$ & 0,09 \\
\hline Egyéni felelősséget hangsúlyozó számonkérés & $\mathbf{0 , 5 0}$ & $\mathbf{0 , 2 0}$ & $\mathbf{0 , 4 0}$ & $\mathbf{0 , 2 9}$ & $\mathbf{0 , 2 7}$ & 0,06 & $\mathbf{0 , 3 1}$ & $\mathbf{0 , 1 9}$ \\
\hline
\end{tabular}

Megj.: félkövér szedés jelzi a 0,01 alatti szinten szignifikáns összefüggéseket; dőlt és félkövér szedés jelzi a 0,01 és 0,05 közötti szinten szignifikáns összefüggéseket. Els.: elsajátítási célstruktúra. Vis.: viszonyitó célstruktúra. 
51. melléklet. Az elsajátitási célstruktúrával mint függö változóval végzett regresszióanalízis évfolyamok szerint

\begin{tabular}{|c|c|c|c|c|c|c|c|c|}
\hline \multirow[b]{2}{*}{ Tanári tevékenységek, társas környezet } & \multicolumn{8}{|c|}{ Évfolyamok } \\
\hline & \multicolumn{2}{|c|}{5.} & \multicolumn{2}{|c|}{6.} & \multicolumn{2}{|c|}{7.} & \multicolumn{2}{|c|}{8.} \\
\hline Tanári támogatás & 1,3 & 0,62 & 14,4 & $<0,01$ & 4,1 & 0,20 & 15,6 & $<0,01$ \\
\hline Pozitív osztálylégkör & 2,0 & 0,05 & 1,3 & 0,29 & 5,1 & $<0,01$ & 0,4 & 0,69 \\
\hline A matematika tanár szabályorientált viselkedése & 4,7 & 0,04 & 0,9 & 0,46 & 4,2 & $<0,01$ & 1,8 & 0,02 \\
\hline Tanulók közötti kölcsönös tisztelet támogatása & 2,8 & 0,22 & 7,2 & $<0,01$ & 10,1 & $<0,01$ & 4,6 & 0,10 \\
\hline Tanulók csoportosítása & 0,2 & 0,65 & 4,1 & $<0,01$ & 0,4 & 0,62 & 0,2 & 0,36 \\
\hline Egyéni felelősséget hangsúlyozó számonkérés & 6,9 & 0,06 & 3,1 & 0,20 & 0,0 & 0,98 & 0,6 & 0,71 \\
\hline Hatás $\left(\mathrm{R}^{2}\right)$ & 28,0 & & 37,2 & & 43,2 & & 50,9 & \\
\hline
\end{tabular}

Megj.: félkövér szedés jelzi a 0,05 alatti szinten szignifikáns összefüggéseket. 
52. melléklet. A viszonyitó célstruktúrával mint függö változóval végzett regresszióanalizis évfolyamok szerint

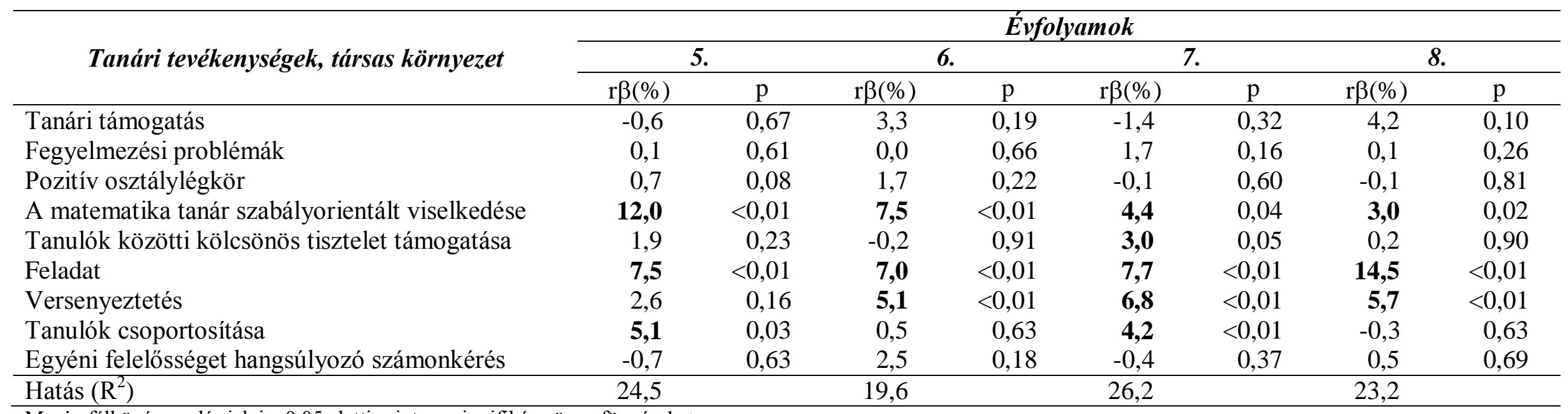

Megj.: félkövér szedés jelzi a 0,05 alatti szinten szignifikáns összefüggéseket. 